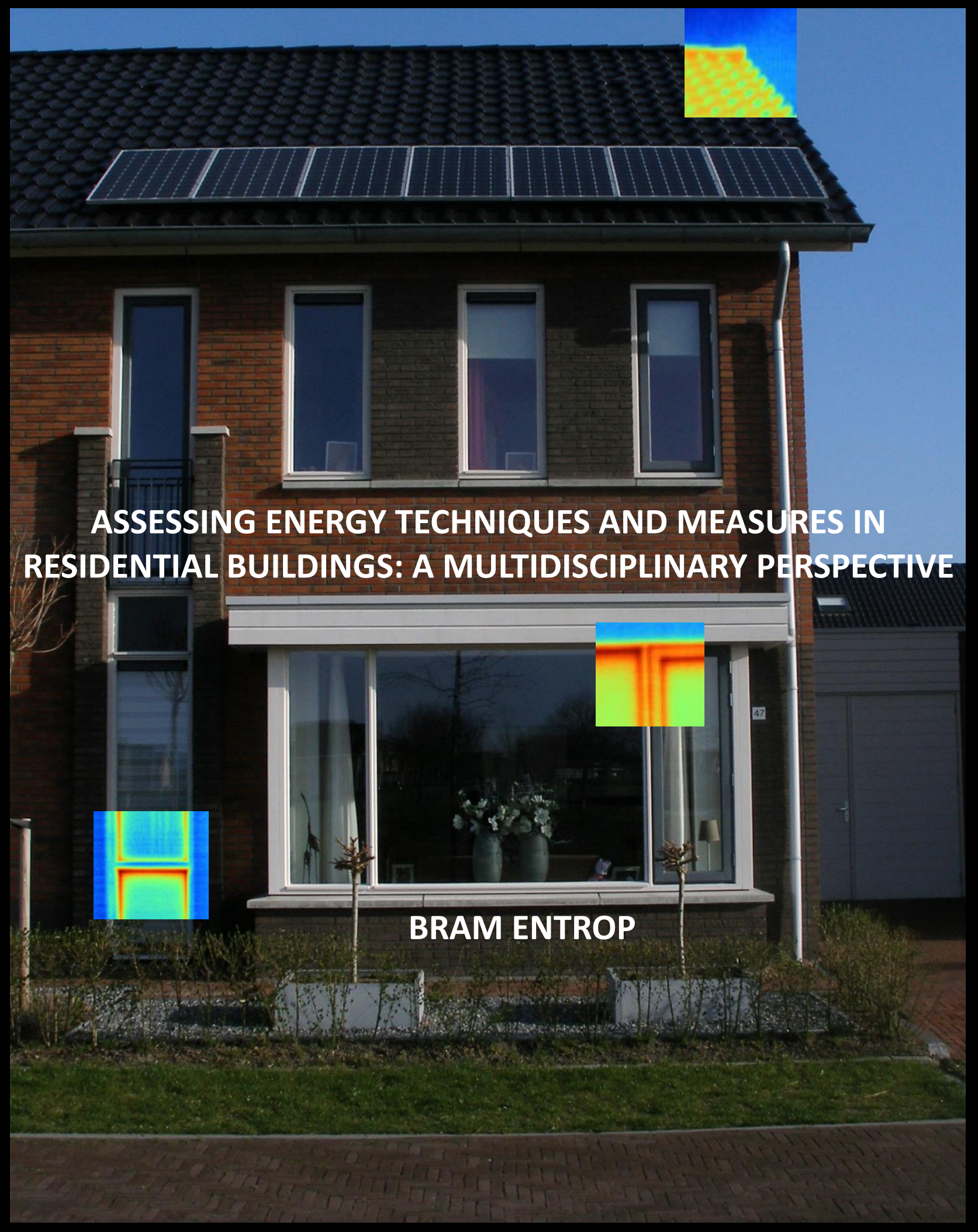


Stellingen horende bij het proefschrift

\title{
ASSESSING ENERGY TECHNIQUES AND MEASURES IN RESIDENTIAL BUILDINGS: A MULTIDISCIPLINARY PERSPECTIVE
}

\author{
door \\ Bram Entrop \\ 12 Juni 2013
}

1. De karakteristieken die worden meegenomen in de bepaling van de energieprestatie-indicatoren voor woningen, zijn ontoereikend (Hoofdstuk 2 van dit proefschrift).

2. Het implementeren van energietechnieken in woningen leidt nauwelijks tot een voor de bewoners waarneembare structurele daling van de maandelijkse energiekosten (Hoofdstuk 3 van dit proefschrift).

3. Huurders van sociale woningbouw hoeven ook de komende jaren geen lastenverlichting van hun vaste kosten te verwachten (Hoofdstuk 4 van dit proefschrift).

4. Op paraffine gebaseerde fase-veranderende materialen (PCMs) zijn in staat de stabiliteit van binnentemperaturen te vergroten; de kans op implementatie in de woningbouw is echter op dit moment vrijwel nihil (Hoofdstuk 5 van dit proefschrift).

5. Door woningen en hun bewoners wordt geen energie verbruikt; er wordt hooguit energie gebruikt $\left(1^{\text {ste }}\right.$ Hoofdwet van de Thermodynamica).

6. Elke woning in Nederland is energieneutraal; de hoeveelheid energie die de thermische schil in gaat, komt er ook weer uit ( $1^{\text {ste }}$ Hoofdwet van de Thermodynamica).

7. Elke onderzoeker die energieprestaties van woningen heeft mogen vaststellen en bestuderen, weet dat Miranda's wereldberoemde zin in "The Tempest" van William Shakespeare had moeten zijn " $O$ brave new world, that has such people and dwellings in 't.".

8. De stelling "Es ist überall nichts in der Welt, ja überhaupt auch außer derselben zu denken möglich, was ohne Einschränkung für gut könnte gehalten werden, als allein ein guter Wille" in "Grundlegung zur metaphysik der Sitten" van Immanual Kant heeft ook betrekking op de intenties van stakeholders in bouwprojecten.

9. Met betrekking tot de toepassing van nieuwe producten wordt het als positief beschouwd wanneer een zogenaamde critical mass (kritische massa) is bereikt, deze positieve associatie bestaat ook bij muziekliefhebbers van de muziekstroming Happy Hardcore, maar eenzelfde positieve associatie mag niet worden verwacht bij patiënten van diëtisten. 


\section{ASSESSING ENERGY TECHNIQUES AND MEASURES IN RESIDENTIAL BUILDINGS: A MULTIDISCIPLINARY PERSPECTIVE}


Promotion committee

$\begin{array}{lll}\text { Chair/Secretary } & \text { prof. dr. F. Eising } & \text { University of Twente } \\ \text { Promotors } & \text { prof. dr. G.P.M.R. Dewulf } & \text { University of Twente } \\ & \text { prof. dr. ir. J.I.M. Halman } & \text { University of Twente } \\ \text { Assistant promotor } & \text { prof. dr. A.H.M.E. Reinders } & \begin{array}{l}\text { University of Twente and } \\ \text { Delft University of Technology }\end{array} \\ \text { Members } & \text { prof. dr. J.Th.A. Bressers } & \text { University of Twente } \\ & \text { prof. dr. ir. A.A.J.F. van den } & \text { Delft University of Technology } \\ & \text { Dobbelsteen } & \\ & \text { prof. dr. ir. J.D.M. van Hal } & \text { Delft University of Technology and } \\ & \text { prof. dr. ir. J.L.M. Hensen } & \text { Eindhonen University of Technology } \\ & \text { dr. J.T. Voordijk } & \text { University of Twente }\end{array}$




\title{
ASSESSING ENERGY TECHNIQUES AND MEASURES IN RESIDENTIAL BUILDINGS: A MULTIDISCIPLINARY PERSPECTIVE
}

\author{
DISSERTATION \\ To obtain \\ the degree of doctor at the University of Twente, \\ on the authority of the rector magnificus, \\ prof. dr. H. Brinksma, \\ on the account of the decision of the graduation committee, \\ to be publicly defended \\ on Wednesday the $12^{\text {th }}$ of June 2013 at $14: 45 \mathrm{hrs}$
}

by

\author{
Alexis Gerardus Entrop \\ born on the $18^{\text {th }}$ of February 1980 \\ in Tiel, the Netherlands
}


This dissertation has been approved by:

Prof. dr. G.P.M.R. Dewulf Promotor

Prof. dr. ir. J.I.M. Halman Promotor

Prof. dr. A.H.M.E. Reinders Assistant promotor

ISBN 978-90-365-3536-6

If one refers to the author, title and year of publication, every part of this thesis may be used for non-commercial purposes, free of charge and free of copyrights in any form or by any means electronic or mechanical, including photocopying, recording or by any information storage and retrieval system, without permission from the author. For commercial purposes or not free of charge usage, written permission from the author is required.

Thesis printed by Gildeprint, Enschede, the Netherlands.

English correction executed by Giles Stacey, Englishworks, Hengelo (Ov.), the Netherlands.

Infrared thermography enabled by B.L.W. Visser B.V, Enschede, the Netherlands.

The research unfolded in this thesis has been conducted with the financial support of SenterNovem (EOS LT02003), since 2010 merged into AgentschapNL of the Ministry of Economic Affairs, which is gratefully acknowledged. 


\section{Preface}

In 2004, the initial idea of studying the financial benefits of sustainable measures in general, in the form of research leading to a PhD, was mooted by prof. dr. ir. H.J.H. Brouwers. During the final stages of my master project on sustainable land use, he suggested that conducting $\mathrm{PhD}$ research could be a promising next step in my career. However, financing the research took a little longer than expected.

After working for some time at the municipality of Hengelo as a sustainable building inspector, the full-time PhD project started with the help of prof. dr. G.P.M.R. Dewulf, prof. dr. ir. J.I.M. Halman and dr. eng. E.C. Boelman MBA on the $2^{\text {nd }}$ January 2006. The focus was narrowed down from the financial benefits of sustainable measures to energy measures that fitted the objectives of the 3TU research project "Exergy in the built environment". Here, the University of Twente's Department of Construction Management and Engineering was responsible for the ' $P$ for Profit' in the PPP triptych People (Eindhoven University of Technology), Planet (Delft University of Technology) and Profit.

Not only financing the project took a little more time than expected, conducting the research also took longer than anticipated. Being attracted by educational activities and several interesting side projects, it was not always easy to focus on the work required to complete this thesis. However, the supervision of (the now) prof. dr. ir. H.J.H. Brouwers, prof. dr. G.P.M.R. Dewulf, prof. dr. ir. J.I.M. Halman and prof. dr. A.H.M.E. Reinders got me back on track many times. I am grateful to them and want to thank them for their patience.

Jos Brouwers, thank you for taking the first initiatives that give me the opportunity to start on a PhD project, and especially for supervising the experimental research. Although the distance between us has been extended from one floor to more than 150 kilometres, I hope and expect our research and interests to remain interlinked.

Geert Dewulf, thank you for your confidence in the educational and research activities I undertook, and hope to continue for many years; thank you for being my promotor and for especially supervising the process research. You know what role the Department of Construction Management and Engineering can play in building processes, and I hope this thesis demonstrates my understanding of the role energy techniques and measures (ETMs) have in buildings and building processes.

Joop Halman, thank you for your intense supervision at critical moments, always supported by calm words and reflective questions, and thank you for being my promotor. You made it possible for the presentation of my research proposal to the department's Scientific Commission to be successful after only nine months, and I hope to match this success at my defence.

Angèle Reinders, thank you for your specific and pertinent feedback especially involving the technical analysis in this thesis. Your background in experimental physics, experience with photovoltaic systems and your position in the Department of Design, Production and Management made it possible for me to look beyond the "ivory" tower. 
Within the Horst tower, where the department of Construction Management and Engineering is located, many colleagues provided and continue to provide a comfortable work sphere. In my initial years there was a strong connection with the research of Martin Hunger and Götz Hüsken, to whom I am grateful for teaching me the skills to do experimental research properly. Also Ariën de Korte was always interested in energy use in the built environment and he was a helping hand in many educational and other activities. Becoming an assistant professor brought me a separate office and enabled me to meet students without disturbing my colleagues, but I also used the office so that HT300 colleagues would not disturb me at critical moments. At such times, I would only leave the room to share coffee with my good colleague Marnix Smit, who would often return the favour by bringing me some hot chocolate with a shot of espresso. Of course, there are many other colleagues and former colleagues in the department worthy of mentioning including Hans Voordijk, André Dorée, Andreas Hartmann, Wilco Tijhuis, Timo Hartmann, Hans Boes, Inge de Kort, Mieke Hoezen, Arjen Adriaanse, Albertus Laan, Jeroen Bemelmans, Maarten Rutten, Tijs de Bree, Julia Wijnmaalen, Hendrik Cramer, Frank Bijleveld and John van Oirschot, who have all contributed, and some still contribute, to the cosy atmosphere.

Regarding my educational activities, I would like to express my gratitude to Gerrit Snellink, with whom I teach the Sustainable Building master course; Robin de Graaf, who supervised my University Didactics Trajectory; Karel Veenvliet, the former educational coach of the department; Annet de Kiewit, study advisor for civil engineering students; and Denie Augustijn with whom I teach the Environmental Aspects of Civil Engineering bachelor course. These colleagues help me to become a better teacher each year. In this regard, all the students also need to be thanked for providing insights which cannot be learnt from books.

Martijn Elferink and Axel Lok, thank you for helping me to cope with software and hardware problems with computers. I also want to thank the secretariat, consisting of Yolanda Bosch, Jacqueline Nijhof and, temporarily, Cecile Strootman, for allowing to make use of their (listening) skills.

My two paranymphs, my dear brother Pim Entrop and good friend Wiet Mazairac, have helped me in organising the defence and will help me during it. I would like to thank them for their unqualified consent to being my paranymphs.

My family also needed quite some patience. For many days and evenings I could not give my wife and daughters the attention they deserved. Thank you llona, Sofie, Lieke and Feline for supporting and helping me. Although I was often brief in explaining the issues I was coping with, you, llona, tried to come up with suggestions to improve and continue my work. Sofie, Lieke and Feline enabled me, through their charming laughs and cheerful playfulness, to clear my mind while remembering what sustainability is all about: the future generation.

My parents, Lex and Els Entrop, provided me with all the opportunities and freedom anyone could wish for, but they also taught me about social responsibility, good behaviour and communication. I hope I will be able to succeed in raising my own children in the same, splendid, way you raised me. Thank you, mum and dad, for stimulating and helping me from the day I was born. 


\section{Summary}

The built environment uses a lot of energy. In the last hundred years, many Energy Techniques and Measures (ETMs) have been developed to reduce the fossil energy use of dwellings, while the level of indoor comfort has been maintained and generally improved. Many ETMs have become widely available and the energy use of dwellings is decreasing. However, the implementation of ETMs still falls short of ambitions to come to a sustainable built environment. To discover where and why the implementation of ETMs has failed to meet this target, a study was conducted with the aim of developing a framework for developers and manufacturers of ETMs to assess the implementation potential of their ETM on the basis of their effects on stakeholders in residential building projects. The following research questions have been formulated:

1. What influence do ETMs have on the energy performance of dwellings?

2. What are the financial impacts of ETMs in residential building projects?

3. How in residential building projects are decisions on the implementation of ETMs taken?

4. How can a novel ETM be implemeneted in residential building projects?

As a first step, an ETM's influencing variables on the energy performance of dwellings were studied. Based on a literature study, five categories of variables were distinguished as characteristics that can be assessed. These categories are: environmental characteristics, occupational characteristics, building characteristics, system characteristics and appliances. Usually, only some of these characteristics are taken into account in calculating the theoretical energy performance of a dwelling. Therefore, the effects of some ETMs are not always taken into account in the three major Energy Performance Indicators (EPIs) in the Netherlands: EPC, $\mathrm{El}_{\text {old }}$ and $\mathrm{EI}_{\text {new. }}$. Case-study research on the energy use of eight houses shows that the three Dutch methods used to determine the energy performance of dwellings lead to different results regarding the theoretical energy use and energy performance of the houses. Even though these methods do not take into account the electric energy used in appliances, the actual total energy use was, in most cases, lower than the calculated theoretical energy use. Being able to interpret the calculated EPIs by also taking into account a specific dwelling and its residents seems desirable if one is to prevent unfavourable decisions regarding the implementation of ETMs. It is less than ideal if the theoretical energy performance is affected by an ETM, but the actual energy use does not change. Conversely, it is unhelpful if the theoretical energy performance is unaffected when an ETM changes actual energy use.

Secondly, the financial effects of ETMs on households were studied. The implementation of an ETM requires an investment that can hopefully be recovered by reduced energy and maintenance costs on the one hand, and by increasing comfort, reliability and the value of the dwelling on the other. A study of more than eighty energy bills from various households shows that the variable costs, those that households can influence by changing their energy use, only constitute a limited component of total energy costs. A significant part of energy costs are governmental taxes. In 2010, taxes amounted to $36 \%$ of total energy costs in the 
households using both electric energy and natural gas in this study. Fixed costs, those that households cannot influence by changing their energy use, increased from $12 \%$ in 2009 to $19 \%$ of total energy costs in 2010. As such, marginal energy costs, rather than average energy unit costs, need to be the focus when calculating the financial efficiency of an ETM. The higher value of dwellings with a green Energy Label compared to similar dwellings with a lower theoretical energy performance can reduce the pay back period of an ETM. The study of energy bills showed that, despite the reduced actual energy use due to both small and large investments in ETMs, energy costs still increase.

Thirdly, the implementation of ETMs in residential building projects was studied. In most building projects, several organizations, such as the architect, principal, advisors and contractors, are involved with different interests that need to be taken into account and weighed against each other. In the process of coming to a design, and eventually to a new or renovated dwelling, decisions need to be taken on the implementation or rejection of ETMs. In a case study, four building projects for a social housing association were studied. Two projects were considering the development of new dwellings and two were renovation projects. This study found that three stakeholders gave shape to the decisions on the implementation of ETMs, namely: the principal, the architect and the installation advisor. As the principal and client, the social housing association took the final decision. The social housing association says that it wants to make implementation decisions that are in the interests of its tenants, who in the future need to be able to pay their rent after paying their energy bills. However, in the studied cases, the investment costs, maintenance costs and reliability were the actual arguments used in deciding on the use of ETMs. Two decisionmaking levels can be distinguished. Among the actors, the national Building Code provides a generally accepted basis for applying conventional ETMs. Any ETM investments that would result in an energy performance exceeding this basic level, receive specific attention from the actors. The outcome is that the actors' assessment framework differs per ETM.

Fourthly, the insights gained on assessing the energy performance, the financial impact of ETMs, and their part in building projects, offer the opportunity to consider the likelihood of a new ETM being implemented. In this study, an implementation study considers the implementation of a novel energy technique, namely Phase Change Materials (PCMs). These materials have been engineered such that they can provide a latent heat capacity at a temperature close to typical indoor temperature. In doing so, they form a storage medium for thermal energy. PCMs have been rarely implemented in the Dutch construction industry. Experimental research on the implementation of paraffin-based PCMs in concrete floors shows that, used passively in this way, these PCMs can increase minimum temperatures and decrease maximum building temperatures. Despite these encouraging results, the implementation study shows that the opportunities to implement this ETM in the Netherlands are limited because little is known about its precise effects in the context of a specific project. Based on this finding for this specific ETM, four different implementation forms are specified for ETMs in general: design implementation, physical implementation, marketing implementation and user implementation in order to make information available 
to specific stakeholders. Ideally, an ETM needs to prove itself in all four fields before the principal, architect, advisors, contractor, owner and residents will willingly and enthusiastically implement the ETM in their project. It is expected that the implementation of ETMs rests on the following five propositions:

A. The chances of a specific ETM being implemented will be greater the more that the actual energy use, as perceived by the resident of the dwelling, is reduced;

$B$. The chances of a specific ETM being implemented will be greater the more the theoretical EPI (EPC, $\mathrm{EI}_{\text {old }}$, and $\mathrm{EI}_{\text {new }}$ ), as perceived by the actors, is reduced;

C. The likelihood of a specific ETM being implemented will be greater the lower the principal of the building project perceives the investment costs $\left(\mathrm{CF}_{0}^{-}=\mathrm{CF}_{0.1 \text {; design }}^{-}+\mathrm{CF}^{-}\right.$

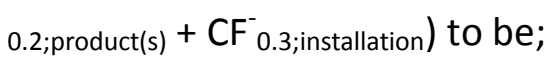

D. The chances of a specific ETM being implemented will increase if the financial benefits $\left(\mathrm{CF}_{\mathrm{a}}^{+}\right)$perceived by the resident are greater;

E. The chances of a specific ETM being implemented will increase if its reliability (CF a;maintenance $+\mathrm{CF}_{\mathrm{a}}^{-}$;reliability) as perceived by the owner of the dwelling is greater.

In this research, it was not possible to determine a specific order for these propositions. However, it was found that the mechanisms that underlie propositions $A$ and $B$ do not necessary align. That is, although an ETM has an effect on the actual energy use of a dwelling and its residents, it is not necessarily shown through an improved theoretical EPI, or vice versa. The same is true for the mechanisms underlying propositions $A$ en $D$. Although the energy use of a dwelling and its residents is reduced by implementing an ETM, the residents would not necessarily financially benefit from its implementation and energy costs could even increase.

The first scientific contribution of the thesis is the developed assessment framework shown in Figure 0-1. This framework makes it possible for developers and manufacturers of ETMs to assess the implementation potential of their ETM by means of (1) its effects on actual energy use and on the theoretical EPI, (2) its financial impact on investment costs and annual cash flows, and (3) its compliance with the interests of the stakeholders involved. The propositions and the assessment framework suggest directions for those who develop new ETMs, or improve existing ones, and offer them to stakeholders in residential building projects. Furthermore, they can be useful in explaining why certain ETMs are successful and others not.

The second scientific contribution is the insight gained that it is almost impossible for a novel ETM to be implemented in residential building projects due to at least five barriers. These barriers are (1) the complexity of how the energy use of dwellings and their residents is constituted and influenced, (2) the required certification of theoretically achieving a government-stipulated minimum energy performance, (3) split incentives among stakeholders, (4) the composition of energy costs, and (5) that the underlying mechanisms of the preceding four barriers are often changed.

Naturally, to improve the implementation of ETMs requires the efforts of all stakeholders. Here, efforts that enable transparency in a specific situation are especially needed. More 
data are needed on what effects ETMs have when they are applied in a specific dwelling with all its characteristics. To achieve this in the construction industry, where almost every dwelling is the unique result of a collaboration of many stakeholders with short-term interests, and with often no future user in sight, it is recommended that the government initiates and stimulates pilot projects. These pilots need to be intensively monitored for the effects of the ETM on the actual energy use, on the theoretical energy performance, the financial costs and benefits, and the strategy applied to offer stakeholders customized information. 


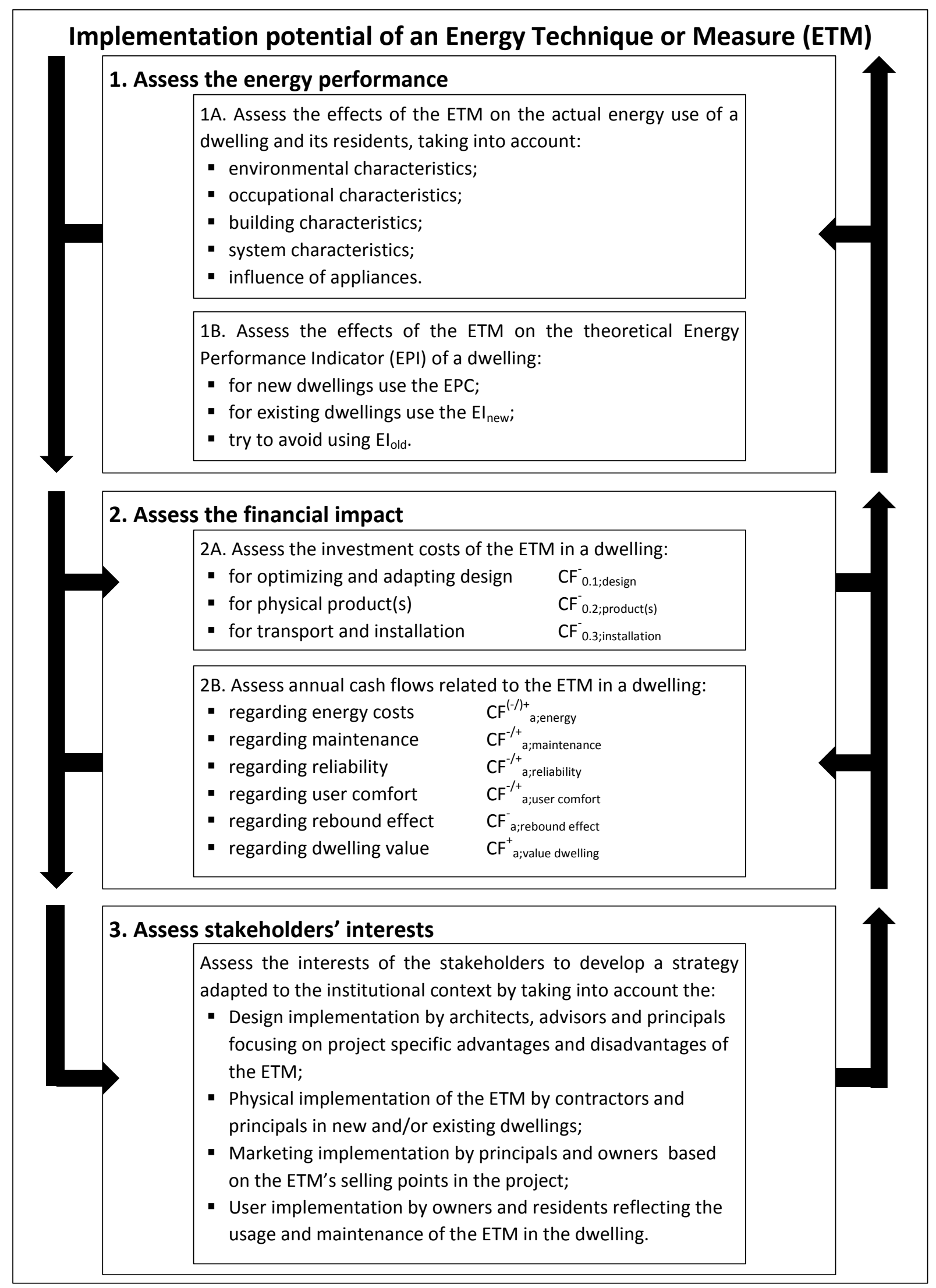

Figure 0-1: Framework for developers and manufacturers of Energy Techniques and Measures (ETMs) to assess the implementation potential of an ETM in residential building projects. 


\section{Samenvatting}

In de gebouwde omgeving wordt veel energie gebruikt. In de afgelopen honderd jaar zijn er diverse EnergieTechnieken en -Maatregelen (ETMs) ontwikkeld om het gebruik van fossiele brandstoffen voor woningen te reduceren en het comfort te handhaven, zo niet te vergroten. De beschikbaarheid van deze ETMs is inmiddels groot en het energiegebruik vertoont voor woningen een dalende lijn. Toch blijft de toepassing van ETMs in het algemeen achter bij de doelstellingen om tot een duurzame gebouwde omgeving te komen. Om te achterhalen waar deze implementatie stagneert, is er een studie uitgevoerd met het doel een raamwerk op te stellen voor ontwikkelaars en producenten van ETMs, waarmee het implementatie potentieel van ETMs kan worden vastgesteld op basis van hun effecten voor belanghebbenden in woningbouwprojecten. De volgende onderzoeksvragen zijn geformuleerd:

1. Welke invloed hebben ETMs op de energieprestatie van woningen?

2. Welke financiële impact hebben ETMs in woningbouwprojecten?

3. Hoe worden in woningbouwprojecten beslissingen genomen met betrekking tot de implementatie van ETMs?

4. Hoe kan een nieuwe ETM worden geïmplementeerd in woningbouwprojecten?

Ten eerste is de invloed van ETMs op de energieprestatie van woningen bestudeerd. Er zijn veel variabelen die invloed hebben op het energiegebruik van een woning en haar bewoners. Een literatuurstudie resulteerde in vijf categorieën met variabelen, te weten: omgevingskenmerken, bewonerskenmerken, bouwkundige kenmerken, installatiekenmerken en apparatuurkenmerken. Een deel van deze kenmerken wordt meegenomen in het bepalen van de theoretische energieprestatie van een woning, die kan worden uitgedrukt in één van de drie gebruikte EnergiePrestatiel̈ndicatoren (EPIs): EPC, Eloud en $\mathrm{EI}_{\text {nieuw. }}$. De effecten van sommige ETMs kunnen zodoende niet worden meegenomen. De bestudering van het energiegebruik van acht huishoudens toont aan dat de drie in Nederland gebruikte beoordelingsmethoden kunnen leiden tot verschillende waarden voor het theoretische energiegebruik en de energieprestatie van de huizen. Het werkelijke energiegebruik is in veel gevallen lager dan het berekende theoretische energiegebruik, ondanks dat in deze laatste het energiegebruik van apparatuur niet wordt meegenomen. Een woning- en huishoudengebonden interpretatie van de resultaten qua EPIs lijkt wenselijk, zodat geen verkeerde beslissingen worden genomen die wel de theoretische energieprestatie beïnvloeden, maar niet het werkelijke energiegebruik. Danwel dat ETMs die niet de theoretische energieprestatie beïnvloeden, niet worden toegepast, terwijl ze wel het werkelijke energiegebruik zouden hebben verlaagd.

Ten tweede zijn de financiële effecten van ETMs voor huishoudens bestudeerd. De implementatie van een ETM vraagt om een investering, die kan worden terugverdiend door een verlaging van de energiekosten en onderhoudskosten enerzijds en door een toename van comfort, betrouwbaarheid, en de waarde van de woning anderzijds. Een bestudering van meer dan tachtig energiefacturen van verschillende huishoudens wijst uit dat de variabele kosten, die een woninggebruiker kan beïnvloeden door zijn energiegebruik aan te 
passen, een beperkt deel van zijn totale energieuitgaven zijn. Een aanzienlijk deel van de totale energiekosten vloeit naar de overheid. In 2010 vormden, voor de huishoudens in deze studie met een gas- en elektriciteitsaansluiting, belastingen $36 \%$ van de totale energiekosten. Het aandeel van de vaste kosten, die een woninggebruiker niet kan beïnvloeden door verlaging van zijn energiegebruik, was 12\% in 2009 en nam toe tot $19 \%$ van de totale energiekosten in 2010. De marginale energiekosten zouden zodoende het uitgangspunt moeten zijn bij de berekening van het financieel rendement van een ETM. Aan de andere kant biedt de waardestijging van woningen met een gunstig energielabel ten opzichte van vergelijkbare woningen uitkomst om een deel van de gedane investeringen terug te verdienen. Ondanks dat het totale energiegebruik van woningen en hun huishoudens daalt door kleine en grote investeringen, vertonen de totale energiekosten een stijgende lijn.

Ten derde is bestudeerd hoe de toepassing van ETMs in woningbouwprojecten plaats vindt. In bouwprojecten zijn vaak meerdere organisaties -architect, opdrachtgever, adviseurs en aannemer- betrokken en moeten diverse belangen worden meegenomen en afgewogen. In het proces om tot een ontwerp en, uiteindelijk, een nieuwe of gerenoveerde woning te komen, moeten er ook beslissingen worden genomen over de te implementeren of juist af te wijzen ETMs. Er zijn twee nieuwbouw- en twee renovatieprojecten bestudeerd van een sociale woningcorporatie. Uit deze studie blijkt dat er drie partijen zijn die vorm geven aan de beslissingen omtrent de implementatie van ETMs, namelijk de opdrachtgever, de architect en de installatieadviseur. De woningcorporatie nam als opdrachtgever de uiteindelijke beslissing. In theorie vindt de afweging plaats op basis van het belang van de huurder, die in de toekomst na betaling van energierekening nog voldoende financiële middelen over moet kunnen hebben om zijn of haar woning te kunnen huren. In de bestudeerde projecten bleken echter de investeringskosten, onderhoudskosten en betrouwbaarheid de argumenten te zijn. Er zijn op twee verschillende niveaus beslissingen te onderscheiden. Het Bouwbesluit zorgt voor een algemeen geaccepteerd basisniveau onder de actoren van toe te passen conventionele ETMs. Alle investeringen die verder gaan dan dit energetisch basisniveau, krijgen bijzondere aandacht van de actoren. Met als uitkomst dat het afwegingskader per ETM verschilt.

Ten vierde zijn de verkregen inzichten qua energieprestatiebepaling, financiële effecten en de inbedding in bouwprojecten gebruikt om de implementatiemogelijkheden van een nieuwe ETM te bepalen. Een implementatiestudie is uitgevoerd voor een nieuwe energietechniek, te weten faseveranderende materialen (PCMs). Deze materialen kunnen een latente warmtecapaciteit bieden voor temperaturen dichtbij de binnentemperatuur van een gebouw. Ze fungeren daarmee als een opslag voor thermische energie. Deze PCMs zijn in de Nederlandse bouwsector nog zeer weinig toegepast. Experimenteel onderzoek toont echter aan dat minimale binnentemperaturen stijgen en maximale binnentemperaturen dalen, wanneer PCMs op paraffine basis in betonvloeren worden mee gestort om op passieve wijze de binnentemperatuur te reguleren. Ondanks deze bemoedigende resultaten, lijkt brede implementatie van deze techniek in Nederland nog ver weg, omdat weinig bekend is over de 
precieze effecten van implementatie binnen de context van een specifiek project. Op basis van deze bevinding voor deze ETM, zijn er daarom vier vormen van implementatie onderscheiden voor ETMs in het algemeen, namelijk: ontwerpimplementatie, fysieke implementatie, marketing implementatie en gebruiksimplementatie. Een ETM moet zich dus op veel verschillende vlakken zien te bewijzen, alvorens de opdrachtgever, architect, adviseurs, aannemer, eigenaar en bewoners overtuigd tot implementatie over zullen gaan. Om ontwikkelaars en producenten van ETMs en de overheid met haar duurzame ambities een handreiking te doen, zijn op basis van dit onderzoek de volgende proposities opgesteld:

A. De kans op toepassing van een bepaalde ETM zal groter zijn, naar mate het werkelijk energiegebruik zoals ervaren door de gebruiker van de woning meer wordt gereduceerd;

B. De kans op toepassing van een bepaalde ETM zal groter zijn, naar mate de theoretische energieprestatieïndicator (EPC, $\mathrm{El}_{\text {oud }}$ en $\mathrm{El}_{\text {nieuw }}$ ) zoals ervaren door de actoren meer wordt gereduceerd;

C. De kans op toepassing van een bepaalde ETM zal groter zijn, naar mate investeringskosten $\left(\mathrm{CF}_{0}^{-}=\mathrm{CF}_{0.1 \text {; ontwerp }}^{-}+\mathrm{CF}_{0.2 \text {;product(-en) }}^{-}+\mathrm{CF}_{0.3 \text {;installatie }}^{-}\right.$zoals ervaren door de opdrachtgever van het bouwproject lager zijn;

D. De kans op toepassing van een bepaalde ETM zal groter zijn, naar mate de financiële besparingen $\left(\mathrm{CF}^{+}{ }_{\mathrm{a}}\right)$ zoals ervaren door de gebruiker van de woning groter zijn;

E. De kans op toepassing van een bepaalde ETM zal groter zijn naar mate de betrouwbaarheid $\left(\mathrm{CF}_{\text {a;onderhoud }}^{-}+\mathrm{CF}^{-}\right.$a;betrouwbaarheid $)$zoals ervaren door de eigenaar van de woning groter is.

Er kan op basis van het gedane onderzoek echter geen rangvolgorde aan deze proposities worden toegekend. Er kon in dit onderzoek wel worden vastgesteld dat de inhoud van propositie A wezenlijk kan verschillen met de inhoud van B. Dit betekent dat ondanks dat een ETM invloed heeft op het werkelijke energiegebruik van een woning met haar gebruikers, dit niet tot uitdrukking hoeft te komen in de theoretische energieprestatie, of vice versa. Evenzo hoeft de inhoud van propositie A niet te stroken met de inhoud van D. De situatie bestaat dat de toepassing van een ETM die het werkelijke energiegebruik reduceert, niet leidt tot een financiële besparing. De energiekosten kunnen zelfs stijgen.

De eerste wetenschappelijke bijdrage van dit proefschrift is het raamwerk afgebeeld in Figuur 0-2. Dit raamwerk maakt het ontwikkelaars en producenten van ETMs mogelijk om het implementatie potentieel van een ETM vast te stellen op basis van (1) haar effect op het werkelijke energiegebruik en op de theoretische energieprestatie, (2) haar financiële impact qua investeringskosten en jaarlijkse financiële stromen en (3) haar verenigbaarheid met de doelen van de belanghebbenden. De proposities en het raamwerk kunnen sturing geven aan diegene die nieuwe ETMs ontwikkelen, bestaande ETMs verbeteren en ze aanbieden aan de partijen in woningbouwprojecten. Het raamwerk kan bovendien worden gebruikt om te verklaren waarom bepaalde ETMs wel of niet succesvol zijn.

De tweede wetenschappelijke bijdrage is het inzicht dat het bijna onmogelijk is voor een nieuwe ETM om te worden toegepast in woningbouwprojecten. Er zijn namelijk tenminste 
vijf barrieres te onderscheiden, namelijk (1) de complexiteit van factoren die het energiebruik van woningen en hun bewoners bepalen, (2) de verplichte certificering ten behoeve van het behalen van de benodigde theoretische energieprestatie, (3) de gescheiden incentieven van belanghebbenden, 4) de opbouw van de energiekosten, (5) de veranderlijkheid van de mechanismen, die ten grondslag liggen aan de voorgaande vier barrières.

Om de implementatie van ETMs te verbeteren zullen uiteraard inspanningen nodig zijn van alle betrokkenen in bouwprojecten, maar er zijn met name inspanningen nodig die de effecten van een ETM transparanter kunnen maken. Meer gegevens zijn nodig over de effecten van ETMs, wanneer deze worden toegepast in een woning met al haar kenmerken. Om dit mogelijk te maken in de bouwindustrie waar bijna elke woning het unieke resultaat is van een samenwerking van meerdere partijen met korte termijn belangen en waarbij de gebruiker vaak niet bekend is, wordt aanbevolen dat de overheid proefprojecten initieert en stimuleert. Deze projecten dienen uitgebreid te worden gemonitord met betrekking tot alle effecten van de toegepaste ETM qua werkelijk energiegebruik, theoretische energieprestatie, financiele voor- en nadelen, en de toegepaste implementatiestrategie. 


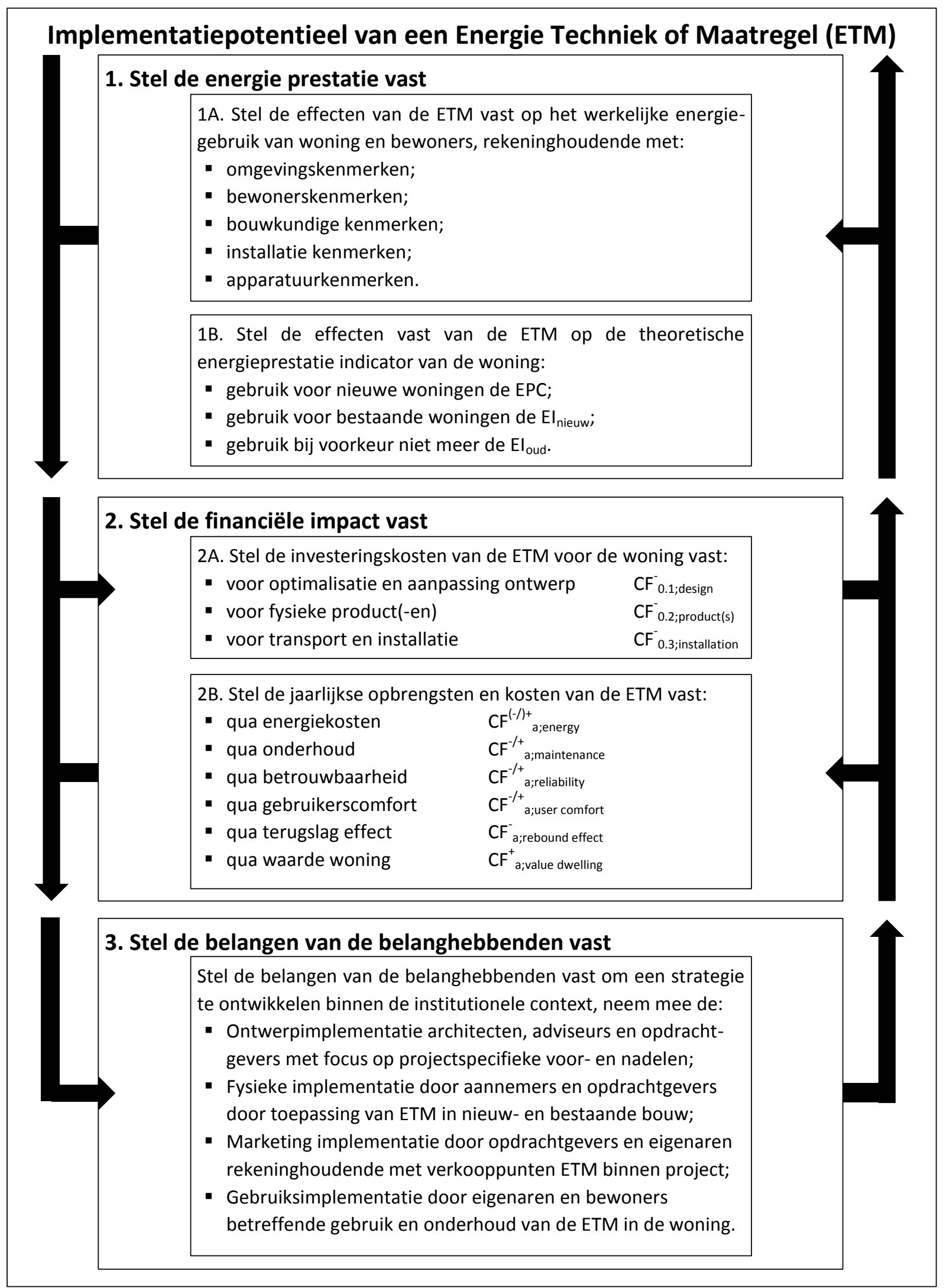

Figuur 0-2: Raamwerk voor ontwikkelaars en producenten van EnergieTechnieken en -Maatregelen (ETMs) om het implementatiepotentieel van een ETM in woningbouwprojecten vast te stellen 


\section{Academic output}

During the research, as presented in this thesis, the following academic output was generated by the author for an international audience.

\section{Journal contributions}

Entrop, A.G., Brouwers, H.J.H., \& Reinders, A.H.M.E. (2011). Experimental research on the use of micro-encapsulated Phase Change Materials to store solar energy in concrete floors and to save energy in Dutch houses. Solar Energy, 85(5), 1007-1020.

Entrop, A.G., \& Brouwers, H.J.H. (2010). Assessing the sustainability of buildings using a framework of triad approaches. Journal of Building Appraisal, 5(4), 293-310.

Entrop, A.G., Brouwers, H.J.H., \& Reinders, A.H.M.E. (2010). Evaluation of energy performance indicators and financial aspects of energy saving techniques in residential real estate. Energy and Buildings, 42(5), 618-629.

Hunger, M., Entrop, A.G., Mandilaras, I., Brouwers, H.J.H., \& Founti, M. (2009). The behavior of self-compacting concrete containing micro-encapsulated Phase Change Materials. Cement and Concrete Composites, 30(10), 731-743.

Müller, A., Kranzl, L., Tuominen, P., Boelman, E., Molinari, M., \& Entrop, A.G. (2011). Estimating exergy prices for energy carriers in heating systems: country analyses of exergy substitution with capital expenditures. Energy and Buildings, 43(12), 3609-3617.

\section{Book contribution}

Entrop, A.G. (2012). Energy-Saving Technologies in the Built Environment. In: Reinders, A., Diehl, J.C., \& Brezet, H. (Eds.), The Power of Design: Product Innovation in Sustainable Energy Technologies (pp. 206-217). John Wiley \& Sons.

\section{Conference contributions}

Entrop, A.G., \& Dewulf, G.P.M.R. (2011). The energy performance of office buildings throughout their building process. International Conference Management and Innovation for a Sustainable Built Environment, 19-23 June, Amsterdam, The Netherlands.

Entrop, A.G., \& Dewulf, G.P.M.R. (2011). Comparative study on the composition of energy bills. International Conference Management and Innovation for a Sustainable Built Environment, 19-23 June, Amsterdam, The Netherlands.

Entrop, A.G., \& Dewulf, G.P.M.R. (2010). Decision making processes and the adoption of energy saving techniques in social housing. ISBN 978-0-7844-1109-4, Proceedings of the 2010 Construction Research Congress, May 8-11, pp. 1416-1426, Banff, Canada.

Entrop, A.G., Brouwers, H.J.H., Reinders, A.H.M.E., \& Muthing, F. (2009). Experimental research on the use of phase change materials to come to passive solar energy concepts. $3^{\text {rd }} \mathrm{CIB}$ International Conferences on Smart and Sustainable Built Environments, June 1519, Delft, The Netherlands.

Entrop, A.G., \& Brouwers, H.J.H. (2009). The relation between the acquaintance of sustainable measures and the use of a sustainable assessment tool for buildings. $3^{\text {rd }} \mathrm{ClB}$ International Conferences on Smart and Sustainable Built Environments, June 15-19, Delft, The Netherlands. 
Hunger, M., Entrop, A.G., Mandilaras, I., Brouwers, H.J.H., \& Founti, M. (2009). The direct incorporation of micro-encapsulated Phase Change Materials in the concrete mixing process - A feasibility study. CMS 2009 conference on Life Cycle Design of Building Systems and Materials, June 12-15, pp. 141-148, Enschede, The Netherlands.

Müthing, F., Entrop, A.G., \& Brouwers, H.J.H. (2009). Research framework for an experimental study on phase change materials in scaled models of Dutch dwellings. CMS 2009 conference on Life Cycle Design of Building Systems and Materials, June 12-15, pp. 85-92, Enschede, The Netherlands.

Entrop, A.G., \& Brouwers, H.J.H. (2008). The profit of exergy in the built environment. Proceedings of the 2008 World Sustainable Building Conference, September 21-25, pp. 3367-3374, Melbourne, Australia.

Entrop, A.G., Brouwers, H.J.H., \& Reinders, A.H.M.E. (2008). Field experiments on the use of phase changing materials, insulation materials and passive solar radiation in the built environment. Proceedings of the 2008 World Sustainable Building Conference, September 21-25, pp. 102-109, Melbourne, Australia.

Entrop, A.G., Brouwers, H.J.H., Dewulf, G.P.M.R., \& Halman, J.I.M. (2008). Decision making processes and the adoption of energy saving techniques in residential and commercial real estate. Proceedings of the 2008 World Sustainable Building Conference, September 2125, pp. 1461-1468, Melbourne, Australia.

Entrop, A.G., \& Brouwers, H.J.H. (2008). Influence of past policies on today's energy saving initiatives. Proceedings of the 2008 World Sustainable Building Conference, September 21-25, pp. 145-152, Melbourne, Australia.

Entrop, A.G., \& Brouwers, H.J.H. (2007). Directing sustainable investments in commercial real estate. Proceedings of the Sustainable Building Conference 2007, September 12-14, pp. 1035-1042, Lisbon, Portugal.

Entrop, A.G., Reinders, A.H.M.E., \& Brouwers, H.J.H. (2007). Evaluation of financial aspects and EPIs of existing residential building stock in the Netherlands. Proceedings of the $2^{\text {nd }}$ International Congress on Environmental Planning and Management; Visions Implementations - Results, August 5-10, pp. 399-402, Berlin, Germany. 


\section{Contents}

Preface. 5

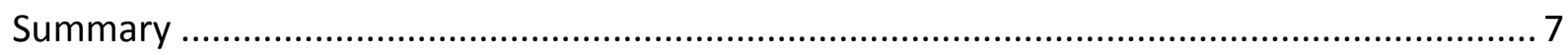

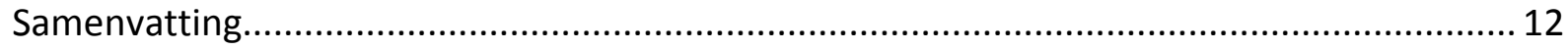

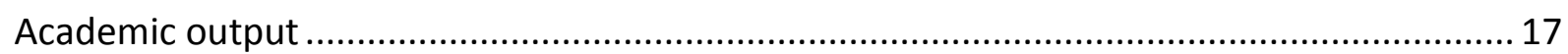

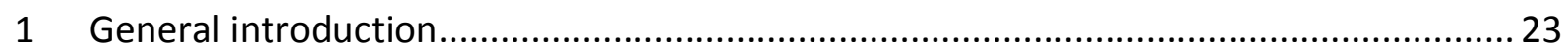

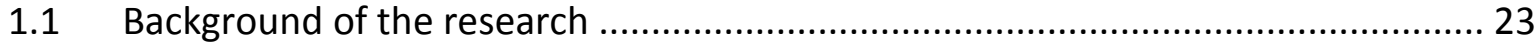

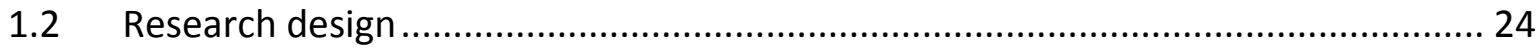

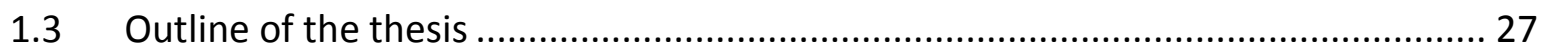

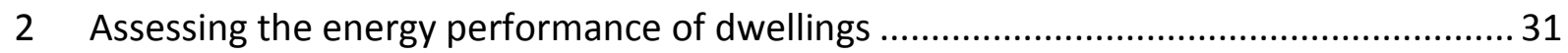

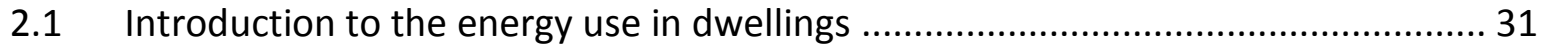

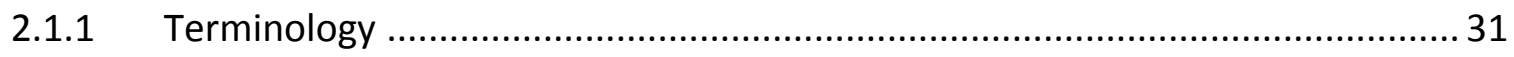

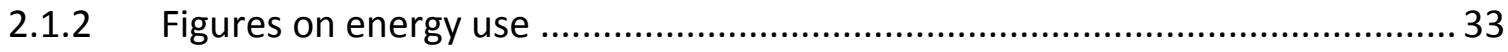

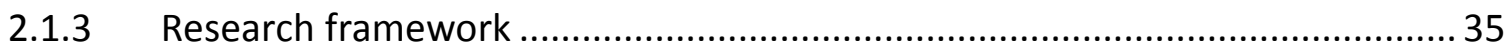

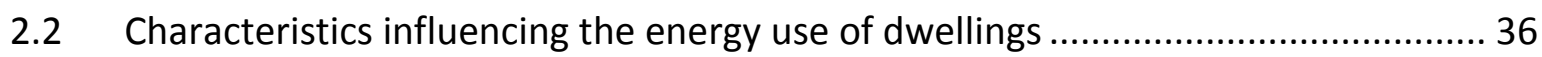

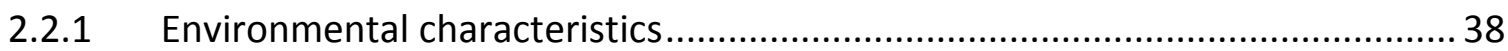

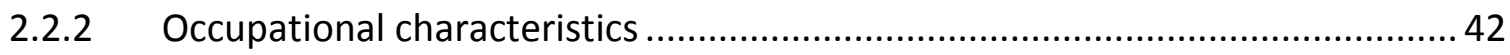

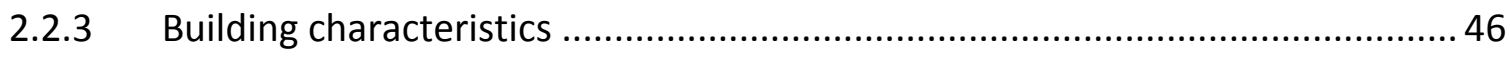

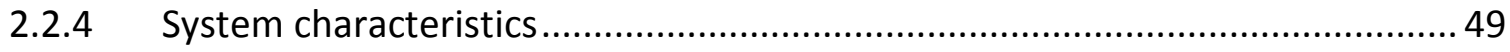

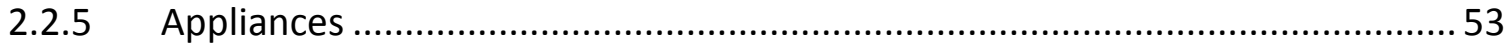

2.3 Methods to assess the energy performance of dwellings .................................... 55

2.3.1 Energy assessment methods for dwellings around the world ..........................56

2.3.2 Energy assessment methods for dwellings in the Netherlands........................ 61

2.4 Assessing the energy performance of dwellings in a case study ............................67

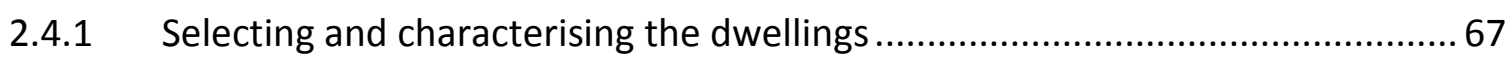

2.4.2 Energy performance of the dwellings based on assessment methods .............69

2.4.3 Household energy based on energy bills .................................................... 71

2.4.4 Energy performance of the dwellings based on energy bills ........................... 73 
2.5 Reflections on assessing the energy performance of dwellings ........................... 73

2.5.1 Reflection on calculated and actual energy uses .......................................... 74

2.5.2 Reflection on characteristics included in the assessment methods.................. 76

2.6 Conclusions on assessing the energy performance of dwellings ............................ 79

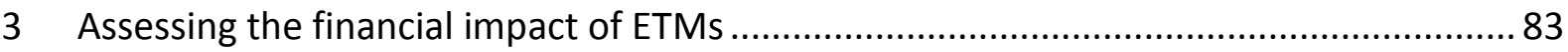

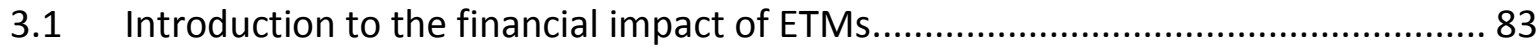

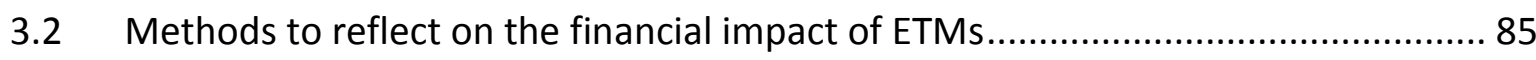

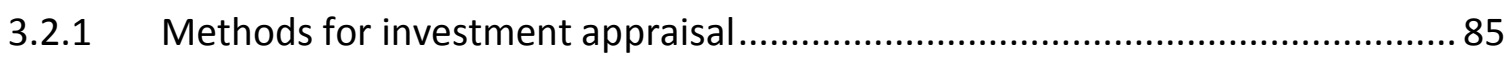

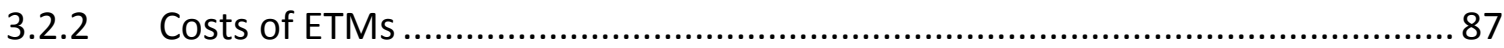

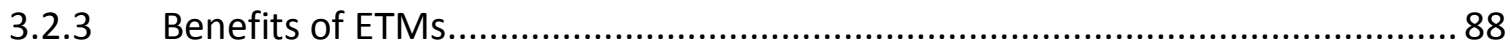

3.3 Constitution of energy costs of dwellings and their residents .............................. 90

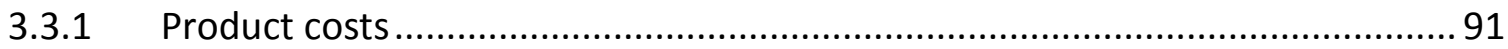

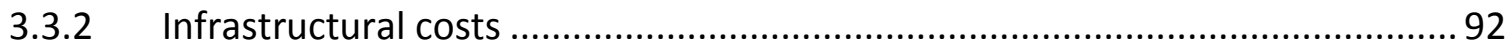

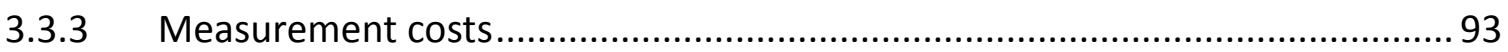

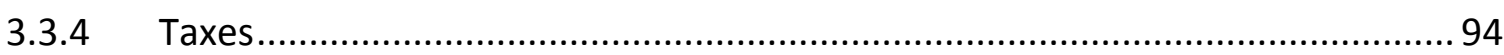

3.4 Constitution of energy costs of seven houses and their residents .......................... 95

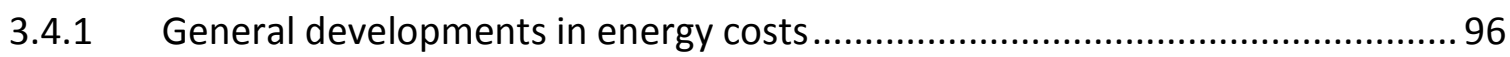

3.4.2 Case-specific developments in energy costs............................................... 98

3.4.3 Average versus marginal energy costs....................................................... 100

3.5 Assessing the financial impact of two ETMs in dwellings .................................... 102

3.5.1 Incorporating the changed value of a dwelling in the financial analysis ......... 103

3.5.2 General economic developments related to dwellings and energy ................. 104

3.5.3 Empirical financial analysis of individual ETMs ............................................. 106

3.6 Reflections on assessing the financial impact of ETMs ..................................... 109

3.7 Conclusions on assessing the financial impact of ETMs...................................... 110

4 Decision-making on ETMs in residential building projects ........................................ 113

4.1 Introduction to ETMs in residential building projects ........................................ 113

4.2 Theoretical background on ETMs in building projects ....................................... 115

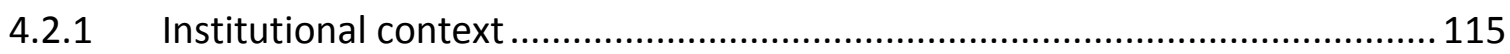

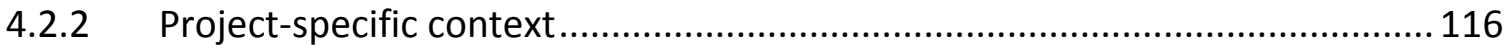

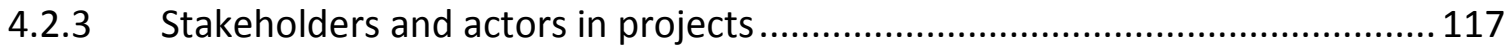




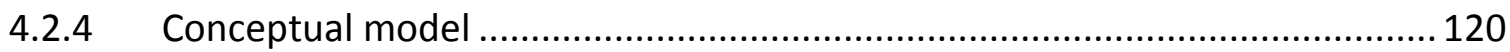

4.3 Research methodology to study decisions on ETMs in building projects .............. 122

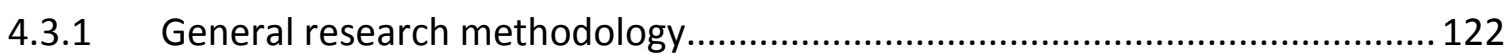

4.3.2 Operationalisation of the institutional context .......................................... 123

4.3.3 Operationalisation of stakeholders in building projects ................................ 124

4.3.4 Operationalisation of motives of stakeholders to implement ETMs............... 125

4.4 Case study on decision-making on ETMs in social housing ................................. 126

4.4.1 Institutional context related to social housing ............................................ 127

4.4.2 Case 1: designing and constructing new terraced houses............................... 133

4.4.3 Case 2: designing and constructing new apartments for seniors .................... 136

4.4.4 Case 3: designing and refurbishing duplex houses ........................................ 140

4.4.5 Case 4: designing the refurbishment of flats ............................................... 144

4.5 Analysing the decision-making on the implementation of ETMs ........................ 147

4.5.1 Analysing the implementation of ETMs within the institutional context........ 147

4.5.2 Analysing the implementation of ETMs by the stakeholders ........................ 150

4.5.3 Analysing the implementation of ETMs by means of project's requirements 152

4.5.4 Analysing the implementation of ETMs by means of used arguments ........... 153

4.6 Reflection on decision-making on ETMs in residential building projects .............. 154

4.7 Conclusions decision-making on ETMs in residential building projects................. 157

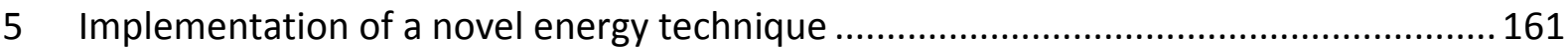

5.1 Introduction to the implementation of a novel energy technique ........................ 161

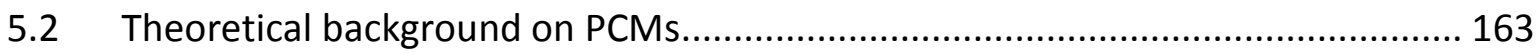

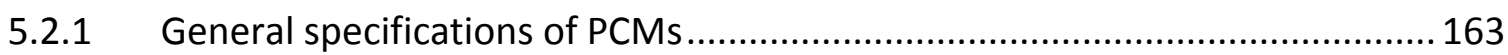

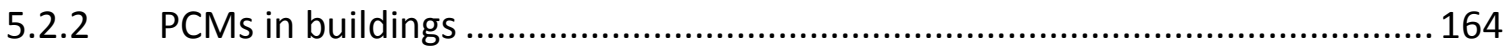

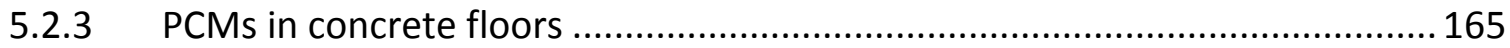

5.3 Assessing the effects of PCMs on the energy performance of dwellings .............. 167

5.3.1 Characteristics of dwellings influencing the performance of PCMs ................ 168

5.3.2 Including PCMs in energy assessment methods ........................................... 173

5.3.3 Reducing fossil energy use in dwellings ........................................................ 174

5.4 Assessing the financial effects of implementing PCMs .................................... 176

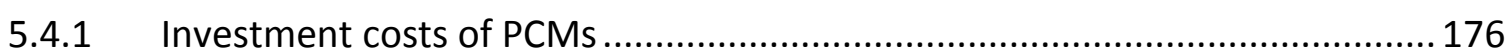

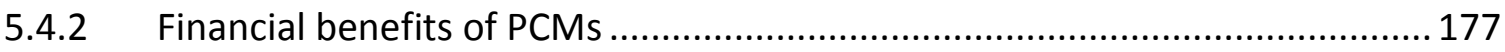


5.5 Assessing the effects for stakeholders of implementating PCMs ........................ 178

5.5.1 Implementing PCMs in floors of new and existing dwellings ........................ 179

5.5.2 Motives for stakeholders to implement PCMs in building projects ................ 180

5.6 Conclusions on the implementation of a novel energy technique ........................ 182

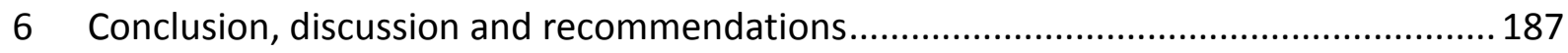

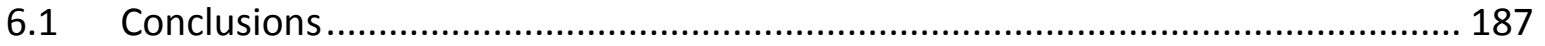

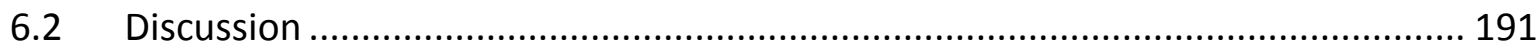

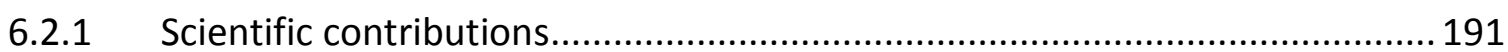

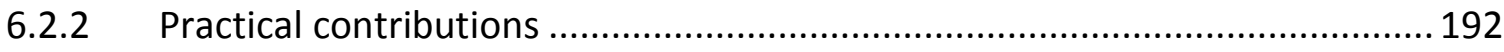

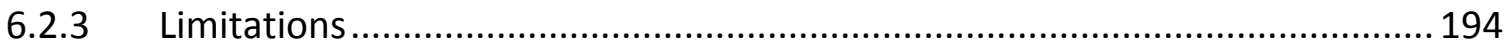

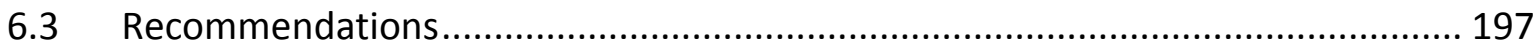

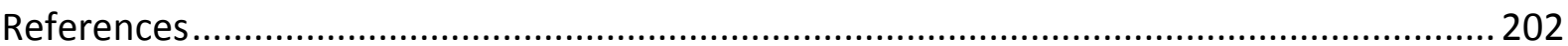

Appendix A: Detailed descriptions objects in case study on dwellings .............................. 213

Appendix B: Detailed overview energy bills in case study on dwellings.............................. 229

Appendix C: Interviews case study on building projects ................................................ 232

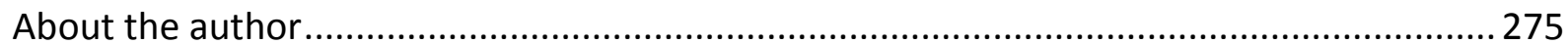




\section{General introduction}

This first chapter forms an introduction to the thesis. The background to the conducted research will be explained, as well as the research set-up and the outline of the thesis.

\subsection{Background of the research}

For thousands of years, people have used shelters to protect them from the natural environment. This natural environment can be too cold, too warm, too wet, too dry, or in some other way too hostile to live comfortably without some form of shelter. Already around 10,000 years ago, the first villages were appearing with buildings constructed from local materials. In 2011, the world population passed the figure of seven billion people (UNFPA, 2011). All these people have the right to grow up in a comfortable environment. Buildings are one of the most important products that can help provide such an environment.

However, as Ljungberg (2007, p. 466) observes, there seems to be at least four basic problems on this planet which are yet to be solved, namely over-consumption, resource utilization, pollution and overpopulation. Although these problems have often been addressed by scholars in the past, a general concept has only relatively recently been conceived to refer to processes that at least have the intention to achieve solutions to these problems. In 1987, the Brundtland Commission introduced the concept of sustainable development: sustainable development is development that meets the needs of the present without compromising the ability of future generations to meet their own needs (UN, 1987, p. 37). Since this concept was introduced, many governments, industries, organizations and people have embraced it and are trying to change their behaviour and actions in order to improve the ability of future generations to meet their own needs.

The construction industry is one that can make an important contribution to achieving a sustainable society. This industry uses a lot of materials and energy, resulting in the depletion of resources and polluting emissions. Buildings, the customary products of this industry, account for a large part of the energy used in most developed countries, again resulting in the depletion of fossil resources and polluting emissions. In the European Union, it is estimated that the built environment accounts for $40 \%$ of total energy use (EC, 2002; EU, 2010). If the construction industry was able to develop buildings that utilized low amounts of energy in providing a comfortable environment, this would amount to considerable progress.

Given that, in most developed countries, many people spend most of their time at home, most buildings are residential buildings and most energy is used in dwellings, this thesis will focus on residential buildings. Many different Energy Techniques and Measures (ETMs), such as insulation, double glazing, photovoltaic systems, thermal solar collectors, heat pumps, balanced ventilation systems with heat recovery, and wastewater heat exchangers, are available with the common aim of reducing fossil energy use in residential buildings. The implementation of these ETMs seems to have benefits for society through slowing the depletion of fossil fuels and cutting emissions (for residents by means of a lower energy use 
and reduced energy costs, and for those that commercially sell these ETMs through generating financial profits. Although benefits and rational behaviour might seem to go hand-in-hand, it is no easy task to understand why, in residential buildings, certain ETMs have been and are being implemented more so than others.

\subsection{Research design}

Research already pointed out that it is not an easy task to understand how the construction of residential buildings with a low environmental impact can be stimulated. It shows that in residential building projects the form of leadership influences how well techniques and measures are actually implemented (Bossink, 1998). Bossink (1998) uses the term goal erosion when the ambitions to implement ETMs, as stated at the beginning of a building project, are not achieved at completion. His research focused on interaction patterns in the process of developing residential buildings with the aim at formulating recommendations to improve the Dutch sustainable building policy. Research of Hoppe (2009) on policies aiming at reducing carbon dioxide emissions in existing residential buildings, also focused on ambitions to improve the energy performance of buildings by highlighting the interaction between stakeholders in residential building projects.

In this thesis the focus will be on ETMs. This research does not aim at providing long lists of ETMs for which the reduction in energy use, investment costs and financial profits are calculated. Although these kinds of data would be useful in building projects, this research wants to contribute to the design sciences, as defined by Van Aken (2004, p. 224), by generating insights into what processes take place in residential building projects that influence the implementation of ETMs. The generated insights need to help developers and manufacturers to improve their ETMs. Reflecting on the described problems in society, the main research question of this study is formulated as follows:

How to assess the implementation potential and impact of ETMs in residential building projects?

Some of the elements in this research question need an explanation. Central among these elements are the ETMs. In this thesis, ETMs are both physical systems and action plans used to accomplish a specific activity or task involving the transfer or conversion of energy to achieve acceptable comfort levels with less fossil fuel. Residential building projects are processes that have the goal of offering new dwellings or, in the case of renovation, improved dwellings to known or unknown future residents, and in which many people and organizations have tasks and interests. In the situation of a block of flats, the residential building will encompass multiple dwellings. The various people and organizations that have a task or interest in such a process are called stakeholders. In this thesis, the implementation potential is the likelihood that stakeholders will decide to use an ETM in a residential building in order to reduce its fossil energy use. This likelihood is based on characteristics of the ETM that have an impact, on energy use and energy costs for example, which depends on the context in which it is implemented and used. 
From a scientific perspective, it is important to have insights into what makes a certain ETM more likely than others to be implemented in residential building projects since implementation involves multi-criteria decision-making in multi-stakeholder projects. This means that the stakeholder that takes the decision to implement an ETM during the design and construction phase of a specific residential building needs to be able to forecast the relative advantage, in all respects, of that technique or measure for themselves and for other stakeholders, and specifically for the future residents. Based on the insights, it is the intent to offer a framework to assess the impact of an ETM in residential building projects.

From a practical viewpoint, it is important to have insights into what makes a certain ETM more attractive to those that buy and use it than others. Such insights will enable developers and manufacturers of ETMs to improve their products, and governments to effectively give direction to their environmental policies aimed at reducing polluting emissions and slowing the depletion of fossil fuels. Having now explained the basic elements reflected in the main research question and its relevance, the research objective in this thesis is summarized as:

To develop a framework to assess the implementation potential of ETMs on the basis of their effects on and for stakeholders in residential building projects.

As is often the case in design sciences (Van Aken, 2004), it is expected that the framework will provide prescriptions of a heuristic nature for ETMs in residential building projects. To be able to develop this framework, it is necessary to specify what effects ETMs have. Given that ETMs are developed and implemented with the aim of improving the energy performance of dwellings, the first element in this research reflects on how to assess energy performance. By implementing an ETM, it is expected that it not only will reduce energy use and improve the energy performance, but also that annual energy costs will fall. In this way, the investment in the ETM can be recouped. Therefore, the second element in this research is assessing the financial impact of an ETM. In building projects, it is expected that these two elements can be weighed up when the implementation of an ETM is being considered by the stakeholders, leading to a decision to either implement or reject. This decision-making process forms the third element of this research. Figure 1-1 shows how the implementation of an ETM is subjected to this multidisciplinary perspective.

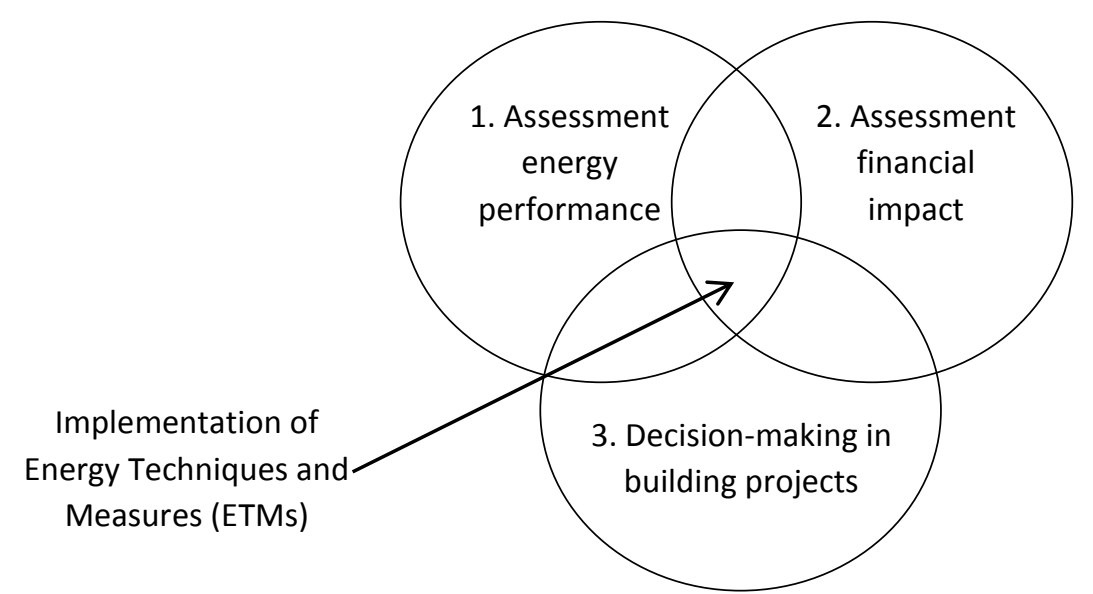

Figure 1-1: Visualization of the three elements forming the multidisciplinary perspective in developing a framework to assess the implementation potential of ETMs. 
The sequence in which these elements will be studied is based on the view that the financial impacts of ETMs are expected to be mainly in the form of reduced energy costs, and that these are based on the energy use of a dwelling and its residents.

As such, it seems logical to first become familiar with what the energy use and performance of dwellings and their residents actually are, before studying the financial element. A second consideration is that many stakeholders are involved in building projects, and these need to make many decisions in coming to the desired building. Some of these decisions will concern ETMs and will be recorded in documents. Other decisions regarding ETMs may be agreed verbally. One would expect all these decisions to be, at least partially, based on information available to the decision-maker. By first studying which calculation methods are applicable for determining the energy performance and financial impact of ETMs, it should be possible for the researcher to more easily interpret the information available in project documents and from the involved stakeholders. The research questions will now be addressed.

\section{Energy performance of residential buildings}

Given that the fundamental purpose of implementing ETMs in residential buildings is to reduce fossil energy use in a dwelling and by its residents, one needs to know what influence ETMs have on the energy use of dwellings. When considering the influence of ETMs on the energy use of a dwelling in relation to its context, the concept of energy performance is used. Therefore, the first task is to gain an understanding of how the energy performance of dwellings is influenced by ETMs. Hence, the first research question is:

Question 1: What influence do ETMs have on the energy performance of dwellings?

A literature study will be undertaken in order to specify characteristics that influence the actual energy use of residential buildings. Armed with this theoretical overview of characteristics, the standardized methods available to assess and calculate the energy performance of dwellings will be studied and analysed. The final step will involve case-study research in which these methods will be applied to existing houses whose actual energy use is known.

\section{Financial impact of energy techniques and measures}

Financial investments are needed to implement ETMs. Given that the financial costs and benefits are generally important, and often the most important argument in making a specific investment, the second element to be studied in this research is the financial impact of ETMs. Therefore, the second research question is formulated as:

\section{Question 2: What are the financial impacts of ETMs in residential building projects?}

Various methods are available in financial management for conducting an investment appraisal. In these methods, the costs and benefits are compared. A literature study on these methods will be conducted and data will be collected to reflect on the influence of the various elements in these investment appraisal methods when applied to ETMs. Given that the main aim is to reduce energy use, the relationship between energy use and costs will be studied on the basis of energy bills from a range of households. 


\section{Decision-making processes for energy techniques and measures in building projects}

The third element in this research considers how decisions on implementing ETMs are taken in building projects. Multiple stakeholders with different interests need to collaborate in such projects. Only some of these stakeholders will have an influence on the decisionmaking process regarding the implementation of ETMs. Some stakeholders will need to invest time and money in the implementation of an ETM while, when the building comes into use, other stakeholders will experience the benefits of the implementation. To gain insights into the ETM implementation process in multi-stakeholder building projects, the following research question is posed:

\section{Question 3: How in residential building projects are decisions on the implementation of ETMs taken?}

It is expected that, maybe unintentionally, some barriers or drivers will exist that respectively prevent or stimulate the implementation of certain ETMs. To address this issue, longitudinal case study research covering several building projects will be conducted in order to find out how stakeholders decide to implement or to reject certain ETMs in the context of specific building projects. The question is who takes decisions, and on the basis of what arguments, and what barriers exist to implementation.

\section{Implementation potential of new energy techniques and measures}

The answers to the above three questions are expected to result in insights into the impact of ETMs in residential building projects. These insights can be used in creating guidelines for their use when designing new or improving existing ETMs. They are also expected to form the basis for the assessment framework to be applied to a new ETM. The fourth research question is therefore stated as follows:

\section{Question 4: How can a novel ETM be implemented in residential building projects?}

This fourth and final research question will be answered by investigating one energy technique as a specific case. A novel energy technique will be considered that is generally unfamiliar to stakeholders in the construction industry, namely Phase Change Materials (PCMs). The results of experimental research into the application of PCMs in concrete floors form the starting point. How the insights gained by answering the previous three research questions can be used in assessing the implementation potential of these PCMs in residential building projects will be considered.

\subsection{Outline of the thesis}

The research in this thesis aims to gain insights into the implementation potential of ETMs by means of their influence on the energy performance of dwellings, their financial influence and their role in residential building projects. The chapters are related to the research questions presented above and the research objective as shown in Figure 1-2. The contents of the individual chapters will now be consiely described.

Chapter 2 elaborates on the variables that influence the energy use of dwellings. Some of these variables are already incorporated in the many existing energy assessment methods 
around the world. Three assessment methods, adopted in the Netherlands, will be applied to eight Dutch dwellings to assess the differences that exist between the estimated buildingrelated energy use and the actual energy use of dwellings.

Chapter 3 concerns the financial impacts of ETMs for households. One assumes that an ETM is implemented to reduce energy use and that this is expected to result in lower energy costs. Through this mechanism, the investment in the ETM can be recouped. The constituent components of investment appraisal methods are studied, followed with the suggestion to incorporate additional elements. Seven out of the eight households used in Chapter 2 were able to provide energy bills, from which I could study the components of energy costs over several years. The financial returns on two specific investments made by two households to influence their energy use were calculated.

Chapter 4 focuses on how implementation decisions were made concerning ETMs in building projects where multiple stakeholders needed to collaborate. Literature on the institutional context, project management and stakeholders in projects was first studied in order to develop a research framework for application in a case study. Four social housing projects were chosen as cases. Interviews were held and documents studied in order to gain insights into which ETMs are discussed in residential building projects, and when and why. The chapter explains how energy techniques are either rejected or implemented by some of the stakeholders involved in building projects.

Chapter 5 pulls the insights from the preceding three chapters together. The insights gained into assessing the energy performance, the financial impact and the role of ETMs in residential building projects are used to develop an approach that could boost the likelihood of a novel ETM, namely Phase Change Materials (PCMs), being implemented in buildings. In advance of this study, experimental research was conducted on the thermal effects of incorporating PCMs in concrete. The possibility of improving the thermal capacity and thermal resistance of concrete in this way could reduce fossil energy use in buildings. This chapter explains how the implementation of PCMs in actual building projects could take place.

Chapter 6 is the final chapter of this thesis and presents the conclusions, discussion and recommendations. The conclusions provide an answer to the main research question and present the framework developed for developers and manufacturers of ETMs to assess the implementation potential of an ETM on the basis of their effects for stakeholders in residential building projects. After the conclusions, the contributions and limitations of the research are discussed. In the final section, several recommendations are provided that could help the government, the internal stakeholders in residential building projects and the developers of new ETMs to improve their implementation potential. 


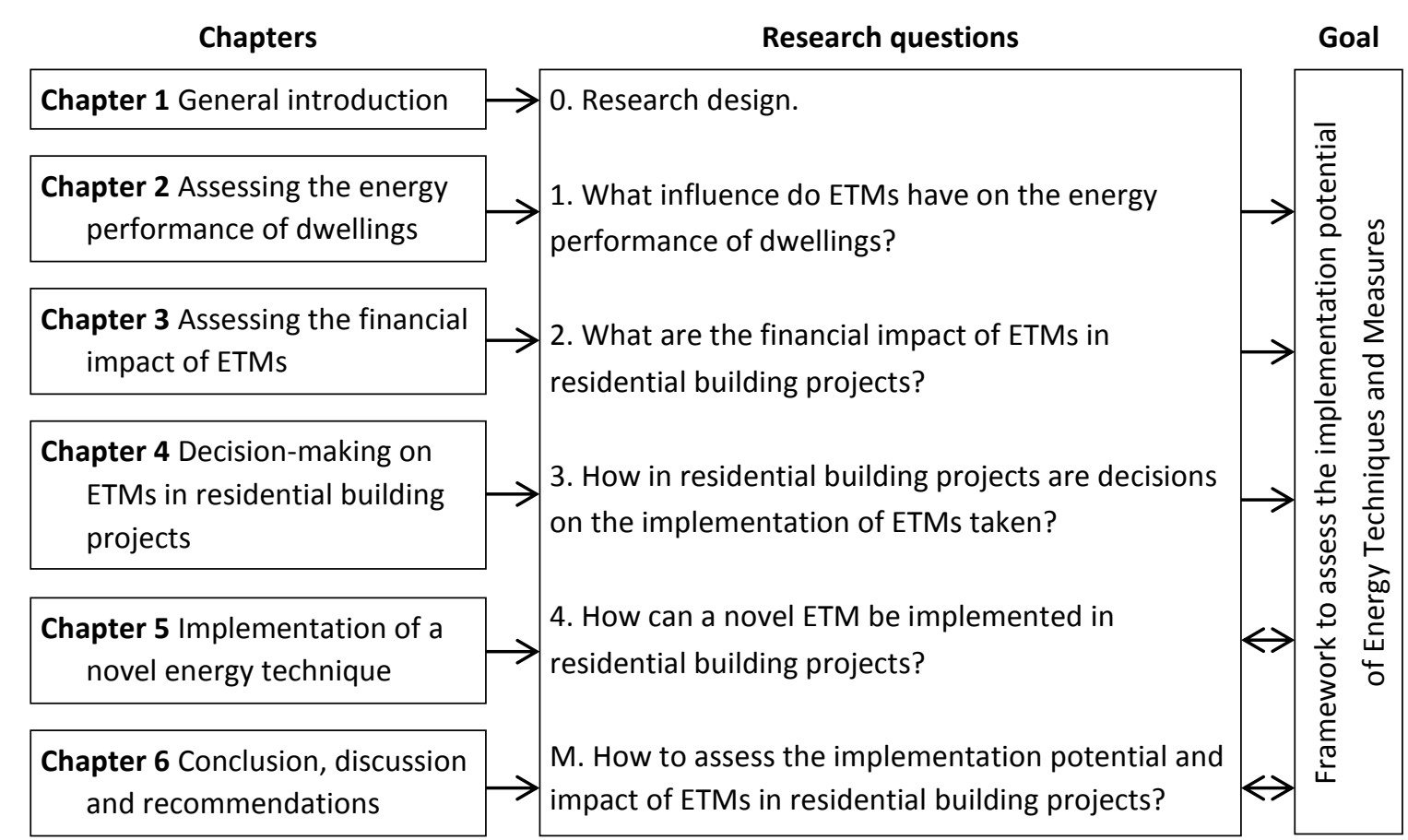

Figure 1-2: Outline of the chapters and research questions leading to satisfying the research objective. 
$-30-$ 


\section{Assessing the energy performance of dwellings}

The first research question, on what influence do ETMs have on the energy performance of dwellings, will be answered in this chapter. A literature study is conducted to find out which characteristics influence the energy use of dwellings. Existing methods to assess the energy performance of dwellings are studied and applied to eight dwellings in a case study. This case study provides insights into which characteristics are taken into account when estimating the energy use of dwellings and calculating their energy performance.

\subsection{Introduction to the energy use in dwellings}

In this introduction, insights are given into the terminology used in discussing energy use in dwellings. Furthermore, some values are presented on energy use in dwellings.

\subsubsection{Terminology}

The term energy is commonly used in the news, in commercials and in daily life. Nevertheless, defining the word is no easy task. The word energy comes from the Greek

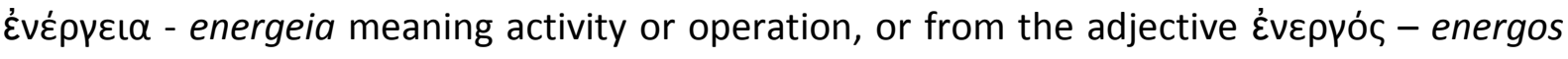
meaning active or working. Energy exists in many forms, for example nuclear energy, chemical energy, kinetic energy and potential energy. The conversion of energy from one form to another is always subject to certain principles, known as the laws of thermodynamics. The first law of thermodynamics states that energy cannot be created, nor destroyed. The quantity of energy stays the same and only its form can change. The second law of thermodynamics is stated in various ways, but essentially expresses the fact that thermodynamic processes take place in such a way that, within a closed system, thermodynamic equilibrium will be achieved over time, e.g. fresh coffee of $60{ }^{\circ} \mathrm{C}$ in a mug will always lose thermal energy in an environment of $20^{\circ} \mathrm{C}$, although the same amount of thermal energy leaving the coffee was also needed to heat it from $20^{\circ} \mathrm{C}$ to $60^{\circ} \mathrm{C}$. Although the amount of energy stays the same in conversion processes, the potential of an amount of energy to conduct work can reduce. By this means energy has a certain quality.

When applying these insights from the field of thermodynamics to the built environment, it will become apparent that the energy input into dwellings, in the form of natural gas, district heating or electric energy for example, is not lost but will leave the dwelling in the form of thermal energy through the thermal shell by means of conduction, convection and radiation. Traditionally, the energy use of a dwelling is considered to be the sum of all the energy forms artificially and externally provided to it by a communal infrastructure. Although many households benefit from solar irradiation, this form of energy is generally not explicitly included when assessing or calculating the energy use of a dwelling. Solar irradiation is however explicitly taken into account when an energy balance is made for a dwelling. An energy balance relates the incoming energy flows with the outgoing energy flows over a certain period. Given the introduction of photovoltaic panels and solar collectors, the energy use of a dwelling in the traditional sense will be further reduced, but the need for energy to operate all the electric, mechanical and heating systems in a dwelling will not be reduced. In other words the amount of energy leaving the thermal shell will not be any lower. This 
means that it is necessary to distinguish between energy use and energy need, as defined in Table 2-1.

Table 2-1: Definitions regarding the energy use of buildings as used in this thesis.

\begin{tabular}{|c|c|}
\hline Terminology & Definition \\
\hline Energy need & $\begin{array}{l}\text { Amount of energy, as the sum of multiple energy forms both natural and artificial, } \\
\text { needed in a house to satisfy the residents' desired indoor climate and use of systems } \\
\text { and appliances, as partially described in Standard EN-ISO } 13790 \text { (ISO, 2008). Within this } \\
\text { definition, solar irradiance is thus explicitly taken into account in the energy balance. }\end{array}$ \\
\hline Energy use & $\begin{array}{l}\text { Amount of energy, possibly a combination of multiple energy forms, that is artificially } \\
\text { and externally provided to a dwelling by a communal infrastructure, as based on the } \\
\text { standard NEN } 7120 \text { (NNI, 2011). In Dutch dwellings, meters are installed showing how } \\
\text { much energy is used in terms of } \mathrm{m}^{3} \text { of natural gas provided by the gas network, kWh of } \\
\text { electrical energy provided by the power grid and/or GJ of thermal energy provided by } \\
\text { district heating systems. In this definition, no typical use is defined and thermal energy } \\
\text { provided by solar irradiance is implicitly used. }\end{array}$ \\
\hline Energy demand & $\begin{array}{l}\text { Amount of energy associated with a typical use of a building in specified climatic } \\
\text { conditions. This includes energy used for heating, cooling, ventilation, hot water and } \\
\text { lighting less the amount of energy provided by energy systems in and on the building } \\
\text { that make use of renewable resources. Energy demand is in other words the building- } \\
\text { related energy use as based on the standard NEN } 7120 \text { (NNI, 2011). }\end{array}$ \\
\hline $\begin{array}{l}\text { Energy } \\
\text { performance }\end{array}$ & $\begin{array}{l}\text { An equation expressing the annual energy demand or building-related energy use of a } \\
\text { building in relation to its size, as based on the EPBD (EU, 2010). }\end{array}$ \\
\hline Primary energy & $\begin{array}{l}\text { Energy that has not been the subject of conversion or transformation processes, as } \\
\text { described in NEN } 7120 \text { (NNI, 2011) and NEN-EN } 15603 \text { (NNI, 2008). For a building, it is } \\
\text { the energy used to produce the energy delivered to the building. It is calculated from the } \\
\text { delivered and exported amounts of energy carriers, using conversion factors (NNI, 2008, } \\
\text { p. 10). }\end{array}$ \\
\hline Secondary energy & $\begin{array}{l}\text { In contrast to primary energy, secondary energy is the energy after one or more } \\
\text { conversion or transformation processes at the direct disposal of the user. }\end{array}$ \\
\hline
\end{tabular}

When assessing buildings, their energy performance is a major point of focus, and this needs to express how well a building was designed and constructed from an energetic point of view. The European Directive on the Energy Performance of Buildings (EPBD) describes calculation methods for the underlying energy performance as follows:

The energy performance of buildings should be calculated on the basis of a methodology, which may be differentiated at national and regional level. That includes, in addition to thermal characteristics, other factors that play an increasingly important role such as heating and air-conditioning installations, application of energy from renewable sources, passive heating and cooling elements, shading, indoor air-quality, adequate natural light and design of the building. The methodology for calculating energy performance should be based not only on the season in which heating is required, but should cover the annual energy performance of a building. That methodology should take into account existing European standards (EU, 2010, p. 153/14).

Following this, the directive gives the following concise definition of the energy performance of a building: the calculated or measured amount of energy needed to meet the energy 
demand associated with a typical use of the building, which includes, inter alia, energy used for heating, cooling, ventilation, hot water and lighting (EU, 2010, p. 153/18). In this definition the concept of energy demand is introduced. Energy demand refers to the energy use in the sense of the total amount of energy externally provided to a building via infrastructural networks to fulfil the basic conditions of a comfortable and healthy building constructed in line with building regulations (see Table 2-1). As such, the energy demand can also be described as the building-related energy use.

In the directive it is also indicated that the annual building-related energy use should be expressed in units of $\mathrm{kWh} / \mathrm{m}^{2}$ of floor surface as a numerical indicator for the energy performance of a building. The energy performance is intended to compare the energy demands of buildings of different sizes with each other. In the remainder of this chapter it will become clear that multiple Energy Performance Indicators (EPIs) exist that incorporate different variables that influence the energy use of dwellings in various ways. For the time being, the definition given in Table 2-1 suffices.

The final terminology that needs attention in this section is the distinction made between primary and secondary energy. Primary energy covers the raw energy forms or fuels that are required as input to an energy conversion process. Examples are crude oil, solar energy and wind energy. Primary energy is often further categorized either as renewable or as nonrenewable energy. When energy conversion takes place, the output is addressed using terms such as energy carriers or secondary energy. Here, one can think of car fuels, electricity, mechanical work. The conversion from primary energy to secondary energy can take place inside or outside dwellings or utility buildings. For example, natural gas is converted into heat inside many Dutch dwellings and into electric energy outside most Dutch dwellings. It is important to be aware that work potential is lost in these processes. In the Netherlands, when a household needs $1 \mathrm{kWh}$ (3.6 MJ) of electricity (secondary energy), $2.56 \mathrm{kWh}$ (9.22 MJ) of primary energy is typically used.

The six definitions in Table 2-1 form a basis for analysing the energy needs, uses and demands of dwellings and households and when studying the many documents that are available on these topics. It is important to distinguish between how much energy residents need (energy need), how much energy residents harvest themselves (energy need minus energy use) and what the minimum requirements could be (energy demand) in order to understand the energy performance of buildings in the past, and whether this can be improved in the future. In this thesis, the focus will be on 1 . the actual energy use of dwellings and their residents and 2. the theoretical building related energy use or energy demand of dwellings and their residents.

\subsubsection{Figures on energy use}

Worldwide, the total energy use is estimated at $500 \mathrm{EJ}\left(500 \cdot 10^{12} \mathrm{MJ}\right)$ per year. According to the European directive on the energy performance of buildings, buildings account for $40 \%$ of the total energy use in the European Union (EU, 2010). The total energy use in Europe was around 114 EJ in 2009 (Eurostat, 2013). Similarly, the United States Energy Information Administration claim that buildings account for roughly $41 \%$ of the total energy use in the 
United States (EIA, 2011). This means that around $42 \mathrm{EJ}\left(42.2 \cdot 10^{12} \mathrm{MJ}\right)$ of energy is used annually in American buildings. In the Netherlands, a total of 3495 PJ (3.5 EJ) of energy was used in 2010 (CBS, 2011a), of which 425 PJ was used in households. This amounts to a decrease of $25 \%$ compared to 2006 when residential buildings accounted for $570 \mathrm{PJ}$, which is around $17 \%$ of total energy use.

The energy use in all buildings was estimated at 950 PJ in 2006 (PeGO, 2007), around 29\% of the total annual energy use at that time. As such, the percentage of energy use in Dutch buildings seems rather low compared to the percentages given for Europe as a whole and the United States. Possible reasons for this difference could be the moderate climate and the relatively high physical quality of the existing building stock combined with a relatively small building shell. Despite the Netherlands having a quite extensive petrochemical industry, the Dutch energy use to national gross domestic product ratio is comparable to other European countries. Further, there are relatively many companies involved in transport and logistics, which are considered to use relatively large quantities of energy, reducing the relative contribution of buildings to total energy use (PBL, 2011).

In the Netherlands, many dwellings receive their secondary energy through connections to the electricity power grid and the natural gas network. A small, but not insignificant, part of the housing stock is connected to a district heating system. In 2010, the average dwelling's primary energy use was $86.1 \mathrm{GJ}$, made up of 3,480 kWh of electric energy and 1,617 $\mathrm{m}^{3}$ of natural gas (Energie-Nederland, 2011a). The average energy use in those dwellings heated by thermal energy from a district heating system was $35.28 \mathrm{GJ}$ of thermal energy in 2010 and 4,050 kWh of electric energy (Energie-Nederland, 2011b). These dwellings are considered comparable with dwellings connected to the natural gas grid that consume $1,380 \mathrm{~m}^{3}$ of natural gas and 4,021 kWh of electric energy on average (Energie-Nederland, 2011b).

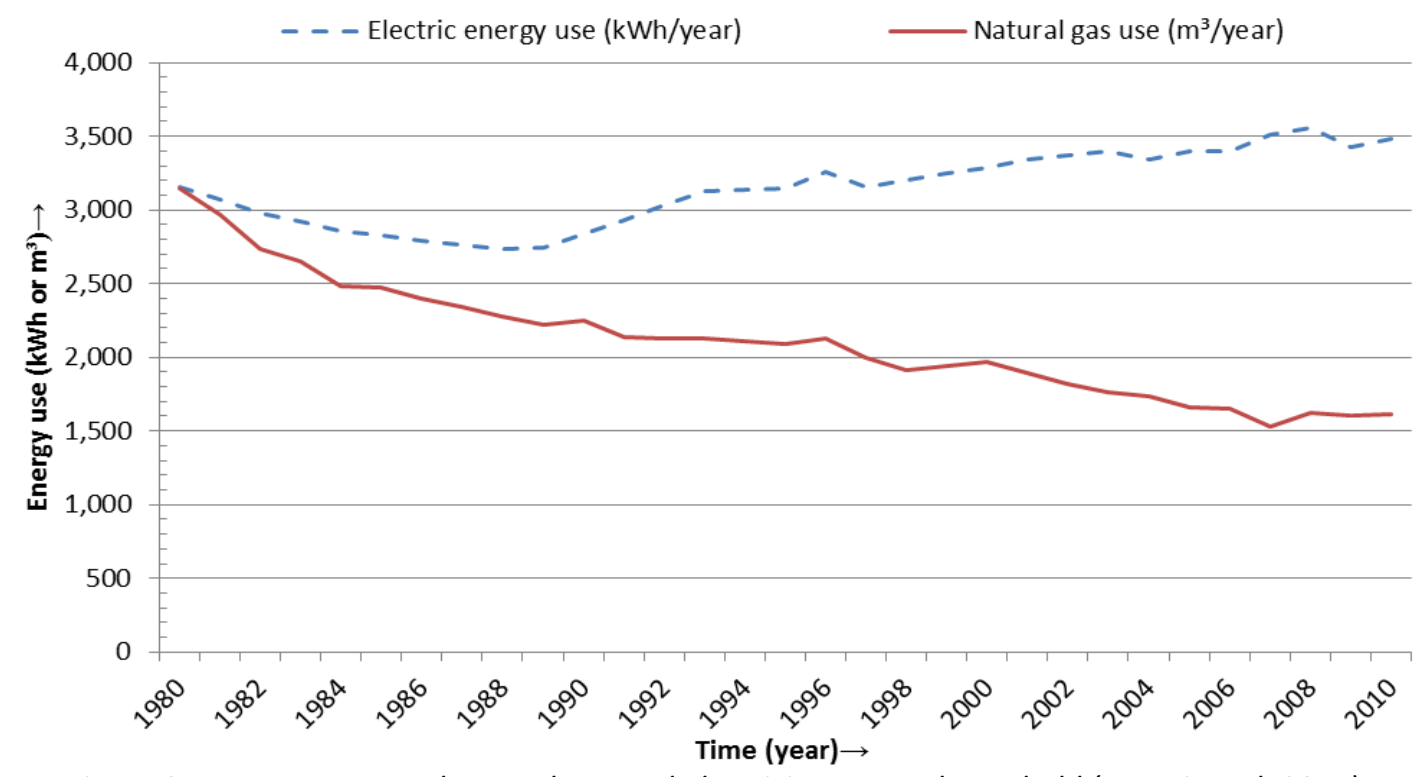

Figure 2-1: Average annual natural gas and electricity use per household (EnergieNed, 2011).

In the past three decades, the average energy use in Dutch houses has been decreasing (ECN, 2011, Energie-Nederland, 2011a) with many technical, social and economic 
developments having had an impact on households' natural gas consumption and electric energy use. The average annual natural gas consumption (generally used for heating living space, for heating tap water and for cooking) decreased from $3,145 \mathrm{~m}^{3}$ in 1980 to $1,617 \mathrm{~m}^{3}$ in 2010. The average annual electric energy use increased from 3,152 to 3,480 kWh over the same period, with a peak of 3,558 kWh in 2008 (see Figure 2-1).

Converting these values of $\mathrm{m}^{3} /$ year and $\mathrm{kWh} /$ year into $\mathrm{MJ} /$ year makes it easier to see how much energy per household is actually used (see Figure 2-2). The energy content of $1 \mathrm{~m}^{3}$ natural gas, based on an average calorific value of $33.41 \mathrm{MJ} / \mathrm{m}^{3}$, is equivalent to $9.3 \mathrm{kWh}$ of electric energy. However, reflecting on the primary energy used to produce electric energy, then $1 \mathrm{~m}^{3}$ of natural gas equals only $3.6 \mathrm{kWh}$ of electric energy ${ }^{1}$. In that case, the total primary energy use in 1980 was $134 \mathrm{GJ} /$ year. By 2010, this had reduced by $36 \%$ to 86 $\mathrm{GJ} /$ year. Although the average domestic natural gas consumption has been decreasing for many years, its share in the total energy use of a dwelling is still around $63 \%$.

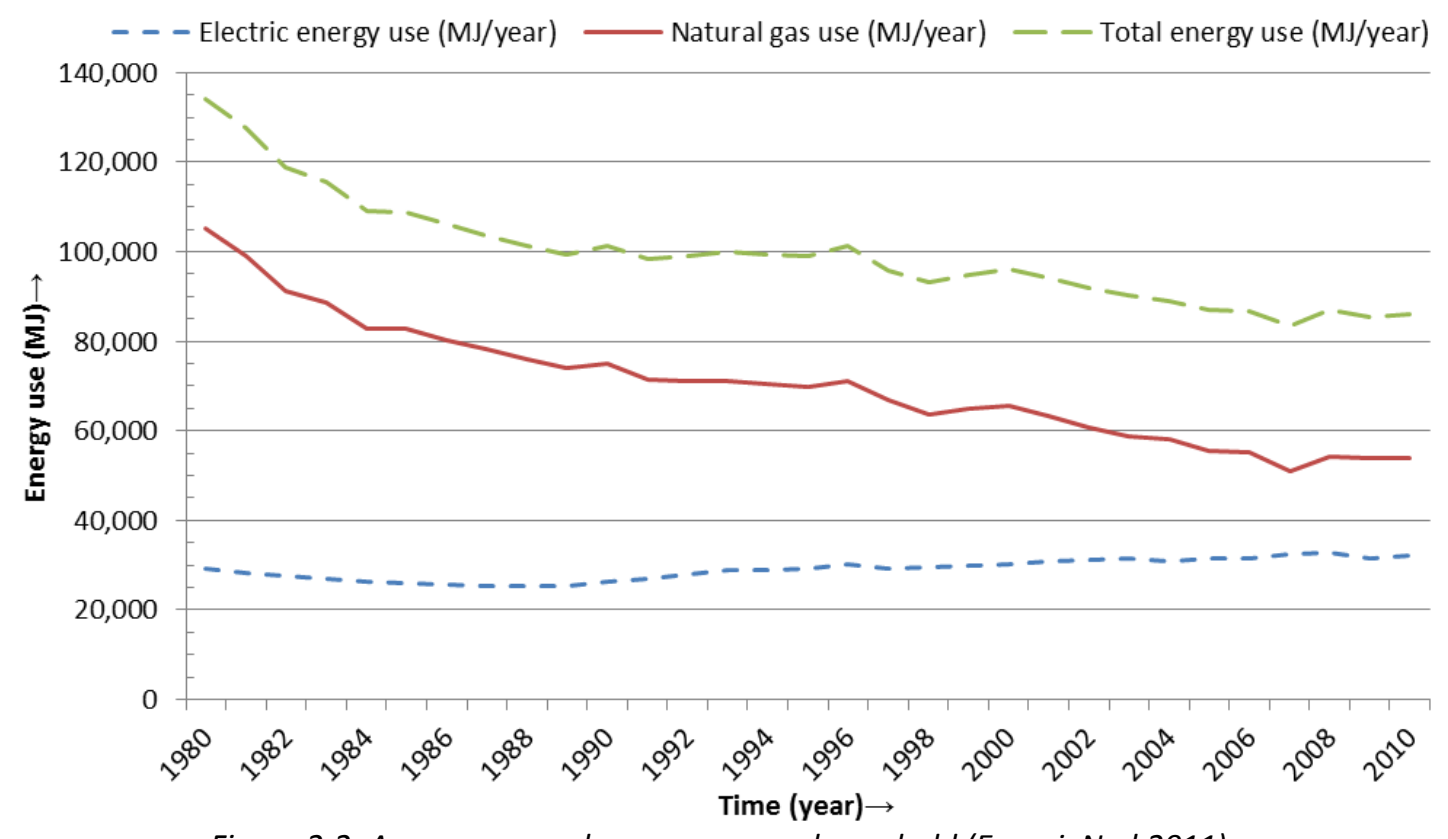

Figure 2-2: Average annual energy use per household (EnergieNed,2011).

\subsubsection{Research framework}

This chapter started with some definitions and figures regarding the energy use of buildings. The following sections will focus specifically on the influence of ETMs on the energy performance of dwellings. This is the first main research question to be answered and, in order to answer this question, three research questions are formulated for this chapter.

\section{A: What characteristics influence the energy use of $d$ wellings and their residents?}

When it comes to dwellings, many different forms and shapes exist. People residing in these dwellings will also differ in terms of their preferences and behaviours regarding building and energy use. Scholars have already conducted research on how energy use is related to

\footnotetext{
${ }^{1}$ In assessing electric energy use, the average efficiency of Dutch power plants $(\eta=0.39$ ) is used to determine the so-called primary energy use. In line with Dutch energy performance calculation methods, no conversion efficiency rate is taken into account with natural gas use.
} 
certain characteristics and so, to answer this first question, a literature study will be conducted on characteristics that influence the energy use of dwellings and their residents.

1B: What methods exist to reflect on the energy use and performance of dwellings?

In the quest to have dwellings that use less fossil fuels, many methods have been developed to reduce their energy use and to improve their energy performance. Within the European Union, every country has developed an assessment and calculation method to reflect on the energy use and performance of buildings. Three Dutch methods will be considered and analysed in this chapter.

\section{C: How can these methods be applied to Dutch houses and their residents?}

After studying the standards underlying the assessment and calculation methods, insights are needed into how they can be applied to actual buildings. To experience what characteristics have a role in assessing the energy performance of houses and to analyse how well the calculated results reflect the actual energy use of the houses, the methods to assess and calculate the energy performance will be applied to eight houses.

\subsection{Characteristics influencing the energy use of dwellings}

In the first section, the concepts of energy need, use and demand were discussed, addressing the different ways in which energy is provided to and used in buildings. In this section, more attention is paid to the various characteristics of dwellings and their users that influence the energy need, use and demand of dwellings.

In the past, many relationships have been examined between the technical characteristics of a dwelling, or the social characteristics of its residents, and, on the other hand, energy need, use or demand. A close look will be taken here at the multiple social and technical relationships associated with energy need, use and demand of dwellings. Many social relationships were addressed by Guerra Santín et al. (2009). Their list of variables and relationships is further extended in this section in order to gain a clear picture of which characteristics eventually influence the energy need, use or demand of a dwelling. A theoretical framework will be developed in this section based on both physical and social variables. Guerra Santín et al. (2009) further provide a comprehensive list of international studies addressing the influence of certain characteristics on a dwelling's energy demand for water and space heating. In this list, they divided the characteristics found in international references into three categories:

1. Building characteristics: here the authors note six elements as having been previously researched, namely: urbanisation rate, age of buildings, design of dwelling, insulation, heating systems, and type of energy;

2. Household characteristics: here they offer four elements as having been researched: age of residents, household size, income of residents, and form of ownership;

3. Behaviour: here they note four elements as having been researched before: space heating preferences, presence at home and associated hot water usage, ventilation, and value patterns. 
Although no detailed definitions of these three categories were offered, and Guerra Santín et al. (2009) only pay detailed attention to household characteristics and behaviour in their literature study, they do analyse the impact of building characteristics using a dataset containing empirical information on the building quality of approximately 15,000 houses.

Guerra Santín et al.'s (2009) "building characteristics" category includes an element entitled "urbanisation rate" despite this not being a characteristic of an individual dwelling, but rather a characteristic of the local environment in which the dwelling is located. Given that they focus on the situation in only the Netherlands, there was little need to incorporate or reflect on other environmental characteristics. However, in an international context the natural meteorological conditions are the main reason that dwellings (or buildings in general) are needed. Providing a comfortable climate for a range of human activities, buildings are, in terms of their energy use, primarily dependent on the environmental conditions. It seems therefore logical to add an "environment" category that encompasses transcendental variables. These variables exceed the level of an individual dwelling, e.g. meteorological conditions, surroundings, etc.

Even after the "urbanisation rate" element is moved to this new "environment" category, the elements in the "building characteristics" category as proposed by Guerra Santín et al. (2009) still seem at odds with insights offered by other scholars such as Poel et al. (2007) and Zheng et al. (2010). Many researchers and assessment methodologies distinguish building or architectural characteristics from system or installation characteristics. In addition to these two categories related to the building itself, the impact of appliances, both small moveable and large immovable, should not be ignored. Guerra Santín et al. (2009) acknowledge this, albeit without giving lighting, appliances and equipment a specific place within their categories, by referring to a value of $11 \%$ of total energy use in European residential buildings being for lighting and appliances (EuroACE, 2004). This percentage dates from 2001, and with the introduction of more advanced and more diverse electric appliances since then, it seem likely this percentage will have increased. In this thesis, three categories will be distinguished: building characteristics, systems characteristics, and appliances.

According to Janda (2011, p. 20) "building users play a critical but poorly understood and often overlooked role in the built environment". The title of her paper "Buildings don't use energy: people do" expresses the important role of buildings users. Guerra Santín et al. (2009) have two categories that can be seen as related to building users, both residents and households, namely "household characteristics" and "behaviour". These two categories seem closely related to each other and it does not seem unreasonable that characteristics such as the age of residents, household size and income have close links with preferences, or choices in, space heating, such as the times when rooms are heated, the number of heated rooms and the temperature. Therefore, in this thesis, all physical and less tangible characteristics related to the users of a dwelling are collected in one category called "occupational characteristics".

In this thesis, the scope is broadened beyond the energy demand for space and water heating to include energy need, use and demand, and all energy forms. Using the variables 
offered by Guerra Santín et al. (2009), that in general reflect the relationship between the residents and the dwelling, rather than the technical characteristics of the dwelling and the relationship between the dwelling and its environment, this section distinguishes the following categories:

1. Environmental characteristics: variables regarding the environment in which a dwelling is constructed, which in general can be classified as natural or artificial;

2. Occupational characteristics: variables regarding the residents and way they use the building which are expected to influence, either positively or negatively, the energy use of the considered building;

3. Building characteristics: variables regarding the architectural building design and construction of a building which, under standard user conditions, would be expected to influence the energy use of the considered building;

4. System characteristics: specifications of the applied heating (space and water), cooling, and ventilation systems, which have similarities in being attached to, or even integrated with, the object and in being able to convert energy forms in order to provide comfortable and healthy living space in the considered building;

5. Appliances: devices using energy, or reducing energy use, located in and around the considered building which are not necessarily fixed to the object and do not necessarily improve comfort or health conditions.

First, the impact of the surrounding environment is discussed, then the role of the residents, followed by characteristics relating to architecture, before finishing the analysis by elaborating on systems and appliances.

\subsubsection{Environmental characteristics}

The environment in which a dwelling is located will have a major influence on its energy use. The outdoor temperature, the availability of solar irradiance and the wind velocity at the location are natural environmental characteristics to be considered. Surrounding buildings and the availability of energy infrastructure are examples of artificial characteristics to also take into account. In this section, these environmental characteristics will first be explained theoretically, before empirical values are provided to describe the particular Dutch thermodynamic environment.

\section{Environmental characteristics influencing energy use}

A dwelling can only make use of those energy forms that are able to reach the exterior or interior of the dwelling in natural or artificial ways. When natural or artificial objects in the surroundings of a building provide shading for solar radiation or shelter from wind and rain, the energy needed to achieve a comfortable living space will be influenced. To these characteristics of the artificial environment, Assimakopoulos (1992) would probably add urbanization rate, as was also mentioned by Guerra Santín et al. (2009), although neither publication offered a definition of the concept or explained the relationship between urbanization and energy use. Besides the artificial environment, a properly 'designed' natural environment can also adapt to the seasons. For example, during summer in moderate climates, trees and plants can provide shading and can retain moisture, but in 
winter the fallen leafs make it possible to let the low levels of solar irradiation through. Table 2-2 brings together and summarises all the environmental characteristics mentioned.

Table 2-2: Environmental characteristics influencing the energy use in dwellings.

\begin{tabular}{|c|c|}
\hline Characteristics & Descriptions \\
\hline $\begin{array}{l}\text { 1. Surrounding buildings } \\
\text { (artificial characteristic) }\end{array}$ & $\begin{array}{l}\text { Depending on the location and orientation of a dwelling, nearby buildings can } \\
\text { provide shading from solar irradiance and can form a screen against wind. Both can } \\
\text { influence the energy use of a dwelling either positively or negatively (Grondzik et al., } \\
2010, \text { pp. 52-55; Masmoudi \& Mazouz, 2004). Guerra Santín et al. (2009) view } \\
\text { urbanisation rate as a building characteristic. }\end{array}$ \\
\hline $\begin{array}{l}\text { 2. Surrounding } \\
\text { vegetation } \\
\text { (natural characteristic) }\end{array}$ & $\begin{array}{l}\text { Depending on the location and orientation of a dwelling, nearby trees and bushes } \\
\text { can also provide shading from solar irradiance and can form a screen against wind. } \\
\text { As with surrounding buildings, both can influence the energy use of a dwelling. } \\
\text { Surrounding vegetation often differs from surrounding buildings in the way that } \\
\text { vegetation changes with to the seasons. When trees near a dwelling lose their } \\
\text { leaves, a dwelling will receive solar irradiance in winter, whereas in summer it can } \\
\text { benefit from the shading the trees can provide (Grondzik et al., 2010, pp. 80-83). }\end{array}$ \\
\hline $\begin{array}{l}\text { 3. Infrastructure } \\
\text { (artificial characteristic) }\end{array}$ & $\begin{array}{l}\text { The infrastructure offers certain types or forms of energy at specific capacities. } \\
\text { These types or forms of energy can have undergone multiple processes by means of } \\
\text { extraction, conversion and transport. In the Netherlands, natural gas and electric } \\
\text { energy are commonly provided. Other dwellings are connected to district heating } \\
\text { systems and the electricity grid. The smaller the capacity, the more important it is to } \\
\text { consider what systems and appliances can operate simultaneously (Brkic \& } \\
\text { Tanaskovic, 2008; Kessides \& Wade, 2011). Guerra Santín et al. (2009) view energy } \\
\text { type as a building characteristic. }\end{array}$ \\
\hline $\begin{array}{l}\text { 4. Air temperature } \\
\text { (natural characteristic) }\end{array}$ & $\begin{array}{l}\text { When the outdoor temperature is close to the desired indoor temperature, little or } \\
\text { no energy is needed for heating or cooling. Depending on the thermal capacity of } \\
\text { the dwelling, certain fluctuations in surrounding temperature (and solar irradiance) } \\
\text { can be accommodated (Hart \& De Dear, 2004). }\end{array}$ \\
\hline $\begin{array}{l}\text { 5. Ground temperature } \\
\text { (natural characteristic) }\end{array}$ & $\begin{array}{l}\text { The ground forms a thermal reservoir. At a relatively shallow depth (often less than } \\
10 \text { metres) one will be able to find a steady temperature that equals the annual } \\
\text { average air temperature above the ground. This thermal reservoir can be used with } \\
\text { heat pumps or by designing partially submerged dwellings (Wood et al., 2010; } \\
\text { Simões \& Serra, 2012). }\end{array}$ \\
\hline $\begin{array}{l}\text { 6. Solar irradiance } \\
\text { (natural characteristic) }\end{array}$ & $\begin{array}{l}\text { Solar irradiance can be used directly to heat and light internal living space. The } \\
\text { energy can also be used indirectly in systems that are capable of storing and/or } \\
\text { transforming it (e.g. thermal solar collectors and photovoltaic panels) (Grondzik et } \\
\text { al., 2010, pp. 57-65). }\end{array}$ \\
\hline $\begin{array}{l}\text { 7. Wind velocity } \\
\text { (natural characteristic) }\end{array}$ & $\begin{array}{l}\text { High wind velocities can be beneficial in providing ventilation and vaporising water } \\
\text { dampness out of constructions. However, during autumn and winter, thermal } \\
\text { energy losses can be large due to cold, high velocity air streams (Grondzik et al., } \\
\text { 2010, pp. 70-74). }\end{array}$ \\
\hline $\begin{array}{l}\text { 8. Precipitation } \\
\text { (natural characteristic) }\end{array}$ & $\begin{array}{l}\text { Low temperature rain water can reduce the temperature of the thermal shell of a } \\
\text { building and can influence the thermal conductivity of materials. The evaporation of } \\
\text { water can reduce the temperature of a building on hot days (Grondzik et al., 2010, } \\
\text { pp. 76-80). }\end{array}$ \\
\hline $\begin{array}{l}\text { 9. Humidity } \\
\text { (natural characteristic) }\end{array}$ & $\begin{array}{l}\text { Low and high levels of humidity are experienced as uncomfortable, and therefore } \\
\text { systems are sometimes used to regulate humidity levels (Grondzik et al., 2010, pp. } \\
96-97) \text {. }\end{array}$ \\
\hline
\end{tabular}


In developed countries, the available infrastructure makes it possible to transport energy in the form of fossil fuels, hot water and/or electric energy to many dwellings. The form in which this energy is offered to a household is decisive in which energy conversion techniques can be used and how effective and efficient these conversion techniques are. Not only the energy form is important but also the quality of the energy form and the quality of the connection to the infrastructure. Energy will be used in transporting energy from its source to the dwelling. Oil can, for example, be transported by a lorry tanker to a fuel tank located near a dwelling. Natural gas can be transported under pressure through pipes from the extraction location all the way to the heating system in a dwelling. Electric energy can be provided by mobile generators or through a connection to a central power grid at various voltages and frequencies, and at some maximum current. If too many appliances and equipment are connected, and the maximum current exceeded, the delivery of electric energy will cease. As such, the availability and quality of infrastructural networks have a large influence on how a dwelling is designed regarding its energy performance, and can be viewed as a boundary condition.

In addition to the environment creating conditions regarding the artificial way in which energy is provided, it also sets conditions from a natural perspective as to how much energy is provided or extracted. The temperature of the environment surrounding a dwelling is a major influence on how much energy needs to be provided by the infrastructure to come to a comfortable indoor climate. Environmental temperatures change both over a year and within a day. In the Netherlands, one sees low temperatures during the winters and relatively high temperatures during the summer. Besides this seasonal cycle, a diurnal (day night) cycle exists. During daytime, the natural environment, the built environment and individual dwellings can absorb thermal energy provided by solar irradiation. During night hours, thermal energy is emitted from the dwelling into the environment.

A large thermal reservoir is provided by the air and by the ground. Over a year, the ground temperature fluctuations are relatively small compared to those in the air. Depending on the climate, the average air and soil temperatures will be relatively low or high, compared to the ambient temperature. At a certain depth, one find a steady soil temperature that will be around the annual average air temperature. As such, the ground can during the heating season function as a very steady heat source, for example for heat pumps and for preheating or pre-cooling in ventilation systems. The steady temperature of the earth can also directly, without the interference of systems, be used. This is, for example, done in the case of earth ships; dwellings that have thick walls of earth or are partially below ground level.

This heat transfer can take place through four ways, namely: thermal conduction, convection, mass transfer and thermal radiation. The higher the temperature difference between the indoor temperature and the outdoor temperature, the greater the heat transfer. Naturally, this heat transfer can take place in two directions, namely heat can flow into a dwelling when indoor temperatures are lower than the outdoor temperatures, and heat can flow out of a dwelling, when outdoor temperatures are lower than indoor temperatures. The sun can provide heat transfer by means of radiation. Solar irradiation will 
enter the dwelling through transparent surfaces (windows) in the building shell, increasing the interior temperature. The solid exterior of a dwelling can also absorb the solar irradiation after which, through conduction, the temperature of internal components can be increased. Objects surrounding a dwelling can provide shading, which can result in a lower cooling load during the summer and a higher heating load during winter months.

The wind velocity is another important climate factor, when considering the energy demand of a house. The higher the wind velocity the easier heat transfer can take place on the exterior surface of a dwelling. High wind speeds also result in higher infiltration and ventilation rates than at low wind speeds, which means that more air is likely to enter a dwelling per unit of time. When the outdoor air temperature is lower than the temperature of the indoor air, the indoor temperature will decrease and additional heating may be necessary.

The final climate conditions that are considered to be relevant are the precipitation and the humidity rates. If rain water has a relatively low temperature, it will lower the temperature of the roof and walls of a dwelling where they come into contact. Further, the thermal conductivity of the wall can be influenced. Both effects can indirectly decrease the indoor temperature of a dwelling. On hot days, the thermal energy needed to evaporate the rainwater can easily be provided. In this way, a passive cooling system could be provided. However, high humidity levels are not regarded as comfortable. If the humidity of the air inside a dwelling is high, dehumidifiers can be installed to actively reduce humidity levels.

\section{Dutch environmental characteristics}

With 402 people $/ \mathrm{km}^{2}$ (CBS, 2011b), the Netherlands is one of the most urbanised countries in the world. The Netherlands covers $41,543 \mathrm{~km}^{2}$, of which $54.8 \%$ is used for agriculture, $11.6 \%$ is covered by forests and other areas of natural beauty and $18.8 \%$ is used for water puposes (CBS, 2008). A large part of population is concentrated in one urbanized area, called the Randstad, in the mid-west and centre of the Netherlands. Particularly in that area, not only is the sub-ground infrastructure dense, this is also the situation above ground level.

However, the height of buildings in the major Dutch cities is generally not as high as in other modern cities with high land prices. Both high and low buildings (and other relatively tall objects) can provide shading and can influence the wind velocity in both positive and negative ways. To guarantee affordability, new residential areas are divided into relatively small land plots. Even detached houses are constructed close to each other, and a gap of less than two metres between your and your neighbour's house is not uncommon. This gives little possibility to design a natural environment around a house that offers shading in the seasons when you would like to have shading. On the other hand, the relatively high density of houses offers the possibility to create small efficient energy networks with many connections.

In the Netherlands, the energy infrastructure for the built environment consists mainly of an extensive electricity power grid of $309,502 \mathrm{~km}$ and an extensive natural gas network of $135,229 \mathrm{~km}$ (Energie-Nederland, 2011a). Additionally, approximately one million residents make use of one of the many district heating systems, which often provide water at a 
temperature of $100{ }^{\circ} \mathrm{C}$ and a pressure of 10 Bar (Energie-Nederland, 2011a). Within Europe, the gas network has an average efficiency of 91\% including distribution losses (EU, 2007, p. 24). The efficiency of Dutch electric energy supply is $39 \%$, which includes conversion and transport (NNI, 2004a, p. 119). Newly constructed dwellings generally have a three phase (plus neutral) connection offering 230 Volts and 25 Ampere per phase. A conventional connection to the natural gas grid can provide a dwelling with up to $10 \mathrm{~m}^{3} / \mathrm{h}$ of gas at a pressure level of 30 mbar (Energie-Nederland, 2011).

When new residential areas are assigned, city developers nowadays commonly consider the orientation of the houses so that solar irradiation can easily heat indoor areas through the glazing. With that same orientation (south facing), and set at the right angle, photovoltaic panels or thermal solar collectors can be used at the highest efficiencies possible. In 2010, 1772 hours of sunshine was measured, 222 hours more than the 1971-2000 average (KNMI, 2011). In an average year, this means that, without shading, an irradiation of around 1,000 $\mathrm{kWh} / \mathrm{m}^{2}$ will be received on a horizontal surface. With a horizontal surface of grass, one will probably measure a steady temperature of $10.8{ }^{\circ} \mathrm{C}$ at a depth of approximately $1.8 \mathrm{~m}$ (Jacobs et al., 2011).

Over the period $1971-2000$, an average temperature of $9.8^{\circ} \mathrm{C}$ and an average rainfall of 797 $\mathrm{mm}$ per year were recorded (KNMI, 2011). A standard year (the average over the period 1971-2000), has eight days on which the maximum temperature is below $0{ }^{\circ} \mathrm{C}$ and 58 days on which the temperature will drop below $0{ }^{\circ} \mathrm{C}$. At the other extreme, there are 77 days when the maximum temperature exceeds be $20^{\circ} \mathrm{C}$, with 22 days when the temperature exceeds $25^{\circ} \mathrm{C}$ and 3 when it goes above $30^{\circ} \mathrm{C}$ (KNMI, 2011).

\subsubsection{Occupational characteristics}

This section focuses on how the energy need, use and demand of a dwelling can be related to its residents.

\section{Occupational characteristics that influence energy use}

Dwellings exist in multiple forms and shapes, providing space for families of different sizes. Much research has been carried out on the relationships between residents' characteristics and the energy need, use or demand of dwellings. The first variable to consider is the number of residents. Families vary from one person up to ten or even more residing in a house. The energy used for space heating is not necessarily higher with more residents, but the energy used to heat tap water and to power appliances can reasonably be expected to be higher in large households than in smaller ones.

Research has also been carried out related to the age of occupants, and there is often a close relationship with family size. Gilly and Enis (1982) specify eleven stages in the family lifecycle. Seven general situations can be used to largely cover the ways in which dwellings are occupied:

- Bachelors: in general young adults under thirty-five years old, often a student, living their individual lives in apartments or in dorms in a group or on a solitary basis; 
- Newlyweds: in general two adults with ages ranging from twenty to thirty-five years old living together without children;

- Young full nesters: two adults in the age range of twenty-five to forty years living together with their young child(ren), that are at home or go to day-care or school;

- Old full nesters: two adults at the age of forty to sixty years old living together with their child(ren) who are teenagers or young adults going to school, college or work;

- Empty nesters: adults in the age range of fifty-five to eighty years old living together without children;

- Seniors: the elderly, generally older than seventy years old, that are in need of additional services at home, or live in homes for the elderly;

- Other households: any household that does not find the descriptions above, for example one parent families.

In these different stages of the family lifecycle, one might expect different patterns in household energy need and, therefore, the energy demand of a dwelling. When children become teenagers, the adoption of electronic appliances is likely to increase. When a family changes from newlyweds to young full nesters, one might expect the use of hot water to increase, and the electric energy use to increase due to the extra laundry and the thermal energy needed to heat living spaces to increase due to an increasing presence at home and the need of a heated bedroom for the baby. In all stages of the family lifecycle, the rate of presence will be an important characteristic.

The age, gender, cultural background and physical condition of the individuals in a household will strongly influence the personal preferences regarding the internal climate. In general, the elderly like higher room temperatures than younger people. The elderly also often appreciate the thermal radiation from a heat source such as a radiator or heater more than the thermal conduction from wall and underfloor heating systems. The room temperature will be experienced differently when occupants, young or old, sit still rather than being active. People with different cultural backgrounds can also have different preferences regarding room temperature. This could be geographically related to the prevailing outdoor and indoor temperatures at the location where they were raised, but it can also be related to the way they were raised. This could include being brought up with an environmental awareness.

Similarly, the income of occupants has already been the object of research (e.g. Biesiot and Noorman, 1999; Guerra Santín et al., 2009; Vringer, 2005). Fully employed newlyweds and empty nesters are expected to have relatively more freedom on deciding how to spend their income than households in other stages of the family lifecycle, where covering the primary necessities of life takes up a large percentage of one's income. Income may also play a role in the fact that social housing tenants generally use less energy than owner-occupiers. It is, however, necessary to note that the average rented house is smaller than the average owner-occupied dwelling, which could also result in a lower need for thermal energy.

A final characteristic brought into relationship of energy use with the occupants of a house is their environmental awareness. It can be expected that residents who are environmenta- 
lists, or who are at least aware of the environmental impact of energy use, will pay more attention to the energy used in their house and its appliances than people who are less conscious about the environment. Those who are environmentally aware, are probably willing to pay for investments that reduce the energy use of their house or to pay more for appliances with improved energy performance. In Table 2-3, the occupational characteristics are brought together with short descriptions.

Table 2-3: Occupational characteristics influencing the energy use in dwellings.

\begin{tabular}{|l|l|}
\hline \multicolumn{1}{|c|}{ Characteristics } \\
$\begin{array}{l}\text { 1. Number of residents } \\
\text { (Guerra Santín et al., } \\
\text { 2009) }\end{array}$ & $\begin{array}{l}\text { The number of residents can be expected to be positively related with natural gas } \\
\text { and electric energy use (Nibud, 2011). The number of residents will be negatively } \\
\text { related with the energy used for space heating in well insulated houses (de Meester } \\
\text { et al., 2013). Therefore, it is possible that it is especially the energy used for water } \\
\text { heating and electric appliances that increases when the family size increases. }\end{array}$ \\
\hline $\begin{array}{l}\text { 2. Age of residents } \\
\text { (Guerra Santín et al, } \\
\text { 2009) }\end{array}$ & $\begin{array}{l}\text { In general the elderly are expected to appreciate higher temperatures, while young } \\
\text { people are expected to make more use of electric energy in a wider range of } \\
\text { appliances (e.g. Assimakopoulos, 1992; Liao \& Chang, 2002; Linden et al., 2006). }\end{array}$ \\
\hline $\begin{array}{l}\text { 3. Residents' living } \\
\text { patterns (Guerra } \\
\text { Santín et al., 2009) }\end{array}$ & $\begin{array}{l}\text { The rate of presence is expected to be positively related with energy use. However, } \\
\text { optimal thermostat management is crucial (de Meester et al., 2013). }\end{array}$ \\
\hline $\begin{array}{l}\text { 4. Internal climate } \\
\text { preferences (Guerra } \\
\text { Santín et al., 2009) }\end{array}$ & $\begin{array}{l}\text { Different people have different preferences regarding what is considered to be a } \\
\text { comfortable temperature, ventilation rate or moisture rate (e.g. Erhorn, 1988; } \\
\text { Iwashita \& Akasaka, 1997; Leth-Petersen \& Togeby, 2001; Linden et al., 2006). }\end{array}$ \\
\hline $\begin{array}{l}\text { 5. Income of residents } \\
\text { (Guerra Santín et al., } \\
\text { 2009) }\end{array}$ & $\begin{array}{l}\text { People with a high income are expected to be more careless in their energy use (e.g. } \\
\text { Biesiot \& Noorman, 1999; Vringer, 2005). }\end{array}$ \\
\hline $\begin{array}{l}\text { 6. Form of ownership } \\
\text { (Guerra Santín et al., } \\
\text { 2009) }\end{array}$ & $\begin{array}{l}\text { Tenants in social housing are expected to generally use less energy than occupants of } \\
\text { houses that are privately owned or rented (e.g. Leth-Petersen \& Togeby, 2001). }\end{array}$ \\
\hline $\begin{array}{l}\text { 7. Environmental } \\
\text { awareness (Guerra } \\
\text { Santín et al., 2009) }\end{array}$ & $\begin{array}{l}\text { It is expected that the higher the environmental awareness of the residents, the } \\
\text { lower their energy use might be (e.g. Vringer et al., 2007). }\end{array}$ \\
\hline
\end{tabular}

\section{Occupational characteristics of Dutch dwellings}

At the end of 2009, 7,140,925 dwellings were available in the Netherlands to house a population of 16,577,612 (CBS, 2010a; CBS, 2010b). Approximately $40 \%$ of these dwellings are rented (CBS, 2010a). A simple calculation gives an average occupancy rate of 2.32 persons per dwelling. Other figures show that approximately 2,619,000 single households and 4,693,000 larger households existed in 2009 (CBS, 2010b), implying that 7,312,000 dwellings were available in 2009 , which is $2.4 \%$ more. However, some residents live in movable properties (like campers and trailers) or properties without a residential function (for example vacant office buildings or utilities are sometimes temporarily and even illegally used as residential space). Leaving these aspects aside, CBS figures indicate that the average size of a household fell from 2.95 people in 1975, to 2.23 in 2009. Table 2-4 shows how family size is related to electric energy and water use according to figures from the Dutch National Institute for Budget Counselling (Nibud, 2011). According to Nibud, the natural gas use is related to the type of dwelling and not the family size. 
Table 2-4: Average electric energy use and water use per dwelling in relation to family size in 2010 (Nibud, 2011).

\begin{tabular}{|l|r|r|}
\hline \multicolumn{1}{|c|}{ Family size } & $\begin{array}{c}\text { Electric energy use } \\
\text { (kWh/year) }\end{array}$ & $\begin{array}{r}\text { Water use } \\
\text { ( } \mathbf{m}^{\mathbf{3}} \text { /year) }\end{array}$ \\
\hline 1 person & 2,405 & 45 \\
\hline 2 persons & 3,533 & 91 \\
\hline 3 persons & 4,114 & 137 \\
\hline 4 persons & 4,733 & 169 \\
\hline 5 persons & 5,337 & 201 \\
\hline 6 persons & 5,430 & - \\
\hline Average per household & 3,480 & - \\
\hline
\end{tabular}

As with many other developed countries, the Netherlands has a growing group of residents that can be considered as elderly, with approximately 2,472,000 people (15\%) older than 65 years in 2009. In that same year 3,934,000 people (24\%) were younger than 20 and often living with their parents. The age at which children were leaving the parental home had been decreasing over two decades up to the beginning of the $21^{\text {st }}$ century (De Graaf, 2004) but then started to increase again, probably because of the limited availability and high prices of lodgings and houses. People aged up to 35 have been less willing to buy a house (Nieuweboer, 2011) and, especially for first-time buyers, it is not easy to get a mortgage for a small or medium sized house in the more densely populated areas of the Netherlands.

The average gross income for a fully employed male is around $€ 38,200$ per year. Many women work part-time, and the average gross income is $€ 30,400$ per person per year (CBS, 2010c). The average privately owned dwelling absorbs $€ 5,500$ per year in mortgage interest and repayments. On top of this, the additional costs for owning living space include energy costs, taxes, waste treatment fees, water costs and insurance costs. These average a total of $€ 3,984$ per household per year. Of this, the energy costs including taxes for privately owned dwellings are on average $€ 1,765$ per household per year, equivalent to $19 \%$ of the total costs of owning a house (COELO, 2010).

These energy costs are for a large part attributed to the preferences of the occupiers to maintain a certain minimum indoor temperature. These indoor temperatures are linked with the residents' patterns of living. In computing the Energy Performance Coefficient (EPC), minimum acceptable temperatures are used for when the residents are at home (NNI, 2004a). The living room or ground level is considered to be $19{ }^{\circ} \mathrm{C}$ during daytime from 7:00 to $17: 00,21{ }^{\circ} \mathrm{C}$ from $17: 00$ to $23: 00$ and from $23: 00$ to 7:00 the thermostat is assumed set to $16{ }^{\circ} \mathrm{C}$ (the average temperature from 23:00 to 07:00 will be higher due to the thermal capacity of the building and its contents). Temperatures are assumed to be lower on upper floors. For five days per week, temperatures are expected to be $16{ }^{\circ} \mathrm{C}$ from 07:00 to 23:00 and $14{ }^{\circ} \mathrm{C}$ from 23:00 to 07:00. For two days per week (the weekend) the internal temperature is assumed equal to that in the living room (NNI, 2004a, p. 178). Note that these are suggested minimum temperatures for 'average' residents. It is likely that the elderly for example will prefer higher temperatures. 
When new houses are designed, a specific heating capacity needs to be provided by the radiators (or other heating appliances) to be able to meet temperatures of at least $20^{\circ} \mathrm{C}$ in the living room, dining room, kitchen and bedrooms and a minimum temperature of $15^{\circ} \mathrm{C}$ in the entrance, hallway and scullery. The bathroom has to have the possibility of being heated to at least $22^{\circ} \mathrm{C}$. It has to be possible to achieve these temperatures even when the outside temperature is $-7^{\circ} \mathrm{C}$ with a wind speed of $5 \mathrm{~m} / \mathrm{s}$. If another house is attached to the house in question, the heating capacity has to be sufficient to meet these targets provided the adjoining property is at $5{ }^{\circ} \mathrm{C}$ ( $\left.\mathrm{NNI}, 1992\right)$. In new buildings with high levels of insulation, it is common for toilets, storage spaces and attics to not have radiators.

\subsubsection{Building characteristics}

Having discussed the influence of the environment and of residents, in this section the focus will be on the object itself. There will be referred to the constructional components that form the thermal shell and enclose the internal living space.

\section{Building characteristics that influence energy use}

The extent to which heat can leave the internal space of a dwelling is related to its size and the thermal resistance of the shell. Depending on the design, this thermal shell in general consists of a ground floor, one or more facades and a roof. Heat flows only exist when there is a temperature difference between the indoor and outdoor air. In semi-detached houses, terraced houses and apartments, one or more facades, and maybe the floor and ceiling, will be adjoining internal spaces that are part of other dwellings. These spaces will probably have similar indoor temperatures and, therefore, little or no heat will flow through these shared interfaces. Consequently, the thermal shell will be relatively small compared to a detached house. In practice, the indoor temperatures within different rooms of a dwelling or in adjoining dwellings will often differ slightly. Particularly during winter this will be a relatively small temperature difference compared to the temperature difference between the internal and external environment.

Acknowledging the importance of temperature differences, it is important to distinguish the type of dwelling and to accurately define internal temperatures per room $\left(\mathrm{K}\right.$ or $\left.{ }^{\circ} \mathrm{C}\right)$, the thermal resistances $\left(\mathrm{m}^{2} \mathrm{~K} / \mathrm{W}\right)$ and specific heat capacity $(\mathrm{J} / \mathrm{kg} \mathrm{K})$ of floors, walls and the roof and surface areas of floors, facades and roofs $\left(\mathrm{m}^{2}\right)$. Depending on how the internal spaces are planned, multiple rooms can sometimes be regarded as one thermal unit with a common temperature. Knowing the type of dwelling can provide direct insights into what the ratio between floor surface area and thermal transmission area is likely to be. Similarly, if the year of construction is known, one can also easily estimate what the thermal resistance of the originally shell is likely to have been.

Heat will not only leave a dwelling by means of radiation and conduction, mass transfer and convection also take place. People and objects enter and leave the dwelling, providing or removing thermal energy in the form of sensible heat. A building is never completely air tight and air will infiltrate, especially at locations where different construction components meet. The amount of air leaving or entering a building, in combination with the temperature difference between inside and outside, will result in certain heating or cooling load. In any 
case, some fresh air is needed to maintain a healthy environment within a dwelling. Due to changing policies and the adoption of new technologies, the age of the dwelling can indicate the likely quality of the thermal shell regarding both thermal resistance and infiltration rates. Depending on the exact function and use of a building, high ventilation rates may be necessary. In dwellings, ventilation can take place by opening windows and doors, and often a mechanical fan is installed to guarantee a minimum ventilation rate. The energy used by mechanical fans will be addressed in the section on systems. In Table 2-5 all the building characteristics so far mentioned are summarised.

Table 2-5: Building characteristics influencing the energy use in dwellings.

\begin{tabular}{|c|c|}
\hline Characteristics & Descriptions \\
\hline $\begin{array}{l}\text { 1. Floor surface } \\
\text { (Guerra Santín et } \\
\text { al., 2009) }\end{array}$ & $\begin{array}{l}\text { Floor surface area is positively related to energy use. Especially the size of the main living } \\
\text { areas can be expected to influence energy use for heating (or cooling) because these } \\
\text { areas are most likely to be kept at a comfortable temperature during the day and in the } \\
\text { evening (Wilson \& Boehland, 2005). }\end{array}$ \\
\hline $\begin{array}{l}\text { 2. Transmission } \\
\text { surface }\end{array}$ & $\begin{array}{l}\text { The transmission surface (including and surrounding the floor) includes all surfaces over } \\
\text { which significant temperature differences can occur as a result of differences between } \\
\text { indoor and outdoor climates. In general, the larger the transmission surface area the } \\
\text { more energy is needed to reach a certain indoor temperature. Improving the thermal } \\
\text { resistance and the heat capacity of the transmission surfaces can reduce energy use. For } \\
\text { glazing, solar energy transmittance and visible transmittance are additional variables that } \\
\text { influence the energy use of a building (e.g. Assimakopoulos, 1992; Haas et al., 1998). } \\
\text { Guerra Santín et al. (2009) refer to the characteristic "insulation". }\end{array}$ \\
\hline $\begin{array}{l}\text { 3. In } \\
\text { alloc }\end{array}$ & $\begin{array}{l}\text { Within the building shell the arrangement of rooms and their functions can influence the } \\
\text { energy use. Temperatures in bed rooms are often lower than the temperature in the } \\
\text { living and bath room. Hallways can form a thermal sluice. Vertical thermal convection } \\
\text { between the living space on the ground floor and the bed rooms on the first floors needs } \\
\text { to be prevented. Furthermore, internal walls can provide mass to store thermal energy. } \\
\text { In analysing their data Guerra Santín et al. (2009) mention that the presence of various } \\
\text { kinds of rooms was taken into account. }\end{array}$ \\
\hline $\begin{array}{l}\text { 4. Type of dwelling } \\
\text { (Guerra Santín et } \\
\text { al., 2009) }\end{array}$ & $\begin{array}{l}\text { Dwellings can be a terraced house, a semi-detached house, a detached house, or an } \\
\text { apartment. These dwelling types have characteristic floor surface/transmission surface } \\
\text { ratios (e.g. Guerra Santín et al., 2009). }\end{array}$ \\
\hline $\begin{array}{l}\text { 5. Age of dwelling } \\
\text { (Guerra Santín et } \\
\text { al., 2009) }\end{array}$ & $\begin{array}{l}\text { In different periods, certain construction methods and installation techniques were } \\
\text { commonplace. The year a building was constructed can often be easily related to various } \\
\text { features, resulting in a typical energy demand. In line with the steady upgrading of } \\
\text { building regulations, newer dwellings tend to use less energy use than older dwellings } \\
\text { (e.g. Assimakopoulos, 1992). }\end{array}$ \\
\hline $\begin{array}{l}\text { 6. Degree of } \\
\text { infiltration }\end{array}$ & $\begin{array}{l}\text { Infiltration is the so-called unwanted ventilation that takes place through and between } \\
\text { different building components. Traditionally, infiltration is most noticeable (in the } \\
\text { winter) around window frames and doors, at connections between walls and saddle } \\
\text { roofs, and between two sections of a saddle roof (Liddament \& Orme, 1998). }\end{array}$ \\
\hline
\end{tabular}




\section{Building characteristics of Dutch dwellings}

Dutch dwellings are in general designed and constructed for service life of fifty to one hundred years (SEV, 2004). The number of dwellings nationally increases by approximately $1 \%$ per year. These new buildings are highly insulated and energy efficient dwellings. Consequently, it is the existing building stock that offers the biggest challenge in reducing energy use in buildings.

The Dutch residential building stock shows certain patterns in terms of form and function and the period of construction. The natural gas use can for example be directly related to the type of dwelling, as is shown in Table 2-6 (Nibud, 2011), or can be related to more than one characteristic. SenterNovem (the former Dutch agency for innovation and sustainability) has developed a system to reflect on the energy performance of 27 sorts of dwellings, that were constructed in large numbers. They are grouped by means of type and, to reflect on implemented ETMs during the construction process, year of construction. The various classifications within this system will now be explained.

Table 2-6: Average natural gas use for different types of dwellings (Nibud, 2011).

\begin{tabular}{|l|r|}
\hline \multicolumn{1}{|c|}{ Type of dwelling } & \multicolumn{1}{c|}{$\begin{array}{c}\text { Natural gas use } \\
\text { ( } \mathbf{m}^{3} \text { /year) }\end{array}$} \\
\hline Flat, apartment & 900 \\
\hline Terraced house, row house & 1350 \\
\hline Corner house, end house & 1590 \\
\hline Semi detached house & 1670 \\
\hline Detached house & 2220 \\
\hline
\end{tabular}

Regarding form, the four main types of dwellings are detached houses, semi-detached houses, row houses (terraces) and apartments (SenterNovem, 2007). These categories are distinguished because the ratio between the floor area and the thermal surface is a characteristic related to the need for thermal energy and to an extent the need for electric energy. Within the category of row houses, one can further distinguish between corner houses and end houses on the one hand and the terraced house positioned between two similar row houses on the other.

Apartments can be enclosed by neighbours both horizontally and vertically. Therefore, depending on the position within a multi-family residential building, eight different apartment types are already possible. Research on the qualitative performance of 15,000 dwellings in the Netherlands also showed that it was necessary to distinguish two types of detached houses, namely those that have a floor surface that is smaller or larger than 150 $\mathrm{m}^{2}$ (SenterNovem, 2007). Houses that have more than $150 \mathrm{~m}^{2}$ of floor space often have bedrooms, studies or other walk-in attic space and this increases the need for thermal heat significantly.

In terms of time periods, SenterNovem (2007) distinguishes three main periods for existing dwellings, namely up to 1965, from 1966 to 1988, and the period 1989-2000. Although SenterNovem only defines three periods, the late-1920s should be noted as an important transition period. In those years, solid walls were gradually replaced in the design of 
dwellings by cavity walls made up of two layers of brickwork separated by a narrow, slightly ventilated, airspace. The cavity wall significantly reduced the relative humidity and heat loss in buildings.

Governmental influence on building quality can also be seen during two oil crises, when subsidies were offered to add insulation and double glazing to new and existing buildings. As of 1992, the national Building Code enforced a minimum thermal insulation of $2.5 \mathrm{~m}^{2} \mathrm{~K} / \mathrm{W}$ for walls and panels and a maximum thermal conduction of $4.2 \mathrm{~W} / \mathrm{m}^{2} \mathrm{~K}$ for doors and windows. In 1995, the EPC, expressing the building-related energy use in relation to its size, provided another legal-based incentive to improve the energy performance of new buildings. Measures linked to design and technology were and are still taken to reduce the buildingrelated energy use in new buildings.

To summarise, the original form and construction date of a building can give a good indication of its building characteristics and featured installations. Based on the date, rough estimates can be made regarding the building-related energy use of a dwelling. However, many houses have undergone one or more modifications or even large scale renovations, which will have influenced energy use. In older houses, single glazing is being replaced by double glazing; and in houses with double glazing higher efficiency glazing is being installed as a replacement. Another example of change is that cavity walls are being filled with foam to increase their thermal resistance. Ground floors and roofs can also often be relatively easily upgraded. SenterNovem (2006) addresses that by the end of 2004 in $78.8 \%$ of the dwellings glass insulation was implemented. Furthermore, $69.6 \%$ of the dwellings implemented roof insulation, $55.6 \%$ wall insulation and $41.8 \%$ floor insulation. However, no exact specifications were given regarding the surface or thermal resistance of the insulation to be adopted. Furthermore, the roll of newly constructed dwellings in these figures was not specified. Given the increasing energy prices and various subsidies available in the period 2004 to 2010, one can assume that adoption rates have further increased in this period. In attempting to make reliable estimates regarding building-related energy use, just assigning an existing house to one of the three time periods mentioned above seems inappropriate and over-simplistic. A more detailed assessment seems necessary to reflect any modifications made.

\subsubsection{System characteristics}

In cold or moderate climates, the natural environment generally fails to provide internal temperatures that are sufficiently high for occupants to feel comfortable, and there does not seem to be enough solar radiation available at every moment of the year to achieve comfortable indoor temperatures. In response, open fireplaces were traditionally used to heat dwellings on many days each year. Today, thermodynamic, mechanical and electronic systems are used in dwellings to ensure a comfortable climate. During the winter, heating systems are used, and, during hot summers, cooling systems provide more comfortable conditions. This section elaborates on building-related systems for space heating, heating water, ventilation and cooling, that influence the energy needs, energy use or energy demand of dwellings. 


\section{System characteristics influencing the energy use}

In many countries, biomass and fossil fuels are used to heat spaces. When the temperature falls below a certain value, a fuel will be burnt to increase the indoor temperature. In modern houses, the incineration of the fuel often takes place at a location outside the living room. For example, when a central heating system is used, heat from a remote boiler is transported using water or air, as a medium, in a network of water pipes or air ducts. In individual rooms, radiators linked to the network of water pipes will emit the heat into the air. When air is the medium used, the hot air will be ducted directly into the room. In some countries, electric energy, usually generated at a central power plant, is used to heat living space. In this situation, the direct conversion from electric energy to heat generally takes place within the room where the heat is needed. In all these networks, multiple conversions take place and distances need to be overcome. At every stage, some irreversible losses can and will occur in terms of the work potential of the energy. It is necessary to make sure at the beginning of the network or system that the energy source has sufficient quality and quantity to enable the required room temperature to be reached. When reflecting on the energy need, energy use and energy demand of houses, it is important to be aware of when and where conversions take place and inefficiencies exist. The efficiency of the overall system should be taken into account.

In dwellings, heat is not only needed to increase indoor air temperatures, but also to heat water for washing, to boil water and to prepare food. The dishwasher, the washing machine and systems to boil water for consumption and to prepare food generally operate on electric energy and are considered as independent of the building-related systems. As such, these systems are often seen as non-building related appliances. However, the integration of these types of appliances in the building-related heating system could result in better overall system efficiencies than when they are operated as stand-alone units. Hot tap water is often provided by the same system that provides space heating, and these are commonly referred to as combination boilers. There may be a reservoir containing a significant volume of heated water (enough to fill a bath for example) to provide instant hot water, or the water may be heated directly from cold on demand. In the latter situation, there may be no reservoir or just a small one. When a solar collector is being used to contribute to the production of hot water, a reservoir or heat storage unit makes it possible to overcome the night and other short periods when there is little or no solar irradiation. In such systems, traditional fuels can be used to boost water temperatures for space heating or tap water.

Ventilation systems, if fitted, are to a large extent also integrated with a building. The energy involved in the mass transfer of air has already been discussed, but a mechanical ventilation system will also use electric energy. The electric energy needed to drive the fan and the thermal energy lost due to the emission and extraction of air are both regarded as buildingrelated energy uses. However, the energy use of the ventilation system only consists of the electric energy driving the electronics and the fan itself. In recent years, balanced ventilation systems have become popular and these offer the possibility of installing a heat exchanger. 
Here, heat from the outgoing flow of warm air is transferred to the incoming cooler air, reducing the thermal energy losses from inside the building to the environment significantly.

The final building-integrated system that could be adopted in a dwelling and is addressed in this section is a cooling system. Mobile air conditioning systems are considered as appliances, but cooling systems that are fixed to, or even integrated with, the construction are considered to have an impact on the so-called energy demand or on the building-related energy use. In general two types of systems can be applied: air conditioning systems and heat pumps. When a heat pump is used in a dwelling, it is possible to some extent to heat the building during the winter and to cool it during the summer with the same system. However, one needs to be aware of possible condensation problems in certain components of the system when cooling. In general, air conditioning systems are better able to cope with higher outdoor temperatures than heat pumps but are not used as a heating system. Various architectural and constructional options can help in preventing the need to install a cooling system that makes use of an external energy source. Installing solar shading (viewed as an appliance), tinted glass (a building characteristic) or phase change materials (a building characteristic possibly in combination with mechanical systems) can all help to maintain comfortable indoor temperatures during warm summer periods. Table 2-7 summarises all the system characteristics elaborated upon in this section.

Table 2-7: System characteristics influencing energy use in dwellings.

\begin{tabular}{|c|c|}
\hline Characteristics & Descriptions \\
\hline $\begin{array}{l}\text { 1. Heating } \\
\text { concept } \\
\text { (Guerra Santín } \\
\text { et al., 2009) }\end{array}$ & $\begin{array}{l}\text { The concept installed for heating the building is directly related to energy use. An efficient } \\
\text { installed concept that makes use of renewable energy sources can result in a low energy } \\
\text { use. In the Netherlands, a commoly used fuel for heating is natural gas. Boilers produce heat } \\
\text { to provide comfortable room temperatures. Often these boilers also provide hot tap water. } \\
\text { However, approximately one million citizens have district heating at their disposal. Recently } \\
\text { (electric) heat pumps are being adopted in a few dwellings. Most houses use water as a } \\
\text { medium to transport heat from the conversion unit to the radiation or convection units. Low } \\
\text { temperature heating systems are often applied in new dwellings (e.g. Leth-Petersen \& } \\
\text { Togeby, 2001). }\end{array}$ \\
\hline $\begin{array}{l}\text { ap } \\
\text { ept }\end{array}$ & $\begin{array}{l}\text { Although room temperatures only need to be around } 20{ }^{\circ} \mathrm{C} \text {, tap water requires higher } \\
\text { heating temperatures. The water needs to be at a temperature of at least } 60{ }^{\circ} \mathrm{C} \text { when } \\
\text { leaving the tap. The lower the temperature, the less thermal energy is needed to heat the } \\
\text { water. The length and diameter of pipes used for transporting heated tap water should be } \\
\text { minimised to reduce energy and water use (e.g. Cheng, 2002; Allen et al., 2010). Guerra } \\
\text { Santín et al. (2009) directly relate presence at home to hot water use, but without } \\
\text { mentioning the impact of the systems that heat the tap water. }\end{array}$ \\
\hline $\begin{array}{l}\text { 3. Ventilation } \\
\text { concept } \\
\text { (Guerra Santín } \\
\text { et al., 2009) }\end{array}$ & $\begin{array}{l}\text { Natural ventilation or mechanical ventilation for incoming and outgoing air flows are options } \\
\text { that influence the use of electric energy. Mechanical ventilation in combination with a heat } \\
\text { exchanger can reduce heat losses during the winter season, thereby reducing the natural gas } \\
\text { consumption (e.g. Iwashita \& Akasaka, 1997). }\end{array}$ \\
\hline $\begin{array}{l}\text { 4. Cooling } \\
\text { concept }\end{array}$ & $\begin{array}{l}\text { In the moderate Dutch climate, cooling systems are not often applied. However, with the } \\
\text { increasing thermal resistance of walls, floors and roofs, indoor temperatures tend to } \\
\text { increase to uncomfortable levels. Ground source heat pumps can be used during summer } \\
\text { months to provide cooling through floors and walls in a more efficient way than traditional } \\
\text { air conditioning systems (Urchueguía et al., 2008). }\end{array}$ \\
\hline
\end{tabular}




\section{System characteristics of Dutch dwellings}

The systems for heating, ventilation and cooling purposes in dwellings seem to generally be less complicated and less advanced than the systems installed in office buildings or other facilities. With heating capacities of $20 \mathrm{~kW}$ to $45 \mathrm{~kW}$, the gas boilers for dwellings are often considerably smaller than the heating systems in office buildings. However, in recent years, a significant increase can be seen in the range of advanced energy-efficient systems available to achieve a desirable indoor climate in dwellings. Hybrid heat pump systems are, for example, now available and can be applied in combination with radiant wall and floor heating. Combined Heat and Power (CHP) systems were once only available for large industrial complexes, but micro-CHP systems are available for households. Given the thick thermal insulation applied in new dwellings and the relatively large south-facing glass surfaces, overheating is increasingly an issue. This can lead to an increased use of mobile or integrated air conditioning systems.

It was only approximately sixty years ago that decentralised heating systems still were being installed that used coal, wood, peat or coal gas to provide thermal energy in just one room. In the Netherlands, the introduction of central heating systems, providing heat for multiple rooms using a network of radiators, started to gain momentum after a large source of natural gas was found at the village of Slochteren in 1959. As of $2004,82.1 \%$ of dwellings had an individual central heating system and $7.7 \%$ of dwellings still had an individual decentralized heating system (SenterNovem, 2007). Since their introduction, the efficiency of the gas systems has improved significantly. Further, due to increasing environmental awareness and progressive legislation in the form of the EPC (sometimes supported by subsidies), energy sources that are considered to be more sustainable, such as solar energy and geothermal energy, are more often used alongside natural gas or as a full replacement.

Until the late 1970s, it was very common to rely on natural ventilation to achieve a certain minimum air refresh rate in dwellings. Since the early 1980s, centralized mechanical ventilation systems are often used. In addition to natural ventilation, a centralized mechanical ventilation system is used to extract air from the toilet, bathroom and kitchen. The created under-pressure ensures that air from other rooms is drawn in. These other rooms receive fresh air through ventilation openings in the building shell. To reduce the electric energy used in fans, alternating current motors were superseded by direct current options in the late 1990s. In the same period, balanced ventilation systems were proposed to reduce thermal losses when heated indoor air was extracted. A centralized heat exchanger made it possible to transfer thermal energy from the outgoing air flow to the incoming air flow. More recent developments are focusing on decentralized systems that combine ventilation and heating functions and that are able to continuously monitor air quality, temperature and room occupancy.

Office buildings usually have a fixed cooling system, whereas most Dutch dwellings do not. The moderate climate in combination with a dwelling's relatively high heat capacity and low to moderate thermal resistance of the shell make a cooling system unnecessary. However, the heat resistance of building shells is increasing, as are average ambient temperatures, and 
the prices of mobile air conditioning systems are falling. Given these trends, the adoption rate of air conditioning systems in dwellings is increasing. These systems use significant electric energy. Heat pumps are able to use thermal energy from a low temperature source for the evaporation of a medium, that under a certain higher pressure is able to condense at a destination with a relatively high temperature. Therefore, heat pumps offer the ability to lower indoor temperatures during summer periods in a more efficient way than air conditioning systems. Heat pumps are increasingly popular in new dwellings as a way to meet building regulations regarding energy performance. However, it is often very difficult to retrofit them in the existing building stock. In some cases, air-source heat pumps can be applied in existing buildings but ground-source heat pumps seem to be only a realistic option for inclusion in the design of new buildings.

\subsubsection{Appliances}

The final category of variables that will influence the energy need, energy use and energy demand of a dwelling are the appliances within it. Appliances are devices that use, generally electric, energy or reduce energy use and that are located in and around the considered building but which are not necessarily fixed to the object and not necessarily improve comfort or health conditions.

\section{Appliances influencing the energy use}

In a typical household many different appliances will be found. All these different appliances require electric energy at different voltages and at different capacities. In the kitchen, a freezer, refrigerator, oven, microwave, coffee machine, kettle and toaster are common examples. In the living room, a television and stereo equipment are often found. Every room will almost certainly have electric lighting. In the bedrooms one can, besides the usual alarm clocks and lights, find computers, mobile telephones that are being charged, and often more televisions. In the bathroom, mirrors are sometimes electrically heated and a pump provides jet streams and bubbles in the bathtub.

Although many of the above mentioned appliances use low voltages and in general need little power to operate, they are being adopted in large numbers and seem to be steadily increasing electric energy use. In most households, electric energy is provided with an alternating current at 110 or 230 Volt. Many appliances reduce this voltage and operate on direct current using an adapter. When one wants to gain an understanding of how the total electric energy use of a dwelling is made up, the number, type, voltages, wattages and usage patterns of appliances need to be listed. Eventually, all the electric energy used in appliances will be transformed into heat and increase the indoor temperature.

Another specific sort of appliances is able to reduce the natural increase in indoor temperatures during summer time, namely blinds, awnings or shutters. These can reduce the amount of solar irradiation that would otherwise enter the thermal shell. Although traditionally they were operated manually, motorized shades are becoming popular. In combination with a sensor, these systems can automatically open and close in response to solar irradiation levels. Although such appliances can be integrated into the facades of buildings, it is rare, at least in the Netherlands, to directly incorporate them during the 
construction of new dwellings. Mobile air conditioning systems are also able to reduce the indoor temperature, but this active cooling technique uses in general much more electric energy than passive cooling techniques, that provide shading or make use of the temperature differences in a day and night cycle.

Active energy techniques that can reduce energy use include photovoltaic panels and small wind turbines. These techniques can transform solar or wind energy into electric energy. This electric energy can be directly used by the appliances in the dwelling such that the energy meter, registering the electric energy provided by the power grid, runs slower. It is even possible to provide any surplus electric energy to the power grid for use in other dwellings. In this situation, the energy meter needs to be able to run backwards or additional meters are required to register how much electric energy is fed to the power grid. Table 2-8 summarises the sorts of appliances described in this section. This table shows that lighting is considered to be a specific sort of appliance, due to its strong relation to the architectural and electro-technical design of a dwelling.

Table 2-8: Different sorts of appliances influencing the energy use in dwellings.

\begin{tabular}{|l|l|}
\hline Characteristics & \multicolumn{1}{c|}{ Descriptions } \\
\hline $\begin{array}{l}\text { 1. Presence of } \\
\text { energy using } \\
\text { appliances }\end{array}$ & $\begin{array}{l}\text { Many household appliances or consumer products are located or charged in houses (e.g. } \\
\text { Assimakopoulos, 1992). For many appliances, Energy Labels are available that specify the } \\
\text { energy use. The average electric energy use per household is steadily increasing and this } \\
\text { trend has been attributed to an increasing number of electric appliances. In general, the } \\
\text { more electric products, the higher the electric energy use. }\end{array}$ \\
\hline $\begin{array}{l}\text { 2. Presence of } \\
\text { lighting }\end{array}$ & $\begin{array}{l}\text { Electric connections are provided at fixed points in the ceilings of dwellings for lighting. As } \\
\text { such, lighting is a characteristic strongly related to the architectural and electro-technical } \\
\text { design of a dwelling. People are likely to install lighting at the provided locations and often } \\
\text { some additional lighting is placed around rooms. By making use of daylight as much as } \\
\text { possible, by reducing the number of lights and by using energy-efficient lighting, the energy } \\
\text { use for lighting can be reduced (e.g. Grondzik et al., 2010). It seems reasonable to assume } \\
\text { that larger houses will use more electric energy for lighting. }\end{array}$ \\
\hline $\begin{array}{l}\text { 3. Presence of } \\
\text { awning }\end{array}$ & $\begin{array}{l}\text { Solar radiation can negative consequences during summer months on thermal comfort. By } \\
\text { providing appropriate shading (or other passive systems) it is possible to avoid the use of an } \\
\text { active cooling concept and its accompanying energy use (e.g. Gómez-Muñoz \& Porta- } \\
\text { Gándara., 2003; Juanicó, 2009). }\end{array}$ \\
\hline $\begin{array}{l}\text { 4. Presence of } \\
\text { construction- } \\
\text { equated energy }\end{array}$ & $\begin{array}{l}\text { In some situations, photovoltaic panels or small wind turbines are installed to reduce the } \\
\text { demand for electric energy from an external source. Conversely, (de)humidification } \\
\text { installations can increase the demand for electric energy (e.g. Pantic et al., 2010). }\end{array}$ \\
\hline
\end{tabular}

\section{Appliances in Dutch dwellings}

The four above mentioned characteristics in the appliance category are applicable to the Netherlands. In general, electric energy use in the Netherlands has been increasing since 1988 (Energie-Nederland, 2010), as was shown in Figure 2-1. However, for certain purposes, electric energy use is decreasing. Energie.nl (ECN, 2010) provides data for specific electric energy use functions. The average energy used for cooling products decreased from 599 kWh in 1995 to $532 \mathrm{kWh}$ in 2009. The energy use for cleaning has also decreased since 2000, from $784 \mathrm{kWh}$ per average household to $683 \mathrm{kWh}$ in 2009. For these end uses, it seems that 
energy product labels have achieved the desired effect. On the other hand, energy use in the audio and television equipment category has significantly increased from $460 \mathrm{kWh}$ in 1995 to $645 \mathrm{kWh}$ in 2009. In the kitchen, much more energy is now also used in preparing food and drinks, an increase from $246 \mathrm{kWh}$ in 1995 to $308 \mathrm{kWh}$ in 2009. This increase can be related to the increasing popularity of electric cooking devices.

Energy use for lighting, rose from $509 \mathrm{kWh}$ in 1995 to $559 \mathrm{kWh}$ in 2000 but has since decreased to $482 \mathrm{kWh}$ in 2009 (ECN, 2010). Incandescent lamps are being banned, in four steps, in the European Union in order to decrease lighting energy use. The sale of 100 Watt incandescent lamps was outlawed on September $1^{\text {st }} 2009$, and since $1^{\text {st }}$ September 2012 it is no longer allowed to trade any incandescent lamps within the European Union (EC, 2009). It is expected that the adoption of fluorescent and LED lamps will increase, as replacements for the traditional incandescent lamps when they fail. Consequently, the energy used for lighting will almost certainly decrease in the near future.

Like already addressed, there are on average 77 days a year on which the maximum temperature exceeds $20^{\circ} \mathrm{C}$. On 22 of these the maximum temperature exceeds $25^{\circ} \mathrm{C}$ and there are only 3 days a year that $30^{\circ} \mathrm{C}$ is exceeded. Most of these warm days are in July and August. As such, in dwellings, a need for cooling is only likely to exist in these months. The use of shading on warm days, possibly combined with night-time ventilation, might for many households be an effective solution, and one that uses no or at least less electric energy than an air-conditioning system. However, new dwellings, which are well insulated and have relatively large glass surfaces oriented to the south, and hence are likely to suffer from overheating in summer, are seldom provided from new with shades. As a consequence, solar irradiation is accumulated quickly within the thermal shell, and it is often cheaper for households to buy a mobile air-conditioning system than install shading.

A good example of construction-related energy equipment is a photovoltaic energy system. The annual average irradiation in the period $1971-2000$ was $347,071 \mathrm{~J} / \mathrm{cm}^{2}$ or $964.1 \mathrm{kWh} / \mathrm{m}^{2}$ (KNMI, 2011). This means that a small unshaded photovoltaic system with $300 \mathrm{Wp}$ of panels, ideally oriented to the South at an angle of approximately $35^{\circ}$ to the horizontal would be able to provide almost $300 \mathrm{kWh} /$ year. According to the CBS (2011c), the electric energy use provided from photovoltaic systems increased from 165 TJ in 2009 to 216 TJ in 2010, but this is still only approximately $0.01 \%$ of the annual Dutch energy use. In 2010 , the contribution of wind energy was $16,210 \mathrm{TJ}(0.70 \%)$ although the vast majority of this was from large wind farms. Although small wind turbines are available to generate electric energy on and around dwellings, their efficiency and adoption rates are relatively low (Mertens, 2009).

\subsection{Methods to assess the energy performance of dwellings}

It is becoming apparent that many characteristics of a dwelling, its location and its users can influence the energy need, energy use and energy demand. When the energy performance of a dwelling is to be determined, various characteristics can be taken into account. When a range of characteristics are tested and listed systematically with the objective of coming to a judgement one speaks of an assessment. Which characteristics are taken into account in an assessment, depends on the calculation method and this can be developed in line with 
political, scientific or commercial ambitions. In this section, it is explained how the energy performance of dwellings can be calculated, being by definition an equation expressing the annual energy demand, or building-related energy use, of a building in relation to its size. The background and the various assessment methods in use are explained.

\subsubsection{Energy assessment methods for dwellings around the world}

In line with the Kyoto protocol, governments around the world are trying to reduce the environmental impact of the built environment. Reducing energy use is one of the ways to reduce the emission of carbon dioxide. There are several reasons for conducting an energy assessment. It is possible that a building user wants to reduce its energy use, improve the internal climate, reduce energy costs, or reduce the environmental impact of a building. For these various purposes, different assessment methods and accompanying computer programs exist. The outcomes of these methods can focus on the environmental impact of energy use, on energy transitions, user comfort and energy costs.

\section{International}

In 2008, the International Energy Agency (IEA, 2008) described and analysed the approaches of various governments in encouraging energy efficiency in the building codes for new buildings. Here, energy assessments are undertaken to comply with political ambitions as stated in national or local regulations. In the research report, various kinds of requirements regarding the energy use of buildings were noted and categorised. The basic requirement types listed in the report are (IEA, 2008, pp. 27-29):

- Prescriptive requirements: these focus on the energy efficiency of an individual component of a building or system. The individual components need to meet a regulation regarding energy use. Examples include minimum heat resistance values for walls, roofs and floors;

- Trade-off requirements: these set values for various components of a building and its systems. However, a trade-off can be made, with some values better and some worse than the requirements. In this situation, the calculations required are fairly simple and are not aimed at providing insights into expected energy use;

- Model building requirements: have the same underlying concept as the trade-off approach. However, in this situation a calculation is required to demonstrate that the actual building will be as good, in terms of energy use, as a 'model' building of the same shape and size. The designed building needs to match or exceed the energy performance of the model building;

- Energy frame requirements: offer a standard procedure with which the architect or constructor has to show that the energy use of their design will not exceed a stipulated value for the building as a whole. Regulations may, for example, lay down a maximum energy use per square meter of building surface;

- Energy performance requirements: these focus on a building's total energy use, its fossil fuel consumption or its emissions of greenhouse gases. The underlying procedure can be similar to the model building or energy frame approach, but the types of energy or fuels being used have to be taken into consideration. 
In many countries combinations of requirements are used to come to a low energy need, use and demand in buildings. Often tools in the form of computer programs are available to address the requirements, especially in the case of trade-off, model building, energy frame and energy performance requirements. The United States' Department of Energy (DoE) has compiled a list of software tools for evaluating energy efficiency, renewable energy and sustainability in buildings. This list contains over four hundred tools and their underlying methods from 28 countries (DoE, 2011a). For each tool a short description of the computer program and the underlying methodology is given. Not all tools listed are energy assessment tools based on a specific assessment method: some tools are based on assessment methods and others have similar foundations in terms of structure or framework. The Energy Performance Building Directive (EPBD) provides a common framework for many European countries when it concerns energy assessment tools. It is difficult to compare all the methods and tools available worldwide but it is useful here to give a short overview of at least some of the commonly used methodologies seen around the world. The focus is on methodologies that align with the ambition of governments to improve the energy performance of buildings in order to reduce their environmental impact. In the remainder of this section a closer look will be paid to the situation in the United States of America and Europe. The Netherlands is part of the European Union, and both the United States and Europe have similar latitudes and economic standings.

\section{United States of America}

In the USA, the individual states are largely responsible for setting standards for the energy performance of buildings. Five federal laws prescribe how agencies should make decisions regarding energy efficiency, fuel choice and energy use (Sunshine, 2011). Here, these federal agencies also have to take into account the energy performance of their own buildings and how they use them. However, no federal laws seem to exist when it comes to the energy performance or energy use of private buildings.

The federal government does offer through the DoE certain information and some sense of unity. The DOE has the mission to ensure America's security and prosperity by addressing its energy, environmental and nuclear challenges through transformative science and technology solutions (DoE, 2011b). In collaboration with this department, the International Code Council (ICC), and the American Society for Heating, Refrigerating and Air-Conditioning Engineers (ASHRAE) provide two commonly used methods for assessing the energy performance of buildings, namely the International Energy Conservation Code (IECC) and the ASHRAE standard (IEA, 2008). Both methods suggest prescriptive requirements for buildings regarding their building and systems characteristics, and these are dependent on an environmental characteristic - the location of the building within the USA. A trade-off can be made between some of the prescriptive requirements provided the total energy use of the design matches the energy use of a design that complies with the prescriptive requirements. The way these calculations should be carried out is also described. The ASHREA Standard 90.1 distinguishes the following elements of new buildings (ASHRAE, 2004): 
- Section 5 Building envelope;

- Section 6 Heating, ventilating and air conditioning;

- Section 7 Service water heating;

- Section 8 Power;

- Section 9 Lighting;

- Section 10 Other equipment;

- Section 11 Energy Cost Budget method.

In Section 5 it is described how the boundaries of the object of analysis need to be viewed and defined. Five different categories of energy use are described in Sections 6 to 10. The method to determine the building's energy performance is described in Section 11. The subjects covered by this index indicate that building characteristics, system characteristics and appliances should be taken into account when new buildings are designed and constructed. At first sight, these sections all seem to be universally applicable to all buildings. However, the ASHRAE standard states that its provisions do not apply to single-family houses, multi-family structures of three stories or fewer above ground level, and manufactured houses (ASHRAE, 2004, p. 4). According to its creators, the IECC is better equipped to assess dwellings. The code details some mandatory measures that need to be applied in all situations, and offers three ways to comply with the low energy use objective in residential buildings up to three floors high as follows (Lucas, 2011):

- Prescriptive requirements: an inflexible but relatively easy way to achieve low energy use, namely by applying prescriptive requirements that do not vary by building size, shape, window area, or other characteristics;

- Trade-off requirements: when it does not seem possible or desirable to apply the prescriptive requirements as they stand, it is possible to relax the thermal resistances specified for certain building components. This is allowed provided the total energy use of the house is no higher than it would have been, had it been built, using the thermal characteristics as stated in the prescriptive requirements;

- Energy performance requirements: the final option is to demonstrate a simulated energy performance that is equal to or better than the reference design that meets the prescriptive requirements. This procedure requires use of a software program, of which Lucas (2011) mentions the following examples: EnergyPlus, REM/Rate, REM/Design, or EnergyGauge.

A new version of the IECC became effective in 2012 and in both the old and the new versions, the following characteristics are addressed (DoE, 2011c):

- Environmental characteristics: The country is divided into eight climatic basic climatic zones, which are distinguished on the basis of the number of heating and cooling degree days. These zones are decisive in determining further regulations regarding the heat resistance of the thermal shell;

- Building characteristics: These focus on the size and design of the building envelope, consisting of the ceilings, walls, windows, floors and foundations. Insulation and 
fenestration levels, and solar heat gain coefficients, are also specified. Furthermore, the airtightness of the building is specified;

- Systems characteristics: maximum space heating, air conditioning and water heating requirements are set. Infiltration through the thermal shell is considered along with infiltration through installed systems such as ducts, air handlers, and filter boxes. However, most equipment efficiency requirements are set by federal law;

- Appliance characteristics are not considered, and requirements are only given for lighting equipment. The earlier requirement for $50 \%$ of lamps to be high-efficiency ones was increased to $75 \%$ in 2012 , or alternatively that $75 \%$ of lighting fixtures should have only high-efficiency lamps.

The ASHRAE Standard 90.1 and the IECC offer two methods to assess the energy use of building designs, when prescriptive requirements cannot be applied or are not desired. Individual states and local governments can refer to these methods, if they have ambitions to reduce the energy use of buildings. For the principal or owner of a building it is not in itself necessary to calculate or to address a minimum energy performance. If one complies with the basic mandatory and prescriptive requirements, this results in a uniform approach that does not deliver prognoses regarding energy performance or energy need, demand or use. The situation in Europe is different from the situation in the USA as explained below.

\section{Europe}

European Union member states are obliged to observe an EPBD which has the objective to promote the improvement of the energy performance of buildings within the European Community (EU, 2010, p. 153/17). This means that all 27 countries use, or should use, an energy assessment methodology that has a common background (Andaloro et al., 2010). Another five countries are candidates for European Union membership and these also need to comply with the same framework provided by the European Parliament and Council.

The annex of the EPBD prescribes a general framework for the calculation of the energy performance of buildings, as is shown in Table 2-9. It states what the input basis for the energy performance of a building needs to be: namely the calculated or actual annual energy demand to achieve a comfortable climate and to satisfy hot water needs in a standardized usage situation. As such, a standard level of occupation needs to be taken into account. It also states what the output of the methodology needs to show, namely an EPI and a numeric indicator of primary energy use. The primary energy use should account for energy transitions and accompanying exergy losses that take place in production and transport facilities outside the thermal shell of an analysed building. Further, the annex indicates that various environmental, occupational, building, systems and appliance characteristics need to be taken into account, but not all the characteristics described in Section 2.2 are included. Furthermore, the annex lists names of aspects, without any description, that can be regarded as environmental, building, systems and/or appliance characteristics.

Even before the 2001 EPBD and its 2010 revision, many countries were developing assessment methodologies for buildings in order to create an indicator of their energy performance (Míguez et al., 2006; Andaloro et al., 2010). European standards have offered a 
uniform method for expressing energy efficiency and building certification (EN15217) since 2007 and uniform definitions for energy ratings (EN15603) since 2008. However, elements of these standards have been adopted in different ways in different countries resulting in different energy certificates and labels. A comparative study among the EU member states by Andaloro et al. (2010) found the implementation of various aspects of energy certification to be very diverse. The researchers relate this to the different conditions and needs of the countries. Furthermore, countries that had a certification system that was very different to the European framework seemed to be slower in aligning themselves with the European standards. Nevertheless, most EU countries have adopted a method involving seven distinct energy classes with labels A to $G$. In some countries, sub-classes are specified. The next section shows that the Netherlands was one of the countries where methodologies to assess the energy performance of buildings were already available before the EPBD was presented in 2001.

Table 2-9: First four articles in Annex I of the EPBD (EU, 2010, p. 153/29).

\begin{tabular}{|c|c|}
\hline & $\begin{array}{l}\text { The energy performance of a building shall be determined on the basis of the calculated or actual } \\
\text { annual energy that is consumed in order to meet the different needs associated with its typical use and } \\
\text { shall reflect the heating energy needs and cooling energy needs (energy needed to avoid overheating) to } \\
\text { maintain the envisaged temperature conditions of the building, and domestic hot water needs; }\end{array}$ \\
\hline & $\begin{array}{l}\text { The energy performance of a building shall be expressed in a transparent manner and shall include an } \\
\text { EPI and a numeric indicator of primary energy use, based on primary energy factors per energy carrier, } \\
\text { which may be based on national or regional annual weighted averages or a specific value for onsite } \\
\text { production. The methodology for calculating the energy performance of buildings should take into } \\
\text { account European standards and shall be consistent with relevant Union legislation, including Directive } \\
\text { 2009/28/EC. }\end{array}$ \\
\hline $\begin{array}{r}\mathrm{Ar} \\
3\end{array}$ & $\begin{array}{l}\text { The methodology shall be laid down taking into consideration at least the following aspects: } \\
\text { 1. The following actual thermal characteristics of the building including its internal partition } \\
\text { a. thermal capacity; } \\
\text { b. insulation; } \\
\text { c. passive heating; } \\
\text { d. cooling elements; and } \\
\text { e. thermal bridges; } \\
\text { 2. Heating installation and hot water supply, including their insulation characteristics; } \\
\text { 3. Air-conditioning installations; } \\
\text { 4. Natural and mechanical ventilation which may include air-tightness; } \\
\text { 5. Built-in lighting installation (mainly in the non-residential sector); } \\
\text { 6. The design, positioning and orientation of the building, including outdoor climate; } \\
\text { 7. Passive solar systems and solar protection; } \\
\text { 8. Indoor climatic conditions, including the designed indoor climate; } \\
\text { 9. Internal loads. }\end{array}$ \\
\hline & $\begin{array}{l}\text { The positive influence of the following aspects shall, where relevant in the calculation, be taken into } \\
\text { account: } \\
\text { 1. Local solar exposure conditions, active solar systems and other heating and electricity systems } \\
\text { based on energy from renewable sources; } \\
\text { 2. Electricity produced by cogeneration; } \\
\text { 3. District or block heating and cooling systems; } \\
\text { 4. Natural lighting. }\end{array}$ \\
\hline
\end{tabular}




\subsubsection{Energy assessment methods for dwellings in the Netherlands ${ }^{2}$}

In this section, the Dutch situation regarding energy assessment methods is explained. Before explaining three different methods in depth, it is important to explain the background to the policy instruments that were used to reduce the environmental impact of society, specifically its buildings, in the Netherlands. The first sustainable step, or rankingbased method, was proposed as a motion by Parliamentarian Lansink in the late 1970s (Raven \& Verbong, 2004, p. 522; Parto et al., 2007, p. 238). Incorporated into the Dutch law on environmental conservation, his scheme - the so called "Lansink's Ladder" - contains seven steps to manage waste disposal (Wet milieubeheer, 1979):

1. Prevention: try to create as little waste as possible;

2. Consideration of the raw materials: use raw materials that do not harm the environment after product usage;

3. Product reuse: try to reuse a product in its original state as often as possible;

4. Material recycling: when the product cannot be used in its original form, then try to recycle its materials;

5. Combustion as a source of energy: when the product is assigned to waste, then try to incinerate it to generate heat and electric power;

6. Combustion: a less favourable option is to burn the waste without generating reusable heat and electric energy;

7. Landfill: the least preferable option for disposing of products and materials.

Later, Duijvestein (1993) introduced a three-step scheme, with each step ranking sustainable measures for the building industry in order of sustainability preference. Most favourable measures were part of the first step, and the least favourable ones formed the last step. The wide range of resources used in a building project were seen as both incoming and outgoing flows. The three steps were specified for both incoming and outgoing flows and showed some similarities with the steps in the "Lansink's Ladder".

The three steps for the incoming flow are:

1. Prevent unnecessary use;

2. Use endless sources, e.g. wind energy, solar energy, loam and wood;

3. Use finite sources as efficiently as possible.

The outgoing flow can be made more sustainable by:

1. Preventing waste;

2. Reusing waste;

3. Disposing of waste wisely.

\section{Trias Energetica}

Duijvestein not only addressed the flow of materials, but also other building-related flows such as water and energy. In many building projects, sustainability only focuses on a low energy use, as is obligated by the Dutch Building Code. Lysen (1996) introduced his threeway strategy for sustainable energy under the title "Trias Energica" - named after Charles de

\footnotetext{
${ }^{2}$ Parts of this section were published elsewhere (Entrop \& Brouwers, 2010; Entrop et al., 2010).
} 
Montesquieu's “Trias Politica" of 1752. The following scheme for a sustainable energy supply was proposed by Lysen:

1. Continuing improvement in energy efficiency;

2. More use of sustainable energy sources;

3. A cleaner use of remaining fossil fuels.

The combination of the three-step strategies of Lysen and of Duijvestein led to the name "Trias Energetica" being commonly used in the Netherlands. Starting in 2001, the Trias Energetica became internationally adopted encouraged by Anne Grete Hestnes, the former president of the International Solar Energy Society. She notes, "It is now more or less universally accepted that the European Commission's 'trias energetica' (first aim for energy efficiency, then use renewable energy, then supply the remaining needs with what the Commission calls 'clean fossil fuels') should be applied" (Hestnes, 2001). In identifying strategies for sustainable housing construction, Klunder (2004, p. 117) refers to Duijvestein as her source for the Trias Energetica. The revised form of the Trias Energetica, to which Hestnes (2001), Lysen (2002), Buvik (2003), Thomsen et al. (2005, p. 119), Sunikka (2006, p. 522), Op 't Veld (2008, p. 1344) and Antvorskov (2008, p. 1350) also refer, provides a more hierarchical approach to sustainability than Lysen's three steps, namely (see Figure 2-3):

Step 1: Prevent the use of energy by reconsidering the energy needs and demands, for example by applying insulation;

Step 2: Use renewable energy sources wherever possible, for example by installing thermal solar collectors, photovoltaic panels or wind turbines;

Step 3: If there remains a need or demand for energy, then use fossil fuels as efficiently and effective as possible, for example by making use of high efficiency boiler systems or micro cogeneration heat-and-power ( $\mu$-CHP) systems.

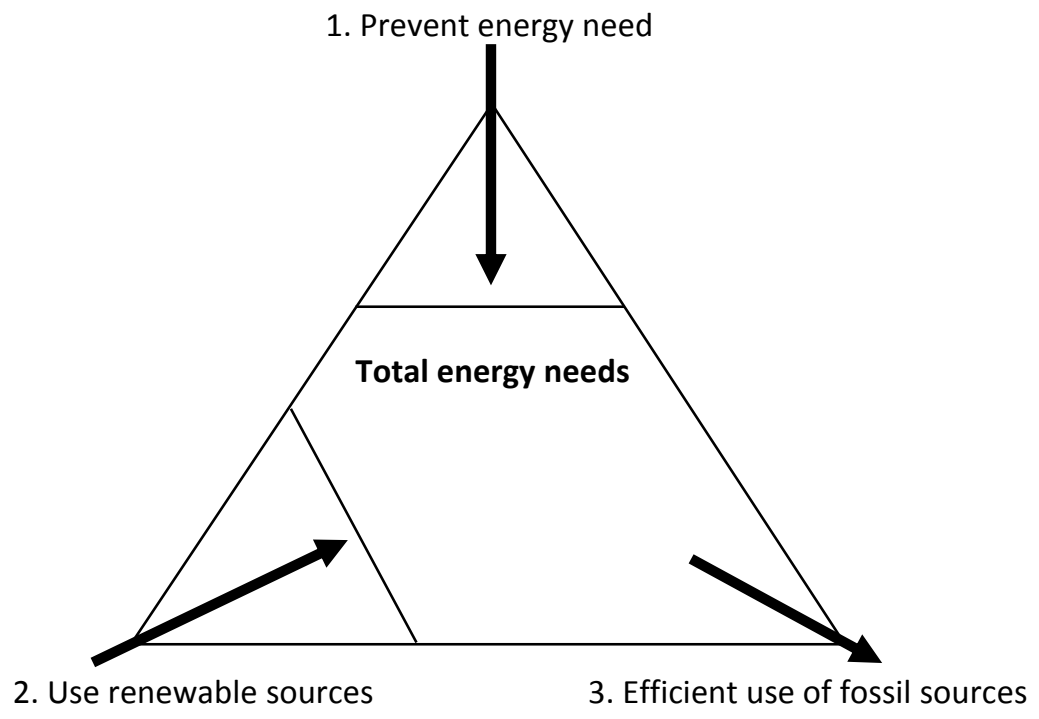

Figure 2-3: The three steps of the Trias Energetica for sustainable energy use.

These three steps - prevention, renewables and the efficient use of fossil fuels- form an important paradigm for architects, project managers and engineers concerned with designing and constructing buildings. It can also be seen in the regulations referred to in the 
Dutch Building Code. Aligned with the first step of the Trias Energetica, meeting a minimum thermal resistance and a maximum infiltration rate have been obligatory since 1992. In 1995, a maximum EPC for new dwellings was incorporated into the Building Code.

\section{Energy Performance Indicators (EPIs)}

The calculation method is based on an assessment of building and system characteristics of the design, and considers the building to be in a standard environment and with a standardised level of occupation. This assessment also takes the steps given by the Trias Energetica into account. Firstly, one has to assess the thermal shell of the dwelling in order to specify the need for energy. Secondly, the systems are assessed knowing how much energy is provided by renewable sources and how efficiently energy conversion takes place. In 1998, another assessment method was introduced for buildings with other functions. Up to July $1^{\text {st }} 2012$, three methods and accompanying indicators were used to assess the energy performance of Dutch residential buildings:

1. Energy Performance Coefficient (EPC): introduced in the Building Code in 1995 for new residential buildings and described in the directives NEN 5128 and NPR 5129 of the Netherlands Normalisation Institute NEN (NNI, 2004a; NNI, 2005);

2. "Old" Energy Index (El old): a voluntary proposal introduced in 2000 for existing residential buildings, and described by SenterNovem (2003);

3. "New" Energy Index (EI ${ }_{\text {new }}$ ): included in regulations in 2008 for existing residential buildings and described in publications 82.1, 82.2 and 82.3 of the Institute for Studying en Stimulating Research in the field of installation systems for buildings ISSO (ISSO, 2007a; ISSO, 2007b; ISSO, 2007c).

The indicators involved in the EPC were also used as part of the energy component of environmental assessment tools, such as GreenCalc and GPR Gebouw. There were two methods to assess the energy performance of utilities and commercial buildings:

1. Energy Performance Coefficient (EPC): introduced in 1998 for new utility buildings and commercial buildings and described in directives NEN 2916 and NPR 2917 of NEN (NNI, 2004b);

2. Energy Index (EI): included in regulations in 2008 for existing buildings and described in ISSO publications 75.1, 75.2 and 75.3 (ISSO, 2007d; ISSO, 2010; ISSO, 2011).

These methodologies for utilities share the basic principles of the EPC and the $E I_{\text {new }}$ approaches for dwellings but are more extensive. One can for example specify the types of lighting systems that have been applied. All the five indicators, indicated above, are based on equations that relate forecasted and permissible energy use. The forecasted energy use is based on the efficiency of the installed equipment, the heat demand, hot water usage and lighting etc. The permissible energy use is mainly based on the size of the object. These indicators enable one to estimate the potential energy savings of a broad range of techniques. At the end of 2011, a new method NEN 7120 was introduced to replace all the existing methods, but the principle of an equation to relate forecasted and permissible energy use remained. The earlier three methods for assessing dwellings will now be explained in more detail. 


\section{Energy Performance Coefficient (EPC) for new dwellings}

The determination method for the EPC for new buildings was developed by the Netherlands Normalisation Institute (NEN). The Dutch Building Code contains regulations regarding the minimum quality of new buildings. Chapter 5 of the Building Code specifies that buildings of a certain type need to achieve a certain EPC. A coefficient of 1.4 or less was formally incorporated in the Building Code in 1995. In 2006 an EPC of 0.8 or less was stipulated, and in 2011 this value was further reduced to 0.6 (NNI, 2013). A building permit will only be issued by a municipality when calculations demonstrate that the required EPC can be met. Two standards to calculate the EPC were issued. NEN 5128 addressed the energy performance of residential buildings (houses, flats and other residential buildings) and NEN 2916 addressed the energy performance of utility buildings and commercial buildings (e.g. office buildings, hotels and prisons). The latter standard has, as it concerns offices, been discussed by Pati et al. (2006).

Between 1995 and 2011, approximately 70,000 to 90,000 new dwellings were constructed each year. The older building stock, constructed before 1995, amounting to more than six million dwellings does not need to comply with an EPC. As an indication of the changes introduced, dwellings built before 1945 use on average 31\% more natural gas (the common fuel for space heating in the Netherlands) than dwellings from the 2000 to 2004 period (CBS, 2007). For residential buildings the EPC is calculated as follows (NNI, 2004a):

$$
E P C=\frac{Q_{\text {total:EPC }}}{C_{1} \times A_{g s ; E P C}+C_{2} \times A_{t s ; E P C}} \times \frac{1}{C_{E P C}}
$$

Equation 2-1

where:

EPC = Energy Performance Coefficient (-)

$\mathrm{Q}_{\text {total:EPC }}=$ annual energy demand (MJ) based on NEN 5128 (NNI, 2004a)

$A_{g s ; E P C}=$ total floor surface $\left(m^{2}\right)$

$A_{t s ; E P C}=$ total thermal transmission surface $\left(\mathrm{m}^{2}\right)$

$\mathrm{C}_{1}, \mathrm{C}_{2} \quad=$ numerical correction factors ${ }^{3}\left(330 \mathrm{MJ} / \mathrm{m}^{2}, 65 \mathrm{MJ} / \mathrm{m}^{2}\right)$

$C_{E P C}=$ correction factor to fit past EPC results (-)

The characteristic yearly energy use (expressed by $Q_{\text {total:EPC) }}$ sums ten categories of energy use (NNI, 2004a):

1. Energy for heating: energy needed to heat indoor spaces to a temperature of $18{ }^{\circ} \mathrm{C}$ for a period of one year by the installed heating system. Besides the physical characteristics of the building, the efficiency of the heat generation, distribution and delivery systems are taken into account;

2. Additional energy: auxiliary electric energy needed to operate the heating system;

3. Heating tap water: energy to heat tap water for washing, showering, bathing etc.;

4. Energy for fans: electric energy needed for mechanical ventilation;

5. Energy for lighting: electric energy use for lighting based on $6.0 \mathrm{kWh} / \mathrm{m}^{2}$ for the total floor surface based on a $39 \%$ efficiency of power stations and the electric grid;

\footnotetext{
${ }^{3}$ These values are chosen in such a way that a standard house with an EPC $=1.0$ has a natural gas consumption of roughly $1,000 \mathrm{~m}^{3}$
} 
6. Summer comfort: energy that would be used to lower the inside temperature to $24{ }^{\circ} \mathrm{C}$, if this temperature is exceeded during the summer. This category is included to ensure that overheating is prevented, for example by installing shades;

7. Energy used for cooling: this category only applies when cooling techniques have been adopted;

8. Energy used for humidification: rarely applies in practice. Humidifiers are namely not often applied in residential buildings;

9. Energy generated by photovoltaic systems: if installed - the adoption of photovoltaic systems on Dutch dwellings shows a small acceleration because of recent subsidies;

10. Energy generation by combined heat and power systems: micro-cogeneration systems for individual dwellings can be classified as innovative techniques in an experimental stage and are not (yet) commonly installed.

\section{Old Energy Index $\left(\mathrm{EI}_{\text {old }}\right)$ for existing dwellings}

The second methodology to be presented in this section is the old Energy Index ( $\left.\mathrm{EI}_{\text {old }}\right)$. This was based on the Energy Performance Advice (EPA) and developed to calculate the energy performance of existing dwellings.

Soon after the introduction of the EPC for new dwellings, an EPI for existing dwellings was suggested by, then the minister for Housing, Spatial planning and the Environment, Pronk. In 2000, an Energy Performance Advice (EPA) was proposed giving residents insight into the energy performance of their house and insights into which energetic improvements could be financially attractive. EPAs were produced by various advisors, who worked on commercial basis, throughout the Netherlands. A computer program to calculate the Energy Index ( $\left.\mathrm{EI}_{\text {old }}\right)$ and to automatically present the advice was provided by the government. All data derived from the assessments were centrally stored at SenterNovem (the Dutch national agency for innovation and sustainable development) for research and inspection purposes.

Between 2000 and 2006, 529,000 EPAs were created, with a peak in 2003 because of available subsidies accordin to the Compendium for the Environment (2010). Approximately 58,000 of the dwellings receiving an EPA were privately owned and the rest were rented. EPAs were not forced by regulations, but subsidies that reduced the costs did stimulate their voluntary adoption. In January 2008, the Dutch government adopted a new indicator for existing dwellings to comply with the European Energy Performance Building Directive, which meant that the traditional EPAs would no longer be produced. In the EPA method, introduced in January 2000, the $\mathrm{El}_{\text {old }}$ is calculated (Hoiting et al., 2004) as follows:

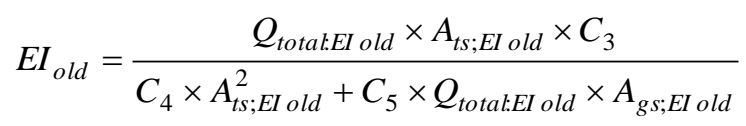
Equation 2-2

where:

$\mathrm{El}_{\mathrm{old}} \quad=$ Energy Index calculated within the EPA procedure (-)

$\mathrm{Q}_{\text {total; } \mathrm{El} \text { old }} \quad=$ annual energy demand (MJ) based on EPA 4.02 (SenterNovem, 2003)

$A_{\mathrm{gs} ; \text { El old }} \quad=$ total ground surface $\left(\mathrm{m}^{2}\right)$

$A_{\mathrm{ts} ; \mathrm{El} \text { old }}=$ total thermal transmission surface $\left(\mathrm{m}^{2}\right)$

$\mathrm{C}_{3}, \mathrm{C}_{4}, \mathrm{C}_{5}=$ numerical correction factors $\left(0.13,56 \mathrm{MJ} / \mathrm{m}^{2}, 0.06\right)$ 
The output of the EPA is given in $\mathrm{m}^{3}$ natural gas for generating heat and $\mathrm{kWh}$ for the electric energy use. Using an average calorific value for natural gas of $33.41 \mathrm{MJ} / \mathrm{m}^{3}$ and a conversion rate of $3.6 \mathrm{MJ} / \mathrm{kWh}$, it is possible to express the results in $\mathrm{MJ}$. In this method, the total foreseen energy use $\left(Q_{\text {total; El old }}\right)$ for existing dwellings is equivalent to the characteristic energy use of the EPC ( $\left.Q_{\text {total:EPC }}\right)$ for new residential buildings. However, only four categories of energy use are covered by $Q_{\text {total; } \text { il old }}$ (SenterNovem, 2003):

1. Energy for heating: energy needed to heat the dwelling. The standard value of $18{ }^{\circ} \mathrm{C}$ can be adjusted depending on the actual indoor temperature and/or the general presence of the habitants;

2. Additional energy: auxiliary electric energy needed to operate the heating system;

3. Heating tap water: in the EPA calculation procedure it is not, unlike with the EPC, necessary to specify the lengths of hot water pipes. One does need however to specify whether pipe insulation, water-saving shower heads, baths, dishwashers and reduced pipe lengths are applied;

4. Energy for lighting: the efficiency of the power station is not incorporated. The standard energy use of $6 \mathrm{kWh} / \mathrm{m}^{2}$ year therefore leads to approximately 39\% higher values for the energy used in lighting in the EPC than in the $\mathrm{El}_{\text {old }}$.

\section{New Energy Index $\left(\mathrm{EI}_{\text {new }}\right)$ for existing dwellings}

The latest Energy Index ( $\mathrm{El}_{\mathrm{new}}$ ) is the third indicator to be considered in this section. This is a direct result of the Dutch implementation of the European EPBD. With the implementation of the EPBD by the European Union Parliament and Council (EC, 2002), new regulations need to be developed by the central governments of EU member states. In the Netherlands, it was necessary to develop a single method to calculate the energy performance of both new and existing buildings. The results are a new Energy Index with an accompanying Energy Performance Certificate. In theory, this new method could replace the methods underlying both the EPC and the $\mathrm{El}_{\text {old }}$. Nevertheless, current Building Codes do not yet refer to this new index, and the indicator has only recently been adopted to assess existing houses. AgentschapNL (formerly SenterNovem) expects the methods underlying the EPC and $\mathrm{EI}_{\text {new }}$ to be combined in one new standard called Energy Performance Buildings and numbered NEN 7120. The link between these two methods was the principle that an $\mathrm{EI}_{\text {new }}$ of 1.0 should be roughly equivalent to an EPC of the same value (AgentschapNL, 2012a).

Although house owners have notionally been obliged since January $1^{\text {st }} 2008$ to obtain an energy certificate prior to selling their house, no penalties are specified for ignoring this regulation. In 2010, a subsidy programme was initiated to stimulate 50,000 private owners to obtain an energy certificate. As of May 2010, 1,649,480 dwellings had an energy certificate specifying its energy performance. In the period January - May 2010, 75,403 labels were issued (AgentschapNL, 2010). It was expected that, by the start of 2011, penalties would be introduced to boost the adoption rate but, as of November 2012, penalties had still not been set. A majority of the certified dwellings are owned by social housing associations, which committed themselves to improving the energy performance of their building stock to achieve at least a ' $B$ ' Energy Label. The combined method for existing 
and new residential buildings uses the following equation to calculate the new Energy Index (EI $I_{\text {new }}$ ) (ISSO, 2007a; ISSO, 2007b; ISSO; 2007c):

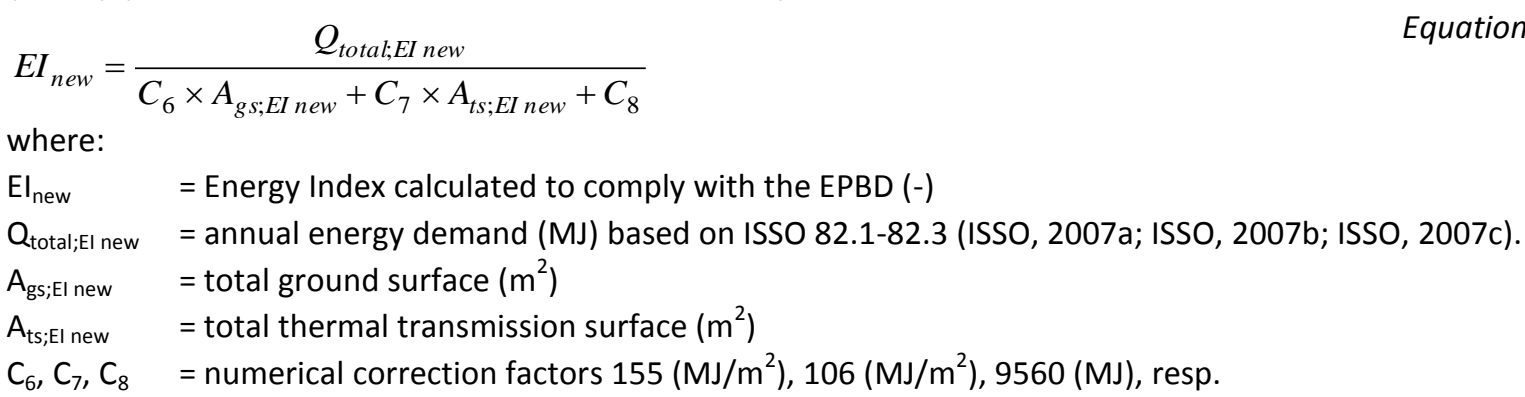

The energy demand of a dwelling, $Q_{\text {total;El new, }}$ in Equation 2-3, covers the same categories of energy use and includes the same underlying assumptions as the $Q_{\text {total:EPC }}$ of Eq.2-1, and therefore their values are very similar. The $\mathrm{EI}_{\text {new }}$ of an analysed building will be converted to an alphabetical classification on the energy certificate. A classification or label ' $A$ ' expresses the best energy performance $\left(E I_{\text {new }}<1.05\right)$ and a ' $G$ ' label the worst $\left(E I_{\text {new }}>2.90\right)$.

\subsection{Assessing the energy performance of dwellings in a case study 4}

In the previous section, the methods offered to assess the characteristics and to calculate energy performance were described. In this section, these methods are applied in a case study to calculate the energy demand and energy performance of eight dwellings. These calculated values will be compared to actual energy use as provided in the energy bills of the households.

\subsubsection{Selecting and characterising the dwellings}

In selecting the research objects for the case study, it was an important consideration that the houses should be representative of the existing Dutch building stock by means of implemented ETMs. As noted in the last section, the Dutch housing stock reflects approximately one hundred years of residential real estate development. The development of cavity walls, double glazing, insulation and efficient natural gas boilers are some of the most important implemented breakthroughs reflected within the selected set of eight dwellings. The scope of this case study is limited to implemented ETMs in houses that were built before the first EPC regulations. Formal national regulations on a minimum insulation level for the building shell were introduced in 1992 for new buildings. In December 1995, the EPC for new dwellings was added to the national Dutch Building Code. Consequently, the newest selected dwelling in the case study was built in 1992. Cavity walls were introduced in the 1920s and the oldest house in the assessment dates from 1913, before cavity walls were introduced.

In total eight dwellings will be used in this case study of which the years of construction are distributed over the period 1913-1992. Eight houses can not statistically represent all dwellings, nor all houses in the Netherlands. However, it is expected that assessing the EPIs of eight fairly different houses -by means of building characteristics and system characteristics- with different households residing in them -occupational characteristics-

\footnotetext{
${ }^{4}$ Parts of this section were published elsewhere (Entrop et al., 2010).
} 
can provide insights on how the energy performance of houses is assessed and on how ETMs fit in an assessment. The number of cases is limited due to the given that not many households agree to let a researcher enter all spaces in their houses and to provide over multiple years detailed information on their house, its characteristics, its use and its energy use. Furthermore, a practical limitation existed by means of limited availability of time, because visiting the objects, interviewing residents and assessing the energy performance of a house in three different ways is quite time consuming.

Table 2-10: Basic characteristics of the eight houses.

\begin{tabular}{|c|c|c|c|c|c|c|c|c|}
\hline & House 1 & House 2 & House 3 & House 4 & House 5 & House 6 & House 7 & House 8 \\
\hline $\begin{array}{l}\text { Year of } \\
\text { construction }\end{array}$ & 1913 & 1925 & 1939 & 1948 & 1964 & 1972 & 1982 & 1992 \\
\hline Location & Enschede & Dirksland & Almelo & Hengelo (Ov) & Den Bosch & Den Bosch & Enschede & Enschede \\
\hline Building type & $\begin{array}{l}\text { Semi-detached } \\
\text { house }\end{array}$ & $\begin{array}{l}\text { Detached } \\
\text { house }\end{array}$ & Row house & $\begin{array}{l}\text { Semi-detached } \\
\text { house }\end{array}$ & Row house & Row house & Row house & $\begin{array}{l}\text { Semi-detached } \\
\text { house }\end{array}$ \\
\hline
\end{tabular}

\begin{tabular}{|c|c|c|c|c|c|c|c|c|}
\hline \multicolumn{9}{|l|}{$\begin{array}{l}\text { Shape of the } \\
\text { object }\end{array}$} \\
\hline Market value & $€ 270,000$ & $€ 365,000$ & $€ 125,000$ & $€ 280,000$ & $€ 350,000$ & $€ 324,000$ & $€ 160,000$ & $€ 265,000$ \\
\hline Habitants & 5 & 5 & $5 \rightarrow 2$ & 2 & $2 \rightarrow 1$ & 2 & $2 \rightarrow 4$ & 2 \\
\hline $\begin{array}{l}\text { Total surface } \\
\text { floors }\left(\mathrm{m}^{2}\right)\end{array}$ & 125.00 & 170.95 & 102.74 & 145.04 & 148.74 & 174.98 & 100.45 & 124.17 \\
\hline $\begin{array}{l}\text { Surface building } \\
\text { shell }\left(\mathrm{m}^{2}\right)\end{array}$ & 354.5 & 440.2 & 196.9 & 262.1 & 296.2 & 214.1 & 158.3 & 232.5 \\
\hline $\begin{array}{l}\text { Perimeter } \\
\text { (m) }\end{array}$ & 25.43 & 50.40 & 16.10 & 21.48 & 23.56 & 14.00 & 10.80 & 19.96 \\
\hline $\begin{array}{l}\text { Thermal resistance } \\
\text { walls }\left(\mathrm{m}^{2} \mathrm{~K} / \mathrm{W}\right)\end{array}$ & 0.21 & $0.28-1.77$ & $0.41-1.19$ & 0.41 & 0.41 & 0.50 & 1.73 & 2.84 \\
\hline $\begin{array}{l}\text { Thermal resistance } \\
\text { floor }\left(\mathrm{m}^{2} \mathrm{~K} / \mathrm{W}\right)\end{array}$ & 0.22 & 0.07 & 0.09 & 1.65 & 0.42 & 0.03 & 0.68 & 2.39 \\
\hline $\begin{array}{l}\text { Thermal resistance } \\
\text { roof }\left(\mathrm{m}^{2} \mathrm{~K} / \mathrm{W}\right)\end{array}$ & 2.13 & 1.38 & $1.19-2.5$ & 1.76 & 2.84 & 2.22 & 1.41 & 2.57 \\
\hline $\begin{array}{l}\text { Type(s) of glazing } \\
\left(\mathrm{W} / \mathrm{m}^{2} \mathrm{~K}\right)\end{array}$ & $\begin{array}{l}\text { Mainly single } \\
5.2\end{array}$ & $\begin{array}{l}\text { Very high } \\
\text { performance } \\
1.8-2.1\end{array}$ & $\begin{array}{l}\text { Mainly high } \\
\text { performance } \\
2.3\end{array}$ & $\begin{array}{l}\text { Mainly single } \\
\text { with double } \\
\text { window frame } \\
2.8-4.5\end{array}$ & $\begin{array}{l}\text { Mainly double } \\
\text { with aluminium } \\
\text { frames } \\
3.0-5.2\end{array}$ & $\begin{array}{l}\text { Mainly double } \\
\text { and high } \\
\text { performance } \\
2.8-5.2\end{array}$ & $\begin{array}{l}\text { Double glazing } \\
\text { with wooden } \\
\text { frames } \\
2.9\end{array}$ & $\begin{array}{l}\text { Very high } \\
\text { performance } \\
1.8\end{array}$ \\
\hline $\begin{array}{l}\text { Infiltration } \\
\left(\mathrm{dm}^{3} / \text { s per }^{2}\right)\end{array}$ & 1.4 & 1.4 & 1.4 & 1.4 & 1.2 & 1.2 & 1.2 & 1.0 \\
\hline Heating system & $\begin{array}{l}\text { Highly } \\
\text { efficient } \\
\text { natural } \\
\text { boiler }\end{array}$ & $\begin{array}{l}\text { Highly } \\
\text { efficient } \\
\text { natural } \\
\text { boiler }\end{array}$ & $\begin{array}{l}\text { Traditional } \\
\text { natural gas } \\
\text { boiler }\end{array}$ & $\begin{array}{l}\text { Efficient } \\
\text { natural gas } \\
\text { boiler }\end{array}$ & $\begin{array}{l}\text { Efficient } \\
\text { natural gas } \\
\text { boiler }\end{array}$ & $\begin{array}{l}\text { Efficient } \\
\text { natural gas } \\
\text { boiler }\end{array}$ & District heating & District heating \\
\hline $\begin{array}{l}\text { Length of hot } \\
\text { water pipes } \\
\text { (m) }\end{array}$ & $\begin{array}{l}\text { Bathroom } 3 \\
\text { Kitchen } 3.5\end{array}$ & $\begin{array}{l}\text { Bathroom } 3 \\
\text { Kitchen } 1 \\
\text { electric boiler }\end{array}$ & $\begin{array}{l}\text { Bathroom } 4.5 \\
\text { Kitchen } 7.5\end{array}$ & $\begin{array}{l}\text { Bathroom } 2 \\
\text { Kitchen } 5.5\end{array}$ & $\begin{array}{l}\text { Bathroom } 10 \\
\text { Kitchen } 7.5\end{array}$ & $\begin{array}{l}\text { Bathrooms } 9 \\
\text { Kitchen } 7.5\end{array}$ & $\begin{array}{l}\text { Bathroom } 15 \\
\text { Kitchen } 7.5\end{array}$ & $\begin{array}{l}\text { Bathroom } 11 \\
\text { Kitchen } 7\end{array}$ \\
\hline
\end{tabular}

\footnotetext{
${ }^{5}$ The specific rates of infiltration are based on a standardized infiltration of 1.0 to $1.43 \mathrm{dm}^{3} / \mathrm{s}$ per $\mathrm{m}^{2}$ floor area (NNI, 2005) and the consideration that flat roof houses have a lower infiltration rate than gable roof houses.
} 
Table 2-10 shows, besides some basic specifications, the results of the calculations on the thermal resistances of floors, walls and roofs. The average value of the eight houses of approximately $€ 267,000$ is above the 2007 national average of $€ 216,0002007$ (CBS, 2010d). The calculations and estimates of thermal resistances of the shell (walls, windows and doors) conformed to national standards such as NEN 1068 "Thermal insulation of buildings Calculation methods", NEN 5128 "Energy performance of residential functions and residential buildings - Determination method", and ISSO 82.1-82.3 "Energy Performance Advice Dwellings". Empirical information was obtained from original drawings of the houses. The information on the drawings was checked by visual inspections and, if necessary, corrected. Except house 2, every house was visited at least two times to make sure all characteristics were correctly incorporated in the calculations methods underlying the EPIs.

The physical quality of a house and any installations are of great importance in determining its energy use. However, not only these technical conditions but also the behaviour of the users can make a large difference to actual energy use. The owners of the houses were asked to supply data on their total electric energy use and natural gas consumption for previous years by providing energy bills. Two of the owners (houses 3 and 5) could supply energy usage data for more than fifteen years. When the old energy bills could not be provided, the energy companies involved were contacted to send copies. Besides studying the drawings of the houses, inspecting and measuring the houses, and collecting data on energy use, questions were asked in an interview to find out which physical and non-physical changes conducted by the household had taken place in and around the house during recent years. Physical changes were explained in terms of financial investments in tangible energy techniques, and non-physical changes addressed issues such as attitudes, presence, lifestyle and household size. When a new energy bill came available for one of the houses, the specific household was again contacted to inform for new recent physical and non-physical changes.

The characteristics of the houses, as obtained from drawings, specifications, measurements and observations, were used to calculate the EPC, $\mathrm{El}_{\text {old }}$, and $\mathrm{EI}_{\text {new }}$ values. These EPIs were introduced and explained in the previous section and will be used in the next section. In Appendix A, the dwellings are described in more detail than in Table 2-10 and some drawings and photographs are provided to give an impression of each house and its current state. Photographs were taken using both conventional and infrared cameras.

\subsubsection{Energy performance of the dwellings based on assessment methods}

The collected specifications of the houses shown in Table 2-10 were used to compute EPC, $\mathrm{El}_{\text {old }}$ and $\mathrm{El}_{\text {new }}$ using three computer programmes: Nationale Praktijk Richtlijn (NPR) 5129 National Practical Directive- (NNI, 2005), Energie Prestatie Advies (EPA) -Energy Performance Advice- (SenterNovem, 2003) and Energieprestatie Certificaatsoftware Woningbouw (ECW) -Energy Performance Certificate Software for Residential Real Estate(DGMR, 2007; ISSO, 2007a; ISSO, 2007b; ISSO, 2007c). NPR 5129 version 2.02 from 2005 was used to calculate the EPC. The El old was calculated using the basic software edition of EPA 
version 4.02 dated June 2003; and $\mathrm{EI}_{\text {new }}$ was calculated using $\mathrm{ECW}$ version 1.11 of October 2007. The results of these calculations are shown in Figure 2-4 for each dwelling.

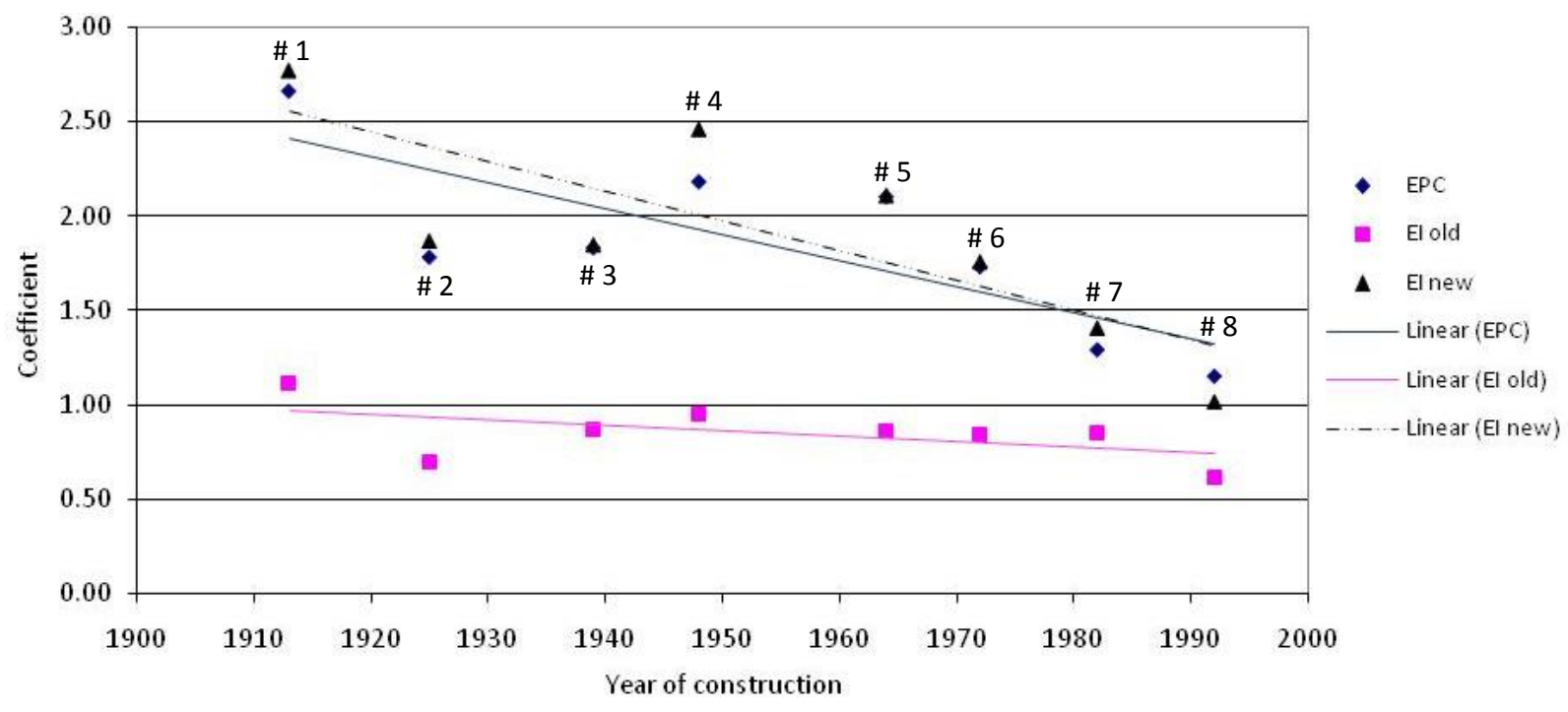

Figure 2-4: Calculated energy performance of eight Dutch dwellings.

The EPC values range from 1.15 for the newest house (house 8 ) to 2.66 for the oldest (house 1). The EPC values are higher for the older houses with the exceptions of houses 2 and 3 that have both undergone refurbishments. For instance, house 2, with an EPC 1.78, has been upgraded with thermal insulation, very high performance glazing and a high efficiency boiler. House 3 achieved an EPC of 1.83 due to recently installed roof insulation, without which the EPC would have been at least 2.07. In three cases, houses 3, 5 and 6, the EPC and $\mathrm{EI}_{\text {new }}$ values were almost identical (see Table 2-11).

The $\mathrm{El}_{\text {old }}$ values of the houses do not show the same trend in energy performance as the EPC values. In particular, the newest two houses are connected to a district heating system. This influences the performance in terms of the energy needed for heating water and the auxiliary electric energy needed to operate the heating system. The values of $\mathrm{El}_{\text {old }}$ range from 1.11 for house 1 to 0.62 for house 8 . Although there are significant differences between the EPCS of houses 5, 6, and 7, their specific $\mathrm{El}_{\text {old }}$ values of $0.86,0.84$ and 0.85 are almost the same. The EPA estimates the energy required to heat water for house number 7 to be much higher than for houses 5 and 6 because of the different interpretations in the EPA and EPC methodologies of the water heating efficiency of district heating systems (see Table 2-11).

The calculated values for $\mathrm{EI}_{\text {new }}$ range from 2.77 (label F) to 1.02 (label A). Again the oldest house (house 1) has the worst theoretical performance and the newest building (house 8 ) the best. The sequence in energy performance is almost the same as with the EPC: only houses 2 and 3 changed positions and this was because the estimated energy used to heat water increased for house 2. 
Table 2-11: Theoretical annual energy performance of the houses: indicators and specifications.

\begin{tabular}{lrrrrrrrr}
\hline Theoretical results EPC & House 1 & House 2 & House 3 & House 4 & House 5 & House 6 & House 7 & House 8 \\
\hline Energy for heating (MJ) & 144,314 & 125,334 & 57,496 & 118,491 & 105,514 & 67,941 & 38,370 & 40,485 \\
\hline Additional energy (MJ) & 2,935 & 4,006 & 4,909 & 3,397 & 3,489 & 4,098 & 0 & 0 \\
\hline Heating water (MJ) & 15,759 & 24,789 & 23,843 & 24,419 & 35,129 & 53,117 & 12,592 & 14,663 \\
\hline Energy for fans (MJ) & 0 & 0 & 0 & 0 & 0 & 0 & 3,245 & 4,011 \\
\hline Energy for lighting (MJ) & 7,051 & 9,643 & 5,796 & 8,182 & 8,390 & 9,871 & 5,666 & 7,004 \\
\hline Summer comfort (MJ) & 1,070 & 1,519 & 1,277 & 1,616 & 4,284 & 1,481 & 1,558 & 4,745 \\
\hline Qtotal;EPC (MJ) & 171,129 & 165,291 & 93,321 & 156,105 & 156,806 & 136,508 & 61,431 & 70,908 \\
\hline EPC (-) & $\mathbf{2 . 6 6}$ & $\mathbf{1 . 7 8}$ & $\mathbf{1 . 8 3}$ & $\mathbf{2 . 1 8}$ & $\mathbf{2 . 1 0}$ & $\mathbf{1 . 7 3}$ & $\mathbf{1 . 2 9}$ & $\mathbf{1 . 1 5}$ \\
\hline
\end{tabular}

\begin{tabular}{lrrrrrrrr}
\hline Theoretical results EPA & House 1 & House 2 & House 3 & House 4 & House 5 & House 6 & House 7 & House 8 \\
\hline Energy for heating (MJ) & 129,330 & 104,907 & 59,804 & 101,566 & 91,777 & 74,504 & 33,176 & 30,737 \\
\hline Additional energy (MJ) & 1,138 & 4,558 & 814 & 1,242 & 1,260 & 1,397 & 1,811 & 2,110 \\
\hline Heating water (MJ) & 18,509 & 16,705 & 16,505 & 15,402 & 13,932 & 12,562 & 19,478 & 24,289 \\
\hline Energy for lighting (MJ) & 2,700 & 3,690 & 2,221 & 3,132 & 3,215 & 3,776 & 2,167 & 2,682 \\
\hline Qtotal;El old (MJ) & 151,677 & 129,860 & 79,343 & 121,342 & 110,184 & 92,240 & 56,632 & 59,818 \\
\hline El $_{\text {old }}$ (-) & $\mathbf{1 . 1 1}$ & $\mathbf{0 . 7 0}$ & $\mathbf{0 . 8 7}$ & $\mathbf{0 . 9 5}$ & $\mathbf{0 . 8 6}$ & $\mathbf{0 . 8 4}$ & $\mathbf{0 . 8 5}$ & $\mathbf{0 . 6 2}$ \\
\hline
\end{tabular}

\begin{tabular}{lrrrrrrrr}
\hline Theoretical results ECW & House 1 & House 2 & House 3 & House 4 & House 5 & House 6 & House 7 & House 8 \\
\hline Energy for heating (MJ) & 131,893 & 116,187 & 58,343 & 119,596 & 105,386 & 75,363 & 34,024 & 26,595 \\
\hline Additional energy (MJ) & 2,915 & 3,527 & 2,088 & 3,181 & 3,230 & 3,580 & 4,647 & 5,413 \\
\hline Heating water (MJ) & 11,946 & 18,481 & 12,912 & 12,805 & 12,805 & 13,185 & 12,805 & 13,718 \\
\hline Energy for lighting (MJ) & 6,923 & 9,471 & 5,688 & 8,031 & 8,236 & 9,692 & 5,566 & 6,879 \\
\hline Qtotal;ECW (MJ) & 153,677 & 147,666 & 79,031 & 143,613 & 129,657 & 101,820 & 57,042 & 52,605 \\
\hline El new (-) & $\mathbf{2 . 7 7}$ & $\mathbf{1 . 8 7}$ & $\mathbf{1 . 8 5}$ & $\mathbf{2 . 4 6}$ & $\mathbf{2 . 1 1}$ & $\mathbf{1 . 7 6}$ & $\mathbf{1 . 4 1}$ & $\mathbf{1 . 0 2}$ \\
\hline Label classification & $\mathbf{F}$ & $\mathbf{D}$ & $\mathbf{D}$ & $\mathbf{F}$ & $\mathbf{E}$ & $\mathbf{D}$ & $\mathbf{C}$ & $\mathbf{A}$ \\
\hline
\end{tabular}

\subsubsection{Household energy based on energy bills}

The three theoretical EPIs addressed are intended to reflect the energetic quality of a built object. In this case study, the energy use of eight houses is being addressed. However, these theoretical computations are not always in line with the actual energy use (see Table 2-12).

Table 2-12: Specifications actual energy use of the eight houses.

\begin{tabular}{|c|c|c|c|c|c|c|c|c|}
\hline Actual energy use & House 1 & House 2 & House 3 & House 4 & House 5 & House 6 & House 7 & House 8 \\
\hline Data period from & Dec ‘06 & May'97 & Oct '86 & Sept '99 & June '89 & Mar '98 & Oct ‘04 & Jan '03 \\
\hline to & Aug '10 & May '10 & Apr '10 & Sep '10 & May'10 & Mar'10 & July ‘09 & May '10 \\
\hline Annual natural gas use $\left(\mathrm{m}^{3}\right)$ & 2,591 & 3,446 & 1,690 & 2,063 & 1,884 & 1,470 & $26.87 \mathrm{GJ}$ & J $34.29 \mathrm{GJ}$ \\
\hline Annual electric energy use (kWh) & 4,645 & 5,820 & 3,281 & 3,868 & 2,082 & 4,264 & 2,552 & 1,701 \\
\hline$\overline{\text { Annual } Q_{\text {total;Actual }} \text { (MJ) }}$ & 129,442 & 168,854 & 86,749 & 104,629 & 82,163 & 88,473 & 50,427 & 49,992 \\
\hline
\end{tabular}

The effects of any technical measures introduced as well as the effects of energy user behaviour are shown for all eight houses in Figure 2-5 and Figure 2-6 for electricity and gas respectively. For houses 4 and 6 a significant decrease in electric energy use occurred, in 2004 and 2006 respectively, due to an adolescent leaving the parental house. Since 2008, house 7 has seen an increase in both electric and thermal energy use, attributed to the birth of two children. In house 2 only the electric energy use increased significantly, when children were born. The increasing electric energy use of house 5 from 2004 onwards is the result of installing underfloor electric heating in the bathroom. In house 6, electric floor heating was 
installed in 2007. House 1 is occupied by five students, and the increasing adoption of electric appliances seems likely to explain the growing electric energy use in house 1. A few of the changes in energy use could not be explained by specific social or technical events, such as those in house 3 in 1990 and 1994. Apart from these changes, the houses demonstrated relatively steady electric energy. The natural gas consumption figures in Figure 2-6 show smaller changes over time than with electric energy use in Figure 2-5.

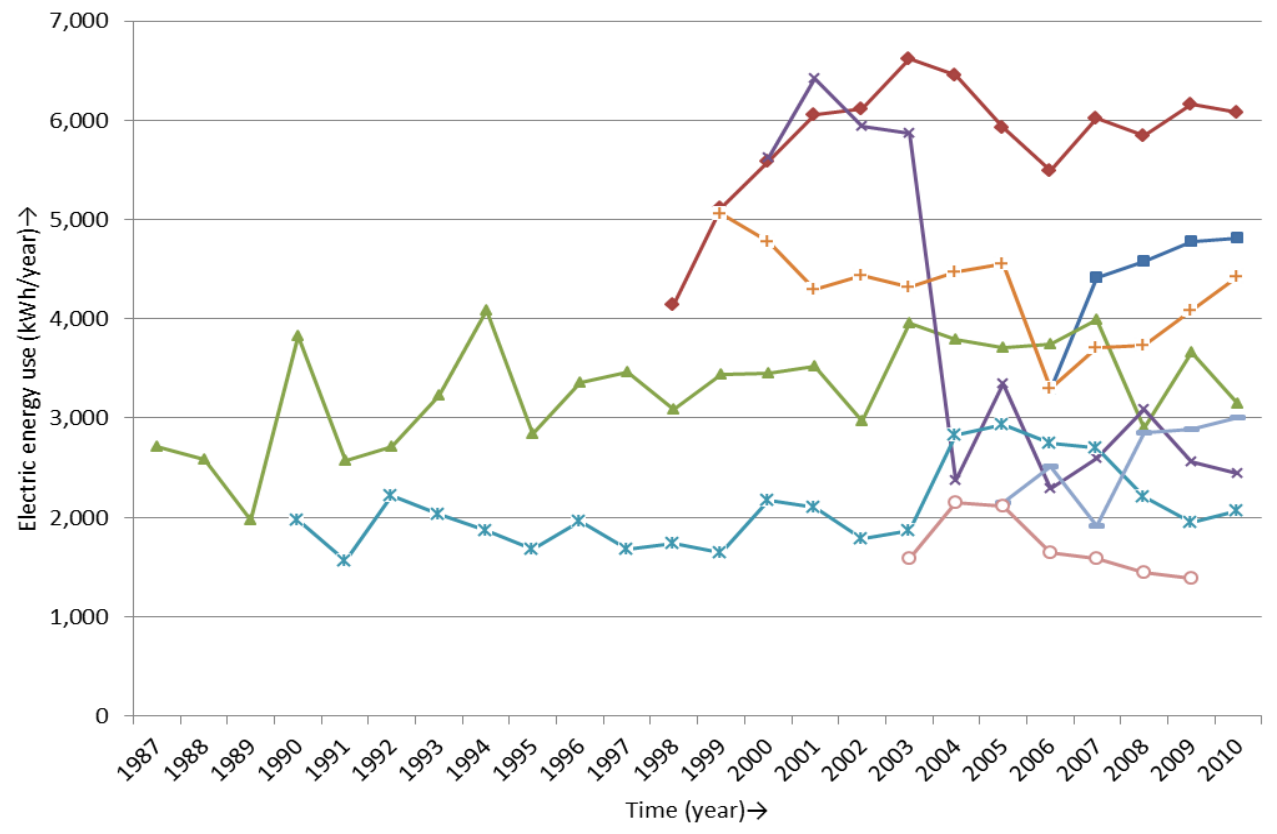

$\rightarrow$ House 1 (1913)

$\longrightarrow$ House 2 (1925)

$\longrightarrow$ House 3 (1939)

— House 4 (1948)

- - House 5 (1964)

- - -House 6 (1972)

- House 7 (1982)

$\multimap-$ House 8 (1992)

Figure 2-5: Annual electric energy use per house based on energy bills.

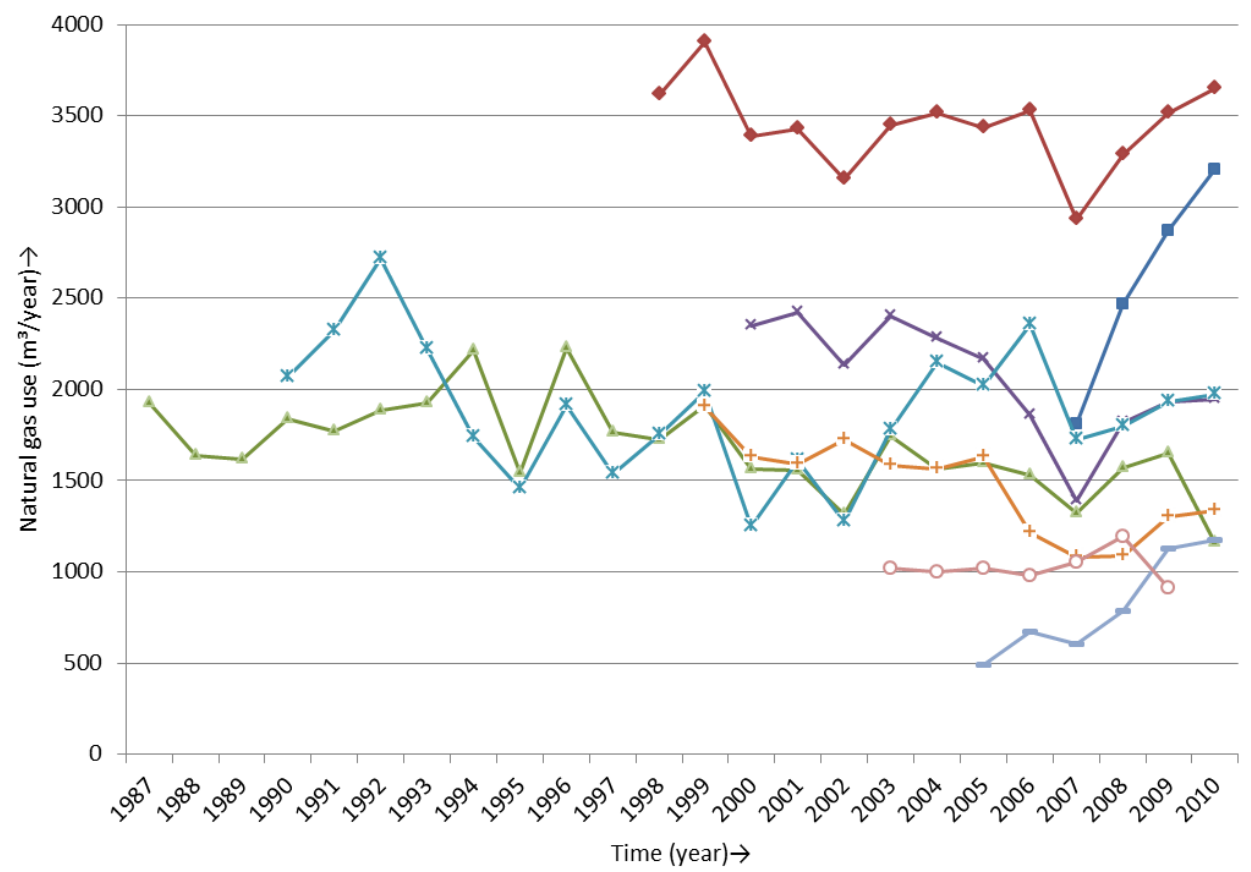

$\rightarrow$ House 1 (1913)

$\longrightarrow$ House 2 (1925)

— -House 3 (1939)

$\longrightarrow$ House 4 (1948)

- - House 5 (1964)

-1-House 6 (1972)

- House 7 (1982)

$\multimap-$ House 8 (1992)

Figure 2-6: Annual natural gas consumption per house based on energy bills.

$-72-$ 


\subsubsection{Energy performance of the dwellings based on energy bills}

The data on the actual energy use by the inhabitants of the houses (see Table 2-12) are used to recalculate the EPIs by replacing $Q_{\text {total;EPC, }} Q_{\text {total; El old }}$ and $Q_{\text {total;El new }}$ with the actual energy use $Q_{\text {totalaactual. }}$ This results in different values of the EPIs than those based on the theoretical $Q_{\text {total }}$ (see Figure 2-7). In general, the EPIs based on actual energy use suggest that the houses have a better energy performance than those using the standardised official calculation methods. In other words, EPIs based on actual energy use are, in most cases, lower than when they reflect a theoretical building -related energy use.

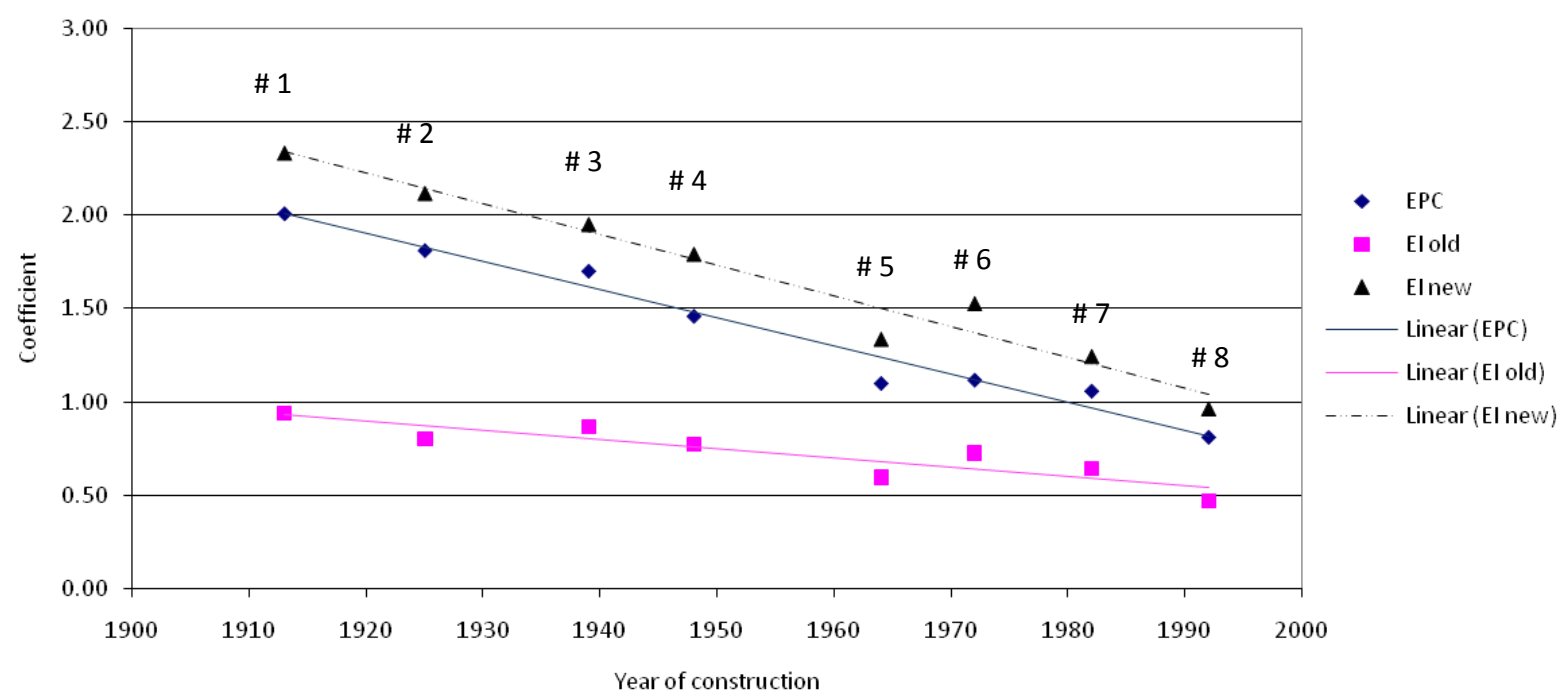

Figure 2-7: Energy performance based on user data of eight dwellings in the Dutch housing stock.

Although the data show that house 2 has the highest energy use, the recalculated EPC and $\mathrm{El}_{\text {new }}$ values indicate that house 1 has the worst energy performance due to its smaller floor surface to building shell surface ratio ( 0.35 for house 1 compared to 0.39 for house 2 ). The energy use of house 5 in relationship to its characteristics seems to be viewed rather positively. The recalculated EPIs for house 5 are all below the trend lines (see Figure 2-7). The recalculated EPC and $E I_{\text {new }}$ values give the same sequence when ranking the houses on energy performance. When looking at El old, two pairings, houses 2 and 3 and houses 5 and 7 , swop rankings compared to EPC and $\mathrm{EI}_{\text {new. }}$. The results using the EPC method show the largest differences, on average $37 \%$, between actual and theoretical EPIs. In comparison, the average differences are $19 \%$ in $\mathrm{El}_{\text {old }}$ and $16 \%$ in $\mathrm{El}_{\text {new. }}$. If the actual and theoretical energy uses per square metre of floor surface are compared, the values based on the EPC again show the largest differences (on average $24 \%$, compared with $6 \%$ with $\mathrm{El}_{\text {old }}$ and $11 \%$ for $\left.\mathrm{El}_{\text {new }}\right)$. Thus, for these eight dwellings, the calculated and the actual energy uses, $\mathrm{Q}_{\text {total, }}$ are less different than the theoretical and actual EPIs that adjust energy use based on the size of the object.

\subsection{Reflections on assessing the energy performance of dwellings}

In this section, the contents of the previous sections will be reflected on. Firstly, the calculated figures for building related energy use are compared with the actual energy use of 
the houses determined from utility bills. Secondly, the assessment methods are confronted with the collected characteristics.

\subsubsection{Reflection on calculated and actual energy uses ${ }^{6}$}

The principle that EPIs only reflect the building-related energy use or energy demand, and not total energy use, led to the expectation that the total energy use of dwellings would be higher than energy demands theoretically predicted or calculated. However, the empirical study of eight houses found that the actual total energy use is in six out of eight dwellings lower than the calculated energy demand. The trend lines expressing the theoretical values of EPIs reveal that the older the building the worse the energy performance is expected to be. However, in houses 2 and 3, built in 1925 and 1939, various measures have been applied that have improved the theoretical EPC and $\mathrm{El}_{\text {old }}$ energy performance values significantly in comparison to the general trend line. However, for house 3, the $\mathrm{El}_{\text {old }}$ value does not suggest a significantly better energy performance relative to the trend line and the other houses. Although for houses 5, 6 and 7 large differences exist between the EPC and $\mathrm{EI}_{\text {new }}$ values, the $E_{\text {old }}$ values are almost the same.

In analysing the actual total energy use per house, it was striking to see the impact of children being born or, when they become adults, leaving the house. Energy use significantly increased or decreased at such events. However, due to the adoption of various energy measures, the total energy use only rose in houses 1 and 7. Figure 2-8 reflects that the energy use in the other six houses remained relatively constant over time. Deviations of $5.0 \%$ to $18.3 \%$ can be found in the annual energy use of the houses studied, which to an extent reflects the standard deviation of $7.7 \%$ in the number of degree days in specific years.

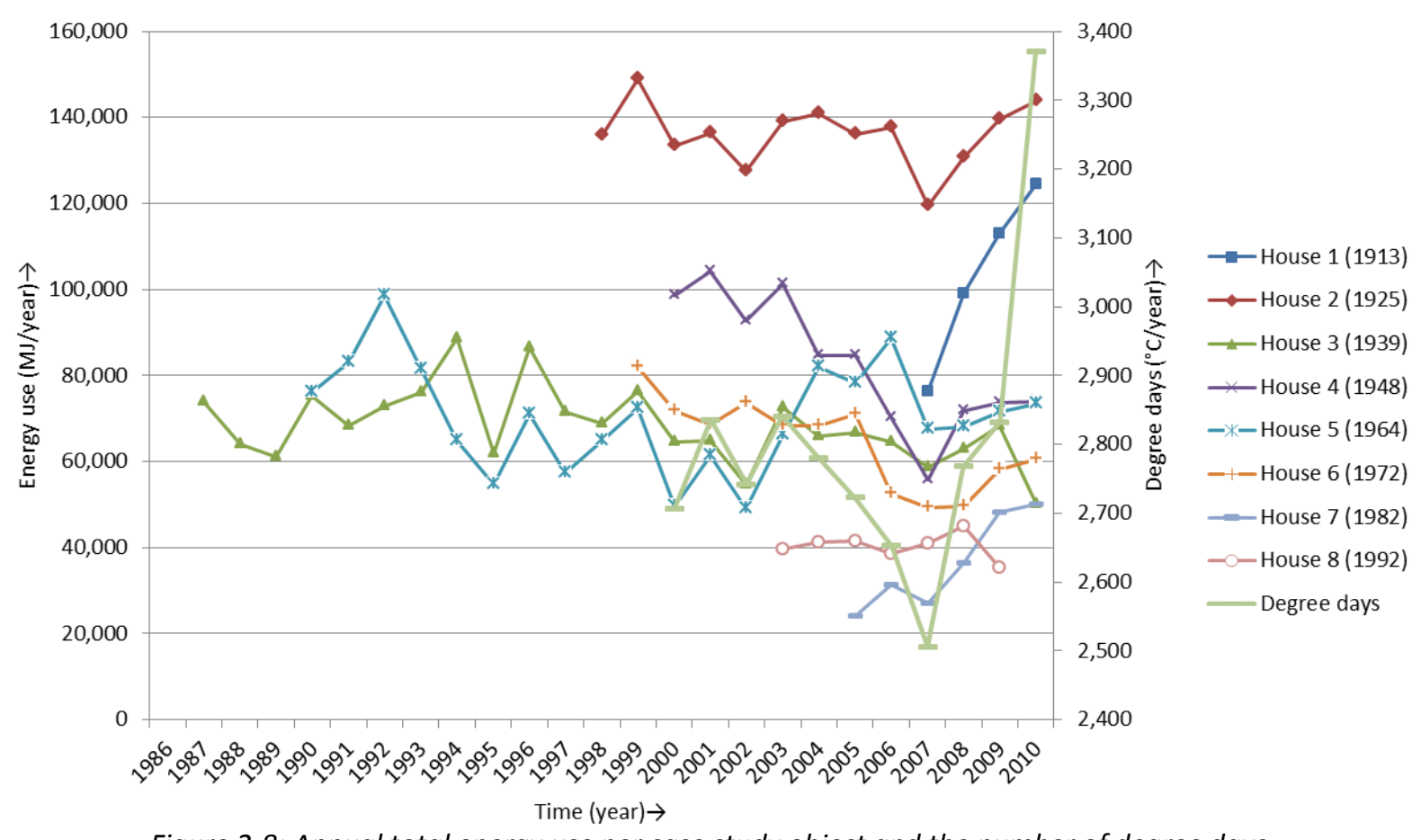

Figure 2-8: Annual total energy use per case study object and the number of degree days.

\footnotetext{
${ }^{6}$ Parts of this section were published elsewhere (Entrop et al., 2010).
} 
Figure 2-8 also shows how the number of degree days is related to changing total energy uses of the dwellings. Degree days express by how much the daily average outdoor temperature differs from a notional constant indoor temperature, and is calculated by subtracting the daily average outdoor temperature from the reference average indoor temperature of $18^{\circ} \mathrm{C}$ (Wever, 2008). If the outdoor average temperature is above this value the degree day value is set to 0 for that day.

From the analysis of the theoretical energy performance in this chapter, Figure 2-4 shows that houses 2 and 3 are not close to the linear trend lines of the theoretical EPC and $\mathrm{EI}_{\text {new }}$ values. However, if the EPC and $\mathrm{EI}_{\text {new }}$ values of houses 2 and 3 were based on actual user data, then the values were close to the trend lines, as was shown in Figure 2-7. If houses 2 and 3 are considered to be outliers and excluded from the data set, the ratio for $\mathrm{El}_{\mathrm{old}}$ of $\mathrm{Q}_{\text {total;actual }} / \mathrm{Q}_{\text {total; theory }}$ is 0.86 ( $\sigma=7.0 \%$ ). When the actual energy use is related to $Q_{\text {total; EPC, }}$ the standard deviation is $10.1 \%$. The average actual energy use is then $68.7 \%$ of the theoretical

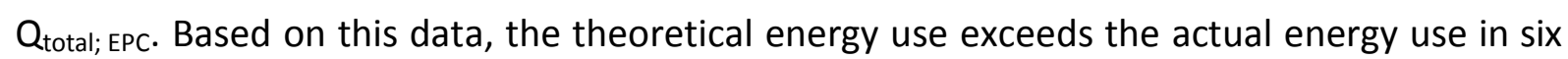
or seven of the eight houses depending on the calculation method employed.

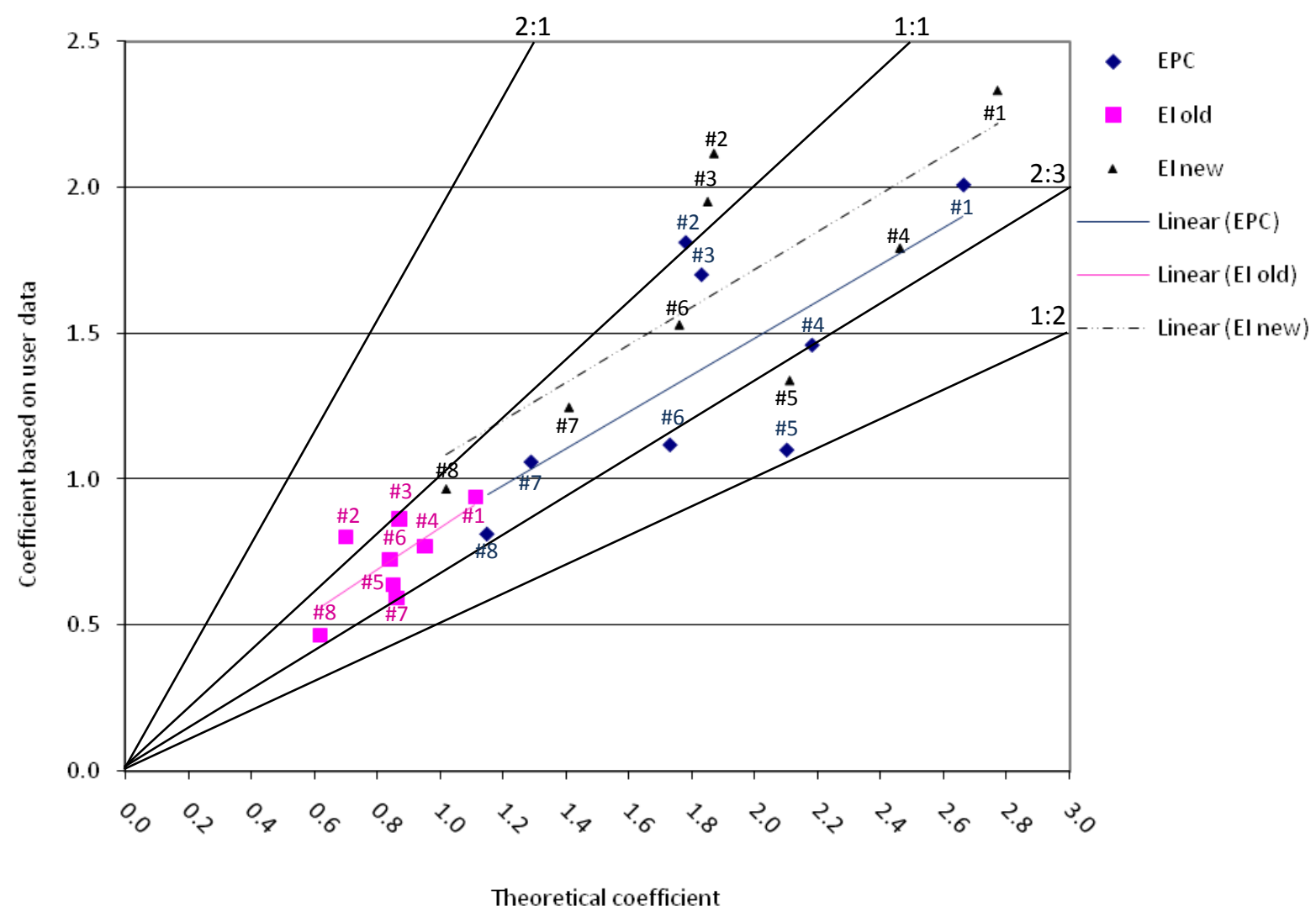

Figure 2-9: Relationships between the EPIs based on assessments and the actual energy use.

As an attempt at an overall average, the calculated theoretical energy use is estimated to be $13.5 \%$ higher than the actual energy use. When excluding houses 2 and 3, where the theoretical energy performance expressed in terms of EPC and $E I_{\text {new }}$ were outliers, the average percentage rises to $21.2 \%$. For the studied cases, $\mathrm{El}_{\text {old }}$ seems to be the best indicator in terms of predicting actual energy use. However, all the calculated $\mathrm{EI}_{\text {old }}$ values are within a 
relatively small range of values suggesting that, maybe, with this indicator relatively small distinctions are made for the various objects, as is shown in Figure 2-9. More cases are needed to draw conclusions regarding this aspect of EPIs.

\subsubsection{Reflection on characteristics included in the assessment methods}

It has become apparent that the energy use of a dwelling can be defined from different viewpoints. For households, the key energy use is expressed by the energy meters and, at the end of the year, by the energy bill. That is, the energy use those households have to pay for. However, in juridical and political terms, an energy performance that is linked to a building-related energy use prevails. New buildings need to achieve a certain energy performance value. For existing buildings, an energy certificate has to be obtained expressing its energy performance. In both situations, assessment methods are applied that use environmental, occupational, building, system and appliance characteristics. These characteristics are used to forecast a dwelling's building-related energy use. An EPI is determined by dividing this building-related energy use by a permissible energy use that is based on the size of the dwelling.

\section{Categories regarding the influence of characteristics}

Many characteristics play a role in this process of calculating building-related energy use. Some characteristics are incorporated in the calculation as static items, and others can be incorporated as a variable item. Individual dwellings can only be characterised by adjusting the variable items, or in other words those characteristics where the specifications can be assessed based on the real-life situation. As such, three categories of characteristics can be distinguished:

1. Characteristics that do not play any role in the assessment methods, because they are not taken into account, either directly or indirectly. These characteristics are listed in the upper left box in Figure 2-10;

2. Characteristics that indirectly play a role because they have been incorporated as a static value or they have been incorporated in such a way they are connected to another variable. These characteristics are indicated as "indirect" in the lower left box in Figure 2-10 ;

3. Characteristics that can be assessed based on the actual situation in or around the house. These characteristics are also shown in the lower left box in Figure 2-10.

In Figure 2-10, the role of all the characteristics suggested at the beginning of this chapter are shown. Some characteristics, those shown in the upper frame, have no influence on the EPIs. The lower frame shows all the characteristics that do play a role in calculating the EPIs. Some of these characteristics are static values that are independent of the house or its residents: air temperature, ground temperature, solar irradiance, living patterns and personal preferences. Other characteristics indirectly depend on values related to the house design such that cross links can exist between the characteristics. 


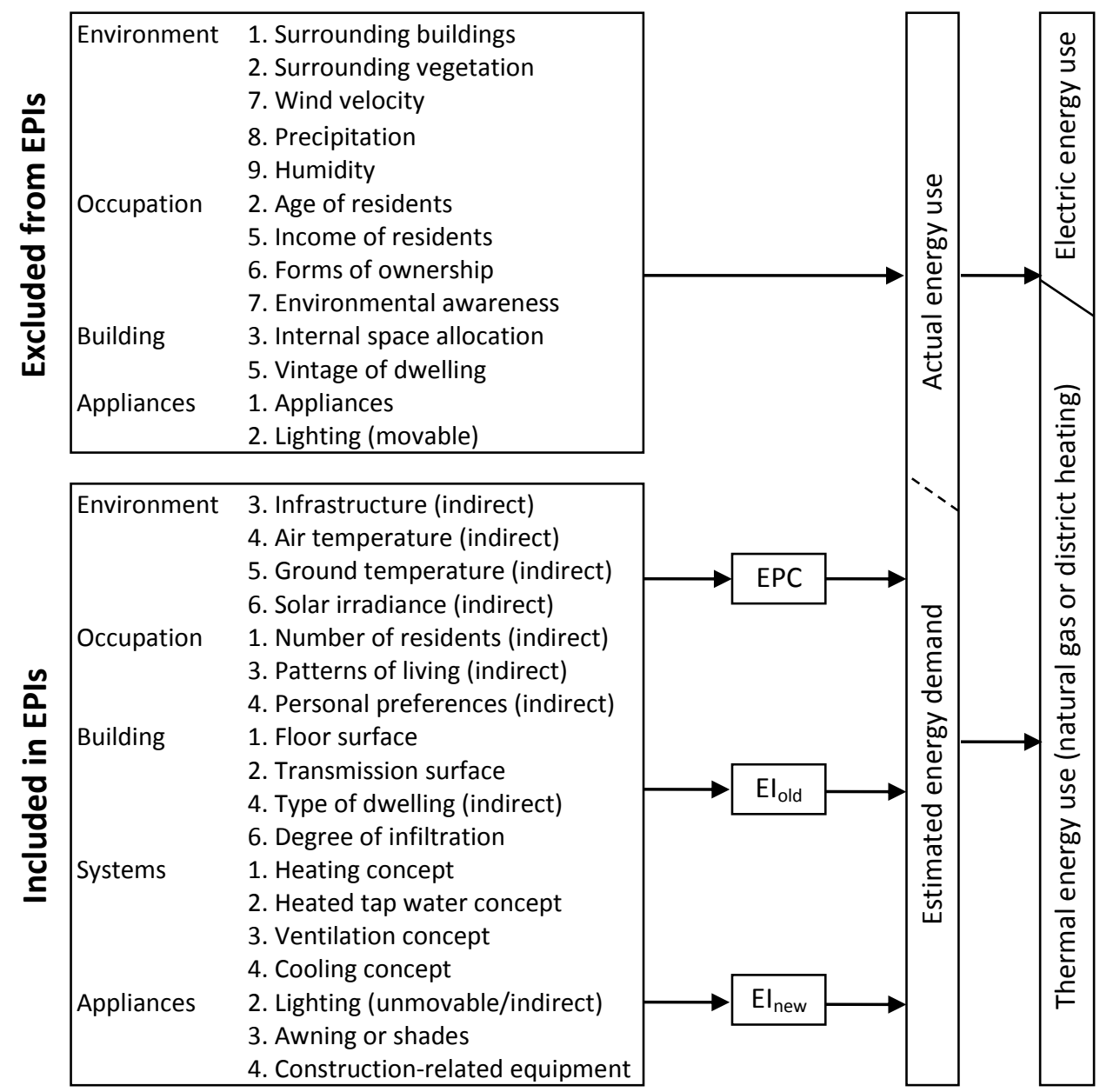

Figure 2-10: Overview of characteristics taken into account in EPIs.

A first example of a cross link is the number of residents living in a house and the size of its floor area. The number of residents influences the thermal energy used for heating tap water and, therefore, the number of residents is indirectly incorporated in the calculation methodologies. The floor area also influences the forecasted energy demand in the form of lighting, which is a fixed amount of $\mathrm{kWh} / \mathrm{m}^{2}$ of floor space. In calculating the energy use in lighting, it does not matter whether incandescent, fluorescent or LED lights are installed because the outcomes are only related to the floor area. A second example is the type of dwelling, that has an indirect influence because any parts of the thermal shell where there are no temperature differences do not need to be taken into account when calculating building-related energy use. There is another indirect link in the case of infrastructure in that if the heating system has an external source (e.g. district heating), the programs automatically assume that hot water is also provided. This influences the overall efficiency of the heating system. A fourth example forms the relationship between the income of residents and the size of a dwelling. A last example regarding links between characteristics is the presence and use of awnings, thermal solar collectors and photovoltaic panels, that are related to the presence of surrounding buildings, surrounding vegetation and solar irradiance. 


\section{General energy balance for a dwelling}

Casals (2006, p.383) states that "The appropriate assessment of building operational energy requirements, ..., requires the use of a complete and detailed dynamic energy simulation tool. This tool should include a detailed thermal modelling, the possibility to evaluate many different HVAC systems and the capability to properly assess the effect of the different couplings found in building energy analysis". Given that not all requirements and not all characteristics are taken into account, no guarantees can be given that the methods to calculate EPIs are complete and thus appropriate. Therefore, theoretical energy performances as specified by the EPC, $\mathrm{EI}_{\text {old }}$ or $\mathrm{EI}_{\text {new }}$ are expected not to be in line with the actual energy use of a household. However, when drawing up an energy balance for a dwelling, the components of an assessment method, that provide an EPI based on a calculated energy demand, do give insight into the purposes that energy is used for. This is demonstrated by the following energy balance for the annual energy use in dwellings:

$$
\begin{aligned}
& E_{\text {in }}=E_{\text {out }} \\
& E_{\text {in }}=E_{\text {district heating }}+E_{\text {natural gas }}+E_{\text {electric }} \\
& E_{\text {out }}=E_{\text {heat space }}+E_{\text {auxiliary }}+E_{\text {heat water }}+E_{\text {fans }}+E_{\text {cooling }}+E_{\text {light }}+E_{\text {cooking }}+E_{\text {appliances }}-E_{p v}-E_{\text {wind }}
\end{aligned}
$$

\section{Energy balance for a dwelling connected to the gas network and electric grid}

A typical Dutch dwelling has three meters: one for water use, one for natural gas and one for electric energy use ${ }^{7}$. In general, two forms of energy are provided to Dutch dwellings: natural gas and electric energy. Traditionally, most households use some natural gas in cooking. It is therefore possible to split the energy use in two separate balances for a typical Dutch dwelling:

$$
\begin{aligned}
& E_{\text {natural gas }}=E_{\text {heat space }}+E_{\text {heat water }}+E_{\text {cooking }} \\
& E_{\text {electric }}=E_{\text {auxiliary }}+E_{\text {fans }}\left(+E_{\text {cooling }}\right)+E_{\text {light }}+E_{\text {appliances }}\left(-E_{p v}-E_{\text {wind }}\right)
\end{aligned}
$$

Equation 2-5

In a situation where photovoltaic panels or a wind turbine are installed, a separate meter is assumed to measure the electric energy generated. However, almost no dwellings have photovoltaic panels or wind turbines. Further, it is rarely recorded which of the two individual energy flows -natural gas and electric energy- is used for which exact purposes. By calculating an EPI, some insights can be obtained regarding $E_{\text {space heating, }} E_{\text {water heating, }} E_{\text {auxiliairy }}$ and $E_{f a n s}$, and partially $E_{\text {light. }}$. The term $E_{\text {cooling }}$ can include energy use in an integrated or mobile air conditioning system in combination with appliances that provide summer comfort ( $E_{\text {summer comfort }}$ ), such as electricity-operated shadings. However, most dwellings do not have any cooling system installed. By making an inventory of the appliances and lighting present in a dwelling, and by specifying the time these appliances are in use, the annual electric energy use of these products can be estimated. The final component, $E_{\text {cooking, }}$ is based on an estimated average of $37 \mathrm{~m}^{3} /$ year of natural gas. However, an increasing number of households are switching to electric ovens and cookers, where the electric energy use is

\footnotetext{
${ }^{7}$ In some cases two meters are used to measure electric energy use. One operates during the day and one at night, when lower tariffs apply.
} 
estimated to be around $500 \mathrm{kWh} /$ year (Milieucentraal, 2011). Based on these values, and an average calorific value of $33.41 \mathrm{MJ} / \mathrm{m}^{3}$ of natural gas, this transition seems to lead to a $45.6 \%$ increase in cooking energy use for individual households.

By using energy assessments and energy balances, measures and estimated values regarding the energy use of a dwelling can be related with each other. However, the likelihood of equilibrium being calculated is small given the relatively large number of characteristics that are standardised or simply ignored. Calculating a theoretical energy use by conducting an assessment of the dwelling will probably result in either an over- or an under- estimation of the total actual energy demand. However, by measuring the actual energy use of buildingrelated equipment and appliances, the various components of energy use could be analysed more accurately.

\subsection{Conclusions on assessing the energy performance of dwellings}

This chapter has presented those characteristics of dwellings and their residents that influence the energy use. Furthermore, various assessment methods for the energy performance of dwellings and a case study on the theoretical and actual energy performance of eight dwellings were presented. This section pulls together the findings.

\section{A: What characteristics influence the energy use of $d$ wellings and their residents?}

From a literature study, five categories of characteristics were identified that are relevant when considering the energy use of dwellings and their residents:

1. Environmental characteristics, encompassing nine different characteristics;

2. Occupational characteristics, covering seven different characteristics;

3. Building characteristics, including six different characteristics;

4. System characteristics, subdivided in four different characteristics;

5. Appliances, encompassing four different characteristics.

The characteristics found in the literature and organised into these five categories are variables that influence energy use in a dwelling. Some characteristics are part of variables that are related with one another. For example, high-income residents (an occupational characteristic) tend to live in houses with relatively high floor areas and volumes (building characteristics) and have more electrical appliances (an appliance characteristic) than households with relatively low incomes. Further, within the category of building characteristics, the type of dwelling and its age are two characteristics that to some extent encompass the other four characteristics within that category.

Given the Dutch situation in which natural gas is generally used for heating purposes and cooking, and electric energy is used for lighting, ventilation, appliances and sometimes cooling, it is possible to distinguish between characteristics that largely influence natural gas use and those that influence electric energy use. In many Dutch dwellings, two electric energy meters are installed making it possible to distinguish "off-peak" electric energy used during weekends, bank holidays and overnight (21:00 or 23:00 to 07:00) from "peak" hour use during working days (07:00 until 21:00 or 23:00). This makes it possible to analyse the influence on electric energy use of some characteristics in more detail. For example, 
overnight, maybe only mechanical ventilation systems and some electric appliances (in standby mode) will continuously use electric energy.

In general terms, most of the natural gas used by dwellings and their residents is for space heating. This energy use largely depends on the climate, on the behaviour of the residents, on the quality and size of the thermal shell, on the ventilation rate and the installed heating system. For several years, this use of natural gas has been decreasing due to more efficient heating systems, better insulation and a growing electric energy use that eventually is converted into thermal energy within the thermal shell of the dwelling. The electric energy use of dwellings and their residents has been steadily increasing over time, although lighting use is falling. The increasing use of electric energy is related to the growing number of relatively small appliances such as mobile phones, home computers and additional kitchen equipment. However, many such appliances now come with Energy Labels, and replacing an old inefficient unit can contribute to lower electric energy use.

The residents of a dwelling contribute in various ways to its occupational characteristics, and have a strong influence on the relationship between the building characteristics, systems characteristics and appliances, on the one hand, and actual energy use on the other. If a high efficiency combination boiler system is installed to replace an old inefficient system, the energy use will not necessarily fall if the residents shower longer, increase room temperatures, start heating more rooms and leave the heating system on while out. Some characteristics are not influenced by the residents, such as climate conditions or the presence of nearby buildings that provide shading or maybe heat through irradiance or conduction.

\section{B: What methods exist to reflect on the energy use and performance of dwellings?}

Up to 2012, three standard methods were used in the Netherlands to express the energy performance of a dwelling, possibly a part of a larger residential building, in terms off an indicator. When assessing a dwelling, environmental, occupational, building and systems characteristics are taken into account (as shown in Figure 2-10) to calculate its energy demand or building-related energy use, assuming that it is used in a certain standardised way. Appliances are not taken into account with the exception that some energy demand is included for lighting, expressed as an amount of electric energy use per square metre of floor space. The calculated total building-related energy use is then divided by a notional energy budget, based on the size of the dwelling in terms of total floor area and the total surface area of the thermal shell, to give a dimensionless EPI.

\section{C: How can these methods be applied to Dutch houses and their residents?}

The current methods to produce an EPI, because many variables are incorporated as fixed values, do not really reflect the residents. The methods only reflect the building-related energy use under certain standard usage conditions in a standard Dutch climate. If the same calculation method is applied to two houses, then the resulting EPIs can be used to compare the energy performance of one house to the other, provided it has comparable properties regarding building type (terraced house, semi-detached house, detached house or flat) and 
size (floor area and surface area of the thermal shell). The EPIs are not really designed to give any indication of actual energy use. The actual energy use can be determined by residents themselves by reading their energy meters. Energy meters may be checked on an annual basis, although the interval is unlikely to be exactly 365 days, and the environmental conditions will also vary from year to year. Given that ambient temperatures and sunlight have large impacts on actual energy use, it is advisable to read the energy meters monthly and preferably over several years, and relate this information to published degree-day data, before estimating an average annual energy use.

Given that only the annual building-related energy use is covered by the standard methods, one might expect that the total energy use of a dwelling and its residents to be higher due to the energy used for cooking and in appliances. Despite this, the case study showed that the methods often overestimated the actual energy use of the studied dwellings. This does not mean that the indicators are pointless. The assessments and the accompanying calculations that result in a building-related energy use and EPI will give some notion to building owners, tenants, future buyers or future tenants regarding the energy demand to achieve a comfortable indoor climate in a building with the assessed characteristics. Many potential occupants of a dwelling used to, and some still do, look at the location of the dwelling, the quality of its kitchen, its bathroom and maybe the beauty of the garden but, with the introduction of these methods, other characteristics are listed and brought together in an EPI which can also be considered. Although the list of characteristics is incomplete, the assessed characteristics are related to energy use and altering them will influence the energy demand and energy use of a dwelling. If an ETM is implemented, the change in actual energy use is unlikely to be the exact value estimated by incorporating it into one of the three methods. This is because it is unlikely that the actual environmental conditions will correspond with the assumed conditions in the method used, and nor will the occupational behaviour or use of appliances be identical to that assumed when the calculation is made.

\section{Question 1: What influence do ETMs have on the energy performance of dwellings?}

It is not an easy task to calculate the exact influence of every available ETM on the energy performance of a dwelling and its residents in terms of numerical values: too many ETMs exist and too many characteristics have an influence. Furthermore, the values of such calculations have a somewhat transitory character due to changing assessment and calculation methods and improvements in the performance of ETMs. The studied assessment methods show that it is possible to simplify the considered situation significantly by assuming that dwellings are used by residents in a certain 'standard' way. As such, the assessment methods offer a framework, an energy demand and an indicator that one can grasp. A major disadvantage is that these standard approaches do not offer the flexibility needed to give insights into the effects of changing several characteristics or implementing many new techniques or measures. For many specific techniques, additional certificates and calculation schemes are needed to calculate the outcomes.

It is hard for those who implement innovative ETMs in their building projects to comply with regulations and standards because the conventional EPI assessments and calculation 
methods are relatively conservative. The question a property developer may choose to answer is not which technique or measure has the most positive effects on the actual energy use of a household, but which technique or measure will have the greatest impact on the EPI. ETMs will always have an influence on the actual energy use of dwellings and their households, but not necessarily on the EPIs calculated on the basis of standardised national assessment methods. 


\section{Assessing the financial impact of ETMs}

ETMs involve investments for which money is required at a certain moment and, after this, financial returns are expected; mainly in the form of reduced energy costs. Therefore, a study of the variables included in investment appraisal methods is a logical starting point to gain insights into the financial impact of ETMs. This chapter focuses on the financial impacts of ETMs in residential building projects.

\subsection{Introduction to the financial impact of ETMs}

Investments made in ETMs are partially or completely paid back, because they lower energy use and therefore energy costs. In some situations, additional subsidies or tax reductions are provided, reducing the investment costs or increasing the financial benefits through other means. Rising energy prices increase the positive financial impact of an investment in an ETM and, therefore, the financial benefits are often higher than was expected based on calculations using the energy prices at the moment the investment took place.

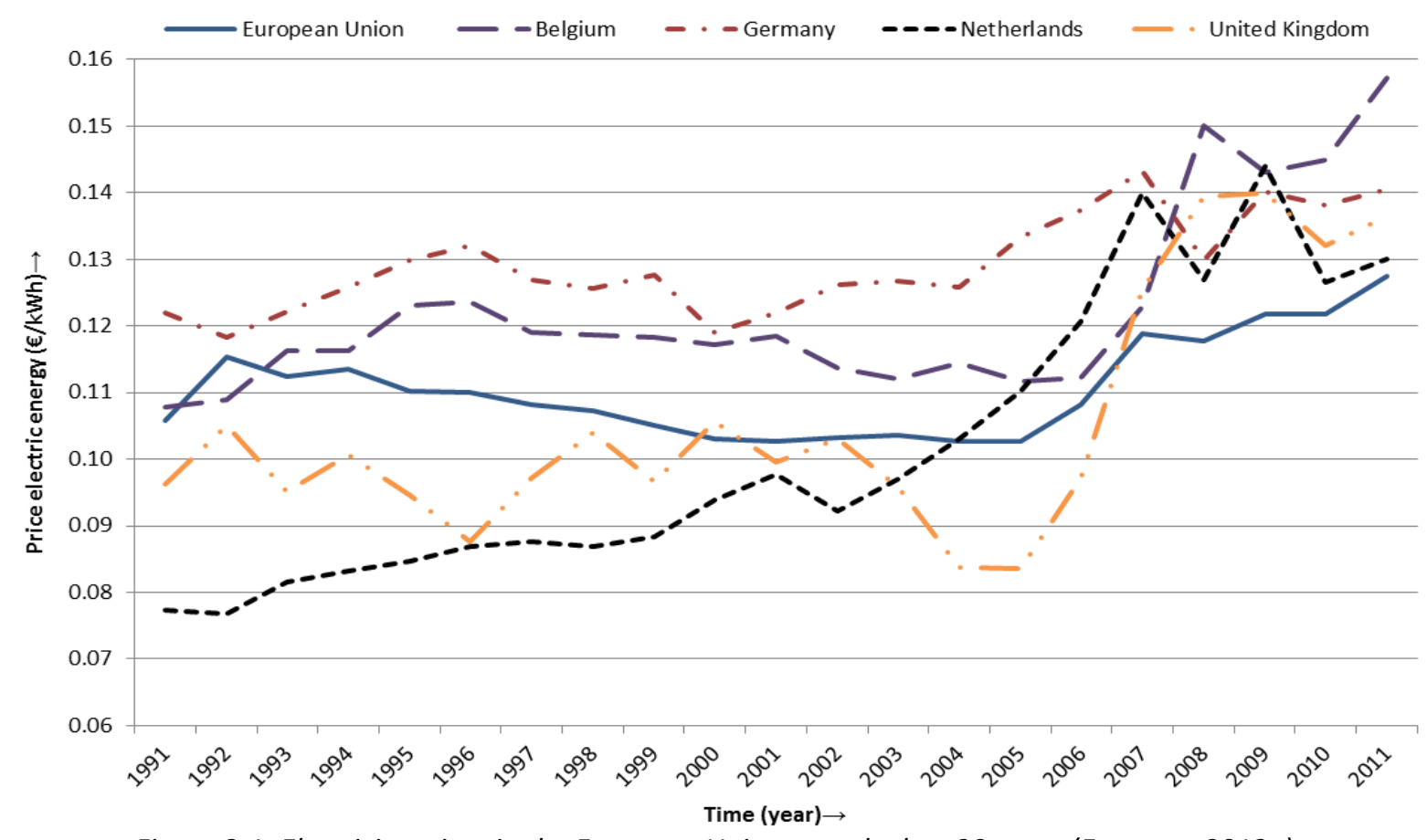

Figure 3-1: Electricity prices in the European Union over the last 20 years (Eurostat, 2012a).

To gain an impression of how energy prices have changed over the last two decades, Figure 3-1 and Figure 3-2 show the average energy prices in Europe overall and in certain countries including the Netherlands. In Europe, electricity prices have increased on average by $20.5 \%$ and natural gas prices increased by $63.9 \%$ over twenty years. However, it should be noted that the 1991 data are based on 15 European countries and that 27 countries provided data in 2011 (Eurostat, 2012a; Eurostat, 2012b). In the same period, Dutch electricity prices increased by $68.0 \%$ and natural gas prices by $93.7 \%$. Price data for Belgium, Germany and the United Kingdom are also included in the figures because these are neighbouring countries directly connected to the energy networks and with comparable living standards. The Dutch power grid is also connected to Norway. The Norwegian prices for natural gas are not available, but the price of electric energy increased dramatically in 2005 when a tax on 
carbon emissions was implemented. In Norway, the impact of this tax on prices was much higher than increases seen in the United Kingdom, Germany, the Netherlands or Belgium around that time.

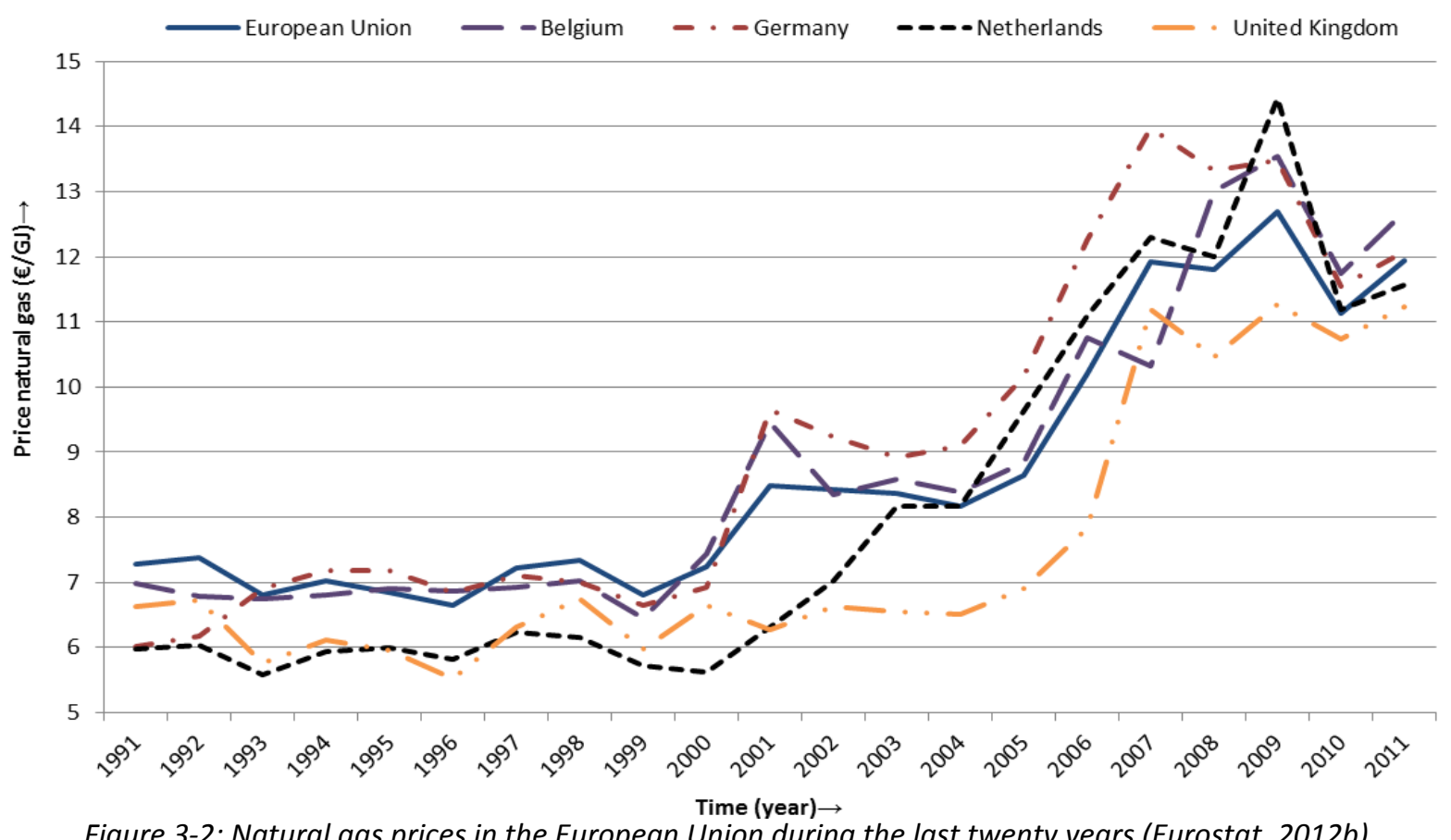

Based on the total expenditures of Dutch households, as collected by Statistics Netherlands (CBS, 2011d), the 1992 annual natural gas costs for heating living space, heating tap water and cooking were on average $€ 835$ per household, or $4.5 \%$ of all annual household expenditures. In 2007, gas costs had increased to $€ 987$ per year but fallen to $3.3 \%$ of annual household expenditure. The costs of average household electric energy use rose from an annual $€ 283$ (1.5\% of total expenditure) in 1992 to $€ 832$ (2.8\% of the total expenditure) in 2007. The total energy costs per household are slightly lower than the sum of these two components, namely $€ 835$ or $4.5 \%$ in 1992 and $€ 1,660$ or $5.5 \%$ in 2007, due to some, mainly small, households not using natural gas but district heating or other sources for heating.

In the United States, the experiences regarding energy prices are comparable. In 1970, $\$ 82.9$ billion was spent by consumers on energy use, including fuels for transport purposes. By 2008 , this value had increased to $\$ 1,408.7$ billion, before it decreased to $\$ 1,061.3$ billion in 2009 (EIA, 2011). In the same period the Gross National Product (GNP) increased by $1280 \%$. The energy expenditures increased by $1600 \%$. Although it is shown that over this long period of almost thirty years energy prices have been increasing, research by Edelstein and Kilian (2009) shows that a sharp rise in gasoline prices particularly has a significant effect on consumer expenditure for approximately six months. After this short period, the behaviour of the consumer seems to return to its old pattern and the energy use, in the case of Edelstein and Kilian (2009) gasoline, will increase again.

This introduction on some trends in energy prices shows that energy costs are increasing. To reduce these energy costs one or more ETMs can be implemented, but time and money 
need to be invested. This chapter elaborates on the research conducted to answer the second research question: what are the financial impacts of ETMs in residential building projects? In order to answer this question, three research sub-questions are formulated:

\section{A: What methods exist to reflect on the financial impact of ETMs?}

In the field of financial appraisal, various methods exist to reflect on investments and their perceived financial benefits and costs. Implementing ETMs is associated with various financial costs that ideally need to be paid back during their technical lifetime. The earnings or financial benefits are largely considered to consist of reduced energy costs, but a literature study may suggest other financial costs and benefits.

It will only be possible to relate reduced energy use through ETMs to the financial benefits, if one knows how those two are related. Therefore, the second question is:

\section{$2 B$ : How are the energy costs of dwellings and their residents constituted?}

Each year, the residents of a dwelling receive an energy bill detailing various cost components. The energy bills of various households and energy companies will be studied in order to understand how energy bills have been constituted over recent years.

Given that these households will have implemented various ETMs in the past, and that these will be reflected in their energy bills, a third research question will focus on what the results of such investments are.

2C: What are the results when these appraisal methods and the applicable energy costs are applied to ETMs found in Dutch dwellings?

To answer to this research question, specific investments in ETMs will be assessed by applying methods that have been developed on the basis of the literature study in combination with empirical data on energy costs.

\subsection{Methods to reflect on the financial impact of ETMs}

When considering an ETM, the potential adopter is likely to weigh up the financial costs and benefits and so have to adopt some financial perspective. These financial costs and benefits may be evaluated alongside other non-financial advantages and disadvantages. The various methods to evaluate these financial benefits and costs are collectively referred to as investment appraisal. In applying investment appraisal to a certain ETM, it needs to be decided which costs to include and how the benefits are to be weighed. Once this is determined, one also needs to be aware of uncertainties in the calculation methods that are applied and in the values that are weighed.

\subsubsection{Methods for investment appraisal}

The time frame plays an important role in investment appraisal because money that is immediately available has a higher value than money that becomes available by means of positive cash flows in the future. Therefore, one should include interest rates and inflation rates when comparing the upfront investments involved in implementing an ETM with the cash flows generated in the future. One can recalculate the value of future benefits back to when the investment in an ETM is made, or one can recalculate the value of costs and 
benefits to some future moment in time, for example to the end of the equipment's technical lifetime. A third option is to estimate the moment in the future when costs equal benefits. There are many calculation methods that take such considerations regarding timing into account and provide a solid basis for an investment appraisal. However, there are three methods that are frequently used as the basis for an investment appraisal: the payback method, the rate of return and the Net Present Value (NPV).

Lefley (1996) describes the payback method as a method of financial appraisal that calculates the return each year from the start of the project until the accumulated returns equal the cost of the investment, at which time the investment is said to have been paid back. The payback period is thus the time taken to achieve break even. A major disadvantage of this method is that the returns after the payback period are ignored, even though the economic or technical life of the investment may continue for many years. In a discounted payback method, the costs of capital are taken into account by applying an interest rate.

The second method, the rate of return, is based on comparing relative capital flows. The basic idea is that consumers, or companies, expect to generate some return on their invested capital or, vice versa, always need to pay to acquire capital for an investment. A private individual can, for example, put money into a bank account and receive interest. If the interest rate on savings is higher than the interest rate paid for a loan to finance capital, one could in theory increase capital. When an investment appraisal is being conducted on the basis of the rate of return, the relative advantage of an investment is computed (for example annually) for the technical lifetime of the investment. When this rate of return, or return on investment, exceeds the relative capital costs and the relative returns of comparable investment projects, the investment project can be regarded as financially sound.

The third method, the calculation of the so-called Net Present Value (NPV), is an elaboration on the rate of return approach. If the term discounted cash flow is used, then the costs of capital, $r$, are considered (Mills, 1988). Any investment amounts to a negative cash flow, $\mathrm{CF}_{0}^{-}$, that is counteracted by the (annual) positive cash flows, $\mathrm{CF}_{\mathrm{a}}$, in the form of products sold or money saved. The formula to calculate the NPV is as follows:

$$
N P V=C F_{0}^{-}+\sum_{a=1}^{n} \frac{C F_{a}}{(1+r)^{a}}
$$

Equation 3-1

where:

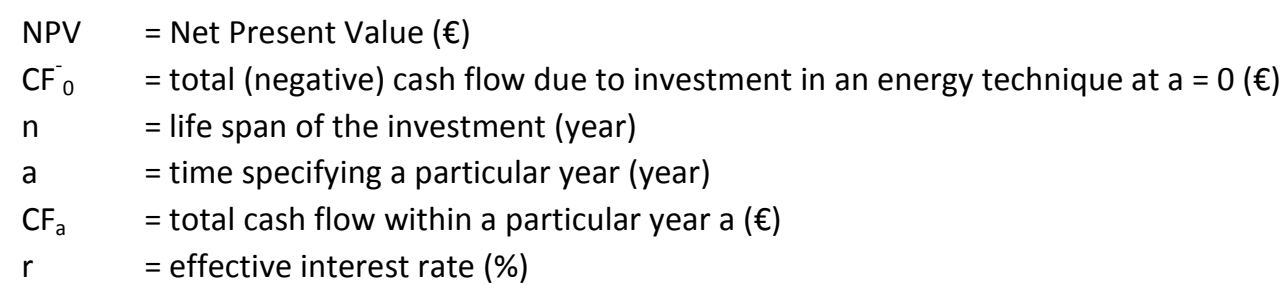

In all three methods, the investment costs and the financial gains are two key elements. In discounted cash flows, the effective interest rate comes into play. In a particular year the effective interest rate is the capital interest rate minus the inflation rate (Moyer et al., 2006, 
p. 163). When the rate of return or NPV is calculated, the technical lifespan of the technique or measure, in which money has been invested, is also a variable to take into account. The two variables, costs and benefits, will now be considered in more detail because the principal or decision-maker in charge of the implementation process can influence or even control these variables more than the lifespan or effective interest rate. The cash flows $\mathrm{CF}_{0}^{-}$ and $\mathrm{CF}_{\mathrm{a}}^{-}$are considered to be the negative financial consequences of the disadvantages associated with an ETM. In other words, these are the costs. Conversely, the cash flows $\mathrm{CF}^{+}{ }_{\mathrm{a}}$ are the positive financial consequences of the possible advantages of an ETM. In other words, these cash flows are financial gains or benefits.

\subsubsection{Costs of ETMs}

A recognizable disadvantage of ETMs, before they are even used or can become effective, is that effort, knowledge and capital are needed to implement them. An ETM often needs investment in terms of time and money when they are installed. Some measures, generally those that focus on the behaviour of the building users, e.g. reducing shower time and turning off appliances that are not in use, do not need capital to be invested. When capital is required, the investment includes the cost of the physical product that makes it possible to reduce the energy demand or use of a building. Besides these product costs, some implementation costs can be involved. Systems need to be incorporated in the design, to be transported to the construction site and to be installed. These negative cash flows are expressed as the non-recurrent investment costs $\mathrm{CF}_{0}^{-}$in Equation 3-2.

$$
C F_{0}^{-}=C F_{0.1 ; \text { design }}^{-}+C F_{0.2 ; \text { product(s) }}^{-}+C F_{0.3 \text { installation }}^{-}
$$

Equation 3-2

$$
\begin{array}{ll}
\text { where: } & =\text { total negative cash flow due to investment in an ETM at } \mathrm{a}=0(€) \\
\mathrm{CF}_{0}^{-} & =\text {negative cash flow related to adapting and optimizing the design of the product and the } \\
\mathrm{CF}_{0.1 ; \text { design }}^{-} & \text {building in mutual relationship with each other at a }=0.1 \text { before ordering and installing it }(€) \\
\mathrm{CF}_{0.2 ; \text { products })}^{-} & =\text {negative cash flow related to acquiring the physical product(s) -forming the ETM- at a }=0.2, \\
& \text { before installing the energy technique }(€) \\
\mathrm{CF}_{0.3 ; \text { installation }}^{-} & =\text {negative cash flow for physically transporting and installing the ETM in an existing or new } \\
& \text { building at a }=0.3, \text { immediately after the energy technique has been installed }(€)
\end{array}
$$

Equation 3-1 also incorporates, through $\mathrm{CF}_{\mathrm{a}}$, the costs $\mathrm{CF}_{\mathrm{a}}^{-}$related to the disadvantages during the usage phase of an ETM. The disadvantages of using an ETM that reduces energy use can be expressed in terms of maintenance $\mathrm{CF}^{-}$;maintenance, reliability $\mathrm{CF}^{-}$;reliability, user

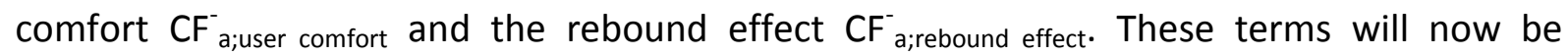
explained.

Li et al. (2011) distinguish two forms of maintenance, namely ad hoc emergency maintenance costs and planned routine maintenance costs. Both forms have similar cost components, namely material, equipment, transportation and labour costs (Li et al., 2011). Maintenance and reliability are often strongly related to each other. If equipment is well maintained, it will probably be more reliable and emergency maintenance less likely. Note that maintenance and reliability are not always related: a photovoltaic system is relatively 
reliable but ideally should be regularly maintained in the sense of cleaning the glass surface. To most people it is also quite a familiar concept that certain brands, or relatively expensive products, offer better reliability than white label or relatively cheap products. Here, maintenance and reliability can be seen as variable annual costs that are related to the initial investment costs, against which they can be weighed.

Many ETMs also aim to improve user comfort (Boonekamp, 2007) and if a technique or measure fails this can also influence user comfort. Again a strong relationship exists between maintenance and reliability. If the aim of an ETM is not fulfilled in terms of user comfort, it seems likely that additional techniques or measures will be adopted or used to reach the desired level of comfort. In this case, it is possible that the adoption of a technique or measure to reduce energy use is overshadowed by the adoption of another technique or measure that increases the energy use. For example, if a house is well-insulated but without applying techniques to prevent over-heating, an air-conditioning system may be bought. It is also possible that the behaviour of the users changes. This is called the rebound effect. For example, one might leave the lights on for longer if traditional incandescent lamps are replaced by light emitting diode (LED) or compact fluorescent light (CFL) bulbs. In Equation 3-3, the four addressed costs are brought together in a total annual negative cash flow.

$$
C F_{a}^{-}=C F_{a, \text { maintenane }}^{-}+C F_{a, \text { reliability }}^{-}+C F_{a ; \text { usercomfort }}^{-}+C F_{a ; \text { reboundeffect }}^{-}
$$

where:

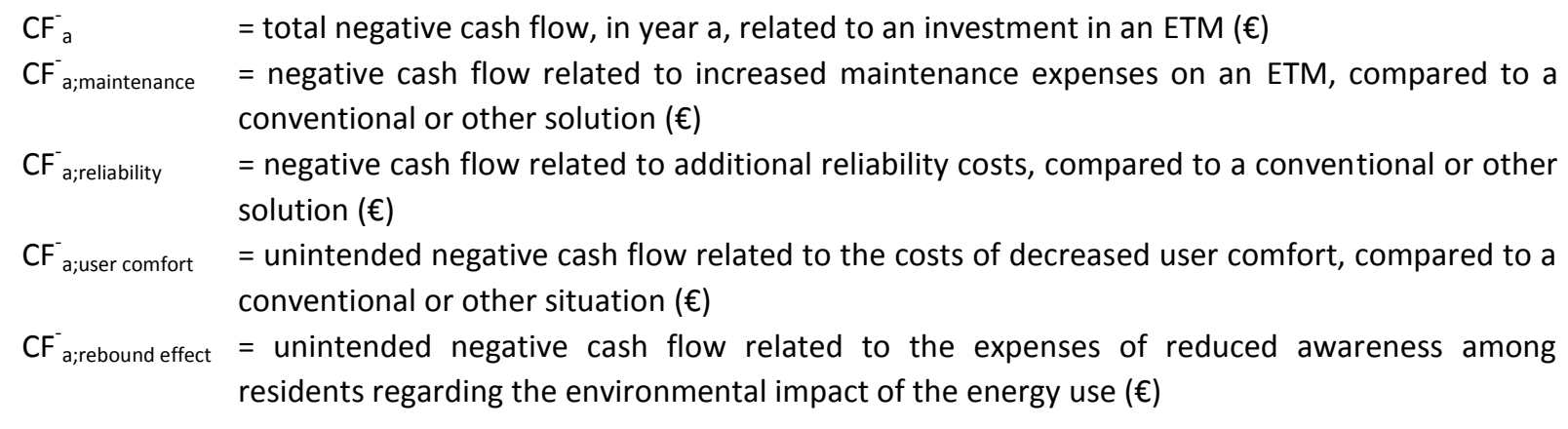

\subsubsection{Benefits of ETMs}

Having addressed the costs or negative cash flows, it is now time to discuss the benefits of ETMs, and the positive cash flows. As Van Hal (2000, p. 146) addresses it: "A requirement for the diffusion of an environmental innovation (possibly an ETM) in housing is that the innovation not only has environmental qualities but also has financial quality (...). Other qualities of the innovation such as comfort, livability, status and flexibility have a considerably lesser measure in the diffusion." The main benefit that these ETMs generally aim for is to reduce energy use (as defined in Table 2-1). When an ETM is successful, it is expected-assuming all other things remain unchanged-that its adoption results in reduced energy costs compared to the situation before adopting it, and so enables the investor or principal to earn their investment back. These financial benefits $\mathrm{CF}^{+}$;energy use are related to the prices of the energy carriers used. In the Netherlands, natural gas or district heating and electric energy are commonly used. Depending on the availability of connections to these 
energy networks, and on the specific ETM employed, use of one or more of these energy forms can be reduced. In general, it can be stated that the more the energy use of a household is reduced, the greater the expected financial benefits.

There are, however, other advantages to consider. Three out of the four components which were addressed in the last section, can also be advantages in certain circumstances. When an ETM is adopted, the maintenance costs can be reduced $\mathrm{CF}^{+}$; maintenance, the reliability can be improved $\mathrm{CF}_{\text {a;reliability }}^{+}$and the experienced user comfort increased $\mathrm{CF}_{\text {a;user comfort }}^{+}$ compared to the situation before the ETM was adopted. In this situation, the advantages need to be capitalized as financial gains rather than as disadvantages that result in financial costs. One benefit is that increased reliability can reduce the dependence on the conventional energy infrastructure. Just as it is interesting and wise for an investor to have a mix of shares, bonds and options, it might -in certain situations- be advantageous to use different energy sources and reduce dependency on a single energy form or provider.

Furthermore, ETMs can be advantageous in the sense of increasing the value of the building in which they are incorporated $\mathrm{CF}^{+}$a;value dwelling. ${ }^{8}$ The best way to explain this is through an illustration. Many people seem to have little difficulty in justifying the costs of repainting the external timber parts of their house. This form of maintenance, and the improved aesthetics, is easily regarded as a financial investment that repays itself when the house is sold. However, the work will not influence the direct monthly costs of using the building. When an ETM is being considered, many households want to know how it will reduce their monthly costs. Only a very few will consider the potential increase in value of their dwelling, even though the investment could be repaid when selling the house in the future. Brounen and Kok (2011) conducted a study regarding the relationship between energy performance, expressed by an energy certificate based on Equation 2-3, and the value of Dutch dwellings. This study considered 177,000 transactions and concluded that the value of a dwelling is positively influenced if it has better energy performance. Therefore, ETMs not only provide direct financial benefits but also indirect financial benefits. In Equation 3-4, all the financial benefits are brought together in a single formula expressing the total positive annual cash flows:

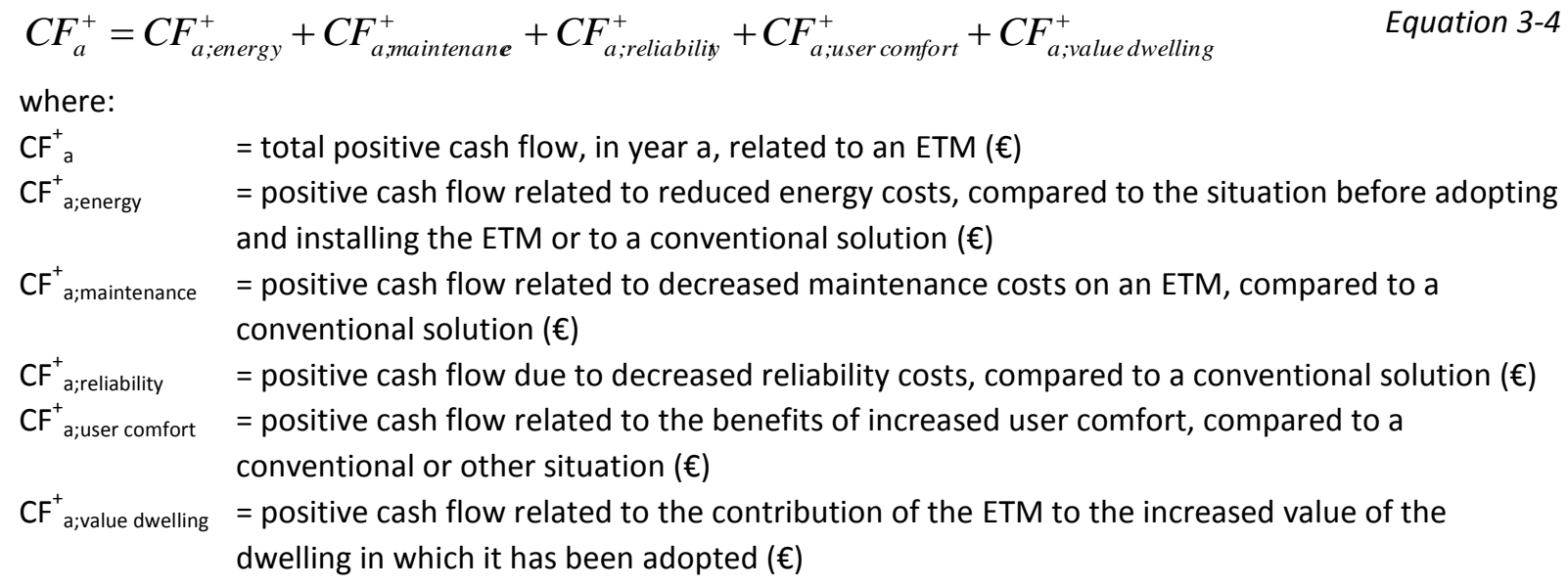

${ }^{8}$ This principle was presented and published by Entrop et al. (2010). 


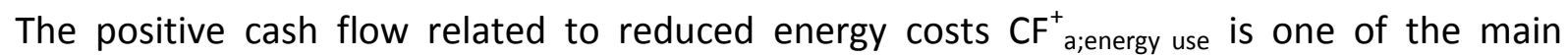
reasons why ETMs are considered as investments. Annual energy bills make people aware of the fact that such an investment can generate financial returns (see Equation 3-5).

$$
C F_{a ; \text { energy }}^{+}=\Delta E C_{a}=E C_{a ; b \text { beforeadoption }}-E C_{a ; \text { after adoption }}
$$

where:

$\mathrm{CF}^{+}{ }_{\text {a;nergy }}=$ (positive) cash flow in year a related to reduced energy expenses, compared to the situation

before adopting and installing the ETM or ETMs $(€)$

$\triangle \mathrm{EC}_{\mathrm{a}} \quad=$ difference in total energy costs of a household in a particular year ( $€$ )

$\mathrm{EC}_{\mathrm{a} ; \text {;efore adoption }}=$ total energy costs of a household, before an ETM was or ETMs were adopted in a year $(€)$

$\mathrm{EC}_{\mathrm{a} \text {;after adoption }}=$ total energy costs of a household in a year, after an ETM was or ETMs were adopted $(€)$

The financial returns depend on the way energy costs are calculated and by how much energy use, and in which form, is reduced. To understand this better, the next section will explain how energy costs are calculated in Dutch energy bills.

\subsection{Constitution of energy costs of dwellings and their residents}

The reason for energy bills is so that an energy company can receive payments for the delivered service. Here, the service consists of providing and delivering a rather intangible product, namely a quantity of fossil fuels, thermal energy and/or electric energy. From the customer's viewpoint, an energy bill should specify the delivered product or products, the costs per product (including and excluding taxes) and details of how the payment should be made. The basic principle underlying an energy bill does not differ from a bill for clothing or groceries. However, there are major differences in that clothing and groceries are tangible whereas energy is not, and clothing and groceries are paid for directly whereas energy is paid for on an annual basis. In the Netherlands, the costs of energy use are usually billed once a year after a meter reading, generally after making eleven monthly 'advance' payments based on estimated use.

To become familiar with the makeup of energy bills, the energy bills from several years of seven households were obtained. The energy bills, some dating back to the 1980s, show many different aspects for which the consumer has at times been billed. In the past, it was even common to specify and include the costs of cable television and radio. In other years, VAT rates were changed, additional taxes were charged or subsidies were provided by the energy company. Apart from these changes, which are not directly related to energy costs, the energy bills studied mention up to 23 different energy costs. Therefore, it is not an easy task to determine the impact of an ETM on the energy costs of a household. When comparing recent energy bills, the various energy costs seem to be divided into four main categories:

1. Product costs: costs of the consumed fossil fuels, used electric energy and/or used thermal energy;

2. Infrastructural costs: costs related to the transport and infrastructure enabling the provision of fossil fuels, electric energy and/or thermal energy at an address or connection point; 
3. Measurement costs: costs involved in quantifying the amounts of fossil fuels, electric energy and/or thermal energy delivered to a certain address or connection;

4. Taxes: additional costs based on legislation; these are strongly dependent on the political regime.

The total energy costs are calculated as the sum of these four categories as expressed by Equation 3-6. The four cost categories are explained in more detail in the following four sections.

$E C_{a}=E C_{a ; \text { products }}+E C_{a ; \text { infra }}+E C_{a ; \text { measurement }}+E C_{a ; \text { taxes }}$

Equation 3-6

where:

$\mathrm{EC}_{\mathrm{a}} \quad=$ total annual energy costs, in year $\mathrm{a}$, of a household $(€)$

$\mathrm{EC}_{\mathrm{a} ; \text { products }} \quad=$ energy product costs of a household in a particular year as billed by the energy company $(€)$

$\mathrm{EC}_{\mathrm{a} \text {;infra }} \quad$ infrastructural energy costs of a household, in year a, as billed by the network company $(€)$

$\mathrm{EC}_{\mathrm{a} \text {;measurement }}=$ energy measurement costs of a household, in year a, as billed by the measuring company ( $€$ )

$\mathrm{EC}_{\mathrm{a} ; \mathrm{taxes}} \quad=$ energy costs of a household in the form of national taxes raised by the government in year a $(€)$

\subsubsection{Product costs}

Natural gas is the most commonly used fossil fuel in the Netherlands to heat living space and tap water. In many dwellings natural gas is also used for cooking although electricity-based ways of cooking have become more popular in the last decade due to the introduction of many new systems using induction and ceramic techniques. A Dutch user of electric energy can choose to be billed based on a single tariff or a double tariff. With a double tariff structure, night-time electric energy prices are slightly lower than daytime prices. Depending on consumer behaviour and specific energy prices, a single or double tariff can be financially beneficial for individual houses. In addition to these variable costs based on energy usage, fixed annual costs for making use of electric energy are charged by the energy company.

Table 3-1: Different categories of product costs involving energy use.

\begin{tabular}{|l|l|}
\hline \multicolumn{1}{|c|}{ Variable } & \multicolumn{1}{c|}{ Description } \\
\hline $\begin{array}{l}\text { Providing } \\
\text { natural gas }\end{array}$ & $\begin{array}{l}\text { Natural gas is provided at a price per cubic metre }\left(€ / \mathrm{m}^{3} \text { ) plus a relatively small annual fee }\right. \\
(€ / \text { year). In the Netherlands, the price of natural gas is related to international oil prices. } \\
\text { Depending on the quality of the natural gas in a certain region, a correction factor is used to } \\
\text { compensate for variations in the calorific value of the provided natural gas. }\end{array}$ \\
\hline $\begin{array}{l}\text { Providing } \\
\text { electric energy }\end{array}$ & $\begin{array}{l}\text { Electric energy is provided for a price per kilowatt hour }(€ / \mathrm{kWh} \text { plus a relatively small } \\
\text { annual fee (€/year). In the Netherlands, electric energy is mainly generated by burning } \\
\text { natural gas, coal and biomass. A single or double tariff system can be applied. The latter } \\
\text { results in a relatively high tariff during daytime and a lower tariff during night time. }\end{array}$ \\
\hline $\begin{array}{l}\text { Providing } \\
\text { thermal energy }\end{array}$ & $\begin{array}{l}\text { Thermal energy through district heating systems is provided to households at a price per } \\
\text { gigajoule (€/GJ). This price is based on the Not More Than Different principle, that district } \\
\text { heating should not be more expensive than using natural gas for heating purposes. }\end{array}$ \\
\hline
\end{tabular}

Four per cent of the approximately seven million dwellings in the Netherlands are heated by district heating schemes (Energie-Nederland, 2010). The costs of the heat are calculated every half year on the basis of a comparison between houses connected to the gas grid and houses connected to district heating. Using averaged electric energy use and an averaged natural gas use figures, and their accompanying prices, the situation of a dwelling connected to district heating is compared. By using this method, the energy companies and the 
government try to ensure that in both situations an owner pays the same for fulfilling their energy use. The three main subcategories of product costs are described in Table 3-1. The total costs for energy, as a product, can be calculated using Equation 3-7. Where a single electric energy tariff applies, only single values for electric energy use and its price are used.

$$
\begin{aligned}
E C_{a ; \text { products }}= & \left(q_{a ; n g} \cdot C_{9} \cdot \dot{p}_{a ; \text { productng }}+p_{a ; \text { productng }}\right)+\left(q_{a ; e_{\text {low }}} \cdot \dot{p}_{a ; \text { producte } e_{\text {low }}}+\right. \\
& \left.q_{a ; e_{\text {high }}} \cdot \dot{p}_{a ; \text { producte }_{\text {high }}}+p_{\text {producta;e }}\right)+\left(q_{a ; t h} \cdot \dot{p}_{a ; \text { producth }}\right)
\end{aligned}
$$

where:

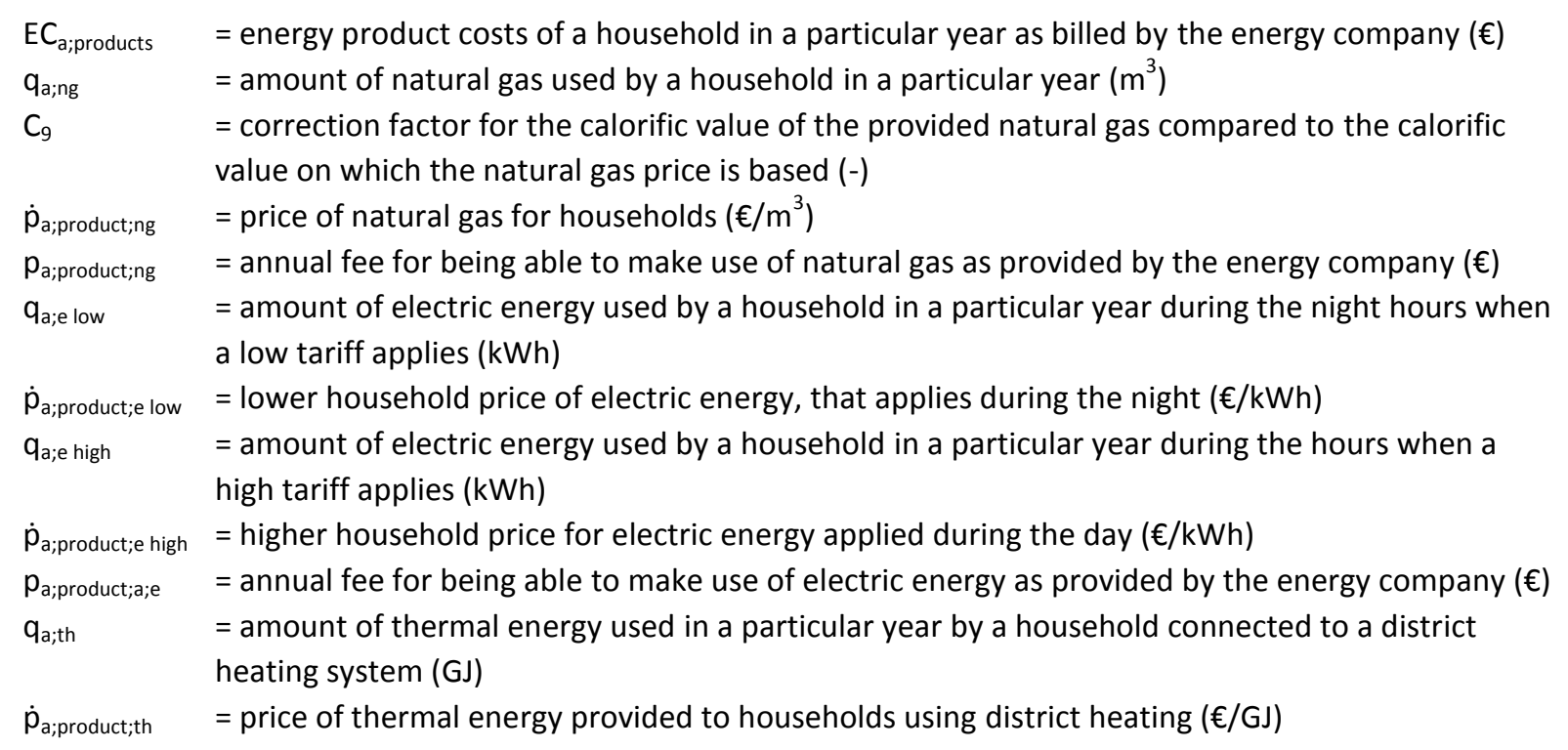

\subsubsection{Infrastructural costs}

The Netherlands, with a surface area of less than $34,000 \mathrm{~km}^{2}$, has a dense natural gas pipe network with a total length of almost $139,000 \mathrm{~km}$ and $6,981,100$ connections to buildings. The electric power grid amounts to $259,241 \mathrm{~km}$ and has $7,872,000$ connections. The many small and large scale district heating networks have a combined length of approximately 4,711 km (Energie-Nederland, 2010). Large investments have been made and are still needed to improve, maintain and expand the gas network and the power grid. These costs are included in the energy bills sent to consumers by the local network companies as described in Table 3-2 and by Equation 3-8.

Table 3-2: Different categories of costs involving the infrastructure for energy carriers.

\begin{tabular}{|l|l|}
\hline \multicolumn{1}{|c|}{ Variable } & \multicolumn{1}{c|}{ Description } \\
\hline $\begin{array}{l}\text { Transporting } \\
\text { natural gas }\end{array}$ & $\begin{array}{l}\text { Infrastructure firms maintain and improve the gas grid. Previously, a price per cubic metre } \\
\left(€ / \mathrm{m}^{3} \text { adjusted for the calorific value) plus a fixed annual contribution ( } € / \text { year) were charged }\right. \\
\text { for delivery. Since } 2009 \text {, only an annual contribution ( } € / \text { year) based on the capacity of the } \\
\text { connection is paid by the consumer to the network company. }\end{array}$ \\
\hline $\begin{array}{l}\text { Transporting } \\
\text { electric energy }\end{array}$ & $\begin{array}{l}\text { Infrastructure firms maintain and improve the electricity grid. Pre-2009, a price per kilowatt } \\
\text { hour of electric energy }(€ / \mathrm{kWh}) \text { plus a flat-rate annual contribution ( } € / \text { year) were charged } \\
\text { for transportation. Since } 2009 \text {, only an annual contribution ( } € / \text { year) based on the capacity of } \\
\text { the connection has to be paid by the consumer to the network company. }\end{array}$ \\
\hline $\begin{array}{l}\text { Transporting } \\
\text { thermal energy }\end{array}$ & $\begin{array}{l}\text { Based on the principle that users of a house connected to a district heating system should } \\
\text { pay the same total energy costs as an equivalent house connected to the natural gas } \\
\text { network, an annual contribution }(€ / \text { year) for district heating has to be paid. }\end{array}$ \\
\hline
\end{tabular}




$$
\begin{aligned}
E C_{a, \text { infra }}= & \left(q_{a ; n g} \cdot C_{9} \cdot \dot{p}_{a, \text { infraing }}+p_{a ; \text { infrang }}\right)+\left(q_{a ; e_{\text {low }}} \cdot \dot{p}_{a, \text { infra } e_{\text {low }}}+\right. \\
& \left.q_{a ; e_{\text {high }}} \cdot \dot{p}_{a, \text { infra } \text { p }_{\text {high }}}+p_{a, \text { infrap }}\right)+\left(p_{a, \text { infra; } t h}\right)
\end{aligned}
$$

where:

$\mathrm{EC}_{\mathrm{a} ; \text {;infa }} \quad=$ infrastructural energy costs of a household in a year as billed by the network company $(€)$

$\mathrm{q}_{\mathrm{a} ; \mathrm{ng}} \quad=$ amount of natural gas used by a household in a particular year $\left(\mathrm{m}^{3}\right)$

$\mathrm{C}_{9} \quad=$ correction factor for the calorific value of the delivered natural gas $(-)$

$\dot{\mathrm{p}}_{\mathrm{a} ; \mathrm{infra} ; \mathrm{ng}} \quad=$ price for transporting natural gas over the network to households $\left(€ / \mathrm{m}^{3}\right)$

$\mathrm{p}_{\mathrm{a} ; \mathrm{infra} ; \mathrm{ng}}=$ annual fee for being connected to the gas network with a certain capacity $(€)$

$\mathrm{q}_{\mathrm{a} ; \mathrm{e} \text { low }} \quad=$ amount of electricity used by a household in a particular year during the night, when a low tariff applies (kWh)

$\dot{\mathrm{p}}_{\text {a;infra; low }}=$ price for transporting electricity over the grid to households during the low-tariff period $(€ / k W h)$

$\mathrm{q}_{\mathrm{a} ; \mathrm{e} \text { high }} \quad=$ amount of electricity used by a household in year a during the day, when a high tariff applies $(\mathrm{kWh})$

$\dot{\mathrm{p}}_{\text {a;infra; }}$ high $=$ price for transporting electricity over the grid to households during the high-tariff period $(€ / \mathrm{kWh})$

$\mathrm{p}_{\mathrm{a} ; \mathrm{infra} ; \mathrm{a} ; \mathrm{e}} \quad=$ annual fee for a connection with a certain capacity to the power grid $(€)$

$p_{a ; i n f r a ; h}=$ annual fee for being connected to a district heating system $(€)$

\subsubsection{Measurement costs}

In all buildings with a connection to the natural gas network or to the electricity grid, meters are installed to measure the amount of energy used (see Table 3-3).

Table 3-3: Different subcategories of costs involving the measurement of energy use.

\begin{tabular}{|l|l|}
\hline Variable & \multicolumn{1}{c|}{ Description } \\
\hline $\begin{array}{l}\text { Natural } \\
\text { gas meter }\end{array}$ & $\begin{array}{l}\text { Consumers pay an annual rent for using a natural gas meter ( } € \text { /year). These costs also incorporate } \\
\text { maintenance costs and costs for reading the meter. This is to check that the energy use as } \\
\text { specified in the bill agrees with the actual energy use of a household. }\end{array}$ \\
\hline $\begin{array}{l}\text { Electricity } \\
\text { meter }\end{array}$ & $\begin{array}{l}\text { Consumers pay an annual rent for using an electricity meter with multiple counters ( } € / \text { year). One } \\
\text { counter is needed in case of a single tariff. Two counters are needed to quantify low tariff and } \\
\text { high tariff electric energy use. Likewise, one or two counters might be required to measure } \\
\text { electric energy produced by the household, such as by a photovoltaic system. Maintenance costs } \\
\text { and the costs for reading the meter are included in the rent. Meter readings ensure the energy } \\
\text { billed matches the energy used. }\end{array}$ \\
\hline
\end{tabular}

The meters are owned by companies dedicated to measuring natural gas and electric energy flows. Compared to the other costs, the annual measurement costs, as expressed by Equation 3-9, are relatively low in a typical household. Since January 2008, maximum household measurement costs for standard electric energy meters and natural gas meters are set annually by the Netherlands Competition Authority (NMA, 2013). With district heating, the costs for measuring energy use are incorporated in the product and infrastructural costs.

$E C_{a ; \text { measurement }}=p_{a ; \text { measurement;ng }}+p_{\text {a;measurement } ; e}$

Equation 3-9

where:

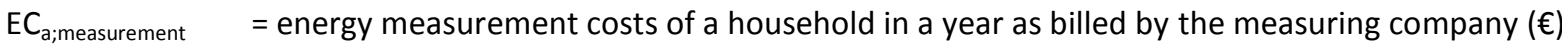

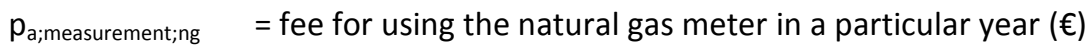

$\mathrm{p}_{\mathrm{a} ; \text { measurement } \mathrm{e}} \quad=$ fee for using the electric energy meter in a particular year $(€)$ 


\subsubsection{Taxes}

In the period from 1987 to 2011, various forms of energy taxes were introduced by the Dutch government. One of these, Environmental Quality Electricity Production (EQEP; Milieukwaliteit ElektrciteitsProductie), was abandoned after 3.5 years. Energy companies function as an intermediary in collecting these taxes. In some cases, the government has also provided subsidies on products that reduce energy use or make use of renewable energy sources. In the past, energy companies were also intermediary in providing these subsidies. Since the privatization and liberation of the Dutch energy market at the $1^{\text {st }}$ of July 2004, subsidies are directly provided to households by governmental entities themselves, e.g. national governmental agencies, municipalities, and provinces.

Table 3-4: Different subcategories of costs involving taxation of energy use.

\begin{tabular}{|c|c|}
\hline Variable & Description \\
\hline $\begin{array}{l}\text { Regulating Energy Taxes } \\
\text { (RET) }\end{array}$ & $\begin{array}{l}\text { In } 2013 \text {, households pay } € 0.1165 \text { (plus VAT) per kWh of electric energy used up to } \\
10,000 \mathrm{kWh} / \text { year and } € 0.1862 \text { (plus VAT) per } \mathrm{m}^{3} \text { of natural gas up to a use of } \\
170,000 \mathrm{~m}^{3} \text { to the government. }\end{array}$ \\
\hline $\begin{array}{l}\text { Tax Credit on Regulating } \\
\text { Energy Taxes (RET) }\end{array}$ & $\begin{array}{l}\text { An annual tax credit of } € 318.62 \text { (excluding VAT) per household per year applies to } \\
\text { the use of electric energy. This effectively reduces the overall RET fee. }\end{array}$ \\
\hline $\begin{array}{l}\text { Surcharge for } \\
\text { Sustainable Energy (SSE) }\end{array}$ & $\begin{array}{l}\text { In } 2013 \text {, households pay } € 0.0011 \text { (plus VAT) per kWh of electric energy used up to } \\
10,000 \mathrm{kWh} / \text { year and } € 0.0023 \text { (plus VAT) per } \mathrm{m}^{3} \text { of natural gas up to a use of } \\
170,000 \mathrm{~m}^{3} \text { to the government (Stb. } 673,2012 \text { ). }\end{array}$ \\
\hline Value-Added Tax (VAT) & $\begin{array}{l}\text { Value-added tax is applied to all energy products and the RET. The Dutch VAT rate } \\
\text { increased from } 19 \% \text { to } 21 \% \text { on } 1^{\text {st }} \text { October } 2012 \text {. }\end{array}$ \\
\hline
\end{tabular}

Currently, Regulating Energy Taxes (RET; Regulerende Energiebelasting), a Surcharge for Sustainable Energy (SSE; Opslag Duurzame Energie) and Value-Added Tax (VAT; Belasting Toegevoegde Waarde) apply. The RET are based on a multistage system in which a certain amount of tax has to be paid for each $\mathrm{kWh}$ and each $\mathrm{m}^{3}$. These costs, per unit of energy decrease once certain thresholds are passed. The SSE was introduced at the end of 2012 in order to generate funds for use as subsidies to stimulate the implementation of energy techniques that use renewable sources. The SSE is also based on a multistage system in which a certain amount of tax has to be paid for each $\mathrm{kWh}$ and each $\mathrm{m}^{3}$ used. Together, the RET, SSE and VAT form the fourth category of energy costs (see Table 3-4 and Equation 3-10).

$E C_{a ; \text { taxes }}=\left(q_{a ; n g} \cdot C_{9} \cdot \dot{p}_{a ; \text { taxes;ng }}\right)+\left(q_{a ; e} \cdot \dot{p}_{a ; \text { taxes } ; e}+p_{a ; \text { taxes } ; e}\right)+V A T \cdot E C_{a ;-V A T}$

Equation 3-10

where:

$E C_{a ; t a x e s}=$ energy costs of a household in the form of national taxes raised by the government in a year $(€)$

$\mathrm{q}_{\mathrm{a} ; \mathrm{ng}} \quad=$ amount of natural gas used by a household in a particular year $\left(\mathrm{m}^{3}\right)$

$\mathrm{C}_{9} \quad=$ correction factor for the calorific value of the delivered natural gas (-)

$\dot{\mathrm{p}}_{\mathrm{a} ; \mathrm{taxes} ; \mathrm{ng}}=$ RET and SSE charges on natural gas use by households in a particular year $\left(€ / \mathrm{m}^{3}\right)$

$\mathrm{q}_{\mathrm{a} ; \mathrm{e}} \quad$ = amount of electric energy used by a household in a particular year (kWh)

$\dot{\mathrm{p}}_{\mathrm{a} ; \mathrm{taxe} ; \mathrm{e}} \quad=$ RET and SSE charges on electricity use by households in a particular year $(€ / \mathrm{kWh})$

$\mathrm{p}_{\mathrm{a} ; \text { taxes } \mathrm{e}} \quad=\mathrm{RET}$ refund in a particular year per household connected to the power grid ( $€$ - negative)

VAT $\quad=$ Value-Added Tax (\%)

$\mathrm{EC}_{\mathrm{a} ; \mathrm{VAT}}=$ total energy costs of a household excluding VAT in a particular year $(€)$ 


\subsection{Constitution of energy costs of seven houses and their residents 9}

To learn about the composition of Dutch energy bills and the costs specified in energy bills, more than eighty energy bills were collected. The energy bills are related to seven of the eight houses presented in Chapter 2. It was not possible to obtain the energy bills for house 1. Given the differences in both building and household characteristics, the houses also have different energy usages in terms of quantity and form as was addressed in Chapter 2. For example, houses 7 and 8 do not use natural gas and are connected to a district heating system, receiving thermal energy in the form of hot water. Although the number of houses to which the energy bills are related, seems small, the energy bills give from a longitudinal perspective a broad overview of which costs were charged in the period 1987-2010 (see Appendix B). Furthermore, the available energy bills were dispatched by nine different companies, namely Cogas, Elektran (now known as MainEnergy), Eneco, EnergieDirect, Essent, GreenChoice, MainEnergy, Nuon and PNEM (now named Essent), which makes it possible to get an overview of how different companies bill their customers. Often, these different energy companies offer only a few different deals to private customers by means of variable costs per unit of energy and fixed energy costs per year. This means that if one has the energy bill of a specific year of an energy company, it is likely that other private customers of the same company were billed in the same year on basis of comparable or even equal costs. Therefore, the studied energy bills are expected to represent the energy bills of many Dutch houses and their residents. However, there are some difficulties in comparing the energy bills and energy costs of the different households as follows:

The format of the energy bill differs by energy company. The extent to which the energy costs are specified and the order in which the cost calculations are made vary. Some companies add VAT directly to the costs for the individual services listed in the energy bills, others add VAT to the total costs at the end. Some energy companies total all the product costs directly, and others distinguish the variable from the fixed costs. As such, it becomes necessary to use the four cost categories specified in the last section and separate variable and fixed costs in order to compare.

The form and the amount of used energy differs per house. District heating, natural gas and electric energy are the three forms of energy most commonly used in the Netherlands, but each can be used for different purposes and in different amounts. When the financial benefits of energy measures are addressed, it is important to reflect on the way the energy price per $\mathrm{m}^{3}$, per $\mathrm{kWh}$ and/or per MJ was calculated. In coming to electricity prices per MJ for households, a conversion rate of $3.6 \mathrm{MJ} / \mathrm{kWh}$ is used. A conversion rate for natural gas of $33.41 \mathrm{MJ} / \mathrm{m}^{3}$ was used, being the mean of the standard lower and higher calorific values of natural gas in the Netherlands.

The billing periods vary and are seldom exactly one year. The third and final difficulty addressed here is that electric energy use and natural gas consumption are not proportional to the number of days between meter readings because of variations in ambient temperatures, wind speeds and the availability of natural daylight. The start and end dates

\footnotetext{
${ }^{9}$ Parts of this section were published elsewhere (Entrop et al., 2010).
} 
of the billing periods are specified in the energy bills and, in this chapter, this issue is dealt with by assigning the time periods covered by energy bills to calendar years by means of chronological rounding.

Attention will be given to the breakdown of the costs, developments regarding price levels and to the ability of households to influence energy costs by implementing energy measures. The last aspect will be important in financially analysing ETMs, because the reduced energy costs need to generate an annual positive cash flow if they are to earn back the initial investment.

\subsubsection{General developments in energy costs}

The average electricity use of a Dutch household was 2,829 kWh/year in 1985 and 3558 kWh/year in 2008 (Energie-Nederland, 2010). Average natural gas consumption per household fell from $2475 \mathrm{~m}^{3}$ /year in 1985 to 1,625 m³/year in 2008 (Energie-Nederland, 2010). According to Statistics Netherlands (CBS, 2011e), electricity prices increased from $0.278 € / \mathrm{m}^{3}$ for natural gas and $0.125 \pm 0.005 € / \mathrm{kWh}$ for electric energy in 2000 to $0.591 € / \mathrm{m}^{3}$ and $0.282 \pm 0.019 € / \mathrm{kWh}$ respectively in 2009. Although the average natural gas use decreased, figures from Statistics Netherlands and others published in the media and issued by energy companies all show increasing prices for electric energy and natural gas and increasing energy costs for households. Before addressing the energy costs of the studied dwellings, some general trends regarding energy costs for Dutch households in general are described.

The early energy bills collected show that households were once billed only for product costs. Product costs per cubic metre $\left(€ / \mathrm{m}^{3}\right)$ and per kilowatt hour $(€ / \mathrm{kWh})$, plus relatively small fixed costs ( $€ /$ year), were included in bills for natural gas and electric energy. In later years, starting in 2000-2005 and depending on the specific energy company, variable and fixed costs for transporting natural gas and receiving electric energy using the natural gas network and power grid were identified on utility bills.

Charging variable costs for transport and infrastructure was no longer allowed after $1^{\text {st }}$ January 2009, when a fixed annual fee was introduced based on the capacity of the individual connection. In 2010, depending on the specific network provider, the fixed costs for a basic connection to the natural gas grid were approximately $€ 100$ to $€ 110$ per year for a connection with a maximum capacity of $10 \mathrm{~m}^{3} / \mathrm{h}$. In the same year, the fixed costs for a connection to the electricity grid were approximately $€ 160$ to $€ 180$ per year for a basic connection with a capacity of $3 \times 25$ A or $1 \times 40 \mathrm{~A}$. In both cases, the capacities are adequate for most domestic dwellings.

The energy bills indicate that measurement costs were paid in the form of a rent for the energy meters starting in the period 2002-2005. These costs also included labour costs for if the meters need to be replaced and for them to be read. The fixed prices gradually increased to approximately $€ 16$ to $€ 20$ per year for a gas meter. The fixed prices for electric energy meters hovered around $€ 25$ per year. For 2012, the maximum price for a gas meter was set at $€ 19.29$ per year (plus VAT) and this rose to $€ 19.73$ for 2013 (NMA, 2011a; NMA, 2012a). 
For electric energy meters, the maximum prices were $€ 26.38$ and $€ 26.98$ (plus VAT) for the same two years (NMA, 2011b; NMA, 2012b).

Table 3-5: Energy taxation based on the energy bills of eight Dutch households (CBS, 2012).

\begin{tabular}{|c|c|c|c|c|c|}
\hline Year & $\begin{array}{c}\text { Regulating } \\
\text { Energy Taxes } \\
\text { Gas } \\
€ / \mathrm{m}^{3}\end{array}$ & $\begin{array}{c}\text { Regulating } \\
\text { Energy Taxes } \\
\text { Electricity } \\
€ / \text { kWh }\end{array}$ & $\begin{array}{c}\text { Environmental } \\
\text { Quality Electricity } \\
\text { Production } \\
€\end{array}$ & $\begin{array}{l}\text { Discount } \\
\text { Energy } \\
\text { Taxes } \\
€\end{array}$ & $\begin{array}{l}\text { Value } \\
\text { Added } \\
\text { Tax } \\
\%\end{array}$ \\
\hline $1987-1988$ & - & - & - & - & 20.0 \\
\hline 1989-1991 & - & - & - & - & 18.5 \\
\hline 1992-1995 & - & - & - & - & 17.5 \\
\hline 1996 & 0.01452 & 0.0134 & - & 22.34 & 17.5 \\
\hline 1997 & 0.02902 & 0.0134 & - & 33.94 & 17.5 \\
\hline 1998 & 0.04325 & 0.0134 & - & 45.32 & 17.5 \\
\hline 1999 & 0.07251 & 0.0222 & - & 75.77 & 17.5 \\
\hline 2000 & 0.09448 & 0.0372 & - & 105.34 & 17.5 \\
\hline 2001 & 0.12025 & 0.0583 & - & 141.58 & 19.0 \\
\hline 2002 & 0.12400 & 0.0601 & - & 142.00 & 19.0 \\
\hline 2003 January & 0.12850 & 0.0639 & - & 142.00 & 19.0 \\
\hline 2003 July & 0.12850 & 0.0639 & 34.00 & 176.00 & 19.0 \\
\hline 2004 & 0.14290 & 0.0654 & 39.00 & 181.00 & 19.0 \\
\hline 2005 & 0.14940 & 0.0699 & 52.00 & 194.00 & 19.0 \\
\hline 2006 & 0.15070 & 0.0705 & 52.00 & 197.00 & 19.0 \\
\hline 2007 & 0.15310 & 0.0716 & - & 199.00 & 19.0 \\
\hline 2008 January & 0.15540 & 0.0727 & - & 199.00 & 19.0 \\
\hline 2008 July & 0.15540 & 0.0752 & - & 199.00 & 19.0 \\
\hline 2009 & 0.15800 & 0.1085 & - & 318.62 & 19.0 \\
\hline 2010 & 0.16290 & 0.1114 & - & 318.62 & 19.0 \\
\hline 2011 & 0.16390 & 0.1121 & - & 318.62 & 19.0 \\
\hline
\end{tabular}

Taxes are strongly related to the political regime. In the period 1987-2010, households were required to pay the standard VAT at a rate that varied between $17.5 \%$ up to $20 \%$ (see Table 3-5). In 1996, RET were introduced, today often referred to as Energy Taxes. These taxes were paid per kWh of electric energy and per $\mathrm{m}^{3}$ of natural gas and were increased to $€$ $0.1121 / \mathrm{kWh}$ and $€ 0.1639 / \mathrm{m}^{3}$ in 2011. The RET values shown in Table 3-5 are valid up to an energy use of $5,000 \mathrm{~m}^{3} /$ year and $10,000 \mathrm{kWh} /$ year. Above these values, lower rates apply but very few households exceed these thresholds. In 2009, 2010 and 2011 an annual discount, or rebate, of $€ 318.62$ was given on the electric energy taxes. Earlier, in the period 1996-2000, a discount was given in the form of a RET-free energy allowance of $800 \mathrm{kWh}$ of electric energy and $800 \mathrm{~m}^{3}$ of natural gas per year.

In the period 2003-2006, additional taxes were introduced to finance subsidies to reduce the emissions from electric energy production, as was explained in Section 3.3.4. This so-called Environmental Quaility Electricity Production (EQEP) was incorporated directly in the general energy discount. In this same period, the RET increased but without the discount tariff changing. 


\subsubsection{Case-specific developments in energy costs}

This section describes developments in each cost category for the dwellings in the case study. The four cost categories remain product costs, infrastructural costs, measurement costs and taxes. Detailed cost information on the energy use of the seven households is provided in Appendix B.

\section{Product costs}

A standard Dutch household with a connection to the gas grid and the electricity network is free in choosing any of the many energy companies to deliver natural gas and electric energy. One is able to choose a sustainable, or so-called "green", form of energy, to choose a certain quality of services and to choose (maybe most importantly) based on the price of natural gas and electric energy. In other words, in the "product costs" category, one can freely choose a specific product (natural gas and electric energy) with variable and fixed costs provided one is connected to the natural gas network and the power grid as maintained and provided by the local network company.

A household occupying a house connected to the district heating network is bound to the company that provides the heat and maintains the local heat infrastructure. In this research sample, the households occupying Houses 7 and 8 were not able to choose another supplier. They were tied to Essent Local Energy Solutions BV that provided heat in the form of hot water. Nevertheless, these two households could choose their electric energy providers. However, if a household purchases electric energy without purchasing natural gas, the fixed annual costs are often relatively high because suppliers often offer discounts when both natural gas and electric energy are purchased. On average, product costs amounted to $51 \%$ to $54 \%$ of total energy costs over the last three years. Figure 3-3 provides an overview of the energy costs per cost category for the period 2008-2010. The product costs form the largest element of the total energy costs of all the studied households.

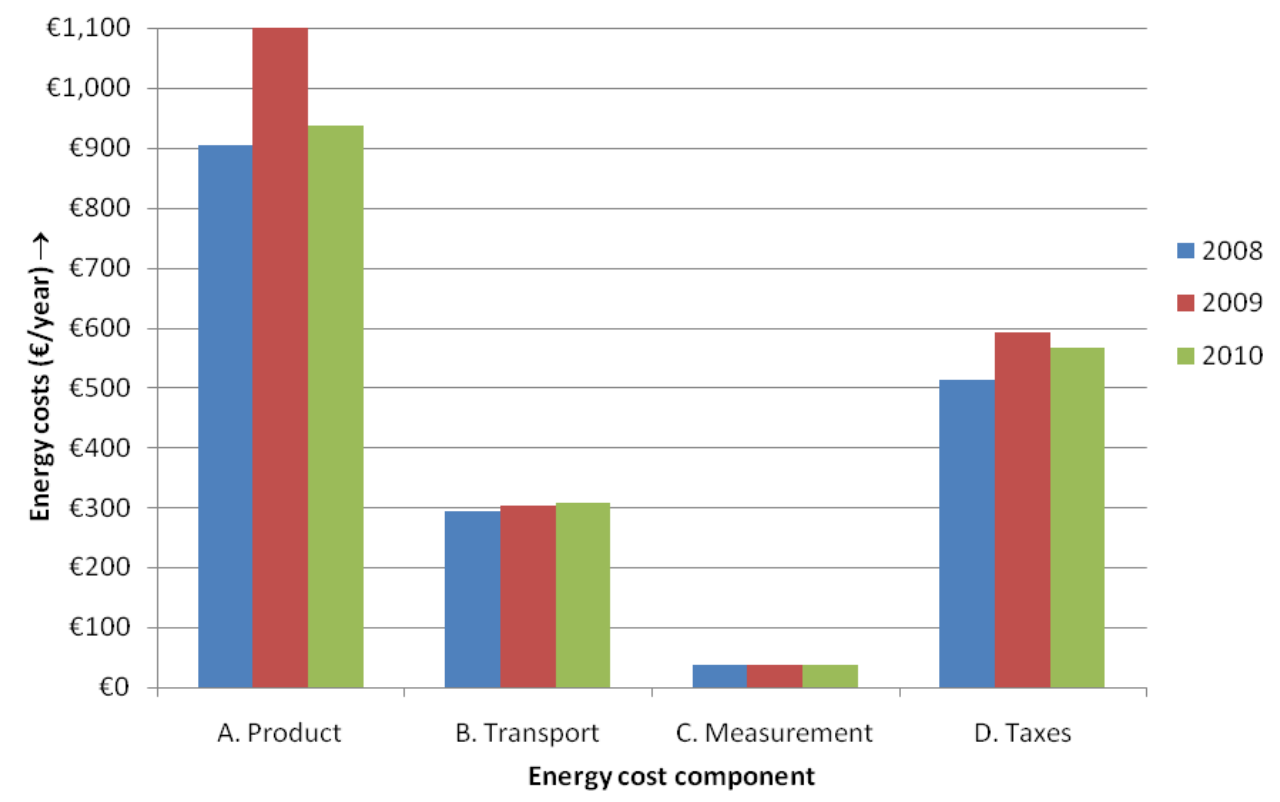

Figure 3-3: Average energy costs by cost category. 


\section{Infrastructural costs}

Based on a house's location, it is connected to a specific part of the gas grid and electricity network. A household may receive a separate bill from the regional network provider, or the infrastructural costs may be incorporated in the energy bill from the energy company. Energy companies provide the natural gas and electric energy, and bill for product costs. There is no possibility for a household to switch to a different network provider, for example to reduce the infrastructural costs, unless they move to another location outside the region of their current network provider.

In the past, a major part of the invoiced infrastructural costs were related to the amount of natural gas and electric energy used by the household. Infrastructural costs for the houses that used natural gas for heating in the case studies were typically around 15 to $17 \%$ of total energy costs. Today, there are fixed annual costs, and infrastructural costs for households with an average or high energy use are now less in percentage terms. Houses 7 and 8, which are on a district heating system, have always paid a fixed fee for infrastructural costs and today have slightly higher transport costs than the studied houses connected to the gas grid.

\section{Measurement costs}

Traditionally, the company responsible for providing measurement equipment and services was linked to the regional network provider. Nowadays, the possibility exists for consumers to freely choose from a range of certified company offering energy measurement services. However, few consumers are aware of this possibility. Further, little financial benefit could be expected from switching to another company since measurement costs are only around $€$ 25 (plus VAT) per year, around $2 \%$ of annual energy costs.

\section{Taxes}

The fourth and final category considered is the component that is set by the government and collected on their behalf. Here, very little influence can be exerted by households or consumers to reduce these costs. In the past ten years, taxes have significantly increased energy costs through Regulating Energy Taxes (RET), Environmental Quality Electricity Production (EQEP), Surcharge for Sustainable Energy (SSE) and the more widely applied Value-Added Tax (VAT).

These taxes amount to a fixed component plus a variable amount based on energy use. Until 2007, a fixed amount, the EQEP, had to be paid annually, notionally to improve the environmental quality of the energy product. Since 1996, a fixed compensatory tax credit is granted each year. The discount for 2010 was roughly equivalent to the RET levied on 1,000 $\mathrm{m}^{3}$ of natural gas and 1,400 kWh of electric energy, which approximates half of the average energy use of a Dutch household.

On top of the costs outlined above -product costs, infrastructural costs, measurement costs and the energy taxes- VAT has to be paid. In Houses 2 to 6 , all these various taxes amounted to some 38 to $40 \%$ of the total energy costs in the period 2008-2010. Houses 7 and 8 are connected to a local heat network and consequently some of these taxes are 'hidden' in the thermal energy product costs. 


\subsubsection{Average versus marginal energy costs}

Four different cost categories have been specified and these include fixed and variable costs. Fixed costs in this thesis are defined as those costs that have a certain price per unit of time. Variable costs are costs that have a price per unit of energy. If the amounts of natural gas, electric energy and thermal energy used are known, then the total energy costs can be calculated. The characteristics of a dwelling and the behaviour of its household will influence energy use. However, a household can only influence the variable energy costs and, indirectly, that part of the taxation that is variable. In principle, there are no limitations on a household in terms of reducing energy use or choosing an energy company with different product costs. Unfortunately, a household is not free in choosing which taxes to pay. Thus, two levels of influence can be seen, as expressed in Equation 3-11 and Equation 3-12.

$$
E C_{a}=E C_{a ; \text { variable }}+E C_{a ; \text { fixed }}+E C_{a ; \text { taxes }}
$$

where:

$$
E C_{a ; t a x e s}=E C_{a ; \text { taxes; variable }}+E C_{a ; t a x e s ; \text { fixed }}
$$

where:

$$
\begin{array}{ll}
\mathrm{EC}_{\mathrm{a} ; \mathrm{variable}} & =\text { variable energy costs as charged by companies in a particular year }(€) \\
\mathrm{EC}_{\mathrm{a} ; \mathrm{fixed}} & =\text { fixed energy costs as charged by companies in a particular year }(€) \\
\mathrm{EC}_{\mathrm{a} ; \mathrm{taxes} ; \mathrm{variable}} & =\text { taxes in a particular year based on energy use }(€) \\
\mathrm{EC}_{\mathrm{a} ; \text { taxes;fixed }} & =\text { taxes in a particular year independent of energy use }(€) \\
\mathrm{EC}_{\mathrm{a} ; \text { taxes }} & =\text { sum of variable and fixed taxes in a particular year }(€) \\
\mathrm{EC}_{\mathrm{a}} & =\text { total annual energy costs of a household in a particular year }(€)
\end{array}
$$

In a typical Dutch household, where natural gas and electric energy are used, one can therefore speak of six different "average" energy costs. The average electric energy costs per $\mathrm{kWh}$ can be calculated based on the sum of all the variable and fixed electric energy costs (including or excluding taxes) divided by the amount of electric energy used. The average natural gas costs per $\mathrm{m}^{3}$ can similarly be calculated based on the sum of all variable and fixed natural gas costs (including or excluding taxes) divided by the amount of natural gas consumed. Finally, the average energy costs per MJ can be calculated based on the sum of all variable and fixed energy costs (including or excluding taxes) divided by the amount of energy used by expressing the natural gas consumption and/or electric energy use in MJ. Equation 3-13 shows how these average energy costs, including taxes, can be calculated. To exclude taxes, the total energy costs $\mathrm{EC}_{\mathrm{a}}$ can be reduced by $\mathrm{EC}_{\mathrm{a} \text {; taxes. }}$

$$
A E C_{a}=\frac{E C_{a}}{q_{a}}
$$

Equation 3-13 where:

$$
\begin{array}{ll}
A E C_{a} & =\text { average energy costs of a household in a particular year }\left(€ / \mathrm{m}^{3}, € / \mathrm{kWh} \text { or } € / \mathrm{MJ}\right) \\
\mathrm{EC}_{\mathrm{a}} & =\text { total household energy costs in a particular year }(€) \\
\mathrm{q}_{\mathrm{a}} & =\text { amount of energy used by a household in that year (expressed in } \mathrm{m}^{3}, \mathrm{kWh}, \text { or } \mathrm{MJ} \text { ) }
\end{array}
$$

The difference between average costs and marginal costs are determined by the share of the total costs that are fixed. Marginal costs can be seen as the costs billed for using one unit of energy $\left(\mathrm{m}^{3}, \mathrm{kWh}\right.$, or $\mathrm{MJ}$ ) above some reference situation. In a situation of reducing energy use, marginal benefits are the financial benefits a household accrues by using one unit of 
energy $\left(\mathrm{m}^{3}, \mathrm{kWh}\right.$, or $\left.\mathrm{MJ}\right)$ less than in the reference situation. Equation 3-14 shows how the marginal energy costs can be calculated, including the influence of variable taxation costs.

$M E C_{a}=\frac{\Delta E C_{a}}{\Delta q_{a}}=\frac{\Delta E C_{a, v a r i a b l e}+\Delta E C_{a ; \text {;axes;variable }}}{\Delta q_{a}}$

Equation 3-14

where:

$\mathrm{MEC}_{\mathrm{a}}=$ marginal energy costs of a household in a particular year (expressed in $€ / \mathrm{m}^{3}, € / \mathrm{kWh}$ or $€ / \mathrm{MJ}$ )

$\triangle \mathrm{EC}_{\mathrm{a}} \quad=$ change in total household energy costs due to a change in energy use in a particular year $(€)$

$\Delta \mathrm{q}_{\mathrm{a}} \quad=$ change in the amount of energy used by a household in a year (expressed in $\mathrm{m}^{3}, \mathrm{kWh}$ or MJ)

$\mathrm{EC}_{\mathrm{a} ; \mathrm{variable}} \quad=$ total variable energy costs charged in a particular year $(€)$

$\mathrm{EC}_{\mathrm{a} \text {;taxes; } ; \text { ariable }}=$ sum of variable energy costs due to taxes in a particular year $(€)$

Figure 3-4 shows how the share of fixed costs are increasing compared to the variable costs in recent years. The developments result in lower marginal costs per unit of energy, but relatively high average costs per unit of energy.

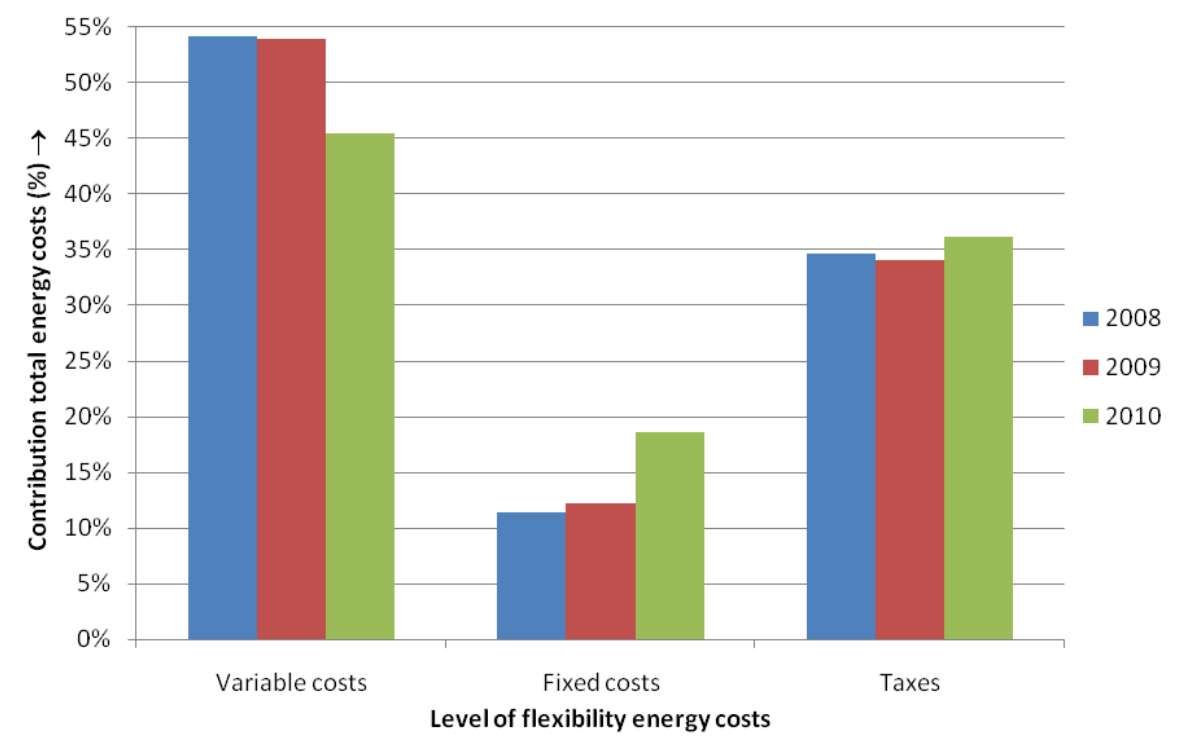

Figure 3-4: Energy costs in terms of level of flexibility (Houses 2 to 6).

To make the difference between average costs and marginal costs more explicit, a standard energy use is considered. For 2010, Energie-Nederland (2010b) uses the following standard energy usages $1372 \mathrm{~m}^{3}, 4116 \mathrm{kWh}$ and $34.99 \mathrm{GJ}$. The natural gas and electricity prices are taken from the Essent energy bills of Houses 4 and 8 (price levels at end of 2009). The price of heat per GJ was taken from energy bills of Houses 7 and 8, that both have district heating. When considering this standard energy use, the electric energy costs are calculated at $€ 802$ in 2010. In that same year, the natural gas costs at $€ 870$ and the price for thermal energy when using district heating at $€ 976$. The calculations used in creating Table 3-6, show that average and marginal prices are quite different from each other and also the prices differ widely between energy forms. Taxes form between 33.4 to $41.4 \%$ of the average energy costs, but 47.1 to $65.0 \%$ of marginal energy costs. In line with the law, the compensating annual tax credit firstly reduces the electricity costs. This results in average electric energy prices that are lower than the marginal costs. 
Table 3-6: Illustrative example of the differences between average and marginal energy prices.

\begin{tabular}{|l|r|r|r|r|r|r|}
\hline & $\begin{array}{c}\text { Electric } \\
\text { energy } \\
\boldsymbol{\epsilon} / \mathbf{k W h}\end{array}$ & $\begin{array}{c}\text { Electric } \\
\text { energy } \\
\mathbf{\epsilon} / \mathbf{M J}\end{array}$ & $\begin{array}{c}\text { Natural } \\
\text { gas } \\
\mathbf{\epsilon} / \mathbf{m}^{3}\end{array}$ & $\begin{array}{c}\text { Natural } \\
\text { gas } \\
\boldsymbol{\epsilon} / \mathbf{M J}\end{array}$ & \multicolumn{1}{|c|}{ Heat } & Heat \\
\hline Average costs including taxes & 0.1948 & 0.0541 & 0.6339 & 0.0180 & 27.89 & 0.0279 \\
\hline Marginal costs including taxes & 0.2273 & 0.0631 & 0.5105 & 0.0145 & 20.02 & 0.0200 \\
\hline Relative price difference & $+16.7 \%$ & $+16.7 \%$ & $-19.5 \%$ & $-19.5 \%$ & $-28.2 \%$ & $-28.2 \%$ \\
\hline Average costs excluding taxes & 0.1297 & 0.0360 & 0.3715 & 0.0106 & 17.21 & 0.0172 \\
\hline Marginal costs excluding taxes & 0.0796 & 0.0221 & 0.2678 & 0.0063 & 10.59 & 0.0106 \\
\hline Relative price difference & $-38.6 \%$ & $-38.6 \%$ & $-27.9 \%$ & $-27.9 \%$ & $-38.5 \%$ & $-38.5 \%$ \\
\hline
\end{tabular}

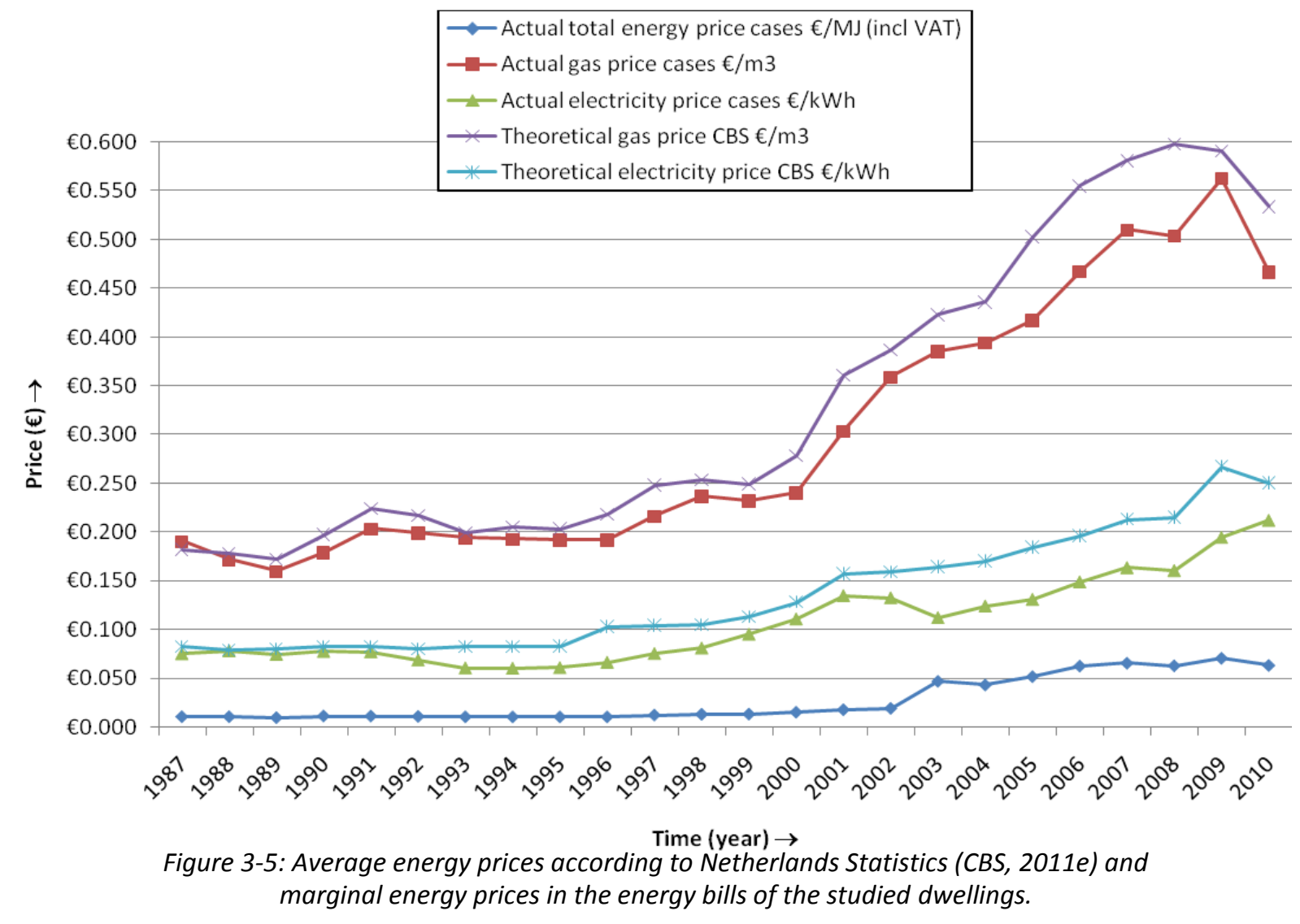

By using the cost data of all dwellings, as shown in Appendix B, it was possible to calculate the marginal energy prices for multiple years. Figure 3-5 shows that these marginal energy prices, as paid by the studied households, are lower than the energy prices provided by Statistics Netherlands (CBS, 2011e). This does not mean that the data are wrong or incorrectly used, but it does highlight the importance of using the appropriate energy prices in calculating the financial benefits of an ETM, that possibly is going to be implemented in a dwelling of a household.

\subsection{Assessing the financial impact of two ETMs in dwellings ${ }^{10}$}

Having broadly considered household energy costs, the focus will now be narrowed to two investments that influence a dwelling's energy use and energy performance. The financial benefits of ETMs have traditionally been calculated using the electric energy price (in

\footnotetext{
${ }^{10}$ Parts of this section were published elsewhere (Entrop et al., 2010).
} 
$€ / \mathrm{kWh}$ ), the natural gas price (in $€ / \mathrm{m}^{3}$ ) and the estimated or experienced electric energy $(\mathrm{kWh})$ and natural gas $\left(\mathrm{m}^{3}\right)$ savings. If district heating is used, then the amount in $\mathrm{GJ}$ and the price $(€ / G J)$ of thermal energy will be used. In this section, the traditional investment appraisal approach is extended. Due to the fact that the payback method does not take into account the returns after the payback period and due to the fact that the rate of return demands the investor to define his or hers relative capital costs, this section makes use of the NPV to assess two energy investments in dwellings. These investments were done by households, not by professional investors who had defined or can define their relative capital costs.

\subsubsection{Incorporating the changed value of a dwelling in the financial analysis}

The basic equation (Equation 3-1) used to calculate the NPV looks deceptively simple, but specifying in detail the cost and benefits of ETMs is not an easy task given that energy prices can widely fluctuate, effective interest rates change and governments frequently alter the taxation regime. With hindsight, knowing what the effective interest rates were in the past and what changes in energy prices occurred, one can determine what the actual financial benefits of adopted ETMs have been. As such, the actual annual energy prices and effective interest rates will be used to calculate the NPV of two illustrative energy investments.

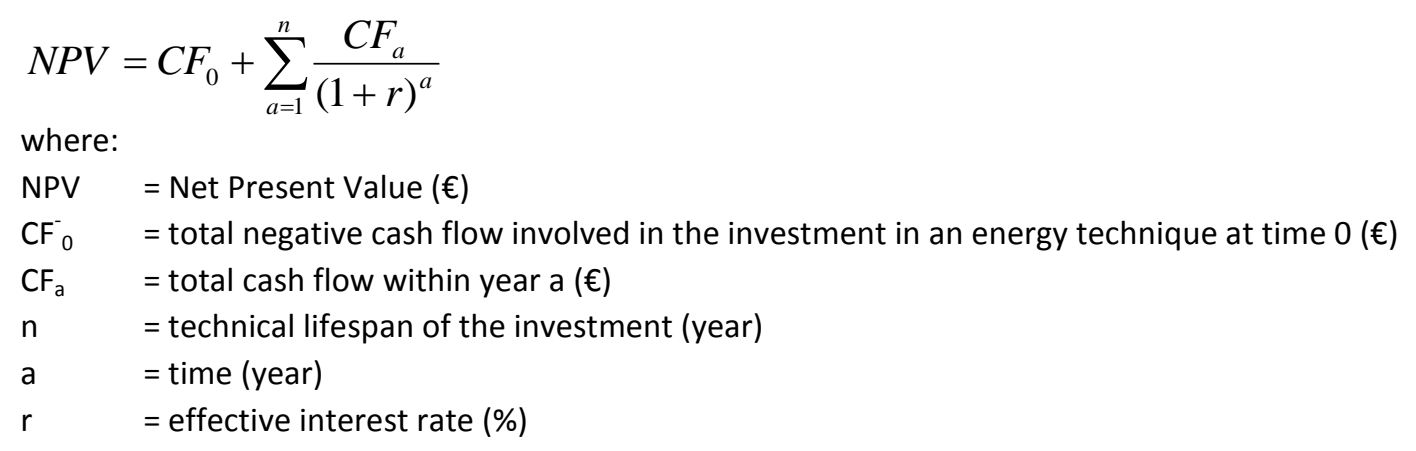

In this section, a relatively little used variable in calculating the financial benefits of an ETM is further elaborated on, namely the cash flow related to the potential increased value of a dwelling in which energy techniques and/or measures are adopted. This positive cash flow $\left(\mathrm{CF}^{+}{ }_{\text {a;value dwelling }}\right)$ was presented as one of the potential benefits in Section 3.2.3. A green Energy Label is seen as resulting in a better market position of buildings (Brounen \& Kok, 2011; Eichholtz et al., 2010) and, in case of commercial buildings, as reducing possible investment risks (Eichholtz et al., 2010). Brounen \& Kok (2011) studied around 177,000 housing transactions in the Netherlands from January 2008 to August 2009. They concluded that homebuyers are willing to pay a premium for dwellings that have been labelled with a green Energy Label, being a label A, B, or C (ibid, p. 177). Eichholtz et al. (2010) focused on office buildings. Their study incorporates more than 10,000 commercial properties of which almost 900 buildings are LEED and/or Energy Star certified. They concluded that rent and selling price increase, when an office building has an Energy Star certificate that expresses an efficient energy use of the building compared to other similar buildings without certificate.

Hence, there is an additional opportunity to assign these financial benefits to distinct components of a building on the argument that the value of a building is the sum of its parts. 
Conversely, building values can decrease as a result of a lack of maintenance and depreciation of applied ETMs. Nevertheless, one may expect that the general value of houses with a green Energy Label will exceed the value of those with a red Energy Label. To this end, the following formula is introduced to calculate the positive cash flow resulting from the contribution of investments in ETMs to an increased value of a dwelling:

$C F_{a \text {;valuedwelling }}^{+}=\Delta V_{a} \times \frac{\left|C F_{0}^{-}\right|-d_{0-a}}{V_{0}}$ with $d_{0-a} \leq\left|C F_{0}^{-}\right|$

Equation 3-15

where:

$\mathrm{CF}^{+}$;yalue dwelling = positive cash flow related to the increased value of the dwelling in which the ETM is adopted, compared to the dwelling without the installed ETM $(€)$

$\mathrm{CF}_{0}^{-} \quad=$ total negative cash flow from an investment in an ETM at time $0(€)$

$\Delta \mathrm{V}_{\mathrm{a}} \quad=$ change in value of the building in a particular year after installing the ETM $(€)$

$\mathrm{d}_{\mathrm{o}-\mathrm{a}} \quad=$ total deprecation, from time 0 to time $\mathrm{a}$, of an ETM $(€)$

$V_{0} \quad=$ value of the building at time 0 directly prior to installing the ETM ( $€$ )

In calculating the NPV using this formula, the costs of removing the ETMs at the end of their lifetime are ignored. The benefits from using energy techniques can be calculated more precisely after several years of use, rather than being based on estimates prior to investment and application. This was one reason why this analysis is based on previous investments in the sample of houses discussed in Section 2.4.

\subsubsection{General economic developments related to dwellings and energy}

Data from Statistics Netherlands (CBS, 2011e; CBS, 2011f) and the National Land Registry (Kadaster, 2011) has been used to obtain information about long-term fluctuations in inflation, effective interest rates (calculated using Equation 3-16 as defined by Moyer et al., 2006 , p. 163), house prices, natural gas prices and electric energy prices (see Figure 3-6). The percentage changes in the value of houses and energy prices in this figure are relative to the price a year earlier. The findings on each aspect are explained below.

$r_{a}=c r_{a}-i r_{a}$

Equation 3-16

where:

$\mathrm{r}_{\mathrm{a}} \quad=$ effective interest rate in a particular year (\%)

$\mathrm{Cr}_{\mathrm{a}} \quad=$ capital interest rate in a particular year (\%)

$\mathrm{ir}_{\mathrm{a}} \quad=$ inflation rate in a particular year (\%)

Inflation: Apart from a small deflation in 1987 of $0.5 \%$, inflation rates varied from $0.2 \%$ to $6.7 \%$ in the period 1980-2010. From 1983 to 2000 the rates were rather stable with an average inflation rate of $2.1 \%$. Considering only the last two decades, the inflation rate for 2001 was with $4.5 \%$ quite high by Dutch standards. With the introduction of the Euro, the rate already decreased again in 2002.

Interest: In the years that inflation rates were relatively high, the interest rates on mortgages were also relatively high. In the last twelve years, interest rates were lower than in previous years, which might explain the increasing house prices. The effective interest rate is calculated as actual interest minus inflation, which varied from $1.4 \%$ to $6.9 \%$. The interest rates on savings are usually slightly below the mortgage interest rate. 
House prices: In the period up to 2008, the value of dwellings in the Netherlands increased significantly but since then prices have been falling. It is not possible to give an overview for the entire three decades, but the period 1993-2010 saw seven years with value increases of more than $10 \%$. The cost of houses is a factor in the cost of living calculations and therefore the inflation rate partially depends on the value of dwellings.

Natural gas prices: Figure 3-6 shows that, over the past thirty years, natural gas prices were more variable than the three factors just considered. The price of natural gas is strongly related to the oil price. Furthermore, the consumer price for gas also depends on the VAT rate and environmental taxes, as discussed in previous sections. In Figure 3-6, the average natural gas prices are those issued by Statistics Netherlands. These prices include the various energy taxes, but VAT is excluded. Van Soest (2005) explains that the effect of these marketbased instruments on the timing of applying ETMs has been discussed by multiple scholars. However, his research shows that environmental taxes and quotas have not stimulated firms to adopt new ETMs (van Soest, 2005).

Electricity prices: The price of electric energy has fluctuated in a similar way to that of natural gas, which is not surprising given that more than $60 \%$ of electric energy production is based on natural gas (EC, 2007). Further, the natural gas price is also linked to other fossil fuels (coal and oil) that are used for electricity generation. The introduction of environmental taxes in 1996 and 1997 had a strong impact on household electricity prices. The environmental taxes were significantly increased over the next four years, but these increases came to almost a halt in 2002. In Figure 3-6, the average electric energy prices shown are as stated by Statistics Netherlands (CBS, 2011e). These prices include the variable energy taxes, but VAT and the annual energy tax refund are excluded.

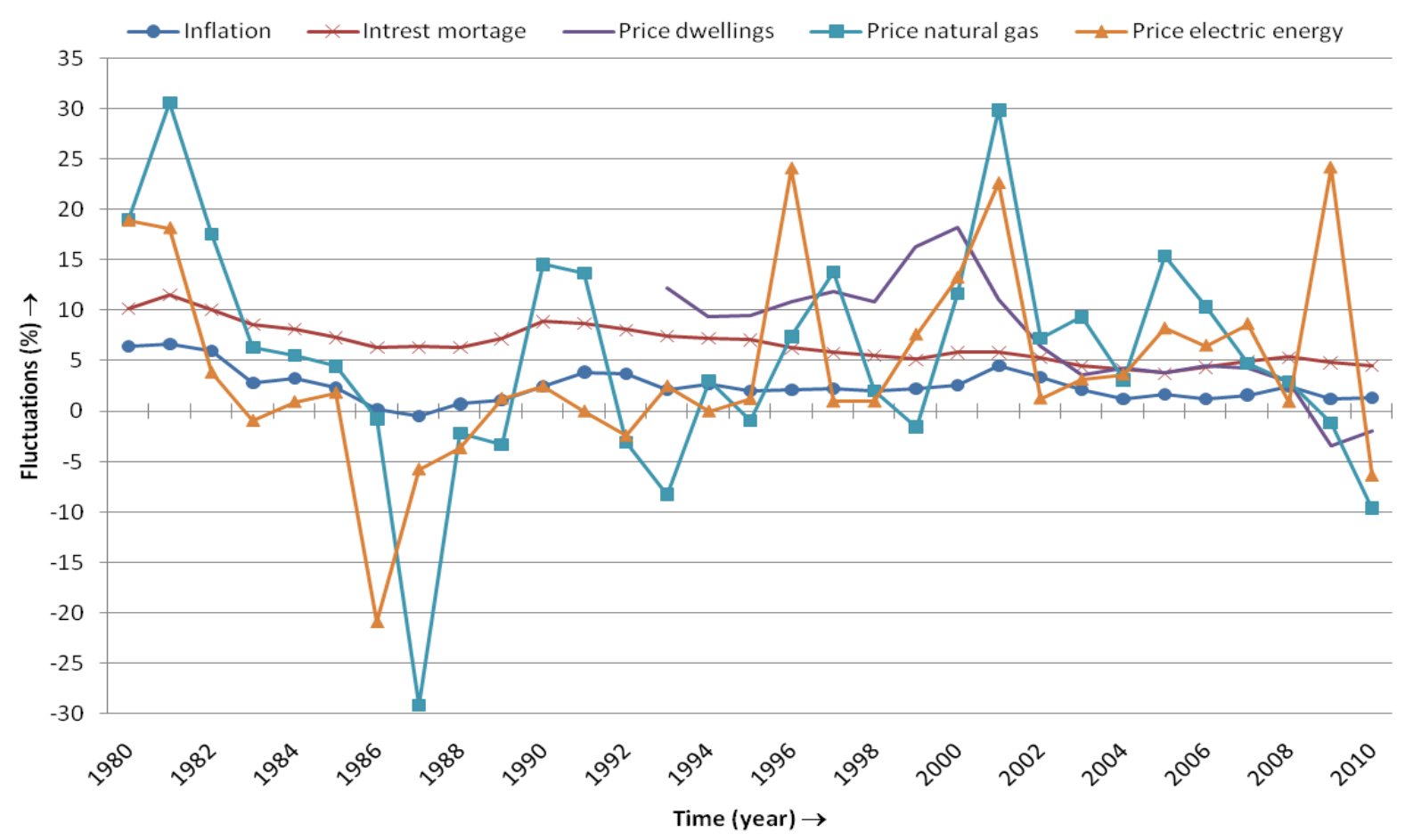

Figure 3-6: Fluctuations in inflation rates, interest rates, house value and energy prices in the period 1980 to 2010 (CBS, 2011e; CBS, 2011f; Kadaster, 2011). 


\subsubsection{Empirical financial analysis of individual ETMs}

The figures on the inflation rate, interest rates, house values and natural gas and electric energy prices enable us to more rigorously reflect on the financial advantages of energy saving measures. Here, two examples are addressed of such measures that were implemented in houses 3 and 6 of the case study sample:

1. The first example is of adding roof insulation. This measure has been widely applied and here the focus is on house 6 built in 1972;

2. The second example is related to house 3 , built in 1939. This involved a ground-level extension at the rear of the house. The roof, walls and windows of this extension have higher heat resistances than the original walls and windows of the house.

The financial benefits or otherwise of these two investments will be calculated in various ways to show the effects of using standard energy prices and actual energy prices as paid by the households and to show how the NPV is affected, when an ETM is regarded as one of the elements that contributes to the market value of a dwelling. Therefore, the standard energy prices, given by Statistics Netherlands (CBS, 2011e), and the actual energy prices derived from the energy bills will both be used. Further, the financial benefits due to reduced energy costs will be considered both with and without the financial benefits due to the increased value of the dwellings. Thus, in total, four different financial approaches are taken.

\section{Example 1: Financial analysis of roof insulation}

Roof insulation was added to house 6 at the end of 1991. The residents hoped to reduce their energy use during winter and improve summer comfort by reducing the indoor temperature. At that time, it was predicted that the investment would repay itself within approximately ten years. The thermal resistance of the entire roof was improved from 1.58 $\mathrm{m}^{2} \mathrm{~K} / \mathrm{W}$ to $2.22 \mathrm{~m}^{2} \mathrm{~K} / \mathrm{W}$. Based on these figures, the EPC was lowered from 1.90 to $1.73, \mathrm{EI}_{\text {old }}$ was lowered from 0.88 to 0.84 and $\mathrm{EI}_{\text {new }}$ was lowered from 1.98 to 1.76 . These last two values for $\mathrm{El}_{\text {new }}$ both indicate an Energy Label $\mathrm{D}$. The reduction in natural gas consumption based on these EPC values is estimated at $416 \mathrm{~m}^{3}$ per year and the increase in electric energy use by the residents is estimated at $16 \mathrm{kWh}$ per year.

The initial investment costs were $€ 1,460$ but a subsidy on thermal insulation of $€ 438$ was provided by the energy supplier. At the beginning of 1992, the value of the house was $€$ 84,900 which had increased to $€ 324,000$ by 2006 based on information from the Netherlands Association of Real Estate Agents (Funda, 2010). Considering that the roof insulation for a small part contributed to this value increase, Equation 3-15 is used to specify what impact this value increase of the house has on the cash flow of the roof insulation, when the house would be sold. Figure 3-7 shows the costs and benefits of the installed roof insulation by making use of Equation 3-1 and Equation 3-15. When using the then annual interest rates for conventional bank savings, it can be seen that the payback period (based on the estimated reduction in energy use, relative contribution to the value of the house, and the average national energy costs) was approximately six years. This break even point was met in 1998. The break even points in 2004 and 2005 were met, when one considers the insulation not to be an inseparable element of the house and the house's value. 


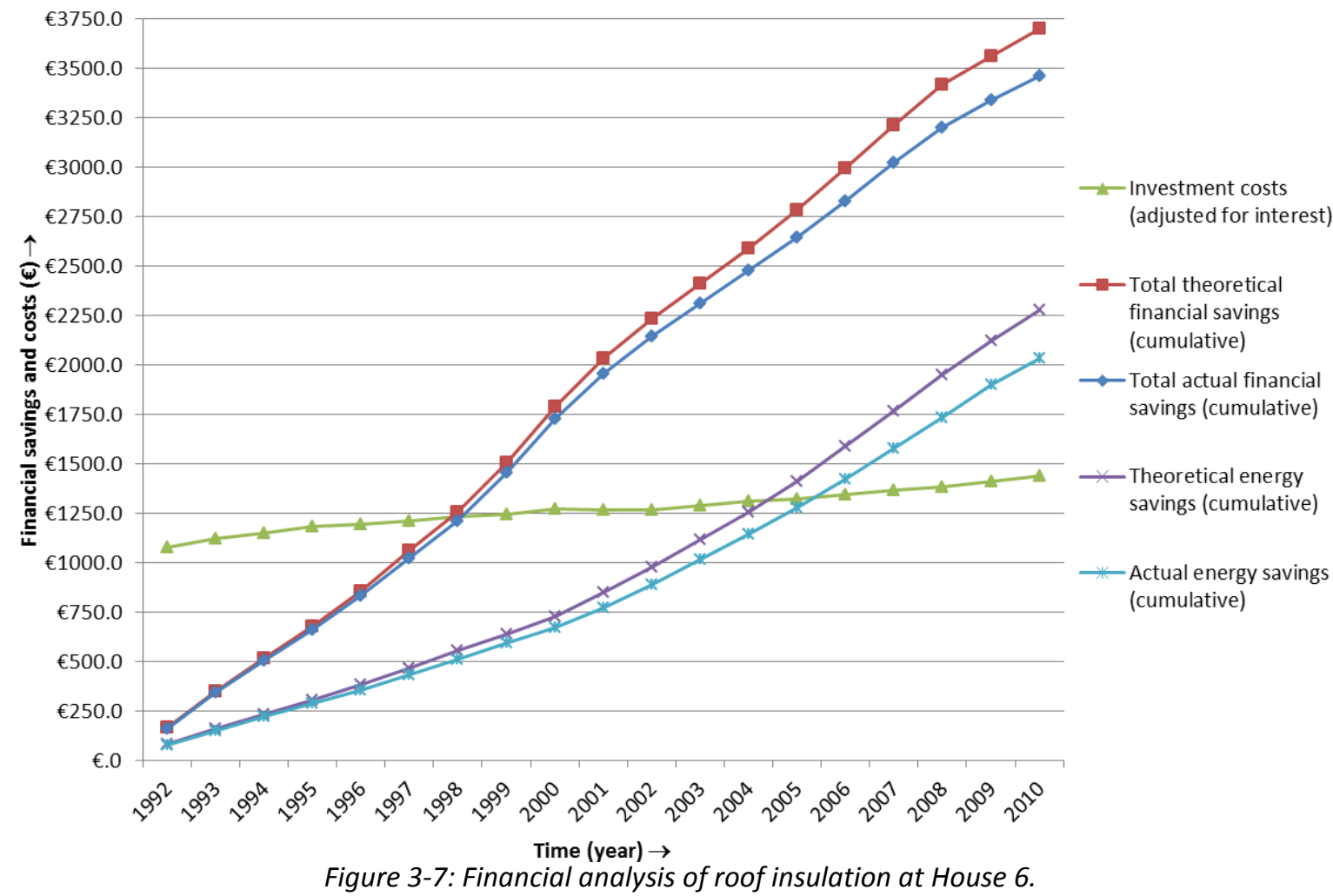

Based on recent energy bills, the actual energy use of the household (not including an external electric efficiency of $39 \%$ ) is approximately half of $Q_{\text {total:EPC. This could suggest that }}$ energy use was actually lowered by $213 \mathrm{~m}^{3}$ of natural gas per year and electricity use increased by $20.5 \mathrm{kWh}$ per year. If this is the case, the payback period using Equation 3-1 will be one year longer, i.e. seven years. Using the conventional method, the payback period is more than eighteen years.

At the end of 1991, the forecasted payback period was ten years. Based on the actual financial values, this period reduces to seven years. After ten years the insulation already had a NPV of $€ 965$,-. By the end of 2010, the NPV was more than $€ 2,250$. When the energy prices actually paid by the residents are used, than the returns on the investment are slightly lower. After eighteen years it makes a total difference of around $€ 250$, because the actual variable energy costs of this household are lower than the national values quoted by Statistics Netherlands.

\section{Example 2: Financial analysis of an extension}

At the beginning of 1996, house 3 was extended at the rear on the ground floor with an additional $16.4 \mathrm{~m}^{2}$ of floor space. Although the main reason was to gain space for the inhabitants, an improvement in thermal comfort was an important side effect. The thermal resistance is estimated to have improved from 0.41 to $1.19 \mathrm{~m}^{2} \mathrm{~K} / \mathrm{W}$ for the walls and from 0.16 to $1.19 \mathrm{~m}^{2} \mathrm{~K} / \mathrm{W}$ for the roof of the extension. This improved the calculated EPC from 2.85 to 2.07 (an EPC of 1.83 was later achieved by installing roof insulation). $\mathrm{El}_{\text {old }}$ was reduced from 1.09 to 0.95 and $\mathrm{El}_{\text {new }}$ was reduced from 2.67 (label F) to 2.09 (label E). Based on the EPC values, this results in a theoretical natural gas reduction of $482 \mathrm{~m}^{3} / y e a r$ and a theoretical increase in electric energy use (for lighting and ventilation) of $204 \mathrm{kWh} / \mathrm{year}$ for 
the residents. Based on the energy bills, natural gas consumption was reduced by $460 \mathrm{~m}^{3}$ and electric energy use reduced by $107 \mathrm{kWh}$ in the period 1 July 1996 to 30 June 1997, compared to a year previously. In the following year (1997-1998) the natural gas consumption fell further by $41 \mathrm{~m}^{3}$ and electric energy use decreased by $382 \mathrm{kWh}$ despite no other significant changes taking place affecting the energy performance of the house. The number of degree days ${ }^{11}$ was lower in 96-97 and 97-98 than in 95-96. Overall, it seems that the calculated energy reductions do approximate the actual reductions in energy use.

The costs of the project were approximately $€ 9,100$, and the increased value of the house after the alteration was $€ 46,740$. The house, with a separate outbuilding added in 1999 , had a market value of $€ 118,000$ in 2006. In 2010, the value of the house was estimated at $€$ 125,000 (Funda, 2010). The financial costs and benefits of this investment are visualised in Figure 3-8. Although the extension was not initiated to lower energy costs, the accumulated financial benefits due to the lower natural gas consumption, due to the improved thermal resistance, were more than $€ 1,000$ over eight years based on the computed EPC. The accumulated financial benefits had surpassed the investment costs by 2005 . In 2008, the NPV peaked at around $€ 1,580$ but, due to decreasing house prices in 2009 and 2010, the NPV had decreased to $€ 971$ in 2010. The fact that the energy prices paid are lower than the values used by Statistics Netherlands results in slightly longer payback periods and a recalculated NPV of approximately $€ 200$ in 2010.

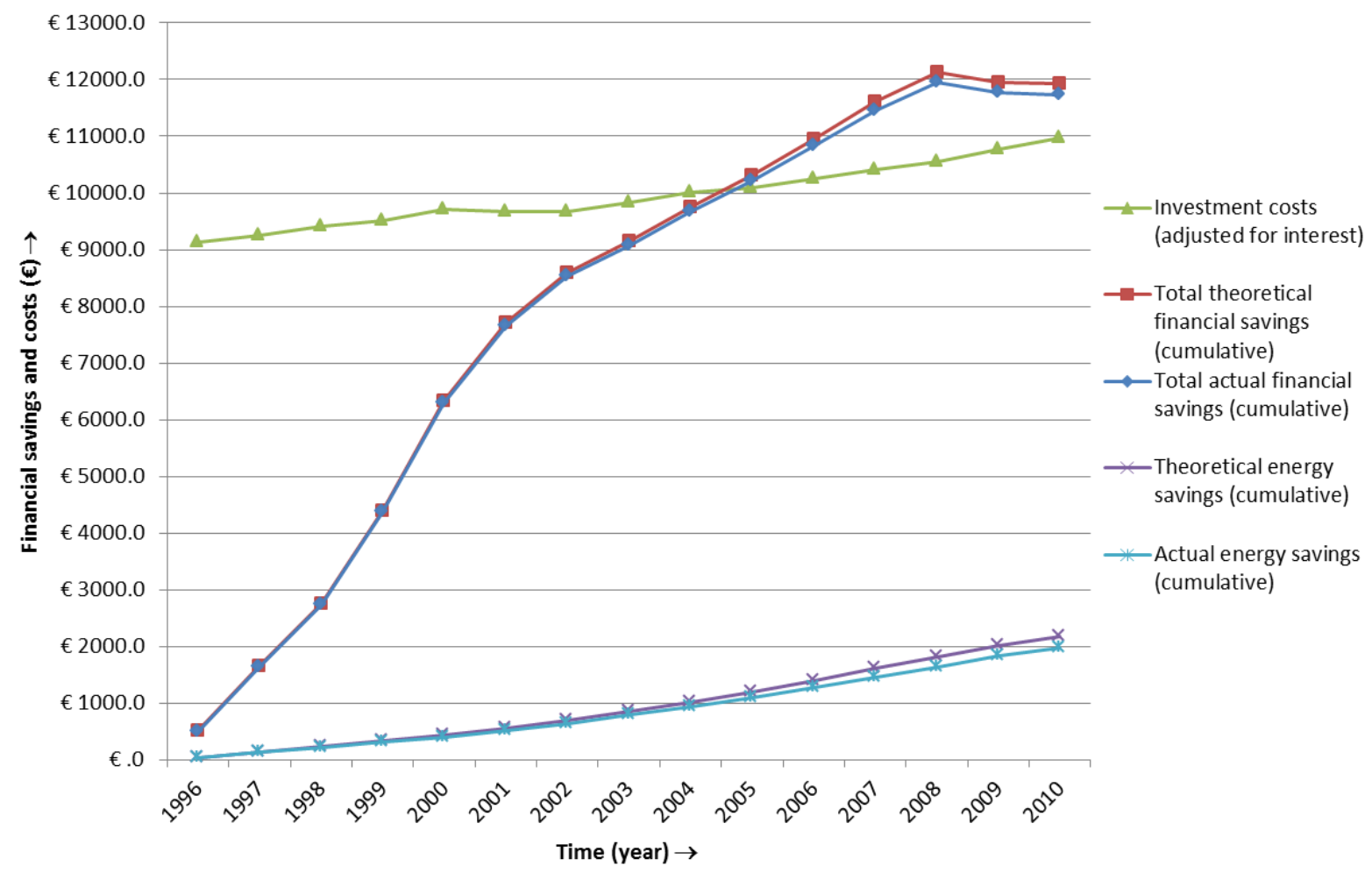

Figure 3-8: Financial analyses of refurbishments within House 3.

\footnotetext{
${ }^{11}$ Degree days express how much the daily average outdoor temperature differs from a daily average indoor reference temperature $\left(18^{\circ} \mathrm{C}\right.$ in the Netherlands) (Wever, 2008).
} 


\subsection{Reflections on assessing the financial impact of ETMs}

In this chapter it is shown that many variables need to be taken into account if one wants to reflect on all the costs and benefits of an ETM. These variables are related to both direct and indirect financial costs and benefits. It is no easy task to estimate the effects of investing in ETMs on the energy use of a household, the costs of maintenance, the reliability of the energy provision, the experienced user comfort and the level of external dependency. Nor is it easy to estimate future energy prices, inflation rates, interest rates and the future value of buildings. The NPV approach is a method to bring these variables together through cash flows at some point in time. Despite the many uncertainties, these variables offer stakeholders who want to implement ETMs a framework to weigh the costs and benefits of a considered ETM.

In general, the more-or-less immediate financial benefits of a decreased energy bill form the basis of the argument to persuade potential adopters. The term "more-or-less" is used because households in most cases pay an estimated energy bill in advance in the form of monthly payments. Having invested in an ETM, the monthly payments are only fully adjusted after a cycle of twelve payments has been completed (two annual meter readings after the ETM is implemented). That is, the direct financial benefits only become transparent to household after receiving their annual energy bill in which the effects of the investment on the energy use over a full year are registered by the energy meter. Within this time frame, it is very unlikely that other aspects will not change within a household such as changes in equipment or occupancy patterns. As such, a household will not precisely know the actual outcome of their investment in ETMs in terms of energy use and energy costs. Therefore, it is also hard or even impossible to check if the forecasted reduction in energy use, when deciding to implement the ETM, was actually achieved.

Furthermore, the effects of an investment on annual energy costs are also obscured by the large number of components that make up an energy bill and total energy costs. Compared with the billing structure in many other countries, the Dutch approach to billing energy costs appears a rather complicated structure of fixed annual costs, variable per unit of energy costs and taxes. The taxation component is made up of a fixed benefit in the form of an annual cost reduction plus variable costs expressed per unit of energy and further as a surcharge in terms of a VAT percentage. This complicated structure, in which only the variable energy costs are influenced by ETMs, makes it complicated to relate costs reductions to an investment. Often it seems that an increase in fixed or annual costs disguises the accomplished reduction in energy use related variable costs. Nevertheless, the energy bills of the studied dwellings show that the energy use in most of these dwellings has decreased for a variety of reasons:

1. Products using energy or converting energy forms, that fail are intentionally or unintentionally replaced by more energy efficient ones. These are seen as investments at so-called natural moments;

2. Over the period studied, the thermal shell of the dwellings has been improved; 
3. Children grow up and leave the parental home. This reduces the energy use of that dwelling but, or course, the energy use of their new dwelling will likely increase.

Given these changes, the total energy costs of the studied dwellings have not increased as much as one might expect based on the externally determined set of cost elements included in the energy bill. That is, these types of changes, partially consisting of investments, have not so much lowered energy costs but in many cases limited the increase in energy costs.

\subsection{Conclusions on assessing the financial impact of ETMs}

In this chapter, various methods that underpin investment appraisal were explained. Attention was given to certain specific aspects involved in determining the NPV of ETMs. The method involving calculating a NPV then applied to investments involving ETMs. The answers found to the sub-questions posed at the start of this chapter, are now summarised.

\section{A: What methods exist to reflect on the financial impact of ETMs?}

Three well-known methods are available that can be applied when an ETM is to be considered as a standard economic investment, namely the payback method, the rate of return and the NPV. Some adjustments seem necessary when these methods are applied to ETMs. Given that fossil fuel prices have significantly increased over many years, it seems reasonable to incorporate this in any chosen investment appraisal method. In appraising the financial performance of an earlier investment in an ETM, it is possible to make a detailed investment appraisal. Here, the actual energy prices and maintenance costs paid by the residents can be used. The next step is to consider an extended investment appraisal that takes into account the increased market value of a dwelling that has added an ETM. Owners and potential buyers appreciate a dwelling with good energy performance and user comfort are good. This appreciation is less if the reliability of the applied ETM is low. Further, a rebound effect can occur if the availability and use of an ETM that was intended to reduce the use of fossil fuels actually results in an increase due to unconsidered effects.

\section{$2 B:$ How are the energy costs of dwellings and their residents constituted?}

The energy costs, as specified in the energy bills of households, can be broken down into four categories: product costs, infrastructural costs, measurement costs and taxes. The product costs are calculated on the basis of the energy used by a dwelling and its residents. The infrastructural costs and measurement costs are fixed annual costs. Currently, taxes are made up of RET, a SSE and VAT. Annually, a fixed refund is given by the government. Taxes increase the costs of every $\mathrm{m}^{3}$ of natural gas and every kWh of electric energy used. Indirectly, these taxes are also incorporated in the price of a GJ of thermal energy from a district heating system. Equation 3-17 shows how the total annual energy costs are made up for residents of dwellings that use natural gas and electric energy.

$$
\begin{aligned}
& E C_{a}=\left(q_{a ; n g} \cdot C_{9} \cdot \dot{p}_{a ; \text { productng }}+p_{a ; \text { productng }}\right)+\left(q_{a ; e_{\text {low }}} \cdot \dot{p}_{a_{a ; p} \text { roducte } e_{\text {low }}}+q_{a ; e_{\text {high }}} \cdot \dot{p}_{a ; \text { producte }_{\text {high }}}+\right. \\
& \left.p_{\text {producta;e }}\right)+\left(p_{a ; \text { infra;ng }}+p_{\text {a;infra;e }}\right)+\left(p_{\text {a;measurement } ; n g}+p_{\text {a;measurement;e }}\right)+\quad \text { Equation 3-17 } \\
& \left(q_{a ; n g} \cdot C_{9} \cdot \dot{p}_{a ; \text { taxes } ; n g}\right)+\left(q_{a ; e} \cdot \dot{p}_{a ; \text { taxes } ; e}+p_{a ; \text { taxes } ; e}\right)+V A T \cdot E C_{a ;-V A T}
\end{aligned}
$$


2C: What are the results when these appraisal methods and the applicable energy costs are applied to ETMs found in Dutch dwellings?

Studying the energy bills of seven households has provided insights into the impacts that ETMs can have. Especially for households with a relatively low energy use, the fixed annual costs can be a significant part of the total energy bill. The fixed costs component tends to be increasing, while the variable costs are slightly decreasing, due to investments by residents in ETMs. Although ETMs might have smaller influences on total energy costs in the future, their impact on the value of houses might increase. In a slow-moving market, with many houses are for sale, a green Energy Label could make the difference between selling your house for a decent price or not.

\section{Question 2: What are the financial impacts of ETMs in residential building projects?}

ETMs have a financial impact in residential building projects, that can be broken down into various elements as shown in Figure 3-9. There is likely to be relatively few uncertainties over the non-recurring investments costs of ETMs, even for those ETMs that are innovative and have never been implemented before. The uncertainties mainly exist in terms of the effects of the ETM during its usage by the residents, and whether these will result in lower or higher financial costs and benefits than expected.

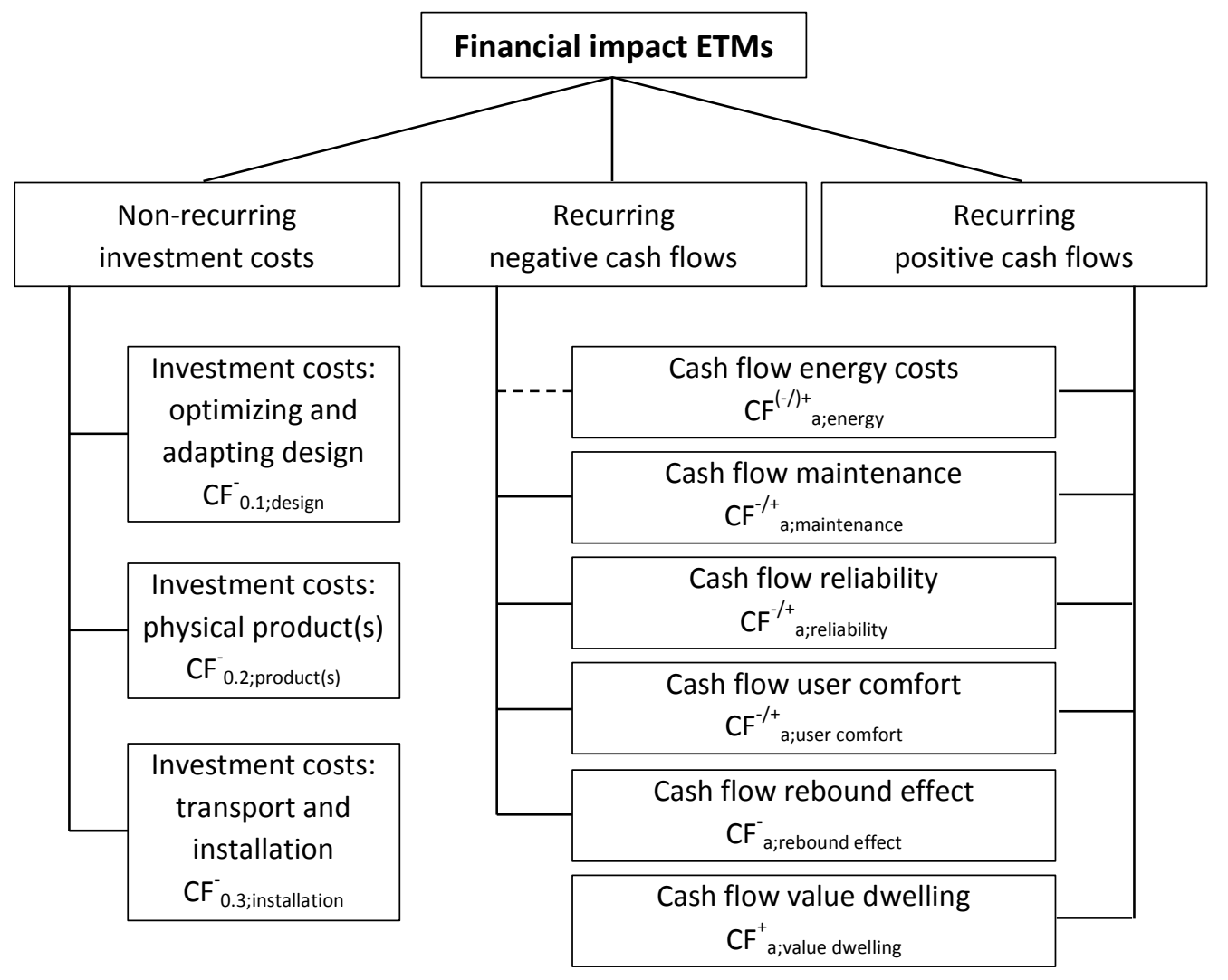

Figure 3-9: Breakdown of structure for the financial impact of ETMs.

Firstly, one needs to recognize that current and future energy prices will differ in terms of both total costs and the components that make these up. National and international data show that prices for electric energy and natural gas in western countries have been increasing in real terms. Extrapolating these trends into the future, and taking inflation into 
account, seems not unreasonable. However, the studied energy bills show that some energy costs can be, and indeed are, influenced by consumers through changing behaviours and implementing ETMs. The implementation of ETMs in the studied dwellings has made it possible to partly counteract rising energy prices although it takes more than a year to see the benefits in the utility bills, by which time rising unit prices can mean that bills are hardly reduced despite falling energy use.

This brings us to a second aspect that is important in the financial impact of ETMs; that average energy prices are not marginal energy prices. Energy bills include various annual costs that do not depend on actual energy use. These fixed annual costs are not influenced when energy techniques or measures are implemented. Only the variable energy costs, charged per unit of used energy, potentially change when an ETM is implemented. It seems unlikely that energy companies, made up of energy producers, local network companies and measurement companies, will want to see a drop in turnover if a majority of households reduce their energy use and thus their variable energy costs. On this basis, when constructing new houses or when existing houses need to undergo major renovation, it seems wise to consider designs in which the number of connections to energy networks is reduced so as to reduce the fixed annual energy costs that already form a substantial part of total annual energy costs.

The third aspect to consider is that ETMs should be considered in their social and practical contexts. In terms of their social context, residents have to apply them and to use them in the correct way to achieve maximum effectiveness and efficiency. The practical context relates to how the ETM is embedded in a dwelling from a constructional, architectural, mechanical, thermodynamic or electrical point of view.

This perspective also offers the opportunity to relate the value of a dwelling to the applied ETMs. In the Netherlands, the acquisition of a dwelling is viewed as a relatively solid investment. The maintenance costs of a dwelling are regarded as acceptable and necessary if the owners want to maintain the market value of their house. In this regard, ETMs are one way to positively differentiate a residential building from others available on the local housing market. Therefore, an increased, or increasing, value can partially be assigned, from every investment that enables a positive differentiation, to a dwelling. This will increase the NPV and reduce the payback time of investments in ETMs.

On the other hand, when trying to access the return on an energy-related investment, the changing context in which ETMs are applied makes it difficult if not impossible to compare identical situations. In the preceding chapter, many variables that influence energy use in dwellings that change year by year or even day by day were addressed. This makes it difficult to specify the energy use reductions as the results of specific ETMs, and which financial benefits and costs were the results of which actions. For a resident and a potential investor in ETMs, it seems advisable to distinguish the dwelling, the make-up of its energy bill and the product information related to the ETM from the "typical" house. Since, this will likely increase the chance for success, by means that the ETM actually reduces the energy costs and has a payback period as expected by the investor. 


\section{Decision-making on ETMs in residential building projects}

In the preceding chapters, it has been illustrated that ETMs, through various variables, can influence the energy use of a household. Further, it was outlined how the billing for the costs of energy use in households is rather complex. Despite it is being difficult to assess the influence of ETMs on energy use and energy costs, decisions are made to implement them in buildings. The use of an ETM by residents in a specific dwelling is viewed as the outcome of a selection and decision process in which the advantages and disadvantages of multiple ETMs were weighed by those who were involved in the design and construction of the building. Referring to the third research question in this thesis, this chapter elaborates on how decisions on the implementation of ETMs are taken in residential building projects.

\subsection{Introduction to ETMs in residential building projects}

It needs to be acknowledged that processes to come to industrial real estate, commercial real estate and residential real estate can differ strongly. Furthermore, processes to develope new or redevelope existing buildings with in the end the purpose to sell or rent them offer different opportunities and threads to implement ETMs. Despite these differences, these processes have in common that the aim is to offer a principal a building and the availability of ETMs to improve the actual energy performance of this future building is large. Many ETMs have existed for decades or even longer such as insulation, double glazing, photovoltaic systems, thermal solar collectors and energy saving light bulbs. Furthermore, every year new innovative ETMs are introduced. There are international and national regulations and programmes that require or stimulate the implementation of ETMs in building projects.

However, the application of many of these ETMs still seems to be relatively low in residential real estate the Netherlands. Only 56,403 out of the 2,111,558 Dutch dwellings that had been labelled at the end of 2011 had one of the best Energy Labels (A, A+ or A++) (AgentschapNL, $2012 b$ ). The worst energy performance is indicated by an Energy Label ' $G$ ' (see Section 2.3.2). Most dwellings for which an Energy Index $\left(E I_{\text {new }}\right)$ has been calculated, which amounts to approximately $30 \%$ of all Dutch dwellings so far, have an Energy Label ' $C$ ' or ' $D$ '. At the end of 2011, around 600,000 dwellings had been placed in each of these the two categories, suggesting that many ETMs could still be adopted to reduce building-related energy use.

In building projects, whether residential building projects or not, many decisions need to be taken in accomplishing the desired design and eventual building. In this process, how do stakeholders address the issue of energy use? One cannot attempt to direct the implementation of ETMs without having a clear understanding of stakeholder behaviour. Examples of the stakeholders involved in building projects are architects, project developers, contractors, clients and end-users (such as residents and office employees). Some stakeholders have a larger influence in the design and construction process of buildings than others. Furthermore, every stakeholder probably has his or her own social and professional networks and has unique experience and knowledge regarding ETMs. 
In this chapter the objective is to contribute to knowledge on decision-making processes by answering the third research question: how in residential building projects are decisions on the implementation of ETMs taken? In coming to an answer, three issues will be investigated:

3A: Who decides on the implementation or rejection of ETMs in residential building projects?

It is expected that some stakeholders involved in the building process will influence the implementation process (Cooke et al., 2007). Some organizations or people are only involved in a building project for a limited time. Further, all the stakeholders involved have different interests and targets. Therefore, there can be many individual reasons to adopt or reject ETMs. This brings us to the next question:

3B: What motivates stakeholders to implement or reject ETMs in residential building projects?

ETMs are being developed and produced to reduce energy use, to make use of renewable sources, and to more efficiently and effectively use fossil fuel sources (see Section 2.3.2). In implementing ETMs in buildings, stakeholders might want: 1) to increase the level of comfort, and/or 2) to reduce the environmental impact, and/or 3) to reduce the annual energy costs of a building. These are just three examples of possible motives related to Elkington's (1999) social, ecological and economic pillars of sustainable development. The last research question in this chapter is:

\section{C: What barriers hamper the implementation of ETMs in residential building projects?}

In general, a building process has multiple phases in which demands, needs and wishes of the various stakeholders are aligned through meetings, documents and designs. All the requirements are stepwise translated into a dedicated building on a real location. This process takes place in a context that, sometimes unintendedly, provides all kinds of barriers or drivers for the stakeholders to implement a certain ETM. In other words, the actors in building projects are expected to be bound by an institutional framework.

To find an answer to these research questions, a case study research will be carried out to study past implementation decisions in building projects. The cases are projects in which designs for new residential buildings or for renovating existing residential buildings were made. Documents were studied and stakeholders were questioned in order to obtain insights into the energy targets, the design process and the roles of individual stakeholders.

This chapter, in which the research converges from managing projects in general into the role of ETMs in social housing projects, is structured as follows. Section 4.2 will elaborate on the literature regarding decision-making in projects in general. The third section then addresses the development of the research framework specifically to study decision-making on ETMs in building projects. Section 4.4 introduces the cases considering residential building projects which are then analysed in Section 4.5, before this chapter ends with reflections and drawing conclusions. 


\subsection{Theoretical background on ETMs in building projects}

Placing a project in its context draws us into what Söderlund (2011) describes as the contingency school in project management research. Researchers in the contingency school saw that not only was the project organization important to the potential success of a project, but also the environment in which the project and the project organization were positioned. This is in line with institutional theory. In studying the role of ETMs in building projects, it is therefore necessary to look at the institutional context in which building projects take place. Secondly, this section addresses the specific context of a project. Thirdly, the role and influence of stakeholders will be explained.

\subsubsection{Institutional context}

The construction industry and project management appear inseparable in the literature. Betts and Lansley (1995) show, for example, that almost $30 \%$ of the papers published between 1983 and 1992 in the International Journal of Project Management involve the construction industry. Project management offers instruments designed to help achieve the goals set in building projects by using available resources within a fixed time frame. However, Kadefors (1995) observed that building projects are often governed by variables that cannot be influenced by project management. She argues that institutionalization is strong in building projects. This brings us to the field of sociology, more specifically the institutional organization theory. Barley and Tolbert (1997) define institutions as shared rules and typifications that identify categories of social actors and their appropriate activities or relationships (ibid., p. 96). Kadefors (1995) comments that the institutional organization theory is a theoretical framework that can help in understanding the inflexibility of building projects, and went on to define the following institutions in the building industry:

- Governmental regulations. Regulations of national and local governments influence the properties of buildings and set requirements concerning the work environment and workers' protection.

- Formal standardization initiated by the industry. Organizations involved in the construction industry come to mutual agreements over technical and organizational standards to improve the quality and efficiency of the design and construction process of buildings or to improve the buildings themselves.

- The tendering system. This mechanism to come to a price for activities and materials that result in a building being constructed according to a given design and specifications, implicitly means that any variation that tenderers have in construction methods is related to the provided building designs and specifications. Whether tenderers can determine a reliable price, depends of their experience with certain construction methods and the principal's requirements.

- Roles and interests of organizations. The construction industry is strongly fragmented with many different specialisms housed in specific organizations and associations. When a building project is started, many people, employed in various organizations, with different backgrounds and interests are involved. In a project, specific individuals, 
such as the architect, will seldom exchange information with others in comparable roles because those actors are involved in other projects.

- Standardization of skills and knowledge. Standardization is a control mechanism based on confidence that is to be found for most occupations on a construction site. Each employer is entrusted to make decisions in their work domain using skills and knowledge that conform to the current standards of workmanship (Kadefors, 1995, p. 403). Many stakeholders and workers will apply their knowledge and skills using certain routines based on actions learnt in earlier projects.

Although the definition of institutions provided by Barley and Tolbert (1997) and the five examples of institutions in the construction industry as given by Kadefors (1995) appear to form rather inflexible boundaries, Barley and Tolbert (1997) also argue that institutions are open and dynamic by nature. This means that projects, as conducted by temporary organizations, are not only restricted or limited by institutions, but that these institutions also offer opportunities for organizations to influence or reshape them. Within the construction industry one can think of the Building Code as an example of governmental regulation, but its final impact on building projects can be the result of how the local building inspector of the municipality interprets this regulation. As Barley and Tolbert (1997, p. 94) put it: "...just as perfect rationality is rare, so too is completely bounded rationality. Through choice and action, individuals and organizations can deliberately modify, and even eliminate, institutions". When studying the role of ETMs in building projects, the institutional context should be studied in order to know how the individuals involved in the project are restricted in their opportunities and behaviour. The following section outlines the characteristics specific to building projects.

\subsubsection{Project-specific context}

Many definitions of the word project can be found in the field of project management. According to Turner (1999, p. 3), a project is an endeavour in which human, financial and material resources are organized in a novel way to undertake a unique scope of work, of given specification, within constraints of cost and time, so as to achieve beneficial change defined by quantitative and qualitative objectives. In a building project, the beneficial change will be a new or improved building. These improvements or, using the term of Turner (1999), beneficial changes can, for example, focus on the capacity of the construction, the climate conditions in the building, the surface or volume of the building. Many scholars have attempted to characterize projects, and the following attributes have been suggested (Meredith \& Mantel, 2010; Winch et al., 2012):

- projects have a lifecycle with clear start and end points;

- projects have their own temporary organization;

- projects have a well-defined outcome.

Based on this definition and characteristics, it is possible to draw boundaries around a building project. These system boundaries can enclose the involved participants in the project organization, can provide time constraints, and/or can incorporate physical elements that, in the building process, form the building at the end of the project. The project and 
process concepts are strongly related to each other. A process is a task, or set of interrelated tasks, that changes input into output. In the construction industry, the project process is one of the three main areas in which Kagioglou et al. (2000) argue improvements are needed. They describe the project process as the roadmap or framework that is used for undertaking the project activities and that delivers value to the supply chain parties (ibid., p. 141).

The better able the participants in the project organization are to meet the project requirements and to execute the project activities, the higher its value can be. Defining the appropriate project requirements and then translating these into a proper design and building are two challenges in a building project. The design process and the construction process are both widely recognised in building projects. However, a building project is often divided into multiple serial processes. Each process forms the link between an input and an output, which results in multiple characteristic phases. Kagioglou et al. (1998) indicate that there can be up to nine phases in building processes (see Table 4-1). When studying the role of ETMs in building processes, these phases can help in specifying which people and organizations are involved, when and for what purpose.

Table 4-1: Phases in building processes (Kagioglou et al., 1998).

\begin{tabular}{ll}
\hline \multicolumn{1}{c}{ Group } & \multicolumn{1}{c}{ Phases } \\
\hline Pre-project phases & 0. Demonstrating the need \\
\cline { 2 - 2 } & I. Conception of need \\
\cline { 2 - 2 } & II. Outline feasibility \\
\hline Pre-construction phases & IV. Oubstantive feasibility study and outline financial authority \\
\cline { 2 - 2 } & V. Full conceptual design \\
\cline { 2 - 2 } & VI. Production design procurement and full financial authority \\
\hline Construction phases & VII. Production information \\
\cline { 2 - 2 } & VIII. Construction \\
\hline Post completion phase & IX. Operation and maintenance \\
\hline
\end{tabular}

It is apparent that what a building project exactly encompasses can be quite complex to describe. There is also an environment, external to a building project, which needs to be taken into account. As such, the system boundaries regarding the participants involved in the project organization can be considered as relatively open, taking into account that many of these participants have several interests, both internal and external to the project, are employed by different organizations and have their own personal and professional networks. These various stakeholders will now be described in more detail.

\subsubsection{Stakeholders and actors in projects}

In project management and in institutions, people matter. Projects have their own temporary organization consisting of various individuals, often employed by different firms, that need to cooperate. Barley and Tolbert (1997) explicitly mention in their definition of institutions social actors. These social actors may be individuals, groups, organizations, or even larger collectives (Barley \& Tolbert, 1997, p. 97). The term stakeholders was used in reflecting on certain people involved in projects but a formal explanation and detailed specifications of stakeholders or actors were not given. Bryson (2004) pulled together multiple definitions of stakeholders: 
- any group or individual who can affect or is affected by the achievement of the organization's objectives (Freeman, 1984, p. 46);

- all parties who will be affected by or will affect (the organization's) strategy (Nutt \& Backoff, 1992, p. 27);

- any person, group or organization that can place a claim on the organization's attention, resources, or output, or is affected by that output (Bryson, 1995, p. 27);

- people or small groups with the power to respond to, negotiate with, and change the strategic future of the organization (Eden \& Ackermann, 1998, p. 117);

- those individuals or groups who depend on the organization to fulfil their own goals and on whom, in turn, the organization depends (Johnson \& Scholes, 2002, p. 206).

Although Bryson (2004) does not explicitly refer to stakeholders in the construction industry, or in building projects, the word "organization" in these five definitions can refer to a temporary organization established for a building project, one of the three attributes that characterize projects. In general, the word organization reflects a group of people that work together. As such, organization can, for example, refer to a project organization, a non-profit organization, a governmental division or a commercial company.

Table 4-2: Overview of stakeholders involved in building projects (Winch, 2010, p. 75).

\begin{tabular}{|ll|ll|}
\hline \multicolumn{2}{|c|}{ Internal stakeholders } & \multicolumn{1}{c|}{ External stakeholders } \\
\hline Demand side & \multicolumn{1}{c|}{ Supply side } & \multicolumn{1}{c|}{ Private } & Public \\
\hline Client & Architects & Local residents & Local government \\
\hline Financiers & Engineers & Local landowners & National government \\
\hline Client's employees & Principal contractors & Environmentalists & \\
\hline Client's customers & Trade contractors & Conservationists \\
\hline Client's tenants & Material suppliers & Archaeologists \\
\hline Client's suppliers & & Non-governmental organizations \\
\hline
\end{tabular}

In building projects, it seems common to speak of stakeholders. Winch (2010) presents a broad overview of stakeholders in building projects (see Table 4-2) in which he distinguishes internal and external stakeholders. Internal stakeholders are, unlike external stakeholders, in a legal contract with the client (ibid., p. 75). In most building projects, actors will be either internal stakeholders or external public stakeholders. Winch (2010) gives little explanation as to how direct or indirect the legal contracts might be. Although their interests are evident, a client's employees, customers, tenants, suppliers and material suppliers seem to have only a background roll in a building project. Newcombe (2003) discusses the importance of identifying stakeholders. In his opinion, each stakeholder will have its own interest in the project, and one that needs to be noted and taken into account by the project management. Each stakeholder can be seen as a client. Newcombe (2003) argues that project stakeholders are groups or individuals who have a stake in, or expectation of, the project's performance and include clients, project managers, designers, subcontractors, suppliers, funding bodies, users and the community at large. In research into the perceptions of stakeholders on alternative energy technologies in buildings, Cooke et al. (2007) distinguished the following eight categories of stakeholders: architects, building services engineers, clients, specialist 
consultants, planners, project managers/quantity surveyors, technology suppliers and contractors.

When multiple stakeholders form a temporary organization with the aim of achieving a welldefined outcome within a clear period of time, decisions will need to be made collaboratively. In this situation, De Bruijn and Ten Heuvelhof (2008) speak of multi-actor decision-making. They distinguish between situations in which decisions (i.e. on the implementation of ETMs) can be unilaterally made by one actor and a situation where an actor needs the support of others. In the latter situation, the actor is in a network. A network is defined by De Bruijn and Ten Heuvelhof $(2008$, p. 1) as: a number of actors with different goals and interests and different resources, who depend on each other for the realization of their goals. The way decisions are made in a network differs from the way decisions are made in a hierarchical structure (De Bruijn \& Ten Heuvelhof, 2008) in certain respects:

1. In hierarchy models, a decision-making process moves in an orderly manner, from problem identification, via a number of phases...to a solution. ...In a network, there is no such regular and phased progress (ibid., p. 26);

2. In a network, the number of rounds in the decision-making does not seem to be limited. A decision taken can often be revoked, when new light is shed on the problem or on a solution to which the original decision was related (ibid., p. 27);

3. In a network, actors may leave and enter decision-making processes. In a new round, new actors may join the decision-making process (ibid., p. 27);

4. In networks, decisions take place in several arenas such that processes might have no clear beginning and end. An actor that lost out in the decision-making over one issue by giving credit to another actor, may have gained credit for the next issue on which a decision needs to be taken by a similar group of actors (ibid., p. 28);

5. The content on which decisions need to be taken in networks is dynamic. Problems for which solutions are available are placed higher on the agenda. Problems for which no instant solution is available, are often redefined over time. Consequently, the availability of solutions is more decisive for the question of what the decisionmaking will be about, than the presence of problems (ibid., pp. 28-29);

6. In networks, many problems on which decisions need to be taken are unstructured. One cannot always objectively establish the exact benefits of the advantages and the costs of the disadvantages of alternative solutions. Further, structured problems that need to be solved in multi-actor networks can become unstructured problems (ibid., p. 29);

7. The dynamics present in networks invite actors to adapt their behaviour to new opportunities that constantly arise, and this will strengthen the dynamic (ibid., pp. 30-31).

The similarities and differences between the group of stakeholders in a project and those in a network, as defined by De Bruijn and Ten Heuvelhof (2008), are evident. In a building project, a number of stakeholders or actors that have different goals and interests, and different resources, depend on each other for the realization of their common goal: a well- 
defined outcome. This situation exists as long as the building project lasts. The different goals and interests can be related to the organizations that employ the individual stakeholders. The resources can be associated with available labour, equipment, materials and money. Of the list above, especially the characteristics 3) that stakeholders enter and leave a building project at different moments in time, 4) that decisions take place in different arenas, and 5) that the content on which decisions need to be taken is dynamic, seem to accord with the general concept of building projects. With a single paying client issuing clear project requirements, with institutions providing bounded rationality and with clear start and end points, with distinct phases in between, the other four characteristics (1, 2, 6 and 7$)$ may to a lesser extent or not at all apply to building projects.

Another difference seems to exist between the way the word actor is used by De Bruijn and Ten Heuvelhof (2008) and the word stakeholder by Bryson (2004). In their treatise on multiactor decision-making, De Bruijn and Ten Heuvelhof (2008) seem to use the word actor in such a way that it transcends an individual stakeholder. In this thesis, actors are regarded as a special kind of internal stakeholder as depicted in Figure 4-1 and as will be explained below.

Society level Persons, Positions and Organizations

Project level

ETM level

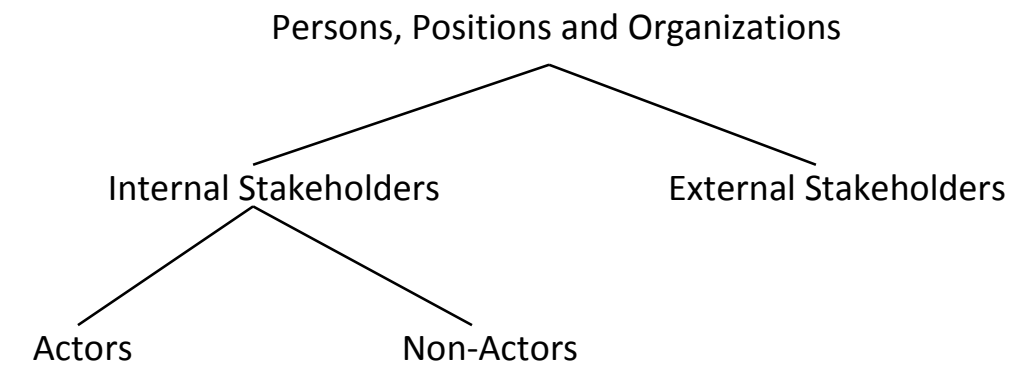

Figure 4-1: Categorizing people, positions and organizations by their influence on the implementation of ETMs.

In this thesis, a stakeholder is an individual or organization with an interest or concern in a building project. This definition shows some resemblance with the definitions given by Freeman (1984) and Bryson (1995). Not all stakeholders can exert a direct influence on the progress and outcomes of a building project. In this thesis, the internal stakeholders that can directly exert influence on the decision-making, or even take decisions, regarding the implementation of ETMs, are referred to as actors. This word has Latin roots and is used here in the sense of "those that set something in motion". The final decision-maker is also an actor, and in some projects he or she might be the only actor. The internal stakeholders that cannot exert influence on a decision regarding the implementation of ETMs are referred to as non-actors. Actors and non-actors are individuals that through the project organization or the project team are collectively involved in building processes in which decisions to implement energy techniques or measures take place. As such, it is likely that they are in a legal contract with the client and therefore they are, as defined by Winch (2010), internal stakeholders.

\subsubsection{Conceptual model}

Having discussed the influence of institutions on building projects, the project-specific context and the role of stakeholders, a conceptual model can now be developed. The point 
of departure for the conceptual model is that a building project is, in essence, a building process. In this building process, certain ETMs are selected by the actors that form the project team. Many ETMs are available, but not all of these will be known to the actors involved in the building project, and neither will all the techniques and measures be compatible with the project requirements that may, for example, include technical or financial limitations. Project requirements can act as barriers to ETMs, such as by influencing their effectiveness or efficiency. Hence, in the building process, only some of the known ETMs will be implemented, those that in the opinion of the internal stakeholders, and especially of the actors, help in fulfilling or at least do not conflict with the project's requirements. In the end, primarily the actors of the internal stakeholders decide to implement specific ETMs (see Figure 4-2).

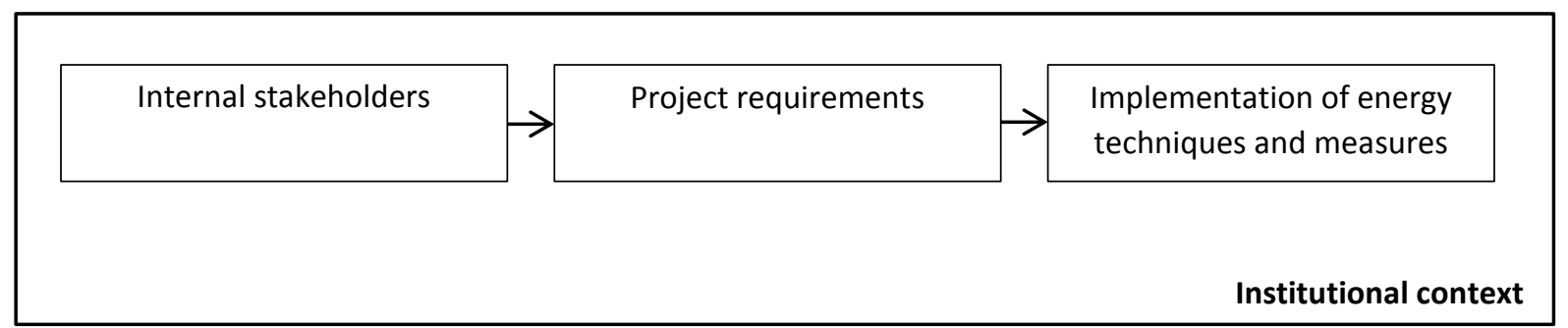

Figure 4-2: Conceptual model of stakeholders in a building project within an institional context of which some are expected, in line with the project requirements, to take decisions on the implementation of ETMs.

Not only is there a large range of ETMs generally available, there is also a wide variety of organizations active in the construction industry. Housing associations, project developers, architects, contractors, installation advisors and many other companies and freelancers can all be involved in building projects. A principal is able to select some of these organisations and people to constitute a project team that aligns with the goals and requirements of the building project. In the different phases of the building project, the team will consist of different internal stakeholders depending on the knowledge, skills and capacity required in each phase. All stakeholders have their own backgrounds in terms of building projects in general and ETMs in particular. In other words, a stakeholder has a certain level of experience, expertise and environmental awareness. This means, for example, that a bad experience with a heat pump in a previous project may well influence a stakeholder against applying this energy technique in a future project. Internal stakeholders are expected to influence project requirements and, in the end, it will be the actors that influence the implementation of ETMs.

The internal stakeholders, the project requirements and the implementation all need to comply with the institutional context. Kadefors (1995) listed various institutions in the construction industry. Some of these institutions are expected to influence the requirements set in building projects. In the Netherlands, new buildings need to comply with a minimum energy performance as specified in the Building Code. Barley and Tolbert (1997) argue that behaviours, for example of actors in building projects, influence institutions and lead to institutional change. However, given the total number of building projects nationwide at any one time, it seems unlikely that a specific building project will influence the institutional 
context. Therefore, in this thesis it is assumed that the institutional context surrounding the case studies is not influenced by the internal stakeholders involved in a building project.

\subsection{Research methodology to study decisions on ETMs in building projects}

In the earlier theoretical background, a conceptual model was developed expressing that, within an institutional context, the internal stakeholders, through the project requirements, influence the implementation of ETMs. In terms of selecting a research methodology, Yin (2003, p. 13) explains that a case study is the appropriate method when one wants to deliberately cover contextual conditions that are believed to be highly pertinent to the phenomenon of study. For this reason, a case study will be conducted on finished building projects.

\subsubsection{General research methodology}

Many different types of buildings, and therefore building projects, exist and, in line with the context of this thesis, it was decided to focus on residential building projects. This section will specifically focus on social housing. Compared to other residential building projects, e.g. as commissioned by commercial project developers or commissioned by private individuals, residential building projects with the aim to develop or renovate social housing, can take place in a different institutional context, with other internal stakeholders and with specific project requirements. However, considering that it is impossible to study all forms of commissioning in residential real estate within the time frame of this research, there are many reasons for deciding to study social housing projects.

Firstly, at the end of 2003, social housing associations owned 2,420,500 houses, more than one-third of Dutch housing (Dekker, 2004). Secondly, social housing seems to experience financial problems in trying to improve energy performance due to a split incentive existing. That is, the housing association has to pay for the investment, while the tenant receives the financial benefits through a lower energy bill. Thirdly, social housing associations are considered to be highly experienced principals, or property developers, when it comes to residential buildings. In general, an objective of a social housing association is to provide houses to those that are not able to obtain and maintain a house themselves.

Building projects with high energy ambitions, innovative energy techniques or exceptionally high energy performance often receive a lot of attention from the authorities, researchers and the media. These projects are often analysed in case studies. However, these ambitious projects do not represent the majority of building projects which comply, sometimes only just, with the minimum quality level specified in the Building Code. Therefore, in this case study, it was decided to study projects which were not specifically presented as the very image of sustainability, but in which some ETMs were required to comply with the Dutch Building Code.

The cases studied in this thesis are all completed projects of one specific social housing association. In these projects, to study the intentions of the internal stakeholders, the implementation decisions and the results these decisions eventually have at the end of the project, it is necessary to conduct longitudinal research from the start through to the end of 
each project. The advantage of longitudinal research is that the ETMs are not simply seen as a collection of characteristics perceived as either positive or negative at a certain moment in time, but as an element in the building process that is influenced by the institutional context, internal stakeholders and project requirements. To ensure that the focus remains on the implementation of ETMs, the projects studied took place under the authority of a single social housing association throughout all the project phases and within a relatively short period of time. In this way, the constitutional context should be acceptably stable.

The use of completed projects, a retrospective study as such, also has some advantages regarding bias: the researcher cannot influence the decision process, nor the outcome of the decision process, nor the arguments for implementation or rejection. Although it might seem that studying building projects of one social housing association is a disadvantage in terms of drawing conclusions for other social housing associations, it is expected, on basis of the institutional context in which all Dutch social housing associations need to operate and need to develop their dwellings, that collected insights will apply to many housing associations, because the possibilities for a social housing association to dinstinguish itself appear to be limited. This institutional context related to social housing will be further explained in Section 4.4.1, before the actual cases are presented.

It was investigated how decisions on ETMs were taken. Two methods were used to collect data on each project, namely a document study and interviews. When a building is designed and constructed, or renovated, several documents need to be prepared such as calculation sheets, drawings, reports and minutes of meetings. These documents have been collected in order to study if, how and when ETMs were documented. Although documents produced in buildings projects are usually dated, the contents of the documents tend not to be referenced in such a way that it is clear which internal stakeholders were the actors that suggested or decided upon the implementation of an ETM. Interviews were, therefore, carried out to determine the roles of the internal stakeholders within the project, and which ETMs were suggested and agreed by whom and for what reason. These interviews can be found in Appendix C.

\subsubsection{Operationalisation of the institutional context}

Kadefors (1995) offers five conditions that can be regarded as institutions in building as they all contribute to homogenizing behaviour in building projects (ibid., p. 401). As already noted, an attempt was made to find projects that took place in roughly the same period to ensure some stability in the institutional context. For the purposes of this case study, the institutional context will be described on two levels:

- Level 1: Institutional context related to social housing. Three institutional conditions noted by Kadefors (1995), namely governmental regulations, formal standardization and the roles \& interests of the organization, will be discussed as these apply uniformly to all social housing projects by the studied housing association during the period in which the projects were planned and executed. Governmental regulations will be studied using three different geographical boundaries, namely on the national, regional and municipal levels. 
- Level 2: Institutional context related to individual projects. Two of Kadefors' (1995) institutional conditions, namely the tendering system and the standardization of skills and knowledge, will be discussed specifically for each case. Given that the tendering system is a specific construction of contractual relationships, that by definition can be linked to the terms internal and external stakeholders, one would expect this aspect to be strongly related to the way that building processes are organized. The standardization of skills and knowledge is directly related to the professionalization of workers (ibid., p. 403), and these workers are internal or external stakeholders employed by an organization.

\subsubsection{Operationalisation of stakeholders in building projects}

Many internal and external stakeholders are involved in building projects. Based on Winch's (2010) list of stakeholders, Table 4-3 provides descriptions of the stakeholders in building projects. The municipality was added to this list because of its role in the Netherlands in developing and enforcing legislation, acquiring land plots and granting building licences. A condition to receive a building licence is that a building design complies with the minimum heat resistance and energy performance figures stated in the Building Code.

Table 4-3: Descriptions of stakeholders in building projects.

\begin{tabular}{|c|c|c|}
\hline & Stakeholders & Description \\
\hline \multirow{5}{*}{$\begin{array}{l}\frac{0}{0} \\
\frac{0}{0} \\
\frac{c}{0} \\
\frac{\pi}{0} \\
\frac{0}{0}\end{array}$} & Client (Cl) & $\begin{array}{l}\text { Internal stakeholder: the principal that requests the construction services of a } \\
\text { professional person or organization. A client can be a property developer. }\end{array}$ \\
\hline & Customer (Cu) & $\begin{array}{l}\text { Internal/external stakeholder: uses the provided building. In the case of } \\
\text { dwellings, the specific future user (owner-occupier or tenant) is often unknown } \\
\text { during early phases of the building process. }\end{array}$ \\
\hline & Warden (W) & $\begin{array}{l}\text { Internal/external stakeholder: responsible for the supervision and maintenance } \\
\text { of the building and its site. A warden is often appointed when construction ends } \\
\text { and the building is taken into use. }\end{array}$ \\
\hline & Property develo & $\begin{array}{l}\text { Internal stakeholder: converts land for a new purpose, usually by constructing } \\
\text { buildings. }\end{array}$ \\
\hline & Project & $\begin{array}{l}\text { Internal stakeholder: plans, organizes and allocates the resources needed to } \\
\text { successfully complete a specific project (as specified by the client). }\end{array}$ \\
\hline & Munici & $\begin{array}{l}\text { External stakeholder: the town or district's local government that enforces } \\
\text { building regulations. }\end{array}$ \\
\hline \multirow{5}{*}{$\begin{array}{l}\frac{0}{n} \\
\frac{2}{0} \\
\frac{2}{2} \\
\text { ज }\end{array}$} & Architec & $\begin{array}{l}\text { Internal stakeholder: designs buildings and sometimes supervises their } \\
\text { construction. }\end{array}$ \\
\hline & Consult & $\begin{array}{l}\text { Internal stakeholder: often an engineer, who provides expert professional } \\
\text { advice e.g. on Heating, Ventilation and Air Conditioning (HVAC) systems. }\end{array}$ \\
\hline & Con & $\begin{array}{l}\text { Internal stakeholder: undertakes a contract to provide materials and/or labour } \\
\text { for a construction project. }\end{array}$ \\
\hline & Trade & $\begin{array}{l}\text { Internal/external stakeholder: contractors that carry out specific work for a } \\
\text { company as part of a larger project. In some instances, a direct contract is } \\
\text { established between the client and the trade contractor although the tasks are } \\
\text { commissioned by the architect or main contractor. }\end{array}$ \\
\hline & Material supplier (Ma) & $\begin{array}{l}\text { Internal/external stakeholder: provides materials and products to be used or } \\
\text { installed during or directly after construction. In rare cases, a direct contract } \\
\text { may be established between the client and the trade contractor although } \\
\text { orders are placed by the architect, contractor or a trade contractor. }\end{array}$ \\
\hline
\end{tabular}


Some of these listed stakeholders are expected to influence the implementation of ETMs in specific projects. All stakeholders will enter and leave a building project at some moment in time. In order to structure the data regarding the involvement of individual stakeholders, a framework is developed in which the influence of stakeholders during the various phases of a building project can be visualized (see Figure 4-3). By conducting the interviews, it was found which stakeholders were involved, and when, in a specific building project.

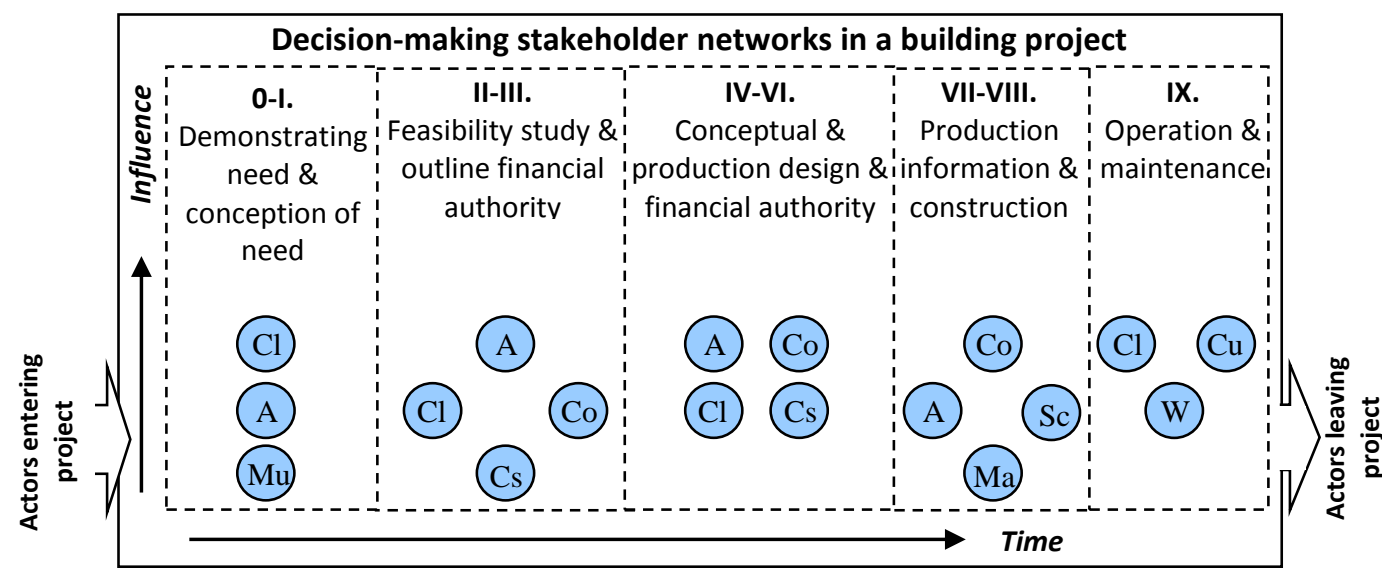

Figure 4-3: Framework visualizing the involvement of particular stakeholders in a building project.

\subsubsection{Operationalisation of motives of stakeholders to implement ETMs}

Knowing which ETMs have been suggested, applied and/or rejected by the actors is the first step. The second step is to gain insights into why the actors implemented or rejected such techniques and measures. If an ETM is perceived as new by a project team, then it can, according to Rogers (2003, p. 12) be regarded as an innovation. Rogers' defines an innovation namely as an idea, practice, or object that is perceived as new by an individual or other unit of adoption (ibid, p. 12). The relative speed at which an innovation is adopted can be explained by what Rogers calls the perceived attributes of innovation. These attributes are (ibid., pp. 229-265):

1. Relative advantage: the degree to which an innovation is perceived as being better than the idea it supersedes (ibid., p. 229). This could, for example, be a financial advantage because energy costs are reduced, or an advantage in terms of comfort such as when single glazing is replaced by double glazing reducing draughts and condensation;

2. Compatibility: the degree to which an innovation is perceived as consistent with the existing values, past experiences and needs of potential adopters (ibid., p. 240). For example, a new high efficiency boiler system needs to fit in the same location as the former boiler and needs to be easily mountable and connectable;

3. Complexity: the degree to which an innovation is perceived as relatively difficult to understand and use (ibid., p. 257). Many innovative ETMs initially appear complex although a small group of innovators will not be intimidated by this. In time, more and more people will understand the innovation and its apparent complexity will fall. When the level of perceived complexity is reduced, the adoption rate will increase; 
4. Trialability: the degree to which an innovation can be experimented with on a limited basis (ibid., p. 258). Potential adopters can sometimes be persuaded by positive experiments. For example, one can try out a single LED lamp in one specific location before changing all the conventional light bulbs in a building to LED. Such trials are often impossible with a heating system in an individual dwelling.

5. Observability: the degree to which the results of an innovation are visible to others (ibid., p. 258). Although photovoltaic panels are sometimes considered as relatively expensive, many commercial organizations install them on facades and roofs to provide a sustainable or green company image, rather than adopt hidden ETMs.

However, in advance it is difficult to tell if the actors or project team perceive a certain ETM as new, and it is also not straightforward to unambiguously use the above attributes proposed by Rogers. For example, the relative advantage attribute could encompass many characteristics of a specific technique or measure, and it could also encompass all the other attributes listed. Nevertheless, Rogers' attributes indicate that the potential adoptees, i.e. the internal stakeholders and specifically the decision-making actor, have a choice and that their perceptions of a certain ETM can prevail over objective information. It is expected that the arguments advanced by the actors can be categorized (in line with the financial benefits and costs as described in Chapter 3 ) as follows:

- Arguments considering the environment. e.g. depletion of fossil fuels, use of renewable energy, and the impact of energy use;

- Arguments considering financial aspects. e.g. lowest investment costs, highest financial return for principal, highest financial return for resident, and the availability of a subsidy;

- Arguments considering user comfort. e.g. temperature can be controlled more accurately, overheating is avoided, and the elderly prefer thermal radiation;

- Arguments considering reliability. e.g. compatible with existing technical infrastructure, positive or negative experience with the technique regarding installation or maintenance;

- Arguments considering other aspects. Arguments that do not fit one of the other categories.

\subsection{Case study on decision-making on ETMs in social housing}

In this section, the institutional context and the individual cases are presented. Four projects of a single social housing association were selected. Due to the given that the point of departure for developing new dwellings is different from redeveloping existing dwellings, by means of the possibilities to design freely, the influence of occupants and, thus, to implement ETMs within the project, it seemed wishfull to study both types of building projects. Therefore, two of the cases are building projects in which new dwellings were constructed, and the other two are renovation projects (see Table 4-4). In the end, one of the renovation projects was cancelled for financial reasons just before a building licence was granted. The social housing association instead decided to demolish these blocks of flats. 
The four projects consider two different dwellings, namely terraced houses and apartments, and the projects consider different social target groups, namely elderly and families. Despite these differences regarding physical appearance and target group, it is expected that a general decision-making process leading to the actual implementation of ETMs by internal stakeholders exists in line with the developed conceptual model, as was shown in Figure 4-2. Although some project managers in social housing associations, some architects and some constractors have been or are specializing themselves in a certain residential niche market, this exspectation is based on the idea that many project managers in social housing associations, architects and contractors seem to be capable to handle all these different residential building projects. The exspectation is also based on the idea that the institutional context in which building projects take place and social housing is developed, offers tight conditions. This institutional context will be elaborated on in the next section.

Table 4-4: Overview of the selected cases of a Dutch social housing association.

\begin{tabular}{|l|l|c|c|l|}
\hline \multicolumn{1}{|c|}{ Project name } & \multicolumn{1}{|c|}{$\begin{array}{c}\text { Intended goal } \\
\text { of the project }\end{array}$} & $\begin{array}{c}\text { Start date } \\
\text { of the project }\end{array}$ & $\begin{array}{c}\text { End date } \\
\text { of the project }\end{array}$ & $\begin{array}{c}\text { Physical result } \\
\text { of the project }\end{array}$ \\
\hline 1. Kollenveld & $\begin{array}{l}\text { New social housing } \\
\text { family homes }\end{array}$ & October 2004 & February 2007 & $\begin{array}{l}73 \text { new terraced } \\
\text { houses }\end{array}$ \\
\hline 2. Friso & $\begin{array}{l}\text { New social housing for } \\
\text { the elderly }\end{array}$ & December 2002 & June 2009 & 41 new apartments \\
\hline 3. Kerkelanden & $\begin{array}{l}\text { Renovating 81 duplex } \\
\text { apartments }\end{array}$ & February 2003 & December 2008 & $\begin{array}{l}\text { 54 renovated terraced } \\
\text { houses }\end{array}$ \\
\hline $\begin{array}{l}\text { 4. Rombout } \\
\text { Verhulstlaan }\end{array}$ & $\begin{array}{l}\text { Renovating 102 } \\
\text { apartments }\end{array}$ & December 2004 & October 2008 & $\begin{array}{l}\text { 6 demolished building } \\
\text { blocks }\end{array}$ \\
\hline
\end{tabular}

\subsubsection{Institutional context related to social housing}

In all four projects, the social housing association Beter Wonen was the principal wanting to develop or improve residential buildings from a social perspective in order to rent them out. The projects were located in the municipality of Almelo and took place between December 2002 and June 2009. By the end of 2006, all the design processes had been finished. In this section, the institutional context is explained to the extent that it is considered consistent for all four cases. In other words, governmental policies and regulations on energy use in buildings, formal standardization as initiated by the industry and the roles and interests of the organization are addressed.

\section{Governmental policies and regulations on energy use in buildings}

The policies and regulations are considered on three different levels: national, regional and municipal. For the governmental policies and regulations studied, the location and time frame of the four projects form the boundaries. Four interviews were conducted with employees of the municipality of Almelo. These employees develop or execute policies and regulations that aim to reduce the fossil-based energy use of buildings in Almelo. Further, a broad document study, encompassing policy plans, covenants, letters and brochures was conducted to become familiar with the national, regional and local governmental policies and regulations at that time. Many documents were provided by the environmental affairs policy advisor of the Twente Region (personal contact policy advisor environmental affairs $\mathrm{O}$, 
July $10^{\text {th }}$ 2012), the corresponding policy officer at the municipality of Almelo and the employee responsible for land distribution at the municipality of Almelo.

National level. The Dutch national government wants to reduce the environmental impact of buildings (Hoppe, 2009). Here, one of the focal points is the energy use of residential buildings.

In Chapter 2 it was explained that new residential buildings have to comply with the National Building Code. From 1992 to 2012, the solid non-transparent thermal shell of a building had to achieve a minimum thermal resistance of $2.5 \mathrm{~m}^{2} \mathrm{~K} / \mathrm{W}$, and doors and windows had to have a maximum thermal transmittance of $4.2 \mathrm{~W} / \mathrm{m}^{2} \mathrm{~K}$. Further, since December 1995, the combination of building design and system installations has to comply with a maximum EPC. In January 2000, this EPC was set for residential buildings at a maximum of 1.0 (Stb. 439, 1999; Stb. 513, 1999). Six years later, in January 2006, this EPC value was reduced to 0.8 (Stb. 528, 2005).

In 2006, under pressure from the European Parliament and Council, the Dutch government also introduced a directive on the energy performance of existing buildings. This complies with the European Energy Performance of Buildings Directive (EC, 2002). The final Dutch directive covers new as well as existing buildings. It states that an energy certificate and label, based on the new Energy Index $\left(\mathrm{EI}_{\mathrm{new}}\right)$, are required, when constructing, renting or selling a building (Stb. 608, 2006; Stb. 216, 2007). However, there is no punishment or fine imposed when people do not comply with this directive.

Regional level. The municipality of Almelo, in which the cases are located, is part of the region of Twente. Since 1994, fourteen municipalities have collaborated in the administrative entity Twente Region that has set ambitions in the fields of economics, mobility and sustainability (Regio Twente, 2012). In 1997, nine out of these fourteen municipalities drew up the Sustainable Building Twente Covenant. The municipality of Almelo and the social housing association involved in the four case projects were signatories along with many other organizations (Regio Twente, 1997). The goal of the covenant was to stimulate the adoption of measures that would implement the National Package on Sustainable Building (NPSB). The NPSB is a long list of various measures that can improve the sustainability of a building. The parties signing the covenant agreed to comply with the guidelines of the then Secretary of State, Dick Tommel.

In effect, this meant that, in every residential building project, sixty standard sustainable measures needed to be implemented and a further eighty-eight other measures should be considered. Half of these eighty-eight measures could be implemented without additional investment costs. A checklist was provided that addressed all the measures. Some measures exceeded the regulations formulated in the Building Code. For example, the checklist set a target thermal resistance of $3.0 \mathrm{~m}^{2} \cdot \mathrm{K} / \mathrm{W}$ compared with $2.5 \mathrm{~m}^{2} \cdot \mathrm{K} / \mathrm{W}$ in the Code, and specified high efficiency glazing. One of the measures to be considered was an improved EPC target of 1.2 instead of 1.4. However, at the beginning of 1998 the Building Code was updated, setting the maximum EPC value at 1.2 (Stb. 461, 1997). 
Municipal level. By means of the "Basic Package Sustainable Building and Renovating" covenant, the municipality of Almelo in 1998 effectively started encouraging housing associations, project developers, construction companies and private principals (Gemeente Almelo, 2002) to reduce the EPC of buildings to $10 \%$ below the value stated in the Building Code. The buildings developed by the municipality itself had to achieve an EPC value that was $25 \%$ lower than that stated in the Building Code (interview senior policy officer sustainability A, June $19^{\text {th }}$ 2012). A municipality is not officially allowed to enforce performance levels that go beyond national building regulations as stated in the Building Code. As such, no legal support exists to compel or uphold this EPC minus $10 \%$ measure. Nevertheless, it became one of the main components of the sustainable building policy of the municipality for several years (e.g. Gemeente Almelo, 2003; Gemeente Almelo, 2005).

During an evaluation at the end of 2005, it became apparent that not all measures in the Basic Package were being implemented. It seemed that the local covenant of 1998 needed to be updated (interview senior policy officer sustainability A, 19 June 2012). In 2006, a new covenant was drawn up given the name, loosely translated, of "Living comfortably, healthy and energy efficient - now and in the future" (Gemeente Almelo, 2006). This covenant focused on collaboration between the municipality, housing associations, contractors and the local energy company to achieve a reduced energy use in building projects and an increased use of renewable energy resources. On signing this covenant, there was no longer a requirement to apply specific measures. Rather, from that moment on, the ambitions and targets were to be set collaboratively for each project. Although the EPC minus $10 \%$ was not explicitly stated, in practice it was still communicated by the municipality (Gemeente Almelo, 2008). In most building projects it remains the bottom line for the municipality of Almelo (interview employee land distribution $G$, June $19^{\text {th }}$ 2012; interview senior advisor environmental technology J, June $19^{\text {th }} 2012$; interview advisor building technology $\mathrm{K}$, June $19^{\text {th }} 2012$ ).

\section{Formal standardization initiated by the industry}

The social housing association Beter Wonen is subject to formal standardization through two routes. On one hand, it is an organization active in the construction industry and, as a principal, requests services from architects, advisors, fitters, electricians, contractors etc. to construct new dwellings and to maintain and renovate existing dwellings. On the other hand, Beter Wonen is a member of the national organization for social housing associations, Aedes. As of 2011, this organization represented 396 members (Aedes, 2012) and it sets ambitions for its members including regarding the quality of dwellings for the social housing industry.

As with some other industries, the Dutch construction industry uses many standards to uniformly assess the specifications of building products, buildings, the use of buildings and support services. Dutch standards are required to be in line with those set by the International Organization for Standardization (ISO) and the Netherlands Normalization Institute (NNI) which establishes national standards (NENs). Their standards address for example real estate terminology NEN 2776, thermal resistance of constructions NEN 1068, 
ventilation NEN 8087, lighting NEN 15193 and, as discussed in Chapter 2, the energy performance of buildings in NEN 2916, NEN 5128, and NEN 7120. The Dutch national Institute for Studying and Stimulating Research on installated systems (ISSO) mainly develops standards specifically for the installation industry.

New buildings need to comply with the Building Code and therefore the standards it refers to. When existing buildings are renovated, various standards also apply, but not regulations involving the EPC. Therefore, the standard determination method NEN 7120, which succeeded NEN 5128 andn NEN 2916 in 2012, does not apply. In carrying out the case studies, it was important not only to reflect on the obligatory, planned and achieved energy performance, but also on the way this energy performance was determined. A project team could consider ETMs that they might expect to influence energy use even if they are not included in the standardization protocols or in determining an EPC value. Conversely, in other situations, standards might encourage project teams to consider certain ETMs.

The collective ambitions of the housing associations also lead to standardization. In January 2007, Aedes publically announced its ambition to reduce natural gas use in existing social housing by at least 20\% in the period 2008-2018 (Aedes, 2007a). However, in the same document, Aedes acknowledges the difficulties in achieving this ambition in a cost-effective way. In order to ensure their financial continuity, social housing associations have to recover their investments (Aedes, 2007b, p. 12). These associations are restricted in terms of the rent they can charge. It may not be, or only partially, possible to increase rents to reflect investments that improve energy performance and reduce energy costs. The next section will explain in more detail how the rent for social housing is controlled in the Netherlands.

The ambition of a $20 \%$ reduction in natural gas use became part of the so called "Energy Saving Social Housing Sector Covenant" in October 2008. Here, the reduction was also expressed as a value of $24 \mathrm{PJ}$ in a period of twelve years, namely 2008-2020. For new social housing projects, new ambitions were introduced, namely to reduce the building-related standardized energy use by $25 \%$ from January $1^{\text {st }} 2011$ and by $50 \%$ from January $1^{\text {st }} 2015$ (Aedes, 2008). It should be noted, however, that these ambitions do not seem to differ that much from the standard national regulations expressed as an EPC in the Building Code. Here, the EPC was reduced from 0.8 to 0.6 from the beginning of 2011. Further, the plan is to reduce the EPC to 0.4 in 2015 (AgentschapNL, 2012c).

In order to achieve these goals, the covenant states that, firstly, ETMs will be implemented that reduce (fossil) energy use. Secondly, that social housing associations will make efforts to reduce energy use by influencing the behaviour of tenants through creating awareness and providing information. Thirdly, the energy performance label will be adopted so as to gain insights into the energy performance of existing houses. This label will also be used as a reference when houses are to be renovated. The aim is to achieve an Energy Label B, or at least an improvement of two energy levels (Aedes, 2008). This ambition exceeds the national legislation introduced in 2006 which, as already mentioned, refers to both new and existing buildings. This merely states that an Energy Label is needed when constructing, renting or 
selling a building (Stb. 608, 2006; Stb 216, 2007) but does enforce action to improve the energy performance.

\section{Roles and interests of the organisation}

Almelose Woningstichting "Beter Wonen" or AWS Beter Wonen, loosely translated as Almelo Housing Foundation "Better Living", is a social housing association established under Article 70 of the national Dutch Housing Act, which is called the "Woningwet" in Dutch (Woningwet, 1991). As such, AWS Beter Wonen is obliged to observe a directive that regulates the operations of the social housing sector (Beter Wonen, 2009). In Dutch, this directive is called the "Besluit Beheer Sociale-Huursector (BBSH)" (Stb. 555, 1992). This BBSH defines six main tasks to which social housing associations must direct their efforts (Aedes, 2007b, p. 12):

- to assure good quality in all their dwellings;

- to guarantee their financial continuity;

- to rent out dwellings on a priority basis to groups in need of special attention that have problems in finding, financing and maintaining suitable housing on their own;

- to involve tenants in the policy and management of their organization;

- to contribute to the quality of life in neighbourhoods and communities;

- to contribute to housing people in need of care or supervision.

The BBSH defines a maximum rent that social housing associations can charge. On top of this, to a very limited extent, a social housing association is allowed to bill for some service costs. The maximum rent depends on the quality of the dwelling. A number of value points related to various aspects are assigned to a specific dwelling and, based on the total of these value points, ranging from 40 to 250 , the maximum rent is determined. Normally, maximum rent values are indexed annually relative to inflation. A rent subsidy may be available for residents depending on the level of the rent and their income (Ministerie van BZK, 2011).

Since July $1^{\text {st }} 2011$, the value points, expressing the quality of a dwelling, also reflect the energy performance of a house (Ministerie van VROM, 2009). The energy performance is expressed in terms of $\mathrm{El}_{\text {new, }}$, where the best energy performance $\left(E I_{\text {new }}<0.50\right)$ earns an Energy Label $\mathrm{A}++$, and the worst $\left(\mathrm{EI}_{\text {new }}>2.90\right)$ a label $\mathrm{G}$, as is shown in Table 4-5. The better the energy performance of a dwelling, the higher the maximum rent that can be charged, as shown in Table 4-5. However, rent subsidies were only available in 2012 where the total maximum rent was below $€ 664.66$. This equated to a maximum points value of 139 , which equated to a maximum rent of $€ 663.88$ per month. As such, a newly constructed house with an EPC below 0.6 would already receive $31.65 \%$ of the 'maximum' points through its Energy Label.

Table 4-5 also reflects the significance attached to achieving an Energy Label B. Ten value points can be 'earned' by improving the Energy Label from $C$ to $B$, corresponding to a potential increase in rent of $€ 45.86$ to $€ 50.34$ per month. The precise financial value depends on the total points score of a house and whether this is below or above 80 value points. Before the Energy Label became part of this maximum rent calculation, value points were earned for installing a comfortable and energy efficient heating system (from 
approximately 15 to 25 points) or for the application of thermal insulation (a maximum of 15 points) (Ministerie van BZK, 2011).

Table 4-5: Relationship between Energy Labels, value points and rent (a.o. Ministerie van BZK, 2011).

\begin{tabular}{|l|r|r|r|r|r|r|}
\hline $\begin{array}{c}\text { Energy } \\
\text { Label }\end{array}$ & $\begin{array}{c}\text { Energy } \\
\text { index } \\
\left(\mathbf{E l}_{\text {new }}\right)\end{array}$ & $\begin{array}{c}\text { Energy } \\
\text { Performance } \\
\text { Coefficient } \\
(\mathrm{EPC})^{\mathbf{1 2}}\end{array}$ & $\begin{array}{c}\text { Associated } \\
\text { value points } \\
\text { for houses }\end{array}$ & $\begin{array}{c}\text { Capitalized } \\
\text { value points } \\
\text { max. rent } \\
\text { houses } \\
(€ / \text { month) }\end{array}$ & $\begin{array}{c}\text { Associated } \\
\text { value points } \\
\text { for flats }\end{array}$ & $\begin{array}{c}\text { Capitalized } \\
\text { value points } \\
\text { max. rent } \\
\text { flats } \\
\text { (€/month) }\end{array}$ \\
\hline A++ & $\leq 0.50$ & $0.41-0.60$ & 44 & 221.50 & 40 & 201.36 \\
\hline A+ & $0.51-0.70$ & $0.61-0.80$ & 40 & 201.36 & 36 & 181.23 \\
\hline A & $0.71-1.05$ & $>0.80$ & 36 & 181.23 & 32 & 161.09 \\
\hline B & $1.06-1.30$ & & 32 & 161.09 & 28 & 140.95 \\
\hline C & $1.31-1.60$ & & 22 & 110.75 & 15 & 75.51 \\
\hline D & $1.61-2.00$ & & 14 & 70.48 & 5 & 55.38 \\
\hline E & $2.01-2.40$ & & 8 & 40.27 & 1 & 25.17 \\
\hline F & $2.41-2.90$ & & 4 & 20.14 & 0 & 5.03 \\
\hline G & $>2.90$ & & 0 & 0.00 & 5.00 \\
\hline
\end{tabular}

The role of a social housing association is restricted in terms of some building and buildingrelated activities by its communal character. Investments by a social housing association to improve the energy performance of existing dwellings, or to exceed the minimum requirements as stated in the Building Code or covenants on new dwellings, can be earned back where the possibility exists to acquire additional value points and so increase rents, and the possible loss of the opportunity for tenants to acquire a rent subsidy is accepted. However, it is in their interest to reduce the risk of losing income in the form of rent from tenants which could occur if, in the future, tenants can no longer afford the rent due to increasing energy costs, or a fall in income cannot be made up by a rent subsidy.

Beter Wonen has various departments with different roles regarding the provision of housing to its tenants. In total, it rents out 7,400 properties in the municipalities of Almelo, Hengelo, Wierden and Haaksbergen. Most of these are dwellings. The Wonen/Klant/Markt (Residing/Customer/Market) department wants the dwellings to be developed and renovated for its tenants. This department can be regarded as the client. In order to fulfil this client's needs, the Vastgoed (Real Estate) department provides a project leader that acts as the principal during project phases 0 to VIII (as explained by Table 4-1) in dealing with external organizations. In phase IX, once the building has been constructed, the Wonen/Klant/Markt department will own and maintain (together with some contractors) the built or renovated property.

\footnotetext{
${ }^{12}$ In 2012 AgentschapNL proposed relating the Energy Performance Coefficient to the Energy Index in order to be able to assign Energy Labels to relatively recently constructed buildings (AgentschapNL, 2012a).

${ }^{13}$ As of July $1^{\text {st }} 2012$, based on the average maximum rent of $€ 5.0341$ per value point for a house valued at over 80 points.
} 


\subsubsection{Case 1: designing and constructing new terraced houses}

The institutional context can provide motivations for actors to implement energy techniques or measures. This section elaborates on one specific building project in which the implementation of ETMs has been studied. This first case is the process of building new houses within the institutional context outlined in the former section. The project-specific context, internal stakeholders and the implementation of ETMs are described.

\section{Project-specific context}

In October 2004, a building project was initiated by two social housing associations in which 73 new social houses were to be developed collaboratively on the east side of the city of Almelo. The land for these houses was originally in the hands of two developing contractors but when the municipality demanded social housing be part of that newly urbanized area, the two contractors asked the social housing associations to participate. This collaboration was given shape at the end of 2004. After fourteen months, 35 houses were commissioned by Beter Wonen, as the principal, in March 2006. A further 38 houses were commissioned by St Joseph, another social housing association. Figure 4-4 shows the timeline of Case 1 and its main milestones. The final completion date was in February 2007.

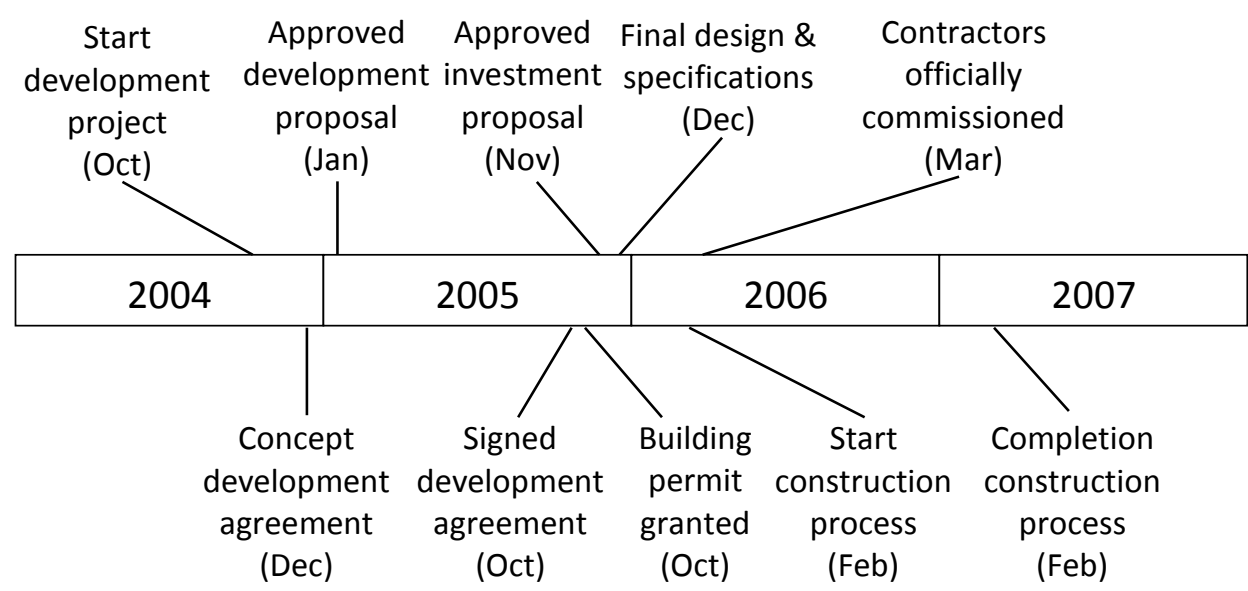

Figure 4-4: Case 1 Kollenveld - timeline building process.

\section{Internal stakeholders}

Given that two developing contractors owned the land plot and two social housing associations were invited to develop social housing as demanded by the municipality, several organizations became involved in two rather small projects (see Table 4-6). Two very similar projects were running simultaneously. Beter Wonen was the principal $_{A}$ for 35 new houses and St Joseph as principal ${ }_{B}$ for 38 new houses. According to the project manager (interview project manager C, April $17^{\text {th }} 2012$ ) of one of the social housing associations, the two principals strongly collaborated. De Witte - Van der Heijden Architects provided the same architect $_{A \& B}$ for both projects. The principals, architect and the main contractors were collaborating as a building team. The project coordinator, Dura Vermeer, was part of the building team from the moment the conceptual design had been developed (personal contact project coordinator $\mathrm{R}$, June $11^{\text {th }} 2012$ ). 
Once the drawings and specifications were prepared, the two housing associations more-orless individually continued the project with their own building contractors. Contracts were made between Beter Wonen and the building combination J.A. Droste BV and Dura Vermeer for 35 houses, and between St Joseph and Van Dijk Groep for 38 houses. The contractors, Van Dijk Groep - Bouw and Dura Vermeer, commented that all the specifications and drawings were ready when the construction phase started. During the construction phase, no significant modifications were requested by the principal (personal contact head sales support and aftercare $\mathrm{N}$, June $6^{\text {th }} 2012$; personal contact planning officer $\mathrm{H}$, June $11^{\text {th }} 2012$ ). Thus, in the views of the head of sales support and the planning officer, no ETMs were introduced or discussed from that moment on.

Table 4-6: Overview internal stakeholders Case 1 (Kollenveld).

\begin{tabular}{|c|c|c|}
\hline Role & Organization & Description \\
\hline Principal $_{A}$ & $\begin{array}{l}\text { Almelose Woning Stichting } \\
\text { Beter Wonen }\end{array}$ & Social housing association \\
\hline Principal $_{B}$ & $\begin{array}{l}\text { Woningstichting St Joseph } \\
\text { Almelo }\end{array}$ & Social housing association \\
\hline Architect $_{A \& B}$ & $\begin{array}{l}\text { De Witte - Van der } \\
\text { Heijden Architecten }\end{array}$ & Designing architect for both collaborating principals \\
\hline Building contractor $_{\mathrm{A}}$ & $\begin{array}{l}\text { Aannemingsbedrijf J.A. } \\
\text { Droste BV }\end{array}$ & $\begin{array}{l}\text { Main contractor for Beter Wonen in the construction } \\
\text { consortium b.c. Kollenveld VOF with Dura Vermeer }\end{array}$ \\
\hline Building contractor $_{\mathrm{A}}$ & Dura Vermeer & $\begin{array}{l}\text { Main contractor for Beter Wonen in the construction } \\
\text { consortium b.c. Kollenveld VOF with J.A. Droste BV }\end{array}$ \\
\hline Building contractor ${ }_{B}$ & Van Dijk Groep - Bouw & Main contractor for St Joseph \\
\hline $\begin{array}{l}\text { Mechanical systems } \\
\text { contractor }\end{array}$ & Hoogstraten Groep Almelo & $\begin{array}{l}\text { Installation of heating and ventilation systems for } \\
\text { Beter Wonen }\end{array}$ \\
\hline Plumbing contractor & $\begin{array}{l}\text { Installatiebedrijf Van } \\
\text { Kooten BV }\end{array}$ & Installation of plumbing for heating and water systems \\
\hline $\begin{array}{l}\text { Electric systems } \\
\text { contractor }\end{array}$ & Electrotechniek Voskamp & Installation of wiring and electric systems \\
\hline $\begin{array}{l}\text { Infrastructure } \\
\text { contractor }\end{array}$ & Roelofs & $\begin{array}{l}\text { Main contractor for infrastructure and the rain water } \\
\text { infiltration system }\end{array}$ \\
\hline $\begin{array}{l}\text { Planner urban } \\
\text { development }\end{array}$ & Municipality of Almelo & $\begin{array}{l}\text { The plan for the new neighbourhood of Kollenveld was } \\
\text { made by the municipality }\end{array}$ \\
\hline $\begin{array}{l}\text { Provider building } \\
\text { permit }\end{array}$ & Municipality of Almelo & Building permits are licenced by the municipality \\
\hline
\end{tabular}

For the electrical and mechanical systems, as well as for the plumbing, other contractors were involved in the project, namely Hoogstraten Groep Almelo, Van Kooten BV and Voskamp. The housing associations have long-term relationships with these three organizations for the maintenance, upkeep and expansion of their building stock (interview project manager C, April $17^{\text {th }}$ 2012).

The municipality of Almelo was involved in this project in several ways. As already mentioned, it demanded the inclusion of social housing and it also initiated the involvement of the social housing associations. Furthermore, an urban development plan was developed, which created a basis for the architect. According to the architect, the municipality's plan 
required the Kollenveld neighbourhood to consist of several courts (interview architect $Q$, June $20^{\text {th }}$ 2012). The plan also proposed the use of so-called "wadis", a form of ditch designed to let rainwater infiltrate easily into the soil. Ultimately, the municipality would have to licence the building permits before construction could start.

The courtyards in the urban redevelopment plan were redesigned by the contracted architect (interview architect $Q$, June $20^{\text {th }}$ 2012). The social housing associations insisted on the use of an underground rainwater infiltration system based on crates instead of an open wadi (interview project manager C, April $17^{\text {th }}$ 2012). The contractor for the infrastructure component that included this rainwater system was Roelofs. Roelofs was assigned by the two social housing associations. Some financial support was provided by the municipality (interview project manager C, April $17^{\text {th }}$ 2012).

\section{Implementation of energy techniques and measures}

In the design process, the pre-construction phases, many thoughts were given to the energy performance of the houses. In January 2005, the development proposal for 35 terraced houses for Beter Wonen shows that the houses were expected to be built with the standard EPC of 1.0 or less. Although the municipality had been requesting social housing associations to achieve, in all their projects, houses with a $10 \%$ lower EPC than this Building Code minimum (Gemeente Almelo, 2002; Gemeente Almelo, 2005; Gemeente Almelo, 2007), it took the social housing associations in this project approximately ten months to incorporate this policy into their design process. In the investment proposal of November 2005, a revised EPC value of 0.9 was mentioned. However, specific ETMs to achieve this EPC were not mentioned in this proposal by Beter Wonen.

By incorporating various measures including a particular type of ventilation, involving natural ventilation at weather-controlled inlets (DucoTop $50 \mathrm{ZR}$ ) and mechanical ventilation at the outlets, the EPCS of the various houses were reduced by the architect to values between 0.81 and 0.95 in September 2005. In this way, an average EPC of 0.90 was achieved over the 35 houses for Beter Wonen before the investment proposal was approved by Beter Wonen. Other energy techniques that were considered by the architect in the original EPC calculation of the designed houses (De Witte - Van der Heijden Architecten, 2005), were an improved heat resistance of the walls $\left(R_{c}=3.5 \mathrm{~m}^{2} \mathrm{~K} / \mathrm{W}\right)$, roof $\left(R_{c}=4.5 \mathrm{~m}^{2} \mathrm{~K} / \mathrm{W}\right)$ and ground floor $\left(R_{c}=4.0 \mathrm{~m}^{2} \mathrm{~K} / \mathrm{W}\right)$. However, according to the drawings of the designed houses the floor had a slightly lower heat resistance of $R_{c}=3.5 \mathrm{~m}^{2} \mathrm{~K} / \mathrm{W}$. Further, the quality certificate for the used high efficiency combination boilers (Intergas Kombi-Kompakt HR 22) that addresses the efficiency of the boiler system in heating tap water is missing from the documents that express the EPC of the dwellings. Although an improved ventilation system was selected by Beter Wonen in 2005, the system defined in the EPC calculations by the architect used alternating current rather than direct current. The latter makes more efficient use of electric energy than the former.

When designing the houses, the option of a thermal solar collector was mentioned according to the project manager of Beter Wonen. However, due to their negative experiences regarding their maintenance in another neighbourhood, this idea was quickly abandoned, 
especially when it became apparent that it was possible to achieve an EPC of 0.9 without them. Already at that time, the total investment costs were expected to exceed the foreseen rental income. Therefore, the investment costs needed to be controlled and ideally reduced (interview project manager C, April $17^{\text {th }}$ 2012).

The architect explained that sustainable building had been boosted when developing the Nijrees neighbourhood, but there was no such impetus when developing Kollenveld. When developing Nijrees, sustainable building was seen as hot and innovative. Further, in Kollenveld, more effort was needed to properly fit social housing within the city plan due to the greater number of moderate and high priced owner-occupied houses compared with in Nijrees. The architect thought that the combination of this challenge, a reduced enthusiasm for sustainable building in general and the forced improved energy performance led to a rather conventional design from an energy perspective. Interestingly, he did not seem familiar with the covenant and the required $10 \%$ improvement in EPC. However, in his opinion, a $10 \%$ reduction could not really be regarded as a challenge (interview architect $Q$, June $20^{\text {th }}$ 2012). The considered ETMs in each project phase are summarized in Table 4-7.

Table 4-7: Overview of the considered ETMs in Case 1 (Kollenveld).

\begin{tabular}{|c|c|c|c|}
\hline Project phase & $\begin{array}{c}\text { Internal } \\
\text { stakeholders }\end{array}$ & ETMs & Arguments for implementation or rejection \\
\hline Phases 0-I & Principal & $\begin{array}{l}\text { Compulsory } \\
\text { EPC } 1.0\end{array}$ & $\begin{array}{l}\text { In the project proposal of Beter Wonen dated } \\
\text { January } 31^{\text {st }} 2005 \text {, an EPC of } \leq 1.0 \text { is stated as } \\
\text { obligatory under the Building Code, but no specific } \\
\text { techniques or measures were mentioned. }\end{array}$ \\
\hline \multirow[t]{2}{*}{ Phases II-III } & $\begin{array}{l}\text { Principal } \\
\text { and } \\
\text { Architect }\end{array}$ & $\begin{array}{c}\text { Thermal solar } \\
\text { collectors }\end{array}$ & $\begin{array}{l}\text { In early } 2005 \text {, the use of thermal solar collectors was } \\
\text { discussed, but due to bad experiences (leakage) by } \\
\text { Beter Wonen in the Nijrees neighbourhood the idea } \\
\text { was rejected by the principal. }\end{array}$ \\
\hline & Architect & $\begin{array}{l}\text { Improved thermal } \\
\text { shell } \\
\text { High efficiency } \\
\text { combination boiler } \\
\text { Ventilation rosters } \\
\end{array}$ & $\begin{array}{l}\text { In the EPC calculation by the architect (dated } \\
\text { September } 21^{\text {st }} 2005 \text { ) EPCs of between } 0.81 \text { and } 0.95 \\
\text { are given. To achieve these values, the architect } \\
\text { slightly improved thermal resistances, added a high } \\
\text { efficiency boiler and special ventilation grills. }\end{array}$ \\
\hline Phases IV-VI & Principal & $\begin{array}{l}\text { Ambition } \\
\text { EPC } 0.9\end{array}$ & $\begin{array}{l}\text { In the investment proposal by Beter Wonen (dated } \\
\text { November } 29^{\text {th }} 2005 \text { ) an EPC of } \leq 0.9 \text { is given based } \\
\text { on a request by the Municipality. }\end{array}$ \\
\hline Phases VII-VIII & Principal & DC fan & $\begin{array}{l}\text { DC fans were installed rather than AC fans to limit } \\
\text { variance in the installed systems in the association's } \\
\text { building stock. }\end{array}$ \\
\hline Phases IX & Owner & Energy Label A & $\begin{array}{l}\text { After construction, an assessment took place and } \\
\text { assigned an Energy Label A to the houses. }\end{array}$ \\
\hline
\end{tabular}

\subsubsection{Case 2: designing and constructing new apartments for seniors}

The second case involves the design and construction process of new apartments for elderly people. 


\section{Project-specific context}

In this project, the social housing association Beter Wonen was asked by a local living and healthcare centre to collaborate in a building project. The living and healthcare centre needed to reduce its planned healthcare accommodation from ninety to sixty rooms. In line with regulations of the College of Healthcare Facilities, this loss in the planned accommodation had to be replaced with a new plan for at least thirty dwellings. The social housing association already owned several dwellings close to the living and healthcare centre and this is why they were asked to develop the needed thirty dwellings on basis of a collaboration (interview project manager C, April $17^{\text {th }} 2012$; interview architect B, July $27^{\text {th }}$ 2012).

The need for thirty dwellings, additional to sixty new rooms of the healthcare centre, was fulfilled by developing an apartment building. A new thirteen-storey apartment building was constructed, providing sheltered accommodation for elderly residents. Initially a tower of seventeen floors was proposed, but the zoning plan did not allow designs higher than thirteen floors. Altering the zoning plan would take too much time and would offer people in the neighbourhood an additional possibility to lodge objections to the project. Therefore, the residential tower was lowered by four floors (interview architect B, July $27^{\text {th }} 2012$ ). In the end, the building offers 41 apartments and 3 penthouses. It is directly attached to the new living and healthcare centre, but is a separate entity regarding construction and installed systems. In other words there are two distinct buildings. Compared to other buildings and dwellings owned by the social housing association, this apartment building has broader doors, wider hallways and a larger elevator which make it possible to manoeuvre mobile hospital beds.

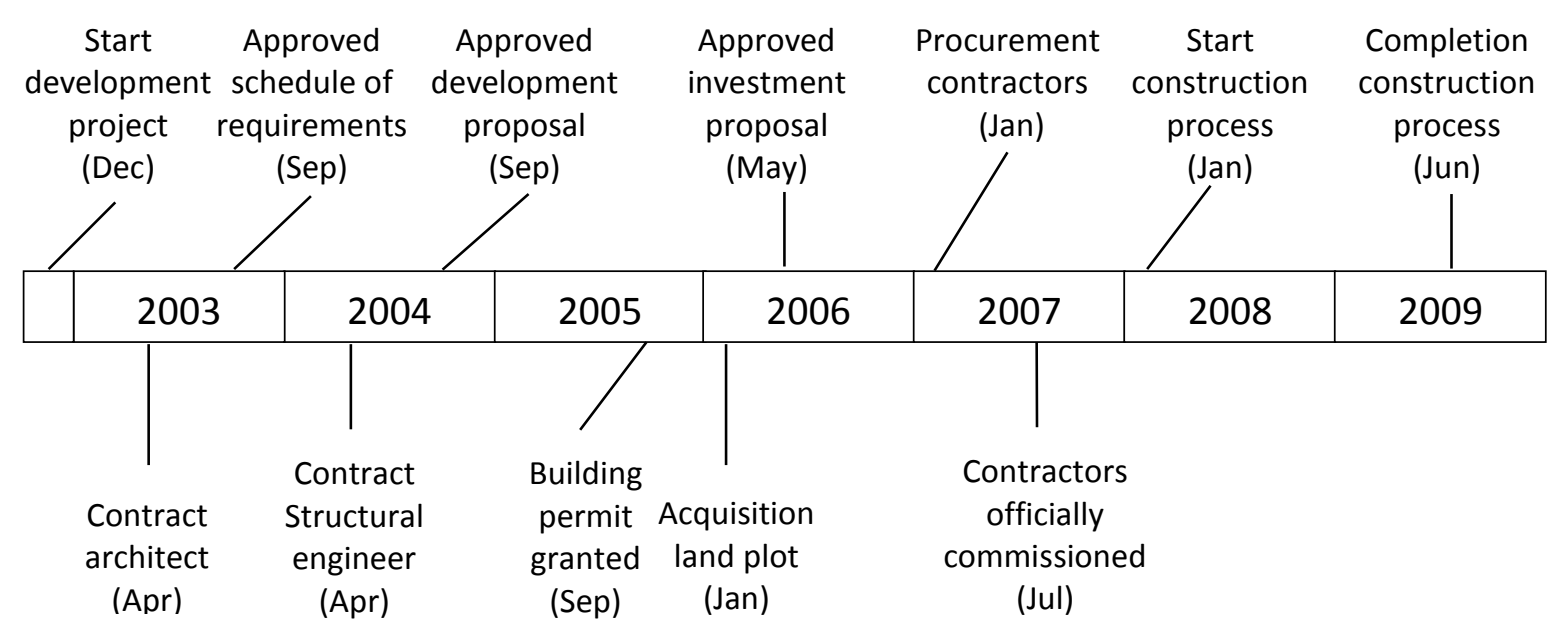

Figure 4-5: Case 2 Friso - timeline building process.

The project started for the social housing association in December 2002. Shortly before the construction process started, $€ 1$ million needed to be saved from the original budget of $€ 12.5$ million for the living and healthcare centre. Some cost reductions were achieved through aesthetic modifications, but no ETMs were abandoned (Van Leeuwen et al., 2009; interview architect B, July $27^{\text {th }}$ 2012). The residential building was completed in June 2009 . Figure 4-5 shows the milestones in the building process. 


\section{Internal stakeholders}

Two principals were involved in this project that resulted in two separate buildings. Apart from the wishes of Friso, the living and healthcare organization, to be able to manoeuvre hospital beds and to use similar architectural features in the two buildings, little influence was exerted by either principal on the other. One could virtually speak of two separate projects, albeit designed by the same architect and structural engineer, and constructed by the same contractors. Friso had already engaged an architect, structural engineer and HVAC advisor when Beter Wonen became involved (interview project manager C, April $17^{\text {th }}$ 2012; interview architect $B$, July $27^{\text {th }} 2012$ ). All the internal stakeholders involved in this project are listed in Table 4-8.

Table 4-8: Overview internal stakeholders Case 2 (Friso).

\begin{tabular}{|c|c|c|}
\hline Role & Organization & Description \\
\hline Principal $^{1}$ & $\begin{array}{l}\text { Almelose Woning Stichting } \\
\text { Beter Wonen }\end{array}$ & Social housing association \\
\hline Principal $^{2}$ & $\begin{array}{l}\text { Stichting Woon- \& } \\
\text { zorgcentrum Friso }\end{array}$ & Assisted living and healthcare centre \\
\hline Architect & $\begin{array}{l}\text { Grunstra Architecten } \\
\text { Groep BNA }\end{array}$ & $\begin{array}{l}\text { Designing architect and process management } \\
\text { for the two collaborating principals }\end{array}$ \\
\hline Advisor structural design & Aveco de Bondt & $\begin{array}{l}\text { Structural engineers providing design input } \\
\text { based on construction calculations }\end{array}$ \\
\hline Advisor HVAC systems & Dijkoraad Wiecherink & $\begin{array}{l}\text { System engineers providing design input based } \\
\text { on thermal, ventilation and energy } \\
\text { performance calculations }\end{array}$ \\
\hline Building contractor & $\begin{array}{l}\text { Aannemingsmaatschappij } \\
\text { Hegeman BV }\end{array}$ & $\begin{array}{l}\text { Main contractor for both collaborating } \\
\text { principals }\end{array}$ \\
\hline Mechanical systems contractor & De Groot Installatiegroep & Installation of heating and ventilation systems \\
\hline Electric systems contractor & Electrotechniek Kemkens & Installation of wiring and electrical systems \\
\hline
\end{tabular}

A major advantage of sharing the architect was in achieving some level of aesthetic uniformity. Existing buildings near the project location showed little uniformity in that regard (interview architect $B$, July $27^{\text {th }}$ 2012). The architectural firm was involved in the project through until after completion because it was responsible for removing the temporary facilities needed for Friso's clients during construction.

In the design phase, the structural engineer provided designs and specifications of structural elements such as floor plans. During the construction, the foundations and structural elements delivered from suppliers were inspected by the structural engineer (personal communication structural engineer $L$, June $6^{\text {th }}$ 2012).

The role of the HVAC advisor was of little interest to Beter Wonen who expected rather standard heating and ventilation systems (interview project manager C, April $17^{\text {th }}$ 2012). Friso had to comply with national regulation regarding climate conditions for elderly people in need of special healthcare (interview architect B, July $27^{\text {th }} 2012$ ). The advisor on HVAC systems was therefore of greater value to Friso. Besides designing the HVAC systems and issuing drawings and specifications, and providing supervision during construction, Dijkoraad Wiecherink also calculated EPC values for both buildings. 
Procurement took place in January 2007. The contractor had intended to start the construction process in April 2007, but this was delayed until January 2008. By choosing a hollow wall construction, rather than an in situ concrete building system, the construction period was significantly reduced (Van Leeuwen et al., 2009). This compensated for the time lost during the preparation of the construction activities. The main contractor, Hegeman, coordinated the building activities. De Groot and Kemkens, and the advisors Aveco de Bondt and Dijkoraad Wiecherink, were collaborating contractors rather than subcontractors.

\section{Implementation of energy techniques and measures}

During the design phase, the property developer, employed in an internal department of Beter Wonen, used his influence to set the ambition of an improved EPC. In September 2003, the ambition to achieve an improved EPC of 0.9 was expressed in the schedule of requirements. Although the client, property developer and project manager all belong to the same organization, the project manager did not share the property developer's ambition to meet the municipality's energy use target.

The building has a compact design with a relatively small thermal shell in relation to its floor area, which has a positive influence on energy performance. In 2005, when the building permit was licensed, the final design had an EPC of 0.98 , only slightly lower than the maximum allowable value of 1.0 in the period 2000-2006. The ETMs considered in each project phase are summarized in Table 4-9.

Table 4-9: Overview of the considered ETMs in Case 2 (Friso).

\begin{tabular}{|c|c|c|c|}
\hline Project phase & $\begin{array}{c}\text { Internal } \\
\text { stakeholders }\end{array}$ & ETMs & Arguments for implementation or rejection \\
\hline Phases 0-I & Principal & $\begin{array}{l}\text { Ambition } \\
\text { EPC } 0.9\end{array}$ & $\begin{array}{l}\text { In Beter Wonen's schedule of requirements (dated August } \\
29^{\text {th }} 2003 \text { ) an EPC of } \leq 0.9 \text { is stated (as requested by the } \\
\text { Municipality), but no specific techniques or measures are } \\
\text { suggested. }\end{array}$ \\
\hline Phases II-III & - & - & - \\
\hline \multirow[t]{2}{*}{ Phases IV-VI } & Principal & Shades & $\begin{array}{l}\text { The principal wants shades on the south side of the } \\
\text { dwellings. The EPC calculation of Dijkoraad Wiecherink } \\
\text { (dated November } 16^{\text {th }} \text { 2005) includes this technique. }\end{array}$ \\
\hline & $\begin{array}{l}\text { Advisor } \\
\text { HVAC } \\
\text { systems }\end{array}$ & $\begin{array}{l}\text { Improved } \\
\text { thermal shell } \\
\text { High efficiency } \\
\text { combination } \\
\text { boilers } \\
\text { DC fan }\end{array}$ & $\begin{array}{l}\text { The EPC calculation by Dijkoraad Wiecherink (dated } \\
\text { November } 16^{\text {th }} 2005 \text { ) gives a value of } 0.98 \text {. To achieve this } \\
\text { value, the advisor used high thermal resistances of } 3.0 \text { to } \\
3.5 \mathrm{~m}^{2} \mathrm{~K} / \mathrm{W} \text {, a low infiltration rate and high efficiency } \\
\text { boilers. The idea of using a heat exchanger was rejected. }\end{array}$ \\
\hline Phases VII-VIII & - & - & - \\
\hline Phases IX & Owner & $\begin{array}{l}\text { Energy Label } \\
\text { C/D }\end{array}$ & $\begin{array}{l}\text { After construction, an assessment took place to assign an } \\
\text { Energy Label to the apartments. }\end{array}$ \\
\hline
\end{tabular}

Relatively high insulation values of $3.0 \mathrm{~m}^{2} \mathrm{~K} / \mathrm{W}$ for the thermal resistance of the ground floor, $3.0 \mathrm{~m}^{2} \mathrm{~K} / \mathrm{W}$ for the facades, and $3.5 \mathrm{~m}^{2} \mathrm{~K} / \mathrm{W}$ for the roof are used in the EPC calculation (Dijkoraad, 2005) for the residential tower. The infiltration rate is relatively low at 0.200 $\mathrm{dm}^{3} / \mathrm{s}$ per $\mathrm{m}^{2}$ despite the infiltration rate being an issue with high-rise buildings due to the 
relatively high wind velocities (interview architect $B$, July $27^{\text {th }} 2012$ ). High efficiency glazing was specified with a heat resistivity of $1.8 \mathrm{~W} / \mathrm{m}^{2} \mathrm{~K}$ and a g-value of 0.58 for the windows, which were and still are typical values. An unusual feature was that solar shading was included in this project, a feature which is not common in residential building designs. Each apartment and penthouse had its own high efficiency combination boiler providing hot water to radiators (at a temperature of more than $55^{\circ} \mathrm{C}$ ) and heated tap water to the kitchen and bathroom. Each unit has a ventilation system based on natural air intake and a mechanical extraction of stale air. In the description of the EPC calculation, it is noted that the ventilation system does not include a heat exchanger. The building encompassing sixty rooms of the healthcare centre does have a heat exchanger in its ventilation system. Beter Wonen rejected the implementation of further ETMs due to the associated investment costs.

In the healthcare centre, a balanced ventilation system with heat recovery was installed to reduce energy use. However, in this project the social housing association made clear that only traditional and proven systems would be allowed in its dwellings. In the past, Beter Wonen had had some negative experiences with balanced ventilation systems and this fed their conservativeness over this point. The architect did not suggest installing specific ETMs in the residential tower, because he was aware of the principal's attitude. The architect also felt that this position was to an extent understandable given the foreseen residents since elderly people might not want to be confronted with advanced ETMs (interview architect B, July $27^{\text {th }} 2012$ ).

\subsubsection{Case 3: designing and refurbishing duplex houses}

In the third case study, outdated duplex houses were to be renovated. In this project the floor area of the dwellings was increased and the energy performance was improved.

\section{Project-specific context}

In this refurbishment project, 81 duplex apartments were to be renovated and transformed into 54 dwellings (Braak \& Rooseboom, 2008). The floor area of one dwelling would become approximately $110 \mathrm{~m}^{2}$. A major goal of the intensive renovation project was to make it possible from an architectural and constructional standpoint to rent these houses for another fifty years with an expected update of the HVAC systems after twenty years. As such, it was necessary to increase the size of the individual dwellings, to improve the thermal comfort, and to reduce future energy costs (interview project manager J, April $5^{\text {th }}$ 2012).

The Kerkelanden neighbourhood, where they are located, is to the west of Almelo city centre. Since 2003, several investments had been made in the local neighbourhood to improve its liveability. The 81 duplex apartments intended for renovation were part of a group of 328 dwellings. The original plans for a facelift were gradually extended to a renovation project in which only the load-bearing structure was preserved.

The duplex apartments were constructed in 1951, and Beter Wonen had taken them over from the municipality in 1995. Prior to this 2003 refurbishment project, the apartments had 
been previously renovated in 1982. The thermal shell of the buildings had already been improved by filling the wall cavities with insulating foam. Once the building permit was granted for this new work, the project was divided into two parts, namely construction work and installation work. Based on drawings and specifications provided by the architect, both parts were individually procured using traditional approaches.

Initially, in 2005, the intention had been to sell one complex consisting of nine apartments but, in the end, all 81 duplex apartments were transformed into seven groups of terraced houses. Given this plan, commissioning took place in April 2007 for the first 72 apartments and in May 2007 for the other 9 apartments (see Figure 4-6). All six complexes of eight terraced houses and one group of six terraced houses were finished in December 2008.

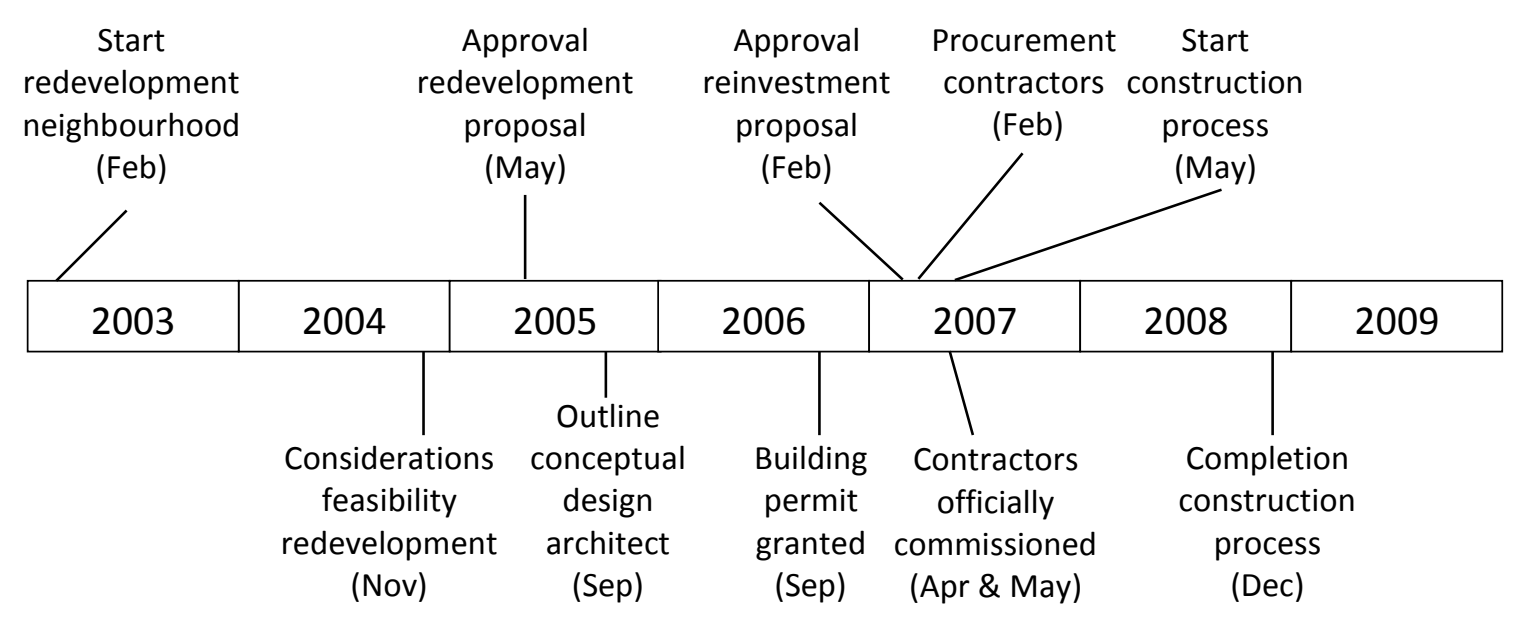

Figure 4-6: Case 3 Kerkelanden - timeline building process.

\section{Internal stakeholders}

In this project, one single principal was involved, namely the social housing association Beter Wonen. Table 4-10 gives an overview of the internal stakeholders involved in this project.

Table 4-10: Overview internal stakeholders Case 3 (Kerkelanden).

\begin{tabular}{|l|l|l|}
\hline \multicolumn{1}{|c|}{ Role } & \multicolumn{1}{|c|}{ Organisation } & \multicolumn{1}{c|}{ Description } \\
\hline Principal & $\begin{array}{l}\text { Almelose Woning } \\
\text { Stichting Beter Wonen }\end{array}$ & Social housing association \\
\hline Architect & $\begin{array}{l}\text { Architektenburo Willem } \\
\text { Smid en Jim Peters }\end{array}$ & Responsible for design, specifications and drawings \\
\hline Building contractor & Roosdom Tijhuis & Main contractor responsible for the constructional activities \\
\hline $\begin{array}{l}\text { Mechanical systems } \\
\text { contractor }\end{array}$ & Feenstra Enschede & $\begin{array}{l}\text { Responsible for installing heating and ventilation systems and } \\
\text { replenishing insulation }\end{array}$ \\
\hline $\begin{array}{l}\text { Electric systems } \\
\text { contractor }\end{array}$ & Cogas & $\begin{array}{l}\text { Responsible for installing smart electricity meters and } \\
\text { assessor of the energy performance }\end{array}$ \\
\hline
\end{tabular}

The architectural firm of Willem Smid and Jim Peters was invited to work on the detail design and provide drawings and specifications. Construction calculations formed one part of their assignment. This architectural firm was also involved in another renovation project in which Beter Wonen was the principal, namely at the Vermeerstraat in Almelo. After the death of Willem Smid, the portfolio of the architectural firm was passed over to the 
architectural firm Boerman, but the information on the case Kerkelanden was no longer available.

The building contractor Roosdom Tijhuis was involved from May 2007 to December 2008. The final activities, following completion, came to an end in February 2009. The contractor operated on the basis of the drawings and specifications provided by the architect. He was not involved in the design process or the decision-making processes regarding ETMs (personal communication contractor $P$, July $23^{\text {th }} 2012$ ).

The company Feenstra was contracted to install heating and ventilation systems and to extend the insulation. Before the renovation started, the cavity in the walls had already been filled with an insulating foam but this had settled and the insulation needed to be extended up into the new roof. The housing association decided to contract Feenstra separately from the building contractor in order to reduce costs on the assumption that the contractor would add a surcharge, if the heating and ventilation systems were installed by a subcontractor. As with the building contractor, Feenstra had no influence on the decision-making process over which ETMs to install (interview project manager J, April $5^{\text {th }}$ 2012).

The final organization involved in this project was Cogas (see Table 4-10), the local energy company that installed new gas meters and smart electric energy meters. The old meters had to be replaced because they were at the end of their lifecycle. At that time, there was also a political debate regarding the possible positive effects of smart meters, which can continuously provide insights into the energy use of a house and its residents. Beter Wonen and Cogas were anticipating that regulations would shortly compel the installation of smart electric energy meters (interview project manager J, April $5^{\text {th }} 2012$; personal communication project leader connections $E$, July $12^{\text {th }} 2012$ ). As such, Cogas was particularly involved at the end of the construction process. In September 2008, Cogas also assessed the energy performance ( $E I_{\text {new }}$ ) of the renovated dwellings (Cogas, 2008).

\section{Implementation of energy techniques and measures}

Before the refurbishment activities took place, an Energy Label had been determined for two of the dwellings, with both achieving an Energy Label D (Plegt, 2009). The first software to calculate the energy performance and to determine the Energy Label dates back to March 2007 (personal communication director F, September $21^{\text {st }} 2012$ ). This means that in March, April or maybe even early May 2007, the Energy Labels for these two dwellings had been determined. Following the renovations, $\mathrm{EI}_{\text {new }}$ values of 1.13 to 1.21 were established, equivalent to an Energy Label B. These green Energy Labels were achieved by taking in the calculation into account floor, wall and roof insulation, with heat resistances of up to 2.11 $\mathrm{m}^{2} \mathrm{~K} / \mathrm{W}$ for the walls and $2.5 \mathrm{~m}^{2} \mathrm{~K} / \mathrm{W}$ for the floor and roof (Cogas, 2008). However, according to drawings, the thermal resistance of the walls, which were already filled with insulation before these renovations, remained at the Building Code standard of $1.3 \mathrm{~m}^{2} \mathrm{~K} / \mathrm{W}$.

Further, high efficiency glazing was installed, resulting in a heat resistivity of $1.6 \mathrm{~W} / \mathrm{m}^{2} \mathrm{~K}$ and a g-value of 0.60 for the windows. The dwellings have high efficiency combination boilers providing hot water to radiators at a temperature above $55^{\circ} \mathrm{C}$ and heated tap water to the kitchen and bathroom (Cogas, 2008). The dwellings have ventilation systems using a DC 
motor based on a natural air intake and a mechanical exhaust of stale air (personal communication project manager J, April $12^{\text {th }}$ 2012). In assessing the energy performance, Cogas incorrectly assumed that AC motors were used, and these would have had a slightly higher energy use (Cogas, 2008).

In the pre-project phase, discussions took place regarding the extent of renovation. The initial idea was a facelift, but this transformed into a plan where each three apartments would be converted into two houses. On this basis, a large-scale renovation was planned in which only the load bearing structure and the outer walls were retained. No explicit ambitions regarding energy use were specified in the project or investment proposal. However, the fact that the houses needed to be rented out for another fifty years (although there would be another large-scale maintenance project after approximately twenty years) implied that some improvements regarding the thermal shell, the heating system and the ventilation system would be necessary (personal communication project manager J, April $12^{\text {th }}$ 2012). The ETMs considered in each project phase are summarized in Table 4-11.

Table 4-11: Overview of the considered ETMs in Case 3 (Kerkelanden).

\begin{tabular}{|c|c|c|c|}
\hline Project phase & \begin{tabular}{c|} 
Internal \\
stakeholders
\end{tabular} & ETMs & Arguments for implementation or rejection \\
\hline Phases 0-I & Principal & $\begin{array}{l}\text { Improving } \\
\text { thermal shell } \\
\text { New HVAC } \\
\text { systems }\end{array}$ & $\begin{array}{l}\text { Beter Wonen decided that the dwellings would be rented } \\
\text { for another lifecycle. It was clear to the project leader of the } \\
\text { social housing association, that the thermal shell and } \\
\text { currently installed systems needed to be upgraded. }\end{array}$ \\
\hline Phases II-III & Architect & $\begin{array}{l}\text { Improved } \\
\text { thermal shell } \\
\text { High efficiency } \\
\text { combination } \\
\text { boilers } \\
\text { DC fan }\end{array}$ & $\begin{array}{l}\text { The architect incorporated improvements regarding the } \\
\text { thermal resistance of the floor, glazing and roof in the } \\
\text { plans. Further, a new combination boiler and ventilation } \\
\text { system were needed so that the dwellings became in line } \\
\text { with current standards. }\end{array}$ \\
\hline Phases IV-VI & - & - & - \\
\hline Phases VII-VIII & $\begin{array}{l}\text { Electric } \\
\text { systems } \\
\text { contractor }\end{array}$ & $\begin{array}{l}\text { Smart electric } \\
\text { energy meters }\end{array}$ & $\begin{array}{l}\text { Cogas anticipated national plans to enforce smart electric } \\
\text { energy metering by installing them in this project. }\end{array}$ \\
\hline Phases IX & Principal & Energy Label B/D & $\begin{array}{l}\text { Immediately after the renovation, the principal decided that } \\
\text { Cogas needed to establish Energy Labels. These are the first } \\
\text { labels for social housing in Almelo. }\end{array}$ \\
\hline
\end{tabular}

Energy performance certificates were obtained for the 54 dwellings largely because of the growing awareness that energy performance certification would be introduced for buildings across the whole European Union. The assessments of the renovated houses resulted in an Energy Label B. This were the first Energy Labels for social housing in Almelo (personal communication project manager J, April $12^{\text {th }}$ 2012). Since the Energy Labels were assessed by Cogas after the other contractors were commissioned (Cogas, 2008), the assessments had no influence on decisions regarding the implementation of ETMs. 


\subsubsection{Case 4: designing the refurbishment of flats}

The fourth and final case in this study also addresses a renovation project. However, the renovation plans were never executed. Instead, the six housing blocks at Rombout Verhulstlaan were demolished to make space for a completely new building project.

\section{Project-specific context}

In 2001, various ideas were explored to demolish the six housing blocks at Rombout Verhulstlaan to make space for new apartments for the elderly. However, little information is available regarding this initiative (Plegt, 2009). In 2004, plans were made to refurbish the same six blocks (see Figure 4-7 for the timeline). A structural engineer was asked to investigate the structural quality of the existing buildings.

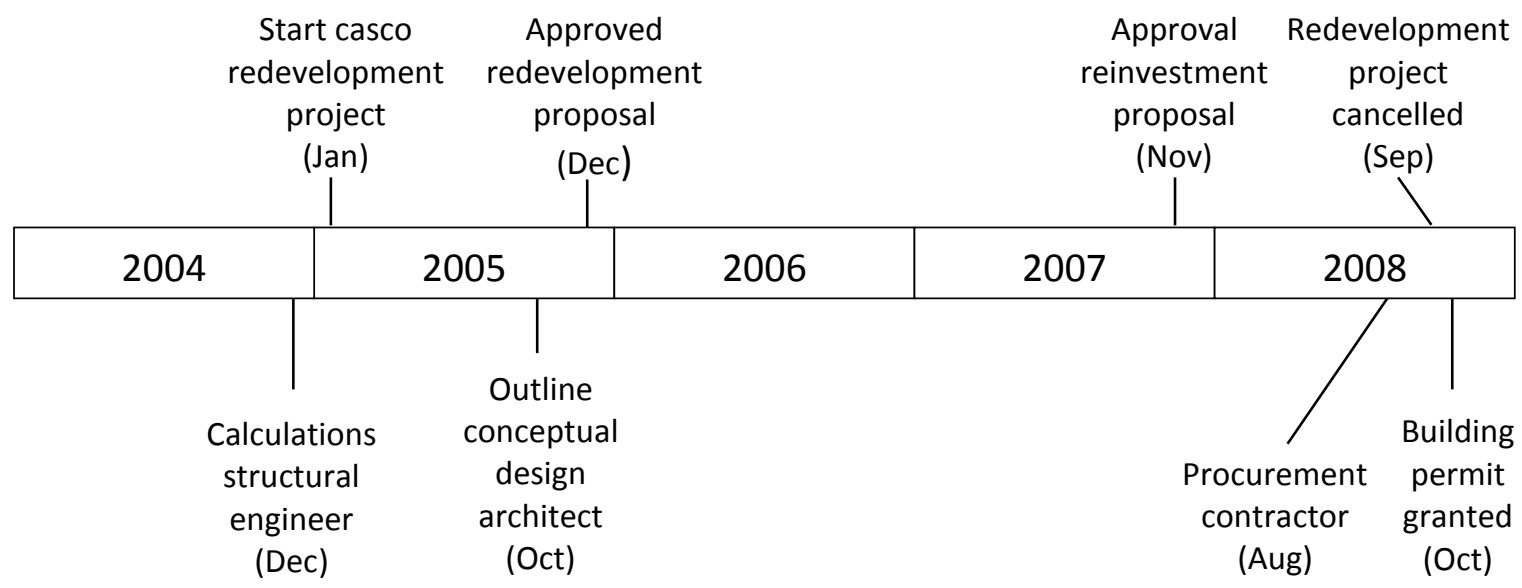

Figure 4-7: Case 4 Rombout Verhulstlaan - timeline building process.

The Rombout Verhulstlaan is located on the west side of Almelo. The building units consisted of main entrances, storage spaces and garages on the ground floor and, above these, three floors of apartments. Six apartments (two on each floor) shared a hallway and entrance. In total, there were 102, almost identical, apartments. These apartments were constructed in 1958 and had been renovated in 1988. In line with the policy of Beter Wonen, the apartments would come to the end of their second lifecycle in 2008, twenty years after the renovation. The main goal of the, studied, renovation project was to make it possible to rent out these houses, from an architectural and constructional standpoint, for another fifty years assuming a further update of the HVAC systems after twenty years (interview project manager J, April $5^{\text {th }}$ 2012).

This renovation project was one of three similar projects the housing association were planning to conduct at that time. The other two were comparable blocks at Rembrandtlaan and at Jan Vermeerstraat. The first of these had already been renovated and the second required renovation. According to a project leader of the social housing association, all three projects were taking place in a period in which relatively much attention was paid to sustainable building (interview project manager J, April $5^{\text {th }}$ 2012). A research report shows evidence of exploring the idea of installing biomass heating systems and achieving energy performance levels that were normally only met in newly built dwellings (DWA, 2008; interview manager energy strategies and concept development $D$, June $29^{\text {th }}$ 2012). 
After almost four years, during which the plans were initiated, developed and costed by a contractor, the project was turned down by the director of the social housing association. The project at Rembrandtlaan was finished in 2007, but executing the Jan Vermeerstraat and Rombout Verhulstlaan projects was regarded as too expensive. One month after this decision, the municipality granted a building permit for Rombout Verhulstlaan, but the permit was not used and the six building blocks were demolished in 2009 (interview project manager J, April $5^{\text {th }}$ 2012; Plegt, 2009).

\section{Internal stakeholders}

In this renovation project, the social housing association as the owner of the 102 apartments was the principal. Relatively early in the project, the association contracted a structural engineer to assess the potential of the existing constructions. This information would be relevant for the architect who was contracted on the basis of his involvement in the earlier plans regarding new buildings at Rombout Verhulstlaan and his experience in renovating a building block for Beter Wonen in Rembrandtlaan.

In this renovation project, which went as far as the "production design procurement" phase (Kagioglou et al., 1998), two organizations were involved concerning the HVAC systems, namely DWA and Matrix I.A. (see Table 4-12). At the end of 2007, DWA was asked to conduct a feasibility study on the application of a wood boiler. These advising engineers had been involved in a project for a housing association in Veenendaal that had decided to install a wood pellet boiler in one of its projects (interview manager energy strategies and concept development $D$, June $29^{\text {th }} 2012$ ). DWA contributed to this new project by offering various alternative design concepts, reflecting different building characteristics and system characteristics, all with an improved energy performance. The energy performances in their concepts were at least as good as the EPCs of newly constructed dwellings of that time (interview manager energy strategies and concept development D, June $29^{\text {th }} 2012$; DWA, 2008).

Table 4-12: Overview internal stakeholders Case 4 (Rombout Verhulstlaan).

\begin{tabular}{|l|l|l|}
\hline \multicolumn{1}{|c|}{ Role } & \multicolumn{1}{|c|}{ Organization } & \multicolumn{1}{c|}{ Description } \\
\hline Principal & Almelose Woning Stichting Beter Wonen & Social housing association \\
\hline Architect & De Witte - Van der Heijden Architecten & $\begin{array}{l}\text { Responsible for the new design of the six } \\
\text { housing blocks }\end{array}$ \\
\hline $\begin{array}{l}\text { Advisor structural } \\
\text { design }\end{array}$ & Bartels Ingenieurs BV & $\begin{array}{l}\text { Structural engineers providing information } \\
\text { regarding the structural quality and options } \\
\text { for the buildings }\end{array}$ \\
\hline $\begin{array}{l}\text { Advisor biomass } \\
\text { heating system }\end{array}$ & DWA Installatie- en Energieadvies & $\begin{array}{l}\text { System engineers providing design input by } \\
\text { investigating the possibility of applying a } \\
\text { biomass heating system }\end{array}$ \\
\hline $\begin{array}{l}\text { Advisor HVAC } \\
\text { systems }\end{array}$ & Matrix Installatie Adviseurs BV & \begin{tabular}{l} 
System engineers providing EPC calculations \\
\hline
\end{tabular}
\end{tabular}

Matrix I.A. was involved to provide procurement specifications and drawings for the building contractor and to prepare the application for the building permit with respect to the heating and ventilation systems (interview project manager J, April $5^{\text {th }}$ 2012). As part of this role, they were responsible for providing EPC calculations. 


\section{Implementation of energy techniques and measures}

By the end of 2004, the plans amounted to stripping the buildings back to the load bearing structure, after which a new building shell would be constructed. There was also an intention to add extra apartments on top of the existing structure of at least two of the six buildings.

In November 2007, the EPC calculations of Matrix I.A. show that the floor space would be increased by $355.81 \mathrm{~m}^{2}$ by adding $4^{\text {th }}$ and $5^{\text {th }}$ floors. These calculations show that an EPC of 0.95 would be achieved for the new dwellings placed on top of the existing blocks by applying various measures. These included a high efficiency combination boiler and an efficient ventilation system based on a natural air intake via self-regulating grills and a mechanical extraction of stale air using a DC motor (Matrix I.A., 2007a). In the same month, Matrix I.A. also provided an alternative EPC calculation in which a hybrid heat pump for space and water heating was considered in place of the high efficiency boiler. By incorporating this heat pump, the EPC was further improved to 0.8 (Matrix I.A., 2007b). Nevertheless, Beter Wonen's project manager does not recall the possible use of a heat pump being discussed (interview project manager J, April $5^{\text {th }}$ 2012). The architect also did not refer to this technique (interview architect $Q$, June $20^{\text {th }}$ 2012). In a meeting between the principal and DWA, another advisor on HVAC systems, it was stressed "do not experiment with heat pumps, because the building permit needs to be applied for in February" (DWA, 2008, p. 38).

In the calculation of both EPC values, the intentions regarding building characteristics were to improve the heat resistance of the walls up to $3.5 \mathrm{~m}^{2} \mathrm{~K} / \mathrm{W}$ and of the roof up to 4.0 $\mathrm{m}^{2} \mathrm{~K} / \mathrm{W}$. The former roof, which would become the floor of the new apartments, would have a resistance of $2.5 \mathrm{~m}^{2} \mathrm{~K} / \mathrm{W}$. The $\mathrm{U}$-value of the windows would be between 1.25 and 1.63 $\mathrm{W} / \mathrm{m}^{2} \mathrm{~K}$ with a g-value of 0.6 . The windows and doors were to be made air tight, resulting in an infiltration rate of $0.625 \mathrm{dm}^{3} / \mathrm{s}$ per $\mathrm{m}^{2}$ (Matrix I.A., 2007a; Matrix I.A., 2007b). DWA was involved between November $28^{\text {th }} 2007$ and February $11^{\text {th }} 2008$ to investigate the possibilities to improve energy performance by installing a wood boiler. Independently of Matrix I.A., DWA suggested three scenarios that would enable Beter Wonen to place the different options in a proper perspective. An EPC of 1.0 could be achieved by applying insulation with a heat resistance of $3.5 \mathrm{~m}^{2} \mathrm{~K} / \mathrm{W}$, high efficiency glazing $1.7 \mathrm{~W} / \mathrm{m}^{2} \mathrm{~K}$, high efficiency boilers, mechanical ventilation with $D C$ fans, and shades on the south side. An EPC of 0.8 was achievable by increasing the thermal resistances and decreasing the infiltration rate. The third scenario offered an EPC of 0.5 that would be met by installing a shared wood boiler. Such a wood boiler was not part of the plans submitted for a building permit.

In March 2008, EPC calculations by Matrix I.A. found that the original units, with a floor surface of 2,364 $\mathrm{m}^{2}$, would have an EPC of 0.79 to 0.83 after renovation. An EPC calculation is not officially required to obtain a building licence, but this does show that it was planned to improve the heat resistance of the thermal shell. The heat resistance of the refurbished walls would be $3.65 \mathrm{~m}^{2} \mathrm{~K} / \mathrm{W}$ by adding a new external shell and the heat resistance of the floors was planned to become $2.61 \mathrm{~m}^{2} \mathrm{~K} / \mathrm{W}$ or even $3.0 \mathrm{~m}^{2} \mathrm{~K} / \mathrm{W}$. The new roof would have a 
heat resistance of $4.0 \mathrm{~m}^{2} \mathrm{~K} / \mathrm{W}$. As with the new "roof-top" flats, the renovated apartments would have a high efficiency combination boiler and an efficient ventilation system based on natural air intake and a mechanical exhaust of stale air using a DC motor (Matrix I.A., 2008). All the ETMs considered in this project are summarized for each project phase in Table 4-13. As already noted, all the buildings were instead demolished, so none of these ETMs were ever applied.

Table 4-13: Overview of the considered ETMs in Case 4 (R. Verhulstlaan).

\begin{tabular}{|c|c|c|c|}
\hline Project phase & $\begin{array}{c}\text { Internal } \\
\text { stakeholders }\end{array}$ & ETMs & Arguments for implementation or rejection \\
\hline Phases 0-I & $\begin{array}{l}\text { Principal } \\
\text { and } \\
\text { Architect }\end{array}$ & $\begin{array}{c}\text { Improved } \\
\text { thermal shell } \\
\text { New HVAC } \\
\text { systems }\end{array}$ & $\begin{array}{l}\text { Beter Wonen decided that the dwellings should be rented } \\
\text { for another lifecycle. It was clear to the principal that the } \\
\text { thermal shell needed to be improved and installed systems } \\
\text { replaced. The architect suggested a new external shell to } \\
\text { ensure little or no thermal bridging would occur. }\end{array}$ \\
\hline Phases II-III & $\begin{array}{c}\text { Advisor } \\
\text { HVAC } \\
\text { systems }\end{array}$ & $\begin{array}{l}\text { Improved } \\
\text { thermal shell } \\
\text { Heat pump } \\
\text { High efficiency } \\
\text { combination } \\
\text { boilers }\end{array}$ & $\begin{array}{l}\text { In one EPC calculation for the additional apartments to be } \\
\text { added (dated November } 12^{\text {th }} \text { 2007) an EPC of } 0.8 \text { was } \\
\text { proposed by including a heat pump in combination with low } \\
\text { temperature heating, high efficiency glazing and thermal } \\
\text { resistances up to } 3.50 \mathrm{~m}^{2} \mathrm{~K} / \mathrm{W} \text {. Using a high efficiency } \\
\text { combination boiler instead, Matrix I.A. calculated an EPC of } \\
0.95 \text { (dated November } 9^{\text {th }} \text { 2007). }\end{array}$ \\
\hline Phases IV-VI & $\begin{array}{l}\text { Advisor } \\
\text { biomass } \\
\text { heating } \\
\text { system }\end{array}$ & $\begin{array}{l}\text { Communal } \\
\text { wood boiler }\end{array}$ & $\begin{array}{l}\text { DWA developed three scenarios for the existing } \\
\text { apartments, resulting in EPCs of } 1.0,0.8 \text { and } 0.5 \text {. Various } \\
\text { ETMs were incorporated, but the main focus was on } \\
\text { whether to include a communal wood boiler. Due to the } \\
\text { investment costs, fuel logistics and foreseen maintenance } \\
\text { risks, Beter Wonen decided to reject this technique. }\end{array}$ \\
\hline & $\begin{array}{c}\text { Advisor } \\
\text { HVAC } \\
\text { systems }\end{array}$ & $\begin{array}{c}\text { Improved } \\
\text { thermal shell }\end{array}$ & $\begin{array}{l}\text { Based on the designs of the architect, Matrix I.A. calculated } \\
\text { EPC values in the range of } 0.79-0.83 \text { (dated March } 21^{\text {st }} \\
\text { 2008). This involved high efficiency glazing, relatively high } \\
\text { insulation values of } 3.65 \mathrm{~m}^{2} \mathrm{~K} / \mathrm{W} \text { for the walls (brickwork) } \\
\text { and } 4.00 \mathrm{~m}^{2} \mathrm{~K} / \mathrm{W} \text { for the roof. Beter Wonen then decided to } \\
\text { abort the renovation project due to the high investment } \\
\text { costs. }\end{array}$ \\
\hline Phases VII-VIII & - & - & - \\
\hline Phases IX & - & - & - \\
\hline
\end{tabular}

\subsection{Analysing the decision-making on the implementation of ETMs}

The four cases will be analysed in four steps. Firstly, attention will be paid to the influence of the institutional context on these projects. Secondly, the influence of the internal stakeholders will be analysed. Thirdly, the analysis will focus on the project requirements. In the final subsection, the analysis focuses on the implementation of ETMs in the various phases of the projects.

\subsubsection{Analysing the implementation of ETMs within the institutional context}

This subsection analyses the influence of the institutional context on the implementation of ETMs in the four projects studied. In all four projects, the thermal shell received a lot of 
attention and the EPC and/or Energy Label, as introduced in national legislation, played an important role (see Table 4-14). Since the start of 2009, social housing associations officially require Energy Labels on every building in their building stock. The Energy Label is based on an assessment of a specific dwelling. The information collected in this assessment is used in a calculation that results in an Energy Index ( $\left.E I_{\text {new }}\right)$ and each Energy Label is linked to a certain range of Energy Indices. Energy Labels are available for all dwellings that were actually constructed or renovated in these four projects.

Table 4-14: Energy performance, techniques and measures discussed in the studied cases.

\begin{tabular}{|c|c|c|c|c|c|}
\hline Case & Phases 0-I & Phases II-III & Phases IV-VI & Phases VII-VIII & Phases IX \\
\hline 1. Kollenveld & $\begin{array}{l}\text { Satisfying } \\
\text { Requirements } \\
\text { EPC } 1.0\end{array}$ & $\begin{array}{l}\text { Thermal solar collectors } \\
\text { Calculated } \\
\text { EPC } 0.81-0.95 \\
\text { Improved thermal shell } \\
\text { High efficiency } \\
\text { combination boilers } \\
\text { Ventilation rosters }\end{array}$ & $\begin{array}{l}\text { Ambition } \\
\text { EPC } 0.9\end{array}$ & DC fan & $\begin{array}{l}\text { Energy } \\
\text { Label A }\end{array}$ \\
\hline 2. Friso & $\begin{array}{l}\text { Ambition } \\
\text { EPC } 0.9\end{array}$ & - & $\begin{array}{c}\text { Shading } \\
\text { Calculated } \\
\text { EPC } 0.98 \\
\text { Improved } \\
\text { thermal shell } \\
\text { High efficiency } \\
\text { combination } \\
\text { boilers } \\
\text { DC fan } \\
\end{array}$ & - & $\begin{array}{c}\text { Energy } \\
\text { Label C/D }\end{array}$ \\
\hline 3. Kerkelanden & $\begin{array}{l}\text { Improving } \\
\text { thermal shell } \\
\text { New HVAC } \\
\text { systems }\end{array}$ & $\begin{array}{c}\text { Improved thermal shell } \\
\text { High efficiency } \\
\text { combination boilers } \\
\text { DC fan }\end{array}$ & - & Smart meters & $\begin{array}{c}\text { Energy } \\
\text { Label B/D }\end{array}$ \\
\hline $\begin{array}{l}\text { 4. Rombout } \\
\text { Verhulstlaan }\end{array}$ & $\begin{array}{l}\text { Improving } \\
\text { thermal shell } \\
\text { New HVAC } \\
\text { systems }\end{array}$ & $\begin{array}{c}\text { Improved thermal shell } \\
\text { Calculated } \\
\text { EPC } 0.8 \\
\text { Heat pump } \\
\text { Calculated } \\
\text { EPC } 0.95 \\
\text { High efficiency } \\
\text { combination boilers }\end{array}$ & $\begin{array}{c}\text { Communal wood } \\
\text { boiler } \\
\text { Calculated } \\
\text { EPC } 0.79-0.83 \\
\text { Improved } \\
\text { thermal shell }\end{array}$ & - & - \\
\hline
\end{tabular}

To acquire a building permit, an EPC needs to be calculated and shown to comply with the current Building Code. From January 2000 up to January 2006, the Building Code required a maximum EPC value of 1.0 for new dwellings. Further, the municipality wanted social housing associations to aim for a value $10 \%$ below this. An average value of 0.9 was indeed met in the Kollenveld project (Case 1) which was completed in February 2007. In Case 2, which was completed in June 2009, an EPC of 0.98 was achieved in the Friso project. Although an ambition to achieve an EPC of 0.9 was stated at an earlier stage in Case 2 than in Case 1, it was not achieved in the final design. The building permit for this first case was granted by the municipality in October 2005 and for the second in September 2005. Despite 
the municipality having access to the calculated EPCs, it seems no request was made at the time to improve the energy performance in the second project by reducing the EPC from 0.98 to 0.9 in line with its own targets.

It is not necessary to calculate an EPC, or to comply with EPC regulations, when renovating a building. Consequently, EPC calculations were not made in the Kerkelanden project (Case 3). In Case 4, new apartments were planned on top of the existing structure and this made it necessary to at least provide an EPC calculation showing a maximum value of 0.8 (the improved standard enforced by this time) for these new apartments. Documents show that EPC calculations were not only made by the advisor on HVAC systems (Matrix I.A.) but also by DWA, the second advisor on the biomass heating system, and in both instances for the entire building units. These calculations were made to gain insight into different scenarios for reducing energy use. Although the principal, Beter Wonen, was aware that an EPC calculation was not necessary in renovation projects, designs based on EPC values of $0.5,0.8$ and 1.0 were illustrated to reflect three different energy performance scenarios. In this final case project, the $10 \%$ improvement in EPC value promoted by the municipality was never addressed in the form of a specification.

Although the apartments in the R. Verhulstlaan project (Case 4) were also assessed by DWA in terms of the expected Energy Label, achieving an Energy Label B, or at least two levels of improvement, a stated goal of Aedes, was never explicitly addressed by any of the internal stakeholders. However, given that the existing flats were rated at Energy Label levels $F$ to $G$ (DWA, 2008, p. 5), one would expect the renovations, with a target EPC of 1.0, to comfortably satisfy this goal.

The minimum thermal resistance of $2.5 \mathrm{~m}^{2} \mathrm{~K} / \mathrm{W}$ specified in the pre-April 2012 Building Code for new dwellings seems to have been satisfied in all the projects apart from the walls in Case 3. These walls, constructed in the 1950s, had already been reinsulated before this renovation took place to boost the thermal resistance to $1.3 \mathrm{~m}^{2} \mathrm{~K} / \mathrm{W}$, the minimum value in the case of alterations. A higher thermal resistance would only be possible by replacing the outer walls to provide more space for a thicker insulation component or by adding an extra internal or external layer. Implicitly, all the internal stakeholders seem to have resigned themselves to achieving the overall minimum value of $2.5 \mathrm{~m}^{2} \mathrm{~K} / \mathrm{W}$, which had been the standard since at least 1992. The minimum thermal resistance of $3.0 \mathrm{~m}^{2} \mathrm{~K} / \mathrm{W}$, as agreed in the Sustainable Building Twente Covenant, does not seem to have been explicitly referred to by any of the internal stakeholders. As of 2012, the new Building Code specifies a minimum heat resistance for walls, roofs and floors of $3.5 \mathrm{~m}^{2} \mathrm{~K} / \mathrm{W}$. Based on the drawings and EPC calculations, this higher value is met by a large proportion of the thermal shells in Cases 1,2 and 4.

The last influence to be considered within the constitutional context is a financial aspect. Financial resources will be limited in every building project, but often investments that improve the quality of the building for its users can be successfully marketed and justified on the basis of asking a higher price. This could easily be the situation for owner-occupied houses developed by professional project developers or for rented houses in the private 
sector. However, with social housing, rents are controlled. Although the maximum chargeable does depend on some features that reflect a house's quality, it is generally difficult, if not impossible, for social housing associations to earn back the investments made through increased rents. This means that little or no financial space is available to invest in ETMs beyond those that are required to comply with building regulations. The designs of these four projects show that ideas perceived by the principal to be linked to a risk of additional maintenance costs are avoided. Instead, techniques are implemented that improve the heat resistance of the thermal shell. These building techniques generally have a significantly longer life expectancy than installed systems. The only project in which an alternative heating system, namely a wood boiler, was seriously studied was Case 4. However, a subsidy was provided by the province for this feasibility study, and with the demise of the project such a boiler was never implemented.

\subsubsection{Analysing the implementation of ETMs by the stakeholders}

According to Winch (2010), internal stakeholders can be found on both the demand and the supply sides of a project. In the four cases studied, the client on the demand side was Beter Wonen, a social housing association. Beter Wonen has several departments with different roles in building projects. The Wonen/Klant/Markt (Residing/Customer/Market) department specifies the target group of future tenants. For example, this department, as the internal client, made clear in Case 2 to the principal that the future residents would be elderly people. In Case 3, the Vastgoed (Real Estate) department, as the principal representing the external organizations, knew the current size of the apartments were inadequate for the group of tenants the client was aiming for - families with children. No matter what size or form the apartments have, in all cases social housing means in the Netherlands that the rent requested is limited. As already was addressed, this is a constitutional element.

On the supply side, Winch (2010) clusters the architects, engineers, contractors and material suppliers as a project's internal stakeholders. In this case study, material suppliers were not considered as internal stakeholders, as they do not have direct contracts with the principal. In the studied cases, the architects, system installation engineers and contractors were seen as the supply-side internal stakeholders with some influence over the implementation of ETMs (see Table 4-15).

In the project studied in Case 1, the principal stated in the project proposal that the project had to achieve an EPC of 1.0. After the architect provided calculations showing that an average EPC value of 0.9 was feasible by applying proven techniques, the investment proposal produced by the principal included an EPC of 0.9 as an ambition. The use of thermal solar collectors was discussed by the principal and the architect but, due to previous bad experiences with leaking thermal solar collectors in another neighbourhood, this technique was not implemented.

In Case 2, the principal stated an ambition of achieving an EPC of 0.9, but the HVAC systems advisor provided calculations for acquiring a building permit showing an EPC of 0.98 . Between these two points in the project, the management of the social housing association was partially replaced and financial budgets were also under pressure. Further, the 
construction costs were higher than initially expected. Therefore, both principals in the overall project sought to cut costs. Although the principal in the project studied had set a target, and the HVAC systems advisor had made several assumptions regarding the thermal shell and the installed systems (to be able to calculate the EPC value), it is debatable whether one can classify these internal stakeholders in this project as decision-makers on ETMs. In reality, little effort was made to implement ETMs that would improve the energy performance significantly beyond the Building Code stipulated EPC of 1.0. To bridge the gap between the principal's ambition and the calculated EPC, one might expect some input from the architect. However, the architect stated that, due to the abovementioned financial constraints, there was no opportunity to discuss ETMs with Beter Wonen. The other principal (Friso) in the larger project did implement some ETMs, as it was operating under a more favourable financial structure.

Table 4-15: Actors regarding the implementation of ETMs (ETMs) in the studied cases.

\begin{tabular}{|c|c|c|c|c|c|}
\hline Case & Phases 0-I & Phases II-III & Phases IV-VI & Phases VII-VIII & Phases IX \\
\hline 1. Kollenveld & $\begin{array}{l}\text { The principal } \\
\text { adopts the } \\
\text { maximum EPC } \\
\text { value of } 1.0 \text { set by } \\
\text { ministerial } \\
\text { regulations }\end{array}$ & $\begin{array}{c}\text { Principal rejects thermal } \\
\text { solar collectors. } \\
\text { Architect proposes ETMs } \\
\text { to achieve an EPC of 0.9, } \\
\text { as requested by the } \\
\text { municipality. }\end{array}$ & $\begin{array}{l}\text { Principal agrees with the } \\
\text { EPC of } 0.9 \text { stipulated in } \\
\text { the investment proposal }\end{array}$ & $\begin{array}{l}\text { DC fans are } \\
\text { applied in line } \\
\text { with principal's } \\
\text { standards }\end{array}$ & $\begin{array}{l}\text { Owner } \\
\text { adopts } \\
\text { Energy } \\
\text { Labels }\end{array}$ \\
\hline 2. Friso & $\begin{array}{l}\text { The principal sets } \\
\text { the EPC ambition } \\
\text { at } 0.9 \text {, reflecting } \\
\text { the municipality's } \\
\text { aims }\end{array}$ & - & $\begin{array}{c}\text { Principal requests the } \\
\text { use of shading } \\
\text { Advisor on HVAC systems } \\
\text { proposes ETMs to } \\
\text { achieve an EPC of } 0.98\end{array}$ & - & $\begin{array}{l}\text { Owner } \\
\text { adopts } \\
\text { Energy } \\
\text { Labels }\end{array}$ \\
\hline 3. Kerkelanden & $\begin{array}{l}\text { Principal foresees } \\
\text { update of thermal } \\
\text { shell and systems }\end{array}$ & $\begin{array}{l}\text { Architect incorporates } \\
\text { ETMs in renovation plans }\end{array}$ & - & $\begin{array}{c}\text { Electric systems } \\
\text { contractor installs } \\
\text { smart meters }\end{array}$ & $\begin{array}{l}\text { Principal } \\
\text { adopts } \\
\text { Energy } \\
\text { Labels }\end{array}$ \\
\hline $\begin{array}{l}\text { 4. Rombout } \\
\text { Verhulstlaan }\end{array}$ & $\begin{array}{c}\text { Principal foresees } \\
\text { update of thermal } \\
\text { shell and systems } \\
\text { Architect }\end{array}$ & $\begin{array}{l}\text { Advisor on installation } \\
\text { systems proposes ETMs } \\
\text { to achieve EPCs of } 0.8 \\
\text { and } 0.95\end{array}$ & $\begin{array}{c}\text { Advisor on biomass } \\
\text { heating systems } \\
\text { proposes ETMs to } \\
\text { achieve EPCs of } 1.0,0.8 \\
\text { and } 0.5 \\
\text { Advisor on HVAC systems } \\
\text { proposes ETMs to achieve } \\
\text { EPCs of } 0.79-0.83\end{array}$ & - & - \\
\hline
\end{tabular}

Since, in the Case 3 project, no new buildings were to be constructed, an EPC calculation was not compulsory. Further, at the start of the project, the Energy Index (El new) and Energy Labels had yet to be introduced. The principle set no ambitions regarding an EPC of 0.9, or an improved Energy Index ( $\left.E I_{n e w}\right)$, or Energy Label. Nevertheless, some ETMs were implemented that significantly improved the energy performance of the relatively old duplex houses. The use of high efficiency glazing, insulation, a high efficiency boiler and a DC fan in the ventilation system were not discussed, but these ETMs were directly introduced through a set of tasks to be executed by the other internal stakeholders. Here, the principal was the actor. In a relatively late phase of the building process, Cogas suggested installing smart electric energy meters. As such, this was the only case study in which a contractor suggested 
and implemented an ETM. Cogas, an internal stakeholder, was also commissioned by the project leader from the Vastgoed (Real Estate) department to determine Energy Labels for the houses on their completion.

In Case 4, the client wanted the building units to be rentable for at least another twenty years. For this to be feasible, the principal knew that the thermal shells needed improving (as in Case 3). The architect, in a very early phase of the building process, suggested wrapping the buildings in new facades that would also avoid thermal bridging in the existing construction. In the next phase, the engineers advising on the systems to be installed included a heat pump in some of their EPC calculations. However, the principal cannot remember a heat pump ever being discussed or considered. In the subsequent phase, a further three concepts were presented, at the request of the principal, by another organization of advising engineers on HVAC systems. Their most innovative concept included a communal wood boiler system. However, none of the three concepts were incorporated in the building design. In the next stage, the first advisor made definitive calculations, with EPCs ranging from $0.79-0.83$, which were accepted by the municipality and a building licence was then granted. These calculations were based on the use of high efficiency glazing, insulation, a high efficiency boiler and a ventilation system operating on a DC fan.

\subsubsection{Analysing the implementation of ETMs by means of project's requirements}

In Case 1, the principal initially inserted an EPC of 1.0 as a requirement. This requirement had the status of a precondition. This specific value was compelled by the national Building Code of that time. Before procurement took place, the required EPC was reduced by the principal to 0.9 in the investment proposal, a value in line with the municipality's goal stated in the covenant. However, this value only became a stated requirement after the EPC calculations had been made. As such, decisions on individual ETMs had already been taken by the architect based on the original EPC value.

In Case 2, the principal inserted an EPC of 0.9 as a requirement in line with the covenant with the municipality to improve on the Building Code's EPC by $10 \%$. Although ETMs were implemented that were comparable to those in Case 1, the eventual EPC was not improved beyond a value of 0.98 . The original requirement by the principal was relaxed due to financial constraints. In hindsight, the initial requirement to achieve an EPC of 0.9 seems to have been more of a wish or a desire rather than a precondition or mandate.

In Case 3, no performance requirement, such as in the form of an EPC, was set by the principal. The Building Code sets conditions regarding the thermal resistance of walls, roofs and floors and the principal adopted this approach. Given that this was a renovation project, the principal was obliged to achieve a thermal resistance of at least $1.2 \mathrm{~m}^{2} \mathrm{~K} / \mathrm{W}$ for roof and floors. However, the principal instead used the guidelines for new dwellings and set the minimum thermal resistance at $2.5 \mathrm{~m}^{2} \mathrm{~K} / \mathrm{W}$. High efficiency glazing with a thermal transmittance of $1.6 \mathrm{~W} / \mathrm{m}^{2} \mathrm{~K}$ was stipulated, well below the Building Code maximum of 4.2 $\mathrm{W} / \mathrm{m}^{2} \mathrm{~K}$. Here it should be noted that this type of glazing was already commonly used and was only slightly more expensive than 'standard' double glazing. No evidence was found in 
this case study of the requirements set by the principal regarding ETMs being altered or debated by other internal stakeholders.

Compared to Case 3, Case 4 saw relatively many discussions between internal stakeholders regarding ETMs. In this renovation project, various scenarios to improve the energy performance of the houses were analysed by two internal stakeholders. The facts that the architect suggested adding apartments on top of the existing buildings blocks and that the Energy Label was introduced in national legislation at the end of 2006 seem to have focussed the attention of the stakeholders on improving the energy performance in terms of the achieved EPC. Originally, as a refurbishment, there were no requirements regarding the energy performance of the buildings. However, by the end of 2007, it was apparent that the principal was interested in achieving an improved energy performance. An Energy Label of B or C would be "acceptable" to the principal. However, this performance can hardly be seen as a wish, let alone a requirement, of the principal. At that same time, the principal stated that an EPC of 1.0 should be considered as the reference situation since the then standard EPC of 0.8 did not apply to renovation projects and was therefore unnecessary.

In all four cases, the requirements regarding ETMs were strongly connected with the institutional contexts in which the projects took place. Specific values laid down in legislation regarding energy performance, thermal resistance and thermal transmittance were adopted by the stakeholders as requirements. The assessment and calculation methods underlying the EPC and Energy Label were simply accepted and used as a design tool. The general approach seemed to be to start with the minimum level of thermal resistance allowed for walls, roofs and ground floors, and combine this with high efficiency glazing, a high efficiency boiler system (HR 107) and a DC fan based ventilation system. If this failed to satisfy the EPC requirement, then the thermal resistance would be increased until the required EPC was achieved. In the first instance, the required EPC was that stated in the current Building Code, and the lower value set in the covenant with the municipality would only be used, if the principal expected this to result in little additional investment and maintenance costs. In renovation projects, achieving an Energy Label B seemed to be viewed as a requirement. Although systems that offered the possibility of achieving an energy performance beyond an Energy Label B or an EPC of 0.9 were discussed, these were eventually rejected.

\subsubsection{Analysing the implementation of ETMs by means of used arguments}

In the four cases, various ETMs were discussed by the internal stakeholders. Techniques that were discussed and then rejected included thermal solar collectors, heat pumps and a communal wood boiler. Various arguments were used in suggesting and later rejecting these ideas. Arguments for their implementation addressed social responsibility in terms of reducing environmental emissions and the financial situation of the tenants. If future energy costs were not reduced, the fear was that it would not be long before future tenants would have difficulties in paying their rent. As such, in Case 3, the heat resistance of the ground floor, windows and roof was significantly improved, and high efficiency boilers installed, to reduce the energy costs of future tenants compared to the situation before renovation took place. 
Arguments that resisted the actual implementation of such techniques addressed both reliability and, again, finance. In Case 1, previous experiences of leaking heating systems with thermal solar collectors was the reason the principal chose not to implement this technique a second time. In Case 2, the principal did not allow space to discuss the implementation of additional ETMs due to financial constraints. In Case 3, advanced ETMs seem generally simply not to have been discussed. In Case 4, the principal opposed heat pumps on the basis of their experimental status. Also in that project, a wood boiler option was considered but rejected due to reliability concerns and excessive investments. In a meeting to consider ETMs for Case 4, it was stated that, in social housing, it was too expensive to invest in improvements that solely address the level of comfort because it was not possible to make a return on these investments by increasing rents (DWA, 2008). As such, arguments beyond the issue of user comfort are necessary for ETMs to be adopted.

A specific ETM that was implemented was the use of smart energy meters in Case 3 . This implementation was driven by Cogas (specifically Cogas Infra \& Beheer BV and Cogas Meetdiensten BV). Although smart meters do not improve the energy performance or Energy Label (because they do not reduce energy use directly or make use of renewable energy sources), smart energy meters are expected to enable residents and energy companies to make more efficient use of electric energy in the near future. A smart energy meter can provide instant information on power demand and energy use. As such, it can be regarded more as an energy measure than an energy technique. Information on energy use can, through the power grid, also be retrieved remotely.

In all the projects, high efficiency boiler systems (HR 107) and mechanical ventilation systems with a natural intake and DC fans were used. Further, high heat resistance values were achieved by applying insulation and high efficiency glass (HR++). However, these implemented techniques were not debated as such but, in the newly developed buildings, simply the way to achieve the required energy performance. In the renovation projects, these measures were part and parcel of the ambition to provide attractive houses that would be rentable for at least the next fifty years, albeit with major maintenance after a further twenty years or so.

\subsection{Reflection on decision-making on ETMs in residential building projects}

Chapter 4 started by presenting a conceptual model (as shown in Figure 4-2). The model expressed the idea that, within an institutional context, the internal stakeholders, through the project requirements, influence the implementation of ETMs. In this section, the four elements of the conceptual model are reflected upon in order to improve the model.

The internal stakeholders can be divided into two groups, which are labelled actors and nonactors. The actors are those able to directly influence the design process in which decisions are taken to implement ETMs. The studied cases show that not all internal stakeholders are able to influence the decision-making process. Given that procurement takes place on the basis of finalized designs and specifications, contractors and side-contractors only become involved in building projects after decisions on the implementation of ETMs have been taken. As such, these people were non-actors. In all the cases, the representatives of the 
social housing association, as principal and client in these building projects, took the final decision on implementing or rejecting ETMs that were suggested by architects and engineers advising on systems to be installed. In one case, the advising engineers were explicitly asked by the principal to provide information on a specific technique, a wood boiler fuelled by pellets, but the idea was later rejected.

In those cases where new buildings were to be constructed, ETMs were implemented to the extent that they were necessary to achieve the maximum EPC allowed in the Building Code. In practice this meant that at least a high efficiency HR 107 combination boiler, an efficient natural-mechanical DC ventilation system and high efficiency $\mathrm{HR}^{++}$glazing were chosen, after which the heat resistance of the floor, walls and roof were set at values that just satisfied the maximum EPC value and the minimum heat resistances given in the Building Code. As such, the preconditions employed by the actors are provided by the institutional context, and more specifically by the Building Code. Although a covenant with the municipality implied that the social housing association Beter Wonen had committed itself to achieving an EPC 10\% lower than the maximum set in the Building Code, the case studies show that this lower value does not form a precondition communicated by Beter Wonen to the designers and contractors. Rather, this $10 \%$ improvement in EPC value is more a wish or desire of the principal, and one that is only implemented when regarded as relatively easy and cheap to achieve.

In the two cases where existing buildings were to be renovated, the institutional context in the form of the Building Code also played a role even though, in such work, actors are not constrained by a maximum EPC. In renovation projects, the Building Code only requires the thermal shell of a building to achieve a relatively modest minimum level of heat resistance. Despite energy efficient systems not being required by the Building Code, efficient HR 107 combination boilers and ventilation systems were implemented in these projects without any discussion among the internal stakeholders and actors. Further, high efficiency $\mathrm{HR}^{++}$ glazing and insulation were included in the plans. Effectively, some of the ETMs required to achieve the standards for new dwellings, became part of the principal's requirements when refurbishing older dwellings. The ambition the principal, showed in these two cases, seems to be based on the ethical principle that the energy performance of existing dwellings should be kept on a par with modern standards. This ethical principle is, in the case of social housing associations, laid down in a covenant established by Aedes (the national organization for social housing associations) with the national government that states that natural gas use in existing social housing should be reduced by $20 \%$ in the period $2008-2018$.

Overall, the institutional context has a significant impact on implementing ETMs in building projects to both develop new dwellings and to renovate existing dwellings for another few decades of use. If and when the national government wants a certain energy performance to be achieved, or a certain ETM to be implemented, then the Building Code seems to be a highly respected avenue that can be used. In the period when the maximum allowable EPC was 1.0, there seemed little need for a debate on what was necessary in terms of implementing ETMs to achieve this maximum EPC value. In the studied projects of this social 
housing association discussions on the advantages and disadvantages of various possibilities only started when system installations were considered necessary to achieve new lower allowable EPC values. Overall, as shown in Figure 4-8, two categories of ETMs can be distinguished:

1. Conventional ETMs that were implemented in new buildings to achieve an energy performance in line with the Building Code. For existing buildings, the use of similar measures was related to the conscious decision that buildings should be 'up-to-date' and able to be rented for a few decades ahead. In the period 2005-2008, this resulted in including an HR 107 combination boiler, an energy efficient ventilation system, $\mathrm{HR}^{++}$glazing and insulation with a thermal resistance of around $2.5 \mathrm{~m}^{2} \mathrm{~K} / \mathrm{W}$ in renovations;

2. Innovative ETMs which were only implemented after thorough discussions among actors and determined on the basis of the principal's requirement, wish or desire that new buildings should achieve an energy performance significantly better than that set in the Building Code, and that existing buildings should achieve an Energy Label A or even better.

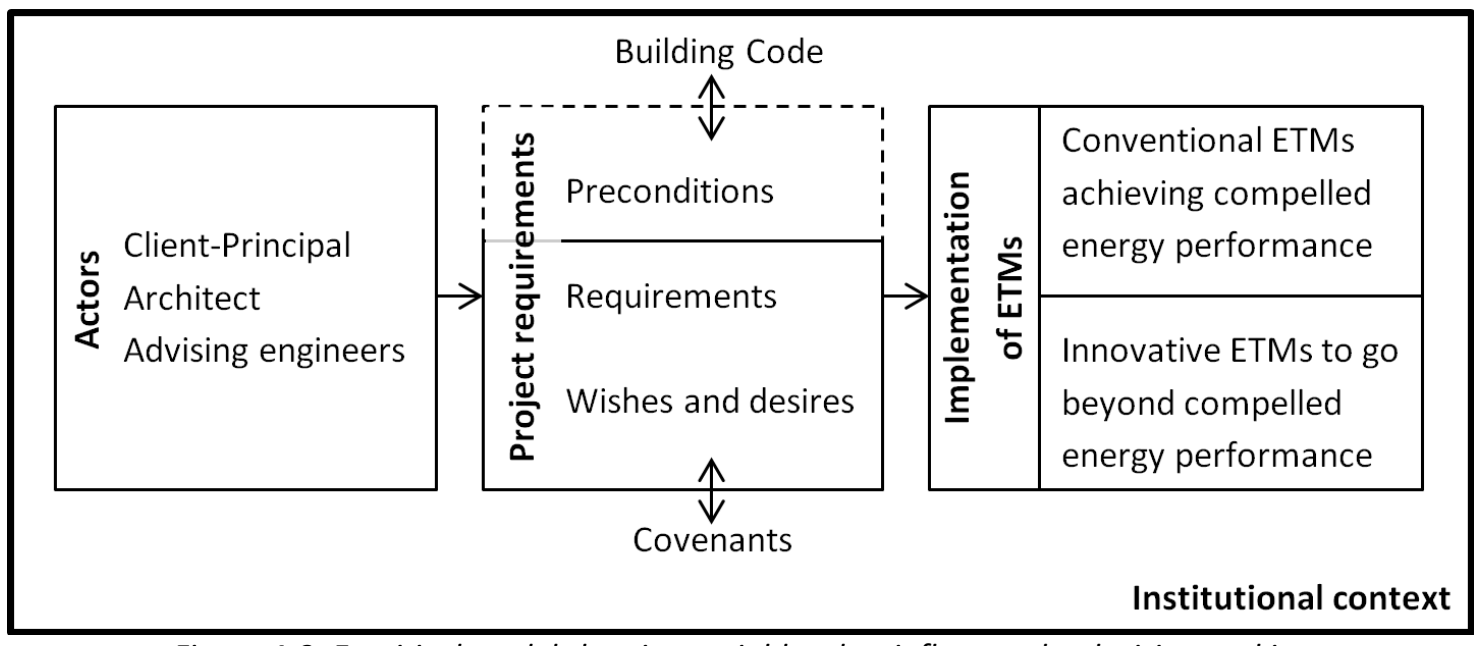

Figure 4-8: Empirical model showing variables that influence the decision-making on the implementation of ETMs in building projects.

When reflecting on the studied implementation processes in the two new-dwelling cases, it is apparent that achieving the maximum EPC, as set in the Building Code and calculated using a standardized method, is the main objective. The focus is not on individual ETMs, or on the actual energy use of future residents. The calculation method underlying this EPI was developed to calculate the building-related energy use under standard user conditions and, as was shown in earlier chapters, it is hard to compare this with the actual energy use of a household in any specific year. Although a major goal of many governments around the world is to reduce fossil energy use and emissions to the natural environment, it seems that this this is not the highest priority for the principals of building projects. Even if this had the highest priority, it could still be debated whether the actors, at least as far as those met in this case study, have the appropriate instruments to calculate and estimate the effects of ETMs on the energy use and environmental emissions of dwellings and their residents. 
In this chapter four different residential building projects of only one social housing association were studied. It needs to be addressed that other social housing associations can have other ambitions regarding the implementation of ETMs, can be differently organised, and collaborate in their projects with other stakeholders. However, even these other social housing associations operate in a comparable institutional context. It seems that not a lack of ambition, by means of good intentions, is forming a barrier in the decision-making to implement ETMs, but it is the institutional context that seems unintentionally to interfere. It is this insight that will be taken into account in developing the assessment framework for the implementation potential of ETMs.

\subsection{Conclusions decision-making on ETMs in residential building projects}

This chapter started with the question: how, in building projects, are decisions on the implementation of ETMs taken? Based on a literature study, a conceptual model was developed including the variables that are thought to influence the implementation of ETMs in building projects. This model formed the basis of a research framework to study and analyse four cases of a social housing association. Now, at the end of this chapter, the following answers can be provided to the research questions.

3A: Who decides on the implementation or rejection of ETMs in residential building projects?

Various names are in use to refer to the different people and organizations that can exert influence on the process and the object of a building project. The term stakeholders is often used in project management to refer to them in general. One person or organization among the stakeholders is expected to be the decision-maker; he, she or it decides to implement or reject one or more ETMs. This decision-maker will collect information to support this decision-making process. This information can be provided by one or more stakeholders and by others. In this thesis, those stakeholders that can actively contribute to and influence the decision-making process are referred to as actors.

In the studied cases the principal, the social housing association Beter Wonen, was the main actor that took decisions on implementing ETMs. This principal based its decisions on information provided by architects and engineers advising over systems that could be installed. However, in reality, there seemed little evidence of decision-making processes on ETMs having taken place. Although several ETMs were implemented, only those that would decrease the EPC significantly below the value stipulated in the Building Code were discussed at length. The ETMs that were implemented to meet the external institutional requirements, were regarded as standard practice that did not require additional discussion.

3B: What motivates stakeholders to implement or reject ETMs in residential building projects?

The literature obtained and the interviews with the project leaders of the cases studied revealed that a major motivation for social housing associations to implement ETMs is to ensure that affordable housing is offered in the future to a target group that would otherwise have problems in finding, financing and maintaining suitable housing. If the energy costs for these tenants can be controlled and even decreased, the housing 
association expects its rental revenues to be secure. This general argument reflects a financial perspective.

When the actors involved in the studied cases were asked for the motives behind implementing certain ETMs, answers were given that did not seem to fit this general reasoning. Some ETMs were rejected on the basis of the investment costs, as with the wood boiler in Case 4, and the experienced reliability, as with thermal solar collectors in Case 1. These two arguments fit within the financial and reliability aspects respectively, but they are not related to the future financial benefits for the residents of the dwellings, which was stated as the general reason for social housing associations to consider ETMs. No arguments were ever given that addressed environmental benefits or user comfort, aspects that are often associated with ETMs. In fact, in one project it was stated that, in social housing, it is too expensive to invest in user comfort. Nevertheless, user comfort will improve when, in renovation projects, single glazing is replaced by high efficiency double glazing and walls are better insulated.

The financial effect of an ETM on the future energy bills of tenants was never offered as a motive to reject or implement a measure. The argument that it was necessary to implement ETMs because of the law (in other words: we implement them because we have to due to the Building Code and the covenants signed) was never given as a reason. However, the achieved theoretical energy performances in the case studies seem to suggest otherwise. That is, the achieved energy performance values are roughly in line with the Building Code or signed covenants valid at the time of the work. The ETMs that were implemented (efficient HR 107 combination boilers, efficient ventilation systems, high efficiency $\mathrm{HR}^{++}$glazing and insulation) are all expected to reduce the actual energy use of a household in comparison to dwellings that lack these ETMs, but investments to further reduce energy use were not seriously pursued by this social housing association.

\section{C: What barriers hamper the implementation of ETMs in residential building projects?}

The case study shows that some ETMs were implemented in the projects, but that investments came to a halt once the energy performance stipulated in the Building Code or referred to in covenants was met. Three categories of barriers to further implementation could be distinguished, namely finance, knowledge and the energy assessment.

The literature review and interviews indicate that in social housing investments in ETMs can only be partially recouped, because the rent social housing associations can demand is limited. The project leaders of this social housing association refer to this situation as the main barrier that prevents further implementation of ETMs. Any additional investment in one of their dwellings is increasingly hard to earn back through rent. On forehand, the housing association calculates what part of the investment costs will be lost, which is that part of the investment that can not be recouped by collecting rent over the lifetime of the dwelling or within the technical lifetime of the ETM. However, at the same time social housing associations have expressed the ambition to provide affordable good quality housing. When a social housing association wants to earn back their investments in ETMs by increasing the rent, then it seems possible that the overall outgoings of the tenants will not 
necessarily be reduced, but rather partly or even completely shifted from the energy company to the social housing association.

In the interviews with the architects and an advisor on HVAC systems, a second barrier was put forward, namely knowledge, or rather lack thereof. Little is known about how to make estimates of the effects of ETMs in buildings on the energy use or costs in advance, and how to appropriately implement ETMs. The advisor on installing systems explained that the best way to get an ETM implemented was for there to be previous positive experiences. That is, ideally, the principal has positive experiences with certain ETMs. If architects and advisors are enthusiastic, this will also help lower the threshold. On the other hand, if an actor has had a negative experience with an ETM this will probably overshadow any objective information and rule out further discussion. In such situations, it is very hard to persuade a principal to take a positive decision and adopt the ETM.

A final barrier to implementing ETMs seems to arise from the current forms of EPIs and the methods used to compute them. In the case of social housing associations, the debate should be focussing on how to provide a comfortable and affordable shelter, i.e. housing, for their tenants, but the decisions taken in the projects studied seemed to focus on how to achieve the required EPI while minimizing investment and maintenance costs. The effect of an ETM is primarily valued on its effect on the EPI, and little if any consideration is given to the effect on the energy costs for future tenants. Further, some ETMs that would reduce the tenants' energy costs are not included in the methods to determine an EPI. These ETMs have little chance of being discussed by the actors and are unlikely to be implemented by the principal. Further, even though the effects of many ETMs can be incorporated in the calculations, these only estimate the effects on building-related energy use under certain user conditions and in a certain standard climate.

\section{Question 3: How in residential building projects are decisions} on the implementation of ETMs taken?

Having specifically addressed the actors, motives and barriers, it might have become apparent that decisions on ETMs in building projects are, to a certain extent, taken automatically and implicitly. If the energy performance surpasses the standard obligations set by the national government or municipality, then the decision-making process becomes explicit. In one case, different scenarios were studied with standard and improved EPCs for the proposed dwellings, even though this indicator and the software was not originally developed for this purpose. In comparing to the situation with the 'standard' energy performance, as specified in the Building Code for example, one or more ETMs were replaced or added to come to a new scenario. However, when more than one technique or measure are simultaneously considered, information is not available on what the effect of a single technique or measure on the building-related energy use might be. Although information was collected on the effects of ETMs on the EPI and, in one case, on the energy use and energy costs of the tenants, decisions were taken by the principal on the basis of perceived investment costs and reliability. 
It perhaps seems optimistic to think that principals will take more notice of the possibilities that ETMs offer to improve the value of their dwellings, both for themselves and for future residents. All the consequences and effects of a certain energy performance, and the presence or absence of ETMs, need to be clearly explained by advisors and architects to the principals and at the same time, or shortly after, by the principals to the residents. Ideally, these explanations by advisors and architects would be based on calculations that accurately take into account the specific situation of an individual dwelling and its future residents, which both need to be correctly described and visualized. Currently, the only number that seems to prevail is the investment costs. 


\section{Implementation of a novel energy technique}

Having gained insights into how the energy performance of ETMs in dwellings can be evaluated, into how their financial performance can be assessed and in what role they can play in decision-making in building projects, the main elements are in place to specify what characteristics a novel ETM ideally needs, and how it can be implemented in building projects. In this chapter, the insights discerned in preceding chapters will be applied to a new innovative technique.

\subsection{Introduction to the implementation of a novel energy technique}

Many different ETMs are available that enable principals in new building projects and owners of existing buildings to reduce the fossil energy use of a dwelling and its residents. Through ongoing research, existing ETMs are improved and new ETMs are introduced. Experimental research can demonstrate what effects a new ETM can have on the energy use of a building, but for successful implementation further characteristics need to be considered than the thermodynamic effects seen in experimental set-ups.

In this chapter, the fourth main research question will be addressed: how can a new ETM be implemented in residential building projects? Here one specific technique, the new and innovative application of Phase Change Materials (PCMs) in concrete floors, is considered. PCMs have the ability to store latent heat at an engineered temperature. As such, they can act as a form of battery that stores thermal energy.

PCMs are not widely available and PCMs are not well known in the Dutch construction industry, and have only been applied in a very limited number of buildings. In 2011, a survey was taken among 31 people attending the Sustainable Building course at the University of Twente. The interviewees were working at construction departments of municipalities, architectural firms, installation companies, contractors and social housing associations. Offered a list of sixteen different energy techniques, PCMs was the least known technique to reduce fossil energy use.

Given this situation and using Rogers' definition (that already was introduced in Section 4.3.4) of an innovation being an idea, practice, or object that is perceived as new by an individual or other unit of adoption (Rogers, 2003, p. 12), PCMs can be seen as an innovation in the construction industry. According to the Organisation for Economic Cooperation and Development (OECD), an innovation is an iterative process initiated by the perception of a new market and/or new service opportunity for a technology-based invention which leads to development, production and marketing tasks striving for the commercial success of the invention (as cited in Garcia \& Calantone, 2002, p. 112). Although many other definitions are available (Van der Kooij, 1988), this extended definition of the OECD has the advantage that it addresses tasks and includes the element of commercial success. In this chapter these tasks and striving for commercial success will play an important role, when considering the possibilities to implement PCMs in residential buildings.

Compared to many other innovative energy techniques, an advantage of PCMs is the possibility of using them in constructional elements of buildings as well as in installed 
systems. Therefore, a range of stakeholders could suggest their implementation and benefit from it, provided they are familiar with the technique and its benefits. Furthermore, PCMs can influence both natural gas use as well as electric energy use. When PCMs are used as part of the heating concept, they can reduce natural gas use. When PCMs are used as part of a cooling concept, they are likely to reduce electric energy use.

This chapter is related to the fourth research question, which is: how can a novel ETM be implemented in residential building projects? This study will focus on how PCMs can align with the interests of the government, principals, architects, advisors and residents from an energy perspective, from a financial perspective and from the perspective of a building project. These aspects will be considered in answering the following three research questions:

\section{A: What is the effect of a novel ETM on the energy performance of a dwelling?}

If stakeholders are considering implementing PCMs in concrete floors, their manufacturer or a sales representative will need to be able to specify the effects of implementation. To a certain extent, fossil energy use will be reduced, but the actual reductions are hard to estimate and implementation will not necessarily improve the assessed energy performance. Chapter 2 showed that many characteristics influence the energy needs of a particular dwelling, but that not all characteristics are taken into account when calculating the EPIs. In answering this first research question, the problems that occur when attempting to estimate the reduction in fossil energy use due to installing PCMs will be specified.

4B: What are the financial effects of implementing a novel ETM in a dwelling?

Stakeholders are often eager to know what the investment costs will be and the effects on future annual energy costs. The lower the investment costs and the greater the reduction in energy costs, the more likely it is that implementation will take place. When the implementation of PCMs is being considered, the investment costs and the expected energy cost reductions need to be assessed. In line with the research in Chapter 3, this research question focuses on the financial costs and benefits of PCMs.

4C: What are the effects for stakeholders of implementing a novel ETM in a dwelling?

Chapter 4 showed how various variables influence the implementation of ETMs in residential building projects. ETMs need to comply with the institutional context and need to be known by the stakeholders and especially the actors. The possibilities of physically implementing PCMs in new and existing dwellings need to be considered. Furthermore, the arguments for actors to implement PCMs in residential building projects need to be considered.

Together with colleagues from the Department of Construction Management and Engineering at the University of Twente, experimental research was conducted on the effects of including PCMs in concrete with results disseminated by Hunger et al. (2009) and by Entrop et al. (2011). That research will be explained in some detail in the second section of this chapter to introduce and explain the features and possibilities of PCMs in the construction industry. 


\subsection{Theoretical background on PCMs}

Firstly, this section explains PCMs in general terms. Secondly, the possibilities of using PCMs in the construction industry are discussed. Following this, the experiments carried out on the use for heating purposes of micro-encapsulated PCMs in concrete floors are presented.

\subsubsection{General specifications of PCMs}

PCMs have the ability to take in and to release thermal energy at a specific temperature when their state (solid, liquid, or gas) changes to another state under a steady pressure (Mondal, 2008). The thermal energy required or released by a material to make this transition from one state to another is called latent heat. Besides this latent heat, PCMs also store sensible heat in a similar way to all the other materials found in dwellings. The latent heat capacity of a material is generally much larger than the sensible heat capacity. For example, in the case of water, the sensible heat capacity is $4.2 \mathrm{~kJ} /(\mathrm{kg} \mathrm{K})$ whereas the latent heat capacity is $334 \mathrm{~kJ} / \mathrm{kg}$ in the ice/water phase change and $2260 \mathrm{~kJ} / \mathrm{kg}$ in the water/steam phase change (the specific values are taken from Verkerk et al., 1992).

Given that any material can exist in three different states at the right combinations of temperature and pressure, all materials can absorb and release latent energy and so could be regarded as a PCM. However, in general, the term PCM is reserved for those materials that have been designed or engineered to change state at a specific temperature under standard atmospheric pressure. Three main groups of PCMs can be distinguished (Zalba, 2003; Pasupathy et al., 2008a). The first group consists of organic PCMs, encompassing alkanes, waxes and paraffins. The second group are the inorganic PCMs consisting of hydrated salts. The final group are the so-called eutectics, which are mixtures of organic or inorganic chemical compounds or elements that have a single chemical composition. An eutectic system solidifies at a lower temperature than any other composition of the same ingredients (Smith \& Hashemi, 2006).

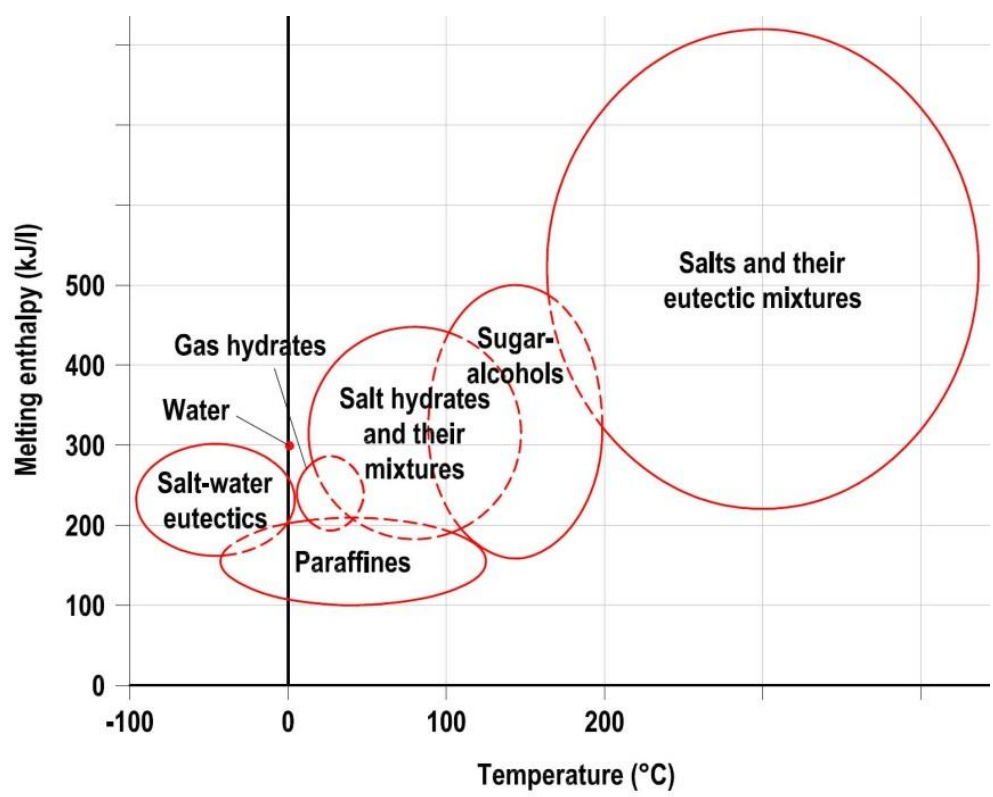

Figure 5-1: Overview of latent heat capacities and melting temperatures of different groups of PCMs (Dieckmann as cited in Baetens et al., 2010). 
Salts, hydrated or as part of a eutectic system, can offer a high latent heat capacity or melting enthalpy, as is shown in Figure 5-1, but only at temperatures well above those required in dwellings. Further, the stability of their performance is debatable because, after some cycles of melting and solidification, the need for nucleating agents can become imperative (Pasupathy et al., 2008a), reducing the ability of the PCM to store latent heat. Paraffins melt at more appropriate temperatures, but have relatively low latent heat capacities compared to other PCMs. Furthermore, paraffins are flammable, although this risk can easily be reduced by proper encapsulation. For a specific purpose, the thermodynamic, kinetic, chemical and economic features of PCMs need to be considered in choosing or developing the right product (Abhat, 1983). In practice, melting occurs in a small temperature range where the transition from liquid to solid, or vice versa, takes place. In the next section the possibilities of PCMs to reduce the fossil energy use of buildings are discussed.

\subsubsection{PCMs in buildings}

In buildings, energy is used in many ways. In the Netherlands, thermal energy is needed to come to a comfortable indoor climate. Natural gas is often used to provide this thermal energy during the heating season. On the other hand, indoor temperatures can also rise beyond comfortable levels, especially during summer, and then a cooling system may be used to reduce the indoor temperature. In this case, electric energy is often used. Many variables play a role in what the users of a building perceive to be a comfortable temperature. As Van der Linden et al. (2006) noted, most people have an increasing tolerance of higher indoor temperatures as ambient temperatures exceed approximately 10 to $12{ }^{\circ} \mathrm{C}$. Below these temperatures, the acceptable band is $\approx 2.5^{\circ} \mathrm{C}$ and in a hot summer period this increases to $\approx 4.3^{\circ} \mathrm{C}$. During a winter's day with an ambient temperature of $3{ }^{\circ} \mathrm{C}$, the indoor temperature preferably needs to be between 20.5 and $23{ }^{\circ} \mathrm{C}$. With an ambient temperature of $9{ }^{\circ} \mathrm{C}$ in spring or autumn, the indoor temperature needs to be between 21.2 and $23.7^{\circ} \mathrm{C}$. However, when the average ambient temperature on a summer's day reaches $22{ }^{\circ} \mathrm{C}$, the preferred indoor temperature can be between 22.7 and $27.0{ }^{\circ} \mathrm{C}$. PCMs can potentially help to keep the indoor building temperatures in the ranges that are regarded as comfortable by most building users.

Many PCMs are available that have melting temperatures close to these favoured indoor temperatures (Zalba et al., 2003; Baetens et al., 2010). At the ambient temperature falls below these melting temperatures, the latent heat in the PCMs will be emitted to the surroundings. When the ambient temperature rises, the thermal energy necessary for liquefaction will be taken from the surroundings. The PCMs will thus act as a battery storing thermal energy. This makes it possible to increase the thermal capacity of buildings and to reduce extreme temperatures. Pasupathy et al. (2008a) distinguish three ways to use PCMs in buildings: 
1. In walls (e.g. Peippo et al., 1991; Cabeza et al., 2007; Chen et al., 2008);

2. In other building components (e.g. Nagano et al., 2006; Pasupathy et al., 2008b) and;

3. In separate heat or cold storages (e.g. Esen \& Ayhan, 1996; Esen et al., 1998; Esen, 2000; Zhu et al., 2009).

These three ways of using PCMs cover two basic concepts. The PCMs can be applied passively in the construction, where they become a building characteristic, or they can be applied actively as part of the HVAC systems to heat or cool the building, when they become a system characteristic. This study focuses on the passive use of PCMs in concrete floors. Many scholars have conducted research on the use of PCMs in the building material concrete.

Zhang et al. (2007, p. 654) noted that the "combination of buildings materials and PCM is an effective way to enlarge the thermal energy storage capacity of building components for the purpose of direct thermal energy storage in buildings". Furthermore they stated that "porous building materials have advantages of low cost, ease of fabrication and widespread application in building industries" (ibid., p. 654). Concrete is a commonly used material in buildings. The heat capacity and high density of concrete combined with the characteristic feature of PCMs of storing latent heat can result in new concrete mixes in which high temperatures can be avoided during hydration improving the compressive strength and durability. Further, this can result in new or better construction elements that, for example, could store thermal energy provided by solar irradiation (Hunger et al., 2009). Concrete incorporating PCMs can be used to store thermal energy, thus lowering the energy use of buildings and increasing thermal comfort (Khudhair \& Farid, 2004; Bentz \& Turpin, 2007; Pérez-Lombard et al., 2008).

Bentz and Turpin (2007) specified potential applications of PCMs in concrete by analysing the calorimetry of PCMs embedded in porous lightweight aggregates. They addressed the need for further research and field testing. Hunger et al. (2009) showed that microencapsulated PCMs can be applied in self-compacting concrete mixes reducing the peak temperatures during hydration. Cabeza et al. (2007) offered valuable field data when using micro-encapsulated PCMs in concrete walls. Li et al. (2009) used micro-encapsulated PCMs in composite floor elements made out of high density polyethylene and wood. However, the research at the University of Twente on the passive use of PCMs in concrete floors for heating purposes seems to have been the first in this area.

\subsubsection{PCMs in concrete floors}

There are several reasons to study the implementation of PCMs in concrete floors for heating purposes. First of all, as already noted, PCMs are not well-known in the Dutch construction industry. Secondly, stakeholders that opt to implement ETMs want them to be reliable and easily maintained. They also need to fit easily in current construction practices. Concrete floors containing PCMs do not need maintenance and are a passive part of the construction of a building. As such, this idea would seem to fit well with these stakeholder demands. Including PCMs in these floors makes them part of the construction for multiple decades. Finally, solar irradiation provides possibilities to reduce the use of fossil fuels in 
buildings, even in the Netherlands, and so this development of a new energy technique that makes use of solar irradiation seems attractive.

Conceptually, in moderate climates, concrete floors incorporating PCMs could be used to store thermal energy provided by solar irradiation that directly enters dwellings through the windows during the day. This solar energy could then be released in the evening to reduce the energy demand for thermal comfort during the relatively cold night. Depending on the transition temperature, which should be around a comfortable room temperature, the PCMs can be expected to be most effective during spring and autumn. In these seasons, daylight and ambient temperatures should be sufficient to 'charge' the PCMs during daytime, and during the evening or night the ambient temperatures should be low enough to 'discharge' the PCMs. An experimental set-up was developed to test the viability of using PCMs in concrete floors for this space heating purpose.

In order to determine how much the energy use can be reduced by applying PCMs in concrete floors, experiments were conducted in the Dutch climate. For practical considerations, an experiment was developed that used boxes rather than real houses to test the effects that PCMs in concrete floors had on indoor temperatures. This experimental set-up (see Figure 5-2), consisted of four insulated boxes with concrete floors, two with and two without PCMs. The effects of the PCMs on the indoor temperature were studied by monitoring weather conditions and indoor temperatures at different locations in the boxes.

In this experiment, Micronal DS $5008 \mathrm{X}$ micro-encapsulated PCMs produced by BASF were used. According to the manufacturer's product specifications, the latent heat capacity is 110 $\mathrm{J} / \mathrm{g}$ and the transition temperature is $23^{\circ} \mathrm{C}$ (BASF, 2005). However, product information that was released three years later, speaks of a latent heat capacity of $100 \mathrm{~J} / \mathrm{g}$ (BASF, 2008). Research by Hunger et al. (2009, p. 733) showed that the melting and solidification of the paraffin mix within the polymethyl methacrylate capsules occurs over a small temperature range. By using differential scanning calorimetry, they measured an exothermic enthalpy for solidification of $102.8 \mathrm{~J} / \mathrm{g}$ with an onset temperature of $22.12{ }^{\circ} \mathrm{C}$, and an endothermic enthalpy for melting of $99.7 \mathrm{~J} / \mathrm{g}$ with an onset temperature of $25.20^{\circ} \mathrm{C}$. Although Micronal is offered for use as a support for or a replacement of cooling systems, there were no PCMs with lower melting temperatures available on the Dutch market at that time.

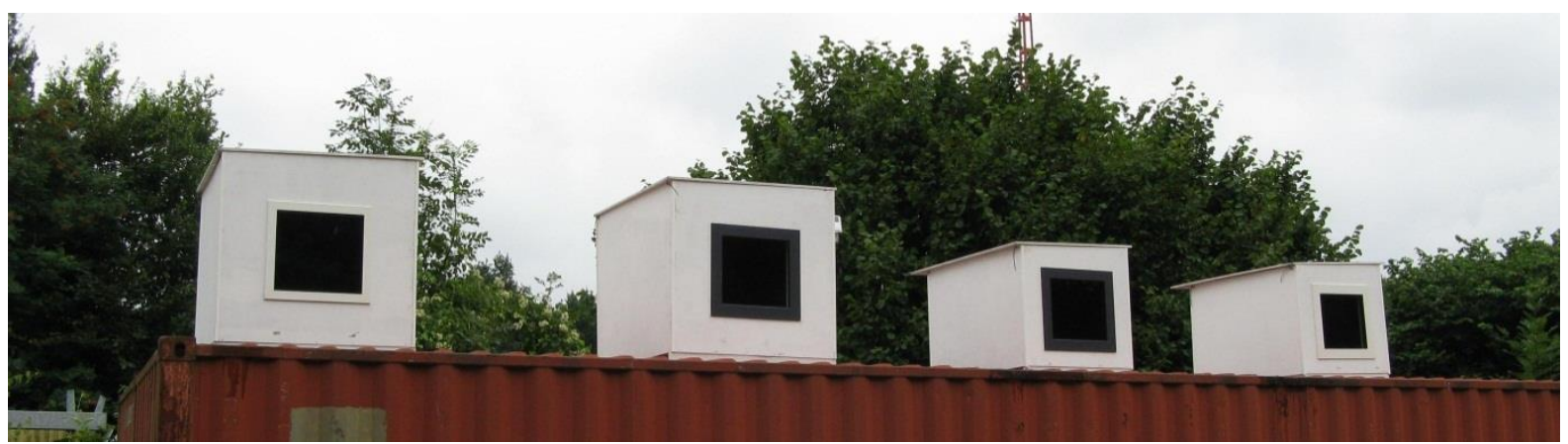

Figure 5-2: Four insulated boxes containing concrete floors, with and without PCMs, as part of the experimental set-up at the University of Twente. 
Based on the melting temperature and considering different weather conditions, three situations can be distinguished regarding the thermal battery that PCMs form:

1. at low levels of irradiance and low ambient temperatures, the PCMs in the concrete have a temperature below $22.1^{\circ} \mathrm{C}$ and are, therefore, not thermally charged;

2. with significant irradiance and ambient temperatures above $25.2{ }^{\circ} \mathrm{C}$ during the day, and falling below $22.1^{\circ} \mathrm{C}$ overnight, most or even all the PCMs are thermally charged during daytime and discharged during the night;

3. with high levels of irradiance and high ambient temperatures continuously above $22.1^{\circ} \mathrm{C}$, all the PCMs remain thermally charged throughout day and night.

Although the Netherlands are not known for their high temperatures or high levels of solar irradiance, the data collected in June 2010 showed that the PCMs in combination with an advanced glazing system helped to increase minimum temperatures by $7 \pm 3 \%$ in the boxes with light weight thin insulation. Furthermore, it helped to decrease maximum temperatures by $11 \pm 2 \%$ in the boxes with light weight thin insulation and $16 \pm 2 \%$ in boxes with heavy weight thick insulation. Analysing the experiments raised considerations which one should be aware of when applying PCMs in dwellings:

1. the sensible heat capacity of conventional building materials used in floors, walls and roofs of actual dwellings will probably be relatively large compared to the latent heat capacity of the amount of PCMs that can be applied in concrete floors without reducing their compressive strength significantly. In the experiments, $5 \%$ of the floor mass was made up of PCMs;

2. the ratio of the internal volume to the floor surface that is illuminated and heated by solar irradiation would be significantly larger in an actual house than in the experimental boxes;

3. the melting and solidification temperatures of the PCMs used are above the ideal for a heating technique that aims to reduce fossil fuel use by increasing the minimum indoor temperature through solar energy.

Although the latent heat capacity and the melting temperature of the used Micronal leave room for further improvement, the investments needed for further research can only be justified if there is a realistic chance that this energy technique will be implemented by actors in building projects. Encouraged by the positive results found in the literature and demonstrated in these experiments, a further study on the possibilities for implementing micro-encapsulated PCMs in concrete floors has been undertaken.

\subsection{Assessing the effects of PCMs on the energy performance of dwellings}

This section starts with analysing the effects of the PCMs on the energy performance of a dwelling. It will be explained how characteristics that influence the energy use of dwellings can also have an impact on the effects of the PCMs. Then, the possibilities for PCMs to influence the EPIs will be studied. Finally, the effects in the case of a reduction in fossil fuel use are addressed. 


\subsubsection{Characteristics of dwellings influencing the performance of PCMs}

When Phase Change Materials are included in a dwelling as an energy technique, their impact on the energy use of the dwelling and its residents depends not only on the specifications of the PCM itself, but also on the environment in which the PCMs are located. Figure 5-3 illustrates how the solar irradiation (an environmental characteristic) enters a dwelling through the glazing (a building characteristic) to supply the floor containing PCMs with thermal energy. The dwelling, located in an external environment, provides an internal environment that needs to offer appropriate conditions if the PCMs are to be used effectively and efficiently. The overall effect of the PCMs on the fossil energy use of a dwelling and its residents will depend on the context in which they are applied. It was shown in Chapter 2 that five categories of characteristics can be distinguished when considering dwellings and their residents. PCMs can either be part of construction elements or of an installed HVAC system. Considering here the passive use of PCMs in concrete floors, then various characteristics are important. In this section, all the effects of PCMs in concrete floors will be qualitatively assessed using the framework of characteristics that was developed in Chapter 2. The relevant environmental characteristics, occupational characteristics, building characteristics, system characteristics of the dwelling and the appliances in the dwelling will now be explained.

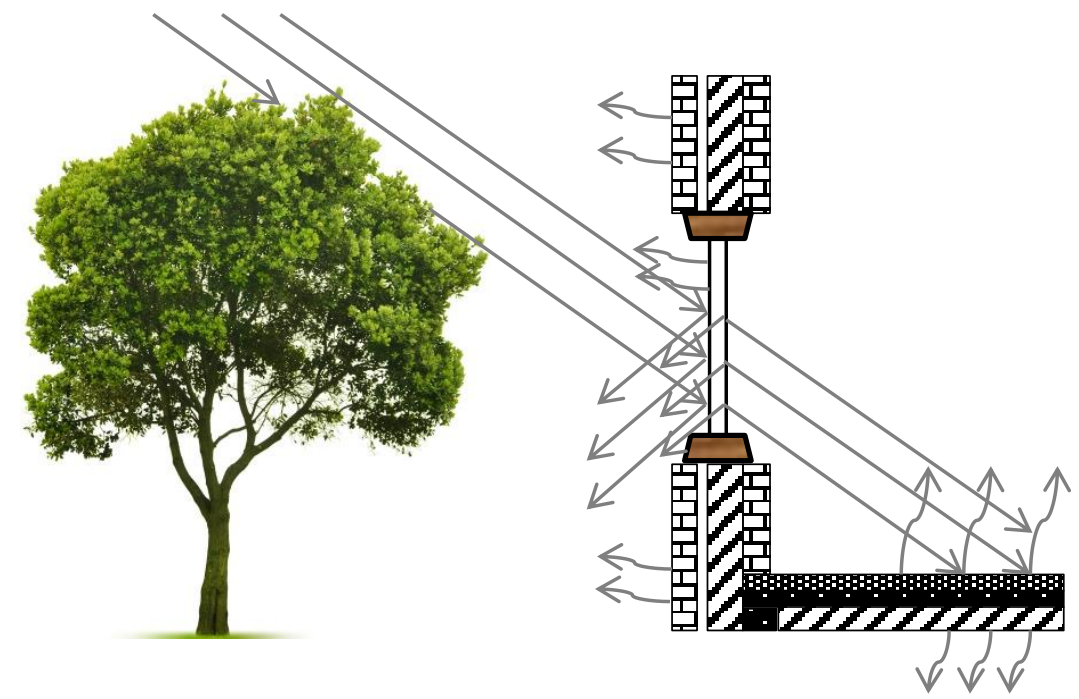

Figure 5-3: Cross-section showing how solar energy can enter and indirectly leaves a dwelling.

\section{Environmental characteristics}

The temperature of the concrete directly surrounding the PCMs influences to what extent the PCMs are charged and discharged. Hence, the ambient temperature, which influences the indoor temperature, and the ground temperature, that together with the ambient temperature influences the temperature in the air space below the floor, and the solar irradiance, that is capable of warming the top surface of the floor, are the important environmental characteristics to consider when passively applying PCMs in concrete floors for heating purposes.

Figure 5-4 shows how much solar irradiance is available and typical ambient temperatures in the Netherlands. Over a period of more than twenty years, the average solar irradiation in 
de Bilt has been $2.67 \mathrm{kWh} / \mathrm{m}^{2}$ per day, equivalent to $974 \mathrm{kWh} / \mathrm{m}^{2}$ annually (Velds, 1992). In the period 1981 to 2010, the average temperature in de Bilt was $10.1{ }^{\circ} \mathrm{C}$ (KNMI, 2011). To what extent the temperature of the concrete floor responds to the ambient temperature and solar irradiance depends, in the case of passive use of PCMs, especially on the building characteristics.

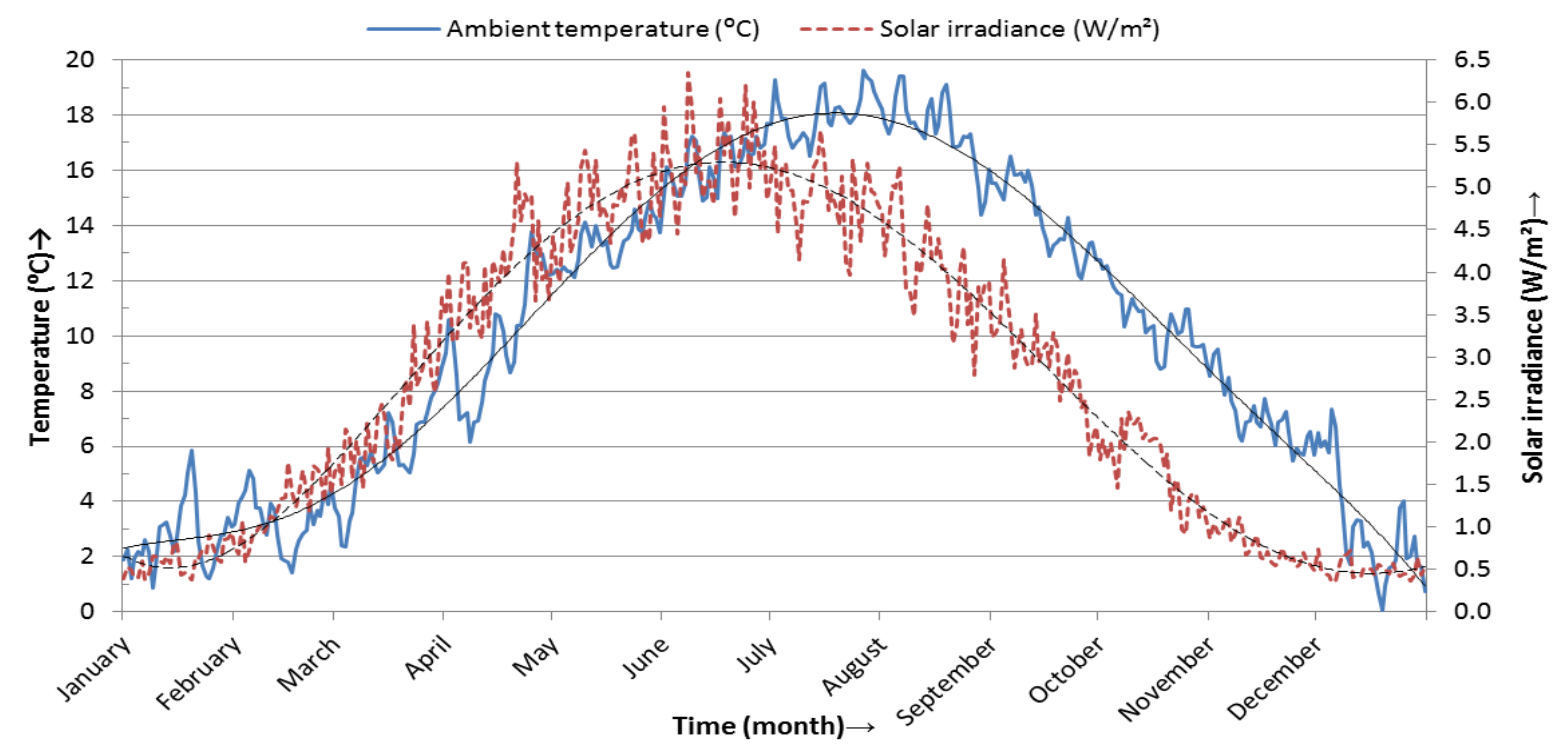

Figure 5-4: Solar irradiance and ambient temperatures in Twente, data from 2001 to 2010 (KNMI, 2010).

\section{Building characteristics}

A concrete ground floor has a relatively high sensible heat capacity. Typically, it has insulation on the underside and could include a top layer that contains PCMs. The floor forms a boundary between the ground, or crawling space, and the internal heated space. The ground floor often contains a living room, dining room, kitchen and hallway. It would also be possible to apply PCMs in other floors. Although the ground temperature is not an influence with upper floors, temperature differences can still exist, for example between that in the living room and in the bedrooms above. These floors are often not insulated, but still have a relatively high sensible heat capacity.

In both situations, solar irradiance provides radiation through the windows located in the walls. This solar irradiance is converted into thermal energy when it hits the floor. The availability of solar irradiance will depend on the orientation of the dwelling, characteristics of the windows and the glazing, and the presence of shading from surrounding buildings and vegetation. Depending on the indoor temperature, some of the thermal energy provided by solar irradiance will be used to increase the indoor air temperature and some will be stored in the form of sensible and maybe latent heat in materials. Latent heat will only be stored if the temperature of the concrete surrounding the PCMs exceeds the melting temperature of the PCMs. Here, the exact location of the PCMs in the floors is expected to have an effect. The closer the PCMs are to the surface, the lower the thermal resistance of the concrete surrounding the PCMs will be (of course the concrete's thermal conductivity stays the same), and this will enable the thermal energy provided by the solar irradiation to be stored more easily in the form of latent heat. 
During the heating season, the indoor air temperature, which significantly influences the floor temperature, is for a large part of the day controlled by the residents through a thermostat. Without this 'interference', it would depend on a range of factors including the ambient temperature, occupational characteristics, building characteristics and appliances in use. This brings us to the occupational characteristics.

\section{Occupational characteristics}

The performance of PCMs in the sense of their ability to lower the energy use of a dwelling depends on how the residents use their thermostat. If PCMs are charged by solar irradiance then they can contribute to reducing fossil fuel use, primarily in late spring and early autumn. In high summer, PCMs can help by reducing peak temperatures, if they can be discharged during the night. In the heating season, the use of the thermostat is expected to depend on the residents' living patterns and their preferences regarding indoor temperature. In the heating season, a comfortable indoor temperature is traditionally provided by the heating system.

In a family with parents employed fulltime and children that daily attend school, the heating system is often turned off during the day. In the morning all wake up, get prepared and leave the house, and maybe without needing to heat spaces if the floors contain PCMs. During their absence, the PCMs would ideally be recharged by solar irradiation. In the late afternoon, or early evening, the family return and the thermostat is probably set at a temperature of around $20^{\circ} \mathrm{C}$, which is regarded by many people as comfortable. Ideally, this will be slightly lower than the transition temperature of the PCMs in the concrete floor. Only a small difference is required because a thermostat is typically located at around 1.5 metres above the floor, where the temperature is slightly higher than at floor level. The PCMs will then experience a slightly lower ambient indoor temperature which will trigger them to solidify and so PCMs offer thermal energy to the surrounding concrete in the floor.

Provided that the solar irradiation was sufficient to charge the PCMs in the floors during the daytime. Furniture and belongings covering the floor can in this regard form barriers for solar irradiation in heating the floor. The number of residents will indirectly influence the performance of PCMs. It can be anticipated that more residents will result in more furniture and belongings covering the floor. Also, having more occupants increases the likelihood of interference with indoor temperature controls.

\section{System characteristics}

There is also the possibility of charging the latent heat capacity of the floor by thermal energy, provided by the heating system that consumes natural gas, rather than by thermal energy provided by solar irradiation. This will occur if the thermostat is set at a temperature exceeding the melting temperature of the PCMs while the PCMs are uncharged. This would likely occur after the residents went to bed during the heating season. Normally, the thermostat, which would have been set at a temperature exceeding the melting temperature of the PCMs prior to retiring for the night, is turned down and the indoor temperature will drop such that the PCMs solidify. The latent energy stored in the PCMs will then be released. As long as the solidification process continues, the temperature of the 
floor and the air directly above it will remain close to the melting temperature of the PCMs. In this situation, the thermal energy provided earlier that day by burning natural gas is released to an indoor space, when it is not required. Overall, this will probably increase fossil energy use relative to a situation in which the concrete floors do not contain PCMs.

Although low temperature heating systems are generally regarded as a relatively sustainable technique that enables residents to reduce fossil energy use compared to the traditional medium to high temperature radiator-based heating systems, it is not clear which approach would work best with a floor containing PCMs for heating purposes. In both situations, it is possible that the PCMs will be charged by thermal energy provided by the heating system. The aim of the 'box' experiments was to reflect on the passive use of PCMs, and so the boxes were not equipped with a heating system. This situation is comparable to certain sustainable housing concepts such as earth ships and passive houses.

\section{Appliances in the dwelling}

The last group of characteristics to consider are the appliances in the dwelling. Within this category, sun shades, blinds or awnings can strongly influence the extent to which the PCMs in the concrete floor can be charged by solar irradiance. When the PCMs are charged, an electronic system that monitors the solar irradiance level, wind speed and indoor temperature could be used to control electric motors to lower or withdraw the shades, blinds or awnings.

Other appliances in a dwelling will provide some thermal energy some of the time since almost all electric energy used is eventually converted into thermal energy. In very well insulated houses, appliances can contribute significantly to the thermal energy needed. This thermal energy increases the indoor temperature and so could also charge the PCMs in the floor. An oven used for cooking can provide a relatively high level of thermal energy in a short period, and this could locally charge some of the PCM.

\section{PCMs in their context}

All the categories of characteristics listed in Chapter 2 can have some influence on PCM use (see Table 5-1). This shows that many variables play a role when explaining how the performance of PCMs is affected by the context. Architects and advisors on building conditions could use the listed characteristics to stepwise explain to the principal, and maybe future owners and residents, which elements need to be taken into account if one wants to effectively and efficiently use PCMs in concrete floors.

If PCMs are implemented in a dwelling that is then used by its residents in a certain way, the PCMs become a part of a complex system where many different variables influence each other and the final energy performance of the whole. The overall effect of PCMs on the energy use of a dwelling and its residents can therefore probably only be accurately assessed through a real-life experiment where the energy use of several similar houses with and without concrete floors containing PCMs, with comparable residents and appliances and similar use, are carefully monitored over comparable weather conditions across all seasons. Such experiments are very difficult to organize. Therefore, when expressing views on the 
effects of PCMs in concrete floors, one needs to make clear what circumstances are assumed.

Table 5-1: Characteristics that directly and indirectly influence the performance of PCMs in concrete floors in dwellings.

\begin{tabular}{|c|c|c|}
\hline & Characteristics & Explanations \\
\hline \multirow{5}{*}{ 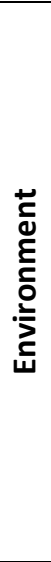 } & $\begin{array}{l}\text { 6. Solar } \\
\text { irradiance }\end{array}$ & $\begin{array}{l}\text { The available solar irradiance directly influences the indoor temperature of } \\
\text { dwellings and, after passing through the glazing and warming the floor, the charging } \\
\text { process of PCMs embedded in the concrete floor. }\end{array}$ \\
\hline & $\begin{array}{l}\text { 4. Air } \\
\text { temperature }\end{array}$ & $\begin{array}{l}\text { The outdoor air temperature directly influences the temperature in the ventilated } \\
\text { crawl space below the ground floor, and indirectly the indoor temperature of } \\
\text { dwellings. }\end{array}$ \\
\hline & $\begin{array}{l}\text { 5. Ground } \\
\text { temperature }\end{array}$ & $\begin{array}{l}\text { Depending on the type of floor and construction, the ground temperature can } \\
\text { directly influence the floor temperature through conduction or indirectly by } \\
\text { convection in the crawl space. }\end{array}$ \\
\hline & $\begin{array}{l}\text { 1. Surrounding } \\
\text { buildings }\end{array}$ & $\begin{array}{l}\text { Other buildings near a dwelling can block solar irradiance at certain times and can } \\
\text { therefore indirectly influence the performance of PCMs. }\end{array}$ \\
\hline & $\begin{array}{l}\text { 2. Surrounding } \\
\text { vegetation }\end{array}$ & $\begin{array}{l}\text { Vegetation near a dwelling can block solar irradiance at certain times and can } \\
\text { therefore indirectly influence the performance of PCMs. }\end{array}$ \\
\hline \multirow{4}{*}{ 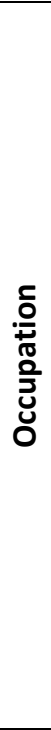 } & $\begin{array}{l}\text { 3. Residents' } \\
\text { patterns of } \\
\text { living }\end{array}$ & $\begin{array}{l}\text { The presence of residents will result in a need for heating during the heating season } \\
\text { (and maybe cooling during high summer). The particular use of the thermostat will } \\
\text { influence what energy is stored in PCMs and whether this thermal energy is } \\
\text { provided by solar irradiance or through the heating system by fossil fuels. }\end{array}$ \\
\hline & $\begin{array}{l}\text { 4. Preferred } \\
\text { internal climate }\end{array}$ & $\begin{array}{l}\text { If residents prefer an indoor temperature above the transition temperature of the } \\
\text { PCMs, the possibility exists that the PCMs will not discharge or be charged by solar } \\
\text { irradiance. This means that the transition temperature of the PCMs needs to match } \\
\text { the residents' preferences if they are to work effectively. }\end{array}$ \\
\hline & $\begin{array}{l}\text { 2. Age of } \\
\text { residents }\end{array}$ & $\begin{array}{l}\text { In general, elderly residents prefer higher room temperatures than young people. } \\
\text { Elderly people are usually more often at home, which means that the heating } \\
\text { system will be on more often and solar irradiance will have little chance to charge } \\
\text { PCMs in the floors. Thus, the age of the residents can indirectly influence the } \\
\text { performance of the PCMs. }\end{array}$ \\
\hline & $\begin{array}{l}\text { 1. Number of } \\
\text { residents }\end{array}$ & $\begin{array}{l}\text { The number of residents will indirectly influence the performance of PCMs. It can be } \\
\text { anticipated that more residents will result in more furniture and belongings covering } \\
\text { the floor. Also, having more occupants increases the likelihood of interference with } \\
\text { indoor temperature controls. }\end{array}$ \\
\hline \multirow{3}{*}{ 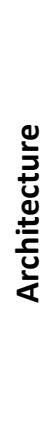 } & 1. Floo & $\begin{array}{l}\text { The more PCM that is in the concrete floor in range of solar irradiance entering the } \\
\text { dwelling, the more free thermal energy that can be stored. Therefore, the floor area } \\
\text { is of direct influence. }\end{array}$ \\
\hline & $\begin{array}{l}\text { 2. Transmission } \\
\text { surface }\end{array}$ & $\begin{array}{l}\text { The transmission surface or thermal shell of a dwelling influences how much solar } \\
\text { irradiance can enter and reach the floor. It also effects how quickly thermal energy } \\
\text { can leave the dwelling. Therefore, the transmission surface has both direct and } \\
\text { indirect influences. }\end{array}$ \\
\hline & $\begin{array}{l}\text { 3. Internal } \\
\text { space allocation }\end{array}$ & $\begin{array}{l}\text { Internal walls obstruct solar irradiance. Floors on the north side of a Dutch dwelling } \\
\text { see little sunlight. Further, not all rooms are heated (e.g. bedrooms). Therefore, } \\
\text { internal space allocation has both direct and indirect influences. }\end{array}$ \\
\hline 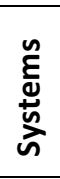 & $\begin{array}{l}\text { 1. Heating } \\
\text { concept }\end{array}$ & $\begin{array}{l}\text { Floors incorporating PCMs can be installed in a wide range of dwellings with heating } \\
\text { systems that make use of solar collectors, heat pumps, natural gas combination } \\
\text { boilers, radiators, wall heating and floor heating. The amount of fossil fuels saved } \\
\text { will depend on the particular role of the PCMs in the total heating system. }\end{array}$ \\
\hline $\begin{array}{l}\stackrel{\text { Uू }}{\frac{\pi}{0}} \\
\frac{.0}{0} \\
\frac{0}{2}\end{array}$ & $\begin{array}{l}\text { 3. Presence of } \\
\text { shades }\end{array}$ & $\begin{array}{l}\text { Shades and awnings can prevent the PCMs from charging. However, if a room } \\
\text { temperature significantly increases above the transition temperature of the PCMs, } \\
\text { then shades or awnings can be (automatically) lowered to prevent overheating and } \\
\text { the necessity of a cooling or air conditioning system. }\end{array}$ \\
\hline
\end{tabular}




\subsubsection{Including PCMs in energy assessment methods}

It was explained in the previous section how many variables can play a role in determining how well PCMs function in dwellings. This section explains how PCMs can be included in the Dutch energy assessment methods that result in the EPIs described in Chapter 2.

The use of PCMs in dwellings for cooling or heating, either passively in building materials or actively in installed systems cannot directly be assessed in any of the three assessment and calculation methods available. It is not possible to include this energy technique in any of the

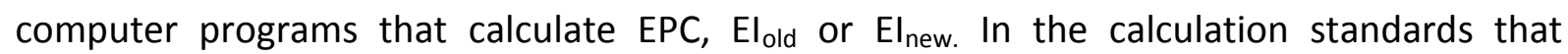
underlie these EPIs, the existence of PCMs is not mentioned. Consequently, PCMs cannot contribute to achieving a target EPI.

The effect of PCMs can theoretically be taken into account in certain forms of active use. The term active here refers to their incorporation in installed systems. If PCMs are for example integrated in a boiler system for space and/or tap water heating, or integrated in a heat exchanger of a ventilation system, they can contribute to the efficiency of that component of the system. If an official certificate, as provided by KOMO or Gastec, specifies the efficiency of a heat exchanger or boiler system incorporating PCMs, then the effects of the PCMs will indirectly be incorporated in calculating EPIs.

As with any passive use of PCMs, the use of PCMs in concrete floors for heating purposes cannot be taken into account in the assessment methods available for calculating EPIs. In calculating the EPC, the sensible heat capacity of a building is taken into account in determining the energy required for cooling to come to a comfortable indoor temperature during summer. This is the amount of energy needed to keep the indoor temperature below a maximum of $24{ }^{\circ} \mathrm{C}$. The 'weight' of the construction is assessed by distinguishing three options that are based on two categories of construction materials (NNI, 2004a):

1. Heavyweight construction materials, such as stone and concrete, with an average mass across the total floor surface area of the dwelling of more than $100 \mathrm{~kg} / \mathrm{m}^{2}$;

2. Miscellaneous lightweight construction materials with an average mass across the total floor surface of $100 \mathrm{~kg} / \mathrm{m}^{2}$ or less.

The three options one can chose from in assessing dwellings are (NNI, 2004a):

1. Traditional heavyweight dwellings with massive walls and floors. Such dwellings are assumed to haves an average heat capacity of $450 \mathrm{~kJ} / \mathrm{m}^{2} \mathrm{~K}$ related to the heated floor surface;

2. Lightweight dwellings with lightweight walls and construction design, but heavyweight floors. Such dwelling have an assumed average heat capacity of approximately $350 \mathrm{~kJ} / \mathrm{m}^{2} \mathrm{~K}$ related to the heated floor surface;

3. Lightweight dwellings with a timber frame construction and lightweight floors. Here, the dwelling is assumed to have an average heat capacity of approximately $80 \mathrm{~kJ} / \mathrm{m}^{2} \mathrm{~K}$ related to the heated floor surface.

The best, i.e. lowest, EPC is calculated if the first option is chosen. When the third option is chosen this gives the highest EPC, with a value that is approximately 0.05 higher than the first. Although PCMs only offer a latent heat capacity, the negative thermal effects one can 
experience in lightweight constructions due to the low sensible heat capacities can be reduced or even overcome by using PCMs. Based on an equivalence idea, a lightweight construction where PCMs were properly implemented, could be assessed as a traditional heavyweight one. However, in most cases, where a principal opts for a traditional dwelling constructed out of heavy materials, the implementation of PCMs will not result in a better $\mathrm{EPC}, \mathrm{El}_{\text {old }}$ or $\mathrm{El}_{\text {new. }}$ In these cases, PCMs will have little added value for the principal in terms of complying with the Dutch Building Code. In such circumstances, a principal will first have to ensure that the design meets EPC requirements before considering any other ETMs, such as PCMs, if there is any budget left.

An inventor or organization aiming to get PCMs implemented in the construction industry is advised to ensure that the technique will be assessed in the prevalent energy assessment method employed in the specific country. In the Netherlands, the National Normalisation Institute, NEN, and the Institute for Studying and Stimulating Research in the field of building installation systems, ISSO, are both involved in developing standards for EPIs. New energy techniques or measures can be introduced to these organizations when the efficiency and effectiveness of the ETM is clear and indisputable. The costs of experiments to scientifically determine the effects of a new ETM can act as a major bottleneck, especially for start-ups.

\subsubsection{Reducing fossil energy use in dwellings}

Residents generally want to increase their comfort and reduce their costs through a decrease in natural gas $\left(\mathrm{m}^{3}\right)$ and electric energy $(\mathrm{kWh})$ use. When a principal wants to get a building permit for a new dwelling, the plans need to demonstrate compliance with the EPC requirements. One of the reasons why the Dutch national government aspires to lower energy use is to reduce greenhouse gas emissions. When attempting to introduce an energy technique based on PCMs, it is therefore necessary to explain or model how much the energy use and the use of fossil fuels can be reduced.

Unfortunately, the effects of incorporating PCMs in concrete floors are hard to model and to estimate. Shrestha et al. (2011) have implemented an insulation system incorporating PCMs in Energy+, an energy simulation computer program available in the USA. Müthing (2010) developed a model in COMSOL, a software package for multiphysics finite element analysis, and Prins (2012) in VENSIM, a software package for dynamic simulations. Both of these latter two models were able to simulate the effects of PCMs in concrete floors on the indoor temperature of the boxes used in the experiments conducted at the University of Twente.

PCM Express is a software package developed at the request of BASF, the manufacturer of several PCMs that can be used in buildings. PCM Express is a planning and simulation program for buildings PCMs. "It aims to support architects and planners in planning by facilitating reliable decision-making in dimensioning the system and by speeding up the market launch of PCMs" (Valentin, 2013). Although the possibilities of incorporating a specific building design and accompanying HVAC systems in this software are limited, it can indicate how indoor temperatures will be influenced by the use of PCMs in different construction components. However, the program focuses only on the passive use of PCMs for cooling, not for heating. 
The models of Müthing (2010) and Prins (2012), which reflect the experiment with the four boxes, excluded the use of heating systems, cooling systems, shading, internal heat loads, metabolism of occupants and any occupant interference. Despite this, the complex behaviour of the PCMs was already hard to model properly. PCMs provide a latent heat capacity that increases and decreases within a small temperature range, and that is different for the exothermic and the endothermic cycles. This behaviour is not compatible with the static values used to express the sensible heat capacity and thermal resistance of traditional materials used in dwellings. To make the situation even more complex, the ability of PCMs to store latent heat can reduce significantly as the number of usage cycles increases. The technical lifespans of PCMs have been categorised, and range from 50 cycles up to 10,000 cycles or more. In the Dutch climate, if PCMs are used from the first category and only last around 50 cycles, then the technical lifetime will only be around one year, if the transition temperature is roughly 21 to $23{ }^{\circ} \mathrm{C}$. Further, at this moment the commonly used Dutch software (e.g. Bink and VABI) that has been developed to simulate the indoor climate in buildings does not offer the possibility to incorporate PCMs. If one wants to achieve wide scale implementation of PCMs in the Netherlands, it will be necessary for their effects to be modelled not only in the software underlying the EPIs but also in software that can simulate the thermal behaviour of buildings.

In order to gain an impression of the effects of PCMs on the energy use of dwellings, one has to remember that the PCMs considered can store and release approximately $0.1 \mathrm{MJ} / \mathrm{kg}$ of latent heat. To place this value in perspective, $1 \mathrm{kWh}$ of electric energy equals $3.6 \mathrm{MJ}$, and 1 $\mathrm{m}^{3}$ of natural gas has a calorific lower heating value of $31.65 \mathrm{MJ}$, and a higher heating value of $35.17 \mathrm{MJ}$. This makes the latent heat capacity of the PCMs relatively low. In that it seems that $36 \mathrm{~kg}$ of Micronal is needed to 'store' $1 \mathrm{kWh}$ of electric energy, or over $300 \mathrm{~kg}$ to 'store' the equivalent of $1 \mathrm{~m}^{3}$ of natural gas. However, it should be emphasized that PCMs do not store electric energy or natural gas, but can only store thermal energy at a certain temperature. In the case of Micronal DS $5008 \mathrm{X}$, as used in the experiments at the University of Twente, the melting temperature is around $23^{\circ} \mathrm{C}$. When electric energy or natural gas is used to heat a living space, the transport of the energy and its conversion from fossil fuel, via electric energy in case of electric heating, to heat should be taken into account. Given the efficiencies of distribution and energy conversion, namely 39\% when producing and transporting electric energy and $91 \%$ for the distribution of natural gas and $96 \%$ for the conversion of natural gas to heat, an additional $156.4 \%$ and $14.5 \%$ of primary energy can respectively be saved on top of the reductions in energy use as recorded by the energy meters in a dwelling.

Since 2012, the carbon dioxide emission resulting from electric energy use is set at $0.1569 \mathrm{~kg}$ $\mathrm{CO}_{2} / \mathrm{MJ}$ (assuming $\eta_{\mathrm{e}}=39 \%$ ) and from natural gas use it is $0.0506 \mathrm{~kg} \mathrm{CO} / \mathrm{MJ}$ (with $\eta_{\mathrm{ng}}=$ 100\%) (NNI, 2011). Depending on the number of cycles that PCMs are charged and discharged, fossil energy can potentially be saved and carbon dioxide emissions reduced. For every cycle, one can save $0.016 \mathrm{~kg} \mathrm{CO} 2$ or $0.006 \mathrm{~kg} \mathrm{CO}$ per $\mathrm{kg}$ of Micronal respectively depending on whether electric energy or natural gas is being replaced. That is, from a $\mathrm{CO}_{2}$ 
emission standpoint. It seems better to reduce electric energy use than natural gas use in a dwelling.

To finalize this section, in which the influence of PCMs on the energy performance of dwellings has been assessed, it can be summarized that little insight exists into what extent the implementation of PCMs in concrete floors for heating purposes would reduce fossil energy use in a Dutch dwelling. However, it was possible to qualitatively outline which characteristics would be influenced. Furthermore, it can be stated that PCMs with a larger latent heat capacity would be advantageous and that, for heating purposes, a lower transition temperature than $23{ }^{\circ} \mathrm{C}$ would be beneficial. It is also necessary that simulation software becomes available in which different quantities of PCMs with various transition temperatures can be modelled. If such software was available, one could assess whether it is better to target a heating function and so reduce natural gas use or to target cooling and a reduction in electric energy use.

\subsection{Assessing the financial effects of implementing PCMs}

In order to assess the financial performance of an ETM, it is necessary to specify the associated costs and the benefits. This section reflects on the investment costs and the possibility that PCMs will reduce energy costs.

\subsubsection{Investment costs of PCMs}

The investment costs of PCMs can be expressed by Equation 3-2. This equation takes into account the costs of implementing PCMs in the design of a dwelling and the costs of physically implementing the PCMs, including both product and installation costs, in a dwelling during the construction phase.

The costs of incorporating PCMs in the design of a building can be related to the number of hours that architects and advisors will spend on providing the principal with information on the possible effects of the PCMs and on optimizing the location and quantity of PCMs in the dwelling that is being designed. Given that Dutch advisors do not have the appropriate software to simulate the effects of PCMs for heating purposes and architects do not have experience with PCMs for heating purposes, the first principals that consider applying PCMs for heating are likely to be confronted with relatively high investment costs for implementing PCMs in the design, if they want to know exactly what the effects on thermal comfort and energy use will be in advance. In this study, it is assumed that the initial applications of PCMs for heating purposes will receive direct support from the manufacturer of the product. Therefore, the investment costs associated with their implementation in the design are not taken into account.

The next component of the investment costs is the product costs. According to Mehling and Cabeza (2008, p. 43), product costs of commercial PCMs are in the range of $€ 0.50$ to $€ 10$ per kg. PCMs based on salt hydrates are relatively cheap, namely $€ 1$ to $€ 3$ per kg (ibid, p. 18). PCMs based on paraffins are generally more expensive. The Micronal that was used in the concrete floors of the experimental boxes had to be ordered from Germany at a price of $€ 8$ per kg (including VAT, 2007 price). Although the prices of chemical products in a 
competitive market generally decrease over time, one has to recognize that the prices of many raw materials have been increasing in recent years. Therefore, in assessing the financial performance of PCMs the abovementioned product costs of $€ 8$ per $\mathrm{kg}$ will be used.

Given the passive application of micro-encapsulated PCMs in concrete floors, it is possible to make them part of the concrete mix and, therefore, the installation costs should be low. The micro-encapsulated PCMs will replace or reduce the volume of one of the standard components of a standard concrete mix. A downside of this approach is that some of the capsules will inevitably break during the mixing process, which needs to be factored in when addressing the reliability of this energy technique. The investment costs for installing the PCMs for the application in this study are set at zero.

\subsubsection{Financial benefits of PCMs}

Given the relationships between several characteristics that influence the energy performance of a dwelling and the effects that PCMs can have on the energy use for space heating, the financial benefits of PCMs are explicitly interpreted as independent of a particular dwelling and household. By taking into account the price per kilogram, one can calculate how much the energy use in terms of kWh of electric energy or $\mathrm{m}^{3}$ of natural gas needs to be reduced in order to cover the investment costs. Equation 3-6 reflected the breakdown of energy costs in the annual energy bills of Dutch households. The annual infrastructural and measurement costs will not be taken into account, since these fixed costs are unlikely to alter when using PCMs. The product costs and taxes will, through the variable costs, be influenced by adding PCMs to concrete floors. Equation 3-7 and Equation 3-10 expressed the price of natural gas as follows:

$\dot{p}_{a ; \text { totaling }}=(V A T+1)\left(C_{9} \cdot \dot{p}_{a ; \text { productng }}+C_{9} \cdot \dot{p}_{a ; \text { taxes } ; n g}\right)$

Equation 5-1

where:

VAT $\quad=0.21$ since October $1^{\text {st }} 2012$

$C_{9} \quad=1.00049$ from Oct 2011 to Oct 2012 in Twente (GreenChoice, 2012)

$\dot{\mathrm{p}}_{\text {a;producting }}=€ 0.3516 / \mathrm{m}^{3}$ price level 2013 (Essent, 2013)

$\dot{p}_{\text {a;taxes;ng }}=€ 0.1862 / \mathrm{m}^{3}+€ 0.0023 / \mathrm{m}^{3}$ for an energy use below $5000 \mathrm{~m}^{3} /$ year

In a dwelling with a single electricity tariff structure, where the same electric energy prices apply night and day, the price of electric energy can be expressed as follows:

$\dot{p}_{\text {a;totalie }}=(V A T+1)\left(\dot{p}_{\text {a;producte }}+\dot{p}_{\text {a;taxes } ; e}\right)$

Equation 5-2

where:

$\dot{\mathrm{p}}_{\mathrm{a} \text {;product; }} \quad=€ 0.0666 / \mathrm{kWh}$ price level 2013 (Essent, 2013)

$\dot{\mathrm{p}}_{\mathrm{a} ; \mathrm{taxes} ; \mathrm{e}} \quad=€ 0.1165 / \mathrm{kWh}+€ 0.0011 / \mathrm{kWh}$ for energy use below $10,000 \mathrm{kWh} /$ year

On this basis, the 2013 Essent price for natural gas is $€ 0.6538$ per $\mathrm{m}^{3}$ and for electric energy $€ 0.2229$ per kWh. On this basis a kilogram of Micronal needs to see a reduction of $12.2 \mathrm{~m}^{3}$ of natural gas or $35.9 \mathrm{kWh}$ of electric energy use within its technical lifespan. Given that one kilogram of PCM can store $0.1 \mathrm{MJ}$, and that the energy efficiency of a heating boiler is around $96 \%$ and the average calorific value of natural gas is $33.41 \mathrm{MJ} / \mathrm{m}^{3}$, the PCMs will 
need to be fully charged and effectively discharged 3,913 times before the breakeven 12.2 $\mathrm{m}^{3}$ of natural gas is saved. In the similar electric energy calculation, the PCMs need to complete 1,292 cycles to save the $35.9 \mathrm{kWh}$ assuming the conversion of electric energy to heat in the room where the PCMs are applied is $100 \%$ efficient.

The number of days where the maximum temperature exceeds the melting temperature of $23{ }^{\circ} \mathrm{C}$ is unfortunately relatively low. Between 1981 and 2010, the maximum temperature reached or exceeded $20{ }^{\circ} \mathrm{C}$ on an average of 83 days per year, and $25{ }^{\circ} \mathrm{C}$ on 27 days per year (KNMI, 2011). This suggests that there will only be around fifty days a year when it is possible to properly load the PCMs. On this basis, to achieve the number of cycles calculated in the previous paragraph, the life time of the PCMs needs to be at least 26 years (electric) or 78 years (gas). Furthermore, it needs to be taken into consideration that not after every warm day the PCMs will be able to completely discharge all latent heat. If PCMs with a lower melting temperature were available, the PCM could be charged on more days. However, the melting temperature needs to remain above the temperature the residents favour in order to ensure that the PCMs are not charged by the central heating systems rather than by solar irradiation. Although the prices of natural gas and electric energy are expected to increase, the financial benefits from applying PCMs as a supporting heating system appear relatively low.

When PCMs are used (maybe in walls and ceilings) to avoid the need to install an air conditioning system, or as a replacement for a broken air conditioning system, the investment costs of the avoided system can be directly deducted from the investment costs of the PCMs. This will reduce the payback period significantly. Further, research shows that people residing and working in green buildings, e.g. that lack a cooling system, have a greater tolerance of high temperatures than people in non-green buildings with a cooling system (de Dear \& Brager, 2002; Leaman \& Bordass, 2007). In summer, people in general also appreciate slightly higher indoor temperature than during winter (Van der Linden et al., 2006). As such, a building with PCMs can be experienced as more comfortable at slightly higher indoor temperatures than would be the case in buildings with a cooling system.

Independent of the envisaged situation, if PCMs are to be used to heat or cool a building, it is clear that reducing the costs of the PCMs and increasing their latent heat capacity need to be prioritized. As such, salthydrates with their low costs and higher latent heat capacity seem to offer potential advantages over flammable paraffin-based PCMs, especially if they can offer the same reliability and technical lifespan.

\subsection{Assessing the effects for stakeholders of implementating PCMs}

PCMs have only been applied in a few Dutch office buildings to reduce the use of cooling systems or to make cooling systems redundant. As far as in known, PCMs have not yet been used in concrete floors to specifically support or replace heating systems in dwellings. Hence, few stakeholders have experience of the effects of using PCMs. This section considers what the effects would be for stakeholders involved in developing, designing and using dwellings. The starting point is to assess the possibilities of physically implementing PCMs in the 
concrete floors of new and existing dwellings. Following this, the arguments used by stakeholders to implement energy techniques will be addressed.

\subsubsection{Implementing PCMs in floors of new and existing dwellings}

When developing a new product, a target group is often identified. Those wanting to implement PCMs in the concrete floors of residential buildings could focus on two target groups: principals that are developing new dwellings, and owners that want to improve or renovate existing dwellings. The Dutch housing stock consists of more than seven million dwellings but, as was shown in Section 2.3.2, only a relatively small number of new dwellings are added to this stock each year. Therefore, a developer of an ETM has a much larger group of potential clients if the product can be implemented not only in new but also in existing dwellings.

In new dwellings, the floor is part of the structure and is often finished with a layer of concrete that is $\approx 50 \mathrm{~mm}$ deep to cover the pipes and tubes of the installed systems. As in the experiments with the boxes discussed earlier (Entrop et al., 2011), the micro-encapsulated PCMs could be added as the final ingredient during mixing, just before the final cement layer is poured onto the floor construction. PCMs will reduce the strength of the concrete, but up to $5 \%$ of the mass can safely consist of PCMs (Hunger et al., 2009). A major advantage of applying PCMs in new dwellings is that future residents will not experience any inconvenience. The concrete layer will take approximately the same time to dry out whether or not PCMs are added.

In existing dwellings, the implementation of PCMs in concrete floors for heating purposes is only likely to take place if extensive renovation is planned, such as if an old wooden floor is to be replaced by a new insulated concrete floor (similar to the situation in Case 3 described in Section 4.4.4). Here, as in a new build, a layer of concrete containing PCMs could be poured on top of the new floor construction. Adding a layer containing PCMs to floors of existing dwellings would demand quite some effort from the residents, who would need to temporarily move and store their furniture in a different location. Further, they will not be able to use the rooms in which the floors are being modified for a few days. If the kitchen or bathroom were to be re-floored, it is likely that the residents would need to be temporarily accommodated elsewhere.

It is worth mentioning that incorporating PCMs in concrete could mean that activities in the domain of building physic would be allocated to a group of contractors that have not been intensively involved with thermal comfort before. A heating system would still be necessary, so system installation contractors will probably not experience any less involvement in these building projects. For those involved in designing the concrete mix and in preparing and pouring the concrete, attention would have to be paid to the quantity and quality of the micro-encapsulated PCMs.

In designing the dwelling, there would be a task for consulting engineers with expertise in building physics regarding the quantity and quality of PCMs. Their knowledge on the thermal behaviour of buildings, plus use of simulation software and the correct product information 
from PCM manufacturers, would create an appropriate platform for determining how much PCM, with what melting temperature, should be included to reduce the need for using fossil fuels to heat the dwelling. In collaboration with the architect, specifications of the dwelling would be taken into account when simulating the thermal behaviour. Given that the behaviour of the future residents will influence the effectiveness of the PCMs, it would be advantageous if the principal $(A)$ is the future resident, $(B)$ knows the future residents, or (C) can select future residents such that they match the occupational behaviour assumed when designing the dwelling. Why residents might want to implement PCMs will now be explained.

\subsubsection{Motives for stakeholders to implement PCMs in building projects}

In the phases preceding the construction phase, many decisions have to be taken in finalizing the design and construction plans of the future dwelling. Many ETM investments can and will be considered, and some will be implemented and some rejected. Although the developer of PCMs will need to explain to the contractor how to apply them correctly in the construction phase, actual implementation will not take place unless stakeholders are convinced in the pre-project and pre-construction phases that PCMs are a worthwhile investment. Another reason why PCMs might be implemented in concrete floors for heating purposes would be if it was to become compulsory, but this seems unlikely.

If PCMs were to be made compulsory, or were useful in achieving a compulsory energy performance, the financial benefits would be less critical than if they are merely regarded as an optional extra investment on top of other ETMs that are necessary to comply with the law. The national government could, through the Building Code and the standards assigned therein, influence the relative advantage of PCMs in meeting compulsory energy levels. Municipalities that check applications for building permits for their compliance with the Building Code would then have the task of checking if the impact of the PCMs on the energy performance was correctly calculated.

Given the current situation, in which PCMs do not have a role in the theoretical energy performance of a dwelling, stakeholders need to be persuaded by other means. While an investment could result in higher maintenance costs, lower reliability, decreased user comfort and a negative rebound effect (as addressed in Section 3.2.2), a sounder investment could alternatively see energy use reduced, maintenance costs drop, reliability increase, user comfort improve and the value of dwelling increase (as addressed in Section 3.2.3). From the perspective of the owner of the dwelling and its residents, the costs of an ETM could discourage investment while the benefits could encourage it. Arguments that consider the reductions in energy use and accompanying environmental emissions, and the reduced energy costs, were addressed in the previous two sections of this chapter. Consequently, only considerations related to reliability and maintenance, to user comfort, possible negative rebound effects and the value of the dwelling are addressed in this section.

Compared to a situation where PCMs are not used, maintenance costs are not expected to increase for the resident. A decrease in maintenance costs for the conventional system could be possible if the number of evenings in which the heating system is required to heat water for the radiators and the pump employed to pump this heated water around the radiators is 
reduced. Maintenance costs are also unlikely to increase, given the passive use of PCMs with no moving parts and no mass being transferred by any means.

In terms of reliability, large differences in quality can exist between the PCMs of different producers. The manufacturer of the PCMs used in the experiments, BASF, has committed itself to German quality standards for PCMs as specified in RAL-GZ 896 (RAL, 2009). The Micronal DS $5000 \mathrm{X}$ and Micronal DS $5001 \mathrm{X}$ products have been certified with an A-label that guarantees more than 10,000 cycles of use (RAL, 2010). The product used in the experiments was DC $5008 \mathrm{X}$ which is based on almost the same paraffin mix as DS $5001 \mathrm{X}$, but with a $3{ }^{\circ} \mathrm{C}$ lower melting temperature (BASF, 2008). Comparing the PCMs with a cooling or heating system in which the technical life expectancy will be fifteen to twenty years at most, this means that the PCM could be charged 500 times per year for the same lifespan. However, given that only roughly fifty days a year are expected to provide the proper ambient conditions to cycle the PCMs, their working life is hypothetically estimated at 200 years.

However, reliability remains an issue. Although the product information provided by the manufacturer is positive about the ability of the micro-capsules to withstand drilling (BASF, 2008), the process of mixing the concrete puts severe strains on the capsules. In the experiments conducted by Hunger et al. (2009), a significant proportion of the capsules were found to be broken once mixing and hydration of the concrete had taken place. Given this information, it seems likely that some of the paraffin wax will leak away and may in the long run partially evaporate. If this occurs, the amount of PCMs in the mix will provide a smaller latent heat capacity than anticipated based on the original product information. If this occurs, residents of a dwelling with a floor containing PCMs might notice that the reductions in energy use are less than expected and that these reduce further over time.

Although PCMs implemented for heating purposes will not always discharge during high summer, and therefore overheating can still occur, user comfort is nevertheless expected to rise. The inclusion of the PCMs provides a latent heat capacity that will reduce the use of the sensible heat capacity of the dwelling's materials. Therefore, the number of days that a living room, or even the whole dwelling, becomes uncomfortably warm should be reduced.

A rebound effect can occur if an ETM is not used by the residents as the developer, manufacturer, architect or advising engineer thought it would be. In such situations, an ETM may reduce the energy use less than expected or even increase the energy use. In installing PCMs in concrete floors, one needs to avoid natural gas being used to charge them rather than solar irradiation. For this to be avoided, the melting temperature needs to be close to the temperature that is regarded as comfortable by the residents, and preferably by unknown future residents. Further, it will need to be clearly communicated to current and future residents how they can make effective and efficient use of the PCMs. If residents experience an added value of PCMs, it is likely, provided that this is properly marketed, that the value of dwellings with floors containing PCMs for heating purposes will see a premium over dwellings without this technique. A well-known example of such an effect was with the 
introduction double glazing in the 1970s, which quickly became and remains valued as a means of increasing property value.

\subsection{Conclusions on the implementation of a novel energy technique}

In this chapter, the implementation of PCMs in concrete floors for heating purposes was studied using insights from the previous three chapters. The research questions raised are now answered, firstly considering the PCMs in concrete floors and, secondly, new ETMs in general. This could help developers of new ETMs become aware of what advantages their innovation can offer and what shortcomings still need to be overcome.

\section{A: What is the effect of a novel ETM on the energy performance of a dwelling?}

Experimental tests show that PCMs are to some extent able to reduce maximum temperatures and increase minimum temperatures of the indoor environment. In the experimental set-up, PCMs with a latent heat capacity of $0.1 \mathrm{MJ} / \mathrm{kg}$ and a melting temperature of $23{ }^{\circ} \mathrm{C}$ were used passively in concrete floors that received solar irradiance within a scaled semi-adiabatic closed environment. If the same PCMs were used in a fullscale dwelling, it is expected that many kilograms of PCMs would be needed to provide sufficient latent heat capacity in relation to the size of the living room, that should remain at a desired temperature given the sensible heat capacity of the floor construction, walls and ceiling.

Furthermore, the melting temperature of $23^{\circ} \mathrm{C}$ is too high if one wants to use PCMs to assist in heating living spaces in late spring and early autumn in Dutch residential buildings. A melting temperature that is only slightly higher than the temperature residents are comfortable with should offer better possibilities to reduce the natural gas use for heating. This will be however only occur if, during daytime, enough thermal energy is provided to the $\mathrm{PCM}$ from the natural environment to melt them and then, during the evening, sufficient thermal energy is released from them to maintain a comfortable indoor temperature. Here, interactions with variables in all five categories of characteristics play a role.

Although many scholars have addressed the possibilities of PCMs being used to reduce fossil energy use in the built environment, the precise impact on energy performance is hard to estimate. A large number of variables influence the performance of the PCMs and the energy performance of a dwelling. Given that current Dutch assessment methods do not take the presence of PCMs into account, PCMs do not have any effect on the theoretical building-related energy use or on current EPIs. The EPC does take into account the sensible heat capacity of a dwelling by distinguishing three different weights of construction. These construction categories are assumed to have average heat capacities of $80 \mathrm{~kJ} / \mathrm{m}^{2} \mathrm{~K}, 350$ $\mathrm{kJ} / \mathrm{m}^{2} \mathrm{~K}$ and $450 \mathrm{~kJ} / \mathrm{m}^{2} \mathrm{~K}$ respectively. With a lightweight dwelling, with a structural heat capacity of $80 \mathrm{~kJ} / \mathrm{m}^{2} \mathrm{~K}$, an architect can attempt to show that a design, for example with PCMs, can boost the heat capacity. This has the potential to improve the EPC by up to 0.05 points.

In general, an ETM not only influences the actual energy performance of the dwelling, but the latter also influences the performance of the ETM. From a marketing perspective, the 
best outcomes are often highlighted. However, the highest energy reductions can only be achieved if the context in which the ETM operates is ideally matched. In that sense, an ETM needs to be custom-made. The highest energy reduction is not necessarily achieved in practice even if one or more of the EPIs are showing the best values, since the standardized assessment and calculation methods do not take account of the influence of all variables. The context can be made explicit by making use of characteristics in the categories identified in Chapter 2: environmental characteristics, occupational characteristics, building characteristics, system characteristics and appliances. Quantitatively specifying all the links between the characteristics will in most circumstances be impossible, or at least time consuming, but an initial qualitative study can identify some of the more critical characteristics that can be considered for further research. To accurately estimate the effects of implementing PCMs in concrete floors, for heating purposes, on the energy use of a specific dwelling and its residents requires more data. These data could be obtained from carefully monitored pilot projects, in which dwellings with different occupational, building and system characteristics and located within a certain environment have a mix of concrete floors with and without PCMs.

\section{B: What are the financial effects of implementing a novel ETM in a dwelling?}

The financial analysis of the implementation of PCMs shows that the investment costs are relatively high compared to the variable energy costs that can be saved. If PCMs are considered to support a commonly used high efficiency natural gas boiler system, the payback time will be long due to the high investment costs, the limited latent heat capacity that can store only $0.1 \mathrm{MJ}$ per kg per cycle, the low natural gas prices and the high efficiency at which natural gas is converted into thermal energy. In situations where PCMs support an electric heating system, the payback time should be shorter due to the high price of electric energy relative to natural gas. The actual payback time again depends on the efficiency of the electric heating system used.

If using PCMs meant that a connection to the gas network or the power grid was no longer required, the annual fixed energy costs would be reduced, but the implementation of PCMs alone is not expected to result in such a situation. To achieve such a situation would require several ETMs, if thermal comfort was not to be reduced. Then, the financial benefits due to the reduction in fixed annual energy costs would need to be shared among the various ETMs and not only attributed to the PCMs.

Estimating the influence of the implementation of PCMs on maintenance, reliability, perceived user comfort, rebound effects and the value of a dwelling can hardly be quantified due to a lack of data on user experience. Although PCMs have been used in experimental set-ups in offices and dwellings, most such implementations have been aimed at reducing the energy used for cooling rather than for heating. The available data on these cooling applications offer some insight into the influence of PCMs on indoor temperatures, but not yet on the monetization of the indirect costs and benefits. To understand the effects on maintenance, reliability, perceived user comfort, rebound effects and the value of the 
dwelling requires longitudinal research. Overall, at this time, only limited financial insights into these effects of PCMs exist.

The same issues can be expected for many or even all new ETMs. Experiments can provide preliminary insights into the most important aim of an ETM, namely reducing energy use. The results of such experiments make it possible to develop an initial product that can be implemented in buildings. To justify the investment costs of an ETM, the reduced energy costs need to be calculated on the basis of an expected reduced energy use. During actual usage, teething problems can come to light resulting in additional costs. From a financial perspective, the accompanying costs for the developer, owner and residents can be short term, if these problems and malfunctions can be successfully resolved. When implementation leads to positive experiences for developer, owner and residents, a financial appreciation, alongside the reduced energy costs, will be in sight.

\section{C: What are the effects for stakeholders of implementing a novel ETM in a dwelling?}

The implementation of a new ETM requires various efforts from the stakeholders involved both before and during a building project. The principal, the actor that invests in the ETM, has certain expectations about its performance after implementation. These expectations can be based on information provided by the manufacturer, the architects or the advisors on HVAC systems for example. When a principal considers implementing a very new ETM that has not been implemented by any of the involved stakeholders before, it is important to ask the developer, manufacturer or sales person to specify what reduction in kWh of electric energy, $\mathrm{m}^{3}$ of natural gas or GJ of thermal energy can be anticipated for dwellings and residents in what circumstances. The effects of implementation, in terms of energy use, user comfort, maintenance, reliability, rebound effects and the value of the dwelling should be made as explicit as possible for the specific context in which the ETM is to operate.

The architect would seem to be the appropriate stakeholder to specify and to explain this context. In some cases, advisors on HVAC systems can assist the architect or even take on this role of explaining the context in which the new ETM is to be implemented. However, one should recognize that in many small residential building projects advisors are not contracted to design the installed systems. Architects or advisors may, on the basis of their experience, have some views on an ETM. If simulation tools are available, it is also possible to try and simulate the effects of the ETM. Simulating the effects within several implementation scenarios may offer insight into how the reduction of the energy use can be maximized in relation to the financial costs. The actual physical implementation during construction will be carried out by a different stakeholder. This contractor or installer needs to be well informed about the assumptions made during the design phase in order to understand the implications for their activities.

When the government considers the effects of an ETM, the focus may be on environmental considerations regarding emissions and the depletion of fossil fuels. If so, it is important to consider the origins of the energy forms whose use is being reduced. Natural gas needs to be extracted and transported through a vast network of pipelines. Fossil fuels are converted into electric energy that is then transported through the power grid. Every element in this 
production and transport process results in a loss of exergy: the potential of the energy flow to perform mechanical work. This means that the reduction in energy consumption is greater than that recorded by the final consumer on their domestic meters.

\section{Question 4: How can a novel ETM be implemented in residential building projects?}

In this implementation study on paraffin based PCMs in concrete floors, the following observations were made:

1. the effects on the EPIs and on the actual energy use of a dwelling and its residents cannot be accurately assessed at this time;

2. only the investment costs of the actual product, the micro-encapsulated paraffinbased PCMs, can be assessed;

3. the way the PCMs will behave when actually implemented in a dwelling and used by residents over several years, cannot be accurately predicted.

Given these observations, it can be concluded that, in order to make implementation in residential building projects possible, more insights are needed into the behaviour of PCMs in concrete floors in the context of specific building projects with their stakeholders and actors, and after completion the users of the specific building. Such insights could be obtained by conducting a pilot study in which PCMs are actually applied in concrete floors of several dwellings, either in already occupied renovation actions or in new projects which will then become occupied. Although experimental studies were conducted prior to this implementation study, for practical reasons it was not possible to conduct a pilot study as part of this thesis research.

Reflecting on how an ETM could be implemented in residential building projects does fit within the scope of this thesis. In a building project where the designed dwelling already complies with the Building Code, the principle is free to decide whether to implement additional ETMs. This decision will be taken based on various factors including information to hand on the considered ETMs. In general, such information does not take into account the context in which a specific project takes place. As such, time and money need to be invested in order to gain reliable information on the effects of an ETM in the context of a specific environment, building and residents, all with their unique characteristics. This information could be provided by the organization that offers the ETM, by the architect or through advisors. This element of the implementation is referred to here as the design implementation by the architect, principal and advisors.

Before approving the actual physical implementation, the principal has to be able to finance the investment costs and have confidence that the ETM will sufficiently reduce the energy use of the dwelling over a long enough period to see the investment as financially sound. Only if these considerations are made, and positively assessed by the stakeholders, will the principal give an order enabling a contractor or installer to apply or install the ETM. This element of the implementation process is referred to as the physical implementation by the contractor and principal. 
Where the principal is both the owner of the dwelling and its resident, not many stakeholders need to be persuaded. However, when the principal, the owner and the residents are different organizations or persons, their perceptions are likely to differ and alternative aspects of the implementation might be carefully weighed by these various stakeholders. Here, the principal not only needs to be convinced of the advantages of the ETM, they also have to be able to sell the objective of the implemented ETM to the future owner. This element of the implementation process is referred to as the marketing implementation by the principal and owner.

The future owner needs to explain to the future residents how they can ensure the implemented ETM functions properly, producing the greatest benefits for them. If an ETM is not used correctly, then the implementation should not be regarded as successful. This element of the implementation process is referred to as the user implementation by the owner and residents.

The four implementation relationships identified among the stakeholders in a residential building project are shown in Figure 5-5. Anyone offering a new ETM needs to consider what information and tools will be required to persuade stakeholders in each of the four implementation relationships. As outlined in this chapter, when considering PCMs, each relationship needs its own specific kind of information and tools in order to persuade the stakeholders that an ETM can be implemented and that it is worth implementing. If any of the stakeholders surrounding the principal convinces the principal that the ETM cannot be implemented, does not offer additional value, or seems to be unreliable, then rejection is likely. In the case of PCMs in concrete floors for heating purposes, there are inadequate insights, a lack of detailed information, and no appropriate simulation tools available. Here, the government in its various roles as a principal, legislator, enforcer of the Building Code and a champion of reducing fossil fuel use could take on the important role of initiating and stimulating pilot projects.

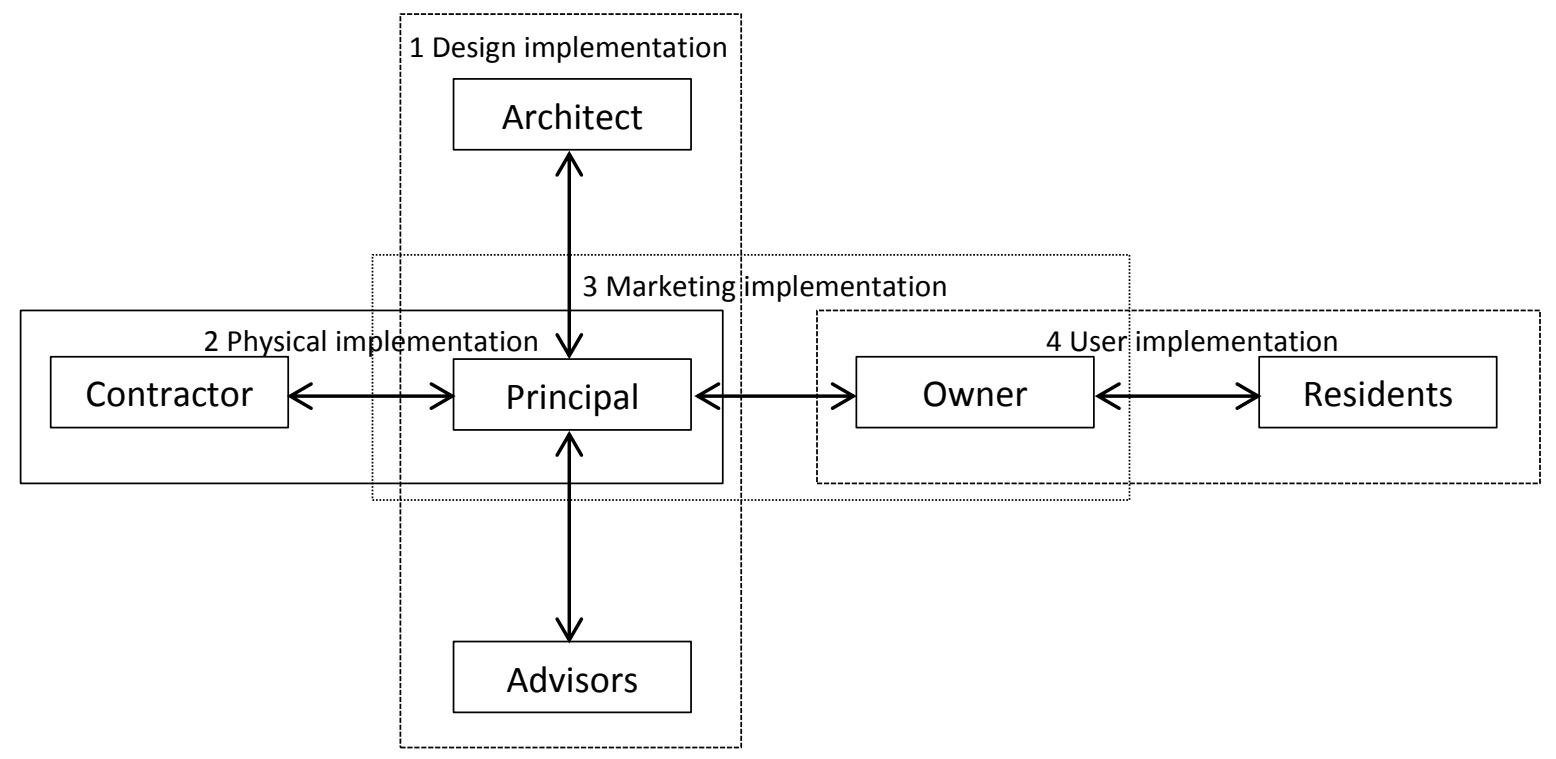

Figure 5-5: Visualization of the relationships among internal stakeholders in building projects as related to the implementation of ETMs. 


\section{Conclusion, discussion and recommendations}

Chapter 6 pulls together the findings from the previous chapters and provides the conclusions, discussion and recommendations.

\subsection{Conclusions}

After having studied the effects of ETMs on the energy performance of houses, the financial impact of ETMs, the decision-making over their inclusion in residential building projects and the potential of PCMs to be implemented, this section answers the main research question:

\section{How to assess the implementation potential and impact of ETMs in residential building projects?}

The impact of an ETM cannot be assessed without taking account of the context that involves the dwelling in which the ETM is applied and its residents. A technique or measure does not in itself decide to use energy or to reduce energy use. People residing in dwellings decide when energy is used and for what purpose. How much energy is needed to achieve the intended purpose can depend on what ETMs are used. Further, the impact of ETMs on the energy use of a dwelling and its residents depends on environmental characteristics, occupational characteristics, building characteristics, system characteristics and appliances. Many characteristics are taken into account when dwellings are assessed to calculate theoretical EPIs, but many other environmental characteristics, occupational characteristics, the internal allocation of space and the presence of moveable electric appliances cannot be made specific or are simply not taken into account. A case study on eight Dutch dwellings found that the total actual energy use is often much lower than the calculated theoretical energy use despite the fact that, in the latter, the electric energy used in moveable appliances is not taken into account.

When a principal wants to construct a new dwelling and needs to assess the impact of an ETM, two EPCs could be calculated: one with and one without the proposed ETM in the design of the house. However, this is only viable if the assessment and calculation method underlying the EPC can incorporate the ETM, and this is not always possible. Even if the ETM can be incorporated in the assessment and calculation method, the calculated reduction in theoretical building related energy use is not necessarily the same as the reduction in actual energy use experienced by the future household. Here, the assessment and calculation methods underlying the EPC were never intended to be a complete and accurate model of the actual energy use of a dwelling. Nevertheless, specific EPC values are compelled by law for new buildings. In that sense, they are an objective to be achieved by principals, architects and building advisors in the design phase in order to gain a building permit. In reality, these stakeholders seem to assess the impact of ETMs on the basis of their investment costs and impact on the EPC, rather than on of their impact on the actual energy use of the dwelling during its future use by the residents. When the possibilities to achieve a better energy performance than that enforced by the EPC are explored by the internal stakeholders, their assessment framework for the effects of an individual ETM tend to be more extensive with, for example, more severe reliability and maintenance criteria. 
A principal that wants an existing dwelling renovated does not need the refurbished dwelling to comply with an EPC stipulated by the Building Code. In the case study of social housing projects, some consensus seemed to exist among stakeholders about which ETMs to implement as a basis for extending the useful life of the renovated houses. Here, the thermal resistance of the building shell is improved, an energy efficient fan is included as part of the ventilation system and a highly efficient boiler system is installed. In the past, an $\mathrm{El}_{\text {old }}$ could be calculated to express the theoretical energy performance of existing dwellings and, since 2007, an $\mathrm{El}_{\text {new }}$ can be calculated. Given that a minimum energy performance is not stipulated for existing dwellings by law and that penalties are not imposed when a dwelling is sold without having been assessed in terms of an $\mathrm{El}_{\text {new }}$ having been calculated, the status of an Energy Label based on an $\mathrm{El}_{\text {new }}$ is not comparable with that of an EPC for new dwellings. Nevertheless, given the introduction of covenants in social housing and a range of subsidy programmes that require an energy assessment and Energy Label, the $\mathrm{EI}_{\text {new }}$ concept has been embraced. However, in the case of existing dwellings, decisions to invest in ETMs seem to be based on the anticipated effects on actual energy use and energy costs, rather than on the investment costs and the effect on theoretical energy performance, as is the case with new dwellings.

Given the similarities explained in the appraisal of ETMs in building projects, the implementation potential of an ETM in residential buildings rests on five different propositions as shown in Figure 6-1 and summarized below:

A. The likelihood of a specific ETM being implemented will increase the greater the resident's perceived reduction in actual energy use;

B. The more a specific ETM is perceived by the actors as lowering the theoretical EPI ( $E P C, \mathrm{El}_{\text {old }}$ and $\mathrm{EI}_{\text {new }}$ ) the more likely it is to be implemented;

C. The lower the principal of the building project perceives the investment costs of a specific $\mathrm{ETM}\left(\mathrm{CF}_{0}^{-}=\mathrm{CF}_{0.1 \text {; design }}^{-}+\mathrm{CF}_{0.2 \text {; product(s) }}^{-}+\mathrm{CF}_{0.3 \text {;installation }}^{-}\right.$the more likely it is to be implemented;

D. The greater the financial benefits of a specific ETM $\left(\mathrm{CF}^{+}{ }_{\mathrm{a}}\right)$, as perceived by the resident, the greater the likelihood of its implementation;

E. The greater the reliability $\left(\mathrm{CF}_{\text {a;maintenance }}^{-}+\mathrm{CF}_{\text {a;reliability }}^{-}\right.$), of a specific ETM, as perceived by the owner of a dwelling, the more likely it is to be implemented.

From Figure 6-1, it can be concluded that difficulties may exist in that some of these propositions cannot necessarily be achieved simultaneously, or to a similar extent, as is represented by the two dotted arrows. An ETM can, in a specific situation, significantly reduce perceived energy use in terms of proposition $A$, but not necessarily be reflected by an improved energy performance as stated in proposition B. Further, an expected decrease in energy use, boosting likelihood of implementation through proposition A, does not necessarily result in lower energy costs as referred to in proposition $D$. These five propositions are important points to consider when internal stakeholders are planning to implement an ETM. 


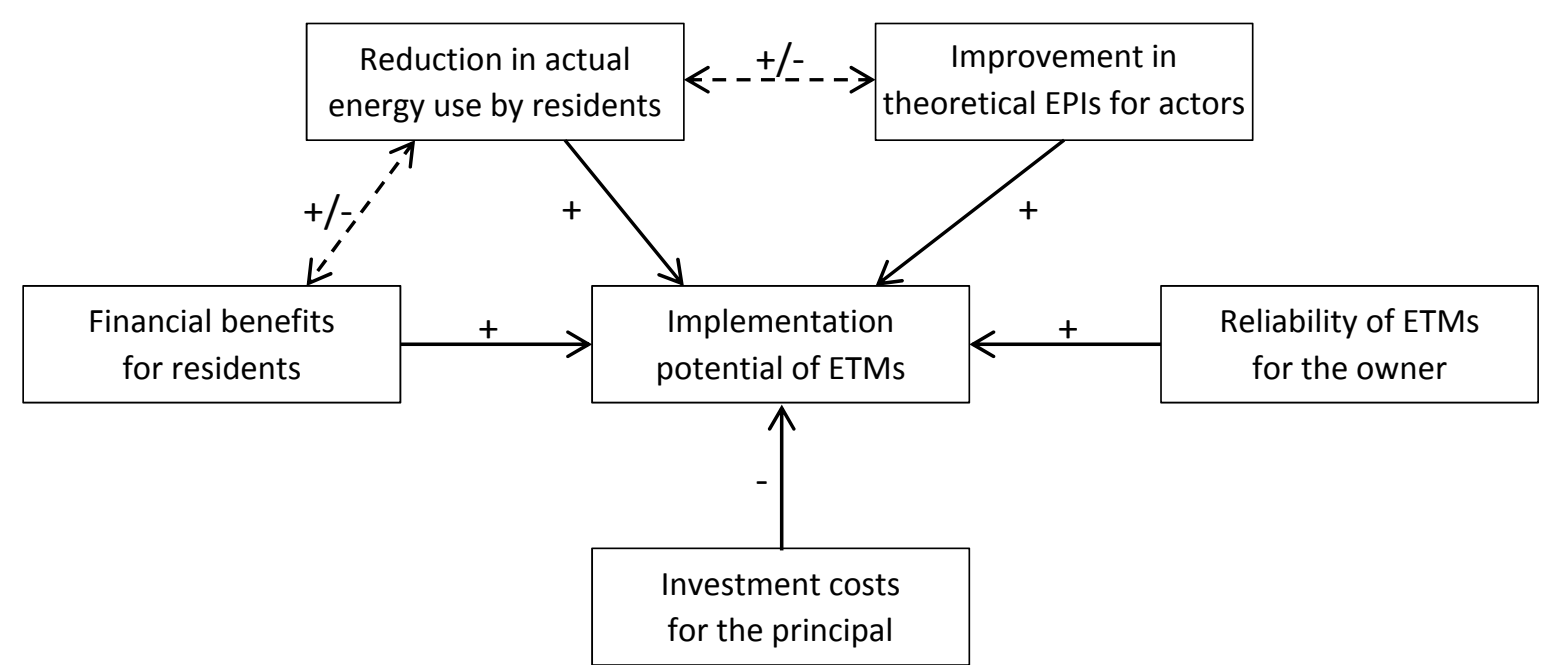

Figure 6-1: Diagram showing the impact of characteristics of ETMs on their implementation potential.

Figure 6-1 also shows that the perception of what constitutes good performance varies for the different stakeholders, namely the residents, actors, owner and principal, as was seen in the case study on social housing projects and in the implementation study for PCMs. As such, one needs to consider which stakeholder needs what information about a proposed ETM. A developer or manufacturer of a new ETM will only be able to provide the required information if experiments are conducted in a real-life context in the form of a pilot project. In such pilot projects, data need to be collected on how the ETM effects energy use, what the financial impact is, and what are the perceptions of stakeholders.

The insights in the influence that ETMs have on the energy performance of dwellings, their financial impact in residential building projects and how decision-making on their implementation takes place and the test how a new ETM can be implemented; have made it possible to develop an assessment framework, as is shown in Figure 6-2. This framework can be used by developers and manufacturers of ETMs to assess the implementation potential of not only PCMs but also other ETMs in residential building projects. In order to evaluate the implementation potential of an ETM, one needs to (1) assess its energy performance, (2) assess the financial impact and (3) assess how it addresses the interests of the stakeholders. When assessing the effect on energy performance, one needs to consider both $(1 \mathrm{~A})$ the effects on the actual energy use of the dwelling and its residents and (1B) the theoretical energy performance as expressed in EPIs stipulated by law. In assessing the financial impact, it is important to consider (2A) the investment costs in relation to (2B) the annual positive and negative cash flows. Although the investment costs and the cash flows may be attributed to different stakeholders, only a complete assessment that takes account of all the costs and benefits can show how advantageous an ETM can be within a certain building project. In order to determine how specific advantages and disadvantages, both financial and non-financial, effect individual stakeholders one should address (3) design implementation, physical implementation, marketing implementation and user implementation. In this way, the institutional context and the project requirements become part of the assessment framework through the decision-making processes of the stakeholders. 


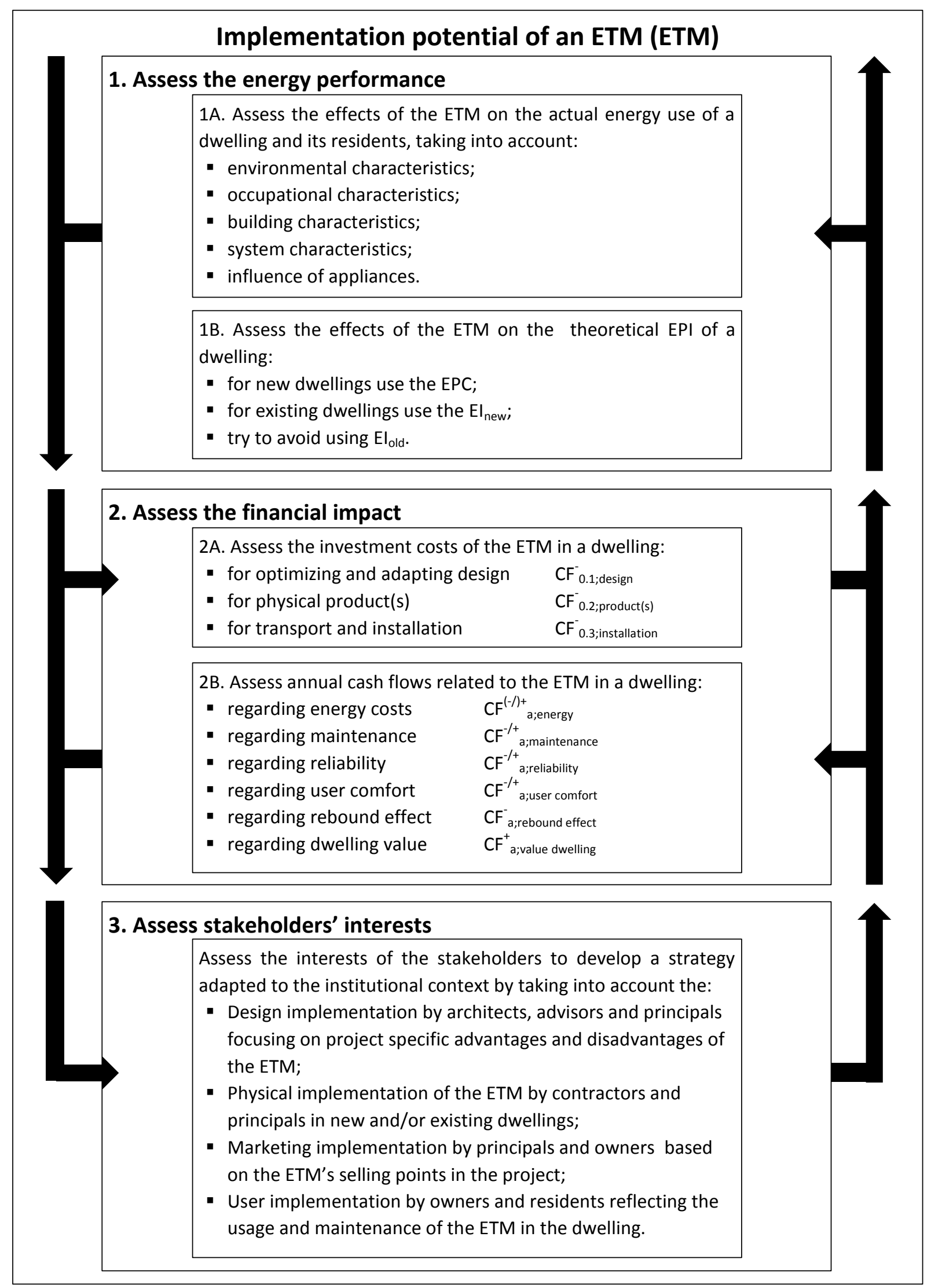

Figure 6-2: Framework for developers and manufacturers of ETMs to assess the implementation potential of an ETM in residential building projects. 
When assessing the decision-making, both the assessed effects on the energy performance and the assessed financial impact should be inputs, as indicated by the arrows on the left side of the framework in Figure 6-2. Both energy performance and financial impact have major roles in the communication between the various stakeholders that can lead to a decision to implement an ETM. This communication normally focuses on achieving project requirements that often only to a small extent take into account ETMs. When an assessor applying this framework comes to the conclusion that an ETM does not comply with the project requirements of one or more stakeholders, it is possible for the developer or manufacturer of the technique or measure to follow the arrows on the right side of the framework in Figure 6-2. The assessor can use the framework to identify what needs to change to meet the project requirements of the stakeholders and how these relate to the financial impact and energy performance of the ETM considered. In many residential building projects, the focus seems to be on assessing the effects on the theoretical performance indicators $(1 B)$ and investment costs $(2 A)$, with other elements of the framework largely disregarded.

\subsection{Discussion}

In this section, the scientific contributions, practical contributions and limitations of the conducted research are discussed.

\subsubsection{Scientific contributions}

This thesis offers two main scientific contributions. The first is a comprehensive framework that has been developed to assess the implementation potential of ETMs. This framework is based on insights derived from a multidisciplinary approach. Although various studies have been conducted on how ETMs influence the energy use of buildings and their occupants, how energy costs of buildings and their occupants are influenced by ETMs, and how ETMs are or can be implemented in building projects, no literature seems to be available where building physics, financial management and building project management are combined to study integrally the mechanisms influencing the implementation of ETMs in residential buildings.

The second contribution this thesis offers is the insight that it is currently almost impossible for new and novel ETMs to get implemented in residential building projects. This thesis shows that at least five barriers exist:

1. The first barrier is raised by the complexity of how the energy use of dwellings and their residents is constituted and influenced. It is no easy task to specify how an ETM will exactly influence the actual energy use of a dwelling with its residents. In many situations it is unknown who will be living in the specific dwelling;

2. A second barrier exists in the form of the minimum energy performance, the EPC, laid down in the Building Code for new dwellings, and the sometimes requested energy performance standard for existing dwellings, El $\mathrm{I}_{\text {new. }}$. If an ETM cannot be directly incorporated in the calculation method underlying these EPIs, the likelihood of implementation is small. A developer or manufacturer can apply for certificates 
addressing the impact of the ETM on the theoretical building related energy use, and hence the EPIs, but this procedure costs time and money and thus forms a barrier for the manufacturer or developer. Further, even if a certificate is obtained, the actual energy use of a future resident may be affected differently to that reflected in the theoretical calculation;

3. A third barrier results from the split incentive that occurs when the stakeholders that invest in an ETM differ from those who benefit from it. This barrier was already addressed as it operates in social housing at least thirty years ago (De Man, 1983), but it still exists;

4. A fourth barrier is raised by the way energy costs are constructed. Not all energy costs are proportional to the amount of natural gas, electric energy or heat used in a dwelling by its residents, and so a reduction in energy use may not lead to a significantly lower energy bill;

5. The fifth and final barrier identified is that the mechanisms underlying the above barriers are constantly influenced by external variables such as political decisions and economic changes.

Considering the existence of these barriers and the relevance of the direct and indirect context in which ETMs are implemented, more attention needs to be paid to how to customize or adapt an ETM and its usage to the dwelling in which it will used and to the residents by who it will be used. In this regards, the developed assessment framework for the implementation potential of ETMs can be of assistance. Data is needed on what the effects of individual ETMs are under what specific circumstances. In pilot projects in which residential buildings, after they have designed and constructed, are actually used by residents, intensive monitoring can provide the data needed to verify simulations and convince stakeholders of the added value of ETMs.

\subsubsection{Practical contributions}

This thesis offers a practical contribution for those interested in understanding and improving the implementation potential of ETMs in residential building projects.

A first practical contribution is provided by distinguishing which characteristics are directly, indirectly or not taken into account in the three Dutch energy performance methods. Energy performance advisors can use this overview to specify and emphasize the limitations of EPIs as a way to compute the influence of ETMs on actual energy use. Although some ETMs cannot, or cannot appropriately, be incorporated in the available methods, the outputs of these assessment and calculation methods can still give insights into how much energy is theoretically used under standard environmental and user conditions for various categories of energy use. This information helps in determining an energy balance of a dwelling and its residents. Given that expected natural gas and electric energy use can be separately determined by using the outcomes of these EPI calculation methods, two independent energy balances can be made. The theoretical building related energy use as calculated in the energy performance methods can be compared with the actual energy use as given by energy bills. The next step is to compare specific categories of energy use by measuring the 
energy use of systems and appliances within the dwelling. In this way, uncertainties about how accurate the calculated theoretical building related energy use is, can be assessed for each category of energy use since the actual energy use can accurately be assessed for some categories, which helps to solve the individual energy balances, natural gas and electric energy, and eventually the total energy balance.

A second practical contribution is offered to those who want to calculate the financial effects of ETMs. Past data on seven households show that many of the costs included in an energy bill are not related to energy use at all. The implementation of ETMs will often only influence the variable costs that exist in the form of product costs per unit of energy, taxation per unit of energy and the accompanying Value-Added Tax. When calculating the financial benefits of an ETM, one should consider these marginal costs rather than the average energy costs. Special attention should be paid to ETMs that might need infrastructural adjustments, such as large-capacity heat pumps in combination with electric cookers or large photovoltaic systems. Here, if the capacity of the power grid connection (or the natural gas network) needs to be enlarged, there will be significant infrastructural costs. Conversely, if one can reduce the capacity or even give up a connection to an energy infrastructure, then costs can be significantly reduced.

A third practical contribution is offered in the form of a research framework that can be used to study the decision-making over the implementation of ETMs in residential building projects. First, as suggested by Kadefors (1995), the institutional context of building projects can be studied in the form of governmental regulations, formal standardization and the roles $\&$ interests of the organizations involved. Depending on how the administrative bodies are organized in individual countries, governmental regulations may need to be considered on three levels, namely national, regional and municipal. Secondly, the project-specific context can be studied by specifying the general aim and location of the building project, how it is commissioned and what timescale applies. Thirdly, the internal stakeholders with their own interests and contributions should be addressed in detail. Fourthly, and finally, the implementation of ETMs should be considered regarding the timing of implementation, the internal stakeholders involved and arguments for and against implementation. This developed research framework can function as a practical instrument for other researchers wanting to study the ETM implementation process in other building projects.

A fourth practical contribution is offered to those that are developing PCMs for the construction industry. This thesis shows that, although experiments showed positive results, the implementation potential of micro-encapsulated paraffin based PCMs in concrete floors to support or replace heating systems is expected to be relatively low in the Netherlands. A list of perceived shortcomings is provided, which can be used by developers and manufacturers of PCMs. The following shortcomings identified in this research could be addressed: 
- The relatively low latent heat capacity of paraffin-based PCMs compared to the relatively high sensible heat capacity of materials used in Dutch residential buildings;

- The climate that offers only a few days each year to passively charge and discharge PCMs set in concrete floors;

- The limited availability of computer programs to simulate the effects of PCMs in a building, specifically of incorporating PCMs in the floors of dwellings for heating purposes;

- The inability to incorporate PCMs in the calculation method for EPIs;

- The relatively high investment costs in terms of PCM material costs;

- The relatively low price of natural gas compared to the price of electric energy;

- Stakeholders' low familiarity with PCMs;

- The relatively limited availability of PCMs compared to other ETMs such as insulation materials, high efficiency boiler systems, photovoltaic systems and thermal solar collectors;

- The required user pattern for residents to make full use of the ability to passively charge and discharge PCMs;

- The reliability of PCMs which still need to demonstrate their technical life when applied in concrete floors.

\subsubsection{Limitations}

The first limitation of this research to be considered is the focus on residential buildings, when comparable challenges on the reduction of fossil energy use also exist in other buildings. The first case study focused on houses and their residents. Three EPIs for residential buildings were presented and then applied to eight houses. The energy bills of those houses and their residents provided empirical input for the research on the financial effects of ETMs. When studying building projects, residential buildings were considered that were being both newly developed and renovated on behalf of a social housing association. The possibilities of using PCMs to reduce the energy used for space heating was similarly consider only for houses. Despite this focus on residential buildings, it is expected that many of the insights will also apply to non-residential buildings. Naturally, the EPIs are assessed slightly differently for non-residential buildings, the energy prices can differ and the building projects are often larger in terms of the number of stakeholders, the costs and the volume of the building. Further, such building projects might also be considered as more unique than residential buildings. However, such buildings also need to comply with an energy performance stipulated in the Building Code, investments are again considered from a financial perspective, and building projects take place in an institutional context in which internal stakeholders impose project requirements, that can result in the implementation of ETMs.

However, in buildings processes that aim to develop relatively large buildings, engineers are often specifically involved to design the heating and cooling systems to ensure thermal comfort. Here, the budgets for HVAC systems often include an allocation to cover the costs of advice on cooling and heating systems. In designing these larger buildings, simulation 
software is more often used than in residential buildings to study the effects of different building designs and systems on the indoor temperature and energy use. In many residential building projects, such experts and tools are often not involved. In residential buildings, one seldom finds integrated cooling systems. For heating systems, standard rules of thumb seem to suffice in deciding how large radiators need to be and what capacity the boiler system should have. No or little budget is reserved for advice that could contribute to lowering energy costs during the use of the dwelling.

The second limitation of this research concerns the geographical boundaries that were imposed when collecting empirical data. This research focuses on the Netherlands. In other countries, different climate conditions apply, other EPIs exist, energy costs are constituted differently and building projects are organized and executed in other ways in other institutional contexts. Nevertheless, with the adoption of the Energy Performance Building Directive (EPBD) in 2002, governments of European Union countries are obligated to develop methods to calculate the energy performance of buildings and to encourage and enforce low energy use in buildings in relation to the occupancy and local conditions (EC, 2002). In 2012, the intentions were formulated even more strongly: it is the responsibility of Member States to set minimum energy performance requirements for buildings and building elements (EC, 2012 , p. 18). This means that every country in the European Union should have a method to assess and calculate the energy performance of a building. Thus, in terms of the institutional context, these countries are expected to all set minimum requirements regarding energy performance. Although the climate conditions, energy costs and building projects will vary, the framework developed on the characteristics that influence energy use, the categorization of energy costs and the approach used to study building projects can all be used to structure empirical data from other countries.

A third limitation exists in the fact that the decision-making processes on ETMs were studied on the level of building projects, and the influence of institutions was studied with a focus on social housing projects. However, institutions do not only influence a project, they also influence, on a higher level, society as a whole and, on a lower level, the individual stakeholders. Every stakeholder is also an actor with a background and interests that are exceeding the boundaries of an individual building project. For example, they will previously have had experience of certain ETMs or have read about them. For the future, they will have new ambitions and plans. Therefore, decisions taken on the implementation of ETMs will not always be rationally based and in the best interest of the specific project. Furthermore, individuals, whether involved in building projects or not, can influence policymakers and even society. The research undertaken for this thesis did not consider how the internal stakeholders in the projects influenced the institutional context, nor the influence that other institutional contexts could have on the decision-making process in the projects studied.

A fourth limitation forms the time frame in which the research needed to be conducted. Decisions needed to be taken to limit the number of aspects to focus on and the amount of empirical data that needed to be collected. All empirical data regarding the characteristics and energy use of the houses in Chapter 2, the energy bills of households in Chapter 3, the 
social housing projects in Chapter 4 and the effects of PCMs in Chapter 5 have been collected by the researcher himself.

The case study In Chapter 2 encompassed eight Dutch houses having implemented different numbers of ETMs. The number of cases is too small to draw conclusions regarding the effects on the energy use of houses or flats when implementing a specific ETM, but it does give insights in how the methods are applied and how the results can be interpreted. To estimate the effect of an individual ETM on the actual and theoretical energy use of a specific type of dwelling more cases need to be studied, in which only that particular technique or measure has been implemented and of which data is available of multiple years before and after its implementation. In these years, all other characteristics preferably stay the same, but this situation of "ceteris paribus" is very hard to expect or to achieve. The validity of these kinds of standardised values seems to be limited for an individual actor, because the chance that insights are available for the situation in which an actor wants to implement a specific ETM will be small due to the large number of variables. To study how houses are assessed, eight cases seem to be sufficient, because the process of schematizing them by means of heated areas, the process of assessing the quality and size of the thermal shell, and the process of assessing the HVAC systems, are in all cases comparable.

In Chapter 3, the information in the energy bills clearly showed how in time certain sorts of costs were introduced, changing and even abondened. Although the number of cases is again limited, the energy bills provided the proper terms to search with a clear focus for sources that specify the sort and amount of costs. With the current knowledge of how energy costs are constituted in the Netherlands, additional energy bills of houses and residents that make use of heat pumps, cogeneration systems, solar collectors, and photovoltaic systems or that do not have a connection to the power grid, natural gasnetwork or even both, can be interesting to study. In these situations the ratio between fixed and variable costs is expected to differ from an average Dutch dwelling and its residents that use natural gas or district heating and electric energy. However, the current study on how energy costs are calculated, does provide the theoretical background by means of formulas, which also apply for these newly suggested cases. When average energy costs for specific types of dwellings and their residents need to be known, much more cases that use energy of different energy companies are needed to come to statistically sound values.

In Chapter 4 case study research was conducted on four building projects of a social housing association. This study did not consider the phase of usage, but the phases in which initiative, design and construction took place. Two buildings projects were aiming the development of new dwellings and two building projects were aiming at the renovation of existing dwellings. Incorporating the analyses of building projects in a research project is not an easy task due to the relatively long time frames that can apply. The building projects in this case study took on average approximately 56 months from initiative till completion. Reflecting on this case study, it can be questioned if it was wise to decide to use building projects of only one social housing association. On forehand, the consideration to chose one social housing 
association was that the context in which Dutch social housing associations operate will be comparable; the same BBSH, Building Code, and the decree on Energy Certificates apply. However, social housing associations in other municipalities can be influenced by municipalities and internal stakeholders in a different way and to another extend than the association, of which the projects were studied, was influenced by the municipality of Almelo, the architects and the advising engineers on HVAC systems. The insight gained after having conducted this specific study is that it seems wishfull to study building projects of multiple housing associations. In order to reduce time constraints, one can decide to study only building projects aiming at the development of new buildings projects or only projects aiming at the renovation of existing building stock.

The preparations for the implementation research, as described in Chapter 5, took a lot of time. A first series of experiments focused on the behaviour of concrete incorporating 1, 3 and $5 \%$ mass of PCMs before and after hydration. The second series of experiments was conducted to test the effects of PCMs in insulated environments in which solar irradiation provides thermal energy via a window at the south side. The implementation research in this thesis -on floors incorporating micro encapsulated paraffine based PCMs-could only take place with the data provided by these experiments. At the start of the experimental research no data was available on the behaviour of these PCMs in floors in the Dutch moderate climate. It is important to consider that any new ETM needs to prove itself to get a position between all other ETMs available to the construction industry. Hence, time consuming experiments are probably for every ETM needed as a first research method to assess its implementation potential and to study the possibilities to improve it, before actual implementation takes place.

\subsection{Recommendations}

The conducted research has shown that many variables play a role and should be addressed when one wants to assess the implementation potential of an ETM. Many of the variables and the mechanisms through which they operate were introduced by the national government and they regularly change. The requirements regarding the energy performance of buildings become more severe every few years, the required calculation method is frequently changed and the taxes on energy use are often increased annually. This final section presents several recommendations that have managerial and policy implications. They are addressed to the national government, to developers of energy performance software and to energy companies and aim to make the situation in which decisions on the implementation of ETMs are taken more complete. However, in the end, it is the stakeholders involved in building projects, and specifically the actors, that take the decision on which ETMs to implement and which to reject.

\section{Recommendations regarding assessing energy performance}

It needs to be made clear to stakeholders that the compulsory EPIs only reflect building related energy use under standard user conditions, and not the energy use of the dwelling and its residents in reality. When the estimated reduction in energy use due to an ETM is overestimated, investors, house owners and tenants can all become disappointed, and the 
chances that these stakeholders -being potential actors- will implement ETMs in the future are reduced. If, conversely, the reductions in energy use are underestimated, the investor may decide not to implement the proposed ETM because the benefits appear too small. Therefore it seems desirable that the theoretical energy performance is considered in conjunction with the actual environmental conditions, occupational behaviour and the presence of appliances - that is in relation to the total energy actually used over a number of years. The total actual energy used can be calculated from the annual energy bills from the various suppliers. Even greater insight can be obtained if the gas and electric energy balances are broken down such that they reflect the different categories of energy use for each energy form. Given that the national government compels the calculation of EPIs, it is recommended that it provides better information on what the EPC and the $\mathrm{EI}_{\text {new }}$ actually reflect, and what is excluded from the calculations. Further, it needs pointing out that although $1 \mathrm{kWh}$ of electric energy is around one-third of the price of $1 \mathrm{~m}^{3}$ of natural gas, few people are aware that $1 \mathrm{~m}^{3}$ natural gas is roughly equivalent to $10 \mathrm{kWh}$ of electricity in terms of the amount of energy delivered.

In calculating the theoretical energy use and the energy performance of new and existing buildings, various conversion processes are implicitly included. Advisors on HVAC systems, architects and principals need to understand that the conversion from natural gas to thermal energy takes place at two different efficiency rates: one reflecting the efficiency at which the living space is heated and one reflecting the efficiency at which tap water is heated. Another important efficiency rate, set at 39\% in the calculation method, reflects on the efficiency of the production and transport of electric energy. However, no similar losses are taken into account when it comes to natural gas provided to a building. Therefore, the use of natural gas seems to be favoured over electric energy. A figure that precisely indicates which conversions take place and at what efficiencies in the different energy flows from source through to final use would help stakeholders in building projects to identify where large improvements in energy performance can be made. These processes are often represented in Sankey diagrams. Since all the characteristics needed to produce a Sankey diagram are already required in current computer programs, and are set by the standard calculations for EPIs, the implementation of this recommendation should not be that difficult. It is recommended that the national government requests developers of the calculation methods and computer programs to make the conversion processes inside and outside the building more explicit by presenting them visually and providing insights into the efficiencies at which these conversions take place.

Currently, not all the characteristics that influence the energy use of dwellings are taken into account in the calculation methods for EPIs. Not all the available ETMs can be assessed, and there seems to be a considerable threshold for new and innovative ETMs to overcome before they can be incorporated in the assessment and calculation method. In order to reduce the risk that ETMs that do reduce the fossil energy use of buildings are not implemented due to the absence of any significant influence on an EPI, it is recommended 
that the national government improves the flexibility of EPIs as much as possible to enable new ideas to be reflected.

\section{Recommendations regarding energy pricing mechanisms}

In this thesis research, more than eighty energy bills from various energy companies were studied. Each energy company has its own layout and it is not easy to identify what is exactly paid for which service or product, or on what basis. Sernhed et al. (2003) considered the expressed preferences of Swedish customers regarding electricity bills. They found that "the households with high electricity costs in relation to the total household budget tend to read the electricity bill more carefully" (ibid, p. 1150). One Swedish energy company has actually designed their energy bills after the wishes of those that read the information in the energy bill most carefully (Sernhed et al., 2003). In the Netherlands, a national guideline (NMA, 2010) has been issued to standardize the format of energy bills since 2010, but the use of different names for services and products by energy companies still makes it hard to understand energy bills.

Firstly, it is recommended that energy companies, in their energy bills, provide figures that reflect total energy use and the overall marginal costs of natural gas, thermal energy and electric energy per unit of energy. In this way residents could directly see what costs they could save by reducing energy use.

Secondly, it should be considered that many households are only confronted with their energy use twice a year, namely when they need to provide meter values to the measurement company and when they receive the subsequent annual energy bill. It is recommended that households receive information on how their energy bill and energy use compare to similar households and to previous years. This enables them to place their energy use in perspective. Residents would more easily be able to compare energy bills of different years and of comparable dwellings, for example their neighbours, if consistent terminology was used for the various cost components.

Thirdly, it was found that although the prices of services and taxes are sometimes altered several times a year, it was not always possible to identify these alterations and their dates in the energy bills. In some energy bills, the different periods in which particular prices were used are given whereas some energy bills simply indicate an average price. Here, it is debatable what an average price means when energy use is not evenly distributed over the year. For example, recently VAT was increased from $19 \%$ to $21 \%$ on October $1^{\text {st }}$, but what method is used to determine which part of a household's annual energy use is taxed at $19 \%$ rate and how much at $21 \%$ when the meters are read annually on some other date? The same is true for the price of the energy delivered by the energy company. These prices are often adjusted annually on July $1^{\text {st }}$ but again not every annual contract starts and finishes on that particular date, nor are all energy meters checked. It is recommended that energy meters be read more often (perhaps on a monthly basis) and that the dates on which prices are altered are made to coincide with the date on which meters are checked.

Fourthly, a recommendation is offered to the national government concerning energy taxes and the generally applied principle that the polluter pays. In the current taxation approach, 
both the Regulating Energy Taxes (RET) and the Surcharge for Sustainable Energy (SSE) decrease per unit of energy as more energy in the form of natural gas or electric energy is used. Up to 2013, the first threshold regarding use of natural gas was set at 5,000 $\mathrm{m}^{3} /$ year. From 2013 onwards, the first threshold becomes 170,000 $\mathrm{m}^{3} /$ year, after which the RET of $€$ 0.1862 per $\mathrm{m}^{3}$ reduces by $76.4 \%$ and the SSE of $€ 0.0023$ per $\mathrm{m}^{3}$ by $60.9 \%$. For electric energy the first threshold is set at $10,000 \mathrm{kWh} / \mathrm{year}$, after which the RET of $€ 0.1165$ per $\mathrm{kWh}$ reduces by $63.6 \%$ and the SSE of $€ 0.0011$ per $\mathrm{kWh}$ first increases to $€ 0.0014$ per $\mathrm{kWh}$ before reducing to $€ 0.0004$ per $\mathrm{kWh}$ for those using between 50,000 and $10,000,000$ $\mathrm{kWh}$ /year. Although the total amount of tax increases with use, it is hard to explain on the basis of the polluter pays principle why the energy costs are relatively high for those whose energy use is below $170,000 \mathrm{~m}^{3}$ and $10,000 \mathrm{kWh}$ annually. Further, those households that opt to purchase 'green' energy provided by energy companies from renewable sources still pay RET and SSE taxes even though few or no polluting emissions have occurred during conversion.

\section{Recommendations regarding ETMs in building projects}

Considering the role of ETMs in building projects, the first recommendation is related to the aim of the Building Code to provide minimum standards regarding the quality of buildings in the Netherlands. Many organizations active in the construction industry view the Building Code as a guide in determining minimum investment requirements. That is, if the quality of a building design exceeds the requirements of the Building Code, this is interpreted by many in the construction industry as indicating that the costs of materials and labour can be reduced. However, if these stakeholders were able to better communicate with the future owner and residents about investments made to improve the quality of the dwelling, and to reduce its energy use compared to typical dwellings, it might be possible to justify a higher investment through an enhanced value and selling price. As such, it is recommended that project developers and house agents work to improve the positioning of energy performance and implemented ETMs as selling points. The stakeholders involved in building projects are also recommended not to overly focus on the existing methods to calculate EPIs, since many ETMs cannot be incorporated in these methods, but to consider the reductions in actual energy use of future residents. This will give a value to those ETMs whose benefits are not reflected in the EPIs.

The Building Code provides minimum requirements regarding the energy performance and infiltration rates of new buildings and regarding the thermal insulation of both new and renovated buildings. Considering the important role the Building Code has in setting a minimum energy performance for new buildings, it is recommended that a comparable compulsory minimum requirement is set for refurbishing existing buildings. This is seen as important since only a relatively small number of new dwellings are constructed each year, while the existing housing stock still offers many opportunities for improvements. However, it will not be an easy task, and maybe impossible, to introduce and enforce regulations regarding the energy performance of existing buildings because the current energy performance of many dwellings is not known, ETMs are often applied without needing a 
building permit and municipalities do not have sufficient capacity to check whether energy performance calculations correspond to the actual situation. However, there are many voluntary covenants involving umbrella organizations of principals in the construction industry that are already encouraging green Energy Labels for existing dwellings and also subsidy programmes in place to stimulate owners and residents to improve their homes to achieve a green Energy Label. Nevertheless, considering the major impact of the Building Code on the project requirements set by internal stakeholders in building projects, it is believed that enforcing an EPI for existing dwellings, or even establishing one covering buildings in general comparable to the EPC for new buildings, could be of great value.

\section{Recommendations regarding new ETMs for the construction industry}

This thesis showed that obstacles need to be overcome before micro-encapsulated paraffinbased PCMs in concrete floors will have an acceptable implementation potential for heating purposes in Dutch dwellings. In the discussions section of this chapter, a list of identified shortcomings was provided. Here the main recommendation is to develop software to simulate the effects of PCMs in buildings. Further, rather than develop a stand-alone software package, this ETM should be embedded in existing simulation programs that compute indoor temperatures and energy use of proposed new buildings or existing buildings that will undergo renovation. The advantage of using an existing computer program is that these are already used by many stakeholders and an update to these computer programs can be disseminated more easily than trying to introduce a standalone computer program and generate awareness among potential users.

Before including PCMs in simulation software, more research is needed into how to model the influences of environmental characteristics, occupational characteristics, building characteristics, system characteristics and appliances on the actual energy use of dwellings and their residents both with and without the implementation of a new ETM. To verify this kind of model, pilot projects are needed in which data are collected on the effects of implementing a new ETM while considering all relevant characteristics, including its financial impact and its effects on the stakeholders in the building project. Given that the Dutch government has not been able to stimulate the development (Noailly \& Batrakova, 2010) or implementation (Beerepoot, 2007) of innovations through its energy performance policy, it is recommended that the government, in collaboration with developers and manufacturers of new ETMs, takes the initiative to start such pilot projects. In these pilot projects, stakeholders can gain experience with new ETMs with little risk attached. Further, data can be collected to study the effects on energy use, the financial impact and the perceptions of the various stakeholders. These last two recommendations not only apply to PCMs but also to other novel and future ETMs targeted at the construction industry. 


\section{References}

A

Abhat, A. (1983). Low temperature latent heat thermal energy storage: heat storage materials. Solar energy, 30(4), 313-332.

Aedes (2007a). Antwoord aan de samenleving van de wooncorporaties verenigd in Aedes.

Aedes (2007b). Dutch social housing in a nutshell.

Aedes (2008). Convenant energiebesparing corporatiesector.

Aedes (2012). Feiten \& cijfers. Retrieved from http://www.aedes.nl

AgentschapNL (2010). Ruim 75.000 vernieuwde energielabels afgegeven. Retrieved from http://www.senternovem.nl/energielabelgebouwen/nieuws

AgentschapNL (2012a). Voorstel koppeling EPC en energielabel. Retrieved from http://www.agentschapnl.nl

AgentschapNL (2012b). Registratiesysteem voor energielabels van gebouwen 2010-2011. Retrieved from http://www.agentschapnl.nl

AgentschapNL (2012c). EPC van 0.4 voor woningbouw. Retrieved from http://www.agentschapnl.nl.

Aken, J.E. van (2004). Management research based on the paradigm of the design sciences: the quest for field-tested and grounded technological rules. Journal of Management Studies, 41(2), 219-246.

Alanne, K., Söderholm, N., Sirén, K., \& Beausoleil-Morrison, I. (2010). Techno-economic assessment and optimization of Stirling engine micro-cogeneration systems in residential buildings. Energy Conversion and Management, 51(12), 2635-2646.

American Society of Heating, Refrigerating and Air Conditioning Engineers (ASHRAE). (2004). Energy standard for buildings; except low-rise residential buildings.

Andaloro, A.P.F., Salomone, R., loppolo, G., Andaloro, L. (2010). Energy certification of buildings: a comparative analysis of progress towards implementation in European countries. Energy Policy, 38, 5840-5866.

Antvorskov, S. (2008). Introduction to integration of renewable energy in demand controlled hybrid ventilation systems for residential buildings. Building and Environment, 43(8), 1350-1353.

Assimakopoulos, V. (1992). Residential energy demand modelling in developing regions; the use of multivariate statistical techniques. Energy Economics, 14(1), 57-63.

B

Baetens, R., Jelle, B.P., \& Gustavsen, A. (2010). Phase change materials for building applications: A state-of-the-art review. Energy and Buildings, 42(9), 1361-1368.

Barley, S.R., \& Tolbert, P.S. (1997). Institutionalization and structuration: studying the links between action and institution. Organization Studies, 18(1), 93-117.

BASF (2005). Micronal DS 5008 X; Experimental product - Phase-change material (PCM) used in building materials to store latent heat.

BASF (2008). Micronal ${ }^{\circledR}$ PCM; Intelligent temperature management for buildings.

Beerepoot, M. (2007). Public energy performance policy and the effect on diffusion of solar thermal systems in buildings: a Dutch experience. Renewable Energy, 32, 1882-1897.

Bentz, D.P., \& Turpin, R. (2007). Potential applications of phase change materials in concrete technology. Cement and Concrete Composites, 29(7), 527-532.

Beter Wonen, (2009). Ondernemingsplan 2009-2013.

Betts, M., \& Lansley, P. (1995). International Journal of Project Management: A review of the first ten years. International Journal of Project Management, 13(4), 207-217.

Biesiot, W., \& Noorman, K.J. (1999). Energy requirements of household consumption: a case study of The Netherlands. Ecological Economics, 28(3), 367-383.

Boonekamp, P.G.M. (2007). Price elasticities, policy measures and actual developments in household energy consumption; a bottom up analysis for the Netherlands. Energy Economics, 29(2), 133-157.

Bossink, B.A.G. (1998). Duurzaam bouwen in interactie; doelontwikkeling in de woningbouw (PhD thesis). University of Twente, Enschede. 
Braak, M., \& Rooseboom, R. (2008). Renovatie woningen Kerkelanden in volle gang. Unknown magazine, 3-4.

Brkic, D., \& Tanaskovic, T.I. (2008). Systematic approach to natural gas usage for domestic heating in urban areas. Energy, 33(12), 1738-1753.

Brounen, D., \& Kok, N. (2011). On the economics of Energy Labels in the housing market. Journal of Environmental Economics and Management, 62(2), 166-179.

Bruijn, H. de, \& Heuvelhof, E. ten (2008). Management in networks; on multi-actor decision making. ISBN 9780415462495, Routledge Taylor \& Francis Group, Oxon.

Bryson, J.M. (1995). Strategic planning for public and non-profit organizations; a guide to strengthening and sustaining organizational achievement. Jossey-Bass Publishers.

Bryson, J.M. (2004). What to do when stakeholders matter: stakeholder identification and analysis techniques. Public Management Review, 6(1), 21-53.

Buvik, K. (2003). Solar Energy in Buildings; Design Strategies and Control - General Guidelines.

C

Cabeza, L.F., Castellón, C., Nogués, M., Medrano, M., Leppers, R., \& Zubillaga, O. (2007). Use of microencapsulated PCM in concrete walls for energy savings. Energy and Buildings, 39(2), 113-119.

Casals, X.G. (2006). Analysis of building energy regulation and certification in Europe: Their role limitations and differences. Energy and Buildings, 38(5), 381-392.

Centraal Bureau voor de Statistiek (CBS) (2007). Statistisch jaarboek 2007.

Centraal Bureau voor de Statistiek (CBS) (2008). Historie bodemgebruik naar gebruiksvorm. Retrieved from http://statline.cbs.nl

Centraal Bureau voor de Statistiek (CBS) (2010a). Kerncijfers Bouwen en Wonen. Retrieved from http://www.cbs.nl

Centraal Bureau voor de Statistiek (CBS) (2010b). Kerncijfers Bevolking. Retrieved from http://www.cbs.nl

Centraal Bureau voor de Statistiek (CBS) (2010c). Kerncijfers Inkomen en Bestedingen. Retrieved from http://www.cbs.nl

Centraal Bureau voor de Statistiek (CBS) (2010d). Regionale Kerncijfers Nederland; Gemiddelde woningwaarde. Retrieved from http://www.cbs.nl

Centraal Bureau voor de Statistiek (CBS) (2010e). Kerncijfers wijken en buurten. Retrieved from http://www.cbs.nl

Centraal Bureau voor de Statistiek (CBS) (2011a). Energiebalans; kerncijfers. Retrieved from http://statline.cbs.nl

Centraal Bureau voor de Statistiek (CBS) (2011b). Kerncijfers Bevolking. Retrieved from http://www.cbs.nl

Centraal Bureau voor de Statistiek (CBS) (2011c). Hernieuwbare energie. Retrieved from http://statline.cbs.nl

Centraal Bureau voor de Statistiek (CBS) (2011d). Kerncijfers Inkomen en Bestedingen. Retrieved from http://www.cbs.nl

Centraal Bureau voor de Statistiek (CBS) (2011e). Aardgas en elektriciteit, gemiddelde prijzen van eindverbruikers. Retrieved from http://statline.cbs.nl

Centraal Bureau voor de Statistiek (CBS) (2011f). Consumentenprijzen; inflatie vanaf 1963. Retrieved from http://www.cbs.nl

Centraal Bureau voor de Statistiek (CBS) (2012). Heffingen op energiedragers. Retrieved from http://statline.cbs.nl

Centrum voor Onderzoek van de Economie van de Lagere Overheden (COELO) (2010). Woonlastenmonitor.

Chen, C., Guo, H., Liu, Y. , Yue, H., \& Wang, C. (2008). A new kind of phase change material (PCM) for energy-storing wallboard. Energy and Buildings, 40(5), 882-890. 
Cheng, C.L. (2002). Study of the inter-relationship between water use and energy conservation for a building. Energy and Buildings, 34(3), 261-266.

Cogas (2008). Energie prestatie advies voor woningen; Kerkelanden. Program VABI EPA-W kernel 1.10. Compendium voor de Leefomgeving (2010). Energieprestatieadvies (EPA) voor woningen, 2000-2006. Retrieved from: http://www.compendiumvoordeleefomgeving.nl/indicatoren

Cooke, R., Cripps, A., Irwin, A., \& Kolokotroni, M. (2007). Alternative energy technologies in buildings: stakeholder perceptions. Renewable Energy, 32(14), 2320-2333.

\section{D}

Dear, R. de, \& Brager, G.S. (2002). Thermal comfort in naturally ventilated buildings: revisions to ASHRAE Standard 55. Energy and Buildings, 34, 549-561.

Dekker, S.M. (2004). Prestaties van woningcorporaties in 2003, prestatieafspraken en toezicht in 2004. DGW/SR2004130681, Ministerie van VROM, 's-Gravenhage.

Department of Energy (DoE) (2011a). Energy Analysis Tools. Retrieved from http://www.eere.energy.gov

Department of Energy (DoE) (2011b). Mission. Retrieved from http://www.energy.gov

Department of Energy (DoE) (2011c). Building energy codes; university.

De Witte - Van der Heijden Architecten (2005). Energieprestatie woonfuncties en woongebouwen; Kollenveld Almelo. Program NPR 5129 - EPW Windows v1.2.

DGMR Raadgevende Ingenieurs BV. (2007). Energie Certificaat Woningbouw. versie 1.11.

Dijkoraad (2005). Energie prestatie berekening woontoren Friso - Beter Wonen. Program VABI EPA-W kernel 2.25 .

Duijvestein, C.A.J. (1993). Ecologisch bouwen. Delft University of Technology.

DWA Installatie- en Energieadvies. (2008). Energie-efficiënte renovatie van flats Jan Vermeerstraat te Almelo.

$\mathbf{E}$

Edelstein, P., \& Kilian, L. (2009). How sensitive are consumer expenditures to retail energy prices? Journal of Monetary Economics, 56(6), 766-779.

Eden, C., \& Ackermann, F. (1998). Making strategy: the journey of strategic management. London, Sage Publications.

Eichholtz, P., Kok, N., \& Quigley, J.M. (2010). Doing well by Doing Good? An analysis of the financial performance of green office buildings in the USA. American Economic Review, 100(5), 2492-2509.

Elkington, J. (1999). Cannibals with forks; the triple bottom line of $21^{\text {st }}$ century business $\left(1^{\text {st }}\right.$ edition paperback). Capstone Publishing Limited.

Energie Centrum Nederland (ECN) (2010). Elektriciteitsgebruik huishoudens. Retrieved from http://www.energie.nl

Energie Centrum Nederland (ECN) (2011). Gemiddeld energiegebruik huishoudens. Retrieved from http://www.energie.nl

Energie-Nederland (2010). Energie in Nederland - Energy in the Netherlands 2010.

Energie-Nederland (2011a). Energie in Nederland - Energy in the Netherlands 2011.

Energie-Nederland (2011b). Tariefadvies voor de levering van Warmte aan Kleinverbuikers 2011.

Energy Information Administration (EIA). (2011). Total Energy. Retrieved from: http://www.eia.gov/

Entrop, A.G., \& Brouwers, H.J.H. (2010). Assessing the sustainability of buildings using a framework of triad approaches. Journal of Building Appraisal, 5(4), 293-310.

Entrop, A.G., Brouwers, H.J.H., \& Reinders, A.H.M.E. (2010). Evaluation of energy performance indicators and financial aspects of energy saving techniques in residential real estate. Energy and Buildings, 42(5), 618-629.

Entrop, A.G., Brouwers, H.J.H., \& Reinders, A.H.M.E. (2011). Experimental research on the use of micro-encapsulated Phase Change Materials to store solar energy in concrete floors and to save energy in Dutch houses. Solar Energy, 85(5), 1007-1020. 
Erhorn, H. (1988). Influence of meteorological conditions on inhabitants' behaviour in dwellings with mechanical ventilation. Energy and Buildings, 11, 267-275.

Esen, M., \& Ayhan, T. (1996). Development of a model compatible with solar assisted cylindrical energy storage tank and variation of stored energy with time for different phase change materials. Energy Conversion and Management, 37(12), 1775-1785.

Esen, M., Durmuş, A., \& Durmuş, A. (1998). Geometric design of solar aided latent heat store depending on various parameters and phase change materials. Solar Energy, 62(1), 19-28.

Esen, M. (2000). Thermal performance of a solar-aided latent heat store used for space heating by heat pump. Solar Energy, 69(1), 15-25.

Essent (2013). Producten \& Tarieven. Retrieved from http://www.essent.nl

European Alliance of Companies for Energy Efficiency in Buildings (EuroAce). (2004). Towards energy efficient buildings in Europe.

European Commission (EC). (2007). Netherlands - Energy Mix Fact Sheet. retrieved from http://ec.europa.eu/energy/energy_policy/facts_en.htm

European Council (EC) (2002). Energy Performance Building Directive (EPBD). Directive 2002/91/EC of the European Parliament and Council.

European Council (EC) (2009). Ecodesign requirements for non-directional household lamps. Directive 2005/32/EC of the European Parliament and of the Council.

European Union (EU) (2007). Beschikking van de commissie van 9 november 2007 tot vaststelling van de milieucriteria voor de toekenning van de Europese milieukeur aan elektrische, gas- of gasabsorptiewarmtepompen (2007/742/EG).

European Union (EU) (2010). Directive on the energy performance of buildings. Directive 2010/31/EU of the European Parliament and of the Council.

Eurostat (2012a). Electricity prices by type of user. Retrieved from: http://ec.europa.eu/eurostat

Eurostat (2012b). Gas prices by type of user. Retrieved from: http://ec.europa.eu/eurostat

Eurostat (2013). Consumption of energy. Retrieved from: http://epp.eurostat.ec.europa.eu/

$\mathbf{F}$

Freeman, R.E. (1984). Strategic management: a stakeholder approach. Marshfield, Pitman Publishing Inc.

Funda (2010). Woningaanbod. Retrieved from http://www.funda.nl

G

Garcia, R., \& Calantone, R. (2002). A critical look at technological innovation typology and innovativeness terminology: a literature review. Journal of Product Innovation Management, 19(2), 110-132.

Gemeente Almelo (2002). Milieubeleidsplan 2001-2005; samen naar een duurzaam Almelo.

Gemeente Almelo (2003). Duurzame woningbouw gemeente Almelo; Kollenveld. Afd. Wonen.

Gemeente Almelo (2005). Ons leefmilieu voor nu in de toekomst. Afd. Ruimtelijke Ordening en Milieu.

Gemeente Almelo (2006). Comfortabel, gezond en energiezuinig wonen; nu en in de toekomst.

Gemeente Almelo (2007). Evaluatie gemeentelijk milieubeleidsplan 2001-2005.

Gemeente Almelo (2008). Klimaatbeleid geeft energie; resultaten en leerpunten Klimaat Uitvoerings Programma.

Gilly, M.C., \& Enis, B.M. (1982). Recycling the family life cycle: a proposal for redefinition. Advances in Consumer Research, 9, 271-276.

Gómez-Muñoz, V.M., Porta-Gándara, M.A. (2003). Simplified architectural method for the solar control optimization of awnings and external walls in houses in hot and dry climates. Renewable Energy, 28(1), 111-127.

Graaf, A. de (2004). Jongeren eerder uit huis. CBS Webmagazine, june $28^{\text {th }}$. Retrieved from: http://www.cbs.nl

GreenChoice (2012). Jaarafrekening (JN025349956). Period October $6^{\text {th }} 2011$ to September 30 2012. 
Grondzik, W.T., Kwok, A.G., Stein, B., \& Reynolds, J.S. (2010). Mechanical and electrical equipment for buildings (11th. ed.). John Wiley \& Sons, Inc.

Guerra Santín, O., Itard, L., Visscher, H. (2009). The effect of occupancy and building characteristics on energy use for space and water heating in Dutch residential stock. Energy and Buildings, 41(11), $1223-1232$.

H

Haas, R., Auer, H., \& Biermayr, P. (1998). The impact of consumer behavior on residential energy demand for space heating. Energy and Buildings, 27(2), 195-205.

Hal, J.D.M. van (2000). Beyond the demonstration project; the diffusion of environmental innovations in housing (PhD thesis). Delft University of Technology, Delft.

Hart, M., \& Dear, R. de (2004). Weather sensitivity in household appliance energy end-use. Energy and Buildings, 36(2), 161-174.

Hestnes, A.G. (2001). The new solar buildings. Proceedings of the $9^{\text {th }}$ International Conference on Solar Energy in High Latitudes; 6-8 May, Leiden, The Netherlands.

Hoiting, H., Donze, G.J., \& Nuiten, P.W.G. (2004). Energieprestatiemethoden: Samen sterk? Bouwfysica, 17(1), 24-28.

Hoppe, T. (2009). CO2-reductie in de bestaande woningvoorraad; een beleidswetenschappelijk onderzoek naar ambitie en realisatie ( $\mathrm{PhD}$ thesis). University of Twente, Enschede.

Hunger, M., Entrop, A.G., Mandilaras, I., Brouwers, H.J.H., \& Founti, M. (2009). The behavior of selfcompacting concrete containing micro-encapsulated Phase Change Materials. Cement Concrete Composites, 31(10), 731-743.

I

Instituut voor Studie en Stimulering van Onderzoek voor de installatiesector (ISSO) (2007a). Handleiding Energieprestatie-Advies Woningen Energieprestatiecertificaat + algemeen deel (publicatie 82.1).

Instituut voor Studie en Stimulering van Onderzoek voor de installatiesector (ISSO) (2007b). Handleiding Energieprestatie-Advies Woningen Maatwerkadvies (publicatie 82.2).

Instituut voor Studie en Stimulering van Onderzoek voor de installatiesector (ISSO) (2007c). Handleiding Energieprestatie-Advies Woningen Formulestructuur (publicatie 82.3).

Instituut voor Studie en Stimulering van Onderzoek voor de installatiesector (ISSO) (2007d). Handleiding Energieprestatie-Advies Utiliteitsgebouwen Maatwerkadvies (publicatie 75.2).

Instituut voor Studie en Stimulering van Onderzoek voor de installatiesector (ISSO) (2010). Handleiding Energieprestatie-Advies Utiliteitsgebouwen Formulestructuur (publicatie 75.3).

Instituut voor Studie en Stimulering van Onderzoek voor de installatiesector (ISSO) (2011). Handleiding Energieprestatie-Advies Utiliteitsgebouwen Energieprestatiecertificaat + algemeen deel (publicatie 75.1).

International Energy Agency (IEA) (2008). Energy efficiency requirements in building codes, energy efficiency policies for new buildings.

International Organisation for Standardization (ISO) (2008). NEN-ISO 13790 Energy performance of buildings - Calculation of energy use for space heating and cooling.

Iwashita, G. , \& Akasaka, H. (1997). The effects of human behaviour on natural ventilation rate and indoor air environment in summer - a field study in southern Japan. Energy and Buildings, 25(3), 195-205.

J

Jacobs, A., Heusinkveld, A. \& Holtslag, A. (2011). Long-term record and analysis of soil temperatures and soil heat fluxes in a grassland area, The Netherlands. Agricultural and Forest Meteorology, 151(7), 774-780.

Janda, K.B. (2011). Buildings don't use energy: people do. Architectural Science Review, 54, 15-22.

Johnson, G., \& Scholes, K. (2002). Exploring corporate strategy (6th. ed.). Harlow, Pearson Education. 
Juanicó, L.E. (2009). A new design of configurable solar awning for managing cooling and heating loads. Energy and Buildings, 41(12), 1381-1385.

K

Kadaster, Het (2011). Vastgoed dashboard. Retrieved from http://www.kadaster.nl

Kadefors, A. (1995). Institutions in building projects: Implications for flexibility and change. Scandinavian Journal of Management, 11(4), 395-408.

Kagioglou, M., Cooper, R., Aouad, G., Hinks, J., Sexton, M., \& Sheath, D. (1998). Process protocol. University of Salford, Salford.

Kagioglou, M., Cooper, R., Aouad, G., \& Sexton, M. (2000). Rethinking construction: the generic design and construction process protocol. Engineering, Construction and Architectural Management, 7 (2), 141-153.

Kessides, I.N., \& Wade, D.C. (2011). Towards a sustainable global energy supply infrastructure: Net energy balance and density considerations. Energy Policy, 39(9), 5322-5334.

Khudhair, A.M., Farid, M.M. (2004). A review on energy conservation in building applications with thermal storage by latent heat using phase change materials. Energy Conversion and Management, 45(2), 263-275.

Klunder, G. (2004). The search for the most eco-efficient strategies for sustainable housing construction; Dutch lessons. Journal of Housing and the Built Environment, 19(1), 111-126.

Koninklijk Nederlands Meteorologisch Instituut (KNMI). (2010). Weather conditions per hour and per 24 hours for the weather station Twenthe 2001-2010. Retrieved from http://www.knmi.nl

Koninklijk Nederlands Meteorologisch Instituut (KNMI). (2011). Klimaatatlas. Retrieved from http://www.klimaatatlas.nl

Kooij, B.J.G. van der (1988). Innovatie gedefinieerd; een analyse en een voorstel (oration). Eindhoven University of Technology.

$\mathbf{L}$

Leaman, A., and Bordass, B. (2007). Are users more tolerant of 'green' buildings? Building Research \& Information, 35(6), 662-673.

Lefley, F. (1996). The payback method of investment appraisal: a review and synthesis. International Journal of Production Economics, 44, 207 -224.

Leth-Petersen, S., \& Togeby, M. (2001). Demand for space heating in apartment blocks: measuring effects of policy measures aiming at reducing energy consumption. Energy Economics, 23(4), 387403.

Leeuwen, G. van, Middelkamp, W., Mönnink, H. de, \& Kroese, E. (2009). Bouw toren Friso Almelo drie maanden voor op schema. Bouwen in het Oosten, 17(1), 9-13.

Li, J., Xue, P., Ding, W., Han, J., \& Sun, G. (2009). Micro-encapsulated paraffin/high-densty polyethylene/wood flour composite as form-stable phase change material for thermal energy storage. Solar Energy Materials and Solar Cells, 93(10), 1761-1767.

Li, Y., Lence, B.J, \& Calisal, S.M. (2011). An integrated model for estimating energy cost of a tidal current turbine farm. Energy Conversion and Management, 52, 1677-1687.

Liao, H.C., \& Chang, T.F. (2002). Space-heating and water-heating energy demands of the aged in the US. Energy Economics, 24(3), 267-284.

Linden, A.C. van der, Boerstra, A.C., Raue, A.K., Kurvers, S.R., \& Dear, R.J. de (2006). Adaptive temperature limits: A new guideline in The Netherlands - A new approach for the assessment of building performance with respect to thermal indoor climate. Energy and Buildings, 38(1), 8-17.

Liddament, M.W., \& Orme, M. (1998). Energy and ventilation. Applied Thermal Engineering, 18(11), 1101-1109.

Ljungberg, L.Y. (2007). Materials selection and design for development of sustainable products. Materials and Design, 28, 466-479.

Lucas, R. (2011). Analysis of 2009 International Energy Conservation Code Requirements for Residential Buildings in Mesa, Arizona. Retrieved from: http://www.mesaaz.gov/sustainability/ 
Lysen, E. (1996). The Trias Energica: Solar Energy Strategies for Developing Countries. Proceedings of the EUROSUN Conference. 16-19 September, Freiburg, Germany.

M

Man, R. de (1983). Barriers to energy conservation - the case of the Netherlands social housing sector. Energy Policy, 11(4), 363-368.

Masmoudi, S., \& Mazouz, S. (2004). Relation of geometry, vegetation and thermal comfort around buildings in urban settings, the case of hot arid regions. Energy and Buildings, 36(7), 710-719.

Matrix I.A. (2007a). Energieprestatie woonfuncties en woongebouwen; Flats Rombout Verhulstlaan. Program NPR 5129-EPW v2.1. November $9^{\text {th }}, 2007$.

Matrix I.A. (2007b). Energieprestatie woonfuncties en woongebouwen; Flats Rombout Verhulstlaan. Program NPR 5129 - EPW v2.1. November $12^{\text {th }}, 2007$.

Matrix I.A. (2008). Energieprestatie woonfuncties en woongebouwen; Renovatie flats Rombout Verhulstlaan. Program NPR 5129 - EPW v2.1. March 21 $1^{\text {st }}, 2008$.

Meester, T. de, Marique, F.M., Herde, A. de, Reiter, S. (2013). Impacts of occupant behaviours on residential heating consumption for detached houses in a temperate climate in the northern part of Europe. Energy and Buildings, 57, 313-323.

Mehling, H., Cabeza, L.F., (2008). Heat and cold Storage with PCM: an up to date introduction into basics and applications. Berlin, Germany: Springer.

Meredith, J.R., \& Mantel, S.J. (2010). Project management; a managerial approach (7th. ed.). John Wiley \& Sons, Inc.

Mertens, S. (2009). $1^{\text {ste }}$ Evaluatie meetresultaten testveld kleine windturbines Zeeland.

Míguez, J.L., Porteiro, J., López-González, L.M., Vicuña, J.E., Murillo, S., Morán, J.C., \& Granada, E. (2006). Review of the energy rating of dwellings in the European Union as a mechanism for sustainable energy. Renewable and Sustainable Energy Reviews, 10(1), 24-45.

MilieuCentraal (2011). Energiebesparen; koken. Retrieved from: http://www.milieucentraal.nl

Ministerie van Binnenlandse Zaken en Koninkrijksrelaties (Ministerie van BZK) (2011). Huurbeleid 2011-2012.

Ministerie van Volkshuisvesting, Ruimtelijke Ordening en Milieubeheer (Ministerie van VROM). (2009). Aanpassing woningwaarderingsstelsel. Letter minister E.E. van der Laan, 27 August.

Mills, R.W. (1988). Capital Budgeting The State of the Art. Long Range Planning, 21(4), 76-81.

Moyer, C., McGuigan, J.R., Kretlow, W.J. (2006). Contemporary financial management (10th. ed.). Thomson-South-Western.

Müthing, F. (2010). Energy savings in Dutch dwellings using PCMs in concrete floors (MSc thesis). University of Twente, Enschede.

\section{$\mathbf{N}$}

Nagano, K., Takeda, S., Mochida, T., Shimakura, K., \& Nakamura, T. (2006). Study of a floor supply air conditioning system using granular phase change material to augment building mass thermal storage-Heat response in small scale experiments. Energy and Buildings, 38(5), 436-446.

Nationaal Instituut voor Budgetvoorlichting (Nibud) (2011). Energie en water. Retrieved from: http://www.nibud.nl/uitgaven/huishouden/gas-elektriciteit-en-water.html

Nederlandse Mededingingsautoriteit (NMA) (2010). Richtlijn energierekening voor consumenten 2010. March $31^{\text {st }}$.

Nederlandse Mededingingsautoriteit (NMA) (2011a). Besluit van de Raad van Bestuur van de Nederlandse Mededingingsautoriteit als bedoeld in artikel 81e, tweede lid van de Gaswet $(103739 / 8)$. November $8^{\text {th }}$.

Nederlandse Mededingingsautoriteit (NMA) (2011b). Besluit van de Raad van Bestuur van de Nederlandse Mededingingsautoriteit als bedoeld in artikel 40a van de Elektriciteitswet 1998 (103740/7). November $8^{\text {th }}$. 
Nederlandse Mededingingsautoriteit (NMA) (2012a). Besluit van de Raad van Bestuur van de Nederlandse Mededingingsautoriteit als bedoeld in artikel 81e, tweede lid van de Gaswet. (104054/16). November $23^{\text {rd }}$.

Nederlandse Mededingingsautoriteit (NMA) (2012b). Besluit van de Raad van Bestuur van de Nederlandse Mededingingsautoriteit als bedoeld in artikel 40a van de Elektriciteitswet 1998 (104053/17). November $23^{\text {rd }}$.

Nederlandse Mededingingsautoriteit (NMA). (2013). Tarief meterhuur. Retrieved from: http://www.nma.nl/vraag_en_antwoord/energie/tarieven/

Nederlands Normalisatie Instituut (NNI) (1992). NEN 5066 Warmteverliesberekening voor gebouwen - Berekening van het benodigde vermogen voor het verwarmen van een ruimte.

Nederlands Normalisatie Instituut (NNI) (2004a). NEN 5128 Energy performance of residential functions and residential buildings - Determination method.

Nederlands Normalisatie Instituut (NNI) (2004b). NEN 2916 Energy performance of non-residential buildings - Determination method (ICS 91.120.10).

Nederlands Normalisatie Instituut (NNI) (2005). NPR 5129 Energy performance of residential functions and residential buildings - Calculation program (EPW) with handbook (ICS 91.120.10).

Nederlands Normalisatie Instituut (NNI) (2008). NEN-EN 15603 Energy performance of buildings Overall energy use and definition of energy ratings.

Nederlands Normalisatie Instituut (NNI) (2011). NEN 7120 Energieprestatie van gebouwen Bepalingsmethode.

Nederlands Normalisatie Instituut (NNI) (2012). Normen voor de bouwsector. Retrieved from http://www.nen.nl

Nederlands Normalisatie Instituut (NNI) (2013). Overzicht ontwikkeling Energie Prestatie Coëfficient en bepalingsmethoden. Retrieved from http://www.nen.nl

Newcombe, R. (2003). From client to project stakeholders: a stakeholder mapping approach. Construction Management and Economics, 21(8), 841-848.

Nieuweboer, J. (2011). Jongeren minder bereid een huis te kopen. CBS Webmagazine, November $21^{\text {st }}$. Retrieved from: http://www.cbs.nl

Noailly, J., \& Batrakova, S. (2010). Stimulating energy-efficient innovations in the Dutch building sector: empirical evidence from patent counts and policy lessons. Energy Policy, 38, 7803-7817

Nutt, P.C., \& Backoff, R.W. (1992). Strategic management of public and third sector organizations: a handbook for leaders. San Francisco, Jossey-Bass.

o

Op 't Veld, P. (2008). Introduction to EC RESHYVENT-EU cluster project on demand controlled hybrid ventilation for residential buildings. Building and Environment, 43(8), 1342-1349.

\section{$\mathbf{P}$}

Pantic, S., Candanedo, L., Athienitis, A.K., (2010). Modeling of energy performance of a house with three configurations of building-integrated photovoltaic/thermal systems. Energy and Buildings, 42, 1779-1789.

Parto, S., Loorbach, D., Lansink, A., \& Kemp, R. (2007). Transitions and institutional change: The case of the Dutch waste subsystem. In: S. Parto and B. Herbert-Copley (eds.) Industrial innovation and environmental regulation; developing workable solutions. United Nations University Press, New York, pp. 233-257.

Pasupathy, A., Velraj, R., \& Seeniraj, R.V. (2008a). Phase change material-based building architecture for thermal management in residential and commercial establishments. Renewable and Sustainable Energy Review, 12(1), 39-64.

Pasupathy, A., Athanasius, L., Velraj, R., \& Seeniraj, R.V. (2008b). Experimental investigation and numerical simulation analysis on the thermal performance of a building roof incorporating phase change material (PCM) for thermal management. Applied Thermal Engineering, 28(5-6), 556-565. 
Pati, D., Park, C.S., \& Augenbroe, G. (2006). Roles of building performance assessment in stakeholder dialogue in AEC. Automation in Construction, 15(4), 415-427.

Peippo, K., Kauranen, P., \& Lund, P.D. (1991). A multicomponent PCM wall optimized for passive solar heating. Energy and Buildings, 17(4), 259-270.

Pérez-Lombard, L., Ortiz, J., \& Pout, C. (2008). A review on buildings energy consumption information. Energy and Buildings, 40, 394-398.

Planbureau voor de Leefomgeving (PBL). (2011). Antwoorden op vragen RLI inzake advies naar een duurzame energiehuishouding. Retrieved from: http://www.rli.nl/

Platform Energietransitie Gebouwde Omgeving (PeGO) (2007). Meer met minder. In collaboration with: EnergieNed \& Aedes.

Plegt, M. (2009). System engineering in de woningbouw; toepassing van Systems Engineering in het oplossen van de beheersproblematiek van Beter Wonen (MSc thesis). University of Twente, Enschede.

Poel, B., Cruchten, G. van, \& Balaras, C.A. (2007). Energy performance assessment of existing dwellings. Energy and Buildings, 39(4), 393-403.

Prins, J. (2012). Modelling the effects of phase change materials on the energy use in buildings: results of experiments and system dynamics modelling (MSc thesis). University of Twente, Enschede.

$\mathbf{R}$

RAL German institute for quality assurance and certification (RAL) (2009). RAL-GZ 896 Phase Change Material - Quality assurance.

RAL German institute for quality assurance and certification (RAL) (2010). Verleihungs-Urkunde Micronal DS 5000 X \& Micronal DS $5001 X$.

Raven, R., \& Verbong, G. (2004). Dung, sludge, and landfill; Biogas technology in The Netherlands, 1970-2000. Technology and Culture, 45(3), 519-539.

Regio Twente (1997). Convenant duurzaam bouwen Twente.

Regio Twente (2012). Algemeen. Retrieved from http://www.regiotwente.nl

Rogers, E.M. (2003). Diffusion of innovations (5th. ed.). Free Press, New York.

$\mathbf{S}$

SenterNovem (2003). Handleiding basismethode EPA software (v4.02).

SenterNovem (2006). Cijfers en tabellen 2006 (2KPGE-06.01).

SenterNovem (2007) Voorbeeldwoningen bestaande bouw 2007 (2KPWB0618).

Sernhed, S., Pyrko, J. \& Abaravicius, J. (2003). Bill me this way! - customer preferences regarding electricity bills in Sweden. Proceedings of the ECEE 2003 Summer Study Time to turn down energy demand (pp. 1147-1150).

Shrestha, S., Miller, W., Stovall, T., Desjarlais, A., Childs, K., Porter, W., Bhandari, M., Coley, S. (2011). Modeling PCM-enhanced insulatin system and benchmarking EnergyPlus against controlled field data. Proceedings of Building Simulation 2011: $12^{\text {th }}$ Conference of International Building Performance Simulation Association (pp. 800-807), Sydney, Australia.

Simões, N., \& Serra, C. (2012). Ground contact heat losses: simplified calculation method for residential buildings. Energy, 48(1), 66-73.

Smith, W.F., \& Hashemi, J. (2006). Foundations of materials science and engineering (4th edition).

Söderlund, J. (2011). Pluralism in project management: navigating the crossroads of specialization and fragmentation. International Journal of Management Reviews, 13(2), 153-176.

Soest, D.P. van, (2005). The impact of environmental policy instruments on the timing of adoption of energy-saving technologies. Resource and Energy Economics, 27, 235-247.

Staatsblad van het Koninkrijk der Nederlanden (Stb) 555. (1992). Besluit van 9 oktober 1992, houdende regels betreffende instellingen, werkzaam in het belang van de volkshuisvesting Besluit Beheer Sociale Huursector (BBSH). 
Staatsblad van het Koninkrijk der Nederlanden (Stb) 461. (1997). Besluit van 6 oktober 1997, houdende wijziging van het Bouwbesluit - aanscherping energieprestatiecoëfficiënt voor woningen en woongebouwen 1998.

Staatsblad van het Koninkrijk der Nederlanden (Stb) 439. (1999). Besluit van 11 oktober 1999, houdende wijziging van het Bouwbesluit - aanscherping energieprestatiecoëfficiënt voor woningen en woongebouwen 2000.

Staatsblad van het Koninkrijk der Nederlanden (Stb) 513. (1999). Besluit van 23 november 1999, houdende vaststelling van het tijdstip van inwerkingtreding van het koninklijk besluit van 11 oktober 1999 tot wijziging van het Bouwbesluit - aanscherping energieprestatiecoëfficiënt voor woningen en woongebouwen 2000.

Staatsblad van het Koninkrijk der Nederlanden (Stb) 528. (2005). Besluit van 15 oktober 2005, houdende wijziging van het Bouwbesluit 2003 - wijziging met betrekking tot de aanscherping van de energieprestatiecoëfficiënt voor de woonfunctie en enkele andere wijzigingen.

Staatsblad van het Koninkrijk der Nederlanden (Stb) 608. (2006). Besluit van 24 november 2006 tot implementatie van de richtlijn betreffende de energieprestatie van gebouwen - Besluit energieprestatie gebouwen.

Staatsblad van het Koninkrijk der Nederlanden (Stb) 216. (2007). Besluit van 6 juni 2007, houdende vaststelling van het tijdstip van inwerkingtreding van het Besluit energieprestatie gebouwen.

Staatsblad van het Koninkrijk der Nederlanden (Stb) 673. (2012). Wet van 20 december 2012, houdende regels voor de opslag duurzame energie (Wet opslag duurzame energie).

Stuurgroep Experimenten Volkshuisvesting (SEV). (2004). Bouwen met tijd.

Sunikka, M. (2006). Energy efficiency and low-carbon technologies in urban renewal. Building Research \& Information, 34(6), 521-533.

Sunshine, W.L. (2011). 5 Energy laws that govern federal agencies. Retrieved from: http://about.com T

Thomsen, K.E., Schultz, J.M., \& Poel, B. (2005). Measured performance of 12 demonstration projects - IEA Task 13 "advanced solar low energy buildings". Energy and Buildings, 37(2), 111-119.

Turner, J.R. (1999). The handbook of project-based management (2nd. ed.). Glasgow, McGraw Hill. U

United Nation (UN). (1987). Report of the World Commission on Environment and Development: Our Common Future.

United Nations Population Fund (UNFPA). (2011). The State of World Population 2011; People and possibilities in a world of 7 billion.

Urchueguía, J.F., Zacarés, M., Corberán, J.M., Montero, Á., Martos, J., Witte, H. (2008). Comparison between the energy performance of a ground coupled water to water heat pump system and an air to water heat pump system for heating and cooling in typical conditions of the European Mediterranean coast. Energy Conversion and Management, 49, 2917-2923.

V

Valentin (2013). PCM Express (planning and simulation program). Retrieved from http://www.valentin.de/en/products/pcm/58/pcm-express

Velds, C.A. (1992). Zonnestraling in Nederland.

Verkerk, G., Broens, J.B., Kranendonk, W., Puij, F.J. van der, Sikkema, J.L., \& Stam, C.W. (1992). Binas (3rd. ed.). Wolters Noordhoff, Groningen.

Vringer, C.R. (2005). Analysis of the energy requirement for household consumption (PhD thesis). University of Utrecht, Utrecht.

Vringer, K., Aalbers, T. \& Blok, K. (2007). Household energy requirement and value patterns. Energy Policy, 35(1), 553-566.

W

Wet milieubeheer. (1979). Hoofdstuk 10 Afvalstoffen, Titel 10.2 Het afvalbeheersplan, art. 10.4. Wever, N. (2008). Effectieve temperatuur en graaddagen. Retrieved from: http://www.knmi.nl 
Wilson, A., \& Boehland, J. (2005). Small is beautiful; U.S. House size, resource use and the environment. Journal of Industrial Ecology, 9(1-2), 277-287.

Winch, G.M. (2010). Managing construction projects; an information processing approach (2nd. Ed.). Wiley-Blackwell.

Winch, G., Meunier, M.C., Head, J., \& Russ, K. (2012). Projects as the content and process of change; the case of the health and safety laboratory. International Journal of Project Management, 30, 141-152.

Woningwet. (1991). Afdeling 3. Instellingen werkzaam in het belang van de volkshuisvesting.

Wood, C.J., Liu, H., \& Riffat, S.B. (2010). An investigation of the heat pump performance and ground temperature of a piled foundation heat exchanger system for a residential building. Energy, 35(12), 4932-4940.

Y

Yin, R.K. (2003). Case study research: design and methods (3rd. ed.). Sage Publications.

\section{Z}

Zalba, B., Marín, J.M., Cabez, L.F., \& Mehling, H. (2003). Review on thermal energy storage with phase change materials, heat transfer analysis and applications. Applied Thermal Engineering, 23(3), 251-283.

Zhang, D., Tian, S., \& Xiao, D. (2007). Experimental study on the phase change behavior of phase change material confined in pores. Solar Energy, 81(5), 653-660.

Zheng, Jing, Y., Huang, H., Shi S., Zhang, X. (2010). Developing a fuzzy analytic hierarchical process model for building energy conservation assessment. Renewable Energy, 35(1), 78-87.

Zhu, N., Ma, Z., \& Wang, S. (2009). Dynamic characteristics and energy performance of buildings using phase change materials: a review. Energy Conversion and Management, 50(12), 3169-3181.

\section{Personal communication}

A. Senior policy officer sustainability, municipality of Almelo, interview, June $19^{\text {th }} 2012$

B. Architect and owner, Grunstra Architecten Groep bna, interview, July $27^{\text {th }} 2012$

C. Project manager, social housing association Beter Wonen, interview, April $17^{\text {th }} 2012$

D. Manager energy strategies and concept development, DWA, interview, June $29^{\text {th }} 2012$

E. Project leader connections, Cogas Infra \& Beheer BV, email, July $12^{\text {th }} 2012$

F. Director, VABI Software, phone call, September $21^{\text {st }} 2012$

G. Employee land distribution, municipality of Almelo, interview, June $19^{\text {th }} 2012$

H. Planning officer, contractor Dura Vermeer, email, June $11^{\text {th }} 2012$

I. Senior advisor environmental technology, municipality of Almelo, interview, June $19^{\text {th }} 2012$

J. Project manager, social housing association Beter Wonen, interview, April $5^{\text {th }} 2012$

J. Project manager, social housing association Beter Wonen, email, April $12^{\text {th }} 2012$

K. Advisor building technology, municipality of Almelo, interview, June $19^{\text {th }} 2012$

L. Structural engineer, Aveco de Bondt BV, email, June $6^{\text {th }} 2012$

M. Architect, Architektenburo Smid en Peters, email, July $7^{\text {th }} 2012$

N. Head sales support and aftercare, Van Dijk Groep - Bouw, email, June $6^{\text {th }} 2012$

O. Policy advisor environmental affairs, Twente Region, email, July $10^{\text {th }} 2012$

P. Contractor, Roosdom Tijhuis, email, July $23^{\text {th }} 2012$

Q. Architect and owner, De Witte - Van der Heijden Architecten, interview, June $20^{\text {th }} 2012$

R. Project coordinator, contractor Dura Vermeer, email, June $11^{\text {th }} 2012$ 


\section{Appendix A: Detailed descriptions objects in case study on dwellings}

\section{House 1: 1913}

The first research object is a semi-detached house nearby the city centre of Enschede. By the end of 2009 the municipality of Enschede had approximately 68,000 dwellings to accommodate 156,070 people (CBS, 2010e). The house in this case study was constructed in 1913. At that time, fire places were used for heating purposes. Nowadays a central heating system with a high efficiency boiler (HR 107) has overtaken that function. Five students are living in this house. All students have their own bed room, that offers enough space for a desk to perform their study tasks. Every student owns a computer. This influences the electric energy use significantly compared to standard households.

In general semi-detached houses built before 1966 have a cellar and attic high enough to stand in (SenterNovem, 2007). At the ground floor one student room, the joint living room, kitchen and bathroom are located. Four rooms were originally located at the first floor, but in this case object only two rooms are available. The attic facilitates two student rooms. The kitchen and bathroom are located on short distance enabling heated water to reach taps quickly.

The building related energy use of detached houses of this era is estimated to be $2,947 \mathrm{~m}^{3}$ of natural gas and $232 \mathrm{kWh}$ of electric energy resulting in an Energy Label F (SenterNovem, 2007). This electric energy was in Chapter 2 introduced as auxiliary electric energy needed to operate the heating system. However, this case object has no cavity walls resulting in an even lower thermal resistance of the walls. On the other hand thermal roof insulation was installed and a high efficiency boiler is being used. The reference dwelling only speaks of three inhabitants in a standard family situation instead of five students at the age of 18 to 25 years old.

$\begin{array}{llll}A_{\text {cellar;house }}=8.4 \mathrm{~m}^{2} & \mathrm{~L}_{\text {shower }} & =3.0 \mathrm{~m} \\ A_{\text {groundfloor;house }} & =61.02 \mathrm{~m}^{2} & \mathrm{~L}_{\text {sink }} & =3.5 \mathrm{~m} \\ A_{\text {1st floor; house }}=44.99 \mathrm{~m}^{2} & R_{c ; \text { walls living room }} & =0.211 \mathrm{~m}^{2} \mathrm{~K} / \mathrm{W} \\ A_{\text {2nd floor;house }}=18.99 \mathrm{~m}^{2} & R_{c ; \text { walls kitchen bathroom }} & =0.140 \mathrm{~m}^{2} \mathrm{~K} / \mathrm{W} \\ A_{\text {total; heated }}=124.6 \mathrm{~m}^{2} & R_{c ; \text { roof top }} & =2.134 \mathrm{~m}^{2} \mathrm{~K} / \mathrm{W} \\ A_{\text {total; nonheated }}=8.4 \mathrm{~m}^{2} & R_{c ; \text { flat roof }} & =0.336 \mathrm{~m}^{2} \mathrm{~K} / \mathrm{W} \\ P_{\text {groundfloor }}=25.43 \mathrm{~m} & R_{c ; \text { floor }} & =0.222 \mathrm{~m}^{2} \mathrm{~K} / \mathrm{W}\end{array}$




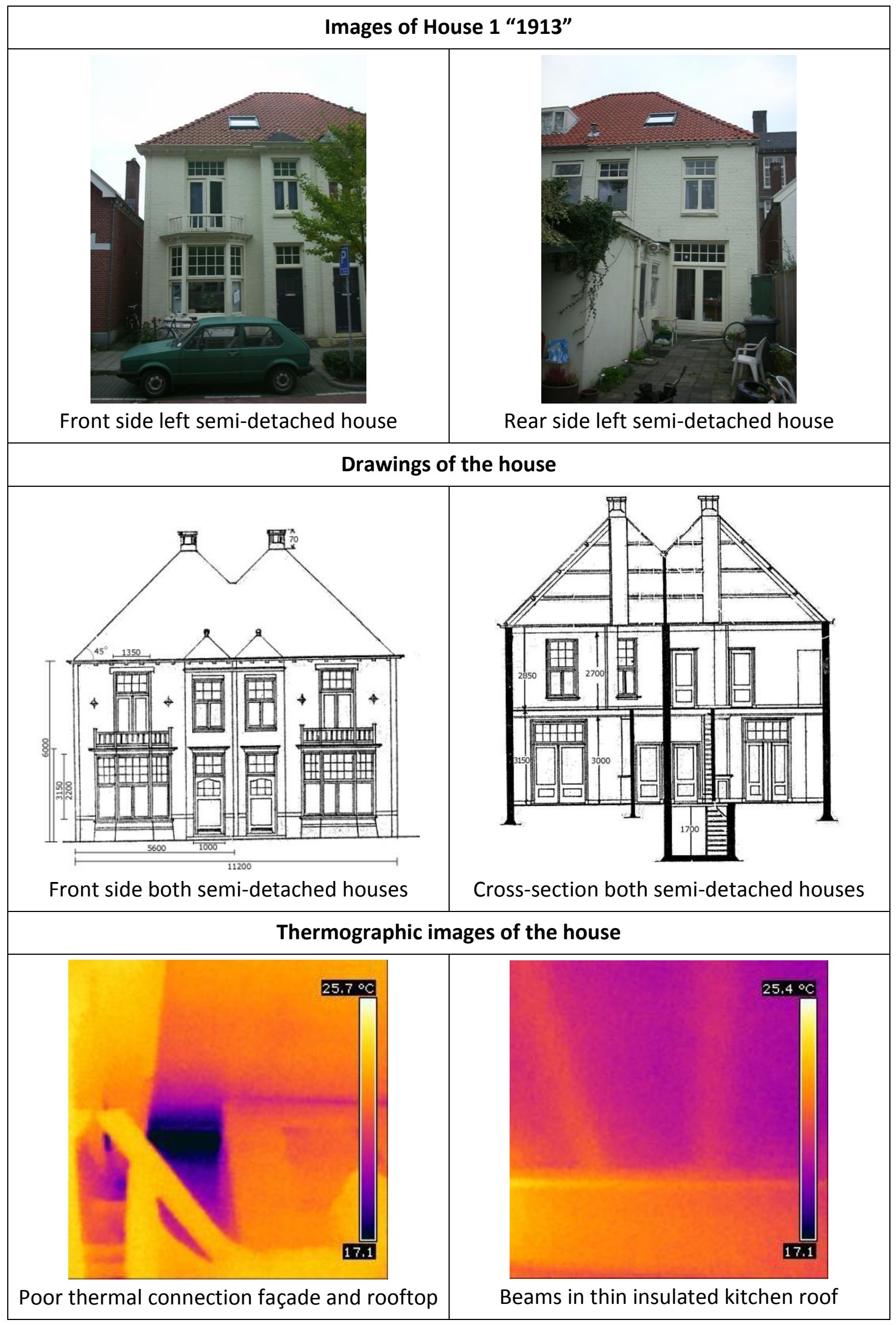




\section{House 2: 1925}

The second case object is located in the municipality of Dirksland. This small municipality consisted by the end of 2009 of 3,311 houses to accommodate 8,350 persons (CBS, 2010e). This particular case object is a detached house at the Tramweg. The front side of the house is orientated towards the north. At the moment of the energetic assessment construction workers were rebedding the joints of the façades, which is shown in the pictures on the next page. A family consisting of five persons, two adults and three children, lives in the house.

Having a total heated surface of $171 \mathrm{~m}^{2}$ this case object belongs, according to SenterNovem (2007), to the category of large detached houses constructed before 1966. This category reflects on 206,000 houses or $2.9 \%$ of the Dutch housing stock. Most houses are privately owned, namely $91 \%$. Just like the semi-detached houses built before 1966, the detached houses also have a cellar and attic high enough to stand in (SenterNovem, 2007). The year 1925 reveals that this object has no cavity walls either. Nevertheless, the walls have been insulated from the inside resulting in a higher thermal resistance compared to the original situation.

A large part of the original glazing has been replaced with double glazing reducing the building related energy use even further. Heat is being supplied by a high efficiency boiler which a large hot water capacity for showering and bathing simultaneously. Additionally, a compact electric boiler has been installed in the kitchen to provide hot water instantly, but this type of boiler does increase energy usage.

\begin{tabular}{|c|c|c|c|}
\hline$A_{\text {cellar;house }}$ & $=7.8 \mathrm{~m}^{2}$ & $\mathrm{~L}_{\text {shower and bath }}$ & $=3.0 \mathrm{~m}$ connected to gas boiler \\
\hline Agroundfloor; house & $=81.64 \mathrm{~m}^{2}$ & $\mathrm{~L}_{\text {sink }}$ & $=1.0 \mathrm{~m}$ connected to electric boiler \\
\hline$A_{1 \text { st floor; house }}$ & $=72.54 \mathrm{~m}^{2}$ & \multicolumn{2}{|c|}{$\mathrm{R}_{c \text {; walls living room }}=1.766 \mathrm{~m}^{2} \mathrm{~K} / \mathrm{W}$} \\
\hline 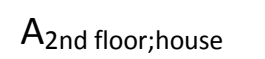 & $=16.77 \mathrm{~m}^{2}$ & $\mathrm{R}_{\mathrm{c} ; \text { walls kitchen }}$ & $=0.275 \mathrm{~m}^{2} \mathrm{~K} / \mathrm{W}$ \\
\hline$A_{\text {total; heated }}$ & $=170.95 \mathrm{~m}^{2}$ & $\mathrm{R}_{c \text {; roof top }}$ & $=1.376 \mathrm{~m}^{2} \mathrm{~K} / \mathrm{W}$ \\
\hline$A_{\text {total; nonheated }}$ & $=24.57 \mathrm{~m}^{2}$ & $\mathrm{R}_{\mathrm{c} \text {; flat roof kitchen }}$ & $=0.0734 \mathrm{~m}^{2} \mathrm{~K} / \mathrm{W}$ \\
\hline \multirow[t]{2}{*}{$P_{\text {groundfloor }}$} & \multirow[t]{2}{*}{$=43.8 \mathrm{~m}$} & $\mathrm{R}_{\mathrm{c} \text {; floor living room }}$ & $=0.204 \mathrm{~m}^{2} \mathrm{~K} / \mathrm{W}$ \\
\hline & & $\mathrm{R}_{c ;}$ floor kitchen & $=0.071 \mathrm{~m}^{2} \mathrm{~K} / \mathrm{W}$ \\
\hline
\end{tabular}




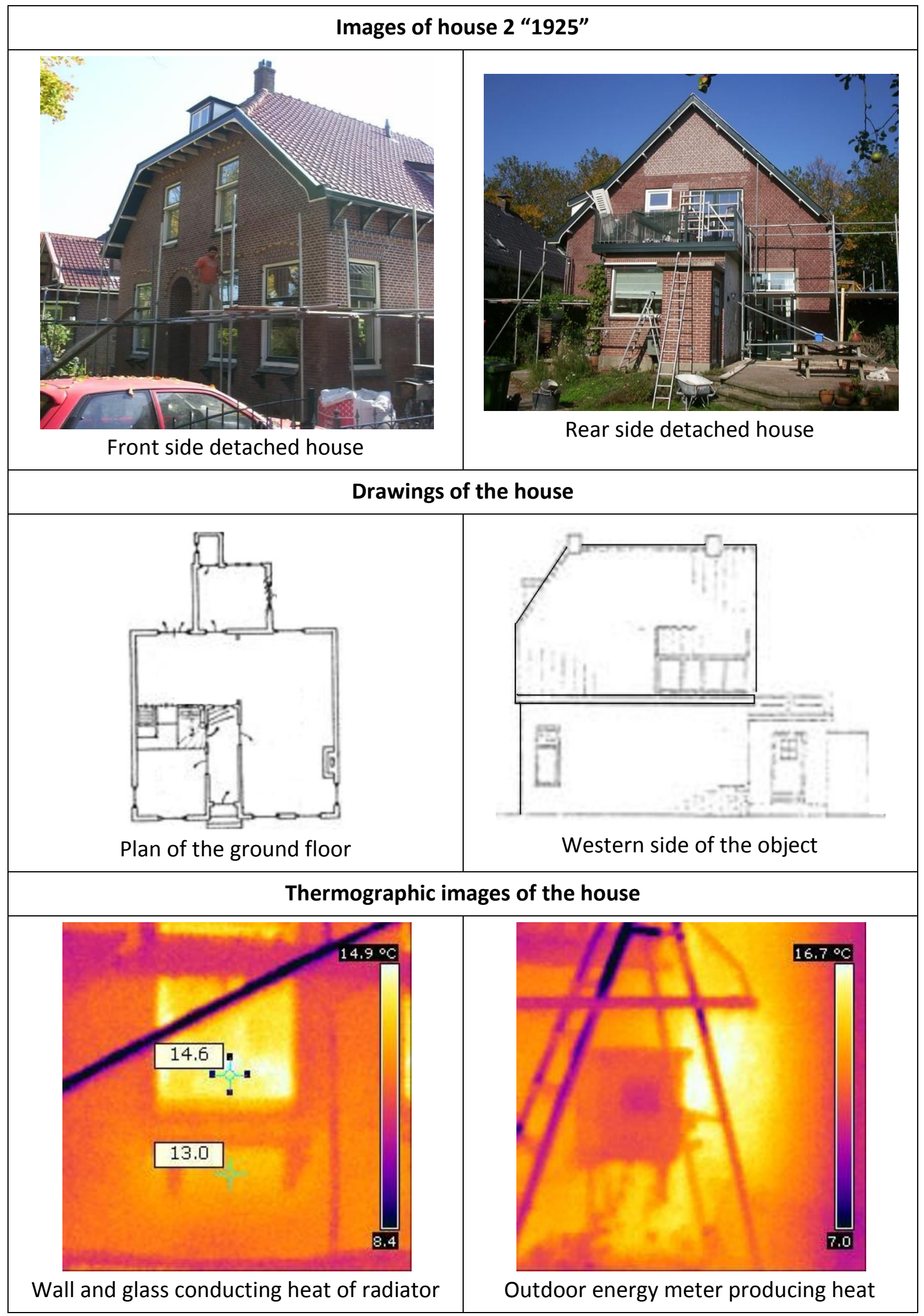




\section{House 3: 1939}

The third object, a row house, was constructed in 1939 and is located at the municipality of Almelo. In 2009 Almelo had 72,430 residents spread over 31,479 houses (CBS, 2010e). This is the first case object with cavity walls. It is one of the 501,000 dwellings in the Netherlands in the category row houses constructed before 1946, which forms $7 \%$ of the total housing stock. A major part of these houses is privately owned, namely $63 \%$. Social housing associations own $21 \%$ of these houses and private parties rent out the remaining $16 \%$ (SenterNovem, 2007).

Original houses from this era are rather small. The standard Energy Label is $E$, which means that the estimated building related natural gas consumption will be $1,896 \mathrm{~m}^{3} /$ year. Many renovation projects have resulted in a lager floor surface by adding an extension at the back side of the house or by adding a shed dormer on the roof. By conducting these renovations one often improved unintentionally the energy performance, because the new walls and windows have a better thermal resistance than the original ones.

This specific house was also extended at the back side in 1996. A kitchen, dining room, hall and bathroom were added. Therefore, a large part of the back side has an improved thermal resistance of $1.19 \mathrm{~m}^{2} \mathrm{~K} / \mathrm{W}$ instead of $0.407 \mathrm{~m}^{2} \mathrm{~K} / \mathrm{W}$. The original single glazing has been replaced by double glazing. In 2006 the roof top was replaced by a slightly lifted and strongly insulated new roof. In the beginning of the analysis three persons were living in the house, but in the end the youngest child moved out of the parental house. Both parents work full time.

\begin{tabular}{|c|c|c|c|}
\hline$A_{\text {groundfloor; house }}$ & $=40.06 \mathrm{~m}^{2}$ & $\mathrm{R}_{\mathrm{c} \text {; walls living room }}$ & $=0.407 \mathrm{~m}^{2} \mathrm{~K} / \mathrm{W}$ \\
\hline$A_{1 \text { st floor; house }}$ & $=29.36 \mathrm{~m}^{2}$ & $\mathrm{R}_{\mathrm{c} \text {; walls back bathroom }}$ & $=1.19 \mathrm{~m}^{2} \mathrm{~K} / \mathrm{W}$ \\
\hline$A_{2 \text { nd floor; house }}$ & $=15.41 \mathrm{~m}^{2}$ & $\mathrm{R}_{\mathrm{c} \text {; roof top }}$ & $=2.397 \mathrm{~m}^{2} \mathrm{~K} / \mathrm{W}$ \\
\hline$A_{\text {total; heated }}$ & $=84.83 \mathrm{~m}^{2}$ & $\mathrm{R}_{\mathrm{c} ; \text { flat roof bathroom }}$ & $=2.414 \mathrm{~m}^{2} \mathrm{~K} / \mathrm{W}$ \\
\hline$P_{\text {groundfloor }}$ & $=13.26 \mathrm{~m}$ & $\mathrm{R}_{\mathrm{c} ; \text { flat roof bay }}$ & $=0.062 \mathrm{~m}^{2} \mathrm{~K} / \mathrm{W}$ \\
\hline$L_{\text {shower }}$ & $=4 \mathrm{~m}$ & $\mathrm{R}_{\mathrm{c} ; \text { floor }}$ & $=0.093 \mathrm{~m}^{2} \mathrm{~K} / \mathrm{W}$ \\
\hline$L_{\text {sink }}$ & $=7 \mathrm{~m}$ & & \\
\hline
\end{tabular}




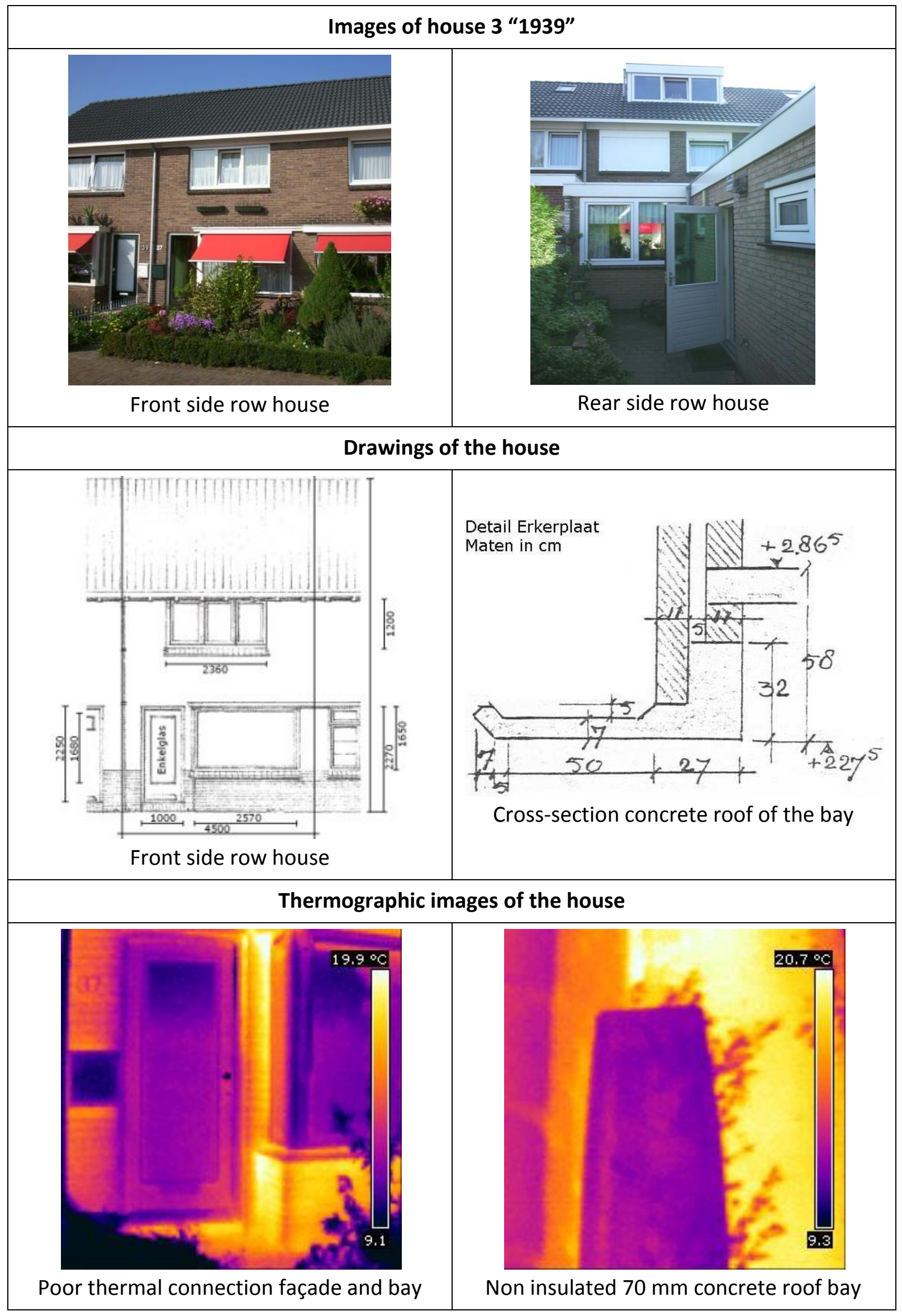




\section{House 4: 1948}

In 1948 case object number 4 was constructed in Hengelo (Overijssel). This municipality had 80,930 inhabitants and 36,731 dwellings in 2009 (CBS, 2010e). According to SenterNovem (2007) this house belongs to the same category of semi-detached houses as house 1 constructed in 1913. This group consists of 393,000 houses representing $5.5 \%$ of the housing stock. Compared with the first object, this fourth object does have cavity walls, which can result in a better heat resistance and a better energy performance.

Originally the house and the house to which it is attached were each used to accommodate six nurses for the nearby hospital. Nowadays both houses are privately owned. Two adults reside in the investigated object. A part of the original single glazing has been replaced by double glazing or the thermal resistance has been improved by secondary glazing. The ground floor in the living room has been insulated. A boiler system with a vessel of $36 \mathrm{I}$ is used for heating tap water by making use of natural gas.

$\begin{array}{llll}A_{\text {cellar; house }}=9.9 \mathrm{~m}^{2} & \mathrm{~L}_{\text {shower }} & =2.0 \mathrm{~m} \\ \mathrm{~A}_{\text {groundfloor; house }}=52.94 \mathrm{~m}^{2} & \mathrm{~L}_{\text {sink }} & =5.5 \mathrm{~m} \\ \mathrm{~A}_{1 \text { st floor; house }}=52.94 \mathrm{~m}^{2} & \mathrm{R}_{\mathrm{c} \text {; walls living room }}=0.406 \mathrm{~m}^{2} \mathrm{~K} / \mathrm{W} \\ \mathrm{A}_{2 \text { nd floor;house }}=39.16 \mathrm{~m}^{2} & \mathrm{R}_{\mathrm{c} \text {; roof top }}=1.762 \mathrm{~m}^{2} \mathrm{~K} / \mathrm{W} \\ A_{\text {total; heated }}=145.04 \mathrm{~m}^{2} & \mathrm{R}_{\mathrm{c} \text {; floor living room }}=1.646 \mathrm{~m}^{2} \mathrm{~K} / \mathrm{W} \\ A_{\text {total; nonheated }}=9.9 \mathrm{~m}^{2} & \mathrm{R}_{\mathrm{c} \text {; floor hall kitchen }}=0.142 \mathrm{~m}^{2} \mathrm{~K} / \mathrm{W} \\ P_{\text {groundfloor }}=21.48 \mathrm{~m} & & \end{array}$




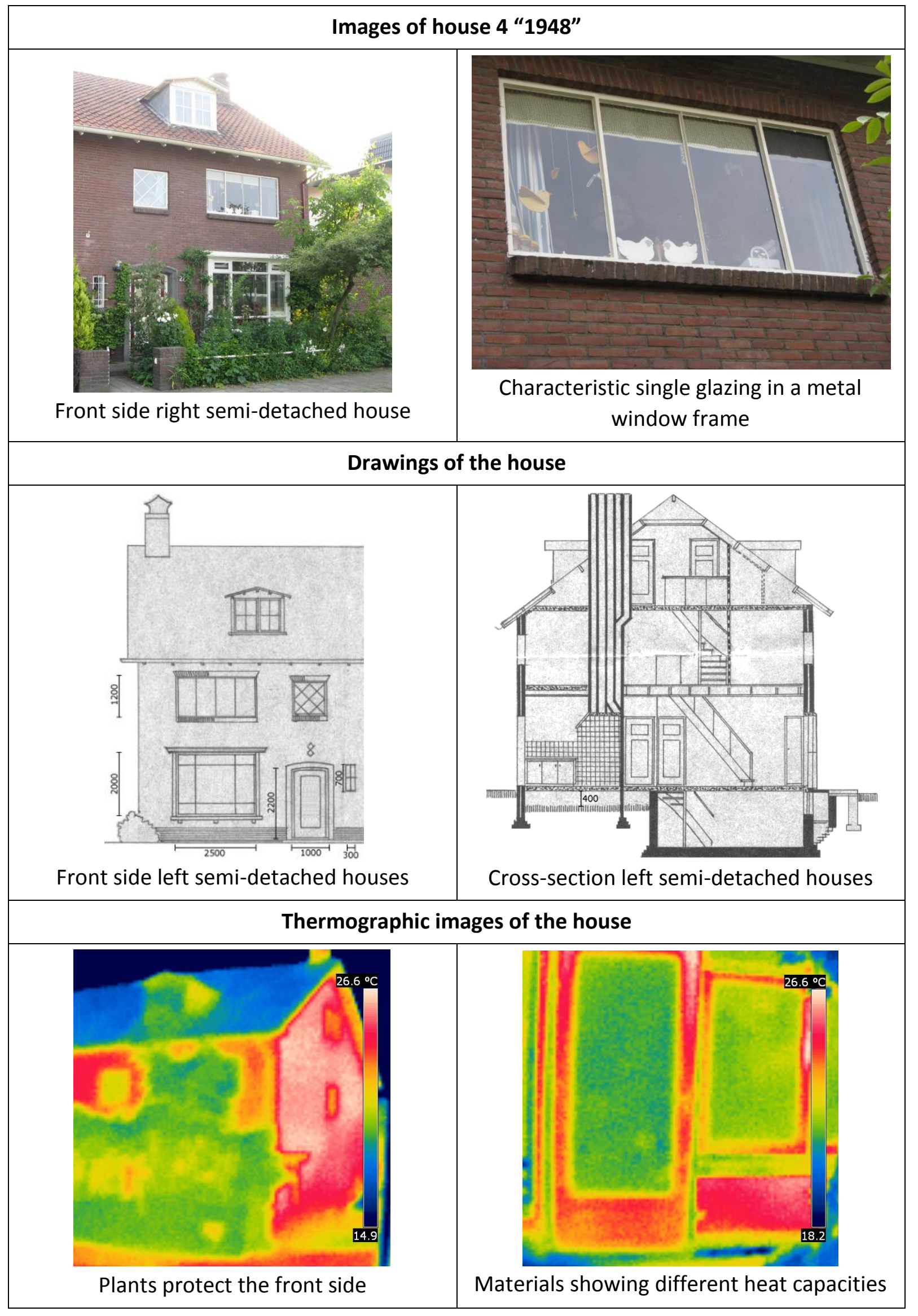




\section{House 5: 1964}

In 1964 the construction was finished of house 5 in 's Hertogenbosch. In 2009 the capital of the provence of Noord-Brabant had 137,780 inhabitants and 61,236 dwellings (CBS, 2010e). In the time period 1946-1965 669,000 row houses were built. These houses represent $9.4 \%$ of the Dutch housing stock. The major part is owned by social housing associations, namely $61 \%$. Privately owned houses form a group of $34 \%$ and private rental organisations own only 5\% (SenterNovem, 2007).

This case object is one of the two research objects with a flat roof. It is the only object consisting of two floors. Houses with a flat roof are generally considered to have a lower infiltration rate than houses with a gable roof, because the connection between walls and roof is more air tight. Originally this house had a garage, but the owners of this house decided to integrate this space. The former garage is now a dining room and openly connected to the kitchen.

Most of the original single glazing has been replaced by double glazing or the thermal resistance has been improved by secondary glazing. The roof has been insulated by placing plates of poly-urethane with a thermal resistance of $1.99 \mathrm{~m}^{2} \mathrm{~K} / \mathrm{W}$ and a new layer of roofing and bitumen on top. All hot water is provided by a combination boiler for central heating and tap water. The tap water for the kitchen is also being heated with an additional geyser almost at the end of the line just before the tap. The bathroom has electric floor heating.

$\begin{array}{llll}A_{\text {cellar; house }}=2 \mathrm{~m}^{2} & \mathrm{~L}_{\text {shower }} & =10 \mathrm{~m} \\ A_{\text {groundfloor; house }}=80.37 \mathrm{~m}^{2} & \mathrm{~L}_{\text {sink }} & =7.5 \mathrm{~m} \\ A_{\text {1st floor; house }}=68.37 \mathrm{~m}^{2} & \mathrm{R}_{\mathrm{c} \text {; walls }} & =0.406 \mathrm{~m}^{2} \mathrm{~K} / \mathrm{W} \\ A_{\text {total; heated }}=148.74 \mathrm{~m}^{2} & \mathrm{R}_{\mathrm{c} \text {; garage door }}=0.845 \mathrm{~m}^{2} \mathrm{~K} / \mathrm{W} \\ A_{\text {total; nonheated }}=2 \mathrm{~m}^{2} & \mathrm{R}_{\mathrm{c} \text {; flat roof }}=2.838 \mathrm{~m}^{2} \mathrm{~K} / \mathrm{W} \\ \mathrm{P}_{\text {groundfloor }}=23.56 \mathrm{~m} & \mathrm{R}_{\mathrm{c} \text {; floor balcony }}=0.173 \mathrm{~m}^{2} \mathrm{~K} / \mathrm{W} \\ & & \mathrm{R}_{\mathrm{c} \text {; ground floor }}=0.082 \mathrm{~m}^{2} \mathrm{~K} / \mathrm{W}\end{array}$




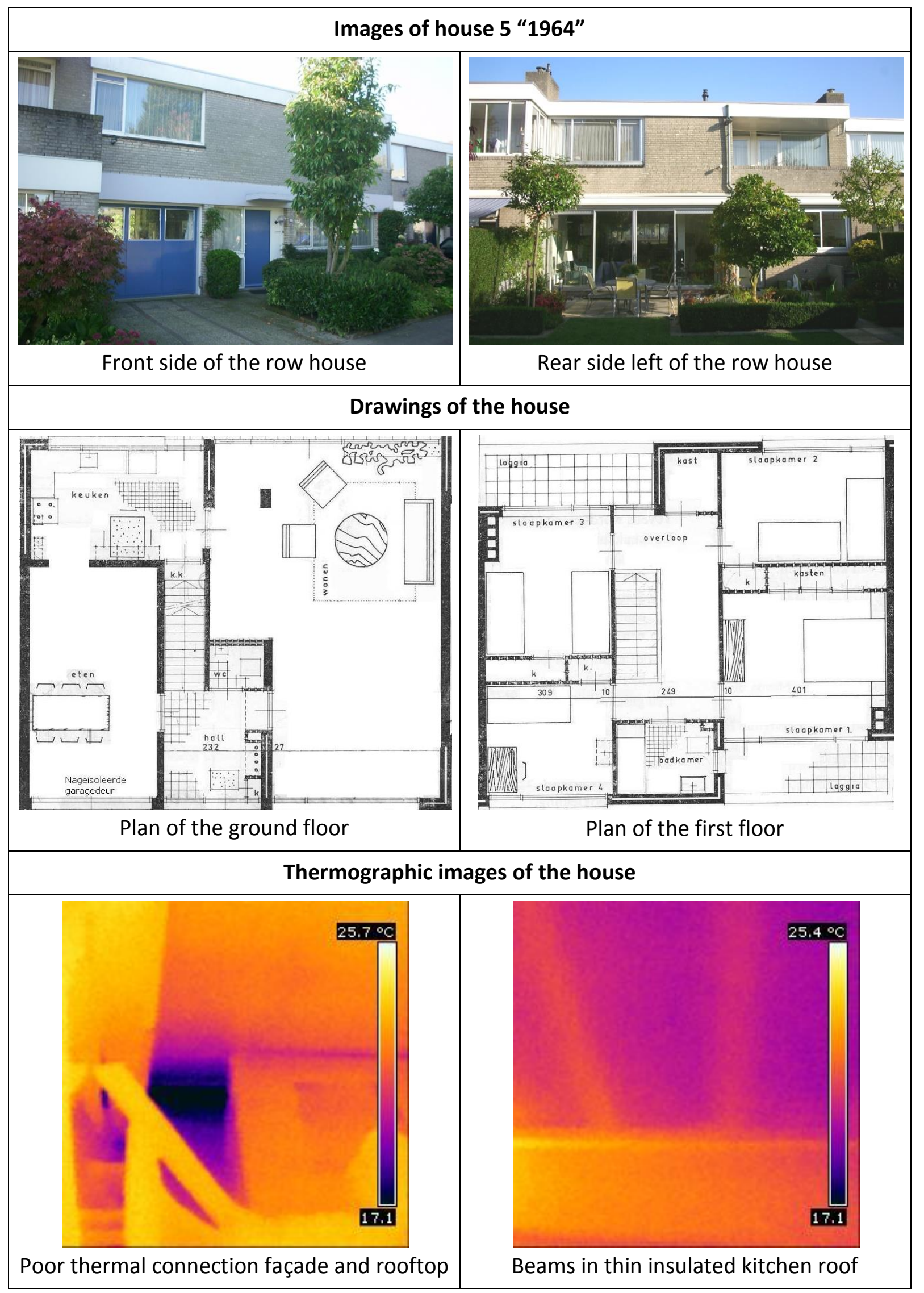




\section{House 6: 1972}

The second case object with a flat roof was constructed in 1972. This object is also located in 's-Hertogenbosch. SenterNovem places this object in the category of row houses 1966-1975. With 654,000 houses this group represents $9.2 \%$ of the housing stock. Half of this group is privately owned. The social housing sector owns $41 \%$ and the private housing sector $9 \%$. In general these houses have originally an Energy Label E. In this time period many houses were constructed with double glazing for the living room and with only a thin layer of insulation for the roof (SenterNovem, 2007).

The research object forms a residence for two employed adults. On the ground level an office is daily used, because the husband works from home. Central heating is even able to heat the garage, although the original garage door was not insulated. On top of the roof an extra package of insulation has been applied in 1992. At the time of the energy assessment the glazing on the ground floor had not yet been replaced. Nowadays the whole house has high efficiency double glazing and standard double glazing. Originally this type of houses had not a ventilation system. In this case the owners installed one ventilator in the bathroom to draw out the humid air during showering. The bathroom also has electric floor heating.

\begin{tabular}{|c|c|c|c|}
\hline$A_{\text {groundfloor;house }}$ & $=57.34 \mathrm{~m}^{2}$ & $L_{\text {shower }}$ & $=4 \mathrm{~m} \& 14 \mathrm{~m}$ \\
\hline$A_{1 s t}$ floor;house & $=58.82 \mathrm{~m}^{2}$ & $L_{\text {sink }}$ & $=7.5 \mathrm{~m}$ \\
\hline$A_{2 \text { nd floor; house }}$ & $=58.82 \mathrm{~m}^{2}$ & $\mathrm{R}_{c ; \text { walls living room }}$ & $=0.502 \mathrm{~m}^{2} \mathrm{~K} / \mathrm{W}$ \\
\hline$A_{\text {total; heated }}$ & $=174.98 \mathrm{~m}^{2}$ & $R_{c ; \text { flat roof }}$ & $=2.219 \mathrm{~m}^{2} \mathrm{~K} / \mathrm{W}$ \\
\hline$P_{\text {groundfloor }}$ & $=14 \mathrm{~m}$ & $\mathrm{R}_{\mathrm{c} ;}$ floor kitchen & $=0.096 \mathrm{~m}^{2} \mathrm{~K} / \mathrm{W}$ \\
\hline & & $\mathrm{R}_{\mathrm{c} ; \text { ground floor }}$ & $=0.030 \mathrm{~m}^{2} \mathrm{~K} /$ \\
\hline
\end{tabular}




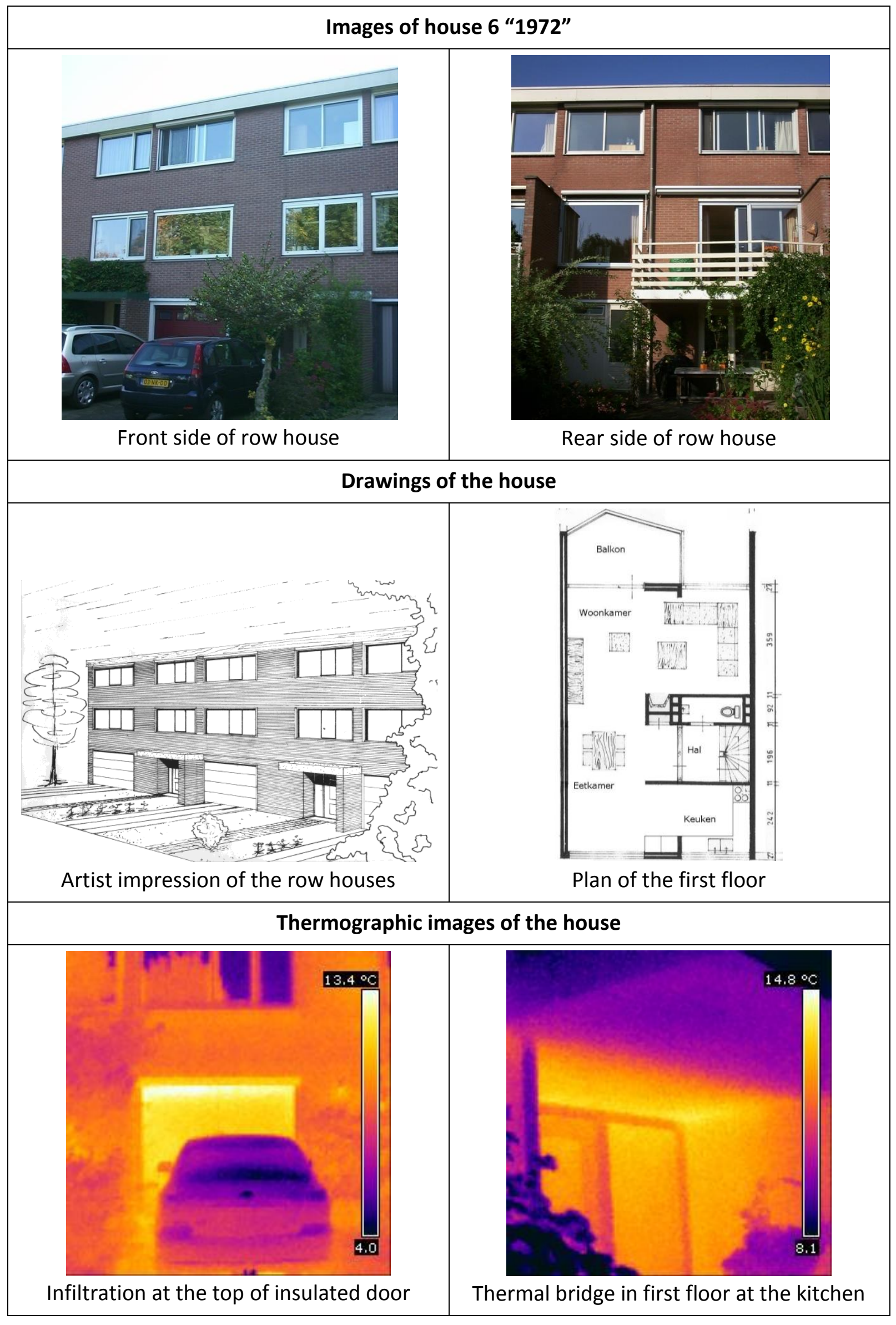




\section{House 7: 1982}

The first residential object in this case study with a connection to district heating was built in 1982. The object is located in Enschede, just like house 1 and 8. This house can be categorized as a row house built between 1980 and 1988. It is one of the 469,000 houses in this category, representing $6.6 \%$ of the housing stock (SenterNovem, 2007). In its original state Energy Label $\mathrm{D}$ can be commonly attributed to these row houses. The building related natural gas consumption is estimated to be $1,417 \mathrm{~m}^{3} /$ year and the auxiliary electric energy use is $222 \mathrm{kWh} /$ year. These houses are moderate insulated with the exception of the ground floor (SenterNovem, 2007).

In this specific house the original heat exchanger has been replaced by a more efficient version. At the time of the energy assessment two residents were leaving in the object. After the energy assessment the owner of the house decided to install roof windows with high efficiency glazing and to install floor insulation. The house has a central ventilation system, that is connected to the kitchen and toilet on the ground floor and the bathroom on the first floor. At this moment a family consisting of four persons, two adults and two young children, lives in the house.

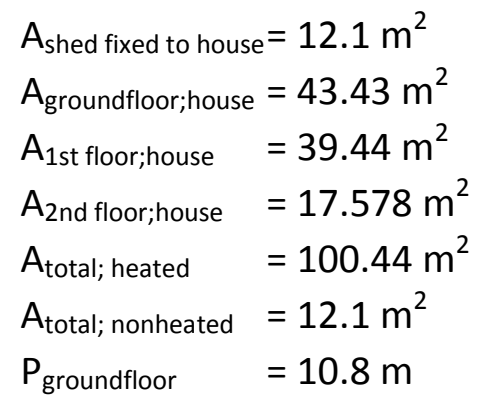

$$
\begin{array}{ll}
\mathrm{L}_{\text {shower }} & =15 \mathrm{~m} \\
\mathrm{~L}_{\text {sink }} & =7.5 \mathrm{~m} \\
\mathrm{R}_{\mathrm{c} \text {; walls living room }} & =1.731 \mathrm{~m}^{2} \mathrm{~K} / \mathrm{W} \\
\mathrm{R}_{\mathrm{c} \text {; roof top }} & =1.41 \mathrm{~m}^{2} \mathrm{~K} / \mathrm{W} \\
\mathrm{R}_{\mathrm{c} \text {; flat roof }} & =1.72 \mathrm{~m}^{2} \mathrm{~K} / \mathrm{W} \\
\mathrm{R}_{\mathrm{c} \text {; floor }} & =0.68 \mathrm{~m}^{2} \mathrm{~K} / \mathrm{W}
\end{array}
$$




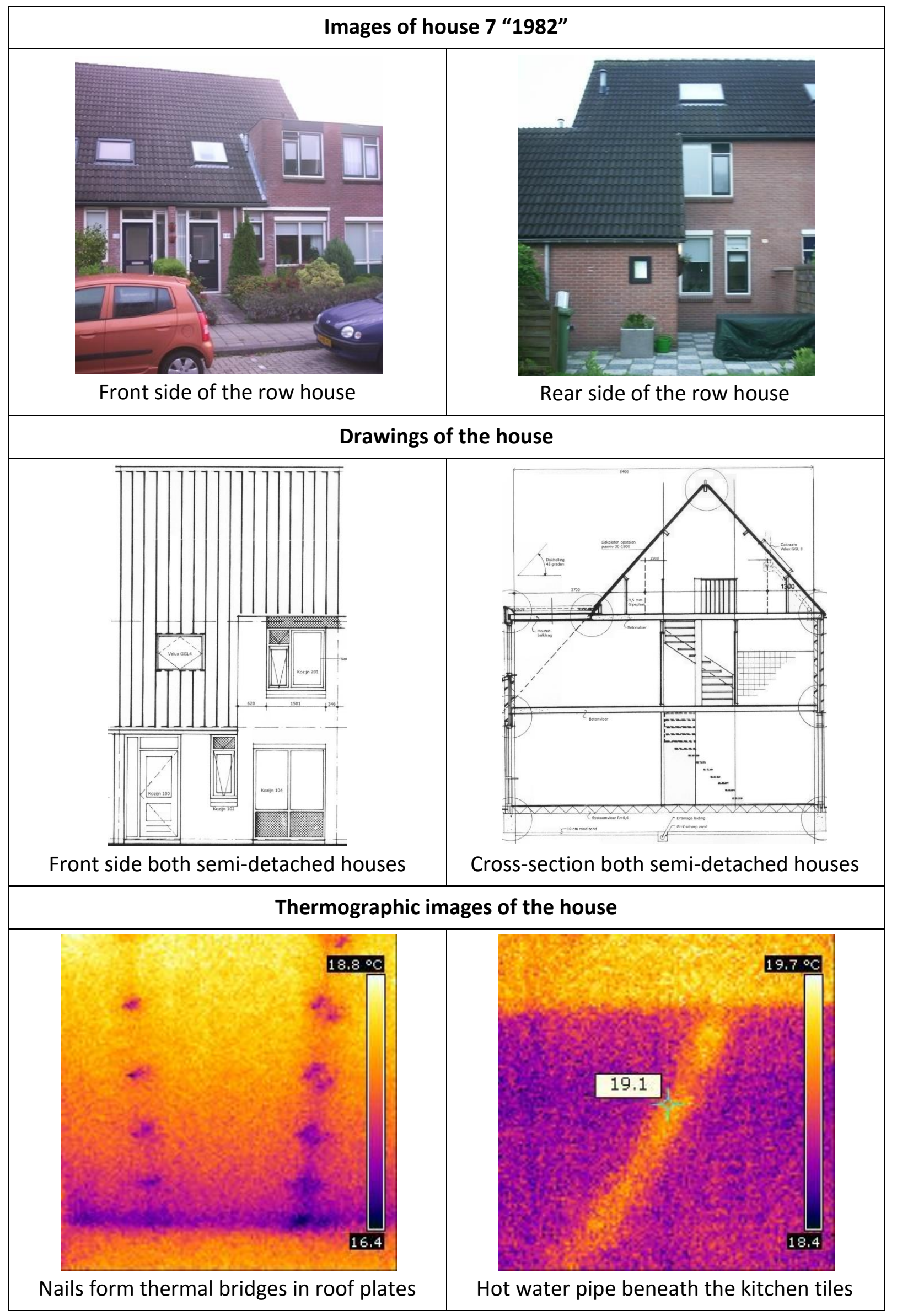




\section{House 8: 1992}

Within the era of 1989-2000 125,000 semi-detached houses were constructed representing $1.8 \%$ of the total housing stock. In general these houses received an adequate insulation package of 2.33 to $2.47 \mathrm{~m}^{2} \mathrm{~K} / \mathrm{W}$ (SenterNovem, 2007). After the introduction of the Building Code in 1992, these values were even slightly higher. According to SenterNovem (2007) private ownership has the upper hand with $96 \%$. The other $4 \%$ is rented and owned by private organizations.

Having a standard natural gas consumption for heating of $1,439 \mathrm{~m}^{3} /$ year and an electric energy use of $633 \mathrm{kWh} /$ year, the label for this category of houses is a ' $C$ ' classification (SenterNovem, 2007). The relatively good energy performance of this house resulted in the fact that no additional energy measures were taken to improve the energy performance. This house is also connected to district heating of Enschede. At the time of the energy assessment two persons were living in the house.

$\begin{array}{llll}A_{\text {garage; house }}=17.10 \mathrm{~m}^{2} & \mathrm{~L}_{\text {shower }} & =11.0 \mathrm{~m} \\ A_{\text {groundfloor;house }}=50.49 \mathrm{~m}^{2} & \mathrm{~L}_{\text {sink }} & =7.0 \mathrm{~m} \\ A_{1 \text { st floor; house }}=47.52 \mathrm{~m}^{2} & \mathrm{R}_{\mathrm{c} \text {; walls living room }}=2.844 \mathrm{~m}^{2} \mathrm{~K} / \mathrm{W} \\ A_{\text {2nd floor; house }}=26.16 \mathrm{~m}^{2} & \mathrm{R}_{\mathrm{c} \text {; roof top }}=2.569 \mathrm{~m}^{2} \mathrm{~K} / \mathrm{W} \\ A_{\text {total; heated }}=124.17 \mathrm{~m}^{2} & \mathrm{R}_{\mathrm{c} \text {; flat roof }} & =2.717 \mathrm{~m}^{2} \mathrm{~K} / \mathrm{W} \\ A_{\text {total; nonheated }} & =17.10 \mathrm{~m}^{2} & \mathrm{R}_{\mathrm{c} \text {; floor }} & =2.39 \mathrm{~m}^{2} \mathrm{~K} / \mathrm{W} \\ P_{\text {groundfloor }}=19.96 \mathrm{~m} & & \end{array}$




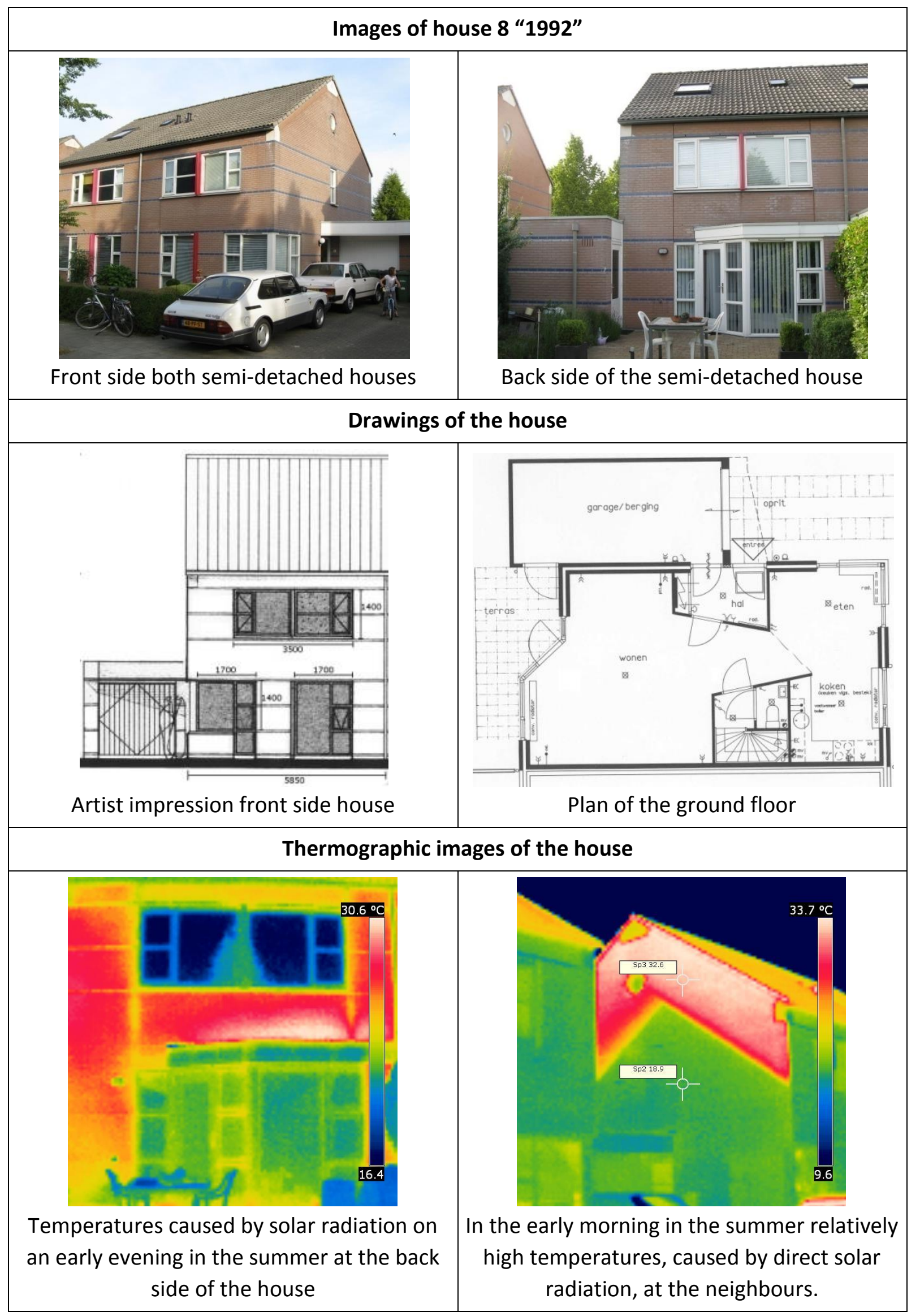




\section{Appendix B: Detailed overview energy bills in case study on dwellings}

\begin{tabular}{|c|c|c|c|c|c|c|c|c|c|c|c|c|c|c|c|c|c|c|c|c|c|}
\hline & \multicolumn{2}{|c|}{ Time period } & \multicolumn{2}{|c|}{ Energy use } & \multicolumn{5}{|c|}{ A. Product costs } & \multicolumn{5}{|c|}{ B. Infrastructural costs } & \multicolumn{2}{|c|}{ C. Measurement } & \multicolumn{5}{|c|}{ D. Taxes } \\
\hline & $\begin{array}{l}\text { Start } \\
\text { date }\end{array}$ & $\begin{array}{l}\text { End } \\
\text { date }\end{array}$ & $\begin{array}{c}\text { Electric } \\
\text { energy } \\
\text { use }\end{array}$ & \begin{tabular}{|l|} 
Natural \\
gas use
\end{tabular} & $\begin{array}{c}\text { Natural } \\
\text { gas } \\
\text { variable } \\
\text { costs }\end{array}$ & $\begin{array}{c}\text { Natural } \\
\text { gas fixed } \\
\text { costs }\end{array}$ & $\begin{array}{c}\text { Electric } \\
\text { energy } \\
\text { variable } \\
\text { costs }\end{array}$ & $\begin{array}{c}\text { Electric } \\
\text { energy } \\
\text { fixed } \\
\text { costs }\end{array}$ & $\begin{array}{c}\text { District } \\
\text { heat } \\
\text { variable } \\
\text { costs }\end{array}$ & $\begin{array}{c}\text { Natural } \\
\text { gas } \\
\text { variable } \\
\text { costs }\end{array}$ & \begin{tabular}{|c|}
$\begin{array}{c}\text { Natural } \\
\text { gas fixed } \\
\text { costs }\end{array}$ \\
\end{tabular} & $\begin{array}{c}\text { Electric } \\
\text { energy } \\
\text { variable } \\
\text { costs }\end{array}$ & $\begin{array}{c}\text { Electric } \\
\text { energy } \\
\text { fixed } \\
\text { costs }\end{array}$ & \begin{tabular}{|c|} 
District \\
heat fixed \\
costs
\end{tabular} & $\begin{array}{c}\text { Natural } \\
\text { gas }\end{array}$ & $\begin{array}{l}\text { Electric } \\
\text { energy }\end{array}$ & $\begin{array}{c}\text { Energy } \\
\text { taxation } \\
\text { natural } \\
\text { gas }\end{array}$ & $\begin{array}{c}\text { Energy } \\
\text { taxation } \\
\text { electric } \\
\text { energy } \\
\end{array}$ & $\begin{array}{l}\text { Tax } \\
\text { credit }\end{array}$ & $\begin{array}{l}\text { EQEP } \\
\text { MEP }\end{array}$ & $\begin{array}{l}\text { VAT } \\
\text { BTW }\end{array}$ \\
\hline & dd-mm-yy & dd-mm-yy & $\mathrm{kWh}$ & $\mathrm{m}^{3}$ & $€$ & $€ /$ year & $€$ & $€ /$ year & $€$ & $€$ & $€$ & $€$ & $€$ & $€$ & $€$ & $€$ & $€$ & & $€$ & $€$ & $€$ \\
\hline \multicolumn{22}{|c|}{ House 2} \\
\hline 1999 & $20-05-98$ & $25-05-99$ & 5120 & 3902 & $€ 743.21$ & $€ 60.25$ & $€ 487.38$ & $€ 25.71$ & $€ 0.00$ & $€ 0.00$ & $€ 0.00$ & $€ 0.00$ & $€ 0.00$ & $€ 0.00$ & $€ 0.00$ & $€ 0.00$ & $€ 185.99$ & $€ 72.92$ & $€ 0.00$ & & $€ 275.71$ \\
\hline 2000 & $26-05-99$ & $15-05-00$ & 5591 & 3388 & $€ 615.74$ & $€ 59.69$ & $€ 528.49$ & $€ 23.98$ & $€ 0.00$ & $€ 0.00$ & $€ 0.00$ & $€ 0.00$ & $€ 0.00$ & $€ 0.00$ & $€ 0.00$ & $€ 0.00$ & $€ 227.42$ & $€ 135.16$ & $€ 0.00$ & & $€ 278.33$ \\
\hline 2001 & $16-05-00$ & 09-05-01 & 6052 & 3428 & $€ 709.59$ & $€ 60.15$ & $€ 581.86$ & $€ 28.80$ & $€ 0.00$ & $€ 0.00$ & $€ 0.00$ & $€ 0.00$ & $€ 0.00$ & $€ 0.00$ & $€ 0.00$ & $€ 0.00$ & $€ 358.11$ & $€ 252.31$ & $-€ 50.04$ & & $€ 354.23$ \\
\hline 2002 & $10-05-01$ & $07-05-02$ & 6119 & 3155 & $€ 734.33$ & $€ 60.16$ & $€ 550.97$ & $€ 40.12$ & $€ 0.00$ & $€ 0.00$ & $€ 0.00$ & $€ 0.00$ & $€ 0.00$ & $€ 0.00$ & $€ 0.00$ & $€ 0.00$ & $€ 397.12$ & $€ 360.63$ & $-€ 140.95$ & & $€ 380.44$ \\
\hline 2003 & $08-05-02$ & $14-05-03$ & 6626 & 3449 & $€ 760.14$ & $€ 9.54$ & $€ 276.24$ & $€ 18.34$ & $€ 0.00$ & $€ 157.40$ & $€ 0.00$ & $€ 250.47$ & $€ 0.00$ & $€ 0.00$ & $€ 0.00$ & $€ 0.00$ & $€ 447.82$ & $€ 407.67$ & $-€ 144.72$ & & $€ 414.75$ \\
\hline 2004 & 09-05-03 & 19-05-04 & 6459 & 3518 & $€ 793.36$ & $€ 9.56$ & $€ 270.10$ & $€ 18.28$ & $€ 0.00$ & $€ 76.19$ & $€ 107.14$ & $€ 247.03$ & $€ 35.86$ & $€ 0.00$ & $€ 9.05$ & $€ 13.26$ & $€ 492.33$ & $€ 417.11$ & $-€ 176.24$ & $€ 32.06$ & $€ 439.49$ \\
\hline 2005 & $20-05-04$ & $15-05-05$ & 5933 & 3431 & $€ 858.19$ & $€ 12.52$ & $€ 279.57$ & $€ 13.54$ & $€ 0.00$ & $€ 48.98$ & $€ 100.64$ & $€ 198.66$ & $€ 39.53$ & $€ 0.00$ & $€ 16.96$ & $€ 24.94$ & $€ 515.86$ & $€ 397.99$ & $-€ 183.52$ & $€ 43.31$ & $€ 441.53$ \\
\hline 2006 & $15-05-05$ & $28-04-06$ & 5498 & 3530 & ,063.02 & $€ 13.46$ & $€ 294.91$ & $€ 13.46$ & $€ 0.00$ & $€ 44.34$ & $€ 96.21$ & $€ 182.27$ & $€ 37.90$ & $€ 0.00$ & $€ 17.96$ & $€ 25.79$ & $€ 530.02$ & $€ 385.52$ & $-€ 185.39$ & $€ 49.86$ & $€ 488.17$ \\
\hline 2007 & $28-04-06$ & $21-05-07$ & 6027 & 2930 & $€ 1,009.69$ & $€ 14.04$ & $€ 398.11$ & $€ 14.04$ & $€ 0.00$ & $€ 36.73$ & $€ 99.13$ & $€ 200.08$ & $€ 38.58$ & $€ 0.00$ & $€ 19.04$ & $€ 27.36$ & $€ 445.11$ & $€ 427.49$ & $-€ 210.18$ & $€ 34.90$ & $€ 485.28$ \\
\hline 2008 & $22-05-07$ & 01-05-08 & 5844 & 3284 & ,118.83 & $€ 14.96$ & $€ 456.18$ & $€ 14.96$ & $€ 0.00$ & $€ 42.22$ & $€ 98.61$ & $€ 196.25$ & $€ 38.04$ & $€ 0.00$ & $€ 19.28$ & $€ 26.56$ & $€ 517.16$ & $€ 420.97$ & $-€ 194.44$ & & $€ 526.22$ \\
\hline 2009 & 01-05-08 & 01-05-09 & 6164 & 3515 & ,458.68 & $€ 17.88$ & $€ 503.54$ & $€ 17.88$ & $€ 0.00$ & $€ 19.97$ & $€ 97.68$ & $€ 136.15$ & $€ 76.48$ & $€ 0.00$ & $€ 19.64$ & $€ 24.73$ & $€ 550.93$ & $€ 533.84$ & $-€ 226.74$ & & $€ 613.82$ \\
\hline 2010 & 01-05-09 & 01-05-10 & 6086 & 3651 & .068.79 & $€ 20.04$ & $€ 488.39$ & $€ 20.04$ & $€ 0.00$ & $€ 0.00$ & 109.44 & $€ 0.00$ & $€ 150.52$ & $€ 0.00$ & $€ 20.45$ & $€ 25.29$ & $\mid € 587.08$ & $€ 666.87$ & $-€ 337.82$ & & $€ 535.63$ \\
\hline \multicolumn{22}{|c|}{ House 3} \\
\hline 1987 & 03-10-86 & 03-10-87 & 2715 & 1923 & $€ 366.59$ & $€ 25.87$ & $€ 204.27$ & $€ 29.50$ & $€ 0.00$ & $€ 0.00$ & $€ 0.00$ & $€ 0.00$ & $€ 0.00$ & $€ 0.00$ & $€ 0.00$ & $€ 0.00$ & $€ 0.00$ & $€ 0.00$ & $€ 0.00$ & & $€ 125.24$ \\
\hline 1988 & 09-10-87 & $10-10-88$ & 2580 & 1640 & $€ 282.50$ & $€ 27.68$ & $€ 202.07$ & $€ 30.86$ & $€ 0.00$ & $€ 0.00$ & $€ 0.00$ & $€ 0.00$ & $€ 0.00$ & $€ 0.00$ & $€ 0.00$ & $€ 0.00$ & $€ 0.00$ & $€ 0.00$ & $-€ 2.93$ & & $€ 108.04$ \\
\hline 1989 & $10-10-88$ & $10-10-89$ & 1976 & 1614 & $€ 258.17$ & $€ 31.31$ & $€ 147.59$ & $€ 32.67$ & $€ 0.00$ & $€ 0.00$ & $€ 0.00$ & $€ 0.00$ & $€ 0.00$ & .00 & $€ 0.00$ & $€ 0.00$ & $€ 0.00$ & $€ 0.00$ & $€ 0.00$ & & $€ 88.83$ \\
\hline 1990 & $10-10-89$ & $25-10-90$ & 3828 & 1840 & $€ 329.39$ & $€ 31.31$ & $€ 297.73$ & $€ 32.67$ & $€ 0.00$ & $€ 0.00$ & $€ 0.00$ & $€ 0.00$ & $€ 0.00$ & $€ 0.00$ & $€ 0.00$ & $€ 0.00$ & $€ 0.00$ & $€ 0.00$ & $€ 0.00$ & & $€ 127.85$ \\
\hline 1991 & $25-10-90$ & $17-10-91$ & 2576 & 1768 & $€ 359.90$ & $€ 33.58$ & $€ 198.96$ & $€ 32.67$ & $€ 0.00$ & $€ 0.00$ & $€ 0.00$ & $€ 0.00$ & $€ 0.00$ & $€ 0.00$ & $€ 0.00$ & $€ 0.00$ & $€ 0.00$ & $€ 0.00$ & $€ 0.00$ & & $€ 115.65$ \\
\hline 1992 & $18-10-91$ & 04-10-92 & 2709 & 1888 & $€ 367.24$ & $€ 35.74$ & $€ 197.44$ & $€ 34.54$ & $€ 0.00$ & $€ 0.00$ & $€ 0.00$ & $€ 0.00$ & $€ 0.00$ & $€ 0.00$ & $€ 0.00$ & $€ 0.00$ & $€ 0.00$ & $€ 0.00$ & $€ 0.00$ & & $€ 114.24$ \\
\hline 1993 & 05-10-92 & $27-09-93$ & 3231 & 1925 & $€ 374.57$ & $€ 37.89$ & $€ 195.92$ & $€ 36.42$ & $€ 0.00$ & $€ 0.00$ & $€ 0.00$ & $€ 0.00$ & .00 & .00 & $€ 0.00$ & 0.00 & $€ 0.00$ & 0.00 & $€ 0.00$ & & $€ 112.84$ \\
\hline 1994 & 27-09-93 & $17-10-94$ & 4088 & 2212 & $€ 426.30$ & $€ 39.25$ & $€ 246.64$ & $€ 36.76$ & $€ 0.00$ & $€ 0.00$ & $€ 0.00$ & $€ 0.00$ & $€ 0.00$ & $€ 0.00$ & $€ 0.00$ & $€ 0.00$ & $€ 0.00$ & $€ 0.00$ & $€ 0.00$ & & $€ 131.07$ \\
\hline 1995 & $17-10-94$ & 30-06-95 & 2845 & 1543 & $€ 296.79$ & $€ 26.32$ & $€ 173.51$ & $€ 24.50$ & $€ 0.00$ & $€ 0.00$ & $€ 0.00$ & $€ 0.00$ & $€ 0.00$ & $€ 0.00$ & $€ 0.00$ & $€ 0.00$ & $€ 0.00$ & $€ 0.00$ & $€ 0.00$ & - & $€ 91.20$ \\
\hline 1996 & 01-07-95 & $30-06-96$ & 3361 & 2226 & $€ 415.21$ & $€ 38.80$ & $€ 207.89$ & $€ 38.12$ & $€ 0.00$ & $€ 0.00$ & $€ 0.00$ & $€ 0.00$ & $€ 0.00$ & $€ 0.00$ & $€ 0.00$ & $€ 0.00$ & $€ 12.69$ & $€ 15.71$ & $€ 0.00$ & & $€ 127.47$ \\
\hline
\end{tabular}




\begin{tabular}{|c|c|c|c|c|c|c|c|c|c|c|c|c|c|c|c|c|c|c|c|c|c|}
\hline 1997 & $-07-96$ & -06-97 & 3468 & 1766 & $€ 360.07$ & $€ 38.12$ & $€ 226.10$ & $€ 39.48$ & $€ 0.00$ & $€ 0.00$ & $€ 0.00$ & $€ 0.00$ & $€ 0.00$ & $€ 0.00$ & $€ 0.00$ & $€ 0.00$ & $€ 21.71$ & $€ 35.72$ & $€ 0.00$ & & $€ 126.21$ \\
\hline 1998 & $01-07-97$ & $30-06-98$ & 3086 & 1725 & $€ 374.52$ & $€ 38.12$ & $€ 219.74$ & $€ 40.16$ & $€ 0.00$ & $€ 0.00$ & $€ 0.00$ & $€ 0.00$ & $€ 0.00$ & $€ 0.00$ & $€ 0.00$ & $€ 0.00$ & $€ 34.34$ & $€ 30.60$ & $€ 0.00$ & & $€ 129.06$ \\
\hline 1999 & $1-07-98$ & 30-06-99 & 3435 & 912 & 371.73 & $€ 38.12$ & 245.82 & 44.24 & $€ 0.00$ & $€ 0.00$ & $€ 0.00$ & $€ 0.00$ & $€ 0.00$ & $€ 0.00$ & $€ 0.00$ & $€ 0.00$ & $€ 65.92$ & $€ 47.23$ & $€ 0.00$ & & $€ 142.28$ \\
\hline 2000 & 1-07-99 & $30-06-00$ & 344 & 1564 & $€ 288.77$ & $€ 38.12$ & $€ 245.97$ & $€ 48.46$ & $€ 0.00$ & $€ 0.00$ & $€ 0.00$ & $€ 0.00$ & $€ 0.00$ & $€ 0.00$ & $€ 0.00$ & $€ 0.00$ & 65.65 & $€ 78.94$ & $€ 0.00$ & & $€ 134.03$ \\
\hline 2001 & $01-07-00$ & 30-06-01 & 3120 & 1558 & $€ 326.03$ & $€ 42.20$ & $€ 241.12$ & $€ 51.87$ & $€ 0.00$ & $€ 0.00$ & $€ 0.00$ & $€ 0.00$ & $€ 0.00$ & $€ 0.00$ & $€ 0.00$ & $€ 0.00$ & $€ 129.14$ & $€ 149.01$ & $-€ 70.79$ & & $€ 158.76$ \\
\hline 2002 & 01-07-01 & $30-06-02$ & 2973 & 1316 & $€ 311.23$ & $€ 37.38$ & $€ 180.53$ & $€ 55.38$ & $€ 0.00$ & $€ 0.00$ & $€ 0.00$ & $€ 0.00$ & $€ 0.00$ & $€ 0.00$ & $€ 0.00$ & $€ 0.00$ & $€ 162.99$ & $€ 176.03$ & $-€ 141.78$ & & $€ 148.53$ \\
\hline 2003 & 01-07-02 & $13-06-03$ & 3957 & 1746 & $€ 441.43$ & $€ 38.93$ & $€ 249.39$ & $€ 38.16$ & $€ 0.00$ & $€ 0.00$ & $€ 0.00$ & $€ 0.00$ & $€ 0.00$ & $€ 0.00$ & $€ 8.56$ & $€ 8.56$ & $€ 222.79$ & $€ 244.88$ & $-€ 134.96$ & & $€ 212.37$ \\
\hline 2004 & $13-06-03$ & 09-06-04 & 3797 & 1566 & $€ 410.22$ & $€ 47.18$ & $€ 235.10$ & $€ 41.74$ & $€ 0.00$ & $€ 0.00$ & $€ 0.00$ & $€ 0.00$ & $€ 0.00$ & $€ 0.00$ & $€ 9.82$ & $€ 9.82$ & $€ 213.73$ & $€ 245.15$ & $-€ 175.05$ & $€ 34.24$ & $€ 197.16$ \\
\hline 2005 & 09-06-04 & 07-06-05 & 3713 & 1596 & $€ 395.03$ & $-€ 4.87$ & $€ 158.42$ & $€ 16.53$ & $€ 0.00$ & 25.99 & $€ 67.14$ & $€ 99.38$ & $€ 56.38$ & $€ 0.00$ & $€ 8.98$ & $€ 27.29$ & $€ 234.20$ & $€ 250.06$ & $-€ 185.59$ & $€ 44.36$ & $€ 218.30$ \\
\hline 2006 & 07-06-05 & 06-06-06 & 3743 & 1533 & $€ 460.22$ & $€ 16.76$ & $€ 203.23$ & $€ 16.76$ & $€ 0.00$ & $€ 16.41$ & 106.13 & $€ 104.54$ & $€ 30.70$ & $€ 0.00$ & $€ 20.82$ & $€ 30.34$ & $€ 231.11$ & $€ 262.60$ & $-€ 194.79$ & $€ 51.82$ & $€ 247.91$ \\
\hline 2007 & 06-06-06 & 20-06-07 & 3988 & 1324 & $€ 460.43$ & $€ 19.40$ & $€ 286.99$ & $€ 19.40$ & $€ 0.00$ & $€ 14.55$ & $€ 112.40$ & $€ 116.45$ & $€ 32.50$ & $€ 0.00$ & $€ 21.79$ & $€ 32.24$ & $€ 203.95$ & $€ 283.12$ & $-€ 205.50$ & $€ 29.75$ & $€ 265.57$ \\
\hline 2008 & 20-06-07 & 30-04-08 & 2899 & 1573 & $€ 509.44$ & $€ 18.13$ & 212.50 & 18.13 & $€ 0.00$ & $€ 17.28$ & $€ 94.57$ & $€ 86.87$ & $€ 27.13$ & $€ 0.00$ & $€ 18.34$ & $€ 27.03$ & $€ 242.20$ & $€ 208.78$ & $-€ 171.71$ & & $€ 248.65$ \\
\hline 2009 & $30-04-08$ & 01-05-09 & 3665 & 1655 & $€ 633.64$ & $€ 42.58$ & $€ 252.07$ & $€ 32.45$ & $€ 0.00$ & $€ 14.45$ & $€ 98.10$ & $€ 71.43$ & $€ 88.12$ & $€ 0.00$ & $€ 21.36$ & $€ 24.74$ & $€ 258.62$ & $€ 316.59$ & $-€ 238.87$ & & $€ 306.89$ \\
\hline 2010 & 01-05-09 & 08-04-10 & 3144 & 1162 & $€ 300.06$ & $€ 53.99$ & 24.32 & 3.99 & 0.00 & $€ 0.00$ & 09.91 & $€ 0.00$ & 183.50 & $€ 0.00$ & 20.43 & 23.65 & $€ 186.40$ & $€ 343.96$ & $-€ 298.54$ & & $€ 228.32$ \\
\hline \multicolumn{22}{|c|}{ House 4} \\
\hline 2000 & 27-09-99 & $05-10-00$ & 5618 & 2347 & $€ 443.58$ & $€ 38.55$ & 27.44 & 9.16 & 0.00 & $€ 0.00$ & $€ 0.00$ & $€ 0.00$ & $€ 0.00$ & $€ 0.00$ & $€ 0.00$ & $€ 0.00$ & $€ 134.35$ & $€ 160.56$ & $€ 0.00$ & & 233.39 \\
\hline 2001 & 05-10-00 & 04-10-01 & 6420 & 2425 & $€ 524.95$ & $€ 40.49$ & $€ 577.80$ & $€ 39.70$ & $€ 0.00$ & $€ 0.00$ & $€ 0.00$ & $€ 0.00$ & $€ 0.00$ & $€ 0.00$ & $€ 0.00$ & $€ 0.00$ & $€ 257.49$ & $€ 334.88$ & $-€ 107.45$ & & $€ 309.63$ \\
\hline 2002 & 01-10-01 & 11-09-02 & 5942 & 2136 & $€ 448.77$ & $€ 0.69$ & $€ 279.27$ & $€ 6.14$ & $€ 0.00$ & $€ 65.36$ & $€ 29.53$ & $€ 214.51$ & $€ 24.59$ & $€ 0.00$ & $€ 10.00$ & $€ 14.60$ & $€ 261.87$ & $€ 354.14$ & $-€ 133.44$ & & $€ 299.45$ \\
\hline 2003 & $12-09-02$ & 11-09-03 & 5870 & 2401 & $€ 544.31$ & $€ 0.84$ & $€ 244.78$ & $€ 0.00$ & $€ 0.00$ & $€ 72.03$ & $€ 56.72$ & $€ 211.90$ & $€ 49.08$ & $€ 0.00$ & $€ 10.00$ & $€ 15.00$ & $€ 304.21$ & $€ 363.27$ & $-€ 134.96$ & E33.98 & $€ 330.06$ \\
\hline 2004 & $12-09-03$ & 21-09-04 & 237 & 2281 & $€ 527.14$ & 4.95 & 54.52 & 8.24 & $€ 0.00$ & $€ 78.24$ & $€ 61.38$ & $€ 90.21$ & $€ 47.86$ & $€ 0.00$ & $€ 18.00$ & 16.25 & 3.41 & $€ 99.95$ & $-€ 160.00$ & $€ 41.04$ & $€ 241$ \\
\hline 2005 & 22-09-04 & 22-09-05 & 3351 & 2170 & $€ 540.83$ & $€ 15.00$ & $€ 186.65$ & 15.00 & $€ 0.00$ & 59.68 & $€ 76.95$ & $€ 117.29$ & $€ 47.12$ & $€ 0.00$ & $€ 15.45$ & $€ 17.25$ & $€ 319.14$ & $€ 216.14$ & $-€ 190.93$ & $€ 48.54$ & $€ 272.76$ \\
\hline 2006 & 23-09-05 & 14-09-06 & 2991 & 1857 & $€ 561.93$ & $€ 13.75$ & $€ 190.83$ & $€ 13.75$ & $€ 0.00$ & $€ 29.34$ & $€ 89.22$ & $€ 98.70$ & $€ 43.55$ & $€ 0.00$ & $€ 14.54$ & $€ 16.19$ & $€ 279.11$ & $€ 210.27$ & $-€ 191.86$ & $€ 50.86$ & $€ 260.17$ \\
\hline 2007 & 15-09-06 & 10-09-07 & 2594 & 1386 & $€ 475.68$ & $€ 15.84$ & 191.70 & $€ 15.84$ & $€ 0.00$ & $€ 15.66$ & 102.26 & $€ 85.08$ & $€ 47.20$ & $€ 0.00$ & $€ 15.96$ & $€ 17.76$ & $€ 211.09$ & $€ 184.95$ & $-€ 196.23$ & $€ 15.39$ & $€ 224.73$ \\
\hline 2008 & 11-09-07 & 11-09-08 & 3092 & 1815 & $€ 599.31$ & 20.04 & C. & $€ 20.04$ & $€ 0.00$ & $€ 20.33$ & $€ 100.10$ & $€ 101.73$ & $€ 47.20$ & $€ 0.00$ & $€ 15.96$ & $€ 22.23$ & $€ 280.42$ & $€ 225.41$ & $-€ 200.09$ & & $€ 282.72$ \\
\hline 2009 & $12-09-08$ & 03-09-09 & 2558 & 1932 & $€ 769.32$ & $€ 20.68$ & $€ 219.99$ & $€ 20.68$ & $€ 0.00$ & $€ 7.34$ & $€ 100.59$ & $€ 26.16$ & $€ 127.81$ & $€ 0.00$ & $€ 16.39$ & $€ 25.16$ & $€ 303.32$ & $€ 251.20$ & $-€ 275.26$ & & $€ 306.54$ \\
\hline 2010 & 04-09-09 & 01-09-10 & 2441 & 1962 & $€ 525.42$ & 1.74 & 194.30 & 1.74 & $€ 0.00$ & 0.00 & 03.27 & $€ 0.00$ & 58.20 & $€ 0.00$ & $€ 16.48$ & 25.34 & 316.27 & 269.45 & $-€ 316.86$ & & $€ 253.72$ \\
\hline \multicolumn{22}{|c|}{ House 5} \\
\hline 2005 & 20-05-04 & 04-05-05 & 2936 & 2021 & $€ 507.82$ & $€ 12.62$ & $€ 156.78$ & $€ 4.94$ & $€ 0.00$ & 1.18 & $€ 61.55$ & $€ 99.24$ & $€ 15.92$ & $€ 0.00$ & 13.95 & 17.49 & $€ 295.77$ & 205.23 & $-€ 167.51$ & $€ 37.21$ & $€ 242.25$ \\
\hline 2006 & 05-05-05 & 06-05-06 & 2742 & 2355 & $€ 723.93$ & $€ 15.00$ & $€ 155.81$ & 5.00 & $€ 0.00$ & 1.24 & $€ 90.22$ & $€ 91.58$ & $€ 47.93$ & $€ 0.00$ & .72 & 17.52 & 53.49 & 92.29 & $-€ 196.10$ & 2.28 & $€ 297.09$ \\
\hline 2007 & 07-05-06 & 08-05-07 & 2699 & 1727 & $€ 608.42$ & $€ 15.00$ & $€ 192.17$ & $€ 15.00$ & $€ 0.00$ & $€ 19.52$ & $€ 102.26$ & $€ 88.26$ & $€ 47.20$ & $€ 0.00$ & $€ 15.96$ & $€ 17.76$ & $€ 262.33$ & $€ 191.36$ & $-€ 198.78$ & $€ 34.05$ & $€ 261.53$ \\
\hline 2008 & 09-05-07 & 05-05-08 & 2210 & 1799 & $€ 614.72$ & $€ 19.20$ & $€ 159.57$ & $€ 19.20$ & $€ 0.00$ & $€ 20.33$ & $€ 102.26$ & $€ 72.71$ & $€ 47.20$ & $€ 0.00$ & $€ 15.96$ & $€ 20.00$ & $€ 277.59$ & $€ 159.12$ & $-€ 197.90$ & & $€ 252.69$ \\
\hline 2009 & 06-05-08 & 01-05-09 & 1952 & 1929 & $€ 755.61$ & $€ 20.04$ & $€ 154.56$ & $€ 20.04$ & $€ 0.00$ & $€ 9.04$ & $€ 96.53$ & $€ 42.67$ & $€ 86.60$ & $€ 0.00$ & $€ 16.09$ & $€ 24.67$ & $€ 302.35$ & $€ 167.82$ & $-€ 236.46$ & -1 & $€ 277.32$ \\
\hline 2010 & 02-05-09 & 05-05-10 & 2070 & 1974 & 77.36 & 0.26 & 65.60 & 0.26 & .00 & .00 & 05.61 & $€ 0.00$ & 54.46 & .00 & $€ 16.64$ & 25.61 & 317.42 & 26.77 & 22.10 & & $€ 288.40$ \\
\hline House & & & & & & & & & & & & & & & & & & & & & \\
\hline
\end{tabular}




\begin{tabular}{|c|c|c|c|c|c|c|c|c|c|c|c|c|c|c|c|c|c|c|c|c|c|}
\hline 1999 & $-04-98$ & L-03-99 & 5057 & 1907 & $€ 360.25$ & $€ 43.70$ & $€ 378.87$ & $€ 32.13$ & $€ 0.00$ & $€ 0.00$ & $€ 0.00$ & $€ 0.00$ & $€ 0.00$ & $€ 0.00$ & $€ 0.00$ & $€ 0.00$ & $€ 65.28$ & $€ 65.19$ & $€ 0.00$ & & $€ 165.45$ \\
\hline 2000 & 01-04-99 & $1-03-00$ & 4772 & 1631 & $€ 297.24$ & $€ 40.84$ & $€ 367.47$ & $€ 27.54$ & $€ 0.00$ & $€ 0.00$ & $€ 12.48$ & $€ 0.00$ & $€ 0.00$ & $€ 0.00$ & $€ 0.00$ & $€ 0.00$ & $€ 72.71$ & $€ 101.45$ & $€ 0.00$ & & $€ 160.95$ \\
\hline 2001 & $1-04-00$ & $-03-01$ & 4298 & 1589 & $€ 328.82$ & $€ 42.18$ & $€ 351.30$ & $€ 13.87$ & $€ 0.00$ & $€ 0.00$ & $€ 47.34$ & $€ 0.00$ & $€ 0.00$ & $€ 0.00$ & $€ 0.00$ & $€ 0.00$ & $€ 99.72$ & $€ 152.33$ & $-€ 34.91$ & & $\varepsilon 179.12$ \\
\hline 2002 & -04-01 & S & 444 & 1727 & $€ 398.24$ & $€ 42.75$ & $€ 351$. & t. & $€ 0.00$ & $€ 0.00$ & $€ 44.10$ & $€ 0.00$ & $€ 0.00$ & $€ 0.00$ & $€ 0.00$ & $€ 0.00$ & $€ 212.07$ & $€ 260.31$ & $-€ 142.00$ & & $€ 224.46$ \\
\hline 2003 & 06-03-02 & 05-03-03 & 4319 & 1581 & $€ 355.25$ & $€ 4.85$ & $€ 201.70$ & $€ 9.12$ & $€ 0.00$ & $€ 35.26$ & $€ 42.57$ & $€ 142.10$ & $€ 55.77$ & $€ 0.00$ & $€ 0.00$ & $€ 0.00$ & $€ 198.73$ & $€ 262.60$ & $-€ 131.88$ & & $€ 223.45$ \\
\hline 2004 & 06-03-03 & 5-03-04 & 4476 & 1561 & $€ 366.84$ & $€ 1.36$ & $€ 205.90$ & $€ 12.50$ & $€ 0.00$ & $€ 39.65$ & $€ 66.46$ & $€ 147.26$ & $€ 60.84$ & $€ 0.00$ & $€ 0.00$ & $€ 0.00$ & $€ 207.46$ & $€ 287.36$ & -€166.47 & $€ 24.09$ & $€ 233.54$ \\
\hline 2005 & 06-03-04 & $14-03-05$ & 4554 & 1632 & $€ 395.49$ & $€ 10.48$ & $€ 215.86$ & $€ 15.00$ & $€ 0.00$ & $€ 42.27$ & $€ 63.35$ & $€ 153.93$ & $€ 44.34$ & $€ 0.00$ & $€ 15.10$ & $€ 16.90$ & $€ 237.01$ & $€ 301.93$ & $-€ 188.06$ & $€ 42.56$ & $€ 251.48$ \\
\hline 2006 & $15-03-05$ & 04-03-06 & 3301 & 1216 & $€ 362.98$ & $€ 15.00$ & $€ 185.12$ & $€ 15.00$ & $€ 0.00$ & $€ 24.37$ & $€ 87.21$ & $€ 110.91$ & $€ 48.12$ & $€ 0.00$ & $€ 15.66$ & $€ 17.46$ & $€ 182.28$ & $€ 231.09$ & $-€ 189.20$ & $€ 50.58$ & $€ 210.14$ \\
\hline 2007 & 05-03-06 & 3-03-07 & 3705 & 1079 & $€ 369.23$ & $€ 15.00$ & $€ 262.68$ & $€ 15.00$ & $€ 0.00$ & $€ 12.19$ & $€ 102.26$ & $€ 121.15$ & $€ 47.20$ & $€ 0.00$ & $€ 15.96$ & $€ 17.76$ & $€ 163.36$ & $€ 261.94$ & $-€ 196.80$ & 43.02 & $€ 229.32$ \\
\hline 2008 & 04-03-07 & 17-03-08 & 3871 & 1137 & $€ 393.40$ & $€ 20.03$ & $€ 285.29$ & $€ 20.03$ & $€ 0.00$ & $€ 12.85$ & $€ 110.78$ & $€ 127.36$ & $€ 51.13$ & $€ 0.00$ & $€ 17.29$ & $€ 20.92$ & $€ 174.98$ & $€ 277.94$ & $-€ 207.18$ & & $€ 247.92$ \\
\hline 2009 & $18-03-08$ & 04-03-09 & 4087 & 1308 & $€ 520.19$ & $€ 18.53$ & $€ 333.50$ & $€ 18.53$ & $€ 0.00$ & $€ 8.61$ & $€ 88.36$ & $€ 110.38$ & $€ 64.10$ & $€ 0.00$ & $€ 14.81$ & $€ 22.70$ & $€ 204.44$ & $€ 328.59$ & $-€ 212.55$ & & $€ 288.84$ \\
\hline 2010 & 05-03-09 & 5-03-10 & 4427 & 1338 & 414.65 & $€ 21.85$ & 72.75 & 1.85 & $€ 0.00$ & $€ 0.00$ & $€ 107.87$ & $€ 0.00$ & $€ 169.12$ & $€ 0.00$ & $€ 17.11$ & $€ 26.28$ & $€ 214.21$ & $€ 483.19$ & $-€ 328.21$ & & $€ 288.93$ \\
\hline House & 7 & & & GJ & & & & & & & & & & & & & & & & & \\
\hline 2005 & 22-10-04 & $05-07-05$ & 2144 & 16.37 & $€ 0.00$ & $€ 0.00$ & $€ 114.19$ & $€ 10.41$ & $€ 298.92$ & $€ 0.00$ & $€ 0.00$ & $€ 65.55$ & $€ 32.60$ & $€ 162.17$ & $€ 0.00$ & $€ 21.12$ & $€ 0.00$ & $€ 138.29$ & $-€ 134.07$ & $€ 34.09$ & $€ 134.74$ \\
\hline 2006 & 06-07-05 & $17-07-06$ & 2341 & 22.44 & $€ 0.00$ & $€ 0.00$ & $€ 142.38$ & $€ 16.25$ & $€ 441.62$ & $€ 0.00$ & $€ 0.00$ & $€ 75.46$ & $€ 51.68$ & $€ 224.32$ & $€ 0.00$ & $€ 33.50$ & $€ 0.00$ & $€ 176.36$ & $-€ 202.01$ & $€ 53.71$ & $€ 182.32$ \\
\hline 2007 & $18-07-06$ & 20-07-07 & 1913 & 20.27 & $€ 0.00$ & $€ 0.00$ & $€ 133.10$ & $€ 13.75$ & 415.33 & $€ 0.00$ & $€ 0.00$ & $€ 55.63$ & $€ 43.27$ & 212.76 & $€ 0.00$ & $€ 28.60$ & $€ 0.00$ & $€ 136.01$ & $-€ 188.81$ & $€ 23.79$ & $€ 161.43$ \\
\hline 2008 & 21-07-07 & 02-07-08 & 2853 & 26 & $€ 0.00$ & $€ 0.00$ & $€ 88.00$ & $€ 27.08$ & $€ 500.75$ & $€ 0.00$ & $€ 0.00$ & $€ 82.28$ & $€ 47.20$ & $€ 199.88$ & $€ 0.00$ & $€ 27.84$ & $€ 0.00$ & $€ 120.06$ & $-€ 199.53$ & & $€ 169.78$ \\
\hline 2009 & 02-07-08 & 15-07-09 & 2888 & 37.18 & $€ 0.00$ & $€ 0.00$ & $€ 303.88$ & $€ 33.41$ & $€ 820.09$ & $€ 0.00$ & $€ 0.00$ & $€ 42.54$ & $€ 112.90$ & $€ 220.57$ & $€ 0.00$ & $€ 25.78$ & $€ 0.00$ & $€ 317.49$ & $-€ 321.32$ & & $€ 295.51$ \\
\hline 2010 & 16-07-09 & 27-07-10 & 3003 & 38.66 & $€ 0.00$ & $€ 0.00$ & $€ 253.46$ & $€ 28.77$ & $€ 645.08$ & $€ 0.00$ & $€ 0.00$ & $€ 0.00$ & $€ 154.14$ & $€ 247.79$ & $€ 0.00$ & $€ 24.19$ & $€ 0.00$ & $€ 330.33$ & $-€ 305.53$ & & $€ 261.86$ \\
\hline House & 8 & & & GJ & & & & & & & & & & & & & & & & & \\
\hline 2003 & 30-01-03 & 29-01-04 & 1582 & 33.97 & $€ 0.00$ & $€ 0.00$ & $€ 63.26$ & $€ 12.25$ & $€ 600.93$ & $€ 0.00$ & $€ 0.00$ & $€ 44.36$ & $€ 63.70$ & $€ 144.94$ & $€ 0.00$ & $€ 0.00$ & $€ 0.00$ & $€ 101.25$ & $-€ 162.23$ & $€ 20.24$ & $€ 165.01$ \\
\hline 2004 & 30-01-04 & 25-01-05 & 2154 & 33.49 & $€ 0.00$ & $€ 0.00$ & $€ 94.23$ & $€ 15.00$ & $€ 598.13$ & $€ 0.00$ & $€ 0.00$ & $€ 64.35$ & $€ 43.95$ & $€ 164.60$ & $€ 0.00$ & $€ 30.05$ & $€ 0.00$ & $€ 141.52$ & $-€ 180.41$ & $€ 39.57$ & $€ 184.57$ \\
\hline 2005 & 26-01-05 & 12-01-06 & 2115 & 34.03 & $€ 0.00$ & $€ 0.00$ & $€ 109.87$ & $€ 13.75$ & $€ 641.81$ & $€ 0.00$ & $€ 0.00$ & $€ 64.40$ & $€ 44.28$ & $€ 182.82$ & $€ 0.00$ & $€ 28.05$ & $€ 0.00$ & $€ 147.84$ & $-€ 187.19$ & $€ 50.25$ & $€ 198.67$ \\
\hline 2006 & 13-01-06 & 22-01-07 & 1640 & 32.75 & $€ 0.00$ & $€ 0.00$ & $€ 106.58$ & $€ 16.25$ & $€ 663.19$ & $€ 0.00$ & $€ 0.00$ & $€ 46.48$ & $€ 51.13$ & $€ 231.28$ & $€ 0.00$ & $€ 33.80$ & $€ 0.00$ & $€ 115.78$ & $-€ 202.51$ & $€ 50.29$ & $€ 201.78$ \\
\hline 2007 & 23-01-07 & $25-01-08$ & 1581 & 35.33 & $€ 0.00$ & $€ 0.00$ & $€ 107.32$ & $€ 17.94$ & $€ 695.65$ & $€ 0.00$ & $€ 0.00$ & $€ 44.44$ & $€ 47.20$ & $€ 213.06$ & $€ 0.00$ & $€ 30.64$ & $€ 0.00$ & $€ 113.36$ & $-€ 200.64$ & & $€ 203.10$ \\
\hline 2008 & 26-01-08 & 20-01-09 & 1447 & 39.91 & 00 & $€ 0.00$ & 03 & $€ 20.12$ & 77 & $€ 0.00$ & .00 & 51 & 2.38 & $€ 217.20$ & $€ 0.00$ & $€ 23.81$ & $€ 0.00$ & 9.97 & $-€ 203.38$ & & 224.09 \\
\hline 2009 & 21-01-09 & 04-01-10 & 1385 & 30.52 & $€ 0.00$ & $€ 0.00$ & $€ 111.67$ & $€ 19.44$ & $€ 604.14$ & $€ 0.00$ & $€ 0.00$ & $€ 0.00$ & $€ 158.86$ & $€ 225.26$ & $€ 0.00$ & $€ 23.38$ & $€ 0.00$ & $€ 150.34$ & $-€ 304.64$ & -1 & $€ 187.81$ \\
\hline 2010 & 10-01-10 & 01-01-11 & 1685 & 39.19 & $€ 0.00$ & $€ 0.00$ & $€ 124.07$ & $€ 20.56$ & $€ 674.60$ & $€ 0.00$ & $€ 0.00$ & $€ 0.00$ & $€ 157.49$ & $€ 226.13$ & $€ 0.00$ & $€ 25.57$ & $€ 0.00$ & $€ 178.85$ & $-€ 310.76$ & & $€ 208.34$ \\
\hline
\end{tabular}




\section{Appendix C: Interviews case study on building projects}

Nine persons were interviewed to become familiar with the cases and their context. The Dutch reports of seven out of nine of these interviews are given in this appendix. Interviews took place with the following persons:

A. Senior policy officer sustainability, municipality of Almelo, June $19^{\text {th }} 2012$;

B. Architect and owner, Grunstra Architecten Groep bna, July $27^{\text {th }} 2012$;

C. Project manager, social housing association Beter Wonen, April $17^{\text {th }} 2012$;

D. Manager energy strategies and concept development, DWA, June $29^{\text {th }} 2012$;

G. Employee land distribution, municipality of Almelo, June $19^{\text {th }} 2012$;

I. Senior advisor environmental technology, municipality of Almelo, June $19^{\text {th }} 2012$;

J. Project manager, social housing association Beter Wonen, April $5^{\text {th }} 2012$;

K. Advisor building technology, municipality of Almelo, June $19^{\text {th }} 2012$;

Q. Architect and owner, De Witte - Van der Heijden Architecten, June $20^{\text {th }} 2012$.

Two interviews, with the projectmanagers, encompassed many questions involving written documents and project specific characteristics. Taking into account all necessary project information the reports on these interviews would become to extended to incorporate. Therefore, these reports are not incorporated in this appendix.

\section{Interview senior sustainability policy officer Almelo}

This section provides the report of the interview with the senior policy officer on sustainability of the municipality of Almelo. Table C.1 provides some general information on the interview and the respondent.

Table C.1: General information on the interview and respondent A.

\begin{tabular}{|l|l|l|}
\hline Function & Senior policy officer sustainability \\
\hline Organisation & Municipality of Almelo \\
\hline Department & Spatial planning and the environment \\
\hline Experience & 22 years of experience in policy affairs of which the last 11 years at municipalities \\
\hline Subject interview & Policies regarding sustainability and enegy use of buildings in Almelo \\
\hline Start time: & $10: 30$ \\
\hline $\begin{array}{l}\text { Date of interview and } \\
\text { feedback }\end{array}$ & $\begin{array}{l}\text { Date interview: June } 19^{\text {th }} 2012 \\
\text { Date feedback: June } 26^{\text {th }} 2012\end{array}$ \\
\hline Location & Stadhuisplein 1 - Almelo \\
\hline
\end{tabular}

\section{A. Kennismaking}

Vanaf 1990 was ze werkzaam bij de provincie Drenthe als beleidsmedewerker afvalstoffen. Daar is ze tevens werkzaam geweest op het gebied van grondwaterbescherming en communicatie. Tot de mogelijkheid kwam tijdelijk juridisch werk voor het eerste provinciale omgevingsplan te doen. Door een reorganisatie is ze projectleider Verkeer en Vervoer geworden; deels beleidsmatig en deels projecten uitvoeren. In 2001 is ze bij de gemeente Hengelo gaan werken en vervolgens in 2008 bij de gemeente Almelo.

\section{A.1. Zou u mij uw functie in één of een paar zinnen willen omschrijven?}

Ze is werkzaam als senior beleidsmedewerker duurzaamheid. Ze initieert nieuwe projecten en stelt beleid op inzake duurzaamheid en klimaatbeleid. 
De Leemslagenplas (interviewer: een plas gelegen aan de zuid-west kant van Almelo) is een voorbeeld van een project, waar de geïnterviewde de bestuurlijke en beleidsmatige kant vertegenwoordigt. In eerste instantie moest de plas worden verondiept. De gemeente Almelo heeft, als eigenaar van de plas, een vooronderzoek laten uitvoeren naar de mogelijkheden van gebruik als koude levering. Het vooronderzoek is deels betaald vanuit "Stimulering Lokale Klimaatinititatieven (SLoK)"-gelden, waarbij het Rijk $€ 200.000$ beschikbaar stelde en een even groot bedrag van $€ 200.000$ door de gemeente beschikbaar moest worden gesteld. In totaal zijn er vijftien projecten betaald met deze vier ton. Er zijn diverse technische medewerkers intern bij de gemeente Almelo bij betrokken, net als de ZorgGroep Twente (ZGT) en Cogas. Deze drie partijen hebben samen de opdracht opgesteld dat er een haalbaarheidsonderzoek moest komen voor verduurzamen van ZGT. Inmiddels is het idee van verondiepen helemaal verlaten. Het college van $B \& W$ wordt binnenkort het resultaat van het onderzoek voorgelegd. Er wordt voorgesteld te gaan aanbesteden, zodat marktpartijen de mogelijkheden van deze plas voor duurzame energieopslag commercieel kunnen oppakken.

\section{B. Beleid energiegebruik gebouwde omgeving}

B.1. Hoe verhouden de termen klimaatbeleid, milieubeleid en energiebeleid zich tot elkaar? In 2001 heeft de gemeente Almelo een Milieubeleidsplan opgesteld. In dat plan waren Duurzaamheid en Energie onderdelen van dat milieubeleid. Almelo was vrij ver, aldus de geïnterviewde, met auto's op aardgas, mogelijkheden voor windmolens, en mogelijkheden voor duurzame energieopwekking in nieuwe woonwijken. Duurzaamheid en energie zijn dus aspecten net als afval bijvoorbeeld. Het Milieubeleidsplan is in 2008/2009 geëvalueerd. Toen besloot men tot een Duurzaamheidsplan te komen met actiepunten. Almelo moest bekijken waarmee men verder wilde, want inmiddels was er voor geluid al een separaat beleidsplan opgesteld. Het milieubeleidsplan is dus globaal en verschillende aspecten worden in afzonderlijke beleidsplannen uitgewerkt.

Het aspect energie had veel aandacht, vandaar dat Almelo bijvoorbeeld auto's op aardgas had en het eerste tankstation hiervoor kreeg. In 2006 werden de mogelijkheden voor windmolens reeds genoemd. De landelijke regelgeving voor geluidsbelasting was nog beperkend op dat moment. Op landelijk niveau is toen, naar aanleiding van deze ervaringen, het geluid van windmolens niet meer als specifieke bedrijfsmatige belasting gezien. De gemeente Almelo bleek echter in de laagvliegroute voor straaljagers van het ministerie van Defensie te liggen en er is een radarverstoringsgebied, waardoor er toch echt geen windmolens konden komen. Als pilot heeft, in samenwerking met Cogas, op het gemeentehuis een kleine windmolen gestaan. Maar door geluidsoverlast bij omwonenden en problemen met loslatende onderdelen elders in het land, is deze kleine windmolen stil gezet. Veel gemeenten lopen nu pas tegen dergelijke problemen aan, waar de gemeente Almelo dat al enkele jaren geleden had.

B.2. Welke ontwikkeling heeft het beleid op het gebied van energiegebruik in gebouwen doorgemaakt?

In 2005/2006 was er wat minder aandacht voor energie, want er was geen geld voor een vaste medewerker duurzaamheid. Daarna kwam er vanuit de Rijksoverheid geld voor het 
klimaat uitvoeringsprogramma, waardoor een medewerker kon worden ingehuurd. Toen de aandacht voor energie doorzette, kon ze intern worden aangenomen.

B.3. Welke ambities heeft de gemeente Almelo op het gebied van duurzaam bouwen in gebouwen?

De gemeente Almelo streeft er naar in concrete projecten en doelen te denken. De geïnterviewde geeft als tegenvoorbeeld de gemeente Enschede, welke wel klimaatneutraal wilde worden, maar dat lukt nog niet echt. De huidige Almelose wethouder wil niet dat er onmogelijke ambities van de daken worden geschreeuwd, maar dat ze met projecten laten zien wat mogelijk is. Er worden geen onrealistische ambities nagestreefd. Opwekking van grootschalige duurzame energie heeft in Almelo de prioriteit. Windmolens zijn weliswaar niet mogelijk, maar andere manieren hebben de aandacht. Het beperken van het energiegebruik en het grootschalig gebruiken van vernieuwbare bronnen, daar wordt op ingezet.

Grootschalig betekent in dit geval op wijkniveau, met als voorbeeld de WKO Leemslagenplas en een bio-vergister op het XL-businesspark. Één wijk (interviewer: van zo'n 850 woningen, Windmolenbroek), maakt daarnaast al gebruik van stortgas voor verwarming, dit wordt verder verduurzaamd. Aan de hand van een kansenkaart zijn de mogelijkheden voor WKO in de bodem op een rij gezet. De gemeente Almelo wil het gebruik van WKO reguleren. Op dit moment zijn er naast de bouwvergunning geen vergunningen nodig voor de toepassing van een gesloten WKO systeem, terwijl de ruimte in de ondergrond beperkt is. Een deel van de ondergrond moet beschikbaar zijn voor warm water en een deel voor koud water. Je mag straks, tenminste dat is een voorstel waar binnenkort nog over besloten moet worden, alleen je eigen perceel en slechts een deel van de openbare ruimte gebruiken. Nu bestaat nog de situatie dat wie het eerst komt, wie het eerst maalt. Met de Rijksoverheid is meegedacht over de nieuwe Algemene Maatregel van Bestuur (AMvB) Bodemenergie die per 1 januari aanstaande van kracht wordt. Nu het politiebureau in Almelo een WKOsysteem heeft wordt het lastig om voor het huidige stadhuis een WKO te installeren mocht de gemeente dat zelf willen of een andere eigenaar in de toekomst. Dit politiebureau maakt reeds van een bodemwater warmtepomp gebruik (interviewer: dit wordt bevestigd in een waterwet vergunning van 16-5-2011).

B.4. Is er uwes inziens sprake van energiebeleid in de gemeente Almelo?

Het duurzaamheidsplan is bedoeld als de paraplu en opvolger van het Milieubeleidsplan. Specifiek voor de binnenstad is een concreet aparte duurzaamheidsvisie opgesteld met duurzame ambities. Deze zijn gericht op bodem energie, water, openbare ruimte, gebouwen, tijdelijkheid, beleving en mobiliteit. $\mathrm{Er}$ is geen aparte nota voor energiebeleid. Het is een onderdeel van het duurzaamheidsplan, welke september in de raad komt. Bij elk project moet specifiek worden bekeken wat de ambitie is qua energie. De geïnterviewde legt uit dat op deze wijze maatwerk wordt verkregen.

\section{Actoren energiebeleid Almelo}

C.1. Welke rol spelen de politieke achtergronden vanuit uw ervaring in de ontwikkeling van beleid op het gebied van energiegebruik in de gebouwde omgeving? 
De PvdA wethouder voorheen had in eerste instantie een focus op windenergie. Hij werkte anders dan de huidige wethouder, maar dit college heb ik niet lang meegemaakt en dat was nog voor de crisis. De nieuwe wethouder is een VVD'er die stelt, net als het hele college, voorop dat de gemeente alleen maar haar taak moet doen en meer de regie neemt en ondersteunt ipv. zoals met vorige college. hele projecten voor te bereiden en uit te voeren. $\mathrm{Nu}$ wordt dus meer aan de markt overgelaten. De nieuwe wethouder stuurt meer aan op resultaten, dan op beleid.

C.2. Welke rol spelen de politieke achtergronden van de raadsleden vanuit uw ervaring in de ontwikkeling van beleid op het gebied van energiegebruik in de gebouwde omgeving?

Met de vorige raad zijn verschillende beleidsateliers en sessies gehouden. In 2008 waren er gezamenlijk ambities opgesteld voor het milieubeleid en laten duurzaamheidsplan, die verder gingen dan haar of de werkgroep Duurzaamheid had verwacht. De ambities waren dus boven verwachting, maar er was geen besluit om middelen ter beschikking te stellen. De visie vanuit de sessie werd vervolgens moeilijk concreet, maar is nu wel als leidraad voor nieuwe duurzaamheidsplan gebruikt.

Gezien de sociaal-maatschappelijke problemen in de gemeente en het laag economisch niveau, moet je in ieder geval de sociale componenten en economische kanten goed meenemen, wanneer je iets met duurzaamheid wilt bereiken. In Almelo zijn bijvoorbeeld energieteams actief geweest. Dit project heeft een gevolg gekregen in de vorm van een bus, waarin burgers werden geïnformeerd over energiebesparing. Via deze campagne om het energiegebruik onder consumenten (met name met een laag inkomen) te verminderen, zijn 3.000-3.500 huishoudens bereikt. In gesprekken zijn de gegevens van de huishoudens genoteerd in de vorm van een enquête-achtig formulier. Besparing werd geschat op $€ 275$,per huishouden per jaar vooraf. Deze mensen wonen vaak in slecht geïsoleerde huizen. Sommige bewoners zijn afkomstig uit andere landen, waarbij verwarmen en ventileren via open ramen gelijktijdig plaatsvinden. Bij een deel van de huishoudens is de energiebesparing na één jaar nogmaals bekeken, toen bleek gemiddeld $€ 220$,- per jaar bij per huishouden te zijn bespaard. (interviewer: op de website energiebesparenalmelo is terug te vinden dat met de energieteams 1.400 energiebesparingsadviezen aan huis zijn uitgevoerd en dat $€$ 200,- per huishouden structureel is bespaard dat was een tussen evaluatie, inmiddels is er een eindevaluatie maar die is nog niet vastgesteld.) Soweco was betrokken bij de uitvoering van het project. Pakketten zijn uitgedeeld met spaarlampen, tochtstrips, waterbesparende douchekop en radiator folie bijvoorbeeld. De radiatorfolie is in een latere fase achterwege gelaten.

In 2008 is een $\mathrm{CO}_{2}$ scan uitgevoerd en er wordt straks een Sustainable Energy Action Plan (SEAP) opgesteld om de $\mathrm{CO}_{2}$ uitstoot te verminderen. Deze scan is apart voor bedrijven, woningen, mobiliteit en eigen gebouwen. Maar de gemeente Almelo spreekt liever niet van $\mathrm{CO}_{2}$, maar van besparing op fossiele brandstoffen in de vorm van vermeden $\mathrm{m}^{3}$ aardgas. Dit zegt namelijk de meeste mensen wat meer. De grootste stap was en is, net als in veel andere gemeenten, te maken in de bestaande woningbouw.

C.3. Op welke manieren draagt de gemeente haar beleid op het gebied van energiegebruik in gebouwen uit? 
Er wordt door de gemeente advies gegeven inzake duurzaamheid, specifiek energie. Het is lastig om de uitvoering beleid af te dwingen. In het najaar (van 2012) worden na vaststelling van de woonvisie prestatie afspraken gemaakt met de woningcorporaties, bijvoorbeeld qua energielabel voor nieuwbouw, groot onderhoud en bij renovatie. De gemeente wil de opwekking van duurzame energie er ook in hebben, maar ze moeten het wel samen afspreken. Wanneer er afspraken zijn gemaakt met woningcorporaties, kan de gemeente de woningcorporaties op deze afspraken houden. Het is echter nooit keihard. In het kader van Bouwbesluit mogen er geen namelijk extra eisen worden gesteld. Je mag niet verder dan het Bouwbesluit gaan. De gemeente kan alleen eisen stellen aan de openbare ruimte en haar eigen gebouwen. Door zelf aan te geven naar projectontwikkelaars toe wat door de gemeente wordt meegenomen, starten de onderhandelingen. Kortom wij als gemeente doen dit, dit en dit aan duurzaamheid, we zouden graag zien dat u het volgende meeneemt. Het vraagt overleg om hier goed samen uit te komen. Ze geeft aan dat steeds vaker door huurders wordt bekeken wat naast de huurlasten de energierekening zal doen.

De gemeente zelf hanteert al jaren het uitgangspunt dat eigen gebouwen een $25 \%$ lagere EPC dan wettelijk verplicht moeten hebben en dat woningen van projectontwikkelaars, particulieren en woningstichtingen in de gemeente een $10 \%$ lagere EPC dan wettelijk verplicht moeten hebben. $\mathrm{Er}$ is een tijd lang voor particulieren een statiegeldregeling gebruikt, waarbij een deel van de grondprijs werd teruggestort bij de toepassing van aanvullende duurzame maatregelen. Dit was echter juridisch niet houdbaar. Projectontwikkelaars weten helaas dat gemeenten niet meer mogen eisen dan het Bouwbesluit. Op projectbasis wordt daarom nu steeds bekeken wat past en haalbaar is. Bij elk project is er een projectleider die intern een uitvraag doet met betrekking tot verschillende beleidsterreinen waaronder duurzaamheid. Bijvoorbeeld de senior adviseur milieutechniek legt in het begin van een project voor wat vanuit de gemeente de wensen of ambities zijn qua milieu en duurzaamheid. Wanneer bepaalde partijen niet actief meewerken, kan bij het onderhandelingstraject in het uiterste geval een bestuurlijk overleg helpen, maar het blijft een onderhandelingssituatie. Voor het Indië terrein stelde de senior adviseur milieutechniek bijvoorbeeld voor of er niet zonder gas of met riothermie kan worden gewerkt. In het project Waterrijk is nu het uitgangspunt neergelegd dat er geen gas wordt gebruikt. De gemeente weet in ieder geval wat de mogelijkheden qua ondergrond zijn. Een dergelijk initiatief bij Waterrijk kwam nu uit de koker van de afdeling ROM. In dit geval werd vervolgens Cogas gevraagd om een aanbieding te doen om de energieinfrastructuur in Waterrijk mogelijk te maken.

\section{Uitvoering beleid}

D.1. Op welke manieren zorgt de gemeente Almelo ervoor dat het energiegebruik vanuit fossiele brandstoffen afneemt?

$\mathrm{Er}$ is bijvoorbeeld een oude schoolbus ingezet, zodat op een laagdrempelige manier de mogelijkheid werd geboden onder het genot van een kopje koffie het energiegebruik te bespreken en daarna bij voorkeur te reduceren. Dit trok veel meer bezoekers dan verwacht, maar wat het precieze effect is geweest is lastig aan te geven. Er is treedt in ieder geval bewustwording op. Een website "energiebeparenalmelo.nl" is beschikbaar om het 
energiegebruik inzichtelijk te maken. Er was tevens een tool "Beter Peter" ontwikkeld, welke via de gelijknamige website beschikbaar is, om bewustwording onder huurders te stimuleren via emails met tips. Woningcorporaties hebben hier niet zoveel aandacht aan besteedt als verwacht. Want de huurders kun je er wel op wijzen, maar de verhuurders vreesden een respons in de zin van "maar wat doen jullie aan mijn woning?".

D.2. Welke stimulansen zijn er om het energiegebruik te reduceren of te verduurzamen? (voor welke partijen zijn deze stimulansen?)

$\mathrm{Er}$ is ondermeer onlangs een subsidieregeling geweest voor bestaande woningen voor de toepassing van isolatie. Deze regeling is inmiddels stopgezet, aangezien de subsidiepot leeg was. Voor de komende jaren wordt ingezet op prijsvragen en het afnemen van groene stroom zal worden gestimuleerd. Er wordt tevens een aansluiting gemaakt op Overijsselse Aanpak 2.0 van de provincie.

D.3. Welke vorm van handhaving is er om ervoor te zorgen dat beleid/afspraken omtrent het energiegebruik in gebouwen worden nagekomen?

De adviseur bouwtechniek handhaaft op een bepaalde EPC bij aanvraag van een bouwvergunning, maar om te handhaven op een bepaalde GPR Gebouw score wordt lastig. GPR Gebouw wordt wel door de gemeente aangeboden aan ontwikkelaars en woningcorporaties voor gebruik.

D.4. Richt de gemeente Almelo zich op specifieke energieconcepten, technieken of maatregelen?

Duurzame energieopwekking is intern het begrip dat wordt gebruikt. Overijsselse aanpak 2.0 wordt ook in Almelo uitgezet voor particuliere huishoudens. Er komt een isolatiepremieregeling en een duurzaamheidslening. Hierbij krijgt men tevens bij samenwerking met buren of wijkgenoten een extra subsidie. Het gedrag van bewoners zal extra aandacht gaan krijgen.

\section{E. Barrières}

E.1. Welke problemen om te komen tot bredere en grotere toepassing van energiemaatregelen in gebouwen zijn reeds overwonnen in de gemeente Almelo uw inziens? De twee problemen voortkomend uit 1) geluidsoverlast regelgeving voor wat betreft windmolens, 2) regulering ondergrond voor warmtepompen zijn reeds in overleg met de Rijksoverheid opgepakt. Wetgeving is aangepast want speelde natuurlijk bij meer gemeenten.

E.2. Welke problemen om te komen tot bredere en grotere toepassing van energiemaatregelen zijn er in de gemeente Almelo nog uw inziens?

Geld is het grote probleem. Er is een cursus aan bouw- en installatiebedrijven geweest met het Centrum voor Innovatie van de Bouwkolom, maar op dat moment kreeg de geïnterviewde de indruk dat de meeste dachten dat energiezuinigheid en duurzaamheid maar een hype zou zien. Inmiddels zie je dat sommige bedrijven de boot hebben gemist, dan wel dat een paar bedrijven zich juist profileren.

Burgers lijken er niet mee bezig te zijn zich bewust te worden van hun uitgaven en de mogelijk besparingen. Wanneer er wel wat geld beschikbaar is, dan wordt dit besteed aan 
de keuken of badkamer. Voornamelijk gezinnen met oudere kinderen lijken wel in te zetten op energiebesparing. In de subsidieregeling voor isolatie was het mogelijk om de isolatie in ieder geval zelf aan te brengen, zodat de investering laag kon blijven. De adviseur bouwtechniek controleerde de aanvraag, welke vijf vragen omvatte. Bij eventuele twijfels qua uitvoering, wordt door hem de uitvoering gecontroleerd.

E.3. Welke barrières zijn er nog te overwinnen, uw inziens, om de toepassing van energiemaatregelen in de woningbouw te laten toenemen?

Het Bouwbesluit is nog een barriére, want je mag als gemeente niet er aan voorbij gaan. Er is op dit moment maar weinig geregeld voor renovatie of verbouwingen wat betreft energiezuinigheid. Ze noemt ook de onmogelijkheid voor woningcorporaties om maatregelen eenvoudig en snel terug te verdienen. Ze kunnen immers nauwelijks de huur verhogen, zonder dat de bewoners hun huursubsidie mislopen.

\section{F. Documentstudie}

F.1. In het Milieubeleidsplan 2001-2005 wordt op blz. 23 gesproken van een actualisatie van het gemeente Energiebeleidsplan 1997-2000 is deze er gekomen?

Nee, deze is er niet meer gekomen.

F.2. GPR gebouw en een infrarood camera zijn aangeschaft, hoe worden deze instrumenten ingezet?

Bennie weet of GPR Gebouw op dit moment nog wordt gebruikt en hij beschikt over de IRcamera. In het verleden is namelijk GPR Gebouw aangeschaft, hier konden verschillende partijen, waaronder Woningcorporaties gebruik van maken. Voor het nieuwe stadhuis wordt BREEAM gebruikt. GPR Gebouw wordt op dit moment aangepast en wat minder gebruikt.

F.3. In het actieplan Milieubeleid 2007-2010 wordt op blz. 20 gesproken van een nieuw convenant Duurzaam Bouwen, wat was het doel van dit convenant en welke afspraken stonden hierin?

$\mathrm{Er}$ is een convenant Duurzaam Bouwen, maar dit moet naar aanleiding van de Woonvisie worden aangepast. Er staat voornamelijk in dat er een werkgroep Duurzaam Bouwen wordt opgericht en dat men per project kijkt wat mogelijk is. Voor de deze werkgroep zal binnenkort worden bekeken hoe en of men verder gaat.

F.4. De symposium bundel spreekt op bladzijde 11 van een 10\% EPC reductie (in 2008), van wanneer tot wanneer is aan deze wens of eis vastgehouden? Hoe kon de gemeente dit verlangen of eisen?

Deze 10\%-regel wordt altijd meegenomen of uitgedragen, maar kan niet worden afgedwongen. Projectontwikkelaars zijn ieder geval niet altijd genegen om verder te gaan dan het Bouwbesluit, aldus de geïnterviewde.

F.5. De Woonvisie 2020 spreekt op blz 8 van een 20\% lagere CO2 uitstoot en energieneutrale nieuwbouwwoningen. Waar komt een dergelijke doelstelling vandaan? Hoe worden deze "twee doelstellingen" gemeten? En hoe kan de gemeente hierop handhaven en/of dit afdwingen? 
Deze doelstelling wordt elke keer wel genoemd, want dat is op Rijksniveau zo bepaald. De gemeente Almelo wil het proberen te bereiken via verschillende wegen, maar zet voornamelijk in op grootschalige duurzame energie opwekking.

\section{Interview architect Friso}

This section provides the report of the interview with the architect involved in the project Friso. Table C. 2 provides some general information on the interview and the respondent.

Table C.2: General information on the interview and respondent $B$.

\begin{tabular}{|l|l|}
\hline Function & Architect / Owner \\
\hline Organisation & Grunstra Architecten Groep bna \\
\hline Department & - \\
\hline Experience & $\begin{array}{l}\text { 24 Years of experience as an architect, since 1994 as an associate of Grunstra } \\
\text { Architecten Groep bna }\end{array}$ \\
\hline Subject interview & Application of energy techniques and measures in Friso \\
\hline Start time: & $12: 00$ \\
\hline $\begin{array}{l}\text { Date of interview and } \\
\text { feedback }\end{array}$ & $\begin{array}{l}\text { July } 27^{\text {th }} 2012 \\
\text { August } 29^{\text {th }} 2012\end{array}$ \\
\hline Location & Enschede - Horsttoren HT 301 (of eventueel HT 415) \\
\hline
\end{tabular}

\section{A. Kennismaking}

\section{A.1. Zou u uw ervaring als architect willen toelichten?}

Het vak van architect ligt op het grensvlak van hard en zacht en wordt, aldus de geïnterviewde, mooi omschreven door het credo van de Universiteit Twente "High Tech; Human Touch". Het één kan niet zonder het ander. Hij heeft Bouwkunde gestudeerd aan de TU Delft van 1982 tot 1988 . Hij is vierentwintig jaar geleden begonnen als architect. In zijn taken is wel de nodige verandering te zien. Hij is gegroeid in zijn rol, waarbij hij in de loop der jaren zich steeds meer is gaan toeleggen op procesmatige zaken en minder op het daadwerkelijke ontwerpen.

\section{A.2. Welke ontwikkeling heeft u waargenomen in uw jaren als architect?}

In de loop der jaren is het ontwerpproces niet zozeer moeilijker, maar complexer geworden. Complexer, doordat er meer partners in het bouwproces betrokken zijn, er is meer regelgeving o.a. vanuit Europa, zowel procesmatige als inhoudelijke regelgeving, en de rol van geld is steeds nadrukkelijker geworden. Er zijn ook inkoopprotocollen vanuit Europa die het project complexer maken. Als architect heb je hier behoorlijk last van. In plaats van gemakkelijker en eenvoudiger wordt het steeds complexer. Je komt dan ook op het gebied van techniek. De invloed van techniek voert steeds verder, wat op zijn beurt weer invloed heeft op het energie, milieu en duurzaamheid. Met begrippen als energieneutraal en luchtkwaliteit krijgt de technische kant van bouwen en het installatietechnische proces meer aandacht met veel rekenwerk, haalbaarheid en politiek. Dit maakt bouwprocessen steeds complexer, waardoor ze langer duren.

\section{A.3. Welk onderscheid is er tussen woning- en utiliteitsbouw?}

Woningbouw is simpeler dan utiliteitsbouw, doordat de basis, het programma van eisen, eenvoudiger en overzichtelijker is op te splitsen. Alhoewel een bepaalde locatie ook woningbouw lastig kan maken. Maar in essentie is woningbouw eenvoudiger. Zodra je het 
hebt over projecten in de algemene ruimte, bijvoorbeeld zorggebouwen en schoolgebouwen, dan is het toch duidelijk complexer.

\section{B. Project- en procesbeschrijving Friso}

\section{B.1. Hoe is het project voor u van start gegaan?}

Het project Friso is in 2003 opgestart als zorgproject met zorgorganisatie Friso als opdrachtgever. Niet veel later is Beter Wonen als tweede opdrachtgever erbij gekomen voor de woningbouw. Het is dus toen een gedeeld opdrachtgeverschap geworden. Voor het zorggedeelte had je toen nog normen qua vierkante meters, aantallen en geld, waarmee je vrij snel tot een ontwerp kon komen. Je moest alleen bij het zorgbureau bepaalde vergunningen aanvragen bij het college Bouw Zorgvoorzieningen, welke wel werden verleend mits je je aan de normen hield. De hele kapitaallast voor veertig jaar werd vastgelegd en verzorgd. Je had dan wel een opstarttraject van anderhalf jaar, maar dan lag alles ook helemaal vast. Je had dus geen financiële procedures of bijbehorende discussies meer. Tegenwoordig (officieel sinds 1 januari 2012 maar ingezet sinds 1 januari 2010) wordt het hele traject aan de markt overgelaten. Een erg beroerd moment aangezien het moeilijk geld halen is op de markt voor dergelijke projecten.

Beter Wonen moest als partner er wel bij betrokken worden, want je zat midden tussen hun woningen. Met de samenwerking bleek pas dat Beter Wonen haar bestand daar wel wilde uitbreiden. Friso moest namelijk terug van 90 naar 60 erkende verzorgingshuisplaatsen. Het zorgkantoor had toen bedongen in de vergunning dat er dus 30 woningen moesten komen, waarop Beter Wonen binnen een paar maanden aanhaakte. Beter Wonen wilde wel een harde scheidslijn tussen haar woningen en de zorg van Friso. Uit locatieonderzoek bleek dat de ruimte op de locatie beperkt was, mede door de noodzaak voor verkeervoorzieningen. Het zorgcentrum mocht programmatisch maar vier lagen hebben. Er moest dus een toren komen voor de woningen. De toren had eerst zeventien verdiepingen, maar de gemeente stond niet meer dan dertien verdiepingen toe. Er was hiervoor heel wat onderzoek qua beeld in het landschap en lichtinval nodig. Het bestemmingsplan moest ook worden aangepast.

\section{B.2. Hoe verhouden de rollen van Beter Wonen en Friso zich tot elkaar?}

Het zijn wat dat betreft twee verschillende projecten geweest met elk zijn eigen opdrachtgever, welke gekoppeld zijn qua ontwerp en in de uitvoering. In de omgeving waren al zo'n 140 aanleunwoningen in verschillende stijlen. Wanneer de gebouwen van Friso en Beter Wonen met de verschillende functies ook nog verschillende stijlen zou vertonen, dan zou het beeld wel erg rommelig worden. $\mathrm{Er}$ was dus een mooi stedebouwkundig uitgangspunt om nu wel qua uitstraling één geheel te maken. De twee gebouwen zijn door de vorm geen kopieën van elkaar geworden, maar er is wel eenzelfde stijl gehanteerd. Er was wat verzet vanuit de omgeving op de hoogte van woontoren, zodat er een plan B was om de bouw van het zorgcentrum eventueel eerder te beginnen. Maar het was niet nodig dit plan in te zetten, waardoor de gehele overlast kon worden beperkt.

\section{B.3. Bij welke processen in de projecten was u betrokken?}

Er moest een planning worden gemaakt met wel vijf of zes verschillende processen met elk hun eigen kritische lijnen. Je moest een bouwvergunning aanvragen en het bouwtraject 
plannen. Daar liep doorheen het slopen van het bestaande gebouw en het omleggen van leidingen. Tijdelijke huisvesting moest worden opgericht na bijbehorende vergunningaanvraag. Na gereedkomen van het nieuwe gebouw, moest de tijdelijke huisvesting ook zo snel mogelijk weer weg. Het kost immers kapitalen dergelijke huisvesting aan te houden. De taken van de architect omvatte dus ook het management van al deze processen en de aanbestedingen daarbinnen. In de ontwerpfase waren advisering techniek/installaties en constructies uitbesteed. Als het eenmaal gaat lopen en de eerste schop de grond in gaat, is de trein niet meer te stoppen. Elke maand werd met tien tot twaalf man bekeken hoe het ervoor stond en waar het naar toe ging.

B.4. Er was sprake van besparingsopgave van één miljoen Euro; hoe is men hiermee omgegaan?

Het zorgcentrum was in een slechte tijd aanbesteed qua prijsvorming. Toen werd door aannemers de prijs met 15\% opgehoogd, wanneer je nu aanbesteedt haal je $15 \%$ van de prijs af. Er moest een miljoen vrij worden gemaakt. Er zijn dus besparingen doorgevoerd, maar de opdrachtgevers hebben ook gedeald en coulant opgesteld. Er zijn door Beter Wonen vierkante meters beschikbaar gesteld aan Friso om niet. De opdrachtgevers hebben zich ook nog even teruggetrokken om gezamenlijk te overleggen over het laatste tekort van twee ton. Het geheel is Europees aanbesteedt, wat niet gemakkelijk is. Er komen echter geen buitenlandse aanbiedingen op af. Europees aanbesteden is wat dat betreft een wassen neus.

\section{Rol aspect energie in project Friso}

C.1. Waren er eisen gesteld of wensen geuit qua energiegebruik van het gebouw vanuit verschillende partijen?

De gemeente heeft geen invloed op de keuzes qua energiemaatregelen in het ontwerp, behalve als ze opdrachtgever is. Zij kan niet opleggen welke keuzes worden gemaakt door de opdrachtgever. Zij toetst alleen maar. De opdrachtgever mag zelf weten hoe hij of zij omgaat met het energievraagstuk. Beter Wonen was dus volledig autonoom in haar keuzes voor wat betreft het woongebouw. Friso was autonoom voor het zorggedeelte. Er waren wel verschillen tussen deze twee. Friso moest zich houden aan de regelgeving vanuit het zorgbureau en moest dus andere keuzes maken. In het Friso deel zit dan ook koeling en WTW. WTW was een keuze die zich snel terugverdiende, maar Beter Wonen wilde dat niet. Koeling was nodig vanuit de norm voor zorggebouwen. De maatschappelijke discussie was toen anders dan nu. Toen was energiezuinig bouwen voornamelijk nog ideologisch. Een paar corporaties waren daar heel vooruitstrevend in; Beter wonen was wat behoudender. Niet in de negatieve zin, maar Beter Wonen gaf in dit project letterlijk aan niet te willen experimenteren.

C.2. Uit documenten blijkt dat de gemeente Almelo graag een $10 \%$ lagere EPC wilde, was $u$ daar bekend mee?

In reactie dat de gemeente een EPC minus $10 \%$ wilde, geeft de geïnterviewde te kennen dat dat misschien wel is behaald, maar het behalen van een EPC van 0,9 geen issue was. Het installatietechnisch concept en het bepalen van de EPC werd door bureau Wiecherink gedaan. Hij is niet bekend met de behaalde EPC-waarde van 0,96. Het staat hem niet bij dat 
er een aanvullende ambitie was wat betreft het behalen van een betere EPC of dat later de EPC alsnog moest worden verlaagd. Wat wel aan de orde was, is dat er bij de adviseur Wiecherink, tegenwoordig Dijkoraad, de derde of vierde adviseur was in dit project. Hij kon toen niet veel invloed meer uitoefenen op het project. Het kan zijn dat zijn voorgangers dat wel konden. Hetzelfde deed zich voor bij Beter Wonen. Er kwam een andere directie en andere projectleiders bij de opdrachtgever. Document met afspraken met voorgaande projectleiders worden niet gelezen of raken zoek. Het management nam meer en meer afstand. Dat is een heel natuurlijk proces, maar dat zorgt er wel voor dat er geen continu proces is. Buiten noodzakelijkheden worden er geen aanvullende zaken, zoals het convenant, nageleefd of wordt besproken.

\section{C.3. Welke technieken zijn er voorgedragen om het energiegebruik te beperken?}

Belangrijk is dat één van de belangrijkste maatregelen om een goede EPC te halen is balansventilatie. Het toepassen van balansventilatie levert veel punten op. Beter Wonen wilde dit pertinent niet op basis van negatieve ervaringen in voorgaande projecten, zoals in Thiemsbrug. Je kunt dus wel op een EPC van 0,90 willen zitten, maar als je een relatief voordelige maatregel niet wilt nemen, dan wordt het al snel te duur en onhaalbaar. Dit kan dus ook een reden zijn geweest, waarom een EPC van 0,9 er niet is gekomen. De geïnterviewde weet eigenlijk wel zeker dat er geen energietechnische maatregelen verder zijn besproken. Gezien de omvang en complexiteit van het project heeft men qua energieinvulling een bewuste keuze gemaakt om niet aanvullende maatregelen toe te passen. Door de stelligheid van Beter Wonen was er ook weinig ruimte tot het bespreken of bediscussiëren van energietechnieken. Wanneer je dat nu zou herhalen, dan zou het wel anders verlopen. De doelgroep was overigens ouderen, wat ook een argument is om in ieder geval geen nieuwe moeilijk bedienbare technieken toe te passen. Bij Friso is dus wel een gebalanceerd ventilatiesysteem met wtw toegepast. Er is echter geen WKO, LTV of iets dergelijks gekomen. Tegenwoordig zou LTV wel standaard zijn.

Friso is een zelfstandige zorginstelling, maar het College Bouw Zorgvoorzieningen (CBZ) hanteerde overkoepelend normen voor alle Nederlandse zorggebouwen en stelde budgeten beschikbaar. De normen stelden installatietechnische eisen. Je moest naast verwarmen kunnen koelen. WTW was de vrije keuze van Friso. Friso heeft er dus wel voor gekozen om balansventilatie met WTW toe te passen, maar Beter Wonen wilde dit pertinent niet.

In het verleden is de werkwijze van het CBZ wel bediscussieert. De vergoeding voor het energiegebruik werd namelijk door het CBZ na één jaar bepaald op basis van het werkelijke energiegebruik. In het eerste jaar kon een bepaalde kwaadwillende zorginstelling bijvoorbeeld het warmtewiel stilzetten. Pas na het vaststellen van het budget werd deze dan weer aangezet. Een ander genoemd misbruik betrof het openzetten van ramen, terwijl de koelmachine maar stond te draaien. Energiebesparen in het eerste jaar leverde je namelijk lagere budgeten op. In welke zorgprojecten dergelijk misbruik precies speelde en hoe vaak dergelijk misbruik werkelijk is voorgekomen, is niet bekend.

C.4. Hoe zou $u$ het proces bij Friso willen karakteriseren qua hoe energiezuinige maatregelen zijn doorgevoerd? 
Het is een traditioneel proces geweest, waarbij met vertrouwde technieken is gewerkt. Risicomijdend heeft misschien een te negatieve lading, maar dat is niet van toepassing. Het was het gebouw niet voor en proces niet naar om ingewikkelde dingen te doen. Wanneer je als woningcorporatie er alleen voor staat zonder dat je rekening hoeft te houden met anderen, dan waren er meer mogelijkheden geweest.

C.5. De $q_{; k a r}$ lijkt met $0,2 \mathrm{dm}^{3} / \mathrm{s}$ per $\mathrm{m}^{2}$ eveneens een beetje aan de lage kant in de EPberekening, hoe is deze bereikt?

Alle kozijnen waren in aluminium uitgevoerd, wat leidt tot extra eisen voor dichtheid. Er zijn daarom ook schuifdeuren en ramen toegepast en niet draaiende delen. De aannemer was alleen op een paar punten afgeweken van de detaillering, dus hier spelen nog een paar punten om op te lossen. Het betreft de aansluiting van de kozijnen met het bouwkundige deel. Bij een hoog gebouw moet je in ieder geval opletten qua luchtdichtheid, anders waai je weg.

\section{Rol aspect energie in projecten in het algemeen}

D.1. Welke ervaringen heeft $u$ op het gebied van ambities op het gebied van energiezuinigheid in bouwprojecten?

In de tijd dat Friso werd gebouwd, speelde een ander vooruitstrevender project in NoordHolland. In dat woongebouw-project werden geïsoleerde sandwich vloeren met koeling in het plafond en LTV-verwarming in de vloeren toegepast. Het geheel was gekoppeld aan WKO. Het Road Energy System (RES) van Ooms werd daarbij ook toegepast. In het asfalt van de weg om het gebouw heen lag dus een buizensysteem om warmte in de zomer en koude in de winter aan te trekken. Het was experimenteel en voor de geïnterviewde een eenmalige ervaring. ledereen wilde er toen mee scoren en de krant halen.

Het scoren is in de loop der tijd vanwege het geld wat minder geworden, maar de maatschappelijke discussie heeft er wel toe geleid dat men steeds verder energiezuinig wil en moet bouwen. De technieken worden overigens steeds beter voor woningbouw en utiliteitsbouw. Om te komen tot energieneutraal en energiezuinig is voor utiliteitsbouw wel eens makkelijker, want je hebt eigenlijk een beetje omvang nodig. Passieve woningen bestaan wel met een dikke en dichte schil, maar het opwekken van energie is voor een groter gebouw vaak wat makkelijker.

De geïnterviewde haalt hierbij het voorbeeld van een brede school op Ameland aan. Deze moet ook passief en energieneutraal worden samen met de gymzaal ernaast. Er wordt hierbij biomassa gebruikt voor verwarming en een flink oppervlak aan pv-panelen voor elektrische energie. Voor ook de brede school is er een berekening gemaakt of de maatregelen wel binnen circa zes jaar worden terugverdiend. Een houtverbrandingsinstallatie wordt gebruikt, waarbij al het afvalhout van Ameland wordt verzameld. Het probleem hierbij is wel dat men bij een ander project niet meer een beroep kan doen op hout, want al het hout is al min of meer geclaimd. Het maken van verdragen of convenanten met dergelijke duurzame ambities, als $\mathrm{CO}_{2}$ neutraal of toepassen van een lagere EPC, kan het voor andere personen lastig maken een project (financieel) haalbaar te maken. Alle mooie terugverdientijden ten spijt, als de investering niet kan worden betaald dan houdt het op. De ontwikkeling van energiezuinige/duurzame projecten wordt vervuild door de 
huidige marktomstandigheden. $\mathrm{Er}$ is geen geld beschikbaar bij gemeenten noch bij woningcorporaties voor energietechnieken.

D.2. Welke energieconcepten, -technieken en/of-maatregelen kunnen het beste worden toegepast in de Nederlandse woningbouw?

Om toch tot energiebesparing te komen moet men niet technieken toepassen, maar gebruik maken van het gebouw zelf; de eerste stap van de Trias Energetica gebruiken. Je moet dus kijken naar het gebouw, situering, materialen, isolatie en kierdichting. Je hebt dan minder brandstof nodig. Je moet je afvragen of je überhaupt wel moet koelen. Lage temperatuur verwarming raad het architectenbureau eigenlijk altijd aan, zodat je voorbereid bent op de toekomst en het systeem altijd nog op WKO kan aansluiten. De grootste kans bestaat uit het maken van een goede gevel. Mensen hebben het niet door, maar zet je kieren goed dicht en reduceer je warmteverliezen enorm. De markt speelt hier goed op in en biedt steeds betere producten, ook in hout. Loop ook de lichtvoorziening goed door, zodat het energiegebruik allemaal wat minder wordt. Reduceer hiermee je energievraag, of je die nu zelf een invulling geeft met energiepanelen of via het netwerk vraagt.

D.3. Welke barrières bestaan er volgens $u$ om energietechnieken en -maatregelen toe te passen?

Er zijn geen echte barrières meer. De markt was een flinke barrière door forse meerprijzen te rekenen voor voorzieningen, waaronder energiezuinige maatregelen. Dit is echter inmiddels wel anders, want de meerprijzen zijn flink gedaald. Wanneer je de EPC meer steeds flink aanscherpt, komt de markt ook wel met oplossingen en producten. Bij de bestaande woningbouwvoorraad ligt nog het grootste probleem. Het extra eisen stellen aan het verbeteren van de bestaande voorraad is echter in de huidige markt niet wenselijk. Er is wel discussie over het verplicht stellen van verbeteringen, maar er is simpelweg geen geld voor. In sommige bestaande gevallen zit je ook technisch gezien niet te wachten op de verplichting de energieprestatie te moeten verbeteren. Bijvoorbeeld 150 jaar oude woningen met een houtenconstructie. $\mathrm{Er}$ is wel voor de echte oude woningen van voor de oliecrisis een kans om veel energie te besparen. Dit zit bij de meeste bedrijven, kantorenbouw en maatschappelijk wel goed tussen de oren. Het besef is er wel, die slag is al wel gewonnen.

Op de vraag of men weet waar men om vraagt in het geval van energieneutraal, antwoordt de geïnterviewde dat bij professionele opdrachtgevers, zoals corporaties, men wel weet over het algemeen waarover het gaat en kan men de gevolgen (qua prijs) wel overzien. Men maakt daar bewuste keuzes. Je moet het wel per project doorrekenen. Bij niet-professionele opdrachtgevers is er minder kennis en worden de gevolgen van hun ambities of wensen onderschat. Ze schrikken dan als ze de berekeningen onder ogen zien. Je moet als architect de opdrachtgever dus goed voorlichting geven zodat ze weten wat het inhoudt. De kosten gaan altijd voor de baten uit, wat betreft hoge ambities met betrekking tot energiezuinigheid, of neutraliteit. Je bent als architect adviseur. Je wordt ingehuurd als kenner en als je het zelf niet weet als architect, schakel je de adviseur techniek of je huurt een adviseur in. Je moet de opdrachtgever dus goed kunnen adviseren in een zo'n vroeg mogelijk stadium; eigenlijk al voordat je een plan maakt. Je moet zeker weten dat ze 
begrijpen waar het over gaat, dat er beperkingen zijn en dat het geld kost. Men is wel bezig modellen te ontwikkelen in het kader van BIM. Over een tijdje zal men wel zover zijn dat daar ook virtueel het energiegebruik aan kan hangen. Maar eigenlijk wil je nog liever dat je het al aan het PvE of een vormfactor kan ophangen. Hier wordt aan gewerkt.

\section{D.4. Wat zou de toepassing van energietechnieken en -maatregelen kunnen beperken?}

Er zijn eigenlijk geen barrières, maar heel banaal gesproken is geld de grootste barrière. Om de energiemaatregelen toch toe te passen, zijn er twee overwegingen. Vanuit ideologie kan de toepassing van energiemaatregelen wel worden gevraagd, vooral in de politiek, maar daarnaast ook geld. Geld is de grootste belemmering en de motivator om energiezuinig te gaan werken. Technisch gezien kan alles of vinden ze het wel uit, als er markt voor is. In het buitenland lijken ze wat dat betreft verder te zijn. In de Scandinavische landen bijvoorbeeld doordat het daar kouder is. Daar komen goede oplossingen vandaan. In verband met het klimaat hoef je vanuit het zuiden geen technieken te verwachten. In Amerika hadden ze al windmolenparken, toen wij nog maar de Kinderdijk hadden, en daar draait het juist om geld.

\section{D.5. Welke energietechnieken of -maatregelen hebben uw voorkeur?}

De visie van het architectenbureau Grunstra is dat iedere installatie die je toevoegt de meter gaat lopen en energie gebruikt, dus die willen ze pas als laatste er aan toe voegen. De eerste stap is het gebouw en isolatie en daarna komt het opwekken. De ambitie op het gebied van energie moet je dus niet alleen met installaties willen waar maken. Er zijn daarnaast diverse duurzame technieken voor het opwekken van energie beschikbaar, zoals windmolens, waar de discussie nog wordt gevoerd in hoeverre de milieubelasting van het product opweegt tegen zijn bijdrage aan de reductie van uitstoot. Daar zijn de meningen over verdeeld en dat zijn discussies die snel verharden. Hij ziet in dat geval weinig verschil tussen een woningbouw of utilitair project, maar bij woningen is de discussie emotioneler dan bij utiliteitsbouw. Een woning staat immers dichter bij de persoon en treft iemands eigen portemonnee, wat bij utiliteitsbouw toch anders.

\section{D.6. Wanneer worden beslissingen omtrent energietechnieken genomen?}

In de pre-project fase moet je al weten wat je wilt. Je moet als opdrachtgever eigenlijk energie al onderdeel maken van je ambitie. Je moet immers weten waar je naar streeft. Om een integraal project af te kunnen leveren, moet je de definities kennen en weten wat je wilt. Hoe flexibel moet een gebouw bijvoorbeeld zijn? Wil je een steenachtig monoliet gebouw? Een basisschool en een zorggebouw moeten flexibel zijn, terwijl voor betonactivering heeft een massief gebouw de voorkeur. Je maakt dus eigenlijk al keuzes, waardoor bepaalde opties worden weggestreept. Verder dan het VO-niveau moet je niet gaan om beslissingen te nemen. Met het SO moeten de keuzes voor energiemaatregelen eigenlijk al vast liggen, dus met "feasibility" en "conception of need". De locatie en oriëntering is immers al bepaald.

Het kiezen voor maatregelen loopt wel in cirkels mee, want je maakt keuzes over producten en maatregelen die al bekend zijn. Met de uitvoering kun je er dan tegen aanlopen dat er nieuwere technieken of producten zijn, waardoor je soms een stapje terug doet en uitgangspunten gaat herzien. Je moet het dus wel als een dynamisch proces. In het geval van een school in Groningen kwam er een luchtwarmtepomp in combinatie met lucht als 
medium in, waarbij dikke buizen werden gebruikt. Dit was in een laat stadium van het ontwerpproces pas beschikbaar. Het hele ontwerp moest worden verbouwd om alle dikke leidingen ook in de school kwijt te kunnen. Het was dus eigenlijk wel te laat, waardoor het ontwerp moest worden "verbouwd". Aan het verbouwen van ontwerpen hebben architecten een hekel. Dit komt helaas vaker voor met installatie adviseurs die te laat informatie aanleveren. Dit soort technieken wil je direct vanaf het begin meenemen, met name wanneer je een $4.000 \mathrm{~m}^{2}$ aan school hebt wat vraagt om heel veel lucht. De markt is nu eenmaal in ontwikkeling.

\section{E. Stakeholders en actoren}

\section{E.1. Wat was de rol van Wiecherink Dijkoraad in het project Friso?}

Het onderdeel installaties en het maken van EP-berekeningen heeft Grunstra in het verleden zelf gedaan, maar is te specialistisch geworden. Zelf waren ze in het project als klassieke architect betrokken, de hele bouwopgave vanaf PvE met voorbereiding, begeleiding en toezicht gedaan. Grunstra heeft zich gericht op ontwerp en bouwtechniek. De installatietechniek is uitbesteedt door Wiecherink gedaan onder een eigen contract met Beter Wonen als nevenaannemer; geen onderaannemer. De constructeur was ook een nevenaannemer. Beiden hadden hun eigen verantwoordelijkheid. Wiecherink had de programmatuur in huis en wist zelf het beste welke installaties zouden worden toegepast. Wanneer het project in total engineering zou zijn uitgevoerd, dan had Grunstra de constructeur en installatieadviseur als onderaannemer ingeschakeld. In het bouwteam vond een groot deel van de communicatie plaats, maar onderling was er ook contact. In het algemeen contracteren veel woningcorporaties direct de adviserende partijen. Dit project kende wel veel versnippering doordat op bepaalde posities andere personen elkaar opvolgden. Dat heeft het een en ander wel vertraagd.

\section{E.2. Wat waren de rollen van Kemkens en De Groot in het project Friso?}

Dit waren nevenaannemers op het gebied van W- en E-installaties met elk hun separaat PvE en bestek. Dit is inherent aan het Europees aanbesteden, waarbij de percelen te groot zijn om deze onderwerpen onder één bestek voor de aannemer en dus die aanbesteding te scharen. De bouwkundige aannemer had ook de coördinatietaak over de W- en Einstallateurs.

E.3. Welke partij zou om energietechnieken of maatregelen moeten vragen of wie zou ze moeten inbrengen?

ledereen speelt er een rol in. In een klassiek bouwproces komt de aannemer pas laat binnen, maar in een DBMO proces komen ze veel eerder en deze processen worden steeds populairder. De aannemer zit dan vroeg aan tafel en wil dan weten hoe het gebouw ontwikkeld wordt. Hij zal dan technieken aanreiken die hem helpen zijn risico's te nemen. De opdrachtgever moet wel een ambitie hebben. Die visie of ambitie ligt vast in de stukken en de marktpartijen kunnen daar hun invulling aangeven. ledereen wil het nieuwste, goedkoopste en zuinigste. Het is net als het kopen van een flatscreen, eigenlijk wil je hem een dag later pas kopen, want dan is die nog nieuwer. Bij bouwprojecten is er ook steeds iets nieuws en iemand met ambitie wil dat hebben. Het moet dan wel goed hanteerbaar zijn en niet ingewikkeld. Een product werkt vaak genoeg niet, omdat men het niet kan bedienen 
of dat het niet goed wordt aangelegd. Wanneer het duur is, niet zuinig is of niet bruikbaar is, dan gebruik je het niet. Als je dus iets wilt toepassen of voorstellen aan de opdrachtgever, dan moet je dus als architect best ervan overtuigd zijn dat het kan werken.

\section{E.4. Hoe leg je een energietechniek of -maatregel voor aan de opdrachtgever?}

Op de eerste plaats geeft de opdrachtgever zelf al aan wat hij weet, kent of wilt. Meestal heeft hij al een vraag in een bepaalde richting. Niet alles hoeft dus vanuit de architect te komen. In het geval van gemeente Ameland wist men dat er een ambitie ligt om in 2020 energieneutraal te gaan. Dat soort uitgangspunten zijn er eigenlijk altijd wel. De opdrachtgever weet daarmee dan nog niet de specifieke techniek of maatregel. Grunstra is wat dat betreft een generalist. Wanneer de opdrachtgever specifiek zich zou willen richten op energiezuinigheid of bepaalde technieken, dan zal hij zich ook wenden dat een bepaalde selectie architecten om daar kennis te halen. Hij komt in dat geval dan regelmatig Kristinsson tegen, maar 90 tot $95 \%$ van de bureaus zal een meer generale aanpak gebruiken. Er zijn een paar bureaus die een hele specifieke visie aanhouden, maar Grunstra richt zich daar niet op.

De geïnterviewde vermeldt als voorbeeld van hoe duurzaamheid en algemene praktijk som lijken te botsen. In het programma GPR Gebouw wordt bijvoorbeeld baksteen heel slecht beoordeeld, omdat we het niet zouden kunnen recyclen. Terwijl loofhout heel goed wordt gewaardeerd, maar je dat niet aan je gevel wilt hebben.

\section{E.5. Moet de overheid haar rol nog herzien?}

Naar de mening van de geïnterviewde doet de overheid al veel. Ze stelt normen vast en scherpen deze aan. Daar ligt wel een sterke ambitie, maar het heeft geen zin om deze verder aan te scherpen als ze niet te realiseren en te handhaven zijn. Heel geleidelijk worden de normen strenger en dat doet ze goed. Handhaven betekent ook dat mensen moeten beseffen wat een getalletje als 0,6 betekent. De handhaving vanuit het ambtelijk apparaat is beperkt. Je moet dus realistisch zijn over wat haalbaar zijn, maar de overheid moet wel prikkels geven. Een prikkel kan ook financieel zijn, zoals een subsidie.

\section{Interview biomass heating advisor Rombout Verhulstlaan}

This section provides the report of the interview with a manager of DWA HVAC systems and energy consultancy. Table C.3 provides some general information on the interview and the respondent.

Table C.3: General information on the interview and respondent $D$.

\begin{tabular}{|c|c|c|c|}
\hline Function & \multicolumn{3}{|c|}{ Manager energy strategies and concept development } \\
\hline Organisation & \multicolumn{3}{|l|}{ DWA Installatie- en energieadvies } \\
\hline Department & \multicolumn{3}{|l|}{-} \\
\hline Experience & \multicolumn{3}{|l|}{ Approximately 17.5 years } \\
\hline Subject interview & \multicolumn{3}{|c|}{ Role in building processes, specifically Jan Vermeerstraat / Rombout Verhulstlaan } \\
\hline Start time: & 09:00 & End time: & 11:00 \\
\hline $\begin{array}{l}\text { Date of interview } \\
\text { and feedback }\end{array}$ & \multicolumn{3}{|l|}{$\begin{array}{l}\text { Date interview: June } 29^{\text {th }} 2012 \\
\text { Date feedback: July } 12^{\text {th }} 2012\end{array}$} \\
\hline Location & \multicolumn{3}{|l|}{ Voorn 47 - Borne } \\
\hline
\end{tabular}




\section{A. Kennismaking}

Ter inleiding legt de geïnterviewde uit, welke werkvelden DWA bedient. DWA heeft vier vestigingen, namelijk in Bodegraven, Ede, Rijssen en Amsterdam. DWA geeft installatie- en energieadvies waarbij in een project wordt bekeken wat technisch, organisatorisch en financieel kan. DWA Rijssen, waar hij manager is, houdt zich voor een belangrijk deel bezig met steunpunten duurzame energie bij provincies en waarbij ook gemeenten zijn aangehaakt. Dit betekent dat ondermeer $\mathrm{CO}_{2}$ monitoring wordt uitgevoerd bij de provincies. Er wordt een nulmeting uitgevoerd en regelmatig wordt berekend hoe de $\mathrm{CO}_{2}$ uitstoot zich ontwikkelt, met een enorme berg data als gevolg.

Een aantal medewerkers houdt zich bezig met financieringsvraagstukken. Hiervoor zijn er ingangen bij verschillende (duurzame) banken. Een werkveld daarbinnen vormen de Energy Service Companies (ESCo's), waarbij de financiering van energie en de energiemaatregelen wordt overgenomen. Als voorbeeld; er kwam een vraag vanuit de gemeente Amsterdam, die graag scholen wil met een goed binnenklimaat en die energieneutraal zijn. Dit mag echter niet meer kosten. Kortom, een leuke uitdaging. Hiervoor is een ESCo bedacht. De financiering hiervan moet van Triodosbank komen. In eerste instantie was de rente op hun lening veel te hoog. De bank wil de ESCo met een lagere rente financieren, wanneer onzekerheden worden gereduceerd. De onzekerheid kan in het geval van een basisschool bestaan vanuit het aantal leerlingen. Het aantal leerlingen bepaalt hoeveel geld naar de ESCo kan vloeien. Gemeenten wordt daarom gevraagd garant te staan voor het aantal leerlingen. In een dergelijke ESCo kunnen vervolgens ouders participeren, de gemeente, maar ook een installatie- of bouwbedrijf die het een leuk en interessant initiatief vindt. De Triodosbank zal het restant financieren. De businesscase toont nu een rendement van ongeveer $5 \%$ voor de deelnemers, wat je bij een bank op dit moment niet krijgt.

Een andere club binnen DWA houdt zich bezig met wat bedacht is aan de voorkant qua haalbaarheid en installaties, of dat ook daadwerkelijk wordt uitgevoerd en behaald. Bestekken en tekeningen worden opgesteld, aanbesteding wordt begeleidt en resultaten worden gecontroleerd. De huidige projecten die doorgaan, dat zijn projecten met een hoge ambitie (bijvoorbeeld het niveau BREEAM Excellent). De projecten waar integrale duurzaamheid in zit, die gaan door. Een mooi voorbeeld is The Bell in Amsterdam (dit was een magazijn uit ca. 1850 dat omgebouwd is tot kantoorgebouw). Na de clash van de kantoorwereld is dit project in Amsterdam toch door gegaan. Het pand moest iets bijzonders worden; goede uitstraling, flexibel, goede ICT-voorzieningen. De verhuurder van dit pand hanteert inmiddels een opzegtermijn van één maand in plaats van een, twee, drie of vijf jaar. Hij kan dit doen omdat de belangstellenden in de rij staan. De korte opzegtermijn in combinatie met de uitstraling van het pand, het hoge niveau van ICT-voorzieningen en het goede binnenklimaat zorgt ervoor dat de belangstellende in de rij staan.

Als laatste, is er een club binnen DWA die zich bezig houdt met prestatieborging. Aan de voorkant van een bouwtraject wordt de prestatie gedefinieerd en zorg dat je ze realiseert. $\mathrm{Na}$ toepassing wordt getoetst of de beoogde prestatie wordt behaald. Wat is er eventueel nog nodig om ze alsnog te halen of, beter nog, te overtreffen? Dit betreft energieprestatie qua energiegebruik, maar ook qua binnenklimaat bijvoorbeeld. De vraagpatronen kunnen 
immers veranderen of het gebruik veranderd. Door even in de regeltechniek te duiken, kan soms tot $€ 30.000$ aan energie worden bespaard. DWA biedt qua prestatieborging in voorkomende projecten een bonus-malus regeling aan; wordt de prestatie niet gehaald dan is er een malus voor DWA (en/of de installateur), maar wordt de prestatie wel gehaald dan ligt er ook een bonus klaar. Installatiebedrijven zijn dan meer bereid mee te denken, als ze een bonus tegemoet kunnen zien. In het verleden werd een brede instelling gebruikt qua klimaatinstallaties, want dan waren de gebruikers qua temperatuur het snelst tevreden en dan liepen de installateurs minder risico terug te hoeven komen. In deze gevallen is het energiegebruik dan wel hoger, maar dan maakt voor de installatiebedrijven niet uit. Wanneer je een bonus geeft voor laag energiegebruik, kun je een dergelijke insteek de kop in drukken.

\section{A. Involvement respondent in the project}

\section{A.1. Welke rol vervulde DWA in het renovatieproject van Beter Wonen?}

DWA is bij Beter Wonen in beeld gekomen voor de renovatie Jan Vermeerstraat, en het beoogde directe vervolgtraject Rombout Verhulstlaan, door een project bij de woningstichting Patromonium in Veenendaal. Beter Wonen had een artikel gelezen over de toepassing van een houtgestookte ketel in de Oranjetoren, welke (volgens de website van die corporatie) in september 2009 werd opgeleverd (toevoeging interviewer). Dit leek de woningstichting Beter Wonen ook wel wat, ze wilde weten wat het opleverde en of ze dat ook konden toepassen. Op dat moment had de Provincie Overijssel nog een potje voor haalbaarheidsonderzoeken voor biomassa en duurzame energiesystemen. De corporatie wilde, toen er werkelijk geld beschikbaar kwam vanuit de provincie, wel een haalbaarheidsonderzoek laten uitvoeren naar de mogelijkheid om een houtgestookte ketel toe te passen. Er speelde al wel een beetje een discussie of er moest gaan worden gerenoveerd of toch slopen en vervangende nieuwbouw plegen, terwijl een jaar daarvoor alleen renovatie als oplossing in beeld was. Maar mocht het met een duurzaam energiesysteem toch interessant worden, dan kon misschien alsnog renoveren aantrekkelijk zijn.

\section{A.2. Wie was de opdrachtgever voor DWA?}

De opdrachtgever van het haalbaarheidsonderzoek was AWS Beter Wonen. Voor de subsidieregeling waren er wel eisen vanuit de provincie, maar het was geen opdrachtgever. Het haalbaarheidsonderzoek moest over een duurzame techniek gaan, welke door de provincie werd gepromoot en er moesten meerdere varianten zijn ter vergelijking.

\section{A.3. Welke taak of taken waren er weggelegd voor DWA?}

De aanleiding was de bestudering van de haalbaarheid van een houtgestookte ketel. Maar deze ketel alleen bekijken, dat was weinig zinvol. Je moet een dergelijke installatie in zijn context kunnen plaatsen, daarom zijn er een aantal varianten opgesteld, die terug zijn te vinden in het rapport.

De opdracht was concreet het verkennen van mogelijkheden om bestaande flat- of appartement-complexen te verduurzamen naar een label B of liever nog A brengen met duurzame energietechnieken. Wat kan technisch? Hoe ziet het leidingtracé er uit? Wat betekent het economisch en qua organisatie? Hoe krijg je dit verhaal gefinancierd? 


\section{B. Decision processes on energy concepts, techniques and measures in the project}

B.1. Waarom werden het energielabel en de EPC gebruikt in de afweging in het haalbaarheidsonderzoek?

Het energielabel is gebruikt omdat dat het bekende verhaal was wat betreft woningbouw. De EPC werd gebruikt omdat de discussie van sloop en nieuwbouw boven kwam, maar ook om de discussie te voeren dat een lage EPC niet zou kunnen worden behaald in een renovatieproject. Bij Beter Wonen leek het beeld te bestaan, dat je nog zo goed je best kon doen, maar nieuwbouw wordt het toch niet qua energieprestatie. Door de EPC te berekenen kon DWA gemakkelijk aantonen dat dat wel haalbaar is en kon een welles/nietes discussie worden voorkomen. Je weet vervolgens dat een A label dan ook mogelijk moet kunnen zijn.

\section{B.2. Wie stelde bepaalde energietechnieken of -maatregelen voor?}

De rol van DWA was in principe specifiek gericht op de houtgestookte verwarmingsinstallatie. De rol van Matrix I.A. lijkt, aldus de geïnterviewde, uitgebreider te zijn. In die zin dat hem het leek dat ze van een vroeger tot een later moment bij het project waren betrokken dan DWA. De toepassing van een Daalderop Combinair, welke in één van de EPC berekeningen wordt genoemd, komt vermoedelijk uit de koker van Matrix I.A., want deze techniek zou DWA in de tijd niet adviseren gezien de minder positieve ervaringen met deze techniek in projecten.

In de beleving van de geïnterviewde was projectmanager $\mathrm{K}$ van Beter Wonen bereid tot toepassing van energiemaatregelen. De architect was gericht op esthetica en heeft zijn inziens niet specifieke maatregelen aangedragen. De betreffende dame vanuit het architectenbureau heeft wel actief meegedacht hoe bijvoorbeeld ruimte te bieden aan de verschillende installaties. Hiervoor zijn de geïnterviewde en zij op locatie ook gaan kijken.

\section{Evaluation of the project by the respondent}

D.1. Hoe zou $u$ het proces beschrijven om te komen tot de beslissing bepaalde energietechnieken en-maatregelen wel of juist niet te implementeren?

Het proces met betrekking tot de mogelijkheid een houtgestookte installatie toe te passen, is deels vastgelegd in het onderzoeksrapport "Energie-efficiënte renovatie van flats Jan Vermeerstraat te Almelo". Uit dit rapport is het volgende op te maken qua beantwoording van deze vraag: "Op 28 november 2007 heeft een overleg plaatsgevonden tussen AWS Beter Wonen, de Gemeente Almelo, en DWA. In dit overleg werden de energiescans van drie grondig te renoveren flats aan de Jan Vermeerstraat besproken aan de hand van een powerpointpresentatie. In dit overleg werden tevens de nieuwe energetische woningconcepten gepresenteerd voor de te renoveren objecten. Het voornaamste uitgangspunt was om te voldoen aan de eisen van het Bouwbesluit, dus een EPC $\leq 0,8$ (energielabel A). Daarnaast werd er aangestuurd op een goed binnenklimaat op basis van mechanische ventilatie, gering (contact)geluid door middel van geluiddemping op vloeren en er moesten individuele en collectieve concepten worden onderscheiden. In totaal zijn er zeven individuele concepten voorgelegd, namelijk: 
1. Een basisvariant met $\mathrm{Rc}=3,5 \mathrm{~m}^{2} \mathrm{~K} / \mathrm{W}$ en geïsoleerde buitendeuren, dubbele kierdichting, HR++ glas, HR 107-combiketel, radiatoren of eventueel vloerverwarming, een gebalanceerd ventilatiesysteem met $95 \%$ warmteterugwinning met by pass en zonwering;

2. Variant comfort met $\mathrm{Rc}=3,5 \mathrm{~m}^{2} \mathrm{~K} / \mathrm{W}$ en geïsoleerde buitendeuren, $\mathrm{HR}++$ glas, $\mathrm{HR}$ 107-combiketel, vloerverwarming met geluiddempende onderlaag, een gebalanceerd ventilatiesysteem met $95 \%$ warmteterugwinning met by pass en zonwering;

3. Bouwkundig minimaal met $\mathrm{Rc}=2,5 \mathrm{~m}^{2} \mathrm{~K} / \mathrm{W}$ en geïsoleerde buitendeuren, dubbele kierdichting, HR++ glas, HR 107-combiketel, radiatoren, een gebalanceerd ventilatiesysteem met $95 \%$ warmteterugwinning met by pass en een warmtewisselaar voor douchewater;

4. Duurzaam met $\mathrm{Rc}=3,5 \mathrm{~m}^{2} \mathrm{~K} / \mathrm{W}$ en geïsoleerde buitendeuren, dubbele kierdichting, HR++ glas, HR 107-combiketel met zonneboiler, radiatoren, een natuurlijke toevoer en mechanische afvoer qua ventilatielucht en een warmtewisselaar voor douchewater;

5. Duurzaam ventilatie met $R c=3,5 \mathrm{~m}^{2} \mathrm{~K} / \mathrm{W}$ en geïsoleerde buitendeuren, enkele kierdichting, HR++ glas, HR 107-combiketel met zonneboiler, radiatoren, zelfregelende ventilatieroosters en een warmtewisselaar voor douchewater;

6. Duurzaam tapwater met $\mathrm{Rc}=3,5 \mathrm{~m}^{2} \mathrm{~K} / \mathrm{W}$ en geïsoleerde buitendeuren, enkele kierdichting, $\mathrm{HR++}$ glas, warmtepompboiler met een COP van 2.2, radiatoren, een natuurlijke toevoer en mechanische afvoer qua ventilatielucht, $10 \mathrm{~m}^{2}$ aan PVpanelen, en zonwering;

7. Variant zeer comfortabel met $\mathrm{Rc}=3,5 \mathrm{~m}^{2} \mathrm{~K} / \mathrm{W}$ en geïsoleerde buitendeuren, dubbele kierdichting, HR++ glas, combiwarmtepomp met een COP van 4.0 voor ruimteverwarming en -koeling en een COP van 2.0 voor tapwater, vloerverwarming en een gebalanceerd ventilatiesysteem met $95 \%$ warmteterugwinning met by pass.

In reactie op de individuele concepten heeft Beter Wonen aangegeven dat 1) investeren in comfort te kostbaar is. Dit kan niet in de huur worden verrekend. Bewoners willen daarnaast 2) geen lawaaierige ventilatiesystemen, die ook nog onderhoud vergen. Bij vloerverwarming werkt natuurlijke ventilatie echter niet goed. 3) Een lage EPC is acceptabel. 4) De etages van de flats zijn laag, dus er kan geen energievoorziening in het plafond of op de vloer worden aangebracht. 5) Geluiddemping is wel wenselijk, welke dan ook een wens is van de architect.

AWS Beter Wonen vraagt in dit overleg om een variant met een EPC van 1,0 . Het betreft immers renovatie, dus ze hoeven niet per se aan de EPC van 0,8 te voldoen. Er zijn door DWA drie collectieve concepten uitgewerkt, te weten:

1. Variant comfortabel met $\mathrm{Rc}=3,5 \mathrm{~m}^{2} \mathrm{~K} / \mathrm{W}$ en geïsoleerde buitendeuren, dubbele kierdichting, $\mathrm{HR++}$ glas, individuele combiwarmtepompen aangesloten op een collectieve aquifer voor verwarming en koeling, vloerverwarming en een gebalanceerd ventilatiesysteem met $95 \%$ warmteterugwinning met by pass; 
2. Variant collectieve warmtepomp met $\mathrm{Rc}=3,5 \mathrm{~m}^{2} \mathrm{~K} / \mathrm{W}$ en geïsoleerde buitendeuren, dubbele kierdichting, $\mathrm{HR}++$ glas, collectieve warmtepomp aangesloten op collectieve aquifer voor verwarming en koeling, tapwater op basis van warmtepomp en centrale ketel, vloerverwarming, en een gebalanceerd ventilatiesysteem met $95 \%$ warmteterugwinning met by pass;

3. Variant houtketel met $\mathrm{Rc}=3,5 \mathrm{~m}^{2} \mathrm{~K} / \mathrm{W}$ en geïsoleerde buitendeuren, dubbele kierdichting, $\mathrm{HR}++$ glas, collectieve houtketel op basis van pellets of snippers voor ruimteverwarming en tapwater, radiatoren en een gebalanceerd ventilatiesysteem met $95 \%$ warmteterugwinning met by pass.

De visie van de woningcorporatie is dat een collectief systeem als nadeel heeft dat je 1) niet individueel kan kiezen. DWA stelt dat dat geen probleem is, want collectieve systemen zijn al vele malen toegepast in Nederland. 2) Het "NMDA" beginsel voorkomt financiële voordelen voor de gebruikers en werkt een financieel voordeel voor de leverancier in de hand bij de in het algemeen stijgende energieprijzen. 3) Een EPC $<0,8$ is helemaal niet nodig voor Beter Wonen. 4) De nadelen onder andere in de onderhoudsfase van verschillende systemen moet beter in beeld worden gebracht. 5) Het moet duidelijk worden na hoeveel jaar de systemen moeten worden vervangen. Tot slot moet er niet teveel worden geexperimenteerd met warmtepompen, want de bouwvergunning moet in februari 2008 klaar zijn.

Naar aanleiding van deze bespreking op 28 november is toen besloten de variant EPC 1,0, variant EPC 0,8 en de houtketel overeind te houden. Deze varianten zijn door AWS Beter Wonen en DWA op 20 december 2007 in meer detail besproken, waarbij de douchewarmtewisselaar als maatregel afviel vanwege het verwachtte bijkomende onderhoud. Van deze bijeenkomst is echter geen verslag beschikbaar. Om toch een EPC van 0,8 te halen is HR+++ glas als alternatief voorgedragen. Deze drie varianten of concepten zijn vervolgens financieel doorgerekend."

De geïnterviewde geeft aan dat bij de bijeenkomsten express is geprobeerd meerdere medewerkers van AWS Beter Wonen bij elkaar te krijgen. Het overleg moest niet alleen met de projectleider van de afdeling projectontwikkeling of projecten plaatsvinden, maar ook met iemand van beheer en bij voorkeur ook iemand van de directie erbij. DWA heeft namelijk de ervaring dat je anders wel de projectleider kunt overtuigen van het nut van een bepaalde maatregelen, maar dat deze ene projectleider vervolgens dit niet intern bij zijn collega's of meerdere volledig weet over te brengen danwel te verdedigen. Hierdoor merkt DWA dat de projectleider vaak wel wil, maar dat de afdeling beheer of de directie ze intern een halt toeroept of terugfluit. Door de hele drie eenheid ontwikkeling - beheer management bij elkaar te zetten, kun je ze allemaal tegelijk uitleg geven en de neuzen dezelfde kant op krijgen.

Argumenten tegen bepaalde energiemaatregelen die voortkomen uit negatieve ervaringen, eigen ervaringen danwel ervaringen vernomen via collega corporaties, zijn soms erg hardnekkig en moet je dus proberen weg te nemen. Woningcorporaties kijken graag naar elkaar. Wanneer iemand negatieve ervaringen heeft met of een negatief beeld heeft van warmtepompen, moet zo'n medewerker en zijn collega's op excursie naar een 
collegawoningcorporatie waar ze positieve ervaringen hebben. Om deze reden organiseert DWA ook af en toe een dergelijke gerichte excursie of werkbezoek.

Hij geeft aan dat het hele bouwproces op duurzaamheid danwel een efficiënt energiegebruik ingericht moet zijn. Je kunt in dergelijke gevallen niet op de traditionele manier tegen de laagste prijs aanbesteden. Alle partijen moeten beseffen wat de consequenties zijn als doelen niet worden gehaald. Anderzijds moet er voor iedereen ook iets te halen zijn of een gerichte bonus zijn voor wanneer de prestaties worden gehaald of in positieve zin worden overschreden.

Terugkijkend op het project, vraagt de geïnterviewde zich hardop af of er niet intern toentertijd bij de woningcorporatie al een beslissing was genomen, dat sloop zou gaan plaatsvinden in plaats van renovatie. Het haalbaarheidsonderzoek werd misschien achter de schermen (misschien dus zelfs achter de rug van de projectleider om) ingezet, als een manier om extra argumenten te krijgen om de sloop en daarna een "echt" duurzame nieuwbouw in plaats van renovatie te verantwoorden.

\section{E. Energy techniques and measures in general}

E.3. Welke argumenten worden er ter tafel gebracht in het besluitvormingsproces omtrent de implementatie van energietechnieken en -maatregelen?

Projectontwikkelaars willen zo min mogelijk gezeur en daarmee dus zo min mogelijk risico's, aldus de geïnterviewde. Het moet dus betrouwbare techniek zijn. De rol van geld is groot; een terugverdientijd van vijf á zes jaar gaat wel door, maar tien jaar of langer is lastig er doorheen te krijgen. Wat de maatregel precies betekent voor de huurder is van ondergeschikt belang, want dat kan maar minimaal worden terugverdiend.

E.3. Welke barrieres bestaan er, uw inziens, om energietechnieken en-maatregelen toe te passen?

Hij stelt zonder enige twijfel dat kennis de meest voorname barrière is. Niet alleen kennis in de zin van, reeds genoemde, vernomen negatieve ervaringen die moeilijk te weren zijn, maar ook kennis bij de aannemers. Een voorbeeld wordt aangehaald hoe een aannemer zelf foutief een vloerverwarmingssysteem had gedimensioneerd, wat bij een toevallige controle door een installateur gelukkig werd ontdekt. Men begeeft zich zonder de nodige kennis op elkaars terrein, terwijl de partijen eerst beter van elkaar moeten weten wat ze doen en waarom ze het zo doen. Op deze wijze sneuvelen projecten.

E.4. Welke motivatie bestaat er, uw inziens, om energietechnieken en -maatregelen toe te passen?

Bij een paar partijen bestaat er een oprecht gevoel van duurzaamheid, welke als drive geldt. Argumenten zijn verder de PR-waarde en ook de financiële voordelen van energiebesparende maaatregelen. Waardestijging, omdat het object een betere energieprestatie heeft of in ieder geval duurzamer is, is echter een weinig gehoord argument bij woningcorporaties.

E.5. Welke energietechnieken en -maatregelen kunnen, uw inziens, het beste worden toegepast in woningen en woongebouwen? 
In het algemeen vragen woningcorporaties om de mogelijke toepasbaarheid van specifieke maatregelen of technieken te kijken. Welke technieken dit zijn, verschilt sterk. Woningcorporaties kijken in ieder geval vaak naar collegacorporaties en willen dan die maatregelen of technieken ook graag hebben, want ze hebben enthousiaste verhalen gehoord, hebben immers ook bepaalde doelstellingen te behalen of willen ook dat de wereld naar hun kijkt. De doelstellingen zijn dan gebaseerd op de afspraken met Aedes. Soms wordt er ook aangegeven dat woningcorporaties denken dat energiebedrijven over de rug van hun huurders veel geld verdienen. Hier willen de corporaties dan iets aan doen. Het besef dat huurkosten en energiekosten naar elkaar toe kruipen, leeft heel sterk bij veel woningcorporaties. Er zijn zelfs al wijken waar de energiekosten de huurkosten overstijgen. ledereen heeft energie nodig en die rekening zal straks eerder worden betaald dan de huur. Dat inzicht leeft heel sterk.

E.6. Welke stakeholders is, volgens $u$, het beste in de positie om beslissingen te nemen over het implementeren van energietechnieken en -maatregelen? Waarom?

Er zijn een aantal woningcorporaties heel erg vooruitstrevend met een duidelijke visie en ambities. We willen in een bepaalde tijd naar een woningbestand dat er zo en zo uit ziet, bijvoorbeeld qua energielabel. Er zijn ook veel corporaties die de Aedes convenanten erkennen en er iets mee willen doen, maar het van de omstandigheden laten afhangen hoe ze het invullen.

Een goed voorbeeld is Eigen Haard in Amsterdam. Dit is een hele actieve club, die de markt uitdaagt en consortia vormt waar ze zelf deel van uitmaakt. Ze is dus een opdrachtgever en projectparticipant. Ze gaat samen met ontwikkelende en bouwende partners in een consortium zitten, waarin samen de lusten en de lasten worden verdeeld. Bij een bepaalde prestatie krijgen ze dan samen een bonus en bij het uitblijven van een dergelijke prestatie wordt dat betaald vanuit een gezamenlijke pot. Je krijgt zo discussies van waar gaan we in investeren in de schil of juist in de installaties.

Bij Domijn en De Woonplaats vinden in mindere mate ook wel dergelijke discussies plaats, waarbij De Woonplaats, maar ook woningcorporaties Wonion (die in het verleden heel erg actief was met innovatieve aanbestedingstrajecten) bijvoorbeeld ietsje terug lijkt te vallen in activisme. Bij de meerderheid is er gewoon een aanzienlijke terughoudendheid. Het voorop lopen lijkt hierbij van de persoon af te hangen; zit er bijvoorbeeld een directeur die open staat voor innovatie. Bij Wonion zit daardoor niet meer in de kopgroep. In de directie of het bestuur moet iemand zitten die risico's goed en op de goede manier kan inschatten, dus niet alleen die risico's ziet. Je hebt ook kartrekkers nodig in een woningcorporatie, die voorop willen lopen en het dan oppakken en uitvoeren. Als die mix hebt, dan zie de woningcorporatie voorop lopen. Een kartrekker zonder ondersteuning vanuit een bestuur redt het niet, maar andersom werkt het ook niet. Je hebt ze beide nodig.

Diegene die uiteindelijk het beste de beslissing kan maken, is in het geval van woningcorporaties een bestuurder van het managementteam, welke de knoop doorhakt en zich laat informeren door een drie-eenheid, namelijk 1) de betrokken medewerker vanuit de afdeling beheer en onderhoud, 2) de projectleider vanuit projectontwikkeling of afdeling projecten, en 3) medewerker klantcontacten. 
E.7. Welke rol vervult of vervulde de overheid bij de implementatie van energietechnieken en -maatregelen?

De gemeente Almelo was als partij betrokken bij het project. Wim Haver was op 28 november 2007 aanwezig. Tevens is de adviseur bouwtechniek op de hoogte van de verkenning geweest. Aangezien er een EPC van 0,8 in eerste werd nagestreefd, waren er geen aanvullende wensen of eisen ingebracht. De ambities vastgelegd in het convenant van de woningcorporaties met de gemeente werden immers al overstegen. De gemeente Almelo bekeek op dat moment wel de mogelijkheden van een houtgestookte ketel voor de gecombineerde warmtebehoefte het Erasmuscollege en het nabij gelegen zwembad, welke samen een relatief grote capaciteit vroegen. Dat was dus het belang wat de gemeente min of meer erbij had om er bij aanwezig te zijn.

E.8 Welke mogelijkheden ziet $u$ om de toepassing van energietechnieken en -maatregelen te vergroten?

Outsourcing kan heel krachtig werken, want de risico's en verantwoordelijkheden kunnen dan bij een andere partij worden neergelegd. Het terugverdienen van de maatregelen kan zelfs bij iemand anders worden neergelegd.

\section{Interview employee land distribution Almelo}

This section provides the report of the interview with the employee in charge of land distribution within the municipality of Almelo. Table C.4 provides some general information on the interview and the respondent.

Table C.4: General information on the interview and respondent G.

\begin{tabular}{|c|c|c|c|}
\hline Function & \multicolumn{3}{|c|}{ Employee land distribution } \\
\hline Organisation & \multicolumn{3}{|c|}{ Municipality of Almelo } \\
\hline Department & \multicolumn{3}{|c|}{ Real estate and taxation - Real estate } \\
\hline Experience & \multicolumn{3}{|c|}{ Approximately 30 years } \\
\hline Subject interview & \multicolumn{3}{|c|}{ Policies regarding sustainability and enegy use of buildings in Almelo } \\
\hline Start time: & $14: 30$ & End time: & $15: 00$ \\
\hline $\begin{array}{l}\text { Date of interview and } \\
\text { feedback }\end{array}$ & \multicolumn{3}{|c|}{$\begin{array}{l}\text { Date interview: June } 19^{\text {th }} 2012 \\
\text { Date feedback: July } 3^{\text {th }} 2012\end{array}$} \\
\hline Location & \multicolumn{3}{|c|}{ Stadhuisplein 1 - Almelo } \\
\hline
\end{tabular}

\section{A. Kennismaking met uw functie}

A.1. Zou u mij uw functie in één of een paar zinnen willen omschrijven?

Medewerker uitgifte van de afdeling vastgoed en belastingen. Met als voornaamste taak de verkoop aan particulieren. Hierbij speelt vaak ook de interactie met makelaars en projectontwikkelaars. Niet alleen verkoop, maar de totale uitgifte, dus ook in de vorm van verhuur en pacht. Er is op dit moment een totale dip qua verkoop aan de particulieren, maar in de loop der jaren zijn er veel projecten in de vorm van gerealiseerde wijken geweest. Almelo Noord-Oost, Waterrijk en een paar projecten in de binnenstad zijn nu stil komen te liggen.

A.2. Door welk beleid van de gemeente Almelo wordt $u$, in uw rol van medewerker gronduitgifte, op welke wijze beïnvloed?

De gemeente Almelo voert een actief grondbeleid, dus actief aankopen en verkopen. De voorkeur heeft verkopen, maar eventueel verpachten is mogelijk. De geïnterviewde heeft 
het maar één keer meegemaakt dat een particulier de voorkeur gaf aan erfpacht boven kopen. Bedrijven pachten wel regelmatig de grond, zodat ze meer geld beschikbaar hebben.

\section{B. Invloed van de gemeente Almelo}

B.1. Is er, naar uw weten, beleid vanuit de Gemeente Almelo inzake de toepassing van duurzame of energietechnische maatregelen?

De geïnterviewde is ook betrokken geweest bij de werkgroep Duurzaam Bouwen voor wat betreft de particulieren. Er is een folder ontwikkeld als een soort promo voor particulieren. ledereen die interesse heeft in een kavel, krijgt deze folder "Zelf je droomhuis laten bouwen" mee.

De eerste keer dat actief werd ingezet op Duurzaam Bouwen was met de wijk Nijrees, waarbij een statiegeldregeling werd toegepast. Deze is van de baan, omdat het juridisch niet klopte. Een hogere grondprijs betalen om vervolgens een deel van je geld terug te kunnen krijgen, omdat je moest voldoen aan bepaalde extra normen, dat mocht niet. Een hogere grondprijs hanteren en een subsidiemaatregel instellen, had achteraf gezien misschien wel gekund.

Toen kwam het beleid om een 10\% lagere EPC aan te houden, bijvoorbeeld in Kollenveld sinds januari 2003. Hiervoor probeert de gemeente de mensen enthousiast te maken, maar eigenlijk hebben ze geen poot om op te staan. In Nijrees was het als ander voorbeeld verplicht kruipruimteloos te bouwen, dat is tevens losgelaten, maar de particulieren wordt nog wel geadviseerd kruipruimteloos te bouwen. Hetzelfde geldt min of meer voor de $10 \%$ lagere EPC. We vertellen het de mensen nog steeds en dit geeft iets meer druk. Het afkoppelen van regenwater is ook een voorbeeld van een duurzame maatregel die is opgenomen in de verkoopovereenkomst (zie document Duurzame Woningbouw Gemeente Almelo).

B.2. Wanneer grond voor B\&U wordt uitgegeven, worden er dan vanuit de Gemeente Almelo eisen gesteld aan de bebouwing die verder gaan dan het Bouwbesluit?

Het team Vastgoed geeft aan particulieren en bedrijven te kennen dat een $10 \%$ lagere EPC verplicht is. Als voorbeeld toont de geïnterviewde een brief, waarin dit vermeld staat. $\mathrm{Er}$ staat echter geen sanctie tegenover. De gemeente Almelo kan het niet afdwingen. Naar aannemers toe wordt ook gevraagd om hun bouwplaats beschikbaar te stellen voor $5 \%$ als leerlingbouwplaats.

\section{Waarde van grond}

C.1. Op basis van welke methode wordt de grondprijs bepaald?

In het Nijrees is één gebouw, naar zijn weten, neergezet met een goede EPC (rond de 0,5 of 0,6; erg goed die tijd), waarvoor de grondprijs wel lager is geworden. Dit is echter eenmalig geweest. Voor particulieren wordt geen residuele grondprijs gehanteerd, want dat werkt niet. Particulieren willen namelijk vooraf weten waar ze aan toe zijn. Voor aannemers en ontwikkelaars wordt hier wel eens meegewerkt.

C.2. In het geval van de residuele grondwaarde, kijk je eigenlijk naar de (toekomstige) in de markt te halen economische waarde. Is het mogelijk de prijs van grond af te laten hangen 
van de toekomstige milieutechnische of energetische eigenschappen of prestaties van de opstallen?

Het is moeilijk om te zeggen hoe in de toekomst de grondprijs en duurzaamheid van de gebouwen van elkaar zullen afhangen. Eigendom is echter een groot recht in Nederland, dus je mag niet zo heel snel extra eisen hieraan stellen. Je moet dus oppassen bij particulieren wat je als voorwaarden stelt. Voor Waterrijk waren er bijvoorbeeld grootse plannen (geen gas, orientatie van daken op het zuiden voor zonnepanelen), maar het is niet altijd allemaal haalbaar. In hoeverre kun je het echt afdwingen? Je kunt met aannemers wel afspraken maken, maar met particulieren niet. Je mag als overheid geen misbruik maken van de kennis die je hebt en de particulier niet heeft. De 10\% lagere EPC kunnen we ook niet afdwingen. In de grondverkoop is het heel vaak nietig te verklaren.

\section{C.3. Hoe komt een bepaalde grondprijs tot stand?}

De kosten van de grond. De kosten van het bouwrijp maken en het ambtelijk apparaat. Daarnaast wordt er natuurlijk gekeken naar Hengelo en Enschede als omliggende grote gemeenten. Er is wel eens overleg geweest om er één grondprijs van te maken, maar dat is bij één overleg gebleven.

\section{Actoren}

D.1. Welke partij kan maatregelen wel afdwingen?

Je moet bij de Rijksoverheid zijn, wil je het echt afdwingen. Met particulieren zijn wij ingestoken vanuit het idee, dit is wat we als gemeente graag willen bereiken. Voor een woningcorporatie, projectontwikkelaars of aannemers is het onderhandelen, waarna is het er wel of niet mee eens zijn.

\section{D.2. Waar hangt het van af of een $10 \%$ lagere EPC door gaat?}

Aannemers en projectontwikkelaars vragen zich vaak af wat het hen kost. Woningcorporaties vragen nog wel wat levert het op. Particulieren moest je proberen te overtuigen. lets meer dan de helft durfde het wel aan, maar er was geen groot verschil in voor- en tegenstanders. Water was makkelijker uit te leggen. Voor wat betreft de afkoppelingsmaatregelen zijn deze goed uit te leggen en te accepteren. Het is voor hen logisch dat je relatief schoon regenwater niet moet mengen met vies water. Gezien de verantwoordelijkheid van de gemeente voor het rioleringsstelsel, kan het afkoppelen wel worden afgedwongen. Om vermenging van waterstromen te voorkomen, moet het regenwater zichtbaar open worden aangeboden.

\section{Betrokkenheid projecten}

D.1. Bent u betrokken geweest bij projecten waar ambities met betrekking tot duurzaam bouwen of energiegebruik golden? Zo ja, kunt u enkele van deze projecten en de ambities noemen?

Voor Kollenveld heeft de geïnterviewde een programma van eisen meegenomen uit januari 2003.

D.2. Bent u betrokken geweest bij de projecten nieuwbouw Kollenveld, nieuwbouw Friso, renovatie Kerkelanden, en renovatie/sloop Rombout Verhulstlaan?

Bij deze projecten speelde eigenlijk geen particuliere grondverkoop, want de woningcorporatie was de opdrachtgevende partij. In het geval van Rombout Verhulstlaan 
was de geïnterviewde rond de sloop betrokken, toen er nog wat grond met de woningcorporatie moest worden geruild. In het geval van Kollenveld was vanaf januari 2003 er een Programma van Eisen "Brochure Woningbouw Gemeente Almelo - Kollenveld".

Tot slot geeft de geïnterviewde aan dat elk jaar op de beurs Huis aandacht wordt besteed aan je eigen droomhuis bouwen, waarbij dus ook de duurzame maatregelen aan bod komen. Er is ook sprake geweest van het beschikbaar stellen van een subsidieregeling voor duurzame maatregelen, maar hier is het voor nieuwbouw niet van gekomen.

\section{Interview senior advisor environmental technology Almelo}

This section provides the report of the interviews with the senior advisor environmental technology of the municipality of Almelo. Table C.5 provides some general information on the interview and the respondent.

Table C.5: General information on the interview and respondent J.

\begin{tabular}{|l|l|l|}
\hline Function & Senior advisor environmental technology \\
\hline Organisation & Municipality of Almelo \\
\hline Department & Spatial planning and the environment \\
\hline Experience & $\begin{array}{l}\text { Approximately } 20 \text { years in the field of environmental sustainability, of which } 5 \\
\text { years in this role at the municipality of Almelo }\end{array}$ \\
\hline Subject interview & Developments in policies on the sustainability and energy use of buildings \\
\hline Start time: & $11: 30$ \\
\hline $\begin{array}{l}\text { Date of interview and } \\
\text { feedback }\end{array}$ & $\begin{array}{l}\text { Date interview: June } 19^{\text {th }} 2012 \\
\text { Date feedback: July } 4^{\text {th }} 2012\end{array}$ \\
\hline Location & Stadhuisplein 1 - Almelo \\
\hline
\end{tabular}

\section{A. Kennismaking}

A.1. Zou u mij uw functie in één of een paar zinnen willen omschrijven?

De senior medewerker milieu ruimtelijke projecten doet de volledige inbreng van milieu bij projecten in planontwikkeling, dus in actualisering en nieuwe bestemmingsplannen maar ook nieuwe lokale initiatieven. Daarnaast ondersteun ik duurzaamheid en duurzaamheidsbeleid. Het betreft hier milieu in het veld van de planologie en de ruimtelijke ordening. Het werkveld loopt in principe tot aan de bouwkunde en installatietechnologie, dus niet tot en met. Echter door de technische achtergrond van de geïnterviewde, bemoeit hij zich vaak genoeg wel met de installaties. Met name wanneer mensen zeggen dat het niet rendabel is, bemoeit hij zich hier graag.

\section{A.2. Wat wordt verstaan onder "milieutechnisch"?}

Er zijn beleidsmedewerkers en technische medewerkers oorspronkelijk onderscheiden bij gemeenten. De geïnterviewde geeft wel input aan beleid, maar zijn hoofdtaak is niet het opstellen van beleidsplannen, maar om technische diensten/ondersteuning te verlenen. Dit is de reden dat er sprake is van "technisch" medewerker.

Het begrip milieu is lastig, want bijna alles kan onder milieu vallen. Milieu gaat in Almelo om geluid, bodem, luchtkwaliteit en bedrijven. Wanneer je duurzaamheid erbij haalt, zoals in Almelo wordt gedaan, dan gaat om bijvoorbeeld materiaalgebruik, mobiliteit en energiegebruik. De range wordt breder. Milieu richt zich op een paar technieken en componenten. Bij duurzaamheid wordt het breder ingezet, zelfs ook sociale duurzaamheid. Bijvoorbeeld met ruimtelijke planners of in termen van levensloopbestendig wonen. 
Het ter hand nemen van verschillende aspecten in een specifiek project ligt sterk aan de omvang van het project. Het maakt nogal uit qua mogelijkheden of het een project van vijf woningen of zeshonderd woningen betreft.

\section{A.3. Welke bronnen gebruikt u om zo'n discussie aan te gaan?}

In principe gebruik je eigen literatuur en internet daarvoor. Je moet in ieder geval dit goed bijhouden qua technologische ontwikkelingen. Er wordt ook gebruik gemaakt van adviesbureaus. Soms wordt namelijk in opdracht van de gemeente aanvullend onderzoek gedaan door een adviesbureau. Er wordt dan bijvoorbeeld het rendement en de terugverdientijd berekend van een bepaalde maatregel, maar deze zijn vaak afhankelijk van locatie en de toe te passen technieken. Op woningniveau kun je wel makkelijker dergelijke berekeningen maken, maar niet op gebiedsniveau.

De cultuur is vrij conservatief en veel mensen (potentiele kopers van woningen) hebben een vrij korte termijn visie, waardoor een investering in energiemaatregelen uitblijft. Hij noemt specifiek een periode van vijf jaar, waarbinnen consumenten de maatregel willen hebben terugverdiend. Ze "moeten" immers de maatregel voor hun verhuizing hebben terugverdiend. De redenering van een hogere marktwaarde van het object op het eind van die vijf jaar blijft uit. Een groot probleem is ook het financieringsplafond. Extra mogelijkheden om bij te lenen voor duurzame maatregelen zijn, ondanks de beschikbaarheid van speciale leningen, beperkt. Men gaat dan liever voor de keuken. Mensen zijn redelijk op de korte termijn gericht.

\section{A.4. Wie zijn uw "opdrachtgevers" danwel "klanten"?}

De geïnterviewde is primair intern gericht, waarbij projectleiders Mark inhuren voor hun project. Bij interne gemeentelijke projecten moeten deze projectleiders, zijnde dus Mark's opdrachtgevers, intern uren afnemen voor advisering. Mark biedt dan input qua thema milieu en duurzaamheid. De belangen zijn dus niet gelijk.

Ze vragen om een milieuinbreng. Voor de opdrachtgever ligt het doel op het realiseren van het project. Het is de taak van de geïnterviewde om de gemeentelijke ambitie qua milieu en duurzaamheid als ondergrens, qua energie concreet de wettelijke EPC minus 25\%, minimaal te behalen. Het streven is altijd maximaal duurzaam, mits haalbaar.

Voor wat betreft het nieuwe stadhuis wordt als voorbeeld gestreefd naar BREEAM Excellent. De investeringen in het energiesysteem hebben daarbij een TVT van pakweg twaalf jaar, maar ze zijn wel maximaal duurzaam. Aan het einde van de rit ook economisch voordelig, want het gebouw gaat gewoon minimaal veertig jaar mee. Maar als je er niet op aanstuurt komt het er niet, want de andere actoren en ook de adviseurs rekenen met een normale return on investment die maximaal acht jaar mag zijn. Maximaal duurzaam is niet gedefinieerd. Het is hierbij noodzakelijk als opdrachtgevende partij voldoende kennis te hebben van technische systemen en niet alleen te leunen op adviseurs.

\section{A.5. Neem u zitting in projectteams van (commerciële) bouwprojecten?}

De geïnterviewde is in principe betrokken bij alle projecten die niet passen binnen een bestemmingsplan. Dit kan in principe zelfs een enkele woning zijn, maar bij een enkele woning wordt het qua benadering sneller aan de bouwkundige ambtenaar overgelaten. Hoe 
groter een project, des te meer zit je als gemeente met de projectontwikkelaars of de gemeente zelf aan tafel. Je probeert de milieu- en duurzaamheidsplannen dan in te brengen, zodat deze in het Programma van Eisen komen. Je probeert binnen de gemeente input te leveren voor de ambities van het project en bij initiatieven van projectontwikkelaars probeer je in ieder geval het gemeentelijk beleid in te brengen. Je probeert dan het project maximaal te verduurzamen. Dat verduurzamen is dan niet aan indicatoren op te hangen, omdat het afhankelijk is van locatie. Bij projectontwikkelaars is dit moeilijk want die kijken voornamelijk naar economische rentabiliteit. Je moet dan steeds een discussie aangaan over de rentabiliteit.

\section{B. Energieconcepten, -technieken en -maatregelen}

B.1. Hoe bepaalt u welk energieconcept, -techniek of -maatregel kan worden toegepast in een bouwproject?

De ambitie van de gemeente Almelo om een EPC van min $25 \%$ te halen wordt als minimum neergelegd voor gemeentelijke gebouwen. Afhankelijk van de locatie wordt bekeken wat er verder mogelijk is. De lagere EPC is vrij concreet en makkelijk te behalen. Hij stelt dat energieneutraliteit redelijk gemakkelijk is te halen, mits het gebied is gedefinieerd. Betreft het bijvoorbeeld woningniveau of gebiedsniveau, danwel totaal energiegebruik of alleen energiegebruik voor verwarming. In werkelijkheid krijg je dit er alleen politiek gezien niet door. Dat betekent dat je beleidsambities een bepaald niveau hebben, terwijl in het document staat dat het maximaal zou zijn. Wat dan maximaal haalbaar is, dat maakt het moeilijk. Alles wat dus niet vast ligt qua ambities, aspecten, gebouwkenmerken en installaties, maakt het moeilijk.

B.2. Welke barrières bestaan er, uw inziens, om energieconcepten, -technieken of maatregelen toe te passen?

In feite is de EPC te star. Ze biedt tevens de mogelijkheid een paar kunstingrepen te doen om aan de wettelijke eisen te voldoen. Je kunt met bepaalde, misschien niet eens zo wenselijke technieken, relatief makkelijk puntjes scoren. Met de NEN 7120 lijkt er iets meer mogelijk, maar dat is even afwachten hoe dat uitpakt.

De EPC biedt een keurslijf wat het niet altijd makkelijk maakt om bepaalde energiemaatregelen te kiezen, maar op woningniveau heb je best wel wat vrijheid. Bij bepaalde risicovolle of laagrenderende projecten, die de gemeente wil ontplooien, is het wel eens lastig om je als gemeente samen te werken met marktpartijen. Dit dan juridisch moeilijk ligt; kan namelijk worden gezien als staatssteun of er zijn aanbestedingsregels. Dit maakt het soms lastig die initiatieven dan verder te ontplooien. Een laag renderend project kent dan een terugverdientijd van zo'n vijftien tot twintig jaar, waarvoor een marktpartij alleen niet snel de investering wil doen.

B.3. Welke energietechnieken en -maatregelen zijn volgens $u$ het beste om toe te passen in de woningbouw?

Omdat de ontwikkelingen hard gaan, is het moeilijk om de juiste keuze te maken. Hier zit een groot gevaar in. Een warmtenetwerk kan bijvoorbeeld over vijf jaar worden gezien als niet meer de beste keuze. Een techniek met veel kansen is moeilijk eenduidig te noemen, want je moet weten waarover het gaat; woningbouw, geconcentreerde woningbouw, 
kantoren of winkels. Hij verwacht in binnenstedelijke geconcentreerde gebieden met eventueel veel kantoren en winkels, in ieder geval in geconcentreerde, voor nieuwe situaties dat een warmte/koudenetwerk een goede oplossing zou zijn. Voor woningbouw, twee onder één kap en vrijstaande woningen, nemen individuele systemen een grote vlucht, waarbij elektriciteit de drager wordt. Voor kleinschalige complexen (30-400 appartementen) worden naar zijn verwachting collectieve systemen interessant, bijvoorbeeld WKO. Hier staat tegenover dat wanneer in $\mathbf{2 0 2 0}$ men energieneutraal moet gaan bouwen, wat dan nog het nut is van een warmtenetwerk.

Wat betreft het gebruik van concepten, zijn er wel een aantal mensen met een visie over energie in de toekomst. Er zijn er maar weinig die een totaalbeeld hebben. Bijvoorbeeld een vertegenwoordiger van warmtepompen heeft wel een visie, maar daarin zijn die warmtepompen dan ook het beste. Qua basisconcept is het de kunst om vraag en aanbod in balans te brengen door energie op te slaan vooral voor grotere gebouwen en gebieden. Al met al is er een vrij grote groep van eenzijdig georiënteerde partijen. Bouwers willen stenen stapelen en isoleren en installateurs willen installaties en installatiewerk. Woningcorporaties zijn niet onder die eenzijdige partijen te scharen, maar zijn, doordat ze de investeringskosten niet kunnen doorberekenen, niet in staat zich een totaalvisie of concept te veroorloven.

B.4. Hoe zou, volgens uw, de toepassing van energietechnieken en -maatregelen kunnen verbeteren?

In de vastgoedmarkt zijn eigenaren niet bereid te investeren voor een lange termijn van bijvoorbeeld twaalf jaar, dit lijkt te spelen in heel Europa, gezien de besprekingen op een Europees overleg van Eurocities. Banken gaan hierin in principe ook niet mee, behalve als de gemeente aangeeft; ik ga het huren voor een lange termijn. In de renovatiemarkt met contracten van vijf jaar hebben de eigenaren al veel moeite met een terugverdientijd van tien jaar. Het zou goed zijn voor het milieu als de energieprijs gewoon verdubbelt. Er zijn paar particulieren of beleggers met een iets langere termijn visie en wat meer vermogen om te investeren in duurzaamheid, maar dit is heel minimaal.

De huursector heeft een groot probleem, wanneer de energieprijs verdubbelt. Er zullen namelijk huurders zijn die dan willen kiezen voor duurzame utiliteits-/kantoorgebouwen. In utiliteits- of kantoorgebouwen zijn de energiekosten nog relatief laag. Maar in de sociale woningbouw zijn de energiekosten wel aanzienlijk, in sommige gevallen zelfs bijna gelijk aan de huurkosten. Op Europees niveau speelt ook hier een probleem. Er is dan ook op de Eurocities bijeenkomst gesteld dat een verdeelsleutel mogelijk moet zijn tussen energie, investeringskosten en huur. Je betaalt bijvoorbeeld $€ 300$ aan huur en $€ 300$ aan energie, dan moet je bij investeringen in energiemaatregelen de gereduceerde kosten aan energie bij de huur moeten kunnen optellen. Dit is op dit moment nog maar in beperkte mate mogelijk.

Naast de interne opdrachtgevers, heb je toch een rol als ambassadeur. Als werkgroep probeer je hier actief invulling aan te geven, waarbij je trekt en duwt aan energie-achtige projecten, die buiten de eigen (gemeentelijke) ontwikkeling liggen. Bijvoorbeeld de koudelevering vanuit de plas, riothermie en een biogasnetwerk. Deze ondersteuning bestaat 
uit kartrekker zijn (waarbij je vervolgens niet de eindverantwoordelijke bent), verbinden van partijen en onderbouwen.

\section{Actoren}

De gemeente kan eigenlijk niet een gelijkwaardige samenwerking aangaan, dat is niet toelaatbaar. Zelfs niet met een partij als het lokale energiebedrijf Cogas, waarvan de gemeente Almelo notabene grootaandeel-houder is.

C.1. Welke partij in een woningbouw of -renovatieproces is het beste in staat beslissingen te nemen met betrekking tot de toepassing van bepaalde energieconcepten, -technieken en maatregelen? Waarom?

Het beste in staat of bij wie liggen de meeste kansen? Er zijn een paar projectontwikkelaars die zich richten op duurzaamheid, die zijn in staat goede beslissingen te nemen. Woningcorporaties zijn in het algemeen nog niet in staat goede beslissingen te nemen, aldus de ervaring van de geïnterviewde. De gemeente zou hier wel een voortouw in mogen nemen. Een paar installateurs zijn in staat goede adviezen te doen, maar een bepaalde eenzijdigheid bestaat dan wel. Ze zijn installatiegericht. De bouwer wil de EPC halen door isolatie toe te passen en een installateur gooit er meer installaties in.

C.2. Welke rol heeft de overheid in de toepassing van bepaalde energieconcepten, technieken en -maatregelen in bouwprojecten?

De geïnterviewde vraagt zich hardop af: Waar ligt je rol als overheid en in hoeverre moet je burgers binden aan bepaalde technieken of technologieën? In hoeverre dwing je burgers te kiezen voor producten van bepaalde bedrijven; gedwongen winkelnering? Dit is een heel lastig aspect. De gemeente Almelo moet redelijk abstract omschrijven wat haar doel of ambitie is. Het is aan de markt om de technologie te kiezen. De praktijk wijst echter uit dat je heel veel kennis moet hebben van concrete technieken en oplossingen, wil je de discussie aan kunnen gaan om de abstracte doelen of ambities te kunnen halen.

In de markt is er wel voldoende kennis voor handen, maar niet iedereen heeft die voldoende kennis. Globaal is er onvoldoende kennis om tot de juiste keuze te komen. Er zijn een paar partijen handig, maar dit geldt voor de meeste niet. Er is niet géén uniform pakket. Er zijn wel twintig varianten om te komen tot. Als voorbeeld kun je je afvragen in hoeverre je wilt isoleren, want je gratis energie kunt opwekken. Er is geen kennisbank hiervoor, er is wel gepleit op Europees niveau om voor onafhankelijke kennisbanken op landelijk of regionaal niveau. 33:40 De ontwikkelingen gaan daarnaast erg hard, die steeds je inzichten kunnen veranderen.

C.3. Welk beleid en welke regelgeving hebben vanuit de rijksoverheid, provincie en de gemeente zelf met name invloed op uw functie?

Op dit moment merkt hij niet dat hij vanuit de provincie meer ambities krijgt opgelegd met betrekking tot duurzaamheid. Hij merkt echter wel dat de provincie bepaalde projecten wel zo belangrijk vindt, dat ze de gemeente daarbij ondersteunen, bijvoorbeeld voor het binnenstadsplan. Deze steun is in de vorm van advies en geld voor adviesbureaus.

C.4. Wat is de rol van de gemeente inzake energie infrastructuur? 
Voor leidingnetwerken hoeft de gemeente geen grond toe te eigenen, je mag voor energie infrastructuur dus van andermans gronden gebruik maken. Als gemeente mag je bijvoorbeeld als er een warmtenetwerk ligt, eisen dat burgers/woningen van die infrastructuur gebruik moeten maken. Je mag als gemeente dus stellen dat er geen gas in een wijk mag worden gebruikt. Een woning mag wel autarkisch zijn, want daarmee wordt het hogere duurzaamheidsdoel wel bereikt. In dat geval hoeft de woning niet perse op een energieinfrastructuur te worden aangesloten.

\section{C.5. Hoe moet de rol van de partijen veranderen?}

Men moet zich veel meer richten op de bestaande woningbouw. Men moet zich minder richten op isolatie, maar veel meer op het totaalpakket qua energie. Met isolatie alleen kom je er niet, dus de partijen in de bouw moeten niet alles op in zetten. Er kan hier ook een rol liggen voor de gemeente Almelo. Er staan een paar partijen op die in dit gat proberen te springen. Ze bieden totaalpakketten aan. Een bewoner is hier echter niet bij gebaat, want het niet meer dan anders principe staat hier voorop. Met ESCo's hoef je daarom niet zo blij te zijn. Het is vaak ook een niet minder dan anders principe. Dit was ook bij de aanbiedingen voor de energievoorziening in Waterrijk een issue, waar prijsstijgingen voor het duurzame alternatief door de gemeente werden beperkt. De overheid kiest er steeds vaker voor dingen niet zelf te doen, geen risico's en geen investeringen. Dit is logisch, maar dan komen sommige zaken ook niet van de grond. Ze moeten dus of meer oppakken of toch beter faciliteren. Op het eind gaat echter toch allemaal om geld.

\section{Interview advisor building technology Almelo}

This section provides the report of the interview with the advisor building technology of the municipality of Almelo. Table C. 6 provides some general information on the interview and the respondent.

Table C.6: General information on the interview and respondent $K$.

\begin{tabular}{|c|c|c|c|}
\hline Function & \multicolumn{3}{|c|}{ Advisor building technology } \\
\hline Organisation & \multicolumn{3}{|c|}{ Municipality of Almelo } \\
\hline Department & \multicolumn{3}{|c|}{ Spatial planning and the environment } \\
\hline Experience & \multicolumn{3}{|c|}{11 years in the field of residential buildings, 9 years on energy performance } \\
\hline Subject interview & \multicolumn{3}{|c|}{ Developments in policies on the sustainability and energy use of buildings } \\
\hline Start time: & $13: 30$ & End time: & $14: 30$ \\
\hline $\begin{array}{l}\text { Date of interview and } \\
\text { feedback }\end{array}$ & \multicolumn{3}{|c|}{$\begin{array}{l}\text { Date interview: June } 19^{\text {th }} 2012 \\
\text { Date feedback: August } 20^{\text {th }} 2012\end{array}$} \\
\hline Location & \multicolumn{3}{|c|}{ Stadhuisplein 1 - Almelo } \\
\hline
\end{tabular}

\section{A. Kennismaking}

\section{A.1. Zou u mij uw functie in één of een paar zinnen willen omschrijven?}

De functie is vrij breed, maar op het gebied van Duurzaam Bouwen komt het erop neer dat de geïnterviewde het duurzaamheidsbeleid uitvoert dat door de senior beleidsmedewerkster duurzaamheid wordt opgesteld. De voorbereiding voor dat beleid wordt deels samen in overleg opgepakt. Voor nieuwe gebouwen moet de wettelijk vastgelegde minimale energieprestatie worden behaald. Dit laatste vloeit niet voort uit lokaal beleid, maar is een landelijk vastgelegd Bouwbesluit-niveau. 
De energieprestatieberekeningen worden door de geïnterviewde allemaal gecontroleerd. Gezien de reacties van aannemers en de architecten, lijkt, aldus de geïnterviewde, dat de gemeente Almelo vrij streng controleert. De controle vindt op papier en deels digitaal plaats. In de digitale berekeningen kun je soms iets meer zien van wat er achter de schermen is gebeurd. Bij verrassende waarden, bijvoorbeeld qua U-waarde van glas, wordt de aanvrager van de vergunning gevraagd om aan te tonen hoe een dergelijke waarde precies wordt gehaald.

De controle op papier is erg goed, maar de controle in de praktijk en de handhaving laat een beetje te wensen over. Met een infrarood camera worden de opdrachtgevers en woningeigenaren gewezen op tekortkomingen qua isolatie, maar hier handhaaft de gemeente niet zelf op. Zij wil niet teveel sores hebben en heeft immers geen contract met de aannemer. De opdrachtgever of woningeigenaar moet zelf de opdrachtnemende partij vragen om het doorvoeren van verbetering. De geïnterviewde verbaast zich daarbij over de houding van de "klant" in de deze, aangezien bij een kras in een nieuwe auto men direct terug gaat naar de leverancier, maar de houding bij een nieuwe woning meestal nonchalanter is. Men lijkt het gekochte product niet perfect aangeleverd te willen hebben. Het is soms te wijten aan de detailleringen, welke bij aanvraag van de bouwvergunning maar principe details hoeven te zijn. Deze detailleringen bepalen vervolgens wel hoe goed of slecht de isolatiewaarde en infiltratiegraad is.

De geïnterviewde voert ook constructieve toetsing uit en werkzaamheden in het kader van de wet Basisregistratie Adressen en Gebouwen (BAG), welke ondermeer de berekening van het aantal vierkante meters van gebouwen omvat.

\section{A.2. Wat valt onder de term "bouwtechniek"?}

De term bouwtechniek heeft nu vooral te maken met duurzaam bouwen en energiezuinig bouwen. Daar spitst het zich op toe.

\section{A.3. In hoeverre verschilt uw rol met die van een bouwinspecteur?}

Het verschil zit hem deels in het buitenwerk met de infraroodcamera. Dat is erg leuk werk maar niet erg comfortabel want je moet 's ochtends vroeg voor zonsopgang en bij voorkeur bij een lage buitentemperatuur op pad. Het was een subsidietraject, waar dit werk onder viel.

\section{A.4. Is er een andere medewerker werkzaam naast u op dit gebied?}

Nee, qua techniek niet eigenlijk. De vergunningverleners heten case-managers. Zij zetten vragen uit naar medewerkers welke er inhoudelijk naar kijken, zodat procedures door lopen.

A.5. Welk beleid en welke regelgeving hebben vanuit de rijksoverheid, provincie en de gemeente zelf met name invloed op uw functie?

De EPC was al genoemd in het gesprek. Maar er was een heel mooi traject binnen de gemeente, waarbij een statiegeld regeling werd toegepast. In Tilburg bestaat het misschien nog wel. Je kreeg bij een kavel van een bepaald formaat geld terug, wanneer je aan een waslijst van maatregelen had voldaan. Mensen wilden tonnen investeren, bij wijze van spreken, om $€ 10.000$ euro terug te krijgen. Dat was echt ongelooflijk. Toen de geïnterviewde begon in 2003 liep het ten einde, toen heeft de stadsadvocaat gevraagd om 
hiermee te stoppen, omdat het illegaal was op basis van artikel 122 van de Woningwet (het verbod op privaatrechtelijke rechtshandelingen van gemeenten). Daarin staat dat de gemeenten geen aanvullende eisen mag stellen die boven de wettelijke norm uit gaan, tenzij in overleg met gelijkwaardige partijen zoals professionele projectontwikkelaars en dergelijke. Het was ook een papieren tijger, dus de gemeente stopte hiermee. De maatregelenlijst was gebaseerd op het Nationaal Pakket Duurzaam Bouwen en de Tommelmaatlat werd gehanteerd. De geïnterviewde heeft uiteindelijk met de controle op de statiegeldlening niet vandoen gehad. Bij grote partijen is in de vorm van een gentlemen agreement een lijst van voorwaarden toegepast, maar dat is op een gegeven moment dood gebloed. Pakket 1 werd ook al snel ingehaald door het Bouwbesluit. Nu bestaat de werkgroep Duurzaam Bouwen. Het draait voor alle partijen er uiteindelijk toch om wat kost het allemaal en wat levert het op. We zijn als Nederlanders behoorlijke boekhouders. Ze moeten toch allemaal de uitgaven verantwoorden, dus "wat kost het?" en "wat levert het op?".

\section{A.6. In hoeverre bent u betrokken bij renovatieprojecten of de bestaande bouw?}

In technische zin is de geïnterviewde hier niet bij betrokken, maar organisatorisch gezien wel. Er was een subsidietraject voor maximaal $40 \%$ subsidie op de investeringskosten van isolatiemaatregelen voor de bestaande bouw; dakisolatie, spouwisolatie, vloerisolatie en dubbelglas. Om de woning qua luchtkwaliteit goed te houden, was ventilatie ook een aandachtspunt. Er moest een maatwerkadvies worden uitgevoerd, welke ook werd gesubsidieerd. De woningen moesten van voor 1996 zijn, want toen kwam de EP-berekening om de hoek kijken. Er moeten nog vijftig aanvragen worden gecontroleerd, maar circa zeshonderd huishoudens zijn hiermee geholpen en de subsidiepot is bijna leeg.

\section{B. Adviezen}

\section{B.1. Wie is uw klant en welke adviezen geeft u?}

De geïnterviewde is in dienst van de gemeente en hij ziet haar als klant, maar bij de controle van een EPC bijvoorbeeld, nodigde hij de betreffende particulier die een woning wilde bouwen wel uit voor een duurzaamheidsgesprekje. In zo'n gesprek blijkt danwel dat particuliere woningeigenaren voor comfort en gezondheid kiezen. Gezamenlijk werd dan de woning doorlopen qua glas, isolatie, lage temperatuurverwarming en ventilatie bijvoorbeeld. Het was vrij intensief en toen er geen subsidie voor de gemeente meer voor was, is het pakweg vier jaar geleden gestopt. Het was geen langdurend traject waarin deze adviezen zijn gegeven en het rendement of de resultaten zij niet bijgehouden. Het is wel bekend dat er soms kleine aanpassingen van de plannen plaatsvonden.

\section{B.2. Heeft $u$ ervaren dat $u$ vanuit de gemeente de toepassing van energiemaatregelen weleens heeft geremd?}

Er was wel eens een EP-berekening binnengekomen die niet klopte en niet de gewenste EPC van toentertijd 0.8 behaald. Toen heeft de aanvrager een bepaalde ingewikkeld apparaat toegepast om installatietechnisch punten te winnen, waardoor ze onder de 0.8 uitkwamen. Vervolgens hadden ze wel de warmteweerstand van het isolatiepakket verlaagd. Toen heeft Bennie wel gedacht, "had ik maar niks gezegd". Hij probeert ze dan ook voor te houden, dat 
voldoen aan het Bouwbesluit maar een rapportcijfer 5.5 is en dus eigenlijk met de hakken over de sloot is.

\section{B.3. In hoeverre is GPR Gebouw gebruikt?}

GPR Gebouw was aangeschaft, maar het gebruik is nooit goed van de grond gekomen. De gemeente heeft het aangeschaft en in de gemeente konden andere partijen het gebruiken. Het idee was om in samenspraak met de woningstichtingen afspraken te maken over duurzaamheidsdoelen, maar het invoeren was toch veel werk.

B.4. Met GPR Gebouw kun je een rapport cijfer bepalen voor een gebouw. Hoe meten danwel berekenen partijen in het algemeen welke maatregel het beste kan worden toegepast?

De EPC berekening is leidend, maar dat is niet zo'n goed instrument als ontwerptool of om gebouwen te managen. Eigenlijk, kun je wel zeggen, dat er niet wordt gemeten. Er wordt zijn inziens nog veel met de 'portemonnee' gestuurd waarbij al op korte termijn return om investment in het zicht moet zijn.

B.5. De term advies suggereert een zekere vrijblijvendheid. Welke "adviezen" zijn daadwerkelijk vrij blijvend? Welke "adviezen" kunnen worden afgedwongen?

Je kunt alleen wettelijke maatregelen afdwingen, andere maatregelen boven het wettelijk niveau niet. Hier is de gemeente Almelo dus wel in 2003 tegen aan gelopen. Sinds die tijd kost het veel moeite extra maatregelen door te voeren boven het Bouwbesluit, misschien wel goed ook want anders zijn er per gemeente andere richtlijnen voor de bouwpartijen. Aannemers en veelvuldige aanvragers van bouwvergunningen hebben lijstjes van welke gemeenten danwel ambtenaren waar op letten qua bouwregelgeving. Men rekent zich een slag in de rondte om niet forfaitaire waarde te hoeven in te vullen, maar in werkelijkheid veranderd er niks. Hij geeft aan dat er soms erg veel tijd en moeite wordt geïnvesteerd in het uitgebreid berekenen van de EPC, bv de uitgebreide methode van de lineaire warmteverliezen, om maar aan de norm te voldoen. Het gebouw zelf wordt hier niet beter van.

B.6. Wat is "de" danwel "uw" werkwijze?

In eerste instantie ging de geïnterviewde naar eigen zeggen vrij ver in zijn duurzaamheidsadvies, waar zelfs rolstoeltoegankelijk-heid en andere verbeteringen werden voorgesteld. Dit ging meestal per mail naar de opdrachtgever. Naar de aannemer toesturen, dat werkt niet.

\section{Energietechnieken en -maatregelen}

C.1. Welke termen worden gebruikt door bouwpartijen naast het begrip EPC om te komen tot een verantwoord object?

De term "duurzaam" wordt gebruikt. Er is over de inhoud veel verwarring. Je hoort ook vaak Passiefhuis. ledereen kan zich ook wel wat voorstellen bij Energieneutraal, maar dat dat betekent dat je in de winter tekort komt en in de zomer een overschot hebt, dat realiseren de meeste mensen zich niet. Het gaat om het jaar rond. Sommige concepten en uitgangspunten gaan ook wel voorbij aan hoe mensen werkelijk leven. Bijvoorbeeld het gegeven dat veel mensen het hele jaar door het raam hebben openstaan op de slaapkamer. Dat is moeilijk te combineren met een temperatuur van $22{ }^{\circ} \mathrm{C}$ in de huiskamer tegen het 
plafond aan. Dan zou je dus de tussenvloer moeten isoleren, wat niet echt lijkt te passen met de huidige bouwpraktijk.

C.2. Welke barrières bestaan er, uw inziens, om energieconcepten, -technieken of maatregelen toe te passen?

Onbekendheid met maatregelen zorgt ervoor dat mensen weinig energiemaatregelen toepassen. Een particulier opdrachtgever laat zich voorlichten door de aannemer, die vaak een sterke mening heeft. De geïnterviewde is daarbij vaak verrast door hoe vaak aannemers en installateurs wel niet warmtepompen aanraden of willen toepassen. In het geval van nieuwbouw maakt de warmte voor tapwater al een groot deel uit van de totale warmtevraag. Een warmtepomp is niet goed in staat op efficiënte wijze dit tapwater te verwarmen. Naar de aannemers toe, maakt hij dan ook wel eens de opmerking dat het lijkt dat ze meer verdienen op de verkoop van gas dan op de verkoop van isolatie. Bennie is van mening dat de warmtepomp bij een woning met een beperkte ruimteverwarmingvraag en een hoog warmtapwaterverbruik een onverstandige investering is. Langzaam begint het tij te keren, bij een bijeenkomst van Bouwen Nederland onlangs, leek dat bij BAM nu de schil een prominentere plaats in gaat nemen.

C.3. Welke energieconcepten, -technieken en -maatregelen zijn volgens $u$ het beste om toe te passen in de woningbouw?

Eigenlijk moet je een stukje vooruit kijken. Wanneer de schil tachtig of honderd jaar blijft staan, maak die dan fatsoenlijk voor elkaar. Het is heel moeilijk die later nog aan te pakken. Maar ja, men blijft een woning maar vol stoppen met techniek. Een oriëntatie van de gevel met glas op het zuiden, zorg voor een goede schil en zorg dat je qua installatietechniek klaar bent voor de toekomst, dus geen hoge maar lage temperatuurverwarming.

Op de vraag wat een goede schil precies is, antwoord de geïnterviewde; iedereen past nu glas met een $\mathrm{U}$ van $1,2 \mathrm{~W} / \mathrm{m}^{2} \mathrm{~K}$ toe, terwijl $1,1 \mathrm{~W} / \mathrm{m}^{2} \mathrm{~K}$, oftewel $10 \%$ beter, nauwelijks meer kost. Driedubbel glas kost maar $€ 40 / \mathrm{m}^{2}$ meer. Dat zou al een verstandige maatregel kunnen zijn, al doe je het alleen maar in de warme ruimtes, zoals de woonkamer en de keuken. Bennie heeft een tijdlang de isolatiewaarden van de woningbouwaanvragen in een bestandje bijgehouden. Hij ziet daarbij dat de isolatiewaarden gestaag verbeteren. Qua Rcwaarde moet je misschien niet beneden de $6.0 \mathrm{~m}^{2} \mathrm{~K} / \mathrm{W}$ gaan zitten. Passiefhuizen zijn nog een hele uitdaging met een Rc van $10 \mathrm{~m}^{2} \mathrm{~K} / \mathrm{W}$, maar als je er nu een huis bouwt ben je daar over tien jaar heel blij mee. Verder gaat Bennie zijn voorkeur naar zo weinig mogelijk techniek erin. Als je heel goed isoleert en je gebruikt elektrische verwarming, dan heb niet eens zoveel zonnepaneeltjes nodig om het jaar rond te komen. Dit is een beetje tegengesteld aan het voorafgaande, aangezien elektrisch verwarming niet efficiënt is. Maar zo lang je mag salderen is dat een goed oplossing. Maar als het salderen is afgelopen... Het is wat betreft wel jammer dat je zo afhankelijk bent van regelgeving. Met een nieuw kabinet is het altijd even afwachten.

\section{Actoren}

D.1. Welke partij in een woningbouw of-renovatieproces is het beste in staat beslissingen te nemen met betrekking tot de toepassing van bepaalde energieconcepten, -technieken en maatregelen? 
Je zou verwachten dat dit de opdrachtgever is, maar die is vaak onwetend, tenzij het een grote partij is zoals een woningstichting. Hij denkt dat de overheid wel de middelen in handen heeft. De opdrachtgever heeft echter het geld voor de investering. De particuliere opdrachtgever moet de investering doen en heeft de baten van een investering in energiezuinigheid. Bij woningcorporaties heeft de huurder de voordelen en kan de huur nauwelijks omhoog.

D.2. Welke rol heeft de overheid in de toepassing van bepaalde energieconcepten, technieken en -maatregelen in bouwprojecten?

Je bent zo afhankelijk van regelgeving. De overheid kan ook belemmerd zijn, zoals tenminste blijkt uit de reactie van de verkopers van zonnepanelen. Die vragen om afschaffing van de subsidies, welke ervoor zorgen dat veel consumenten wachten met bestellen tot de subsidie van kracht wordt.

D.3. Hoe zou de rol van de overheid moeten veranderen om tot meer energiemaatregelen te komen?

De minimale Rc-waarde zou wel omhoog mogen, de SP komt hier ook mee, dacht Bennie. Een minimaal waarde van 5 of 5,5 zou een goed principe zijn. Dan redden we het niet met de huidige spouwmuur. Dan moet er dus wel een nieuwe bouwwijze komen, maar ja in Duitsland krijgen ze het wel voor elkaar. De rol van de gemeente als handhaver moet beter worden uitgeoefend. Handhaving verdient meer aandacht; elk gerealiseerd project zou op essentiële onderdelen moeten worden gecontroleerd, bijvoorbeeld door luchtdichtheids-, infrarood- en Rc-waardemeting.

D.4. In hoeverre beseffen partijen dat de EP-berekening een theoretisch gebouwgebonden energiegebruik uitdrukt?

De geïnterviewde heeft de indruk dat de meeste partijen zich hier wel van bewust zijn, maar hij heeft ze nooit rechtstreeks gevraagd.

\section{D.5. In hoeverre zit u met woningcorporaties om tafel?}

Lange tijd hebben de woningcorporaties een EPC van $-10 \%$ gehanteerd in overleg met de gemeente, maar met de EPC-aanpassing van 1,0 naar 0,8 of van 0,8 naar 0,6 kwam de klad erin. Er was geen geld meer en men ging terug naar het Bouwbesluit. Waarschijnlijk was het van 1,0 naar 0,8 . In het algemeen wanneer er iets niet klopt, gaan de woningcorporaties er makkelijk mee akkoord om het aan te passen. Ze willen de relatie met de gemeente goed houden. Wanneer de huurder zijn energierekening niet kan betalen, kan hij namelijk ook moeilijk de huur betalen. Of anders gezegd als ze in een woning met energielabel $\mathrm{G}$ zitten, dan blijven ze bij een hoge energierekening wel het energiebedrijf betalen, anders worden ze afgesloten. In dat geval komt dus de huurbetaling in het gedrang. Er is regelmatig overleg in de werkgroep duurzaam bouwen.

\section{Interview architect Kollenveld and Rombout Verhulstlaan}

This section provides the report of the interview with an architect of De Witte - Van der Heijden Architecten. Table C.6 provides some general information on the interview and the respondent. 
Table C.6: General information on the interview and respondent $Q$.

\begin{tabular}{|c|c|c|c|}
\hline Function & \multicolumn{3}{|l|}{ Architect / Owner } \\
\hline Organisation & \multicolumn{3}{|l|}{ De Witte - Van der Heijden Architecten } \\
\hline Experience & \multicolumn{3}{|c|}{34 years of experience in the field of architecture and since 20 years self employed } \\
\hline Subject interview & \multicolumn{3}{|c|}{ Application of energy techniques and measures in residential building projects } \\
\hline Start time: & $13: 00$ & End time: & $14: 30$ \\
\hline $\begin{array}{l}\text { Date of interview } \\
\text { and feedback }\end{array}$ & \multicolumn{3}{|c|}{$\begin{array}{l}\text { Date interview: June } 20^{\text {th }} 2012 \\
\text { Date feedback: September } 12^{\text {th }} 2012\end{array}$} \\
\hline Location & \multicolumn{3}{|l|}{ Enschede - Emmastraat 135} \\
\hline
\end{tabular}

\section{A. Kennismaking}

De geïnterviewde architect is in 1978 begonnen bij het architectenburo Kristinsson in Deventer (toelichting interviewer: een architectenburo onder leiding van Jon Kristinsson welke duurzaamheid hoog in het vaandel heeft staan). Het buro hield zich toen bezig met energievraagstukken. Diverse onderzoeken en studies heeft hij aan mee gewerkt. In 1992 is hij voor zichzelf begonnen. Een aantal interessante projecten qua duurzaamheid en energiezuinigheid zijn er toen gedaan.

\section{Voorbeeldproject Oikos}

Met name het gebied Oikos in Enschede; een 'state of the Art' op het gebied van duurzaam bouwen, milieu en energie. Daar heeft hij toen het appartementenbouw Helios ontworpen, waar een aantal behoorlijk nieuwe aspecten zijn geïntroduceerd. Dit ontwerpproces is ongeveer in 1994 begonnen. Er was een stedenbouwkundig plan waarin, langs het centrale plein een appartementegebouw met 48 woningen van de woningstichting moesten komen. De algemene doelstelling van de geïnterviewde was hierbij een appartementengebouw zonder fossiele brandstof.

De gemeente stelde in Oikos voor iedere woning een zonnecollector verplicht. Verder moest er volgens de DCBA methode (van dhr. Duijvestein) allerlei scores worden gehaald op het gebied van duurzame materialen. Hij heeft toen een gebouw ontworpen met een hoge wand aan het plein. Dit gebouw moest een kap hebben, maar deze was, vanwege de hoge pleinzijde, op het noorden georiënteerd. Er is toen een ZON-gevel ontworpen als een geïntegreerde verticale zonnecollector. Deze is geïnspireerd op het door-ontwikkelen van de traditionele gevel, van een steensmuur, een spouwmuur, naar geïsoleerde spouwmuur. Waarbij de buitengevel geen constructieve functie meer had, doch slechts een regenscherm is. De eerste stap was natuurlijk een isolatiepakket met een Rc van 6 toegepast, waardoor de warmtevraag zo klein werd dat de mogelijkheid van all-electric-house in beeld kwam. Er is een gebalanceerd (WTW)ventilatiesysteem toegepast met natuurlijke ventilatie voor 's avonds/'snachts Het kleine beetje energie wat nog moest worden toegevoegd, kon door middel van pv-panelen. De woningen kregen daarmee in hun ZON-gvel een actief zonnegedeelte en een passief zonnegedeelte. Het resultaat was toen in 1995 een EPC van 0,7, welke tegenwoordig 17 jaar later pas zo'n beetje standaard is. De PV-panelen zijn uiteindelijk vanwege de financiële haalbaarheid niet toegepast. De optie warmtepomp was qua ondergrond niet mogelijk zodat uiteindelijk de Mini-wkk's in beeld kwamen, maar die hadden gas nodig. Er waren toen toch fossiele brandstoffen nodig, zei het slechts een heel klein beetje. 
Er waren veel verschillende woningplattegronden, gebaseerd op het wisselbeuk-principe, maar altijd een compacte kern met alle sanitaire en energievoorzieningen en dus korte leidingen. Architectuur en stedebouw was natuurlijk ook van belang, naast techniek en milieu. Het gebouw moest op een verrassende manier een overgang vormen van plein naar bebouwing. $\mathrm{Er}$ is een arcade/gaanderij gemaakt met winkels op de beganegrond en gebogen kolommen, die als een soort baleinen enerzijds het dak en de balkons dragen en anderzijds de overgang maken tussen openbaar en privé. Er werd qua duurzaamheid en materialen een SEV-milieuclassificatie van 8.5 gehaald, wat gewoon uitstekend is.

Toen kwam nog de vraag hoe krijg je mensen er toe dat ze het totaal gaan zien en niet alleen het idee "ik woon in een energiezuinig huis". Het huishoudelijk energiegebruik zou eigenlijk ook moeten worden verlaagd. Er kwam een concept ter tafel, waarbij de bewoner energiezuinige huishoudelijke apparatuur least van de woningcorporatie. Dit is echter niet van de grond gekomen. Er was ook een idee om de meterkasten kwijt te raken door gebruik te maken van hele compacte nette kasten van Holec uit Hengelo waarin alles uit de meterkast zou gaan. Verder het idee om het eigen energieverbruik te vergelijken met het verbruik van de overige bewoners (uiteraard anoniem) ter stimulering van het bewonersgedrag. Zo is er dus geprobeerd naast de opgelegde eisen, heel innovatief bezig te zijn en om architectuur en techniek te integreren. Een later onderzoek, gepubliceerd als het groot variantenboek, toonde een hoge duurzaamheidsscore voor deze woning. De referentiewoning had toen een waarde van 146, terwijl het uitgevoerde ontwerp een waarde van 85 had, waarbij geldt hoe lager hoe beter. Het is al met al één van de belangrijke projecten uit zijn loopbaan.

Toelichting interviewer: Het bureau heeft diverse voltooide projecten met korte beschrijvingen als een soort portfolio aan de muur hangen. Waarom is duurzaam bouwen in de gerealiseerde projecten een aparte categorie van woningbouw, scholen en utiliteitsbouw e.d.?

De geïnterviewde geeft aan dat het eigenlijk geen aparte categorie is maar een ontwerpfilosofie. Sommige opdrachtgevers vragen echter nadrukkelijker om duurzaamheid dan anderen, waardoor er in die projecten nog meer mogelijkheden zijn.

\section{Voorbeeldproject Prijsvraag De Woonplaats}

Een ander voorbeeldproject betrof een project in Winterswijk wat tot stand kwam op basis van een prijsvraag van De Woonplaats. Een project op een moeilijke krappe en schaduwrijke locatie. De opdracht was in het kader van innovatie om belangrijke thema's toe te passen als energieneutraal, cradle-to-cradle, total-cost-of-ownership, grondgebruik, samenwerken met anderen in BIM. Tijdens het ontwerpproces voor de prijsvraag is er een consortium "Denq Duurzaam" samengesteld met daarin de architect, aannemer, installatie-adviseur, installateur en $\mathrm{C} 2 \mathrm{C}$ coach. Het team heeft samen bedacht wat het ontwerp zou moeten behelzen. Het werd daarbij duidelijk dat zelfs bij een professionele opdrachtgever als een woningcorporatie, dergelijke concepten of begrippen niet helemaal helder geformuleerd zijn. Nadat de prijsvraag was gewonnen, is de opdrachtgever gevraagd aan tafel te schuiven om hen deze begrippen en concepten nog eens goed eenduidig uit te leggen. De cradle-to- 
cradle coach liet alle partijen nadenken wat ze gezamenlijk wilden bereiken en een extra kritische houding aannemen bij de materiaalkeuzes die gemaakt moesten worden.

Het is heel goed dat woningcorporaties initiatieven nemen, maar dan is het belangrijk dat men zich realiseert wat er gevraagd wordt en wat er gedaan moet worden als zulke concepten genoemd worden in hun ambities. Het project in Winterswijk toont dit misschien ook wel een beetje aan, omdat het al enkele jaren in de ontwerpfase verkeerd en de bouw nog niet is gestart. Om op de vraag terug te komen, of duurzaam bouwen projecten los staan van de andere categorieën, vertelt de geïnterviewde hoe in twee andere projecten omgegaan is met het materiaalgebruik. In de wijk Stadsveld te Enschede zijn circa 200 woningen van de Click Brick voorzien van Daas Baksteen, welke specievrij wordt gestapeld. Voor het eerst in Nederland een gebouw tot 35 meter hoog met dit materiaal. Je hebt dan geen problemen met voegwerk, welke een gebouw kan maken of breken. Zonder voegwerk zal het gebouw ook niet wit uitslaan en het gevelvlak is kleur-echt. Bij sloop is deze steen zo weer opnieuw te gebruiken.

Een ander project zal een gevel krijgen van gebrand hout, volgens een Japanse traditie. Het materiaal is onderhoudsvrij en brandvertragend en heet Yaki Suki. Niet te verwarren met, Suki Yaki, een gerecht dat de geïnterviewde heeft gegeten in Japan. Het is niet te hopen dat het gebrande hout naar het gerecht is vernoemd vanwege het vergelijkbare uiterlijk.

In Almelo is jaren geleden als een pilot project op het dak van gerenoveerde appartementen van AWS Beter Wonen aan de Goeman Borgesiusstraat luchtzuiverende dakpannen gebruikt, gebaseerd op titaniumdioxide. In totaal is zo'n $900 \mathrm{~m} 2$ dak van deze dakpannen voorzien. Verschillende aspecten werken dus door elkaar heen, maar de ene keer zijn installaties belangrijker en de andere keer materialen.

\section{B. Actoren}

B.1. Wie vraagt er om de duurzame of energiebesparende maatregelen?

De geïnterviewde legt uit dat zijn architectenbureau al sinds 1992 het duurzaam bouwen hanteert als een filosofie, mede ingegeven door de bagage van zijn vroegere werkgevers. De vraag is niet zozeer óf je het doet, maar in welke mate. Je moet dan het 'gevecht' met de opdrachtgever aangaan. Ze geven als ontwerpende partij aan wat ze graag zouden willen gaan doen aan duurzame en ook energietechnische maatregelen. Daarna komen vanzelf de "ja maren" op tafel qua budget.

Hij weet dat binnen de wijk Nijrees wel specifieke maatregelen werden gevraagd voor sociale woningbouw en koopwoningen. $\mathrm{Er}$ werden photovoltaïsche panelen en zonnecollectoren toegepast op de woningen van Beter Wonen in deze Almelose wijk. Vervolgens werd het architectenbureau betrokken bij de Rembrandtlaan. Dat vooruitstrevende renovatieproject is doorgegaan, omdat het integraal werd aangepakt en omdat het technisch vernieuwend was. Het heeft ook landelijk veel aandacht gekregen. De Rombout Verhulstlaan zou min of meer een herhaling van de Rembrandtlaan worden doordat het eenzelfde type appartementen had. In de ogen van de architect is de Rombout Verhulstlaan meer bijzonder en ligt letterlijk en figuurlijk op een A-locatie, gezien de ligging aan de Almelose AA en aan een mooie groenzone. De bewoners zou je dus een beter uitzicht moeten bieden op deze plek. De kopse kanten van de flats 'dringen' als het ware in 
het groen en zouden hierdoor een accent moeten hebben. Met name door de opgetopte appartementen (soort penthouses) kreeg het plan een echt 'smoel' en beoogde een totale metamorfose zoals bij de Rembrandtlaan. Door het 'inpakken' met een goed isolatiepakket zouden de bouwfysische fouten worden afgedekt en de Rombout Verhulstlaan een nieuwe uitstraling geven. De reden waarom dit project echter niet door is gegaan, is de hoogoplopende kosten en misschien heeft het te lang geduurd in de voorbereiding omdat er teveel partijen bij betrokken raakten. De eisen wat betreft de energieprestatie zouden nu vergelijkbaar zijn met de huidige energielabel $A / B$. De precieze rollen van DWA adviseurs en Matrix I.A. in het project, is de geïnterviewde niet bekend maar beiden waren adviseurs tijdens het energetische renovatie plan van de Rombout Verhulst. $\mathrm{Nu}$ is op deze plek een totaal ander woningbouwproject gerealiseerd met behulp van System Engineering, een nieuw concept maar nog wel op basis van het oorspronkelijk, bijzondere stedenbouwkudig plan.

In het project Kollenveld bestond een grotere problematiek dan in de wijk Nijrees. De stedebouwkundige wilde hier hofjes hebben, terwijl de plannen niet als hofjes ontworpen waren. Het ontwerp vroeg dus om een nieuwe ondergrond. Het architectenbureau heeft toen een nieuw stedebouwkundig plan neergelegd, waarbij men echt niet met de auto in het wijkje of hofje mag parkeren. Twee woningbouwverenigingen hadden een opdracht om samen 75 huurwoningen te bouwen in een koopwijk, wat niet een ideale plek was. Beter Wonen vroeg op basis van ervaring expliciet om de geïnterviewde, waardoor ze moesten en gingen samenwerken met St. Jozef. Elke corporatie had zo zijn eigen uitgangspunten voor de geplande woningen, maar de gemaakte ontwerpen voldeden aan beide uitgangspunten. $\mathrm{Er}$ waren niet echt specifieke energie technische maatregelen of noviteiten gevraagd. Er zijn wel kratten gebruikt om regenwater te laten infiltreren in de ondergrond van de hof.

Een verklaring voor het ontbreken van verregaande energietechnische maatregelen in vergelijking tot Nijrees kan zijn, aldus de geïnterviewde, dat Nijrees in de opgaande lijn van het enthousiasme over duurzaamheid, milieu en energie zat. Na enkele jaren nam dit wat af en de lat werd in de tussentijd standaard al hoger gelegd, dus vandaar dat men misschien later teruggreep op het vereiste minimum eisen qua energieprestatie. Water was wel als thema meegenomen. In reactie op de vraag of een EPC eis minus $10 \%$ bekend is, geeft de geïnterviewde aan, dat dit hem A niet meer bekend is, maar B dat het ook een eis van niks is. Wanneer je de EPC met $50 \%$ verlaagt, dan doe je wat. $10 \%$ is niet revolutionair.

Het proces kende een koppeluitvoering. Beter Wonen zat met Droste en Dura Vermeer aan tafel en St Joseph met Van Dijk Bouw, dit had te maken met grondposities. Omdat er geen echte innovatieve maatregelen zijn toegepast, was in het ontwerpproces niet echt een rol weggelegd voor installatie adviseurs of installateurs. De installateurs hadden hun gebruikelijke taken.

\section{B.2. Welke persoon neemt de beslissing over de toepassing van energiemaatregelen?}

Dat is echt maar één persoon, namelijk de opdrachtgever, hij moet betalen. De architect kan heel veel dingen "vinden" en soms zal hij zelfs de longen uit zijn lijf moeten praten om bepaalde dingen geaccepteerd en uiteindelijk gerealiseerd te kunnen krijgen. Het is niet alleen een kwestie van vandaag of morgen. Ze wijzen de opdrachtgever er op dat het ook 
om de lange termijn gaat, dus niet alleen met een korte termijn visie. De opdrachtgever stelt echter vaak dat ze het nu moeten betalen en een exploitatie voor ogen hebben. Geen haalbare exploitatie op lange termijn, dan ook geen gebouw nu, aldus de opdrachtgever.

ledereen is zich in de afgelopen jaren gaan verdiepen in verduurzamen en energie. Nu bieden zich allemaal problemen aan; er is geen normaal verloop meer in de woningmarkt. Het is nu dus weer terug naar de basis, waarbij de investeringen echt niet mogen toenemen. Projecten moeten al voor tweederde verkocht zijn. Er is dus geen ruimte voor filosofie meer. Alleen maatregelen die zich op hele korte termijn terugverdienen zijn dus aantrekkelijk.

\section{Energieconcepten, -technieken en -maatregelen}

\section{C.1. Waar ligt de grens qua toepassing van technieken en maatregelen?}

Op dit moment is het heel belangrijk dat je binnen je budget blijft. Binnen dat budget moet je bekijken wat het maximaal haalbaar is. Dit budget wordt bepaald door de opdrachtgever. Dit budget is, aldus de geïnterviewde, altijd te weinig, want je zou het project altijd mooier en beter willen maken. Als architectenbureau loop je altijd over van ideeën. Het is dus een spel van trekken en duwen; het spel van het elastiekje. De discussies beginnen met concepten. Met bepaalde problemen of uitdagingen moet je in eerste instantie conceptueel omgaan om toch je doelen te bereiken. Later volgen de discussies over minder conceptuele zaken, of zelfs specifieke technieken.

\section{C.2. Is de EPC een kans of een beperking?}

De EPC moet je halen, punt. Dit kan op verschillende manieren; warmtepomp, pv-installatie, etc. Wanneer je deze manieren naast elkaar zet, dan bekijk je welke investeringen er mee gepaard gaan en maak je een keuze. De opdrachtgever is daarbij benieuwd hoe snel zij deze investering, die wettelijk sowieso nodig is, terug verdienen. Dit betreft dus niet de reductie qua energiegebruik, waarvan het financieel voordeel voor de huurder is. Hogere investeringskosten zijn voor de opdrachtgever wel te accepteren, wanneer de uitleg hiervan ook acceptabel of te verantwoorden is.

De EPC zegt niet zoveel. Het zegt niets over minimum energiegebruik, maar geeft wel een randvoorwaarde voor waar je aan moet voldoen. (Overigens is het bewonersgedrag van grotere invloed.) Hij denkt dat de methode niet houdbaar is in de toekomst. BIM kan veel suggesties geven. We kunnen simpele modellen maken die inzichten kunnen bieden en het proces dynamischer kunnen maken.

\section{C.3. Welke barrières zijn er volgens $u$ wat betreft de toepassing van energiemaatregelen?}

De feitelijke omstandigheden vormen de barrières. Als je techniek wilt toepassen, die niet toe te passen is, bijvoorbeeld vanwege grondsoort, of grondwaterstand, of vanwege omliggende grote gebouwen wanneer er onvoldoende zonlicht is. Verder zijn er niet echt barrières. Grote barrières zijn onoplosbare problemen, in de ogen van de geïnterviewde is er weinig onoplosbaar. Het kost alleen allemaal geld en dat is niet altijd beschikbaar.

C.4. Welke technieken en maatregelen kunnen het beste worden toegepast in de sociale woningbouw?

Je moet eigenlijk systemen bedenken waar mensen niet aan kunnen klooien. Mensen gaan overal aan draaien en prutsen. Ze ontregelen hiermee de systemen, waardoor in het 
verleden gevaarlijk situaties zijn ontstaan in de vrij dichte gebouwen. Hij stelt daarom voor om wanneer mensen aan hun systemen zitten, dat dan de TV uitgaat. Gebruiksvriendelijke systemen zijn nodig. Mensen realiseren zich niet wat er gebeurt en wonen gewoon. Sommige mensen ventileren bijvoorbeeld de hele dag in plaats van maar een uurtje. Het raam staat dan open en daarmee heeft een Rc van 5 of 6 voor de muur nog maar weinig zin. Één beste systeem voor de sociale woningbouw heeft de geïnterviewde nog niet ontdekt.

In een bouwproces moet je continu goed nadenken wat je wanneer met wie wilt doen. Het begint bij de initiatieffase wanneer je de locatie al voor je hebt. Het is bijvoorbeeld al bij de locatie bepalend of je een bepaalde invulling kunt geven aan het beperken van de thermische schil.

\section{C.5. Bent u of ziet u uw bureau als een innovator?}

In de jaren '92 tot '99 liep het bureau een straatlengte voorop op het gebied van duurzaamheid. We hadden toen hele vooruitstrevende projecten, maar tegenwoordig is dat al een beetje achterhaald. De laatste jaren is er heel veel veranderd. Door 'strengere' regelgeving is de ondergrens enorm op getrokken. Wat vroeger een bijzondere woning was is nu al gewoon. We werken momenteel aan passief huizen en energie-neutrale woningen en proberen er ook nog C2C bij te betrekken. De geïnterviewde geeft aan dat een EPC van 0,8 of 0,6 technisch niet een groot verschil maakt. De installatiebranche heeft op dergelijke EP-waarden al heel gemakkelijk ingespeeld door vooraf te stellen met welke technieken een waarde van 0,6 kan worden behaald. Dit is echter niet de werkwijze waar de geïnterviewde in gelooft; hij grijpt liever terug op concepten. Hij vindt vanuit een duurzaam concept redeneren veel interessanter dan je te richten op puntje voor puntje scoren om tot 0,6 te komen. Hij gelooft meer in de integrale benadering. 


\section{About the author}

Bram Entrop was born in Tiel on February $18^{\text {th }}$ 1980. After receiving his high school diploma at Gymnasium Bernrode in Heeswijk-Dinther, he started to study Civil Engineering and Management at the University of Twente in Enschede in 1998.

In his master thesis he developed a three-step method to achieve sustainable land use. The research for developing this Trias Toponoma, named after the three-step Trias Energetica model for sustainable energy use, was undertaken at Regio Twente in Enschede and was successfully finished in 2004. He was then employed by the Municipality of Hengelo as a

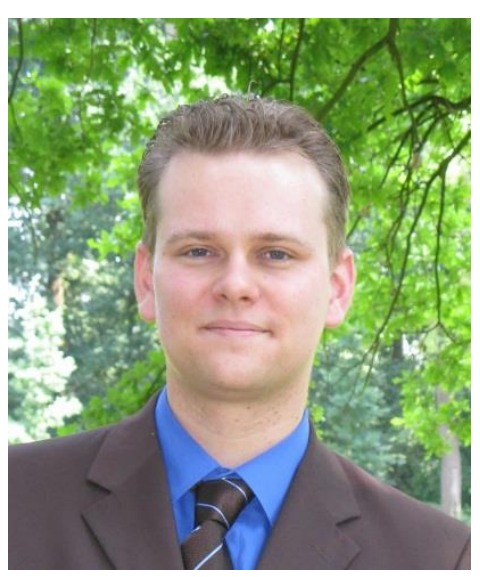
sustainable building inspector.

In 2006, he started his PhD research on the profit of exergy in the built environment in the Department of Construction Management and Engineering of the University of Twente. At that time, he married Ilona Szokoli and together they are raising three daughters. With his interests in education, he became an assistant professor in the same department in 2009 and works on several tasks in educating future civil engineers.

He teaches on design and construction processes, environmental aspects of civil engineering, building physics, installation technology and sustainable building. Furthermore, he is supervising several bachelor and master students who are conducting research in the field of sustainable building. In 2013 he will defend this thesis entitled "Assessing energy techniques and measures in residential buildings: a multidisciplinary perspective". 
Many Energy Techniques and Measures (ETMs) are available to reduce the fossil energy use of residential buildings. However, the rate at which these ETMs are implemented is relatively low. Bram Entrop (1980) addresses, in this design-oriented research, the influence that ETMs have on the energy performance of dwellings, what financial impact they have, how decisions regarding their implementation are taken in residential building projects, and what is required for a new ETM to be implemented in such projects.

It was found that although an ETM has an effect on the actual energy use of a dwelling and its residents, this is not necessarily shown through an improved theoretical energy performance, or vice versa. It was also found that although the energy use of a dwelling and its residents is reduced by implementing an ETM, the residents do not necessarily benefit financially from its implementation.

This thesis offers developers and manufacturers of ETMs an assessment framework that makes it possible to assess the implementation potential of an ETM by means of its effects on actual energy use and on the theoretical EPI, its financial impact on investment costs and annual cash flows, and its compliance with the interests of the stakeholders involved.

Furthermore, the insight is offered that it is almost impossible for a novel ETM to be implemented in residential building projects due to at least five barriers. These barriers are the complexity of how the energy use of dwellings and their residents is constituted and influenced, the required government-stipulated minimum energy performance, that incentives are split among stakeholders, the composition of energy costs, and that the underlying mechanisms of the preceding four barriers are frequently changed.

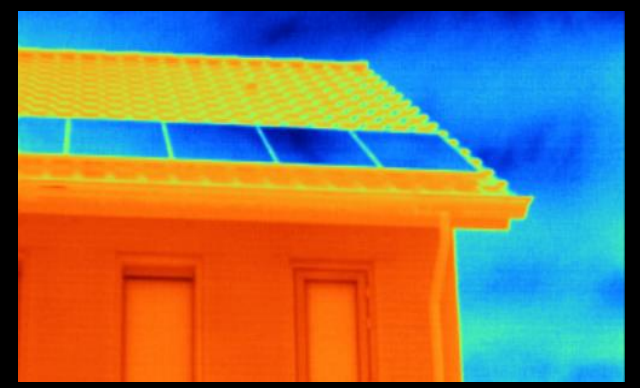

To improve the implementation of ETMs, efforts by all stakeholders are needed. More data are needed on what effects ETMs will have when applied in a specific dwelling with all its characteristics. In order to achieve this in the construction industry, it is recommended that the government initiates and stimulates pilot projects.

ISBN 978-90-365-3536-6 